\title{
New Stream-reach Development: A Comprehensive Assessment of Hydropower Energy Potential in the United States
}

Shih-Chieh Kao, Principal Investigator

Ryan A. McManamay, Kevin M. Stewart, Nicole M. Samu, Boualem Hadjerioua, Scott T. DeNeale, Dilruba Yeasmin, M. Fayzul K. Pasha, Abdoul A. Oubeidillah, and Brennan T. Smith

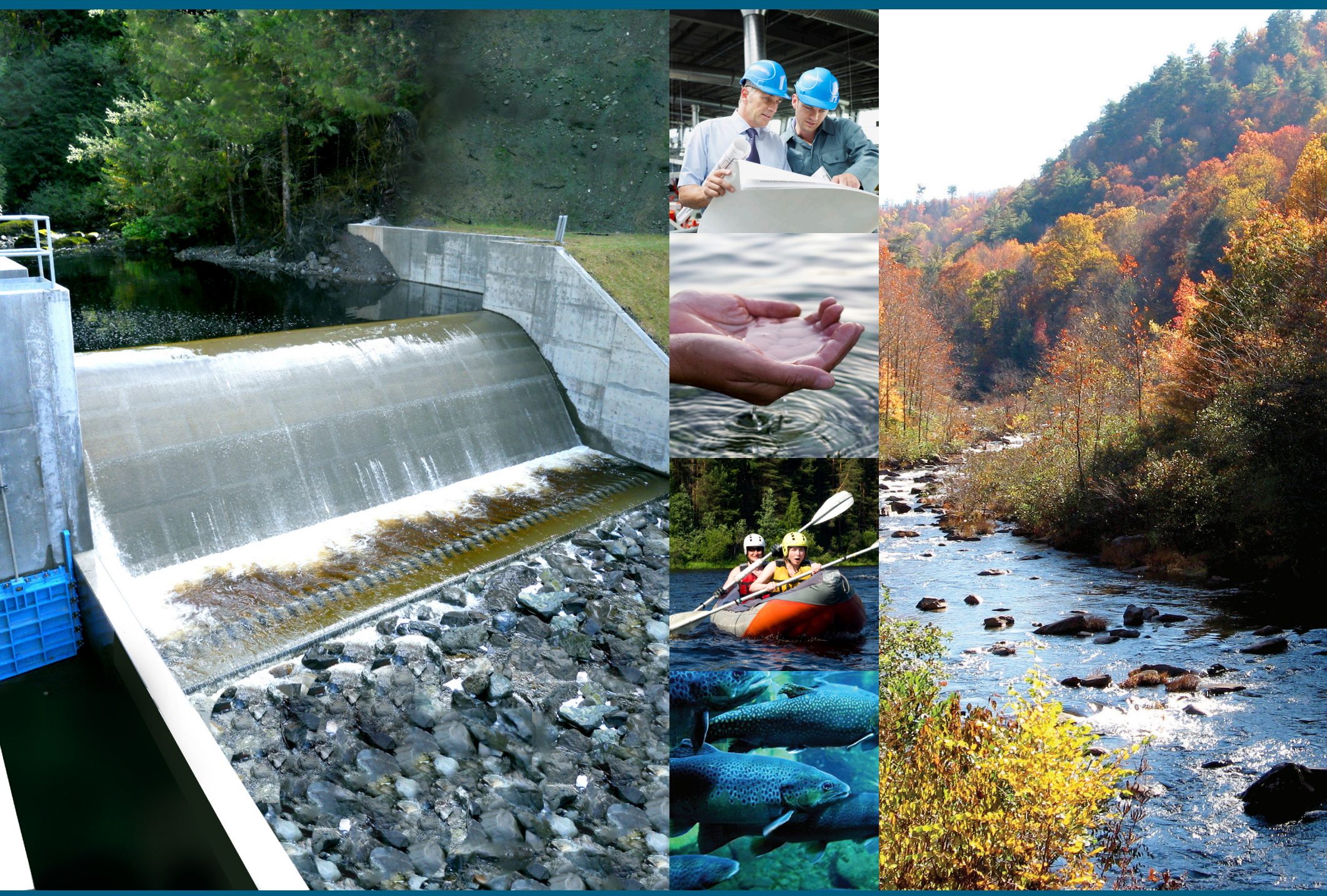

Prepared for

the U.S. Department of Energy

Wind and Water Power

Technologies Office

Budget Activity Number ED 1907042
Prepared by

April 2014

OAK RIDGE NATIONAL LABORATORY

Oak Ridge, Tennessee 37831

Managed by UT-BATTELLE, LLC

for the U.S. DEPARTMENT OF ENERGY

under contract DE-AC05-000R22725 


\section{Front Cover Images}

Left: Youngs Creek Project, Snohomish County Public Utility District, WA (image courtesy of Kim D. Moore and Neil Neroutsos, Snohomish County Public Utility District)

Youngs Creek Project was online in October 2011 with an estimated capacity of 7.5 MW and an annual production of $18,000 \mathrm{MWh}$ - enough to power about 1,500 homes. It is the first new hydro project in Washington state in nearly 20 years. It received the Renewable Energy World magazine's 2012 Hydro Project of the Year award.

Center: Used with license and permissions from iStock and Fotosearch

Right: Cheoah River, Graham County NC (image courtesy of Ryan A. McManamay) 


\section{DOCUMENT AVAILABILITY}

Reports produced after January 1, 1996, are generally available for free via the U.S. Department of Energy (DOE) Information Bridge.

Web site http://www.osti.gov/bridge

Reports produced before January 1,1996, may be purchased by members of the public from the following source.

National Technical Information Service

5285 Port Royal Road

Springfield, VA 22161

Telephone 703-605-6000 (1-800-553-6847)

TDD 703-487-4639

Fax 703-605-6900

E-mail info@ntis.fedworld.gov

Web site http://www.ntis.gov/support/ordernowabout.htm

Reports are available to DOE employees, DOE contractors, Energy Technology Data Exchange (ETDE) representatives, and International Nuclear Information System (INIS) representatives from the following source.

Office of Scientific and Technical Information

P.O. Box 62

Oak Ridge, TN 37831

Telephone 865-576-8401

Fax 865-576-5728

E-mail reports@adonis.osti.gov

Web site http://www.osti.gov/contact.html

This report was prepared as an account of work sponsored by an agency of the United States

Government. Neither the United States Government nor any agency thereof, nor any of their employees, makes any warranty, express or implied, or assumes any legal liability or responsibility for the accuracy, completeness, or usefulness of any information, apparatus, product, or process disclosed, or represents that its use would not infringe privately owned rights. Reference herein to any specific commercial product, process, or service by trade name, trademark, manufacturer, or otherwise, does not necessarily constitute or imply its endorsement, recommendation, or favoring by the United States Government or any agency thereof. The views and opinions of authors expressed herein do not necessarily state or reflect those of the United States Government or any agency thereof.

This report is being disseminated by the U.S. Department of Energy. As such, the document was prepared in compliance with Section 515 of the Treasury and General Government Appropriations Act for Fiscal Year 2001 (Public Law 106-554) and information quality guidelines issued by the U.S. Department of Energy. Though this report does not constitute "influential" information, as that term is defined in DOE's information quality guidelines or the Office of Management and Budget's Information Quality Bulletin for Peer Review (Bulletin), the study was reviewed both internally and externally prior to publication. For purposes of external review, the study benefited from the advice and comments of many different hydropower stakeholders. As noted elsewhere in the report, reviewers included representatives from other federal and state agencies, private corporations, non-profits, and national laboratories. 
(This Page Intentionally Left Blank) 


\title{
NEW STREAM-REACH DEVELOPMENT: A COMPREHENSIVE ASSESSMENT OF HYDROPOWER ENERGY POTENTIAL IN THE UNITED STATES
}

\author{
Shih-Chieh Kao*, Ryan A. McManamay, Kevin M. Stewart, Nicole M. Samu, \\ Boualem Hadjerioua, Scott T. DeNeale, Dilruba Yeasmin, M. Fayzul K. Pasha, \\ Abdoul A. Oubeidillah, and Brennan T. Smith
}

April 2014

\author{
Prepared by \\ OAK RIDGE NATIONAL LABORATORY \\ Oak Ridge, Tennessee 37831-6283 \\ managed by \\ UT-BATTELLE, LLC \\ for the \\ U.S. DEPARTMENT OF ENERGY \\ under contract DE-AC05-00OR22725
}

*Corresponding Author:

Shih-Chieh Kao

Oak Ridge National Laboratory

PO Box 2008

1 Bethel Valley Road

Oak Ridge, TN 37831-6038

Email: kaos@ornl.gov

Phone: 865-576-1259 
(This Page Intentionally Left Blank) 


\section{ABSTRACT}

The rapid development of multiple national geospatial datasets related to topography, hydrology, and environmental characteristics in the past decade has provided new opportunities to refine and more accurately characterize the nation's hydropower resource potential in undeveloped streamreaches. The U.S. Department of Energy (DOE) Water Power Program tasked Oak Ridge National Laboratory with evaluating the new stream-reach development (NSD) resource potential of more than 3 million U.S. streams in order to help individuals and organizations evaluate the feasibility of developing new hydropower sources in the United States. A methodology was designed to identify and characterize stream-reaches with high energy density and, most importantly, to compile and spatially join the energy potential of stream-reaches with information related to natural ecological systems; sensitive species; areas of social and cultural importance; and policy, management, and legal constraints. Additionally, this assessment focuses specifically on undeveloped stream-reaches, unlike previous assessments that covered all types of streams (i.e., including river segments with existing hydropower plants or non-powered dams). An initial report on methodology (Hadjerioua et al., 2013) was reviewed and revised based on comments gathered from two peer review workshops.

This assessment was conducted at a "reconnaissance level" (RETScreen International, 2005) considering the "technical resource" that could be available for development (NRC, 2013), and using present-day assumptions about hydropower technology. The methodology alone does not produce estimates of generation, cost, or potential impacts of sufficient accuracy to determine project-specific feasibility or to justify investments. These potential high-energy-density areas should be regarded as worthy of more detailed site-by-site evaluation by engineering and environmental professionals; not all areas identified in this assessment will be practical or feasible to develop for various reasons. In addition to the resource potential, this assessment includes stream-reach level information on a number of environmental attributes, such as fish habitat and recreational use, to support further market analysis.

The estimated technical resource capacity for new stream-reach development is $84.7 \mathrm{GW}$, with total undeveloped NSD generation estimated at $460 \mathrm{TWh} /$ year. When areas protected by federal legislation limiting the development of new hydropower (national parks, wild and scenic rivers, and wilderness areas) were excluded from the analysis, the estimated NSD capacity falls to 65.5 GW, slightly lower than the current existing U.S. conventional hydropower nameplate capacity (79.5 GW; NHAAP, 2013). Undeveloped NSD generation with these areas excluded is estimated to be $347.3 \mathrm{TWh} / \mathrm{year}$, roughly $128 \%$ of the average 2002-2011 net annual generation from existing plants (272 TWh/year; EIA, 2013). Detailed findings organized by hydrologic regions are presented in separate chapters of this report. 
(This Page Intentionally Left Blank) 


\section{ACKNOWLEDGEMENTS}

The authors would like to acknowledge and express their appreciation to the following individuals and programs for their review, comment and support of this report. The listing of reviewers here does not imply their agreement with all findings of the report. Any remaining errors in this report are the sole responsibility of the authors.

DOE Water Power Program:

- Hoyt Battey

- Rajesh Dham

- Thomas Heibel

- Michael Reed

- Michael Sale

U.S. Army Corps of Engineers:

- Kyle Jones

- William D. Proctor

- Crane Johnson

- Debbie Solis

U.S. Bureau of Reclamation:

- Michael Pulskamp

U.S. Fish and Wildlife Service:

- Frankie Green

U.S. Geological Survey:

- Eric Evenson

- Kernell Ries

- Kristine Verdin

U.S. National Park Service:

- Joan Harn

NOAA National Marine Fisheries Service:

- Timothy McCune

Alaska Energy Authority:

- Doug Ott

- Audrey Alstrom

Bonneville Power Administration:

- Mark Jones 


\section{California Department of Water Resources:}

- Mark Anderson

North Carolina Wildlife Resources Commission:

- Chris Goudreau

Hawaii Department of Business, Economic Development and Tourism:

- Andrea T. Gill

Nongovernmental Reviewers and Commenters:

- Norman Bishop, Knight Piesold

- Linda Church-Ciocci, National Hydropower Association

- Dave Culligan, HDR | DTA

- Don Erpenbeck, MWH

- John Gasper, Argonne National Laboratory

- Ron Grady, HDR

- Paul Jacobson, Electric Power Research Institute

- Kurt Johnson, Telluride Energy

- Jeff Leahey, National Hydropower Association

- Andrew Munro, National Hydropower Association / Grant County Public Utility District

- $\quad$ Rick Miller, HDR | DTA

- Jonathan Higgins, The Nature Conservancy

- James Parham, Parham \& Associates Environmental Consulting, LLC

- Scott Robinson, Southeast Aquatic Resources Partnership

- John Seeback, American Rivers

- Eric Van Deuren, Mead \& Hunt

- Dave Youlen, Eagle Creek Renewable Energy

Oak Ridge National Laboratory:

- Mark S. Bevelhimer

- Robert W. Blackwell

- Glenn F. Cada

- Deborah Melinda Counce

- Maria I. Martinez Gonzalez

- Leslie K. Lauder

- Aaron McClellan

- Clement O. Oigbokie II

- Esther Parish

- Angela M. Pelle

- Michele M. Thornton

- Yaxing Wei 


\section{TABLE OF CONTENTS}

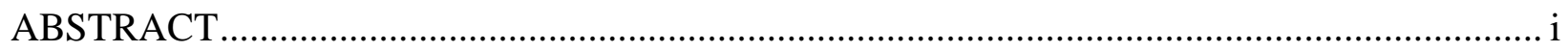

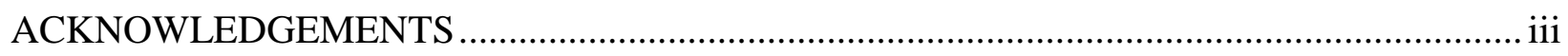

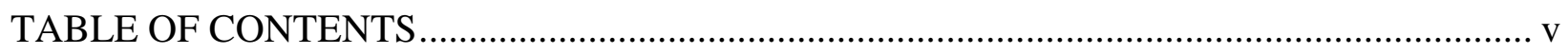

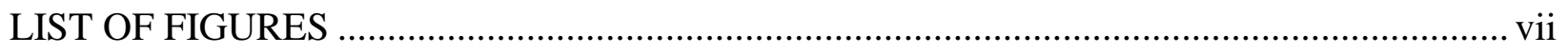

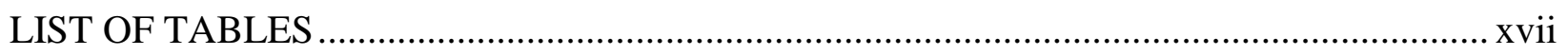

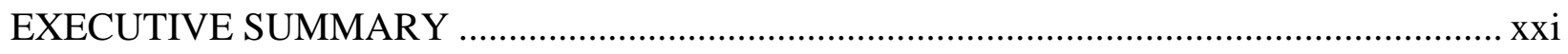

ABBREVIATIONS, ACRONYMS, and INITIALISMS ………………………………....... $\mathrm{xxv}$

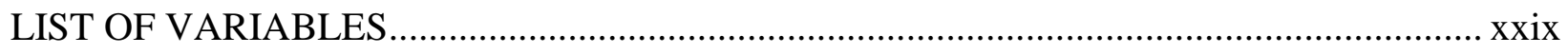

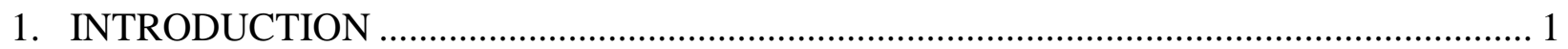

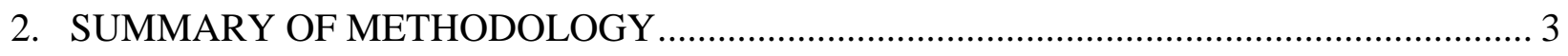

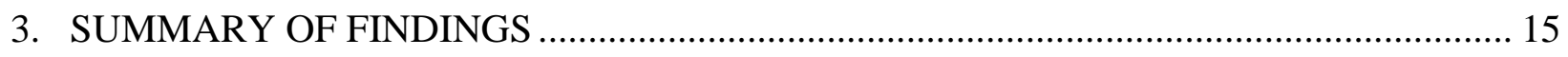

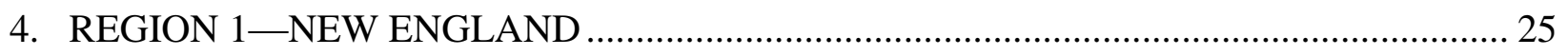

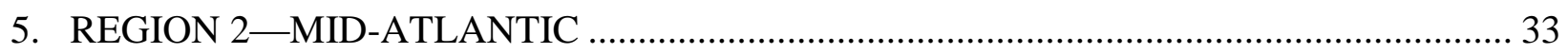

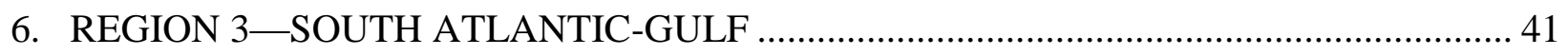

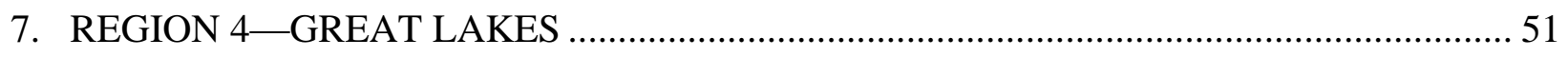

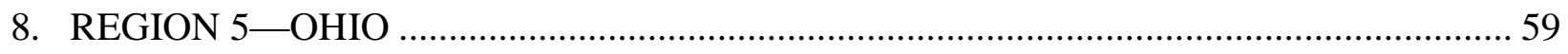

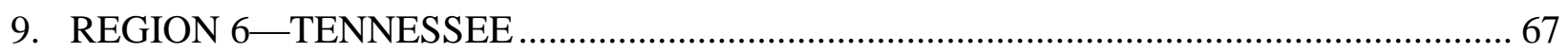

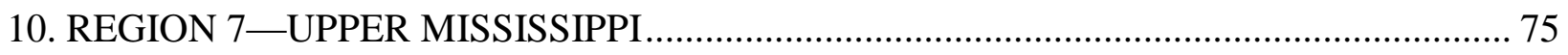

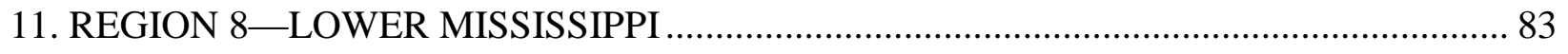

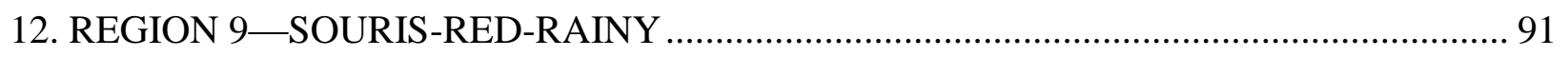

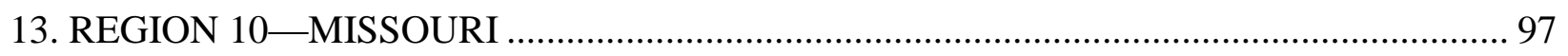

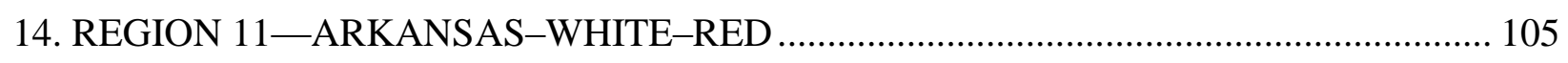

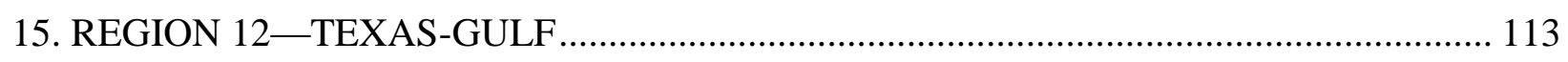

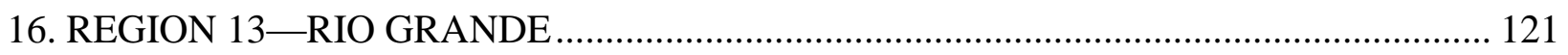


17. REGION 14-UPPER COLORADO .................................................................... 129

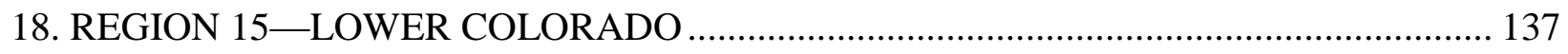

19. REGION 16 — GREAT BASIN ............................................................................ 145

20. REGION 17-PACIFIC NORTHWEST .............................................................. 153

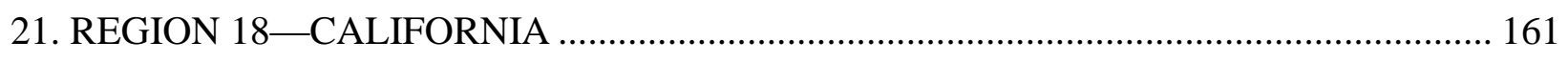

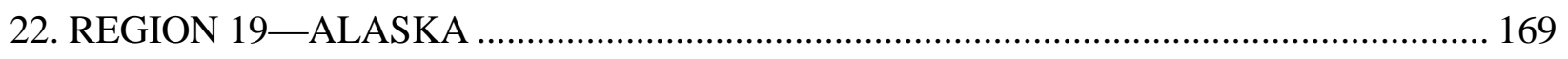

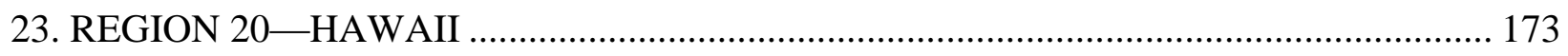

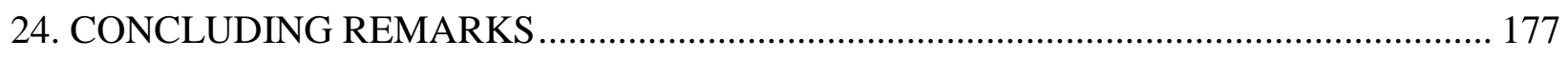

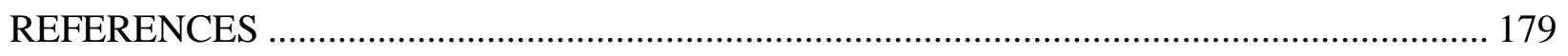

APPENDIX A.SUMMARY OF DIFFERENCES FROM THE PREVIOUS NATIONAL HYDROPOWER RESOURCE ASSESSMENT ............................................................ 183

APPENDIX B.ADDITIONAL ENVIRONMENTAL ATTRIBUTION DATA ..................... 189 


\section{LIST OF FIGURES}

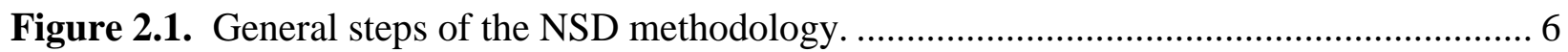

Figure 2.2. Illustration of NHDPlus flowline discretization....................................................... 7

Figure 2.3. Conceptual organization of data layers and variables. .............................................. 11

Figure 2.4. Example of virtual new hydropower site consisting of a point (dam), line (tailwater), and polygon (impoundment) and examples of buffers applied to the point and line. 12

Figure 3.1. Potential new hydropower capacity in the United States (higher-energy-density stream-reaches with >1 MW per reach, aggregated to HUC08 subbasins for illustration).......... 17

Figure 3.2. Overlap between NSD capacity potential and ESA critical habitats (stream-reaches with potential capacity $>1 \mathrm{MW}$ ). 18

Figure 3.3. Overlap between NSD capacity potential and water quality concerns (streamreaches with potential capacity $>1 \mathrm{MW}$ ).

Figure 3.4. Overlap between NSD capacity potential and ESA listed fish (stream-reaches with potential capacity $>1 \mathrm{MW})$.

Figure 3.5. Overlap between NSD capacity potential and U.S. national parks (stream-reaches with potential capacity $>1 \mathrm{MW}$ ).

Figure 3.6. Overlap between NSD capacity potential and Wild and Scenic Rivers (streamreaches with potential capacity $>1 \mathrm{MW}$ ).

Figure 3.7. Overlap between NSD capacity potential and recreational boating locations (streamreaches with potential capacity $>1 \mathrm{MW}$ ).

Figure 3.8. Overlap between NSD capacity potential and fishing access areas (stream-reaches with potential capacity $>1 \mathrm{MW}$ ).

Figure 3.9. Overlap between NSD capacity potential and total freshwater water use (streamreaches with potential capacity $>1 \mathrm{MW}$ ).

Figure 4.1. Locations of water control projects in Region 1-New England............................. 26

Figure 4.2. Annual and monthly rainfall and runoff of Region 1-New England. .................... 27

Figure 4.3. Cumulative distributions of hydraulic head $\mathrm{H}_{\text {ref }}$, design flow $\mathrm{Q}_{30}$, potential capacity $\mathrm{P}_{\mathrm{NSD}}$, inundated area $\mathrm{A}_{\mathrm{NSD}}$, storage $\mathrm{V}_{\mathrm{NSD}}$, and residence time $\mathrm{T}_{\mathrm{NSD}}$ in.....

Region 1-New England.

Figure 4.4. Potential new hydropower capacity in Region $1-\mathrm{New}$ England (higher-energydensity stream-reaches with $>1 \mathrm{MW}$ per reach, aggregated to HUC10 watersheds for 
illustration).

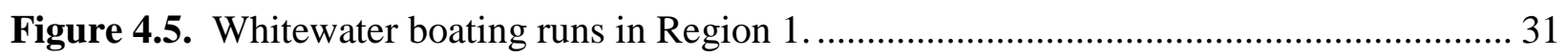

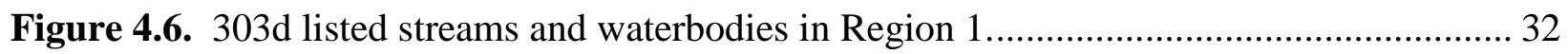

Figure 4.7. The potential capacity, in MW, associated with environmental attributes in..............

Region 1 -New England (stream-reaches with potential capacity >1 MW) . ......................... 32

Figure 5.1. Locations of water control projects in Region 2-Mid-Atlantic.......................... 34

Figure 5.2. Annual and monthly rainfall and runoff of Region 2-Mid-Atlantic................... 35

Figure 5.3. Cumulative distributions of hydraulic head $\mathrm{H}_{\mathrm{ref}}$, design flow $\mathrm{Q}_{30}$, potential capacity $\mathrm{P}_{\mathrm{NSD}}$, inundated area $\mathrm{A}_{\mathrm{NSD}}$, storage $\mathrm{V}_{\mathrm{NSD}}$, and residence time $\mathrm{T}_{\mathrm{NSD}}$ in....

Region 2-Mid-Atlantic. 36

Figure 5.4. Potential new hydropower capacity in Region 2-Mid-Atlantic (higher-energydensity stream-reaches with >1 MW per reach, aggregated to HUC08 subbasins for

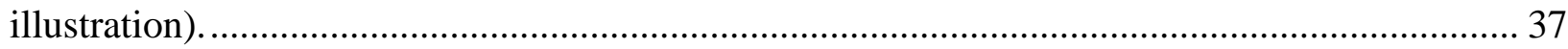

Figure 5.5. Boat ramp and fishing access areas in Region 2. ........................................... 39

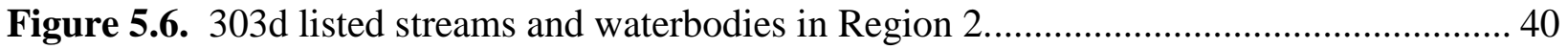

Figure 5.7. The potential capacity, in MW, associated with environmental attributes in..............

Region 2-Mid-Atlantic (stream-reaches with potential capacity >1 MW). .......................... 40

Figure 6.1. Locations of water control projects in Region 3-South Atlantic-Gulf................. 42

Figure 6.2. Annual and monthly rainfall and runoff of Region 3 -South Atlantic-Gulf. ......... 43

Figure 6.3. Cumulative distributions of hydraulic head $\mathrm{H}_{\mathrm{ref}}$, design flow $\mathrm{Q}_{30}$, potential capacity $\mathrm{P}_{\mathrm{NSD}}$, inundated area $\mathrm{A}_{\mathrm{NSD}}$, storage $\mathrm{V}_{\mathrm{NSD}}$, and residence time $\mathrm{T}_{\mathrm{NSD}}$ in.

Region 3-South Atlantic-Gulf. 44

Figure 6.4. Potential new hydropower capacity in Region 3 - South Atlantic-Gulf (higherenergy-density stream-reaches with >1 MW per reach, aggregated to HUC08 subbasins for illustration). 45

Figure 6.5. Fish species of concern (number per HUC08 sub-basin) in Region 3.................. 46

Figure 6.6. Critical habitats of federally endangered and threatened species in Region 3........ 47

Figure 6.7. The potential capacity, in MW, associated with environmental attributes in..............

Region 3-South Atlantic-Gulf (stream-reaches with potential capacity >1 MW). 49

Figure 7.1. Locations of water control projects in Region 4-Great Lakes.......................... 52

Figure 7.2. Annual and monthly rainfall and runoff of Region 4-Great Lakes..................... 52 
Figure 7.3. Cumulative distributions of hydraulic head $\mathrm{H}_{\mathrm{ref}}$, design flow $\mathrm{Q}_{30}$, potential capacity $\mathrm{P}_{\mathrm{NSD}}$, inundated area $\mathrm{A}_{\mathrm{NSD}}$, storage $\mathrm{V}_{\mathrm{NSD}}$, and residence time $\mathrm{T}_{\mathrm{NSD}}$ in.

Region 4-Great Lakes. 54

Figure 7.4. Potential new hydropower capacity in Region 4 Great Lakes (higher-energy-density stream-reaches with >1 MW per reach, aggregated to HUC08 subbasins for illustration).......... 55

Figure 7.5. Critical habitats of federally endangered and threatened species in Region 4........ 56

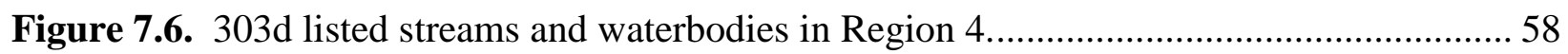

Figure 7.7. The potential capacity, in MW, associated with environmental attributes in.............

Region 4-Great Lakes ( stream-reaches with potential capacity >1 MW)............................ 58

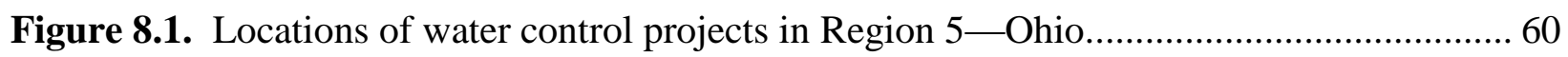

Figure 8.2. Annual and monthly rainfall and runoff of Region 5-Ohio.............................. 61

Figure 8.3. Cumulative distributions of hydraulic head $\mathrm{H}_{\mathrm{ref}}$, design flow $\mathrm{Q}_{30}$, potential capacity $\mathrm{P}_{\mathrm{NSD}}$, inundated area $\mathrm{A}_{\mathrm{NSD}}$, storage $\mathrm{V}_{\mathrm{NSD}}$, and residence time $\mathrm{T}_{\mathrm{NSD}}$ in Region 5-Ohio. 62

Figure 8.4. Potential new hydropower capacity in Region 5-Ohio (higher-energy-density stream-reaches with >1 MW per reach, aggregated to HUC08 subbasins for illustration).... 63

Figure 8.5. Potadromous and anadromous fish species (number per HUC08 subbasin) in......

Region 5. 64

Figure 8.6. Wild and Scenic River Systems in Region 5. 65

Figure 8.7. The potential capacity, in MW, associated with environmental attributes in Region 5-Ohio (stream-reaches with potential capacity >1 MW). 66

Figure 9.1. Locations of water control projects in Region 6-Tennessee............................... 68

Figure 9.2. Annual and monthly rainfall and runoff of Region 6-Tennessee. 69

Figure 9.3. Cumulative distributions of hydraulic head $\mathrm{H}_{\mathrm{ref}}$, design flow $\mathrm{Q}_{30}$, potential capacity $\mathrm{P}_{\mathrm{NSD}}$, inundated area $\mathrm{A}_{\mathrm{NSD}}$, storage $\mathrm{V}_{\mathrm{NSD}}$, and residence time $\mathrm{T}_{\mathrm{NSD}}$ in Region 6-Tennessee. ... 70 Figure 9.4. Potential new hydropower capacity in Region 6-Tennessee (higher-energy-density stream-reaches with >1 MW per reach, aggregated to HUC08 subbasins for illustration)......... 71

Figure 9.5. Fish species of concern (number per HUC08 subbasin) in Region 6.................... 72

Figure 9.6. Critical habitats of federally endangered and threatened species in Region 6........ 73

Figure 9.7. Average water use per HUC08 subbasin in Region 6. ....................................... 74

Figure 9.8. The potential capacity, in MW, associated with environmental attributes in. Region 6-Tennessee (stream-reaches with potential capacity $>1 \mathrm{MW}$ ). 
Figure 10.1. Locations of water control projects in Region 7-Upper Mississippi. ................ 76

Figure 10.2. Annual and monthly rainfall and runoff of Region 7-Upper Mississippi........... 77

Figure 10.3. Cumulative distributions of hydraulic head $\mathrm{H}_{\text {ref }}$, design flow $\mathrm{Q}_{30}$, potential capacity $\mathrm{P}_{\mathrm{NSD}}$, inundated area $\mathrm{A}_{\mathrm{NSD}}$, storage $\mathrm{V}_{\mathrm{NSD}}$, and residence time $\mathrm{T}_{\mathrm{NSD}}$ in.....

Region 7-Upper Mississippi. 78

Figure 10.4. Potential new hydropower capacity in Region 7-Upper Mississippi (higherenergy-density stream-reaches with >1 MW per reach, aggregated to HUC08 subbasins for illustration).

Figure 10.5. Potadromous and anadromous fish species (number per HUC08 subbasin) in Region 7. 80

Figure 10.6. Whitewater boating runs in Region 7. 81

Figure 10.7. The potential capacity, in MW, associated with environmental attributes in. Region 7-Upper Mississippi (stream-reaches with potential capacity >1 MW). 82

Figure 11.1. Locations of water control projects in Region 8-Lower Mississippi................. 84

Figure 11.2. Annual and monthly rainfall and runoff of Region 8-Lower Mississippi. 85

Figure 11.3. Cumulative distributions of hydraulic head $\mathrm{H}_{\mathrm{ref}}$, design flow $\mathrm{Q}_{30}$, potential capacity $\mathrm{P}_{\mathrm{NSD}}$, inundated area $\mathrm{A}_{\mathrm{NSD}}$, storage $\mathrm{V}_{\mathrm{NSD}}$, and residence time $\mathrm{T}_{\mathrm{NSD}}$ in.....

Region 8-Lower Mississippi. 86

Figure 11.4. Potential new hydropower capacity in Region 8 Lower Mississippi (higher-energydensity stream-reaches with >1 MW per reach, aggregated to HUC08 subbasins for illustration). 87

Figure 11.5. Fish species of concern (number per HUC08 subbasin) in Region 8. 88

Figure 11.6. Potadromous and anadromous fish species (number per HUC08 subbasin) in Region 8. 89

Figure 11.7. The potential capacity, in MW, associated with environmental attributes in. Region 8-Lower Mississippi (stream-reaches with potential capacity >1 MW).... 90

Figure 12.1. Locations of water control projects in Region 9-Souris-Red-Rainy. 92

Figure 12.2. Annual and monthly rainfall and runoff of Region 9-Souris-Red-Rainy. 93

Figure 12.3. Cumulative distributions of hydraulic head $\mathrm{H}_{\text {ref }}$, design flow $\mathrm{Q}_{30}$, potential capacity $\mathrm{P}_{\mathrm{NSD}}$, inundated area $\mathrm{A}_{\mathrm{NSD}}$, storage $\mathrm{V}_{\mathrm{NSD}}$, and residence time $\mathrm{T}_{\mathrm{NSD}}$ in..... Region 9-Souris-Red-Rainy. 94 
Figure 12.4. Potential new hydropower capacity in Region 9-Souris-Red-Rainy (higherenergy-density stream-reaches with >1 MW per reach, aggregated to HUC08 subbasins for illustration).

Figure 12.5. Potadromous and anadromous fish species (number per HUC08 subbasin) in Region 9. 95

Figure 12.6. $303 \mathrm{~d}$ listed streams and waterbodies in Region 9. 96

Figure 12.7. The potential capacity, in MW, associated with environmental attributes in Region 9-Souris-Red-Rainy (stream-reaches with potential capacity $>1 \mathrm{MW}$ ). 96

Figure 13.1. Locations of water control projects in Region 10-Missouri............................ 98

Figure 13.2. Annual and monthly rainfall and runoff of Region 10-Missouri....................... 98

Figure 13.3. Cumulative distributions of hydraulic head $\mathrm{H}_{\text {ref }}$, design flow $\mathrm{Q}_{30}$, potential capacity $\mathrm{P}_{\mathrm{NSD}}$, inundated area $\mathrm{A}_{\mathrm{NSD}}$, storage $\mathrm{V}_{\mathrm{NSD}}$, and residence time $\mathrm{T}_{\mathrm{NSD}}$ in.

Region 10-Missouri. 100

Figure 13.4. Potential new hydropower capacity in Region 10-Missouri (aggregated to HUC08 subbasins for illustration). 101

Figure 13.5. Fish species of concern (number per HUC08 subbasin) in Region 10. 102

Figure 13.6. Protected lands according to Gap Status (conservation management regime) in Region 10. 102

Figure 13.7. Average water use per HUC08 subbasin in Region 10. 103

Figure 13.8. The potential capacity, in MW, associated with environmental attributes in Region 10-Missouri (stream-reaches with potential capacity $>1 \mathrm{MW}$ ). 103

Figure 14.1. Locations of water control projects in Region 11-Arkansas-White-Red. ........ 106

Figure 14.2. Annual and monthly rainfall and runoff of Region 11-Arkansas-White-Red. . 107

Figure 14.3. Cumulative distributions of hydraulic head $\mathrm{H}_{\text {ref }}$, design flow $\mathrm{Q}_{30}$, potential capacity $\mathrm{P}_{\mathrm{NSD}}$, inundated area $\mathrm{A}_{\mathrm{NSD}}$, storage $\mathrm{V}_{\mathrm{NSD}}$, and residence time $\mathrm{T}_{\mathrm{NSD}}$ in.

Region 11-Arkansas-White-Red. 108

Figure 14.4. Potential new hydropower capacity in Region 11-Arkansas-White-Red (higherenergy-density stream-reaches with >1 MW per reach, aggregated to HUC08 subbasins for illustration). 109

Figure 14.5. Fish species of concern (number per HUC08 subbasin) in Region 11 109

Figure 14.6. Average water use per HUC08 subbasin in Region 11. 110 
Figure 14.7. The potential capacity, in MW, associated with environmental attributes in. Region 11 -Arkansas-White-Red (stream-reaches with potential capacity >1 MW). 111

Figure 15.1. Locations of water control projects in Region 12-Texas-Gulf. 114

Figure 15.2. Annual and monthly rainfall and runoff of Region $12-$ Texas-Gulf. 115

Figure 15.3. Cumulative distributions of hydraulic head $\mathrm{H}_{\mathrm{ref}}$, design flow $\mathrm{Q}_{30}$, potential capacity $\mathrm{P}_{\mathrm{NSD}}$, inundated area $\mathrm{A}_{\mathrm{NSD}}$, storage $\mathrm{V}_{\mathrm{NSD}}$, and residence time $\mathrm{T}_{\mathrm{NSD}}$ in.

Region 12-Texas-Gulf. 116

Figure 15.4. Potential new hydropower capacity in Region 12-Texas-Gulf (higher-energydensity stream-reaches with >1 MW per reach, aggregated to HUC08 subbasins for illustration). 117

Figure 15.5. Critical habitats for federally endangered and threatened species in Region 12.. 118

Figure 15.6. Average water use per HUC08 subbasin in Region 12 . 119

Figure 15.7. The potential capacity, in MW, associated with environmental attributes in. Region 12-Texas-Gulf (stream-reaches with potential capacity >1 MW). 120

Figure 16.1. Locations of water control projects in Region 13-Rio Grande. 122

Figure 16.2. Annual and monthly rainfall and runoff of Region 13 - Rio Grande. 123

Figure 16.3. Cumulative distributions of hydraulic head $\mathrm{H}_{\mathrm{ref}}$, design flow $\mathrm{Q}_{30}$, potential capacity $\mathrm{P}_{\mathrm{NSD}}$, inundated area $\mathrm{A}_{\mathrm{NSD}}$, storage $\mathrm{V}_{\mathrm{NSD}}$, and residence time $\mathrm{T}_{\mathrm{NSD}}$ in.

Region 13-Rio Grande.

Figure 16.4. Potential new hydropower capacity in Region 13-Rio Grande (higher-energydensity stream-reaches with >1 MW per reach, aggregated to HUC08 subbasins for illustration). 125

Figure 16.5. Fish species of concern (number per HUC08 subbasin) in Region 13................ 126

Figure 16.6. Critical habitats for federally endangered or threatened species in Region 13... 127

Figure 16.7. The potential capacity, in MW, associated with environmental attributes in Region 13-Rio Grande (stream-reaches with potential capacity >1 MW)... 128

Figure 17.1. Locations of water control projects in Region 14-Upper Colorado. 130

Figure 17.2. Annual and monthly rainfall and runoff of Region 14-Upper Colorado. 131

Figure 17.3. Cumulative distributions of hydraulic head $\mathrm{H}_{\mathrm{ref}}$, design flow $\mathrm{Q}_{30}$, potential capacity $\mathrm{P}_{\mathrm{NSD}}$, inundated area $\mathrm{A}_{\mathrm{NSD}}$, storage $\mathrm{V}_{\mathrm{NSD}}$, and residence time $\mathrm{T}_{\mathrm{NSD}}$ in Region 14-Upper Colorado. 132 
Figure 17.4. Potential new hydropower capacity in Region 14-Upper Colorado (higherenergy-density stream-reaches with >1 MW per reach, aggregated to HUC08 subbasins for illustration).

Figure 17.5. Critical habitats for federally endangered and threatened species in

Region 14.

Figure 17.6. Protected lands according to Gap Status (conservation management regime) in Region 14.

Figure 17.7. The potential capacity, in MW, associated with environmental attributes in Region 14-Upper Colorado (stream-reaches with potential capacity $>1 \mathrm{MW}$ ). 136

Figure 18.1. Locations of water control projects in Region 15-Lower Colorado. 138

Figure 18.2. Annual and monthly rainfall and runoff of Region 15-Lower Colorado. 139

Figure 18.3. Cumulative distributions of hydraulic head $\mathrm{H}_{\text {ref }}$, design flow $\mathrm{Q}_{30}$, potential capacity $\mathrm{P}_{\mathrm{NSD}}$, inundated area $\mathrm{A}_{\mathrm{NSD}}$, storage $\mathrm{V}_{\mathrm{NSD}}$, and residence time $\mathrm{T}_{\mathrm{NSD}}$ in.

Region 15-Lower Colorado. 140

Figure 18.4. Potential new hydropower capacity in Region 15-Lower Colorado (higher-energydensity stream-reaches with >1 MW per reach, aggregated to HUC08 subbasins for illustration).

Figure 18.5. Critical habitats for federally endangered and threatened species along with spatial coverage of Grand Canyon National Park in Region 15. 142

Figure 18.6. Protected lands according to Gap Status (conservation management regime) in Region 15. Grand Canyon National Park location is labeled. 143

Figure 18.7. The potential capacity, in MW, associated with environmental attributes in Region 15-Lower Colorado (stream-reaches with potential capacity $>1 \mathrm{MW}$ ). 144

Figure 19.1. Locations of water control projects in Region 16 - Great Basin...................... 146

Figure 19.2. Annual and monthly rainfall and runoff of Region 16-Great Basin. 147

Figure 19.3. Cumulative distributions of hydraulic head $\mathrm{H}_{\mathrm{ref}}$, design flow $\mathrm{Q}_{30}$, potential capacity $\mathrm{P}_{\mathrm{NSD}}$, inundated area $\mathrm{A}_{\mathrm{NSD}}$, storage $\mathrm{V}_{\mathrm{NSD}}$, and residence time $\mathrm{T}_{\mathrm{NSD}}$ in....

Region 16-Great Basin. 148

Figure 19.4. Potential new hydropower capacity in Region 16 - Great Basin (higher-energydensity stream-reaches with >1 MW per reach, aggregated to HUC08 subbasins for illustration). 149

Figure 19.5. Fish species of concern (number per HUC08 sub-basin) in Region 16. 150 
Figure 19.6. Average water use per HUC08 subbasin in Region 16.

Figure 19.7. The potential capacity, in MW, associated with environmental attributes in Region 16-Great Basin (stream-reaches with potential capacity $>1 \mathrm{MW}$ ). 152

Figure 20.1. Locations of water control projects in Region 17-Pacific Northwest. 154

Figure 20.2. Annual and monthly rainfall and runoff of Region 17-Pacific Northwest. ....... 155

Figure 20.3. Cumulative distributions of hydraulic head $\mathrm{H}_{\mathrm{ref}}$, design flow $\mathrm{Q}_{30}$, potential capacity $\mathrm{P}_{\mathrm{NSD}}$, inundated area $\mathrm{A}_{\mathrm{NSD}}$, storage $\mathrm{V}_{\mathrm{NSD}}$, and residence time $\mathrm{T}_{\mathrm{NSD}}$ in.

Region 17-Pacific Northwest. 156

Figure 20.4. Potential new hydropower capacity in Region 17-Pacific Northwest (higherenergy-density stream-reaches with >1 MW per reach, aggregated to HUC08 subbasins for illustration).

Figure 20.5. Fish species of concern (number per HUC08 subbasin) in Region 17. 158

Figure 20.6. Critical habitats for federally endangered and threatened species in Region 17. 158

Figure 20.7. Protected lands according to Gap Status (conservation management regime) in Region 17.

Figure 20.8. The potential capacity, in MW, associated with environmental attributes in..... Region 17-Pacific Northwest (stream-reaches with potential capacity >1 MW). 160

Figure 21.1. Locations of water control projects in Region 18-California. 162

Figure 21.2. Annual and monthly rainfall and runoff of Region 18 - California. 163

Figure 21.3. Cumulative distributions of hydraulic head $\mathrm{H}_{\text {ref }}$, design flow $\mathrm{Q}_{30}$, potential capacity $\mathrm{P}_{\mathrm{NSD}}$, inundated area $\mathrm{A}_{\mathrm{NSD}}$, storage $\mathrm{V}_{\mathrm{NSD}}$, and residence time $\mathrm{T}_{\mathrm{NSD}}$ in.

Region 18-California..... 164

Figure 21.4. Potential new hydropower capacity in Region 18 California (higher-energy-density stream-reaches with >1 MW per reach, aggregated to HUC08 subbasins for illustration). 165

Figure 21.5. Critical habitats for federally endangered and threatened species in Region 18. 166

Figure 21.6. Fish species of concern (number per HUC08 subbasin) in Region 18. 167

Figure 21.7. The potential capacity, in $\mathrm{MW}$, associated with environmental attributes in Region 18 - California (stream-reaches with potential capacity $>1 \mathrm{MW}$ ). 168

Figure 22.1. Map of existing and NSD hydropower sites in Alaska. 171

Figure 22.2. Project size distribution of Alaska NSD sites. 172 
Figure 22.3. Cumulative potential installed capacity by size for Alaska.............................. 172

Figure 23.1. Map of existing and NSD hydropower sites in Hawaii.................................. 174

Figure 23.2. Project size distribution of Hawaii NSD sites. .............................................. 175

Figure 23.3. Cumulative potential installed capacity by size for Hawaii. ............................ 175

Figure A.1. Comparison of (a) total and (b) after deduction annual mean power between Hall et

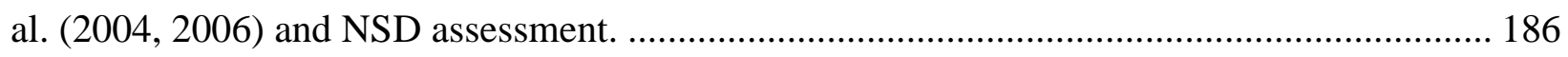


(This Page Intentionally Left Blank) 


\section{LIST OF TABLES}

Table ES.1. Summary of NSD Findings by Hydrologic Regions.........................................xxii

Table ES.2. Summary of NSD Findings by States ……………….....................................xxiii

Table 2.1. Summary of Data Used for Resource Evaluation ...................................................... 4

Table 2.2. Summary of Data Sources Used in the Environmental Attribution............................ 10

Table 2.3. Variable Buffer Widths According to Different Data Layers and Different Site

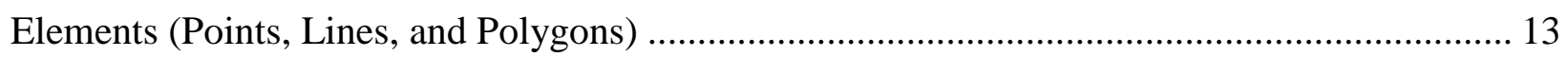

Table 3.1. Summary of NSD Findings by Hydrologic Regions ................................................ 15

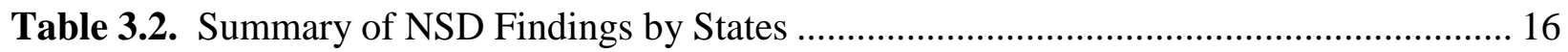

Table 3.3. Summary of NSD Findings by Hydrologic Regions, Excluding Stream-reaches that are in Close Proximity to National Parks, Wild and Scenic Rivers, and Wilderness Areas......... 22

Table 3.4. Summary of NSD Findings by States, Excluding Stream-reaches that Are in Close Proximity to National Parks, Wild and Scenic Rivers, and Wilderness Areas ............................. 23

Table 4.1. Summary of NSD Findings in Region 1-New England ........................................... 25

Table 4.2. Summary of Potential New Hydropower Resources in Region 1-New England (Stream-Reaches with Potential Capacity >1 MW) .................................................................. 27

Table 4.3. Summary of Environmental Variables at HUC04 Subregions within Region 1

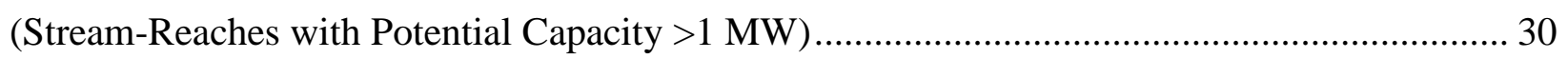

Table 5.1. Summary of NSD Findings in Region 2-Mid-Atlantic .......................................... 33

Table 5.2. Summary of Potential New Hydropower Resources in Region 2-Mid-Atlantic (Stream-Reaches with Potential Capacity >1 MW) ..................................................................... 35

Table 5.3. Summary of Environmental Variables at HUC04 Subregions within Region 2 (Stream-Reaches with Potential Capacity >1 MW) ................................................................... 38

Table 6.1. Summary of NSD Findings in Region 3 - South Atlantic-Gulf ................................ 41

Table 6.2. Summary of Potential New Hydropower Resources in Region 3-South Atlantic-

Gulf (Stream-Reaches with Potential Capacity >1 MW) .......................................................... 44

Table 6.3. Summary of Environmental Variables at HUC04 Subregions within Region 3

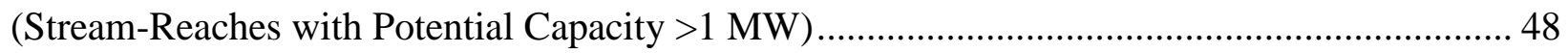

Table 7.1. Summary of NSD Findings in Region 4-Great Lakes............................................. 51

Table 7.2. Summary of Potential New Hydropower Resources in Region 4-Great Lakes 
(Stream-Reaches with Potential Capacity $>1 \mathrm{MW}$ ). 53

Table 7.3. Summary of Environmental Variables at HUC04 Subregions within Region 4 (Stream-Reaches with Potential Capacity $>1 \mathrm{MW}$ )...... 57

Table 8.1. Summary of NSD Findings in Region 5-Ohio ................................................ 59

Table 8.2. Summary of Potential new hydropower resources in Region 5-Ohio (StreamReaches with Potential Capacity $>1 \mathrm{MW}$ ). 61

Table 8.3. Summary of Environmental Variables at HUC04 Subregions within Region 5

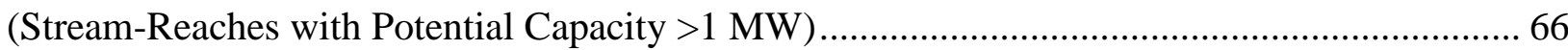

Table 9.1. Summary of NSD Findings in Region 6-Tennessee...................................... 67

Table 9.2. Summary of Potential New Hydropower Resources in Region 6-Tennessee (Stream-Reaches With Potential Capacity $>1 \mathrm{MW}$ )

Table 9.3. Summary of Environmental Variables at HUC04 Subregions Within Region 6 (Stream-Reaches with Potential Capacity >1 MW) ............................................................ 73

Table 10.1. Summary of NSD Findings in Region 7-Upper Mississippi ............................ 75

Table 10.2. Summary of Potential New Hydropower Resources in Region 7-Upper Mississippi (Stream-Reaches with Potential Capacity $>1 \mathrm{MW}$ ).

Table 10.3. Summary of Environmental Variables at HUC04 Subregions within Region 7 (Stream-Reaches with Potential Capacity $>1 \mathrm{MW}$ ). 82

Table 11.1. Summary of NSD Findings in Region 8-Lower Mississippi 83

Table 11.2. Summary of Potential New Hydropower Resources in Region 8 Lower Mississippi (Stream-Reaches with Potential Capacity $>1 \mathrm{MW}$ ). 85

Table 11.3. Summary of Environmental Variables at HUC04 Subregions within Region 8 (Stream-Reaches with Potential Capacity >1 MW). 90

Table 12.1. Summary of NSD Findings in Region 9-Souris-Red-Rainy ............................ 91

Table 12.2. Summary of Potential New Hydropower Resources in Region 9 Souris-Red-Rainy (Stream-Reaches with Potential Capacity $>1 \mathrm{MW}$ ). 94

Table 12.3. Summary of Environmental Variables at HUC04 Subregions within Region 9 (Stream-Reaches with Potential Capacity $>1 \mathrm{MW}$ ). 94

Table 13.1. Summary of NSD Findings in Region 10-Missouri 97

Table 13.2. Summary of Potential New Hydropower Resources in Region 10 Missouri (StreamReaches with Potential Capacity $>1$ MW) 99 
Table 13.3. Summary of Environmental Variables at HUC04 Subregions within Region 10 (Stream-Reaches with Potential Capacity $>1 \mathrm{MW}$ ). 104

Table 14.1. Summary of NSD Findings in Region 11-Arkansas-White-Red 105

Table 14.2. Summary of Potential New Hydropower Resources in Region 11 Arkansas-WhiteRed (Stream-Reaches with Potential Capacity $>1 \mathrm{MW}$ ) 107

Table 14.3. Summary of Environmental Variables at HUC04 Subregions within Region 11 (Stream-Reaches with Potential Capacity $>1 \mathrm{MW}$ ).

Table 15.1. Summary of NSD Findings in Region 12 - Texas-Gulf .

Table 15.2. Summary of Potential New Hydropower Resources in Region 12-Texas-Gulf (Stream-Reaches with Potential Capacity $>1 \mathrm{MW}$ ).

Table 15.3. Summary of Environmental Variables at HUC04 Subregions within Region 12 (Stream-Reaches with Potential Capacity >1 MW).

Table 16.1. Summary of NSD Findings in Region 13-Rio Grande.

Table 16.2. Summary of Potential New Hydropower Resources in Region 13-Rio Grande (Stream-Reaches with Potential Capacity >1 MW).

Table 16.3. Summary of Environmental Variables at HUC04 Subregions within Region 13 (Stream-Reaches with Potential Capacity $>1 \mathrm{MW}$ ). 128

Table 17.1. Summary of NSD Findings in Region 14-Upper Colorado . 129

Table 17.2. Summary of Potential New Hydropower Resources in Region 14-Upper Colorado (Stream-Reaches with Potential Capacity $>1 \mathrm{MW}$ ).

Table 17.3. Summary of Environmental Variables at HUC04 Subregions within Region 14 (Stream-Reaches with Potential Capacity $>1 \mathrm{MW}$ ). 136

Table 18.1. Summary of NSD Findings in Region 15-Lower Colorado. 137

Table 18.2. Summary of Potential New Hydropower Resources in Region 15-Lower Colorado (Stream-Reaches with Potential Capacity $>1 \mathrm{MW}$ ). 139

Table 18.3. Summary of Environmental Variables at HUC04 Subregions within Region 15 (Stream-Reaches with Potential Capacity >1 MW). 144

Table 19.1. Summary of NSD Findings in Region 16-Great Basin ... 145

Table 19.2. Summary of Potential New Hydropower Resources in Region 16-Great Basin (Stream-Reaches with Potential Capacity $>1 \mathrm{MW}$ ). 147

Table 19.3. Summary of Environmental Variables at HUC04 Subregions within Region 16 
(Stream-Reaches with Potential Capacity $>1 \mathrm{MW}$ ). 152

Table 20.1. Summary of NSD Findings in Region 17-Pacific Northwest 153

Table 20.2. Summary of Potential New Hydropower Resources in Region 17-Pacific

Northwest (Stream-Reaches with Potential Capacity >1 MW) 155

Table 20.3. Summary of Environmental Variables at HUC04 Subregions within Region 17 (Stream-Reaches with Potential Capacity $>1 \mathrm{MW}$ ). 159

Table 21.1. Summary of NSD Findings in Region 18 - California 161

Table 21.2. Summary of Potential New Hydropower Resources in Region 18-California (Stream-Reaches with Potential Capacity >1 MW). 163

Table 21.3. Summary of Environmental Variables at HUC04 Subregions within Region 18 (Stream-Reaches with Potential Capacity $>1 \mathrm{MW}$ ). 168

Table A.1. Summary of Difference between Hall et al. $(2004,2006)$ and NSD Assessment... 183

Table A.2. Comparison of Annual Mean Power in Conterminous United States................... 186

Table A.3. Comparison of Annual Mean Power in the Conterminous United States.............. 188

Table B.1. Fish Species Falling Under an ESA or IUCN Vulnerability Category and their Native Hydrologic Region(s).... 189

Table B.2. Average Water Use (liters/day/km2) in Different Usage Categories per Hydrologic Region 195

Table B.3. Approximated Arial Coverage (km2) of Dominant Water-Quality Concerns per Hydrologic Region 196 


\section{EXECUTIVE SUMMARY}

The rapid development of multiple national geospatial datasets related to topography, hydrology, and environmental characteristics in the past decade has provided new opportunities for refining assessments of hydropower resource potential from currently undeveloped stream-reaches. From 2011 through 2013, Oak Ridge National Laboratory (ORNL) was tasked by the U.S. Department of Energy (DOE) Water Power Program with evaluating the new stream-reach development $(\mathrm{NSD})^{1}$ resource potential of more than 3 million U.S. streams. This wide spatial scope demands an approximate methodology that can (1) resolve aggregate potential within hydrologic regions and electric power systems and (2) enable the modeling of regional and national scenarios for existing and new electric power generation technology deployment through the development of curves for hydropower capacity cost versus supply. A methodology was hence designed that contains three main components: (1) identification of stream-reaches with high energy density; (2) topographical analysis of promising stream-reaches to estimate the characteristics of potential inundations of reservoirs; and (3) environmental attribution to spatially join the energy potential of stream-reaches with information related to the natural ecological systems; social and cultural settings; and policies, management, and legal constraints. This refined assessment utilizes a comprehensive set of recent U.S. geographic, topographic, hydrologic, hydropower, environmental, and socio-political datasets, including the Environmental Protection Agency/U.S. Geological Survey (EPA/USGS) National Hydrography Dataset Plus (NHDPlus), U.S. Army Corps of Engineers (USACE) National Inventory of Dams (NID), USGS National Elevation Dataset (NED), USGS National Water Information System (NWIS), USGS WaterWatch Runoff Dataset, DOE/ORNL National Hydropower Asset Assessment Program (NHAAP) Dataset, Federal Emergency Management Agency (FEMA) Flood Insurance Study (FIS), U.S. Fish and Wildlife Service (USFWS) Federally Listed Endangered Species, USFWS Critical Habitats, USGS Gap Analysis Program (GAP) Conservation Lands, and USGS Water Use Dataset. In addition to the new data and methodology, the NSD assessment focuses specifically on undeveloped stream-reaches, unlike previous assessments that examined all types of streams without further breakdown (i.e., including river segments with existing hydropower plants or non-powered dams). An initial report on methodology (Hadjerioua et al., 2013) was reviewed and revised based on the comments gathered from two peer review workshops (December 2011 for resource characterization and June 2012 for environmental attribution).

After the assessment was implemented across the entire United States, major findings were summarized in this final report. The estimated NSD capacity and generation, including both higher-energy-density ( $>1 \mathrm{MW}$ per reach) and lower-energy-density ( $<1 \mathrm{MW}$ per reach) streamreaches, are shown in Table ES.1 for each hydrologic region. The highest potential was identified in the Pacific Northwest Region (32\%), followed by the Missouri Region (15\%) and the California Region (9\%). In total, the undeveloped NSD capacity is $84.7 \mathrm{GW}$, and the undeveloped NSD generation is estimated to be $460 \mathrm{TWh} / \mathrm{year}$. When areas protected by federal legislation limiting the development of new hydropower (national parks, wild and scenic rivers, and wilderness areas) were excluded from the analysis, the estimated NSD capacity falls to 65.5

\footnotetext{
${ }^{1}$ The DOE Water Power Program classifies hydropower potential into multiple resource classes. These are (1) upgrades to existing facilities, (2) expansion of existing facilities, (3) powering of non-powered dams, (4) development at new "heretofore undeveloped" stream-reaches, and (5) energy recovery in constructed waterways. Although it does not yield a net production of energy, pumped-storage hydropower is recognized as a valuable resource for grid flexibility and energy storage.
} 
GW, slightly lower than the current existing U.S. conventional hydropower nameplate capacity (79.5 GW; NHAAP, 2013). Undeveloped NSD generation with these areas excluded is estimated to be $347.3 \mathrm{TWh}$ /year, roughly $128 \%$ of the average 2002-2011 net annual generation from existing plants (272 TWh/year; EIA, 2013). Since the assessment was designed to identify potential run-of-river projects, NSD stream-reaches have higher capacity factors $(53 \%-71 \%)$, especially compared with conventional larger-storage peaking-operation projects that usually have capacity factors of around $30 \%$.

Table ES.1. Summary of NSD Findings by Hydrologic Regions

\begin{tabular}{ll|r|r|r}
\hline & Hydrologic region & Capacity $(\mathbf{M W})$ & Generation (MWh/year) & Capacity factor \\
\hline 01 & New England & 2,143 & $12,433,000$ & $66 \%$ \\
02 & Mid-Atlantic & 4,710 & $25,945,000$ & $63 \%$ \\
03 & South Atlantic-Gulf & 2,561 & $14,205,000$ & $63 \%$ \\
\hline 04 & Great Lakes & 1,425 & $8,444,000$ & $68 \%$ \\
05 & Ohio & 4,757 & $25,288,000$ & $61 \%$ \\
06 & Tennessee & 1,363 & $7,995,000$ & $67 \%$ \\
\hline 07 & Upper Mississippi & 2,081 & $11,546,000$ & $63 \%$ \\
08 & Lower Mississippi & 2,072 & $12,074,000$ & $67 \%$ \\
09 & Souris-Red-Rainy & 151 & 787,000 & $60 \%$ \\
\hline 10 & Missouri & 11,686 & $69,011,000$ & $67 \%$ \\
11 & Arkansas-White-Red & 6,013 & $33,994,000$ & $65 \%$ \\
12 & Texas-Gulf & 783 & $3,666,000$ & $5,310,000$ \\
\hline 13 & Rio Grande & 1,637 & $18,232,000$ & $65 \%$ \\
14 & Upper Colorado & 3,033 & $16,273,000$ & $69 \%$ \\
15 & Lower Colorado & 2,613 & $3,105,000$ & $71 \%$ \\
\hline 16 & Great Basin & 564 & $148,999,000$ & $63 \%$ \\
17 & Pacific Northwest & 25,226 & $37,987,000$ & $67 \%$ \\
18 & California & 7,054 & $($ not estimated) & $61 \%$ \\
\hline 19 & Alaska* & 4,723 & 699,000 & $($ not estimated) \\
20 & Hawaii* & 145 & 54,740 & $53 \%$ \\
\hline & Total & $66 \%, 993,000$ & \\
\hline
\end{tabular}

*The Alaska and Hawaii potential are estimated by a different approach from that used for other regions.

The estimated NSD capacity and generation for both higher-energy-density and lower-energydensity stream-reaches are further summarized in Table ES.2 for each state. The downstream end of a stream-reach is treated as the possible development location to determine specific location within states. When a stream-reach is located on the border of multiple states, the potential capacity and generation are distributed evenly into each neighboring state to compute the statebased totals. The highest potential is found in Oregon, Washington, and Idaho- the three states in the Pacific Northwest - followed by California, Alaska, Montana, and Colorado.

The main NSD findings are aggregated by HUC10 Hydrologic Watersheds and released through NHAAP (http://nhaap.ornl.gov/) to support further hydropower research activities. Detailed results with location-specific features are available through a user agreement to ensure the appropriate use and interpretation of the location-specific results. Note that the primary goal of the NSD assessment is to provide a national-scale, reconnaissance-level analysis to identify highenergy-intensity stream-reaches and classify new potential areas using a range of technical, 
socioeconomic, and environmental characteristics. The NSD assessment is not intended to determine economic feasibility, justify financial investment for individual site development, or replace on-site physical and environmental assessments. For site-specific hydropower development, all design characteristics, including hydraulic head and flow, should be reevaluated based on more accurate direct measurement.

Table ES.2. Summary of NSD Findings by States

\begin{tabular}{lrr|lrr}
\hline State & $\begin{array}{r}\text { Potential } \\
\text { capacity (MW) }\end{array}$ & $\begin{array}{r}\text { Potential generation } \\
(\text { MWh/year) }\end{array}$ & State & $\begin{array}{r}\text { Potential } \\
\text { capacity (MW) }\end{array}$ & $\begin{array}{r}\text { Potential generation } \\
\text { (MWh/year) }\end{array}$ \\
\hline AK* & 4,723 & $($ not estimated) & MT & 4,763 & $28,201,000$ \\
AL & 663 & $3,522,000$ & NC & 857 & $5,067,000$ \\
AR & 1,253 & $6,685,000$ & ND & 252 & $1,524,000$ \\
AZ & 2,484 & $1,5459,000$ & NE & 1,942 & $11,917,000$ \\
CA & $3,7564,000$ & NH & 407 & $2,410,000$ \\
\hline CO & 6,983 & $2,5623,000$ & NJ & 171 & $1,006,000$ \\
CT & 4,295 & 865,000 & NM & 1,280 & $7,193,000$ \\
DE & 151 & 355,000 & NV & 232 & $1,245,000$ \\
FL & 6 & 956,000 & NY & 1,900 & $10,715,000$ \\
GA & 170 & $3,604,000$ & OH & 535 & $2,800,000$ \\
\hline HI & 621 & 699,000 & OK & 1,147 & $5,838,000$ \\
IA & 145 & $3,869,000$ & OR & 8,920 & $53,353,000$ \\
ID & 736 & $41,015,000$ & PA & 2,889 & $15,795,000$ \\
IL & $3,241,000$ & RI & 13 & 71,000 \\
IN & 3,018 & $3,123,000$ & SC & 309 & $1,844,000$ \\
\hline KS & 599 & $14,931,000$ & SD & 230 & $1,363,000$ \\
KY & 581 & $3,301,000$ & TN & 1,002 & $5,618,000$ \\
LA & 2,479 & $4,463,000$ & TX & 1,580 & $8,089,000$ \\
MA & 675 & $1,114,000$ & UT & 1,376 & $8,246,000$ \\
MD & 790 & $1,212,000$ & VA & 1,234 & $6,869,000$ \\
\hline ME & 194 & $6,532,000$ & VT & 401 & $2,344,000$ \\
MI & 223 & $2,866,000$ & WA & 7,381 & $43,788,000$ \\
MN & 1,132 & $3,191,000$ & WI & 556 & $3,513,000$ \\
MO & 449 & $14,514,000$ & WV & 1,851 & $9,910,000$ \\
MS & 568 & $6,449,000$ & WY & 2,960 & $10,776,000$ \\
\hline TH AK & 2,512 & 1,129 & &
\end{tabular}

* The AK and HI potential are estimated by a different approach from that used for the other 48 states. 
(This Page Intentionally Left Blank)

xxiv 


\begin{tabular}{ll} 
ABBREVIATIONS, ACRONYMS, and INITIALISMS \\
ac-ft & acre-foot \\
ACF & Apalachicola-Chattahoochee-Flint Subregion (HUC 0313) \\
ACT & Alabama-Coosa-Tallapoosa Subregion (HUC 0315) \\
AEA & Alaska Energy Authority \\
BLM & Bureau of Land Management \\
COMID & NHDPlus Object Identifier \\
DBEDT & Hawaii Department of Business, Economic Development, and Tourism \\
DOD & Department of Defense \\
DOE & U.S. Department of Energy \\
DOI & U.S. Department of the Interior \\
EDNA & Elevation Derivatives for National Applications \\
EIS & Environmental Impact Statement \\
EPA & Environmental Protection Agency \\
ESA & Endangered Species Act \\
FEMA & Federal Emergency Management Agency \\
FERC & Federal Energy Regulatory Commission \\
FIS & Flood Insurance Study \\
GAP & Gap Analysis Program \\
GIS & Geospatial Information System \\
HUC & hydrologic unit code \\
HUC02 & hydrologic region \\
HUC04 & hydrologic subregion \\
HUC06 & hydrologic basin \\
HUC08 & hydrologic subbasin \\
\hline
\end{tabular}




$\begin{array}{ll}\text { HUC10 } & \text { hydrologic watershed } \\ \text { HUC12 } & \text { hydrologic subwatershed } \\ \text { IUCN } & \text { International Union for the Conservation of Nature } \\ \text { NED } & \text { National Elevation Dataset } \\ \text { NFHAP } & \text { National Fish Habitat Action Plan } \\ \text { NHAAP } & \text { National Hydropower Asset Assessment Project } \\ \text { NHD } & \text { National Hydrography Dataset } \\ \text { NHDPlus } & \text { National Hydrography Dataset Plus } \\ \text { NID } & \text { National Inventory of Dams } \\ \text { NOAA } & \text { National Oceanic and Atmospheric Administration } \\ \text { NPD } & \text { non-powered dam } \\ \text { NPS } & \text { National Park Service } \\ \text { NSD } & \text { new stream-reach development } \\ \text { NSDP } & \text { new stream-reach development population } \\ \text { NRCS } & \text { Natural Resources Conservation Service } \\ \text { NWIS } & \text { National Water Information System } \\ \text { NWSRA } & \text { National Wild and Scenic River Act } \\ \text { ORNL } & \text { Oak Ridge National Laboratory } \\ \text { PAD-US } & \text { Protected Area Database for the United States } \\ \text { Reclamation } & \text { U.S. Bureau of Reclamation } \\ \text { SSP } & \text { stream segment population } \\ \text { USACE } & \text { U.S. Army Corps of Engineers } \\ \text { USFS } & \text { U.S. Forestry Service } \\ \text { U.S. Fish and Wildlife Service } \\ \text { U.S. Geological Survey }\end{array}$


WaterWatch USGS WaterWatch Program

WBD Watershed Boundary Dataset

xxvii 
(This Page Intentionally Left Blank)

Xxviii 


\section{LIST OF VARIABLES}

\begin{tabular}{|c|c|}
\hline $\mathrm{A}_{\mathrm{NSD}}$ & inundated surface area (acre) \\
\hline $\mathrm{c}$ & unit conversion factor, $(0.3048)^{4}$ \\
\hline $\mathrm{E}_{\mathrm{NSD}}$ & potential hydroelectric energy at an NSD stream-reach (watt * hour) \\
\hline GW & gigawatt $\left(10^{9}\right.$ watt $)$ \\
\hline $\mathrm{H}$ & hydraulic head (ft) \\
\hline $\mathrm{H}_{\mathrm{ref}}$ & reference height $(\mathrm{ft})$ calculated from FEMA 100-year flood elevation \\
\hline HQS & the product of $\mathrm{H}_{\mathrm{ref}}, \mathrm{Q}_{30}$ and $\mathrm{S}_{0}$ \\
\hline MW & megawatt $\left(10^{6}\right.$ Watts $)$ \\
\hline MWh & megawatt hour $\left(10^{6}\right.$ watt $*$ hour $)$ \\
\hline $\mathrm{P}$ & hydroelectric power (watt) \\
\hline $\mathrm{P}_{\mathrm{NSD}}$ & potential hydropower capacity at an NSD stream-reach (Watt) \\
\hline Q & flow $\left(\mathrm{ft}^{3} / \mathrm{s}\right)$ \\
\hline $\mathrm{Q}_{30}$ & $30 \%$ exceedance quantile from daily flow-duration curve \\
\hline$Q_{\text {NHDPlus }}$ & annual mean flow $\left(\mathrm{ft}^{3} / \mathrm{s}\right)$ provided by NHDPlus \\
\hline $\mathrm{S}_{0}$ & average channel slope \\
\hline $\mathrm{T}_{\mathrm{NSD}}$ & residence time (day) \\
\hline TWh & terawatt hour $\left(10^{12}\right.$ watt $*$ hours $)$ \\
\hline $\mathrm{V}_{\mathrm{NSD}}$ & reservoir storage (acre $* \mathrm{ft})$ \\
\hline$\eta$ & generating efficiency \\
\hline$\gamma$ & specific weight of water, $9800 \mathrm{~N} / \mathrm{m}^{3}$ \\
\hline
\end{tabular}


(This Page Intentionally Left Blank) 


\section{INTRODUCTION}

\subsection{Scope and Objective}

With the rapid development of multiple national geospatial datasets for topography, hydrology, and environmental characteristics in the past decade, new opportunity arises for the refinement of hydropower resource potential from undeveloped stream-reaches. Through 2011 to 2013, the Oak Ridge National Laboratory (ORNL) was tasked by the U.S. Department of Energy (DOE) Water Power Program to evaluate the new stream-reach development (NSD) ${ }^{2}$ resource potential for more than 3 million U.S. streams. This wide spatial scope demands an approximate methodology that may (1) resolve aggregate potential within hydrologic regions and electric power systems and (2) enable the modeling of regional and national scenarios of existing and new electric power generation technology deployment through the development of hydropower capacity cost versus supply curves. A methodology hence was designed that contains three main components: (1) identification of stream-reaches with high energy density, (2) topographical analysis of opportunity stream-reaches to estimate inundated surface area and reservoir storage, and (3) environmental attribution to spatially join the energy potential of stream-reaches with information related to the natural ecological systems; social and cultural settings; and policies, management, and legal constraints. An initial report on methodology (Hadjerioua et al., 2013) was reviewed and revised based on the comments gathered from two peer review workshops (December 2011 for resource characterization and June 2012 for environmental attribution).

After implementing the assessment for the entire United States, this report summarizes the major findings across various hydrologic regions. A summary of the methodology is provided in Section 2. The national findings are summarized in Section 3. More detailed findings in each hydrologic region are discussed in Sections 4-23. A comparison with the previous resource assessment is provided in Appendix A.

\subsection{Limitations of the Study}

Since this assessment is designed to accommodate the whole of more than 3 million U.S. streams, it is targeted at the higher "reconnaissance level" (RETScreen International, 2005). The methodology considers only the physical characteristics of each stream and landscape and does not consider feasibility issues arising from environmental impacts, cost, or benefits. Although the methodology allows for the identification of stream-reaches of high energy density, and classification of new potential areas for hydropower development using a range of technical, socio-economic, and environmental characteristics, it does not produce estimates of capacity, production, cost, or impacts of sufficient accuracy to determine absolute economic feasibility or to justify financial investments in individual site development. These potential high-energydensity areas should be regarded as worthy of more detailed site-by-site evaluation by

\footnotetext{
${ }^{2}$ The DOE Water Power Program classifies hydropower potential into multiple resource classes. These are (1) upgrades to existing facilities, (2) expansion of existing facilities, (3) powering of non-powered dams, (4) development at new "heretofore undeveloped" stream-reaches, and (5) energy recovery in constructed waterways. Although it does not yield a net production of energy, pumped-storage hydropower is recognized as a valuable resource for grid flexibility and energy storage.
} 
engineering professionals. More detailed information about the assumptions and intended use of these results is available in the NSD methodology report.

\subsection{Availability of the Results}

These results are distributed through the National Hydropower Asset Assessment Project (NHAAP) Public Portal (http://nhaap.ornl.gov/) to support further research activities. The following major variables are available:

- Basic attributes: coordinates, state, county, hydrologic unit, site elevation (ft), river name, channel slope, head (ft), flow (cfs), capacity (MW), monthly energy (MWh), reservoir storage (ac-ft), inundated area (ac), and residence time (day)

- Environmental attributes: critical habitats (no. species), Endangered Species Act (ESA) federally listed fish species (no. species), International Union for the Conservation of Nature (IUCN) species of concern (no. species), potadromous or anadromous fish (no. species), protected land (presence/absence), land-ownership index (no. entities), land-designation index (no. designations), U.S. national park (presence/absence), Wild and Scenic River (presence/absence), 303d listed waterbodies (no. waterbodies), American Whitewater boating runs (no. boating runs), boat ramps (no. boat ramps), fishing access points (no. access locations), surface water use $\left(1 / \mathrm{day}^{-1} \cdot \mathrm{km}^{-2}\right)$, ground water use $\left(1 / \mathrm{day}^{-1} \cdot \mathrm{km}^{-2}\right)$, urban land cover $(\%)$, population density (individuals $/ \mathrm{km}^{-2}$ ), dams in local watershed (no. dams), total dams in entire upstream network (no. dams), land disturbance index (score from National Fish Habitat Action Plan [NFHAP])

The NHAAP-NSD results are available in tiered form to encourage ease of use and appropriate use. Basic results depicting availability of new energy within basins are available from the Public Portal. Detailed results with location-specific features are available through a user agreement to ensure that appropriate use and interpretations of the location-specific results are followed. In particular, neither ORNL nor DOE approves of the use of these results in support of site-specific permit applications to the Federal Energy Regulatory Commission (FERC). 


\section{SUMMARY OF METHODOLOGY}

This section summaries the NSD methodology developed by Hadjerioua et al. (2013). The assessment incorporates, by reference, the hydrologic unit code (HUC) hierarchy of region (HUC02), subregion (HUC04), basin (HUC06), subbasin (HUC08), watershed (HUC10), and subwatershed (HUC12). This hierarchy was originally specified in the U.S. Geological Survey (USGS) Water Supply Paper 2294 (Seaber et al., 1987) and refined and expanded in the Watershed Boundary Dataset (WBD) (USGS and USDA-NRCS, 2009). Within the NSD effort, subregion (HUC04) is selected as the fundamental hydrologic unit for modeling, parameter estimation, and analyses of energy potential. The methodology contained two parts-resource evaluation that quantified hydropower potential at undeveloped U.S. stream-reaches (summarized in Section 2.1) and environmental attribution that labeled environmental and socialeconomical characteristics to the identified NSD stream-reaches (summarized in Section 2.2). Both parts were reviewed and revised based on the comments gathered from two peer review workshops (December 2011 for resource evaluation and June 2012 for environmental attribution). A pilot study was conducted for Alabama-Coosa-Tallapoosa (ACT) and ApalachicolaChattahoochee-Flint (ACF) hydrologic subregions and included in the initial methodology report (Hadjerioua et al., 2013). The methodology was then implemented for the entire conterminous United States. Given that some critical data are unavailable in Alaska and Hawaii, it was decided to summarize the undeveloped hydropower potential from existing literatures in these two regions, rather than conduct new geospatial assessments based on limited data. The Alaska and Hawaii data source and results are reported in Sections 22 and 23.

\subsection{Resource Evaluation}

\subsubsection{Data Sources}

Hydropower resource assessment requires several types of data, including watershed boundaries, river geometry, topography, and water availability. These data enable the estimation of two critical variables for hydropower generation - net hydraulic head (height difference between upstream pool and tailwater elevation) and design flow. Head and flow can then be augmented with data and computation to estimate additional parameters, such as storage volume, inundated area, and other NSD attributes. While the proposed NSD methodology presented herein includes the preliminary objective of maximizing generating capacity per unit of inundated surface area, the scope of the data collection effort is designed to support characterization of sites based upon multiple objectives in future development scenarios. Table 2.1 summarizes the data used for resource evaluation.

\subsubsection{Energy Production Model}

Consistent with previous studies (DOI et al., 2007; Reclamation, 2011), the following power equation is used to estimate hydropower potential $P$ (watt) that may be produced with net hydraulic head $H(\mathrm{ft})$ and flow $Q\left(\mathrm{ft}^{3} / \mathrm{s}\right)$ : 
Table 2.1. Summary of Data Used for Resource Evaluation

\begin{tabular}{l|l|l}
\hline Data type & Data source & Note \\
\hline Watershed boundary & $\bullet \begin{array}{l}\text { USDA/NRCS Watershed Boundary Dataset } \\
\text { (WBD; USGS and USDA-NRCS, 2009) }\end{array}$ & \\
\hline $\begin{array}{l}\text { River geometry, } \\
\text { existing water } \\
\text { bodies }\end{array}$ & $\bullet \begin{array}{l}\text { USGS/EPA National Hydrography Dataset } \\
\text { Plus (NHDPlus; http://www. horizon- } \\
\text { systems.com/nhdplus/ } \\
\text { NHDPlusV1_home.php) }\end{array}$ & $\begin{array}{l}\text { NSD assessment is based on } \\
\text { NHDPlus version 1 }\end{array}$ \\
\hline Existing dams & $\bullet \begin{array}{l}\text { USACE National Inventory of Dams (NID, } \\
\text { http://www.nid.usace.army.mil) }\end{array}$ & $\begin{array}{l}\text { NSD assessment is based on NID } \\
\text { version 2010 }\end{array}$ \\
\hline Topography & $\bullet \begin{array}{l}\text { USGS National Elevation Dataset (NED; } \\
\text { Gesch et al., 2002) }\end{array}$ & $\begin{array}{l}\text { 1/3 arc-second (about 10-m) } \\
\text { resolution is used }\end{array}$ \\
\hline Flow estimates & $\bullet \begin{array}{l}\text { USGS National Water Information System } \\
\text { (NWIS; http://waterdata.usgs. gov/nwis) }\end{array}$ & $\begin{array}{l}\text { Design flow is estimated from } \\
\text { selected NWIS gauges and then } \\
\text { extended to the NHDPlus flowlines. } \\
\text { MSGS WaterWatch Runoff (Brakebill et al., } \\
\text { 2011) } \\
\text { NHDPlus flow time-series is } \\
\text { synthesized from the WaterWatch } \\
\text { runoff }\end{array}$ \\
\hline Flood zone & $\bullet \begin{array}{l}\text { FEMA Flood Insurance Study (FIS, } \\
\text { http://www.msc.fema.gov/) }\end{array}$ & $\begin{array}{l}\text { 100-year flood lines are used to } \\
\text { derive the reference height }\end{array}$ \\
\hline
\end{tabular}

Notes: USDA = US Department of Agriculture; NRCS = Natural Resources Conservation Service; EPA = Environmental

Protection Agency; USACE = US Army Corps of Engineers; FEMA = Federal Emergency Management Agency.

$$
\mathrm{P}=\mathrm{c} * \gamma * \eta * \mathrm{H} * \mathrm{Q}
$$

In Eq. (2.1), $\eta$ is the generating efficiency, $\gamma=9800 \mathrm{~N} / \mathrm{m}^{3}$ is the specific weight of water, and $c=$ $(0.3048)^{4}$ is the unit conversion factor. For the purpose of hydropower resource assessment, future hydropower plant operation is usually considered to be around the optimal operating point; therefore $\eta$ can be reasonably assumed to be a constant 0.85 (e.g., USACE, 1983).

For flow, although there is no precise answer regarding what threshold should be used for hydropower resource assessment, $\mathrm{Q}_{30}$, defined as the $30 \%$ exceedance quantile from the daily flow-duration curve, is generally regarded as a suitable empirical value that would result in an estimate in the range of the optimal installed capacity per dollar of capital investment (Section 3.1, Reclamation, 2011). The NSD assessment hence used $\mathrm{Q}_{30}$ as the plant hydraulic capacity for consistency with Reclamation (2011). As described in the details in Hadjerioua et al. (2013), for each HUC04 subregion, a conversion ratio is estimated by comparing $\mathrm{Q}_{30}$ from USGS NWIS daily streamflow gauge stations to the corresponding NHDPlus annual mean flow, so that the ratio can be used to estimate $\mathrm{Q}_{30}$ for each NHDPlus flowline.

For hydraulic head, a reference height, $\mathrm{H}_{\text {ref }}$, defined as the height from a future development location to the nearest FEMA 100 year flood line, is used to estimate the hydropower potential at an NSD stream-reach. Although the purpose of FEMA flood analysis is unrelated to hydropower, the current flood zones may provide valuable insights for inferring the selection of future NSD stream-reaches. To be more specific, owing to regulatory constraints, there are usually fewer existing residences or civil structures in FEMA 100 year flood zones (i.e., they are relatively empty); hence, the FEMA 100 year flood line can be regarded as an invisible boundary of existing civil development. So if NSD inundation is limited to the regions within FEMA 100 
year flood zones, there is more of a chance that new hydro development will affect fewer existing structures and would potentially be less costly.

With the above simplification, the potential NSD capacity $\mathrm{P}_{\mathrm{NSD}}$ (Watt) can be estimated by

$$
P_{N S D}=c * \gamma * \eta * H_{r e f} * Q_{30}
$$

To estimate the potential energy, we further synthesized 20 years of monthly streamflow time series (from January 1989 to December 2008) using USGS WaterWatch unit runoff (Brakebill et al., 2011) for each NSD stream-reach. In month $m$, let $Q_{W W, m}$ (cfs) be the synthesized WaterWatch streamflow and $T_{m}$ (hour) be the total number of hours; Eq. (2.3) can then be used to estimate the potential energy production, $E_{N S D, m}$ (watt * hour/month):

$$
E_{N S D, m}= \begin{cases}c * \gamma * \eta * H_{r e f} *\left(Q_{30} * T_{m}\right), & Q_{W W, m}>Q_{30} \\ c * \gamma * \eta * H_{r e f} *\left(Q_{W W, m} * T_{m}\right), & 0 \leq Q_{W W, m} \leq Q_{30}\end{cases}
$$

Since our target is new run-of-river projects with limited storage, the flow $Q_{W W, m}$ that is greater than $Q_{30}$ can hardly be stored and is assumed to be spilled directly. After the monthly energy $E_{N S D, m}$ is estimated, the potential mean annual energy production, $E_{N S D}$ (watt $*$ hour/year), and monthly energy production, $E_{J A N}, E_{F E B}, \ldots$, and $E_{D E C}$ (watt * hour/month), can be estimated. The energy estimators can be improved in future studies by increasing the resolution and accuracy of the streamflow time series.

It should be noted that Eqs. (2.2) and (2.3) are based on a reservoir-impoundment model (i.e., the location of a future powerhouse is assumed to be immediately downstream of a dam with all available net hydraulic head resulting from the impoundment). Another common choice is the flow-diversion model, which uses penstocks/conduits to divert water from an upstream intake point to a downstream powerhouse and then return the flow back to the stream. The flowdiversion model does not require a dam higher than the reservoir-impoundment model and so may result in less surface inundation. Nevertheless, since only a portion of water can be diverted through conduits (i.e., sufficient streamflow is needed in the original river channel to sustain the existing ecology and environment), the amount of available energy is generally less than in a corresponding reservoir-impoundment model with a similar head. In order to capture the total U.S. hydropower energy potential, the NSD assessment is based on the reservoir-impoundment model. Based on some further assumptions (see Hadjerioua et al., 2013), the alternative power potential using the flow-diversion model can be calculated by reducing the hydraulic head to account for the frictional loss through diversion.

\subsubsection{Procedures for Resource Evaluation}

The general assessment procedures are described below, with an overall flowchart shown in Figure 2.1.

1. Preliminary selection of stream segment population (SSP). There are around 3 million raw NHDPlus flowlines in the conterminous United States (i.e., geospatial lines with unique NHDPlus COMID identifier). For simplification, a preliminary selection of NHDPlus 
flowlines is performed to eliminate smaller stream segments. Since the focus is on new runof-river projects, it was decided to exclude NHDPlus flowlines with estimated annual mean flow $Q_{\text {NHDPlus }}$ of less than $35 \mathrm{cfs}$, in which the excluded flowlines will need at least $400 \mathrm{ft}$ of head for $1 \mathrm{MW}$ of hydropower potential. Around 2.7 million $(90 \%)$ smaller segments are eliminated and the remaining 300,000 (10\%) NHDPlus flowlines are included in the SSP collection for further assessment. Any flowlines that overlap with existing water bodies are also removed, since the water may have been regulated by existing dams (i.e., not in the new hydro resource class).

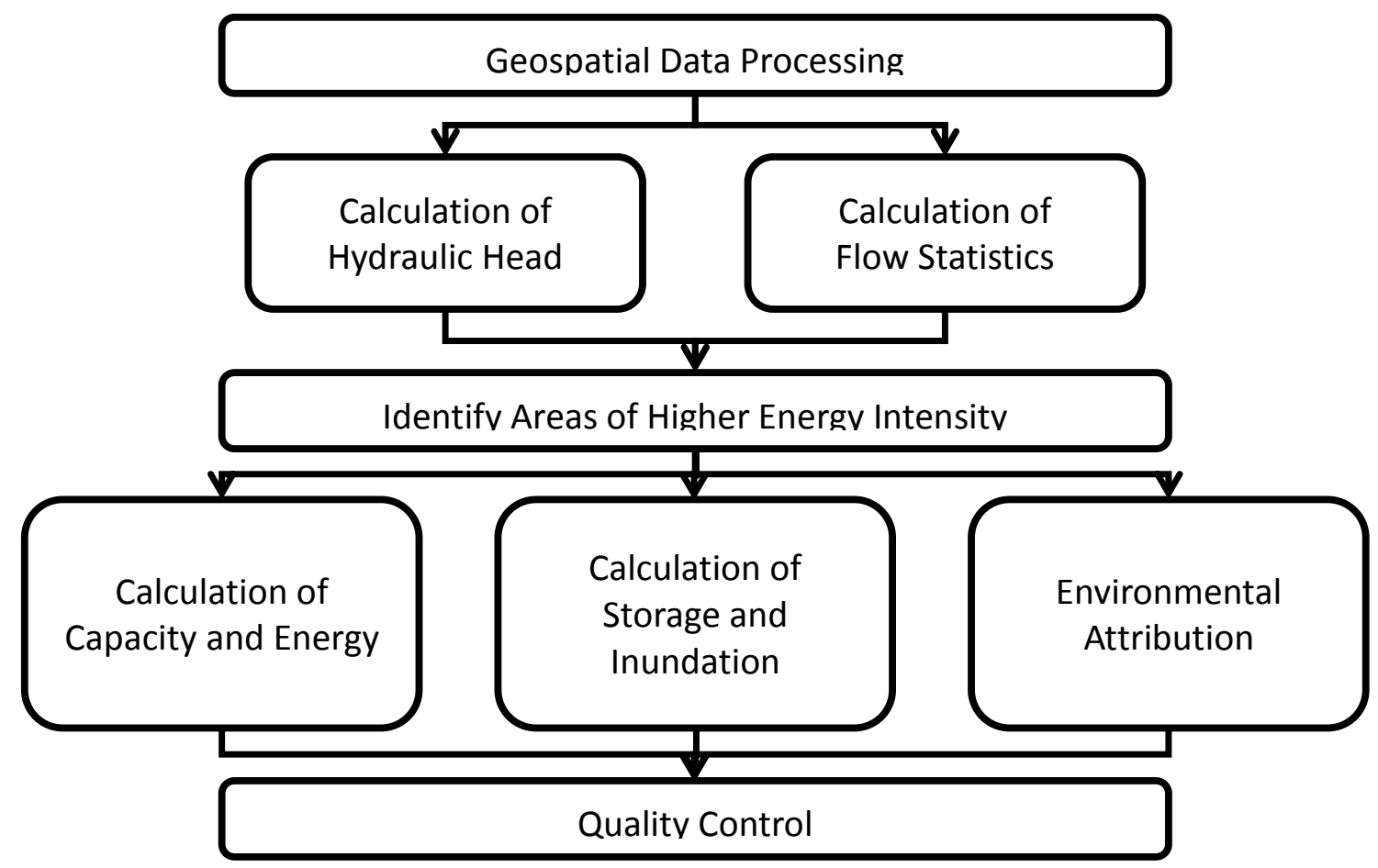

Figure 2.1. General steps of the NSD methodology.

2. Discretization of NHDPlus flowlines. Given that the NHDPlus flowlines vary in length (from less than a mile to several miles), all NHDPlus flowlines in SSP are discretized into $150 \mathrm{~m}$ long subsegments to better identify the potential NSD stream-reaches. For each subsegment, the elevation is linearly interpolated from the starting and ending elevations of the original NHDPlus flowline, assuming no abrupt slope change in between. An illustration is shown in Figure 2.2. The interpolated elevation may be inconsistent with the corresponding 10 meter NED, mainly because the original NHDPlus elevation was derived from the $30 \mathrm{~m}$ NED. Quality control was performed to filter out those stream-reaches with larger inconsistencies in elevation between NHDPlus and NED. Based on the findings from national implementation, elevations from different datasets are mostly consistent at the identified NSD stream-reaches and are not a source of significant uncertainty.

3. Calculation of reference height $\left(\mathbf{H}_{\text {ref }}\right)$. A reference height, $\mathrm{H}_{\text {ref }}$, defined as the height from a discretized subsegment to the nearest FEMA 100-year flood line, is used to calculate the 
potential hydropower at a NSD site. In other words, it is assumed that the new hydro sites will not inundate additional area other than the current 100-year flood zone. For each discretized NHDPlus subsegment, a cross-sectional profile is drawn perpendicular to the subsegment. The end points of a cross-sectional profile are defined when the cross section line touches the FEMA 100-year flood lines. Elevations of these end points are then looked up from the $10 \mathrm{~m} \mathrm{NED}$ and used to calculate $\mathrm{H}_{\text {ref. }}$. If the FEMA 100 year flood lines are missing for too many locations, the median $\mathrm{H}_{\text {ref }}$ from all other identified subsegments in the same HUC04 subregion is used instead.

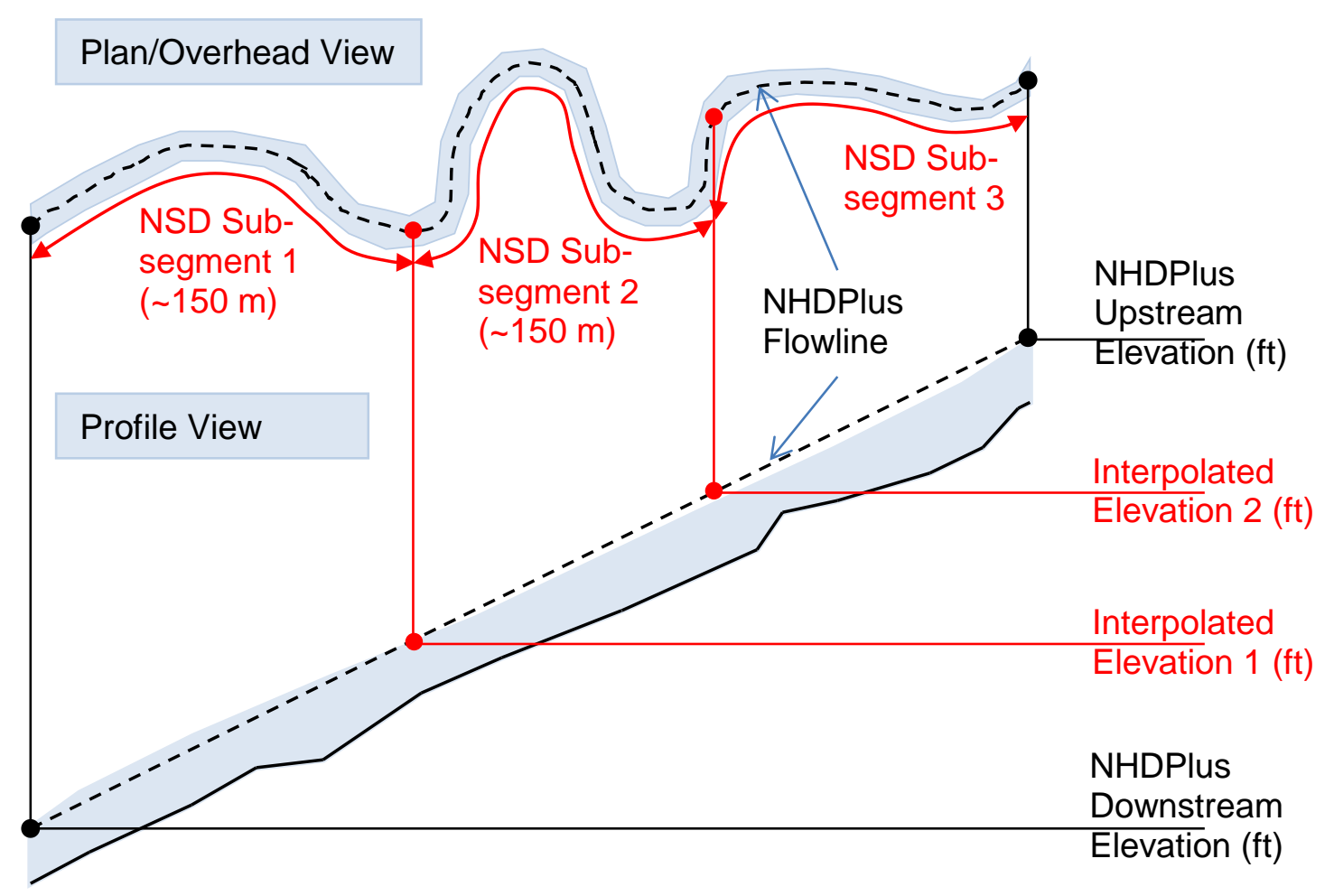

Figure 2.2. Illustration of NHDPlus flowline discretization.

4. Calculation of plant hydraulic dapacity $\left(\mathbf{Q}_{\mathbf{3 0}}\right)$. For each subregion, all USGS NWIS gauge stations with complete 1989-2008 daily observations are identified. The 30\% daily exceedance flow $\left(\mathrm{Q}_{30}\right)$ is then computed at each gauge station. Consistent with Step 1, gauges with $\mathrm{Q}_{30}$ of less than $35 \mathrm{cfs}$ were excluded. At the same location as the USGS gauge station, the corresponding NHDPlus annual mean flow $Q_{\text {NHDPlus }}$ was identified for comparison. Given that a strong linear relationship is typical between $\mathrm{Q}_{30}$ and $\mathrm{Q}_{\mathrm{NHDPlus}}$, a conversion ratio was estimated to calculate $\mathrm{Q}_{30}$ based on $\mathrm{Q}_{\mathrm{NHDPlus}}$, so that the plant hydraulic capacity can be estimated at each NHDPlus subsegment. The QNHDPlus is readily available within the NHDPlus dataset, so the conversion ratio provides a straightforward way to approximate $\mathrm{Q}_{30}$ from available resources.

5. Stream-reach identification. Within each HUC04 subregion, the NSD assessment identifies potential locations for hydropower development in the order of decreasing HQS, a product of $\mathrm{H}_{\mathrm{ref}}, \mathrm{Q}_{30}$, and average channel slope $\mathrm{S}_{0}$ (elevation drop divided by the river length). Although 
the product of $\mathrm{H}_{\text {ref }}$ and $\mathrm{Q}_{30}$ is proportional to power, implying that higher dam height may result in larger power output, raising dam height usually comes with a tradeoff of increasing inundation and may potentially result in greater impacts. Therefore, the channel slope, $\mathrm{S}_{0}$, is included in the optimization, since higher $S_{0}$ usually implies a smaller inundated area. Following the decreasing order of HQS, NHDPlus subsegments are identified and transferred from SSP to the new stream-reach development population (NSDP). All subsegments that will be inundated by the identified NSDP will be removed from the SSP before the next iteration. The process will be repeated until all potential sites with $1 \mathrm{MW}$ of minimum raw potential have been identified and included in the NSDP. The detailed stream-reach identification methods can also be found in Pasha et al. (2014).

6. Calculation of storage $\left(\mathbf{V}_{\mathrm{NSD}}\right)$ and delineation of inundated surface area $\left(\mathbf{A}_{\mathrm{NSD}}\right)$. Once a potential stream-reach and a targeted dam height $\left(\mathrm{H}_{\text {ref }}\right)$ have been suggested, it is of interest to identify those upstream regions that may be inundated as a result of new hydro development. By estimating the flow direction of each $10 \mathrm{~m}$ NED grid based on elevation, the inundated surface area $\left(\mathrm{A}_{\mathrm{NSD}}\right)$ upstream of a new hydro site is delineated and outputted as GIS shapefiles for further geospatial analysis. The total reservoir storage $\left(\mathrm{V}_{\mathrm{NSD}}\right)$ and residence time $\left(\mathrm{T}_{\mathrm{NSD}}\right)$ are also estimated based on the inundated surface area and the estimated annual mean flow $Q_{\text {NHDPlus. }}$ Given that this process is fairly computationally intensive, a customized computational program has been developed to facilitate a great number of potential NSD sites. Since the NSD focus is on smaller hydro sites, the existing $30 \mathrm{~m}$ resolution flow duration grids from NHDPlus dataset are insufficient and must be reestimated (based on the $10 \mathrm{~m}$ resolution NED).

7. Calculation of hydropower capacity $\left(\mathbf{P}_{\mathrm{NSD}}\right)$ and hydroelectricity energy $\left(\mathbf{E}_{\mathrm{NSD}}\right)$. After the reference height $\left(\mathrm{H}_{\mathrm{ref}}\right)$ and plant hydraulic capacity $\left(\mathrm{Q}_{30}\right)$ are estimated, Eq. 2.2 is used to estimate the hydropower capacity $\left(\mathrm{P}_{\mathrm{NSD}}\right)$. Based on $\mathrm{P}_{\mathrm{NSD}}$ and a streamflow time series, the energy production or generation $\left(\mathrm{E}_{\mathrm{NSD}}\right)$ can be calculated. Since the daily or sub-daily resolution streamflow time series are unavailable at most of the ungauged locations, the monthly streamflow time series synthesized from the USGS WaterWatch runoff are used in this NSD assessment as an alternative to calculate $\mathbf{E}_{\text {NSD }}$. Within each month, the part of streamflow higher than $\mathrm{Q}_{30}$ is considered spilled and not used for hydropower generation. By summing all monthly energy from January 1989 to December 2008, and dividing by 20 years, the potential mean annual energy production $\mathrm{E}_{\mathrm{NSD}}$ is estimated. The $\mathrm{E}_{\mathrm{NSD}}$ serves as the baseline estimate of energy and can be improved in the future studies by increasing the resolution and accuracy of the synthesized streamflow time series.

8. Quality control. Given that several different datasets are jointly analyzed in the NSD assessment, data mismatch can occasionally occur. For instance, the NHDPlus elevation is based on the $30 \mathrm{~m}$ resolution NED and it can be inconsistent with the $10 \mathrm{~m}$. NED that was used to derive the inundation polygons. As a result, quality control through manual checking is required to ensure the accuracy of the national estimates.

Because a new hydropower cost modeling effort was just initiated in mid-2013, the originally planned cost estimation task (Hadjerioua et al., 2013) is deferred until more credible cost data and models have become available to the research team. 


\subsection{Environmental Attribution}

In an NSD assessment, environmental attributes are considered to be ecological, socioeconomic, and legal/geopolitical concerns that may arise with regard to potential hydropower development. All of these elements are considered environmental because they share substantial overlap with regard to landscape planning decisions. The environment is considered to be a defined area surrounding each potential hydropower site, the size of which depends upon the particular issue under consideration.

A four-step process is used to discern the ecological, socioeconomic, and legal/geopolitical attributes of interest for each potential area of new hydropower development:

1. Hypothesis generation is used to compile a comprehensive list of potential environmental issues and information required to evaluate each issue.

2. Spatial and tabular datasets are gathered using internet sources. The availability of needed information is assessed, and, based on data availability, a prioritized list of data sets is generated.

3. Some datasets are not in a format or scale applicable to this analysis or lacked additional relevant information. Thus derived datasets are created at similar spatial scales using geospatial processing and tabular data summarization.

4. All spatial datasets are used to attribute each identified stream-reach with environmental information in a tabular format.

\subsubsection{Data Sources}

Assessing potential environmental issues related to hydropower development requires compiling information on natural resources, geopolitical boundaries, existing infrastructure, cultural, aesthetic, and recreational needs. Before any information is gathered, potential impediments to new hydropower development (including possible environmental, geopolitical, and socioeconomic concerns) are identified via external consultation or document reviews. Environmental impact statement (EIS) reports and FERC license approval articles are inspected to identify potential issues. Once a sufficient list of issues is generated, the various types of information required to characterize and analyze each are produced. Information is preferred at the scale of the entire country or conterminous United States. Internet searches are also conducted through USGS, NatureServe, National Fish Habitat Action Plan (NFHAP), U.S. Census Bureau, USACE NID, U.S. Fish and Wildlife, Geology.com, EPA, National Wild and Scenic Rivers, National Atlas, and other webpages, including Google ${ }^{\circledR}$ searches. Potential issues to be characterized and attributed are finalized on the basis of information priority level and availability.

Because most sources of information are not confined to a specific spatial coverage (e.g., land ownership), environmental attribution can be provided at spatial scales congruent with prospective hydropower development areas (e.g., site-level, NHD scale). However, the finest resolution of water use and fish distributions is the HUC08 subbasin; therefore, all potential development areas within the same HUC08 would share similar attribution for these variables. Table 2.2 summarizes the major environmental data sources used in this section. 
Table 2.2. Summary of Data Sources Used in the Environmental Attribution

\begin{tabular}{|c|c|c|}
\hline Data type & Data source & Note \\
\hline $\begin{array}{l}\text { Fish species digital } \\
\text { distribution }\end{array}$ & $\begin{array}{l}\text { NatureServe digital distribution maps } \\
\text { of freshwater fishes of the United } \\
\text { States }\end{array}$ & $\begin{array}{l}\text { Spatially summarizes federally listed } \\
\text { fish species and traits }\end{array}$ \\
\hline $\begin{array}{l}\text { Federally listed species } \\
\text { (ESA) }\end{array}$ & $\begin{array}{l}\text { - U.S. FWS endangered species } \\
\text { program }\end{array}$ & $\begin{array}{l}\text { Species lists provide types of } \\
\text { organisms and listed status }\end{array}$ \\
\hline $\begin{array}{l}\text { Federal and IUCN ranking } \\
\text { status for fish }\end{array}$ & - NatureServe explorer species data & $\begin{array}{l}\text { Lists provide an indication of fish } \\
\text { imperilment and vulnerability }\end{array}$ \\
\hline Critical habitats & - U.S. FWS Critical Habitat Portal & $\begin{array}{l}\text { Polygon and polyline coverage of } \\
\text { federally listed species }\end{array}$ \\
\hline Conservation lands & $\begin{array}{l}\text { USGS GAP analysis-Protected area } \\
\text { database of the United States }\end{array}$ & $\begin{array}{l}\text { Geopolitical boundaries (national } \\
\text { parks, state parks, historic } \\
\text { landmarks) }\end{array}$ \\
\hline County boundaries & - U.S. Census Bureau & $\begin{array}{l}\text { United States county boundaries and } \\
\text { population estimates }\end{array}$ \\
\hline Water use & - USGS Water Use in the United States & $\begin{array}{l}\text { Provide estimates of total } \\
\text { consumptive usage in various } \\
\text { categories }\end{array}$ \\
\hline Water quality (303d listings) & $\begin{array}{l}\text { - U.S. EPA impaired waters and total } \\
\text { maximum daily load }\end{array}$ & $\begin{array}{l}\text { Locations and listings of state } 303 \mathrm{~d} \\
\text { listings }\end{array}$ \\
\hline $\begin{array}{l}\text { Disturbance, } \\
\text { infrastructure, and land use }\end{array}$ & - National Fish Habitat Action Plan & $\begin{array}{l}\text { Population density, number of dams, } \\
\text { mining activity, land use (\% urban, } \\
\text { percent agriculture), and so on }\end{array}$ \\
\hline $\begin{array}{l}\text { Fishing and boat ramp } \\
\text { access }\end{array}$ & $\begin{array}{l}\text { - DeLorme Publishing Company } \\
(2012)\end{array}$ & $\begin{array}{l}\text { Point locations of fishing and boat } \\
\text { ramp access points }\end{array}$ \\
\hline Kayak/raft access & $\begin{array}{l}\text { - American Whitewater, National } \\
\text { Whitewater Inventory (AW, 2012) }\end{array}$ & $\begin{array}{l}\text { Locations of boat launch/take out } \\
\text { points for whitewater boating }\end{array}$ \\
\hline Waterfalls & $\begin{array}{l}\text { - Geology.com, U.S. Waterfalls } \\
\text { (http://geology.com/waterfalls/) }\end{array}$ & $\begin{array}{l}\text { Point locations of each state's } \\
\text { waterfalls }\end{array}$ \\
\hline
\end{tabular}

\subsubsection{Methodology}

All data layers used in this analysis are illustrated in Figure 2.3. Most data sources listed in Table 2.2 can be used directly in assigning environmental attributes to hydropower development areas. However, the existing resolution and presentation of some raw data sources may preclude meaningful environmental attribution. Thus some raw data are summarized into new derived data layers for attribution (Figure 2.3).

Based on Section 2.1, potential stream-reaches for new development and inundated areas were identified, providing virtual dams (points) and associated impoundments (polygons) (Figure 2.4). Because dams have potential downstream effects, downstream stream-reaches (i.e., tailwaters) should be included as elements of each virtual hydropower development. The length of a tailwater affected by hydropower development can vary with dam size and storage, dilution effects (from incoming tributaries), and the presence of migratory species. It was presumed that $16 \mathrm{~km}$ or 10 miles would be sufficient to capture most environmental issues. Based on topographic linkages among upstream/downstream reaches within NHDPlus, tailwater reaches were accumulated from the dam downstream using an additive procedure until their cumulative 
length reached a threshold of $16 \mathrm{~km}$ (Figure 2.4). Because NHDPlus flowlines vary in length, tailwater reach lengths also vary. Environmental attribution was conducted separately for points (dams), lines (tailwaters), and polygons (impoundments).
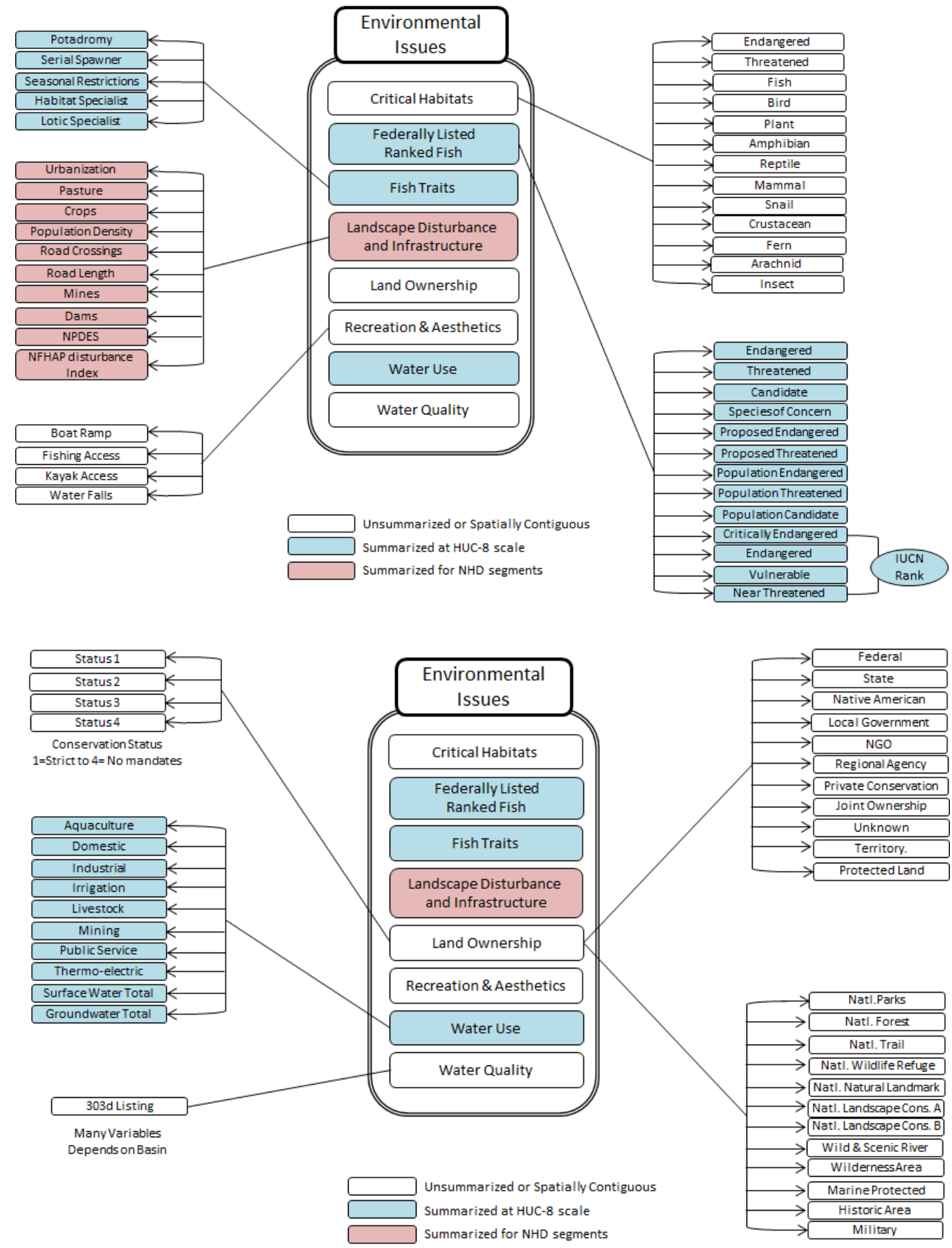

Figure 2.3. Conceptual organization of data layers and variables. Chart does not represent structural linkages (i.e., database connections) but hierarchical organization. Major environmental issue categories in the center are further divided into many variables, which are factors actually attributed to potential hydropower development areas. Color codes represent whether data layers have been summarized and the scale of summarization. 

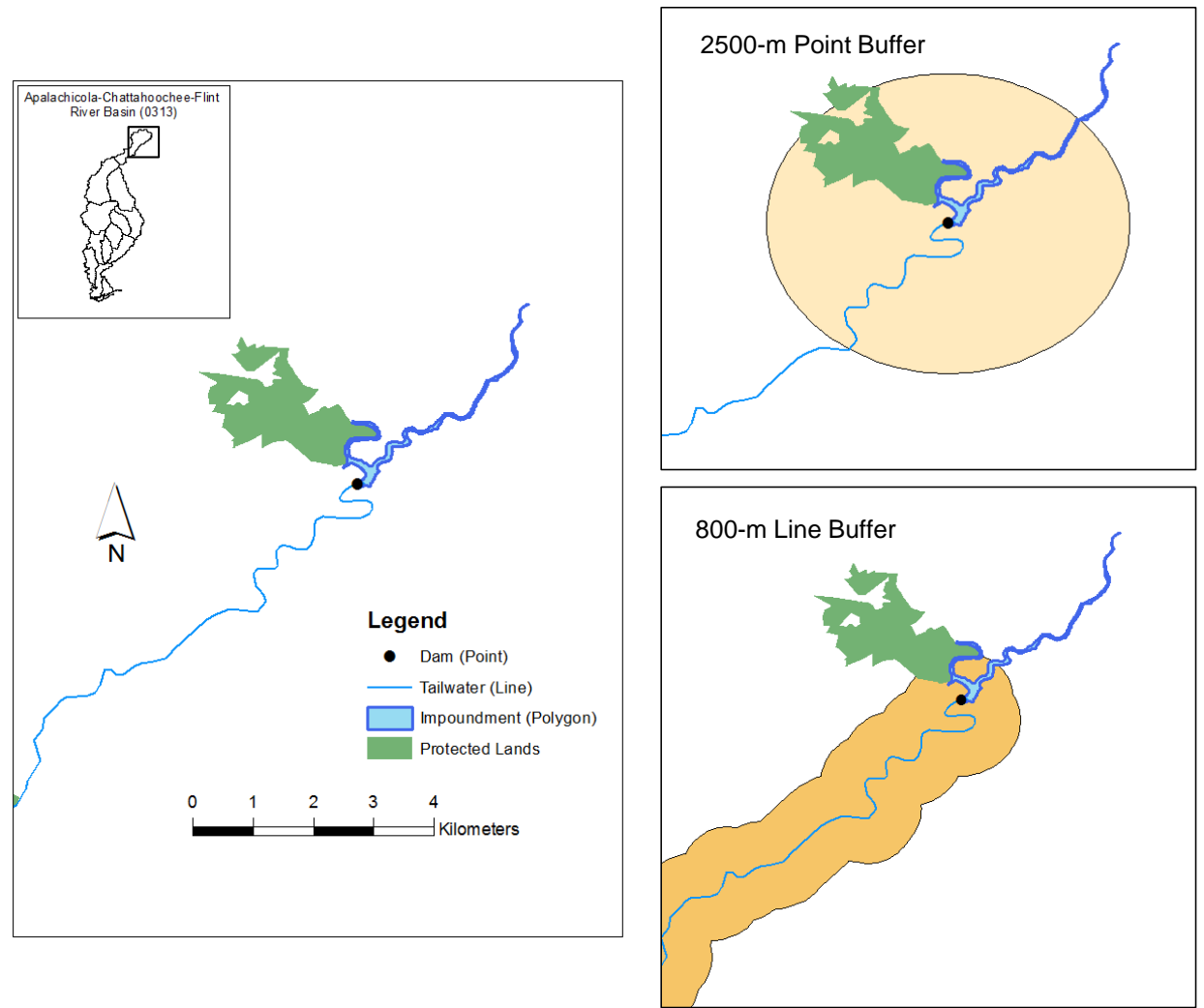

Figure 2.4. Example of virtual new hydropower site consisting of a point (dam), line (tailwater), and polygon (impoundment) and examples of buffers applied to the point and line.

Buffers are required to ensure that layers of different GIS transformations can interact despite potential errors in spatial display or inaccuracies in the underlying data layers. But hydropower developments may be influenced by environmental issues regardless of whether boundaries of potential dam areas touch boundaries of environmental data layers. Buffers are polygons that extend a specified distance from the raw data layer. Different buffer lengths were established to points, lines, and polygons using the buffer analysis tool within ESRI ArcGIS (ESRI, 2012). Although the available literature was used to inform decisions, there was a paucity of information on appropriate buffering distances with regard to energy development. Baban and Parry (2001) used a questionnaire targeting public and private sectors to determine criteria for locating wind farms in the United Kingdom. The resultant criteria suggested that wind farms should not be located within $2000 \mathrm{~m}$ of large settlements, $500 \mathrm{~m}$ of single dwellings, and $1000 \mathrm{~m}$ of ecological areas or historical sites. Krewitt and Nitsch (2003) used $500 \mathrm{~m}$ as a minimum distance from potential wind farms to residential or industrial areas, roads, railroad lines, and nature protection areas. In an economic analysis of the effects of proximity to hydropower dams on property values, Bohlen and Lewis (2009) found very little evidence of any negative economic effects. However, they did suggest that land use within $1500 \mathrm{~m}$ of a property can influence property values and thus public perception.

Buffers of variable widths were applied to points, polygons, and lines depending upon the data layer (Table 2.3). Points were buffered with an $8 \mathrm{~km}$ (5 mile) radius to assess potential critical habitat issues related to potential road development, power line development, and associated construction (Figure 2.4). A brief review of several randomly selected FERC documents revealed 
a variety of transmission line distances associated with hydropower projects, ranging from $61 \mathrm{~m}$ (200 ft), $5.1 \mathrm{~km}$ (3.2 mile), $15.7 \mathrm{~km}$ (9.7 mile), and $32.2 \mathrm{~km}$ (20 mile) (FERC 2003, FERC 2011 a,b,c,d). Two projects reviewed did not have transmission lines associated with facilities because switchyards abutted the powerhouse. Thus the area required for land acquisition and electricity transmittance will in part depend upon generation capacity and the distance to the nearest electrical grid. A $2500 \mathrm{~m}$ radius buffer was applied to points to assess land ownership, designation, and conservation status. Polygon (i.e., impoundment) boundaries were complex because they were derived by highly detailed digital-elevation-model-derived topography. Because of boundary complexity, the buffer function could not be executed in ESRI ArcGIS. However, intersection tools in ESRI ArcGIS do allow a user to define the spatial extent to which layers can be selected from a known location. Thus variable-distance selection measures (500 to $800 \mathrm{~m}$ [0.5 mile]) were used to attribute polygons depending on the data layer (Table 2.3). Best management practices typically recommend $15-30 \mathrm{~m}$ as a minimum forested area for buffering riparian corridors (NCFS, 2006); however, this is primarily related to water quality concerns, such as erosion and sedimentation, in relation to forestry practices or urban areas. Land ownership issues, such as road access, can arise because of land ownership proximity despite touching boundaries. In addition, lake development typically requires purchasing lands outside the potential impoundment. Thus $800 \mathrm{~m}$ buffers provide a distance within the range of existing studies. Similar to polygons, $800 \mathrm{~m}$ radius buffers were also used for polylines because of issues related to land ownership proximity and habitat needs for animals with larger migratory potential (birds, amphibians, reptiles) (Table 2.3).

Table 2.3. Variable Buffer Widths According to Different Data Layers and Different Site Elements (Points, Lines, and Polygons)

\begin{tabular}{llccr}
\hline & & \multicolumn{3}{c}{ Buffer width (m) } \\
Category & Data layer & Point & Line & Polygon \\
\hline Critical habitat & Critical habitats & 8,000 & 800 & 800 \\
Land ownership & Land owner (agency) & 2,500 & 800 & 800 \\
Land ownership & Land designation & 2,500 & 800 & 800 \\
Land ownership & Land conservation status & 2,500 & 800 & 800 \\
Water quality & 303d waterbodies & 500 & 500 & 500 \\
Recreation & Fishing access/boat ramp & 500 & 500 & 500 \\
Recreation & Kayak/rafting access & 500 & 500 & 500 \\
Recreation & Waterfalls & 2,500 & 800 & 800 \\
\hline
\end{tabular}

Environmental attributes were summarized separately for each point (potential dam location), line (tailwater reach), and polygon (impoundment). Attribution ranged from binary responses (1 or 0 ), indicating the presence or absence of a data layer, to counts (e.g., number of federally listed fish species), to continuous variables (e.g., percent urbanization, water use). The method of attribution depended on the environmental issue and the resolution of the data source. For environmental data sources summarized at the HUC08 subbasin scale (maps of water use, listed ranked fish species, and fish traits), point, line, and polygon were attributed with HUC08 values 
based on their location within HUC08 boundaries. For environmental data layers not summarized into arbitrary units (e.g., fishing access points) or those with spatially contiguous coverage (e.g., conservation land polygons), intersection methods were used to determine potential effects for point, lines, and polygons. For layers of information summarized for NHD flowlines, the COMID, a code used for identifying each NHD flowline, was used to link environmental information to each point, line, and polygon.

Conservation lands within the PAD-US database provided a spatial mosaic of merged polygons, each representing a separate entity (e.g., park or landmark). The PAD-US database was used to categorize lands by owner type, designations regarding use and intent, and Gap Analysis Program (GAP) status code (Figure 2.3). Points, lines, and polygons were attributed with a binary response as to whether buffered areas intersected (touched the boundary of) each layer. Other datasets (critical habitats, 303d waterbodies, fishing/boat ramp access points, kayak/rafting access points, and waterfalls) were represented as smaller, more discrete locations rather than extensive spatial coverage. For example, critical habitats represented specific river segments (lines) or blocks of land (polygons) for individual species. For these datasets, rather than only binary responses to indicate the presence or absence of a potential environmental issue, the number of entities possibly affected by hydropower development was indicated. The spatial join function in ESRI ArcGIS was used to join one to many elements to each buffered point, line, and polygon based on intersection. The number of entities intersecting each buffered layer was then enumerated. For critical habitats, the number of species' critical habitats was enumerated within each taxonomic category. The $303 \mathrm{~d}$ waterbody dataset represents each impaired waterbody as a specific point location, stream reach, or lake/impoundment and provides the reason for impairment (e.g., temperature, low oxygen, sediment, pollutant). After 303d waterbodies were joined to buffered layers, the number of water bodies within each impairment category was enumerated. Recreation datasets (fishing/boat ramp points, kayak/rafting points, and waterfall locations) were joined to buffered layers and enumerated.

The NFHAP database includes cumulative fish habitat disturbance indices, a suite of land use variables, and existing infrastructure summarized separately for each local NHDPlus flowline and for the network watershed upstream of each NHDPlus flowline. Data within NFHAP are provided as shapefiles and tabular attributes for all NHDPlus flowlines, each identified by a COMID. Because sites were created in association with NHDPlus flowlines, their locations could be identified by COMID. A simple join procedure was used to attribute points and polygons with NFHAP information. However, tailwaters were represented by two or more NHDPlus flowlines and so have more than one COMID. The most upstream NHDPlus flowline and the most downstream NHDPlus flowline were attributed with NFHAP information. Values for the entire tailwater were then represented by averages of the upstream and downstream flowlines. 


\section{SUMMARY OF FINDINGS}

\subsection{Summary of National Resources}

The estimated NSD capacity and generation, including both higher-energy-density ( $>1 \mathrm{MW}$ per reach) and lower-energy-density (<1 MW per reach) stream-reaches, are summarized in Table 3.1 for each hydrologic region. The highest potential is identified in the Pacific Northwest Region (32\%), followed by the Missouri Region (15\%) and the California Region (9\%). In total, the undeveloped NSD capacity is $84.7 \mathrm{GW}$, around the same size as the existing U.S. conventional hydropower nameplate capacity (79.5 GW; NHAAP, 2013). In terms of energy, the total undeveloped NSD generation is estimated to be $460 \mathrm{TWh} / \mathrm{year}$, around $169 \%$ of average 2002-2011 net annual generation from existing conventional hydropower plants (272 TWh/year; EIA, 2013). Given the run-of-river assumption, NSD stream-reaches have higher capacity factors (53\%-71\%), especially compared with conventional larger-storage peaking-operation projects that usually have capacity factors of around $30 \%$.

Table 3.1. Summary of NSD Findings by Hydrologic Regions

\begin{tabular}{ll|r|r|r}
\hline & Hydrologic region & Capacity (MW) & Generation (MWh/year) & Capacity factor \\
\hline 01 & New England & 2,143 & $12,433,000$ & $66 \%$ \\
02 & Mid-Atlantic & 4,710 & $25,945,000$ & $63 \%$ \\
03 & South Atlantic-Gulf & 2,561 & $14,205,000$ & $63 \%$ \\
\hline 04 & Great Lakes & 1,425 & $8,444,000$ & $68 \%$ \\
05 & Ohio & 4,757 & $25,288,000$ & $61 \%$ \\
06 & Tennessee & 1,363 & $7,995,000$ & $67 \%$ \\
\hline 07 & Upper Mississippi & 2,081 & $11,546,000$ & $63 \%$ \\
08 & Lower Mississippi & 2,072 & $12,074,000$ & $67 \%$ \\
09 & Souris-Red-Rainy & 151 & 787,000 & $60 \%$ \\
\hline 10 & Missouri & 11,686 & $69,011,000$ & $67 \%$ \\
11 & Arkansas-White-Red & 6,013 & $33,994,000$ & $65 \%$ \\
12 & Texas-Gulf & 783 & $3,666,000$ & $53 \%$ \\
\hline 13 & Rio Grande & 1,637 & $9,310,000$ & $65 \%$ \\
14 & Upper Colorado & 3,033 & $18,232,000$ & $69 \%$ \\
15 & Lower Colorado & 2,613 & $16,273,000$ & $71 \%$ \\
\hline 16 & Great Basin & 564 & $3,105,000$ & $63 \%$ \\
17 & Pacific Northwest & 25,226 & $148,999,000$ & $67 \%$ \\
18 & California & 7,054 & $37,987,000$ & $61 \%$ \\
\hline 19 & Alaska* & 4,723 & $($ not estimated) & $($ not estimated) \\
20 & Hawaii* & 145 & $459,993,000$ & $53 \%$ \\
\hline & Total & 84,740 & & $66 \%$ \\
\hline
\end{tabular}

*The Alaska and Hawaii potential are estimated by a different approach from other regions.

The estimated NSD capacity and generation, including both higher-energy-density ( $>1 \mathrm{MW}$ per reach) and lower-energy-density ( $<1 \mathrm{MW}$ per reach) stream-reaches, are further summarized in Table 3.2 for each state. The downstream end of a stream-reach is treated as the possible development location to determine specific location within states. When a stream-reach is located on the border of multiple states, the potential capacity and generation are distributed evenly into each neighboring state to compute the state-based totals. The highest potential is found in Oregon, Washington, and Idaho, the three states in the Pacific Northwest, followed by California, Alaska, Montana, and Colorado. 
Table 3.2. Summary of NSD Findings by States

\begin{tabular}{|c|c|c|c|c|c|}
\hline State & $\begin{array}{r}\text { Potential } \\
\text { capacity }(\mathrm{MW})\end{array}$ & $\begin{array}{r}\text { Potential generation } \\
(\mathrm{MWh} / \text { year })\end{array}$ & State & $\begin{array}{r}\text { Potential } \\
\text { capacity }(M W)\end{array}$ & $\begin{array}{r}\text { Potential generation } \\
\text { (MWh/year) }\end{array}$ \\
\hline $\mathrm{AK}^{*}$ & 4,723 & (not estimated) & MT & 4,763 & $28,201,000$ \\
\hline $\mathrm{AL}$ & 663 & $3,522,000$ & $\mathrm{NC}$ & 857 & $5,067,000$ \\
\hline $\mathrm{AR}$ & 1,253 & $6,685,000$ & ND & 252 & $1,524,000$ \\
\hline $\mathrm{AZ}$ & 2,484 & $1,5459,000$ & NE & 1,942 & $11,917,000$ \\
\hline CA & 6,983 & $3,7564,000$ & $\mathrm{NH}$ & 407 & $2,410,000$ \\
\hline $\mathrm{CO}$ & 4,295 & $2,5623,000$ & $\mathrm{NJ}$ & 171 & $1,006,000$ \\
\hline CT & 151 & 865,000 & NM & 1,280 & $7,193,000$ \\
\hline $\mathrm{DE}$ & 6 & 35,000 & NV & 232 & $1,245,000$ \\
\hline FL & 170 & 956,000 & NY & 1,900 & $10,715,000$ \\
\hline GA & 621 & $3,604,000$ & $\mathrm{OH}$ & 535 & $2,800,000$ \\
\hline $\mathrm{HI}^{*}$ & 145 & 699,000 & $\mathrm{OK}$ & 1,147 & $5,838,000$ \\
\hline IA & 736 & $3,869,000$ & OR & 8,920 & $53,353,000$ \\
\hline ID & 7,018 & $41,015,000$ & PA & 2,889 & $15,795,000$ \\
\hline IL & 599 & $3,241,000$ & RI & 13 & 71,000 \\
\hline IN & 581 & $3,123,000$ & $\mathrm{SC}$ & 309 & $1,844,000$ \\
\hline KS & 2,479 & $14,931,000$ & SD & 230 & $1,363,000$ \\
\hline KY & 675 & $3,301,000$ & $\mathrm{TN}$ & 1,002 & $5,618,000$ \\
\hline LA & 790 & $4,463,000$ & $\mathrm{TX}$ & 1,580 & $8,089,000$ \\
\hline MA & 194 & $1,114,000$ & UT & 1,376 & $8,246,000$ \\
\hline MD & 223 & $1,212,000$ & VA & 1,234 & $6,869,000$ \\
\hline ME & 1,132 & $6,532,000$ & VT & 401 & $2,344,000$ \\
\hline MI & 449 & $2,866,000$ & WA & 7,381 & $43,788,000$ \\
\hline MN & 568 & $3,191,000$ & WI & 556 & $3,513,000$ \\
\hline MO & 2,512 & $14,514,000$ & WV & 1,851 & $9,910,000$ \\
\hline MS & 1,129 & $6,449,000$ & WY & 2,960 & $10,776,000$ \\
\hline
\end{tabular}

*The AK and HI potential are estimated by a different approach from the other 48 states.

The higher-energy-density stream-reaches (>1 MW per reach) are further shown in Figure 3.1, with potential capacity aggregated to HUC08 subbasins for illustration. The detailed regional results are discussed in the remaining sections of this report. For more insight into this new assessment, Appendix A provides a comparison with the previous national hydropower resource assessment.

\subsection{Summary of Environmental Attribution}

The total estimated NSD capacity from higher-energy-density stream-reaches ( $>1 \mathrm{MW}$ per reach) overlapping with various environmental concerns is summarized for each hydrologic region. The proportion of capacity from stream-reaches intersecting environmental concerns varies according to region and the environmental variable. For example, a high proportion of the total NSD capacity in the Pacific Northwest Region is associated with stream-reaches overlapping ESA critical habitats whereas no or very little capacity is associated with streamreaches overlapping critical habitats in the Great Lakes, Mid-Atlantic, Ohio, Texas-Gulf, and Upper Mississippi regions (Figure 3.2). In contrast, water-quality concerns are pervasive, affecting considerable NSD capacity in all regions (Figure 3.3). The Pacific Northwest, California, Lower Colorado, Great Basin, and Upper Colorado regions have higher proportions of NSD capacity from stream-reaches falling within HUC08 subbasins with three or more fish 


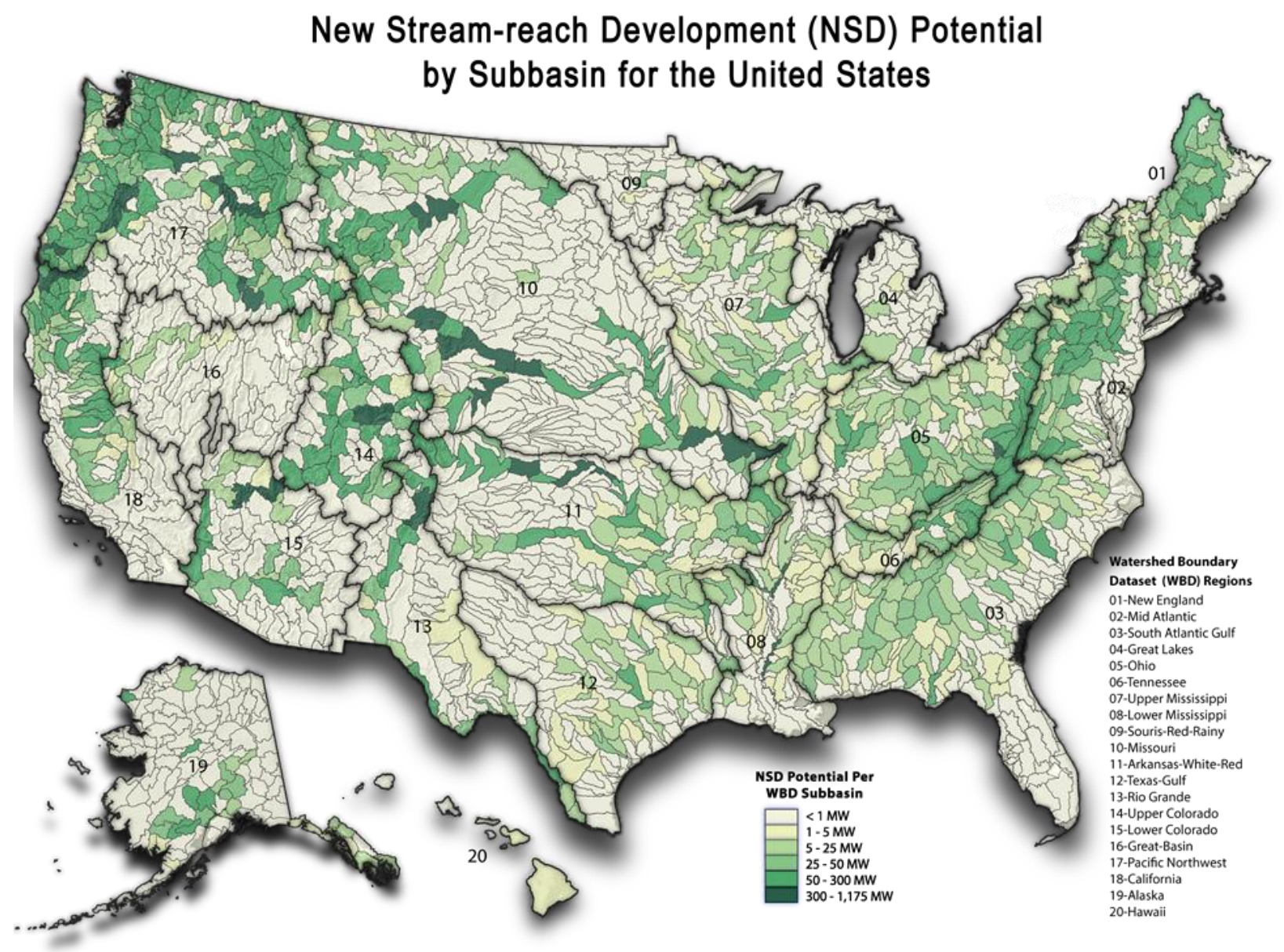

Figure 3.1. Potential new hydropower capacity in the United States (higher-energy-density stream-reaches with $>1$ MW per reach, aggregated to HUC08 subbasins for illustration).

species falling under ESA listing categories (Figure 3.4). A considerable proportion of capacity is associated with national parks in the Upper and Lower Colorado Regions (Figure 3.5). Wild and Scenic Rivers overlap with a large number of stream-reaches in the California, Pacific Northwest, and Rio Grande regions (Figure 3.6). Recreation is prevalent across the nation and commonly overlaps with NSD stream-reaches. Recreational boating was associated with most NSD capacity in the eastern and western hydrologic regions but made up a lower proportion of capacity in the midwestern hydrologic regions (Figure 3.7). The proportion of capacity associated with fishing access areas is consistent across the nation; however, a large proportion was present in the Pacific Northwest Region (Figure 3.8). Water use (1/day $\cdot \mathrm{km}^{2}$ ) is placed into categories of low, moderate, moderate-to-high, high, and very high based on percentile values $(20 \%, 20 \%-40 \%, 40 \%-60 \%, 60 \%-80 \%$, and $>80 \%)$ for each hydrologic region (to standardize usage across regions). Although water use varies greatly across hydrologic regions, the proportion of capacity associated with various use categories is consistent across the nation with the exception of the Upper and Lower Mississippi Regions (Figure 3.9). 


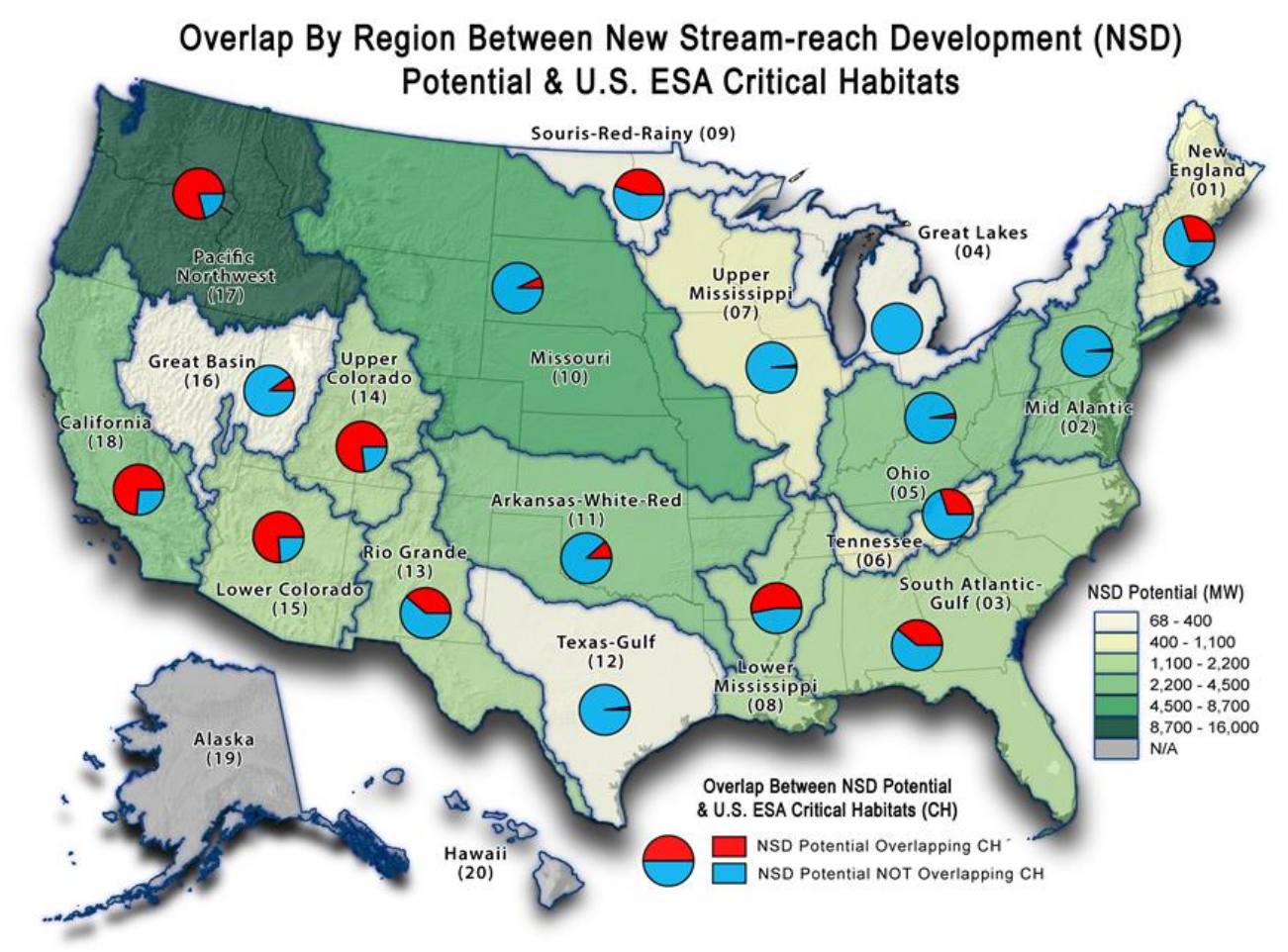

Figure 3.2. Overlap between NSD capacity potential and ESA critical habitats (stream-reaches with potential capacity $>1 \mathrm{MW}$ ).

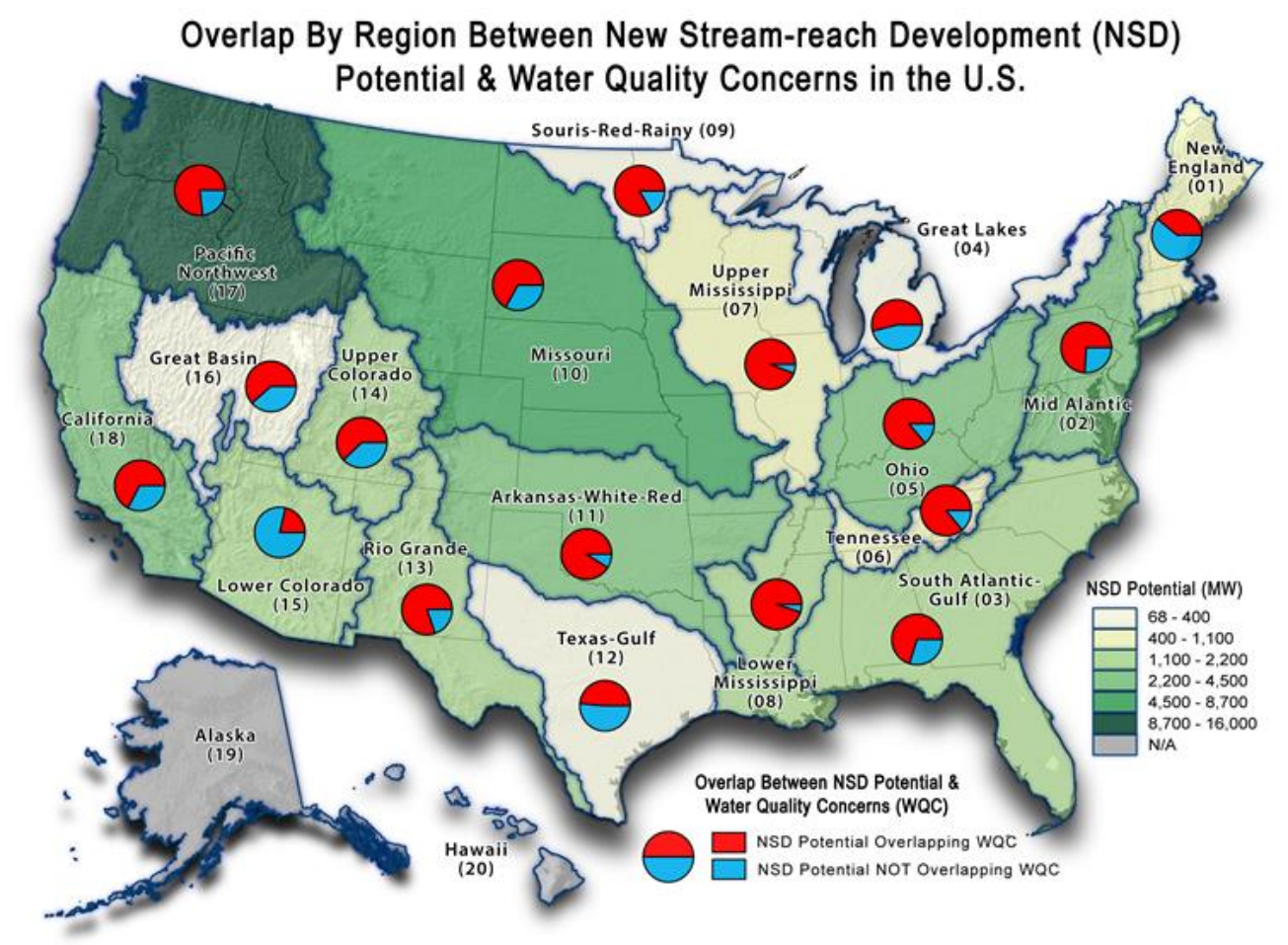

Figure 3.3. Overlap between NSD capacity potential and water quality concerns (stream-reaches with potential capacity $>1 \mathrm{MW})$. 


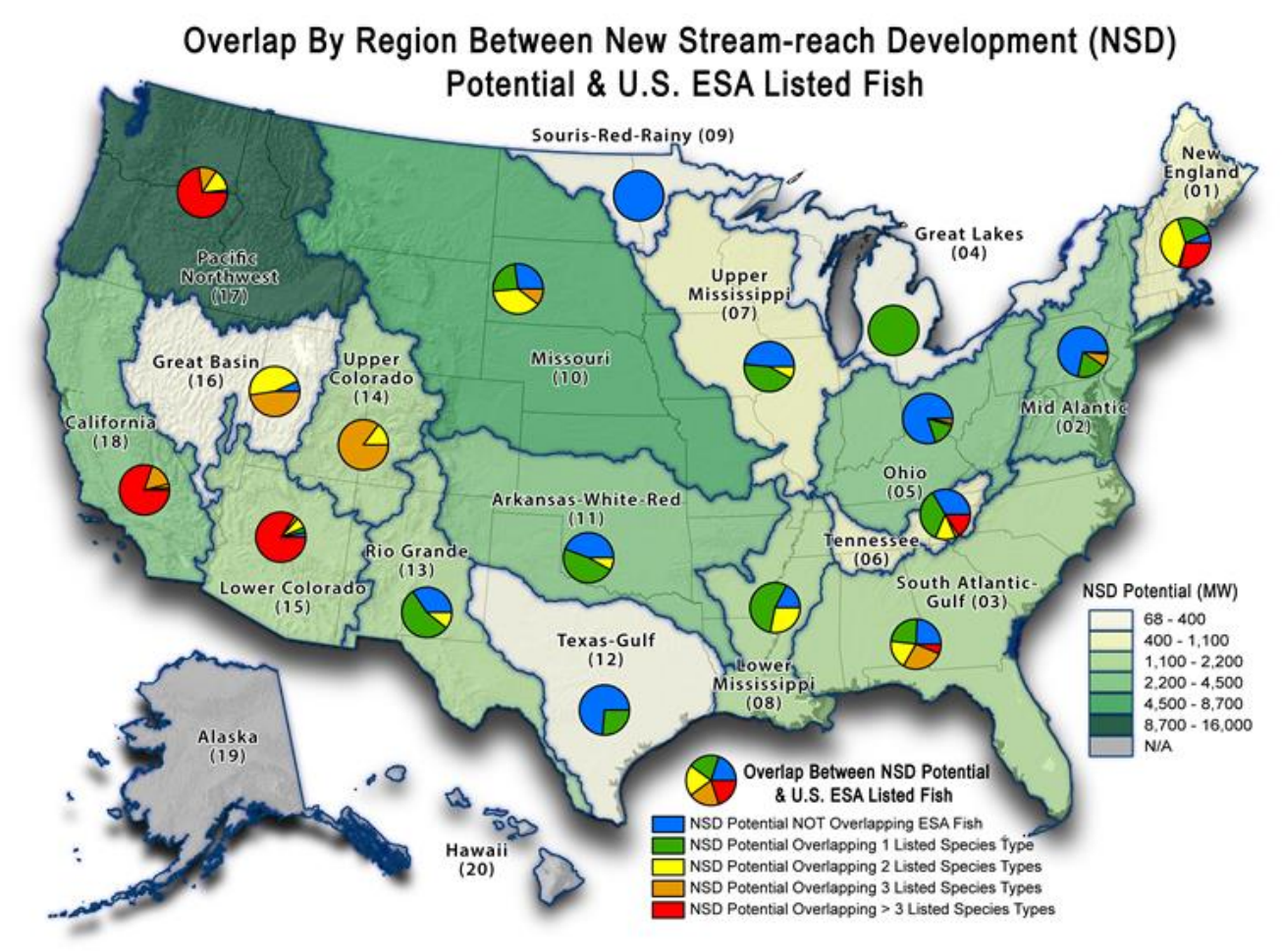

Figure 3.4. Overlap between NSD capacity potential and ESA listed fish (stream-reaches with potential capacity $>1$ MW).

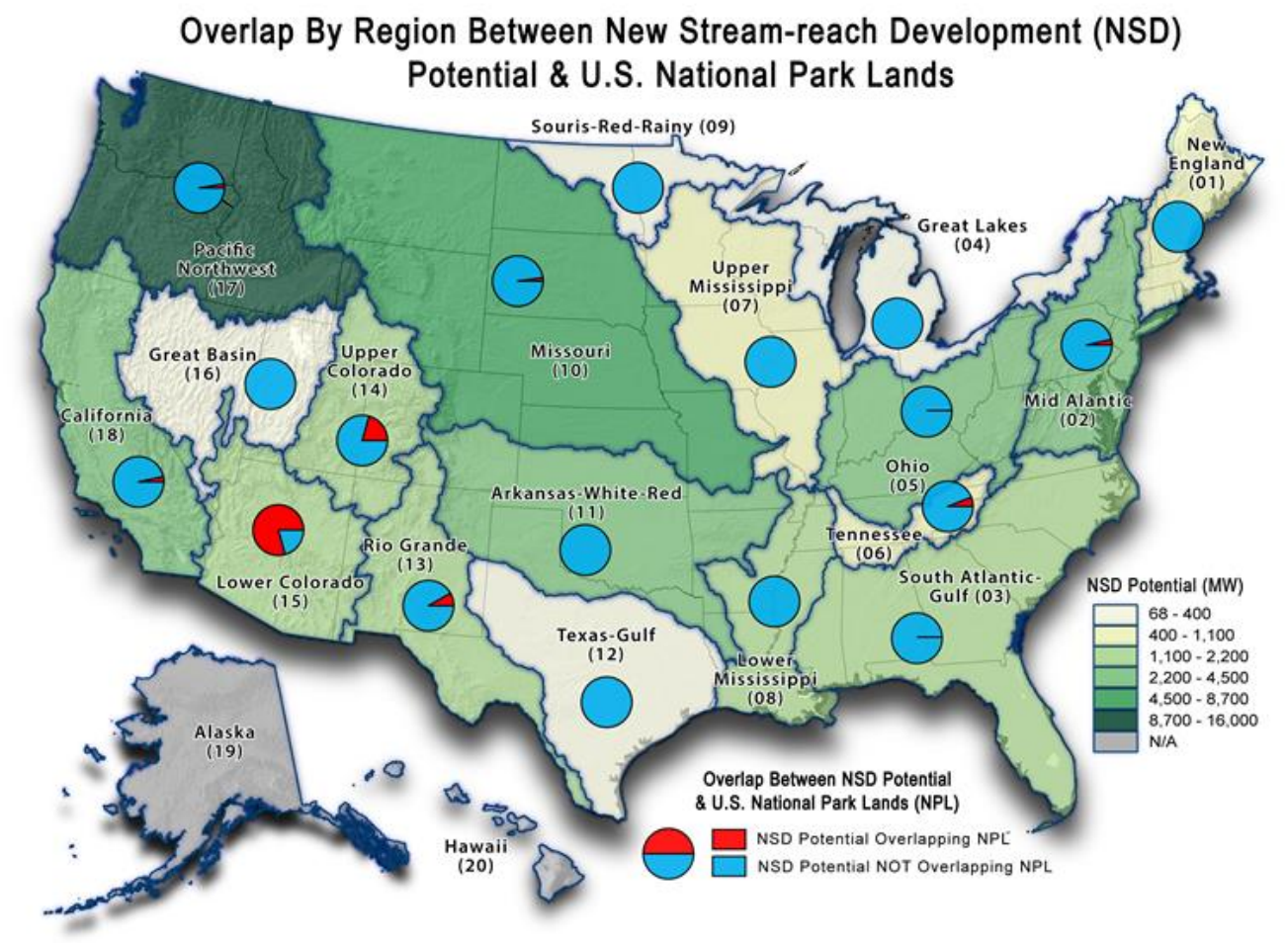

Figure 3.5. Overlap between NSD capacity potential and U.S. national parks (stream-reaches with potential capacity $>1 \mathrm{MW}$ ). 


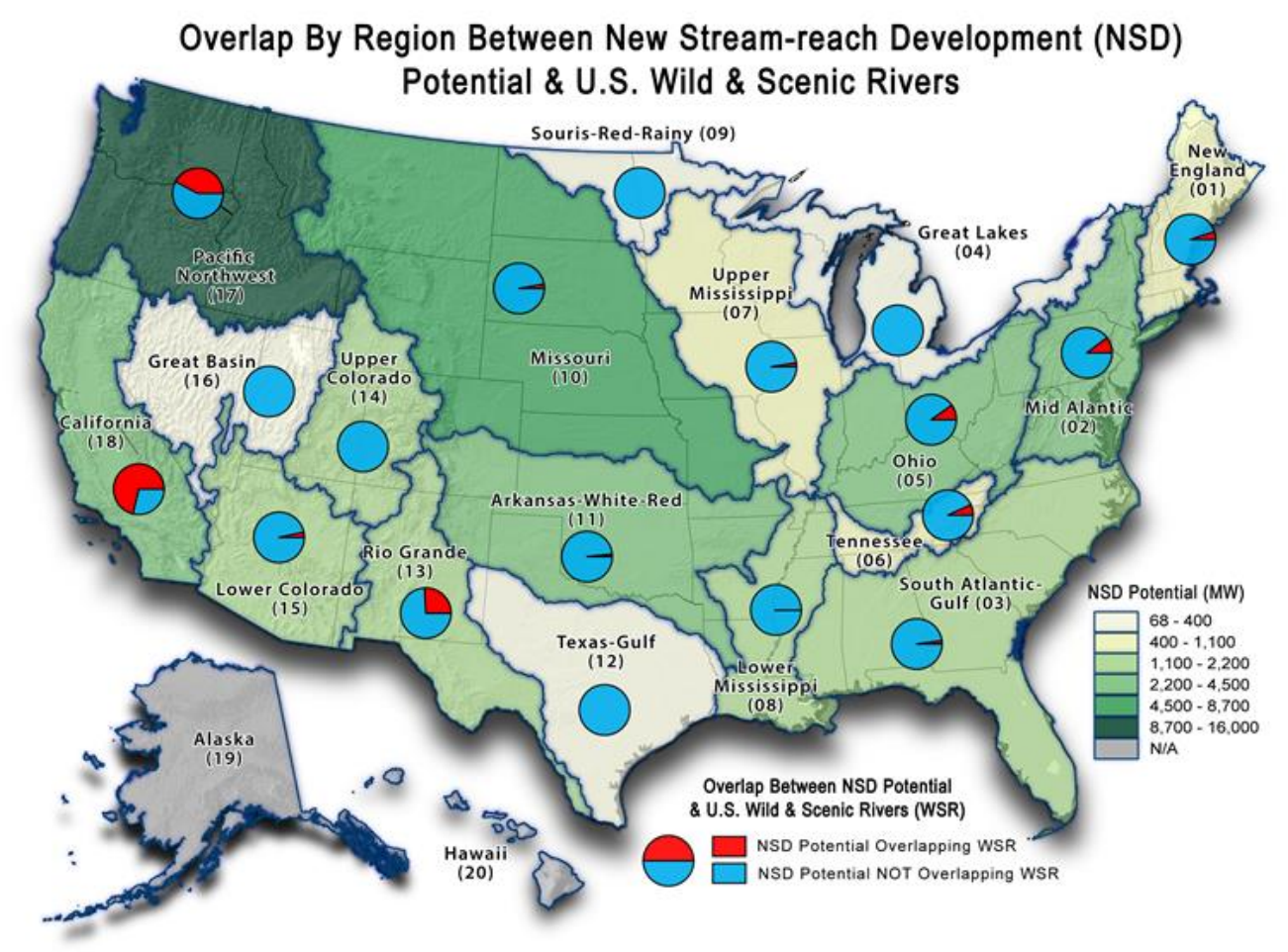

Figure 3.6. Overlap between NSD capacity potential and Wild and Scenic Rivers (stream-reaches with potential capacity $>1 \mathrm{MW})$.

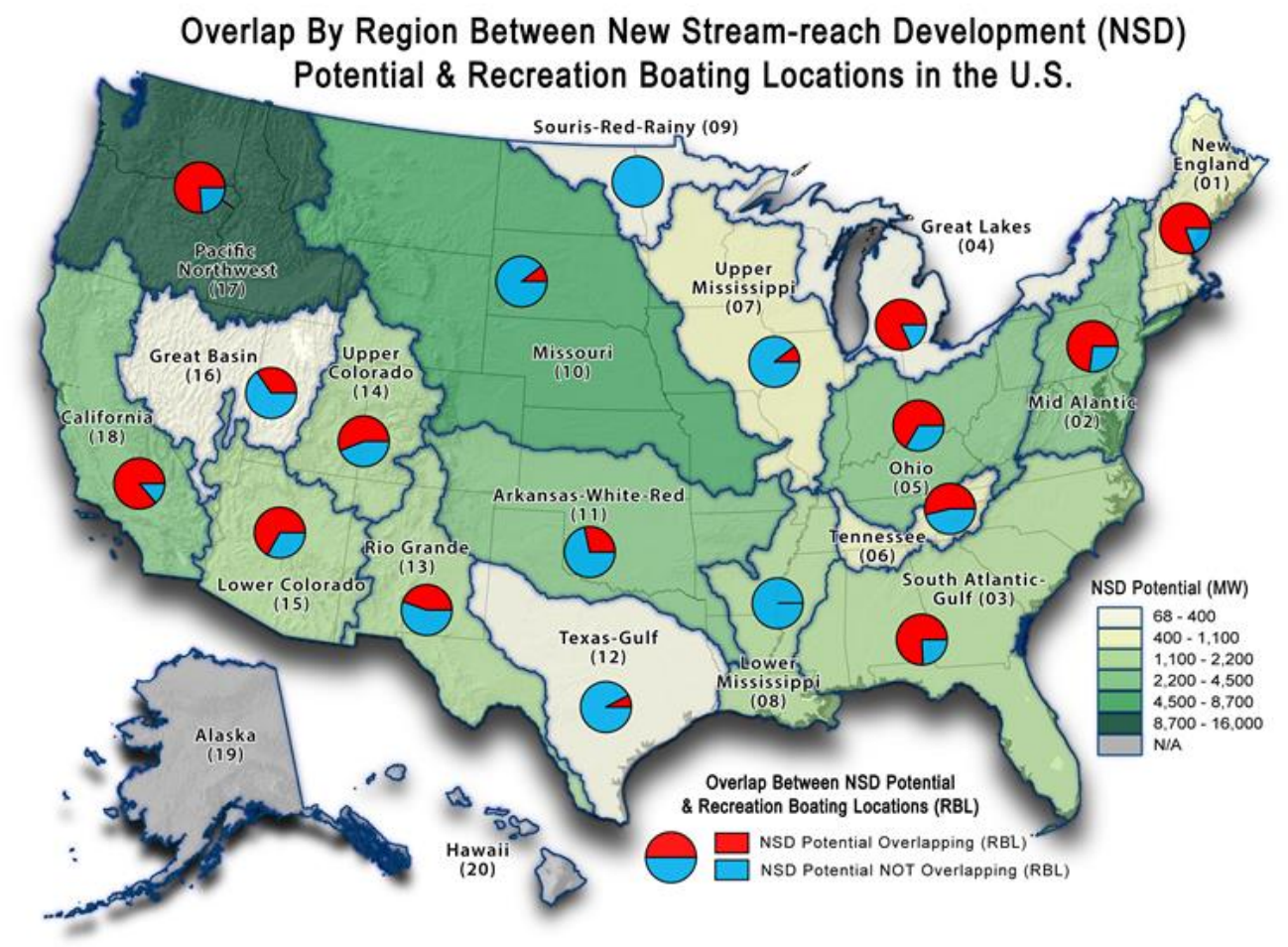

Figure 3.7. Overlap between NSD capacity potential and recreational boating locations (stream-reaches with potential capacity $>1 \mathrm{MW}$ ). 


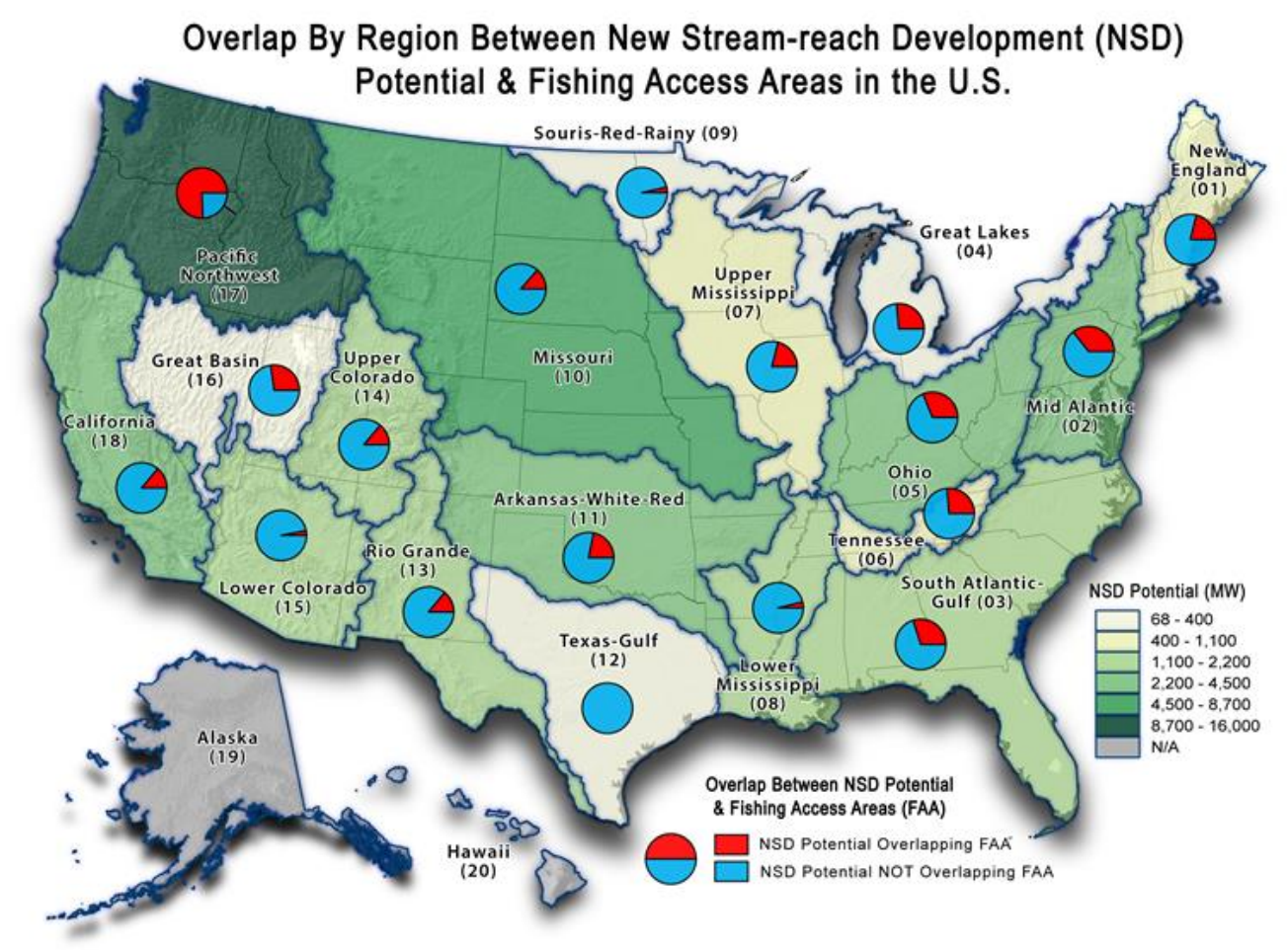

Figure 3.8. Overlap between NSD capacity potential and fishing access areas (stream-reaches with potential capacity $>1 \mathrm{MW})$.

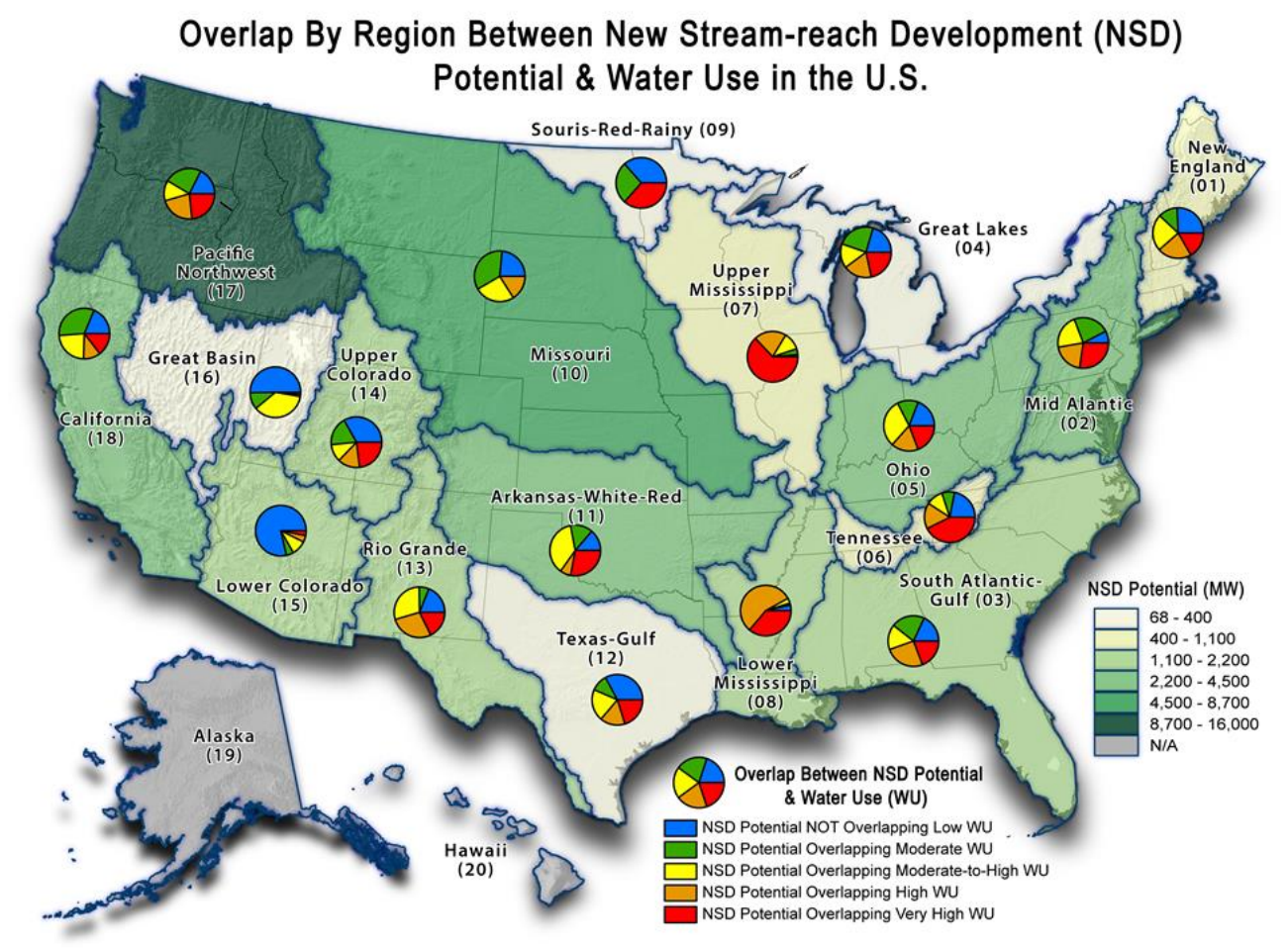

Figure 3.9. Overlap between NSD capacity potential and total freshwater water use (stream-reaches with potential capacity $>1 \mathrm{MW})$. 
By examing multiple environmental attributes jointly, further policy and research questions can be explored. For instance, when areas protected by federal legislation limiting the development of new hydropower (national parks, wild and scenic rivers, and wilderness areas) are excluded, the estimated NSD capacity falls to $65.5 \mathrm{GW}$, slightly lower than the current existing U.S. conventional hydropower nameplate capacity (79.5 GW; NHAAP, 2013), with undeveloped NSD generation estimated to be $347.3 \mathrm{TWh} /$ year, which is roughly $128 \%$ of the average-2011 net annual generation from existing plants (272 TWh/year; EIA, 2013). In terms of hydrologic regions and states (Table 3.3 and Table 3.4), the biggest reductions are found in Pacific Northwest and Oregon, mainly due to the large overlapped with wild and scenic rivers.

Table 3.3. Summary of NSD Findings by Hydrologic Regions, Excluding Stream-reaches that are in Close Proximity to National Parks, Wild and Scenic Rivers, and Wilderness Areas

\begin{tabular}{ll|r|r|r}
\hline & Hydrologic region & Capacity (MW) & Generation (MWh/year) & Capacity factor \\
\hline 01 & New England & 2,025 & $11,791,000$ & $66 \%$ \\
02 & Mid-Atlantic & 4,144 & $22,721,000$ & $63 \%$ \\
03 & South Atlantic-Gulf & 2,439 & $13,494,000$ & $63 \%$ \\
\hline 04 & Great Lakes & 1,338 & $7,870,000$ & $67 \%$ \\
05 & Ohio & 3,795 & $19,986,000$ & $60 \%$ \\
06 & Tennessee & 1,228 & $7,229,000$ & $67 \%$ \\
\hline 07 & Upper Mississippi & 1,983 & $10,937,000$ & $63 \%$ \\
08 & Lower Mississippi & 2,067 & $12,044,000$ & $67 \%$ \\
09 & Souris-Red-Rainy & 142 & 737,000 & $59 \%$ \\
\hline 10 & Missouri & 10,705 & $63,090,000$ & $67 \%$ \\
11 & Arkansas-White-Red & 5,771 & $32,687,000$ & $65 \%$ \\
12 & Texas-Gulf & 762 & $3,565,000$ & $53 \%$ \\
\hline 13 & Rio Grande & 1,103 & $6,237,000$ & $65 \%$ \\
14 & Upper Colorado & 1,914 & $11,481,000$ & $68 \%$ \\
15 & Lower Colorado & 622 & $3,761,000$ & $69 \%$ \\
\hline 16 & Great Basin & 547 & $3,008,000$ & $63 \%$ \\
17 & Pacific Northwest & 16,958 & $97,859,000$ & $66 \%$ \\
18 & California & 3,275 & $18,084,000$ & $63 \%$ \\
\hline 19 & Alaska* & 4,530 & $($ not estimated) & $($ not estimated) \\
20 & Hawaii* & 145 & 699,000 & $55 \%$ \\
\hline & Total & 65,493 & $347,280,000$ & $61 \%$ \\
\hline
\end{tabular}

*Given the different methodology and data format, the AK and HI environemtnal attribution is based on a 2000 meter buffer zone. Environemtnal attribution in other regions is based on the Hadjerioua et al. (2013) appraoch. 
Table 3.4. Summary of NSD Findings by States, Excluding Stream-reaches that Are in Close Proximity to National Parks, Wild and Scenic Rivers, and Wilderness Areas

\begin{tabular}{|c|c|c|c|c|c|}
\hline State & $\begin{array}{r}\text { Potential } \\
\text { capacity (MW) }\end{array}$ & $\begin{array}{r}\text { Potential generation } \\
\text { (MWh/year) }\end{array}$ & State & $\begin{array}{r}\text { Potential } \\
\text { capacity (MW) }\end{array}$ & $\begin{array}{r}\text { Potential generation } \\
(\mathrm{MWh} / \text { year })\end{array}$ \\
\hline $\mathrm{AK}^{*}$ & 4,530 & (not estimated) & MT & 3,914 & $23,413,000$ \\
\hline $\mathrm{AL}$ & 646 & $3,435,000$ & $\mathrm{NC}$ & 796 & $4,697,000$ \\
\hline $\mathrm{AR}$ & 1,108 & $5,964,000$ & ND & 252 & $1,523,000$ \\
\hline $\mathrm{AZ}$ & 515 & $3,090,000$ & $\mathrm{NE}$ & 1,851 & $11,332,000$ \\
\hline CA & 3,360 & $18,570,000$ & $\mathrm{NH}$ & 394 & $2,339,000$ \\
\hline $\mathrm{CO}$ & 3,802 & $22,699,000$ & $\mathrm{NJ}$ & 61 & 359,000 \\
\hline CT & 141 & 807,000 & NM & 917 & $5,113,000$ \\
\hline $\mathrm{DE}$ & 5 & 30,000 & NV & 226 & $1,208,000$ \\
\hline FL & 171 & 962,000 & NY & 1,809 & $10,192,000$ \\
\hline GA & 580 & $3,341,000$ & $\mathrm{OH}$ & 491 & $2,561,000$ \\
\hline HI* & 145 & 699,000 & OK & 1,147 & $5,837,000$ \\
\hline IA & 738 & $3,876,000$ & OR & 4,492 & $25,013,000$ \\
\hline ID & 4,937 & $28,645,000$ & PA & 2,418 & $13,140,000$ \\
\hline $\mathrm{IL}$ & 573 & $3,092,000$ & RI & 13 & 73,000 \\
\hline IN & 582 & $3,132,000$ & $\mathrm{SC}$ & 284 & $1,689,000$ \\
\hline KS & 2,479 & $14,931,000$ & SD & 112 & 633,000 \\
\hline KY & 662 & $3,242,000$ & $\mathrm{TN}$ & 869 & $4,908,000$ \\
\hline LA & 789 & $4,461,000$ & $\mathrm{TX}$ & 1,367 & $6,862,000$ \\
\hline MA & 176 & $1,012,000$ & UT & 678 & $4,005,000$ \\
\hline MD & 189 & $1,036,000$ & VA & 1,080 & $5,963,000$ \\
\hline $\mathrm{ME}$ & 1,059 & $6,146,000$ & VT & 400 & $2,338,000$ \\
\hline MI & 380 & $2,407,000$ & WA & 6,055 & $35,442,000$ \\
\hline MN & 516 & $2,870,000$ & WI & 522 & $3,287,000$ \\
\hline MO & 2,450 & $14,145,000$ & WV & 1,228 & $6,444,000$ \\
\hline MS & 1,112 & $6,361,000$ & WY & 2,476 & $13,949,000$ \\
\hline
\end{tabular}

*Given the different methodology and data format, the AK and HI environemtnal attribution is based on a 2000 meter buffer zone. Environemtnal attribution in other states is based on the Hadjerioua et al. (2013) appraoch. 
(This Page Intentionally Left Blank) 


\section{REGION 1-NEW ENGLAND}

\subsection{Summary of Findings}

Following NSD methodology (Hadjerioua et al., 2013), the potential capacity, annual generation, and mean capacity factors in the New England Region are estimated and summarized in Table 4.1 for both larger $(>1 \mathrm{MW})$ and smaller $(<1 \mathrm{MW})$ stream-reaches. For comparison, the year2011 nameplate capacity, 2002-2011 average annual generation, and capacity factor of existing hydropower facilities are also listed (NHAAP, 2013). The total undeveloped NSD capacity is $2.14 \mathrm{GW}$, around $118 \%$ of existing conventional hydropower nameplate capacity. In terms of energy, the total undeveloped NSD generation is $12.43 \mathrm{TWh} /$ year, around $167 \%$ of annual net generation from existing conventional hydropower plants. Given the run-of-river assumption, NSD stream-reaches have higher capacity factors, especially compared with other larger-storage peaking-operation projects in this region. More detailed topographical analysis and environmental attribution are conducted for larger (>1 MW) stream-reaches and discussed in Sections 4.3 and 4.4.

Table 4.1. Summary of NSD Findings in Region $1-$ New England

\begin{tabular}{l|r|r|r}
\hline & $\begin{array}{r}\text { Capacity } \\
\text { (MW) }\end{array}$ & $\begin{array}{r}\text { Generation } \\
\text { (MWh/year) }\end{array}$ & $\begin{array}{r}\text { Mean Capacity } \\
\text { factor }\end{array}$ \\
\hline Potential in undeveloped stream-reaches $(>1 \mathrm{MW})$ & 1,050 & $6,161,000$ & $67 \%$ \\
\hline Potential in undeveloped stream-reaches (<1 MW) & 1,093 & $6,272,000$ & $66 \%$ \\
\hline Existing hydropower-conventional hydro & 1,821 & $7,436,000$ & $47 \%$ \\
\hline Existing hydropower-pumped storage & 1,571 & & \\
\hline
\end{tabular}

\subsection{Background Hydrologic Setting}

The New England Region encompasses approximately $184,093 \mathrm{~km}^{2}$ of drainage area in the Northeastern United States. The region extends from Maine to southwestern Connecticut, covering Maine, New Hampshire, Rhode Island, Connecticut, most of Massachusetts, part of Vermont, and small section of New York. This region includes the White Mountains in New Hampshire to gentle rolling hills and mountains in Vermont and Massachusetts to the floodplains in Massachusetts and Connecticut.

Several river systems are located in the New England Region (Figure 4.1), including the St. John, Penobscot, Kennebec, Androscoggin, St. Croix, Merrimack, Connecticut, Pawcatuck, and Byram, with a total length of 19,245 km (i.e., total length of streams with estimated discharge greater than $35 \mathrm{cfs}$ ). Metropolitan areas within the region include Portland (ME), Boston (MA), Providence (RI), Hartford (CT), and Manchester (NH). As shown in Figure 4.2, annual precipitation for the New England Region ranges from slightly over 800 to $1500 \mathrm{~mm} / \mathrm{year}$ and annual runoff from about 400 to around $900 \mathrm{~mm} /$ year. Most of the precipitation occurs in the spring. The Connecticut River is tidally influenced from Hartford to Long Island Sound (EPA, 2000). 
Existing hydropower plants and major non-powered dams (Hadjerioua et al., 2012) are also shown in Figure 4.1. The region contains 359 hydropower dams and 102 major non-powered dams, with total storage capacities of around 11,473,000 ac-ft (ac-ft) and 985,000 ac-ft, respectively.

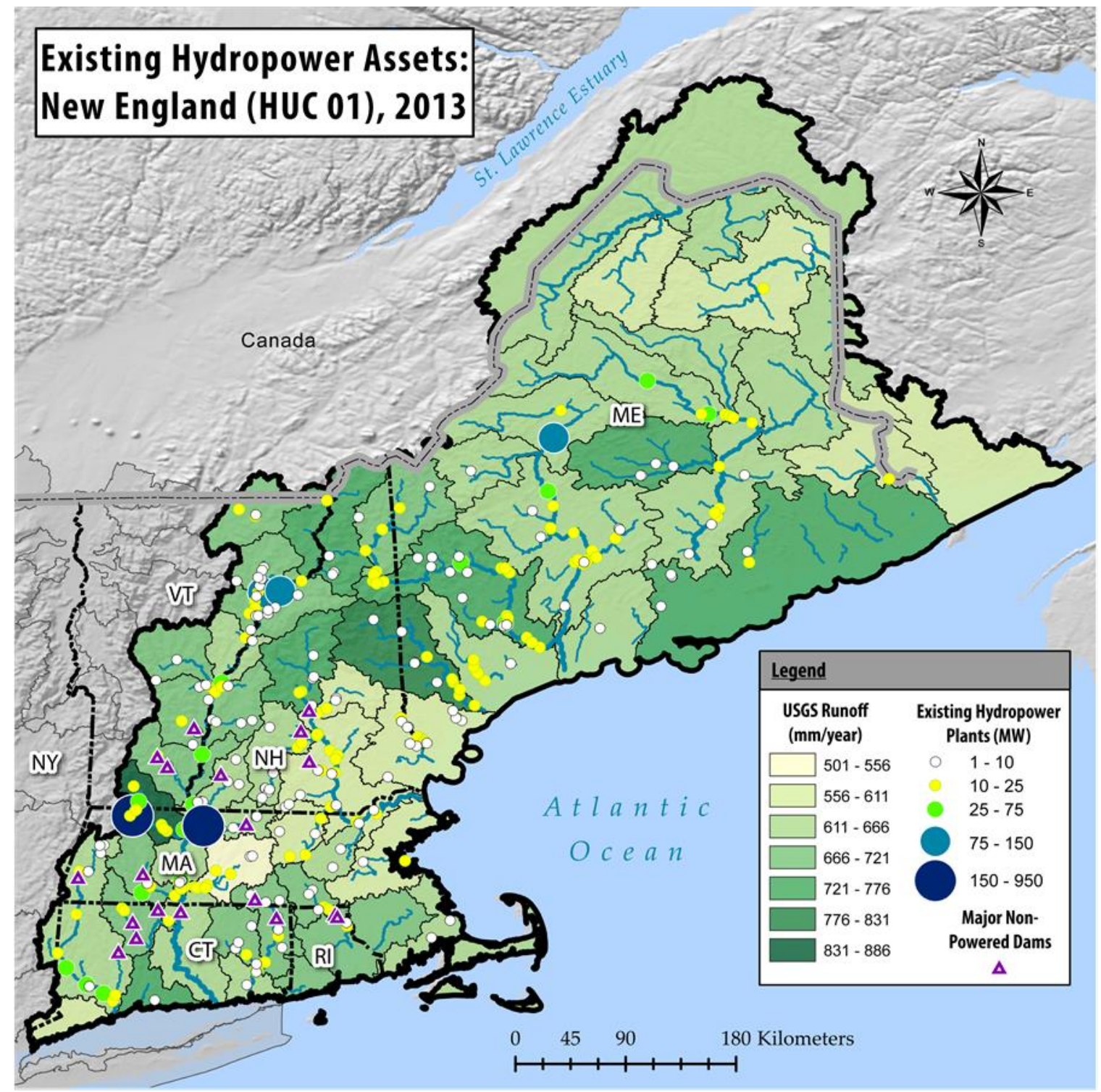

Figure 4.1. Locations of water control projects in Region 1-New England.

\subsection{Potential New Hydropower Resources}

A total of 283 stream-reaches of high energy density (with estimated potential capacity $>1 \mathrm{MW}$ per stream-reach) are identified in the New England Region. The NSD results based on HUC04 subregions are summarized in Table 4.2. The highest hydropower potentials are located in the Connecticut Subregion (HUC 0108) and St. John Subregion (HUC 0101), followed by the Penobscot Subregion (HUC 0102), Kennebec Subregion (HUC 0103), and Androscoggin 
Subregion (HUC 0104). In these subregions, the Connecticut, St. John, Penobscot, Kennebec, and Androscoggin rivers contain the highest potential for hydropower.

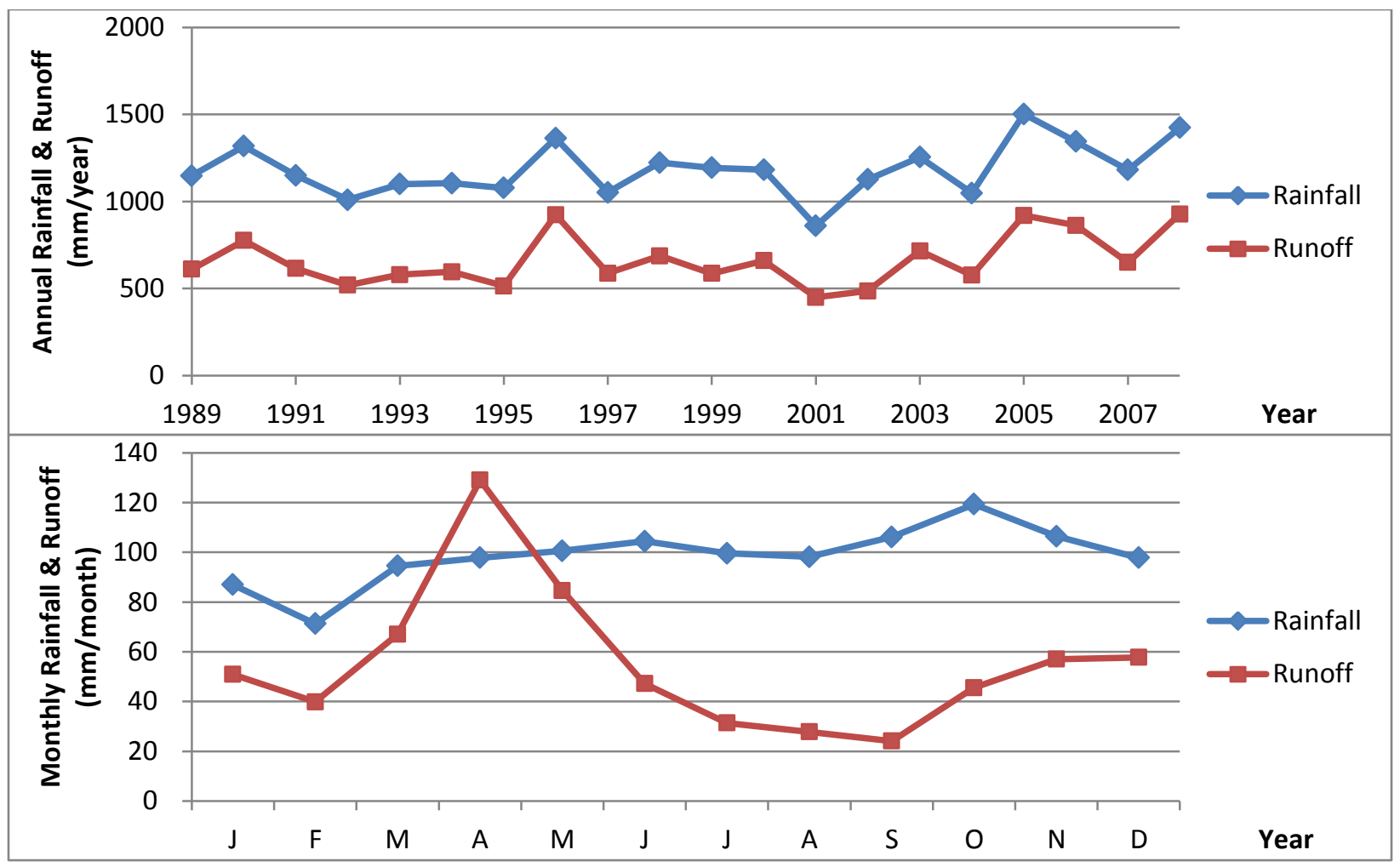

Figure 4.2. Annual and monthly rainfall and runoff of Region $1-$ New England.

Table 4.2. Summary of Potential New Hydropower Resources in Region $1-$ New England (Stream-Reaches with Potential Capacity $>1 \mathrm{MW}$ )

\begin{tabular}{|c|c|c|c|c|c|c|c|c|}
\hline HUC04 & HUC04 name & $\begin{array}{r}\text { \# of } \\
\text { stream- } \\
\text { reaches }\end{array}$ & $\begin{array}{r}\text { Potential } \\
\text { capacity } \\
(\mathrm{MW})\end{array}$ & $\begin{array}{r}\text { Potential } \\
\text { energy } \\
(\mathrm{MWh})\end{array}$ & $\begin{array}{r}\text { Average } \\
\text { head } \\
(f t / r e a c h)\end{array}$ & $\begin{array}{r}\text { Average } \\
\text { flow } \\
\text { (cfs/reach) }\end{array}$ & $\begin{array}{r}\text { Average } \\
\text { storage } \\
\text { (ac-ft/ } \\
\text { reach) }\end{array}$ & $\begin{array}{r}\text { Average } \\
\text { residence } \\
\text { Time } \\
\text { (days) }\end{array}$ \\
\hline 0101 & St. John & 34 & 215.6 & $1,133,846$ & 33.2 & 2,682 & 17,553 & 5.4 \\
\hline 0102 & Penobscot & 55 & 178.8 & $1,017,005$ & 13.9 & 3,199 & 1,551 & 0.3 \\
\hline 0103 & Kennebec & 58 & 174.7 & $1,125,622$ & 14.4 & 2,715 & 1,004 & 0.2 \\
\hline 0104 & Androscoggin & 26 & 110.6 & 720,201 & 17.1 & 3,581 & 1,808 & 0.2 \\
\hline 0105 & Maine Coastal & - & - & - & - & - & - & - \\
\hline 0106 & Saco & 11 & 36.3 & 202,409 & 17.8 & 2,538 & 4,468 & 1.0 \\
\hline 0107 & Merrimack & 14 & 50.0 & 285,880 & 15.6 & 3,206 & 5,485 & 1.3 \\
\hline 0108 & Connecticut & 63 & 238.8 & $1,417,097$ & 37.0 & 1,777 & 17,321 & 9.7 \\
\hline 0109 & $\begin{array}{l}\text { Massachusetts- } \\
\text { Rhode Island } \\
\text { Coastal }\end{array}$ & - & - & - & - & - & - & - \\
\hline 0110 & $\begin{array}{l}\text { Connecticut } \\
\text { Coastal }\end{array}$ & 22 & 45.4 & 259,180 & 20.9 & 1,606 & 1,270 & 0.9 \\
\hline 0111 & St. Francois & - & - & - & - & - & - & - \\
\hline
\end{tabular}


The summary statistics of hydraulic head $\mathrm{H}_{\text {ref }}\left(\mathrm{ft}\right.$ ), design flow $\mathrm{Q}_{30}(\mathrm{cfs})$, potential capacity $\mathrm{P}_{\mathrm{NSD}}$ $(\mathrm{MW})$, inundated area $\mathrm{A}_{\mathrm{NSD}}(\mathrm{ac})$, storage $\mathrm{V}_{\mathrm{NSD}}\left(\mathrm{ac}-\mathrm{ft}\right.$ ), and residence time $\mathrm{T}_{\mathrm{NSD}}$ (day) are shown in Figure 4.3. The hydraulic head $\mathrm{H}_{\text {ref }}$ ranges from $8 \mathrm{ft}$ to the 90 th quantile of $44 \mathrm{ft}$ with a median of about $18 \mathrm{ft}$, suggesting that many of the potential stream-reaches will require low-head hydropower technologies. The design flow $\mathrm{Q}_{30}$ ranges from $300 \mathrm{cfs}$ to the 90 th quantile of 5000 cfs with a median of just under 2000 cfs. The potential capacity $\mathrm{P}_{\mathrm{NSD}}$ ranges from $1.25 \mathrm{MW}$ to the 90th quantile of about 7.5 MW with a median of about 2.5 MW. The inundated surface area $\mathrm{A}_{\mathrm{NSD}}$ ranges from 0 ac to the 90th quantile of $1200 \mathrm{ac}$ with a median of $150 \mathrm{ac}$. This results in storage values $\mathrm{V}_{\text {NSD }}$ ranging from 0 to the 90 th quantile of $12,500 \mathrm{ac}-\mathrm{ft}$ with a median of about $1,250 \mathrm{ac}-\mathrm{ft}$ and very short residence times $\mathrm{T}_{\mathrm{NSD}}$ ranging from $<1$ day to the 90th quantile of 7 days with a median on the order of hours. In general, the relatively small inundation areas and storage volumes paired with the short retention times for this region are characteristic of run-ofriver type hydro facilities. The results of $>1 \mathrm{MW}$ stream-reach potential are illustrated in Figure 4.4, with potential capacity (MW) aggregated to the HUC10 watersheds. The higher-potential capacity sites are generally located on the major rivers in the hillier areas of the region.

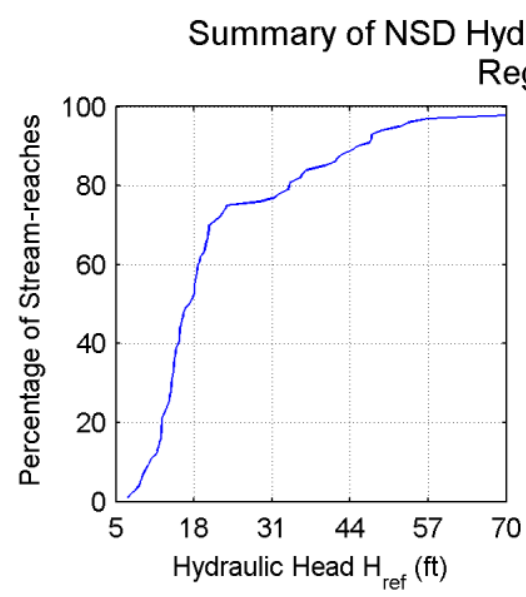

Hydropower Potential (stream-reaches with
Region 1: 283 stream-reaches, $1050 \mathrm{MW}$
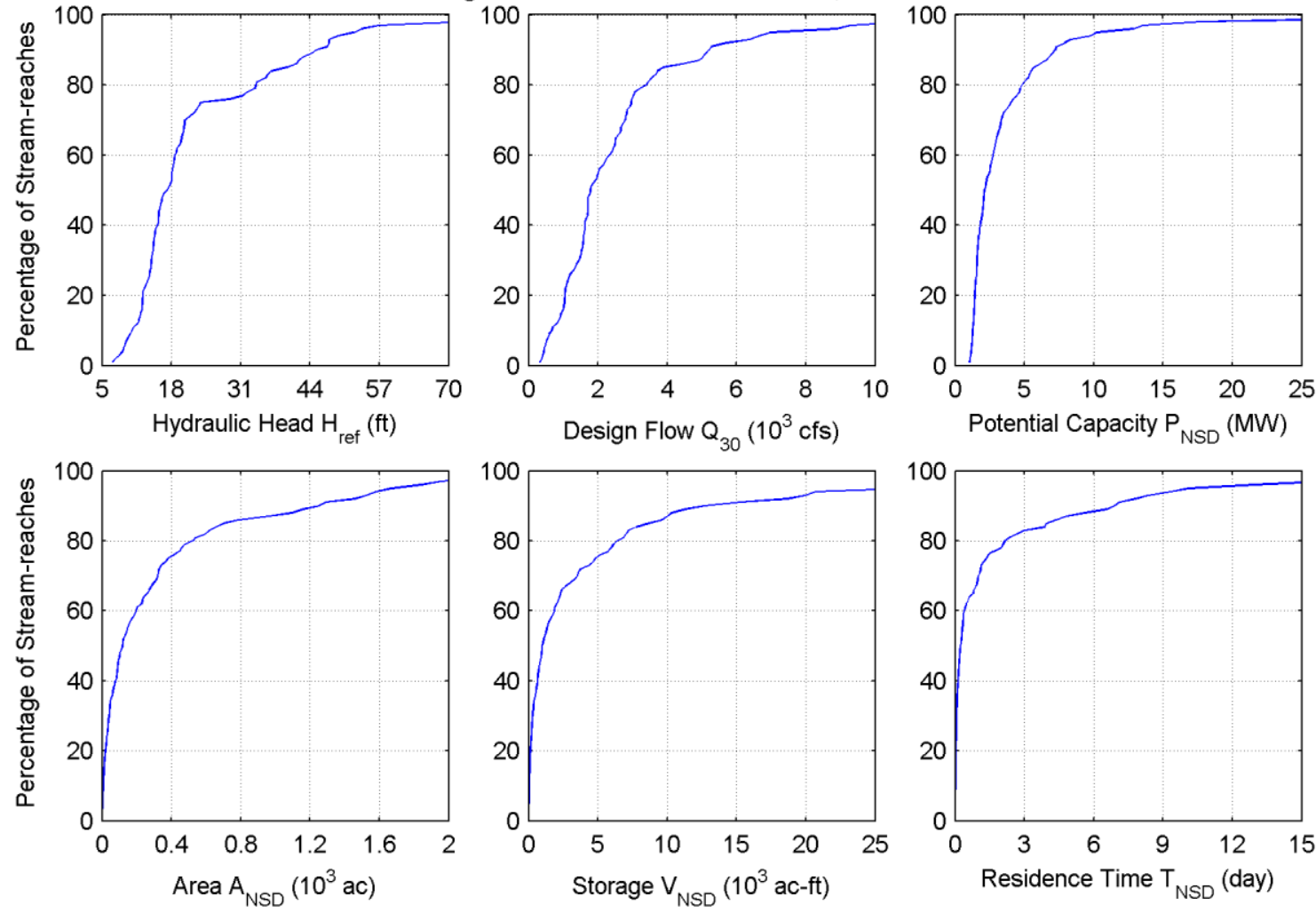

Figure 4.3. Cumulative distributions of hydraulic head $\mathrm{H}_{\text {ref }}$, design flow $\mathrm{Q}_{30}$, potential capacity $\mathrm{P}_{\mathrm{NSD}}$, inundated area $\mathrm{A}_{\mathrm{NSD}}$, storage $\mathrm{V}_{\mathrm{NSD}}$, and residence time $\mathrm{T}_{\mathrm{NSD}}$ in Region $1-\mathrm{New}$ England. 


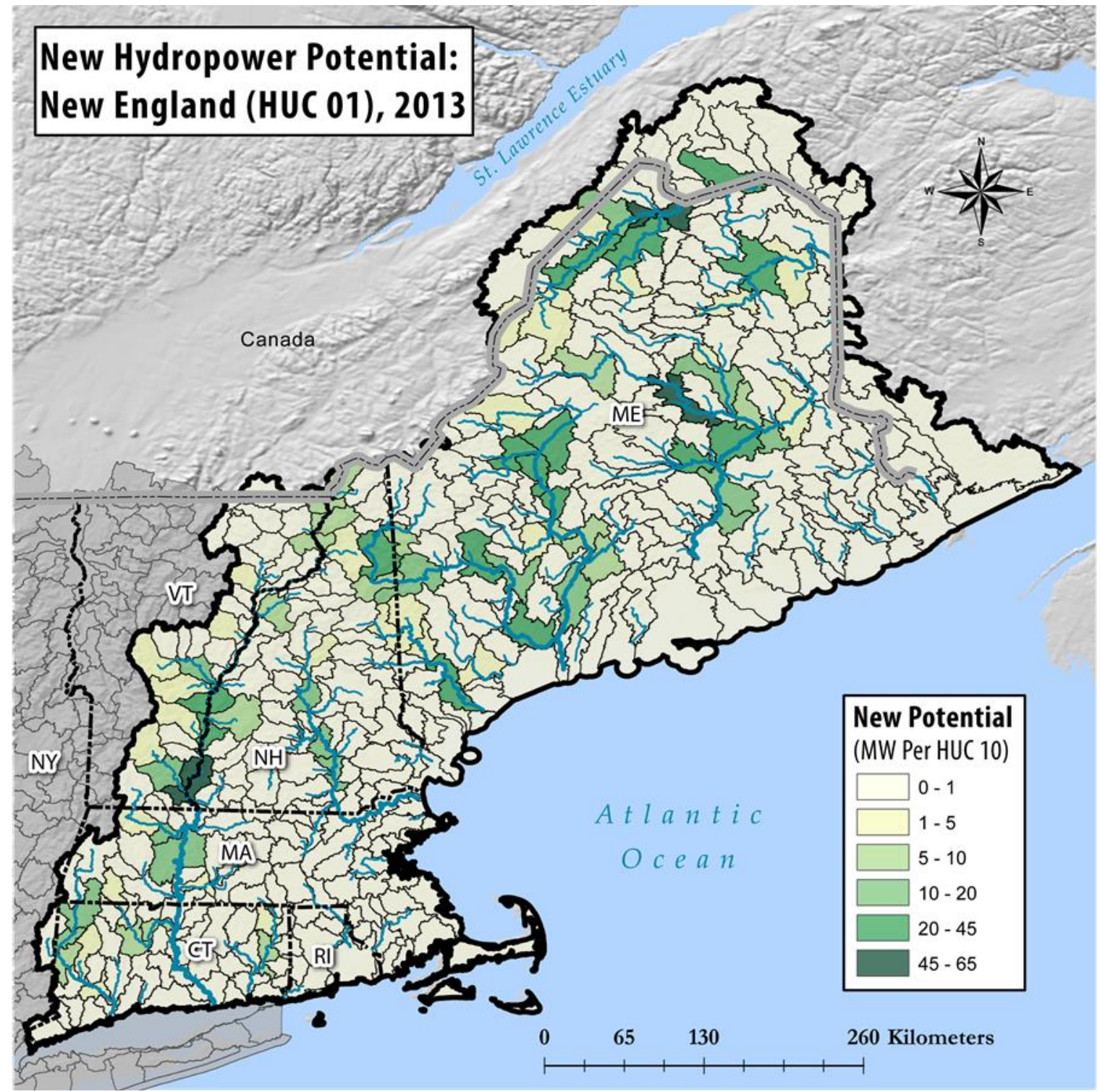

Figure 4.4. Potential new hydropower capacity in Region 1-New England (higher-energy-density stream-reaches with >1 MW per reach, aggregated to HUC10 watersheds for illustration).

\subsection{Environmental Characteristics}

Sixty-two native fish species are documented in Region 1. Six of those species fall under ESA listing or candidate listing status and include alewife (Alosa pseudoharengus), Atlantic salmon (Salmo salar), Atlantic sturgeon (Acipenser oxyrinchus), blueback herring (Alosa aestivalis), shortnose sturgeon (Scaphirhynchus platorynchus), and threespine stickleback (Gasterosteus aculeatus) (Appendix B). Two fish species fall under IUCN vulnerable status. ESA-listed or candidate fish species are found in all subregions. Potadromous and anadromous fish species (10 species total) are also documented in all subregions (Table 4.3). Two HUC08 subbasins, the Mattawmkeag and Upper Connecticut-Masco, are considered critical watersheds and have one and two mussel species at risk, respectively (Master et al., 1998). Only one mammal, the Canada 
lynx (Lynx canadensis), and one reptile, the Plymouth red-bellied turtle (Pseudemys rubriventris bangsi), have critical habitat designations in Region 1 (Appendix B).

Table 4.3. Summary of Environmental Variables at HUC04 Subregions within Region 1 (Stream-Reaches with Potential Capacity $>1 \mathrm{MW}$ )

\begin{tabular}{|c|c|c|c|c|c|c|c|c|}
\hline HUC04 HUC04 name & $\begin{array}{r}\text { \# critical } \\
\text { habitats }\end{array}$ & $\begin{array}{l}\text { \# Potad- } \\
\text { anad fish }\end{array}$ & $\begin{array}{r}\# \\
\text { ESA } \\
\text { fish } \\
\end{array}$ & $\begin{array}{r}\text { \# IUCN } \\
\text { fish }\end{array}$ & $\begin{array}{l}\text { \# recreation } \\
\text { locations }^{a}\end{array}$ & $\begin{array}{r}\% \\
\text { Protected } \\
\text { lands } \\
\end{array}$ & $\begin{array}{r}\text { Population } \\
\text { density } \\
\left(\text { ind } / \mathbf{k m}^{2}\right)\end{array}$ & $\begin{array}{r}\text { Freshwater } \\
\text { use } \\
\left(\mathbf{l} / \mathbf{d a y} \cdot \mathbf{k m}^{2}\right) \\
\end{array}$ \\
\hline 0101 St. John & 1 & 8 & 3 & 0 & $123 ; 25 ; 9$ & 21.54 & 4.28 & 64.41 \\
\hline 0102 Penobscot & 1 & 9 & 6 & 2 & $193 ; 61 ; 48$ & 21.26 & 4.88 & 103.69 \\
\hline 0103 Kennebec & 1 & 9 & 6 & 2 & $188 ; 41 ; 16$ & 5.76 & 3.38 & 189.12 \\
\hline 0104 Androscoggin & 0 & 7 & 5 & 1 & $120 ; 24 ; 26$ & 19.98 & 0.00 & 262.55 \\
\hline 0105 Maine Coastal & 0 & 9 & 5 & 1 & $287 ; 40 ; 14$ & 17.17 & 10.14 & 166.23 \\
\hline 0106 Saco & 0 & 7 & 5 & 1 & $249 ; 34 ; 21$ & 17.47 & 81.77 & 622.68 \\
\hline 0107 Merrimack & 0 & 6 & 4 & 2 & $349 ; 52 ; 21$ & 20.52 & 202.76 & $1,692.99$ \\
\hline 0108 Connecticut & 0 & 7 & 5 & 2 & $478 ; 107 ; 39$ & 25.19 & 88.13 & $1,680.16$ \\
\hline $\begin{array}{ll}0109 & \begin{array}{l}\text { Massachusetts-- } \\
\text { Rhode Island Coastal }\end{array} \\
\end{array}$ & 1 & 4 & 4 & 1 & $177 ; 4 ; 6$ & 20.23 & 387.51 & $1,779.37$ \\
\hline 0110 Connecticut Coastal & 0 & 4 & 4 & 2 & $156 ; 18 ; 14$ & 14.34 & 278.01 & $3,501.04$ \\
\hline 0111 St. Francois & 0 & 6 & 1 & 0 & $78 ; 2 ; 0$ & 19.27 & 12.95 & 85.17 \\
\hline
\end{tabular}

${ }^{a}$ Recreation locations refer to the number of boat-ramp and fishing access points, recreational boating, and waterfalls within each HUC04.

Over 7.5 million acres fall under protected land status in Region 1, almost 17\% of the total area. Protected land coverage is fairly uniform across this region (Table 4.3). Most protected lands are privately owned $(39 \%)$, followed by state $(29 \%)$, federal $(18 \%)$, local government $(6.9 \%)$, and nongovernmental agency $(6.1 \%)$ ownership. Federal lands are predominately owned by the U.S. Forestry Service (USFS) (14\%); state lands have mixed ownership among natural resource departments and state parks. City-owned lands account for $6.7 \%$ of protected lands. The Nature Conservancy owns 3.8\% of protected lands in Region 1. Region 1 includes 6 National Wild and Scenic Rivers. Twenty-one percent of protected lands fall under GAP status 1 and 2, and 71\% and $8 \%$ of lands fall under status 3 and 4, respectively. Approximately 1505 boat ramp locations and more than 930 freshwater fishing access areas are located in Region 1 (Figure 4.5). Waterfalls and recreational boating river sections are abundant, totaling 218 and 409 different locations, respectively.

Water use is below average in Region 1 compared with the entire United States (Appendix B). However, within the region, water use varies considerably, with the Merrimack, Connecticut, Massachusetts-Rhode Island, and Connecticut Coastal subbasins displaying the highest values (Table 4.3). On average, the highest water usage is public consumption, followed by thermoelectric usage (Appendix B). Water quality concerns are average for the region, with most concerns related to mercury contamination, toxins, dissolved oxygen issues, and pathogens (Figure 4.6 and Appendix B). 


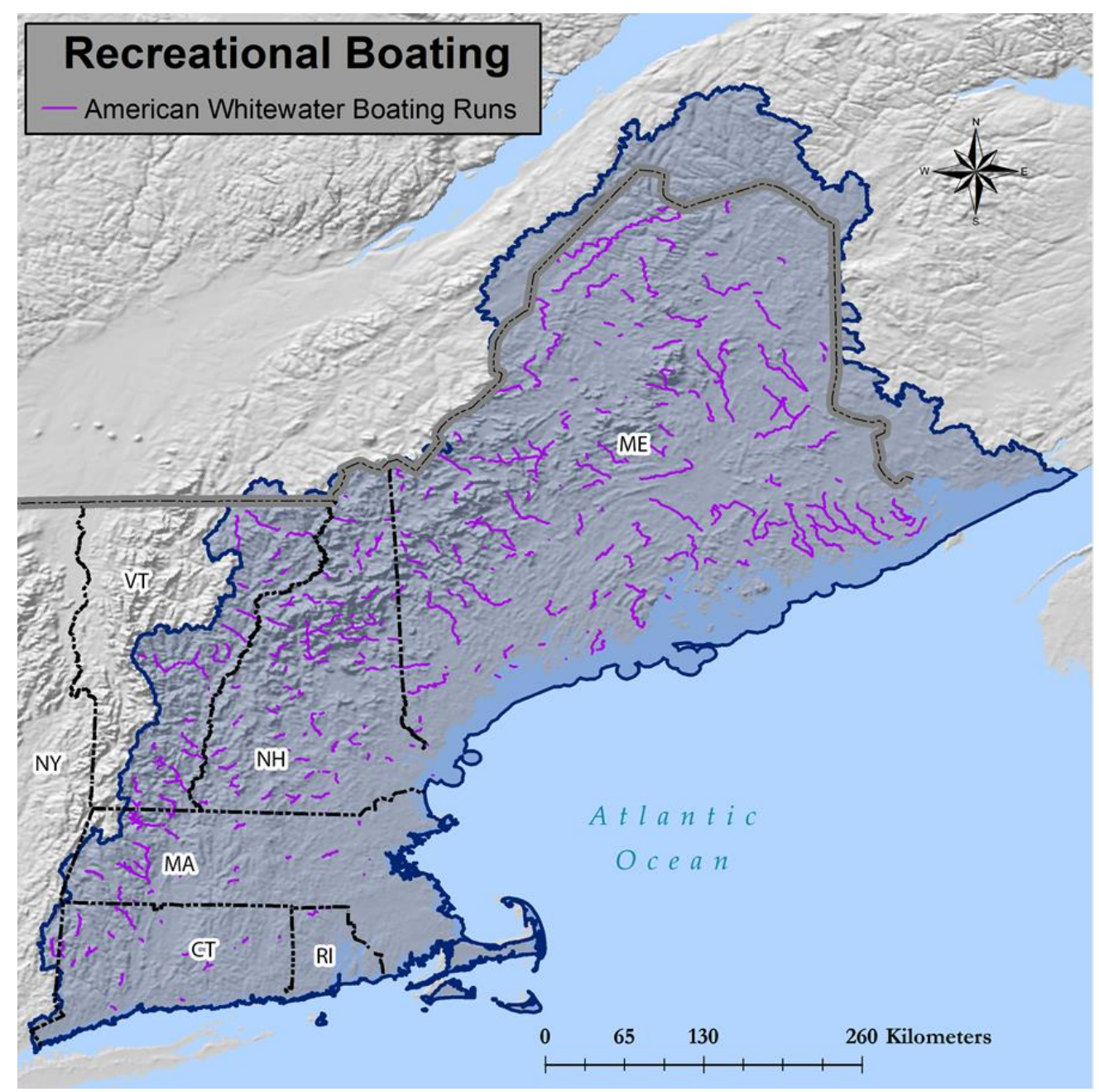

Figure 4.5. Whitewater boating runs in Region 1 .

Most of the 283 new stream-reaches (89\%) in Region 1 are located in HUC08 subbasins with at least one ESA-listed or candidate fish species (Figure 4.7). Critical habitats are present in the vicinity of $26 \%$ of new stream-reach locations. Protected lands are present at approximately $86 \%$ of new stream locations, with no sites intersecting national parks and 3.5\% of sites intersecting Wild and Scenic Rivers (Figure 4.5). Thirty-six percent of stream-reaches intersect at least one 303D listed waterbody. Recreational boating is present on most of the stream-reaches (80\%). Waterfalls, boat ramps, and fishing access locations are present at $36 \%, 48 \%$, and $20 \%$ of new stream-reach locations, respectively. Total freshwater use is broken into five different categories (low, moderate, moderate-to-high, high, and very high) based on percentiles for each region $(<0.2,0.2-0.4,0.4-0.6,0.6-0.8$, and $>0.8)$. 


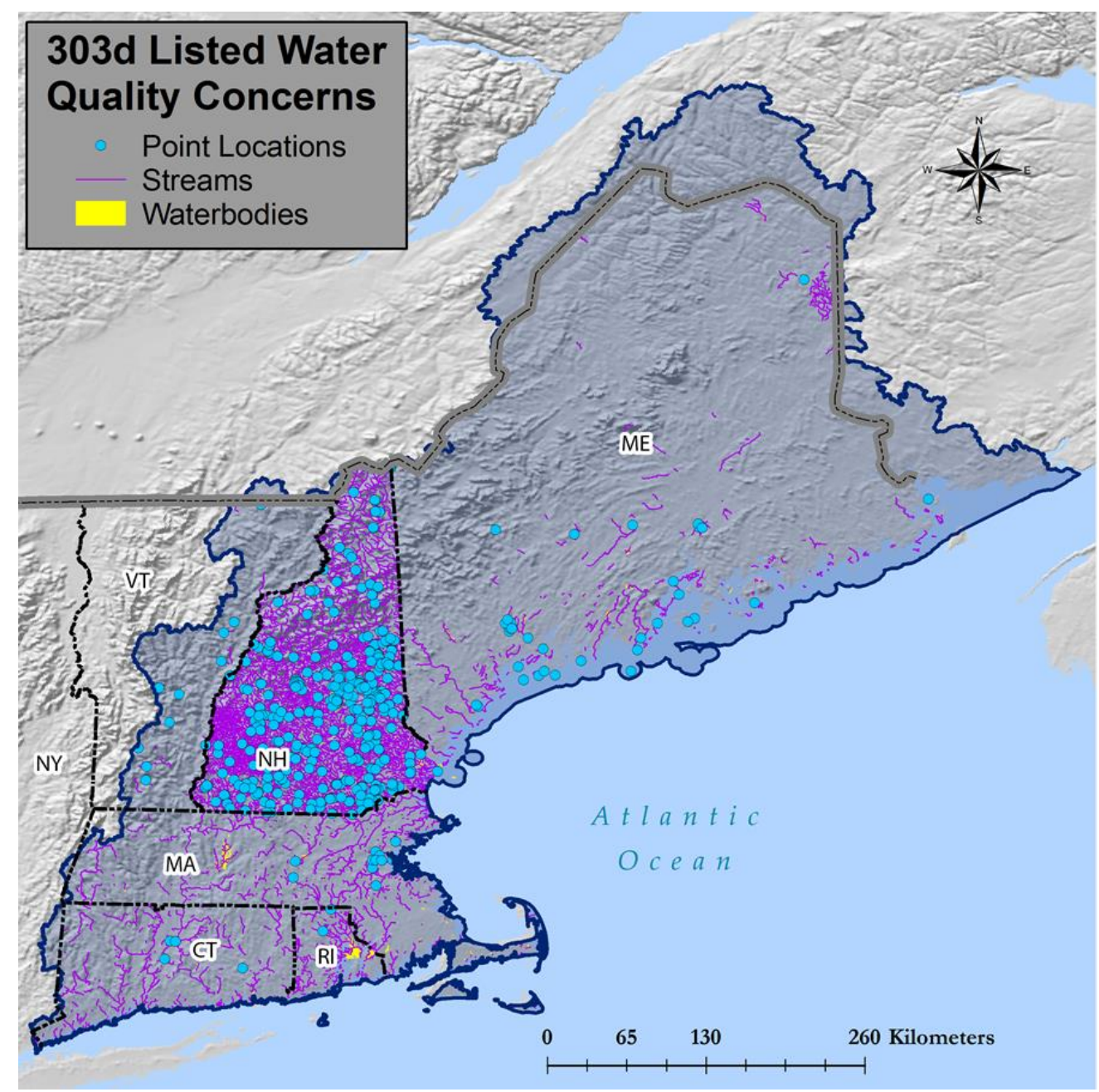

Figure 4.6. $303 \mathrm{~d}$ listed streams and waterbodies in Region 1.

\section{ESA Critical Habitats Number ESA Listed Fish National Park Lands}

Wild and Scenic Rivers

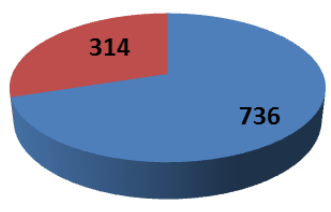

absent $\quad$ Present

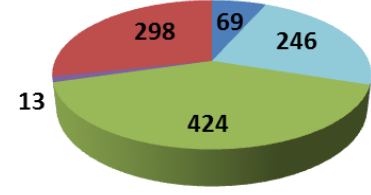

$\square 0 \square 1 \square 2 \square 3 \square>3$

\section{Water Quality Concern}

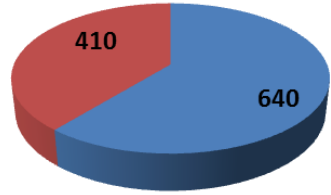

Absent Present

\section{Recreation Boating}

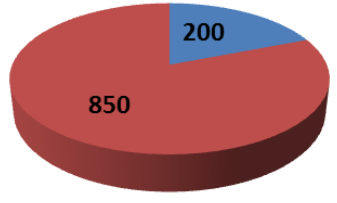

absent Present

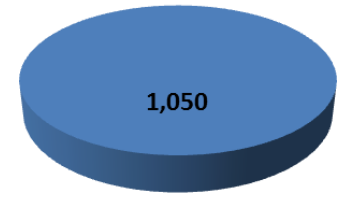

Absent Present

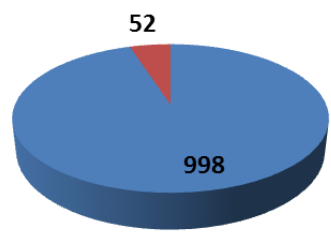

absent $\square$ Present

Water Use

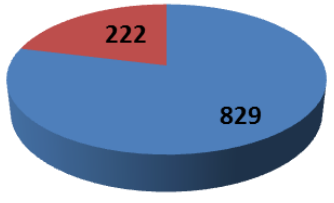

absent Present

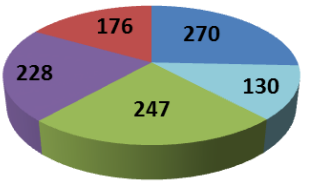

LOW

MODERATE

MODERATE-TO-HIGH - VERY HIGH

Figure 4.7. The potential capacity, in MW, associated with environmental attributes in Region $1-$ New England (stream-reaches with potential capacity $>1 \mathrm{MW}$ ). 


\section{REGION 2-MID-ATLANTIC}

\subsection{Summary of Findings}

Following NSD methodology (Hadjerioua et al., 2013), the potential capacity, annual generation, and mean capacity factors in the Mid-Atlantic Region are estimated and summarized in Table 5.1, for both larger $(>1 \mathrm{MW})$ and smaller ( $<1 \mathrm{MW})$ stream-reaches. For comparison, the year2011 nameplate capacity, 2002-2011 average annual generation, and capacity factor of existing hydropower facilities are also listed (NHAAP, 2013). The total undeveloped NSD capacity is $4.71 \mathrm{GW}$, around $219 \%$ of existing conventional hydropower nameplate capacity. In terms of energy, the total undeveloped NSD generation is $25.95 \mathrm{TWh} / \mathrm{year}$, around $332 \%$ of annual net generation from existing conventional hydropower plants. Given the run-of-river assumption, NSD stream-reaches have higher capacity factors, especially compared with other larger-storage peaking-operation projects in this region. More detailed topographical analysis and environmental attribution are conducted for larger (>1 MW) stream-reaches and discussed in Sections 5.3 and 5.4 .

Table 5.1. Summary of NSD Findings in Region 2-Mid-Atlantic

\begin{tabular}{l|r|r|r}
\hline & $\begin{array}{r}\text { Capacity } \\
(\mathbf{M W})\end{array}$ & $\begin{array}{r}\text { Generation } \\
(\mathbf{M W h})\end{array}$ & $\begin{array}{r}\text { Mean capacity } \\
\text { factor }\end{array}$ \\
\hline Potential in undeveloped stream-reaches $(>1 \mathrm{MW})$ & 3,043 & $16,711,000$ & $63 \%$ \\
\hline Potential in undeveloped stream-reaches $(<1 \mathrm{MW})$ & 1,667 & $9,234,000$ & $63 \%$ \\
\hline Existing hydropower - conventional hydro & 2,148 & $7,818,000$ & $42 \%$ \\
\hline Existing hydropower - pumped storage & 5,387 & & \\
\hline
\end{tabular}

\subsection{Background Hydrologic Setting}

The Mid-Atlantic Region encompasses approximately $297,200 \mathrm{~km}^{2}$ in the eastern United States. The region extends from Vermont to Virginia, covering Vermont, Massachusetts, New York, Pennsylvania, New Jersey, Delaware, Maryland, District of Columbia, West Virginia and Virginia. The region covers from the Adirondack mountainous region in the north to the Appalachian Plateau, covering a large part of central and western New York and Pennsylvania. The topography transitions from the Plateau to the central lowlands and Piedmont areas extending from extreme eastern New York down through central and eastern Virginia. The flat coastal region dominates New Jersey, Delaware, and the extreme eastern section of Virginia (CARA, 2013).

Several river systems are located in the Mid-Atlantic Region (Figure 5.1), including the Hudson, Manasquan, Delaware, Susquehanna, Pocomoke, Potomac, Pocomoke and James rivers, with a total length of 30,686 km (i.e., total length of streams with estimated discharge greater than $35 \mathrm{cfs}$ ). Metropolitan areas within the subregion include Albany (NY), Rochester (NY), Buffalo 
(NY), New York (NY), Pittsburg (PA), Philadelphia (PA), Baltimore (MD), Dover (DE), Washington D.C., and Richmond (VA). As shown in Figure 5.2, annual precipitation for the Mid-Atlantic Region ranges from 850 to $1450 \mathrm{~mm} /$ year and annual runoff from 300 to 800 $\mathrm{mm} /$ year. Most of the precipitation occurs in mid-summer and in early fall. Runoff is substantially lower during this period because of the abundance of vegetation and evapotranspiration in the region. The existing hydropower plants and major non-powered dams (Hadjerioua et al., 2012) are also shown in Figure 5.1. The region contains 187 hydropower dams and 65 major non-powered dams, with total storage capacities of around 14,479,616 and $3,815,575$ ac-ft, respectively.

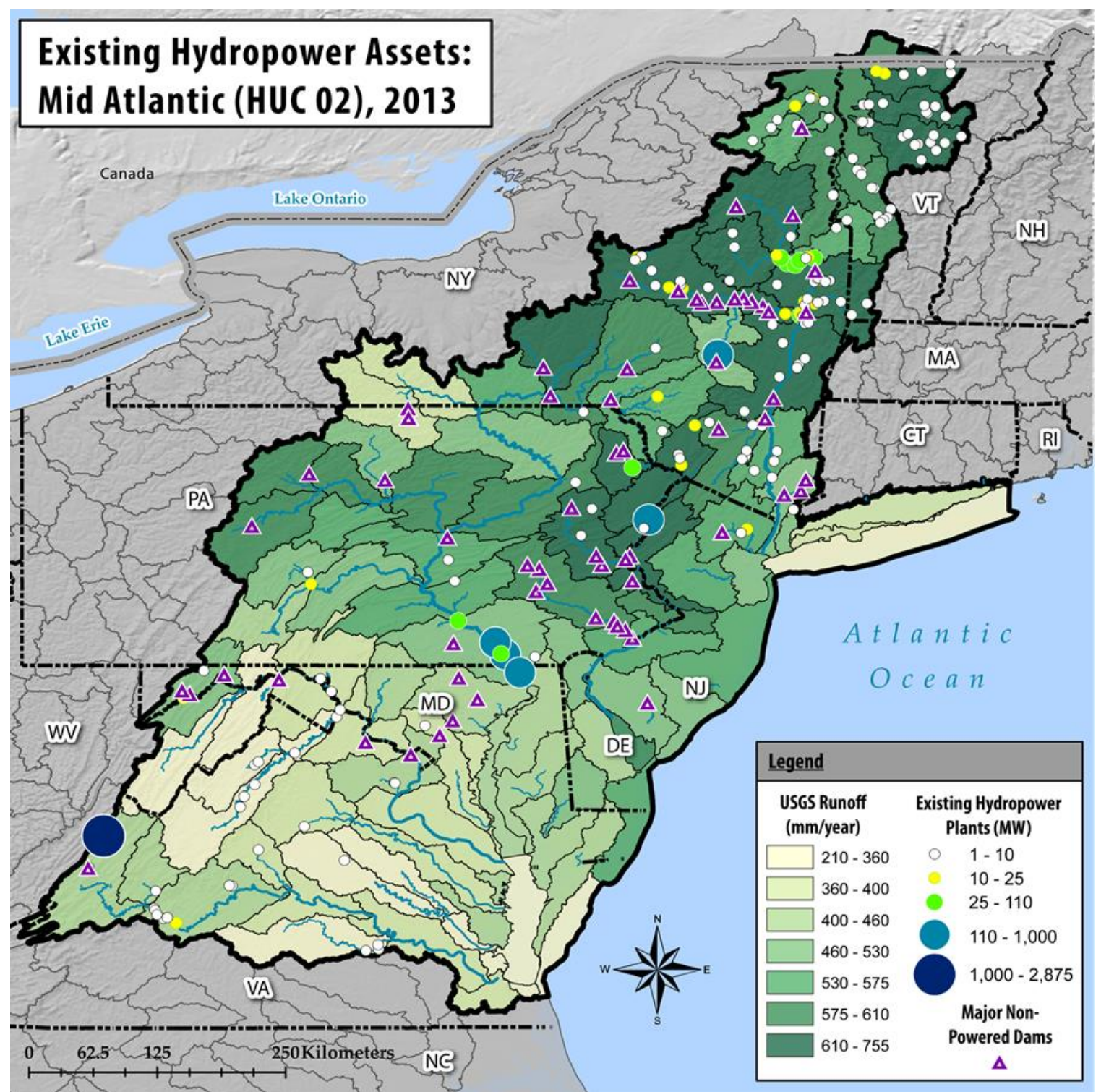

Figure 5.1. Locations of water control projects in Region 2-Mid-Atlantic. 


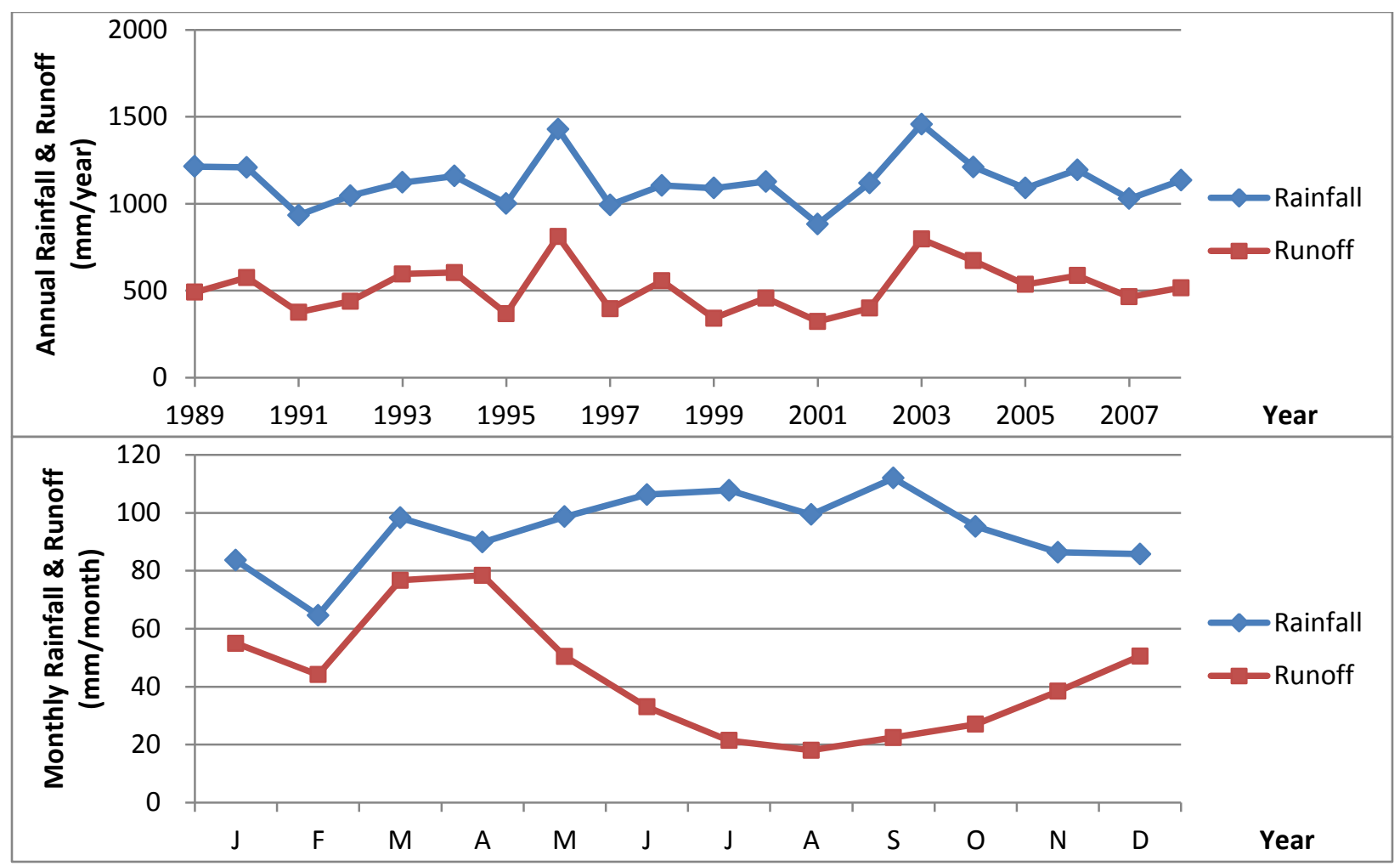

Figure 5.2. Annual and monthly rainfall and runoff of Region 2-Mid-Atlantic.

\subsection{Potential New Hydropower Resources}

A total of 580 stream-reaches of high energy density (with estimated potential capacity $>1 \mathrm{MW}$ per stream-reach) were identified in the Mid-Atlantic Region. The NSD results based on HUC04 subregions are summarized in Table 5.2. The highest hydropower potential is located in the Susquehanna subregion (HUC 0205), yielding almost 100\% more than the next-highest subregion, Delaware (HUC 0204). In the Susquehanna subregion, the Susquehanna and West Branch Susquehanna rivers contain the highest potential for hydropower, followed by the Juniata River.

Table 5.2. Summary of Potential New Hydropower Resources in Region 2-Mid-Atlantic (Stream-Reaches with Potential Capacity $>1 \mathrm{MW}$ )

\begin{tabular}{|c|c|c|c|c|c|c|c|c|}
\hline HUC04 & HUC04 name & $\begin{array}{r}\text { \# of } \\
\text { stream- } \\
\text { reaches }\end{array}$ & $\begin{array}{r}\text { Potential } \\
\text { capacity } \\
(\mathrm{MW})\end{array}$ & $\begin{array}{r}\text { Potential } \\
\text { energy } \\
(\mathrm{MWh})\end{array}$ & $\begin{array}{r}\text { Average } \\
\text { head } \\
(\mathbf{f t} / \text { reach })\end{array}$ & $\begin{array}{r}\text { Average } \\
\text { flow } \\
\text { (cfs/reach) }\end{array}$ & $\begin{array}{r}\text { Average } \\
\text { storage (ac- } \\
\text { ft/ reach) }\end{array}$ & $\begin{array}{r}\text { Average } \\
\text { residence } \\
\text { time (days) }\end{array}$ \\
\hline 0201 & Richelieu & 50 & 114.4 & 683,437 & 37.4 & 1,072 & 9,170 & 5.3 \\
\hline 0202 & Upper Hudson & 115 & 296.7 & $1,647,280$ & 25.4 & 1,799 & 3,142 & 2.6 \\
\hline 0203 & $\begin{array}{l}\text { Lower Hudson-Long } \\
\text { Island }\end{array}$ & - & - & - & - & - & - & - \\
\hline 0204 & Delaware & 113 & 632.8 & $3,693,852$ & 28.7 & 3,199 & 3,681 & 1.4 \\
\hline 0205 & Susquehanna & 129 & $1,261.9$ & $6,731,187$ & 35.2 & 4,199 & 17,852 & 8.1 \\
\hline 0206 & Upper Chesapeake & - & - & - & - & - & - & - \\
\hline 0207 & Potomac & 93 & 428.6 & $2,304,671$ & 26.7 & 2,636 & 5,181 & 1.7 \\
\hline 0208 & Lower Chesapeake & 80 & 308.7 & $1,650,646$ & 27.3 & 2,208 & 8,177 & 4.4 \\
\hline
\end{tabular}


The summary statistics of hydraulic head $\mathrm{H}_{\text {ref }}\left(\mathrm{ft}\right.$ ), design flow $\mathrm{Q}_{30}(\mathrm{cfs})$, potential capacity $\mathrm{P}_{\mathrm{NSD}}$ $(\mathrm{MW})$, inundated area $\mathrm{A}_{\mathrm{NSD}}(\mathrm{ac})$, storage $\mathrm{V}_{\mathrm{NSD}}$ (ac-ft), and residence time $\mathrm{T}_{\mathrm{NSD}}$ (day) are shown in Figure 5.3. The hydraulic head $\mathrm{H}_{\text {ref }}$ ranges from 0 to the 90th quantile of $50 \mathrm{ft}$ with a median of about $28 \mathrm{ft}$. The design flow $\mathrm{Q}_{30}$ ranges from a few hundred cfs to the 90th quantile of $6000 \mathrm{cfs}$ with a median of $1500 \mathrm{cfs}$. The potential capacity $\mathrm{P}_{\mathrm{NSD}}$ ranges from 1 to the 90th quantile of about $9 \mathrm{MW}$ with a median of about $4 \mathrm{MW}$. The inundated surface area $\mathrm{A}_{\mathrm{NSD}}$ ranges from 0 to the 90th quantile of 1100 acres with a median of 250 acres. This results in storage values $\mathrm{V}_{\mathrm{NSD}}$ ranging from 0 to the 90th quantile of 18,000 ac-ft with a median of about 3,000 ac-ft and very short residence times $\mathrm{T}_{\mathrm{NSD}}$ ranging from $<1$ day to the 90th quantile of 11 days with a median of $<1.5$ days. In general, the relatively small inundation areas and storage volumes paired with the short retention times for this region are characteristic of run-of-river type hydro facilities. The results of $>1 \mathrm{MW}$ stream-reach potential are illustrated in Figure 5.4, with potential capacity (MW) aggregated to the HUC08 subbasins. The higher-potential-capacity sites are generally located on the larger rivers in the Appalachian Plateau and Ridge and Valley region of eastern Pennsylvania.

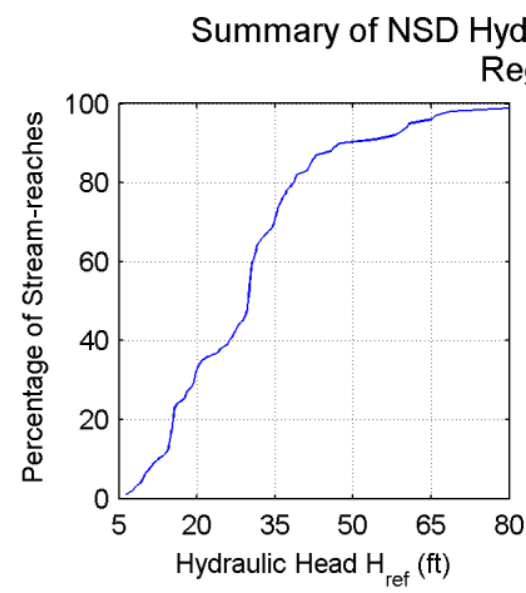

Region 2: 580 stream-reaches, $3042 \mathrm{MW}$
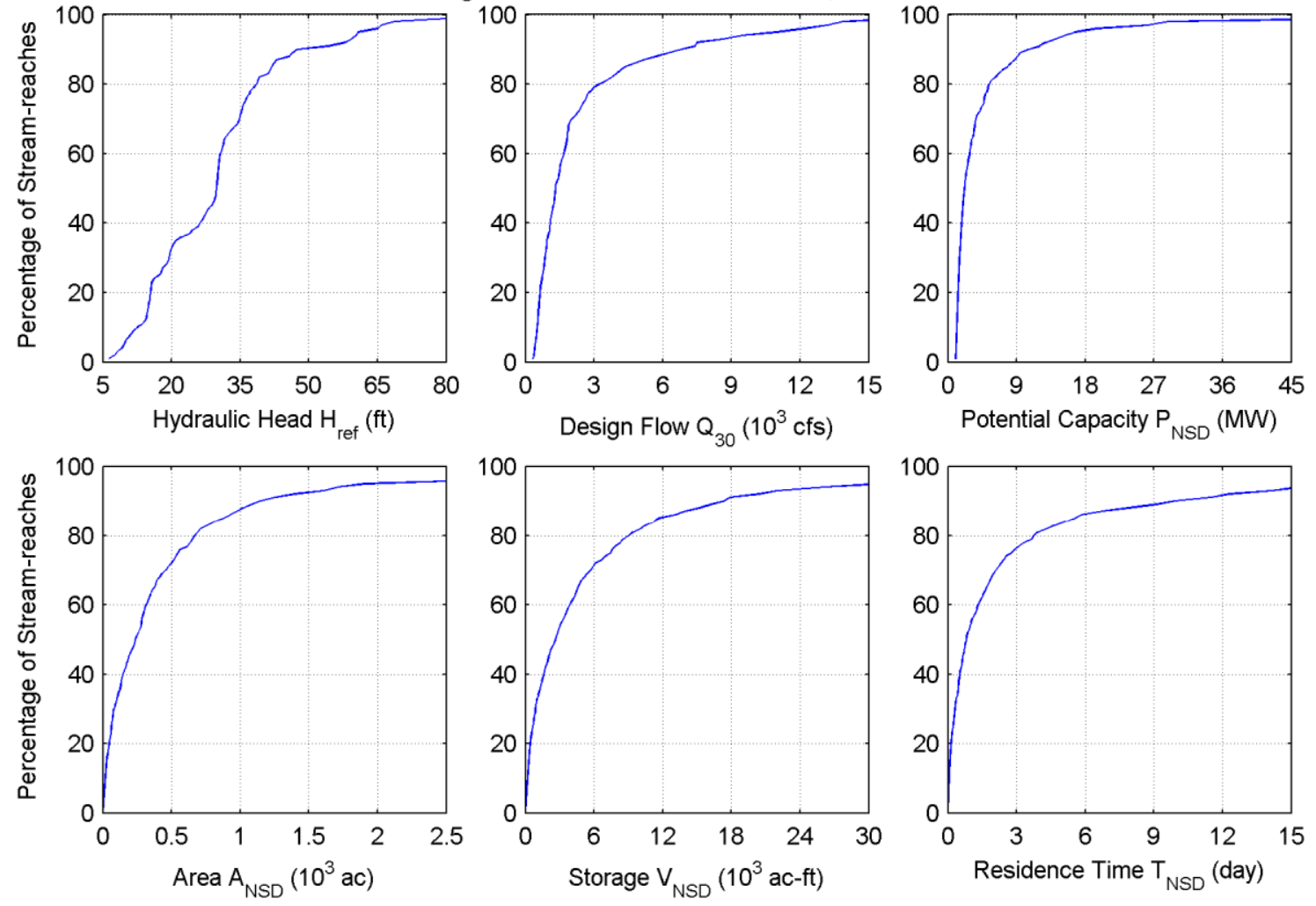

Figure 5.3. Cumulative distributions of hydraulic head $H_{\text {ref }}$, design flow $Q_{30}$, potential capacity $P_{N S D}$, inundated area $\mathrm{A}_{\mathrm{NSD}}$, storage $\mathrm{V}_{\mathrm{NSD}}$, and residence time $\mathrm{T}_{\mathrm{NSD}}$ in Region 2-Mid-Atlantic. 


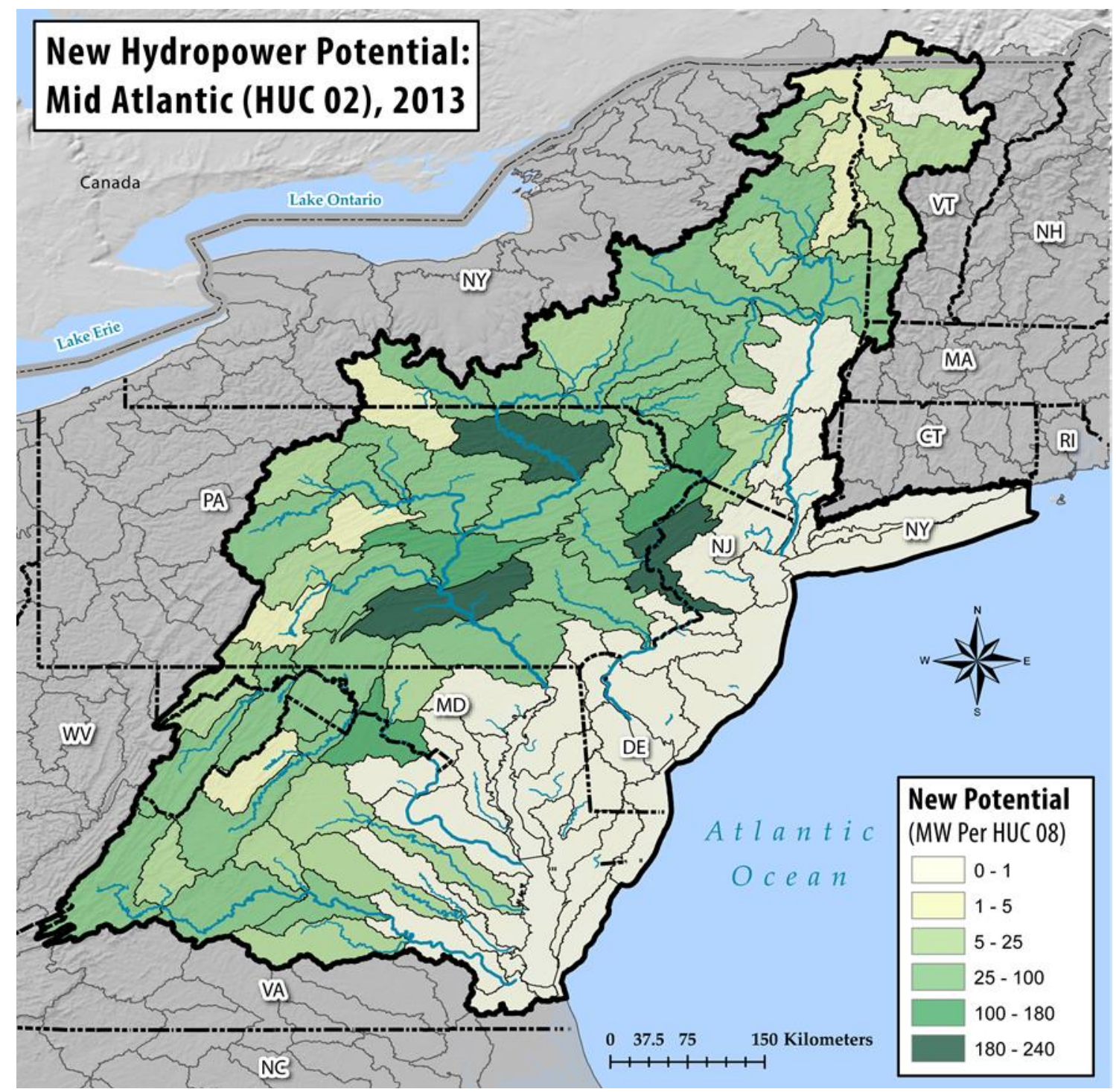

Figure 5.4. Potential new hydropower capacity in Region 2-Mid-Atlantic (higher-energy-density stream-reaches with >1 MW per reach, aggregated to HUC08 subbasins for illustration).

\subsection{Environmental Characteristics}

Region 2 is home to 127 native fish species, 7 of which fall under an ESA category or IUCN vulnerable category (Appendix B). Alewife, Atlantic sturgeon, blueback herring, Maryland darter (Etheostoma sellare, potentially extinct), shortnose sturgeon, and threespine stickleback fall under ESA categories. Orangefin madtom (Noturus gilberti), although not falling under an ESA category, is classified as "vulnerable" under IUCN. Eleven fish species in Region 2 are considered potadromous or anadromous. The Chesapeake Bay drainage has at least four fish species and eight mussel species considered "at risk" (Master et al. 1998). Two species, the Maryland darter and the Virginia big-eared bat (Corynorhinus townsendii virginianus), have critical habitat designations in Region 2. 
Approximately 13.5 million acres of protected lands are located in Region 2 (20\% of total area); most are state owned (55\%), followed by federally (25\%), and privately owned (10\%). State lands include departments of natural resources (26\%), fish and wildlife lands (23\%), and state parks (3.5\%). Protected lands owned by federal entities primarily include USFS (14\%), National Park Service (NPS) (4.3\%), and Department of Defense (DOD) (3.9\%). Most protected lands fall under GAP status 3 (55\%), followed by 2 (22\%), 3 (14\%), and 1 (14\%) status lands. Region 2 includes four national parkways, including a section of the Blue Ridge Parkway, and four National Wild and Scenic Rivers, including sections of the Delaware, Great Egg Harbor, and Maurice rivers. Region 2 also includes more than 1160 boat ramp locations (Figure 5.5), 741 freshwater fishing access locations (Figure 5.5), 175 waterfalls, and 576 recreational boating river sections.

Compared with other U.S. regions, water use is the second highest in Region 2 (Appendix B), with the highest usage occurring in the Lower Hudson-Long Island Subbasin (Table 5.3). The vast majority of water usage is a result of thermoelectric cooling, followed by public and domestic consumption (Appendix B). Similarly, water-quality concerns were also second highest in Region 2; toxins and dissolved oxygen were the main issues (Figure 5.6 and Appendix B).

Table 5.3. Summary of Environmental Variables at HUC04 Subregions within Region 2 (Stream-Reaches with Potential Capacity $>1 \mathrm{MW}$ )

\begin{tabular}{|c|c|c|c|c|c|c|c|c|}
\hline HUC04 HUC04 name & $\begin{array}{r}\text { \# Critical } \\
\text { habitats }\end{array}$ & $\begin{array}{l}\text { \# Potad- } \\
\text { anad fish }\end{array}$ & $\begin{array}{r}\# \\
\text { ESA } \\
\text { fish }\end{array}$ & $\begin{array}{r}\text { \# IUCN } \\
\text { fish }\end{array}$ & $\begin{array}{r}\text { \# Recreation } \\
\text { locations }\end{array}$ & $\begin{array}{r}\text { Protected } \\
\text { lands } \\
(\%)\end{array}$ & $\begin{array}{r}\text { Population } \\
\text { density } \\
\left(\text { ind } / \mathbf{k m}^{2}\right)\end{array}$ & $\begin{array}{r}\text { Freshwater } \\
\text { use } \\
\left(1 / \text { day } / \mathrm{km}^{2}\right)\end{array}$ \\
\hline 0201 Richelieu & 0 & 10 & 0 & 1 & $278 ; 74 ; 36$ & 23.42 & 11.47 & 180.24 \\
\hline 0202 Upper Hudson & 0 & 6 & 5 & 2 & $136 ; 142 ; 42$ & 23.43 & 66.85 & $2,410.01$ \\
\hline $\begin{array}{l}\text { Lower Hudson-Long } \\
0203 \text { Island }\end{array}$ & 0 & 4 & 5 & 2 & $141 ; 18 ; 3$ & 16.09 & $10,401.12$ & $15,736.37$ \\
\hline 0204 Delaware & 0 & 6 & 5 & 2 & $328 ; 71 ; 45$ & 19.99 & 215.59 & $4,392.77$ \\
\hline 0205 Susquehanna & 1 & 6 & 4 & 2 & $295 ; 68 ; 52$ & 17.45 & 51.40 & $1,761.39$ \\
\hline 0206 Upper Chesapeake & 1 & 3 & 4 & 2 & $110 ; 20 ; 1$ & 15.19 & 249.87 & $1,315.72$ \\
\hline 0207 Potomac & 1 & 3 & 4 & 2 & $290 ; 155 ; 15$ & 18.37 & 141.21 & $3,023.86$ \\
\hline 0208 Lower Chesapeake & $\overline{0}$ & 3 & 5 & 3 & $431 ; 102 ; 17$ & 17.26 & 75.53 & $3,031.18$ \\
\hline
\end{tabular}

${ }^{a}$ Recreation locations refer to the number of boat-ramp and fishing access points, recreational boating, and waterfalls within each HUC04 subregion. 


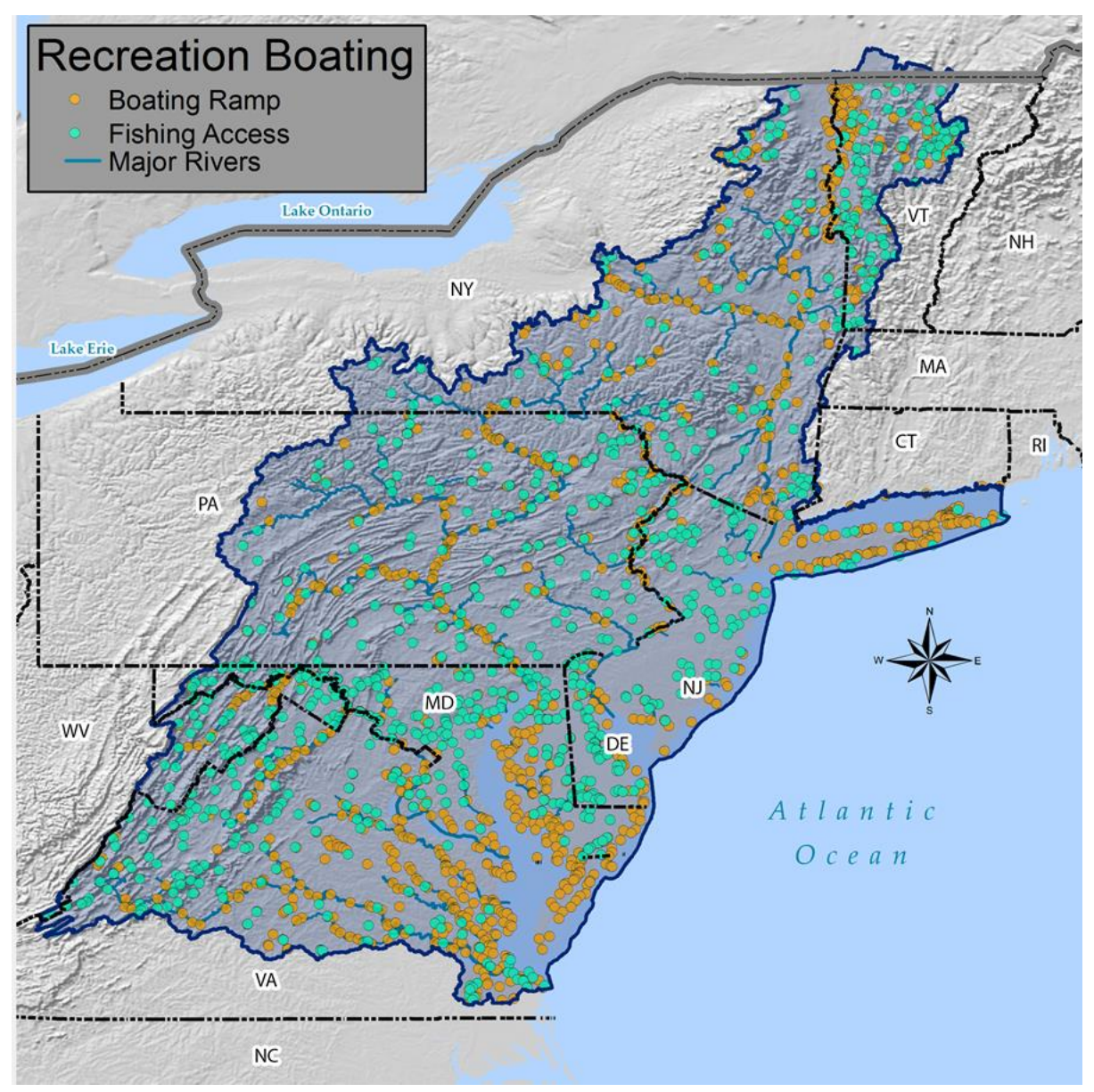

Figure 5.5. Boat ramp and fishing access areas in Region 2.

Only $22 \%$ of new stream-reaches (130 of 580 reaches) in Region 2 are located within HUC08 subbasins with at least one ESA-listed or candidate fish species present (Figure 5.7). Eight new stream-reaches, with a total of $9 \mathrm{MW}$, overlap with designated critical habitats. Almost $95 \%$ of stream-reaches intersect protected lands; however, very few stream-reaches intersect national parks (18 reaches) and Wild and Scenic Rivers (44 reaches). Water quality concerns are prevalent, being present at 378 stream-reaches. Recreational boating is also present at most stream-reaches (74\%); boat ramp and fishing access locations are present in fewer reaches (47\% and $27 \%$, respectively). Almost $42 \%$ of stream-reaches have high or very high water use estimates (>60 percentile for Region 2). 


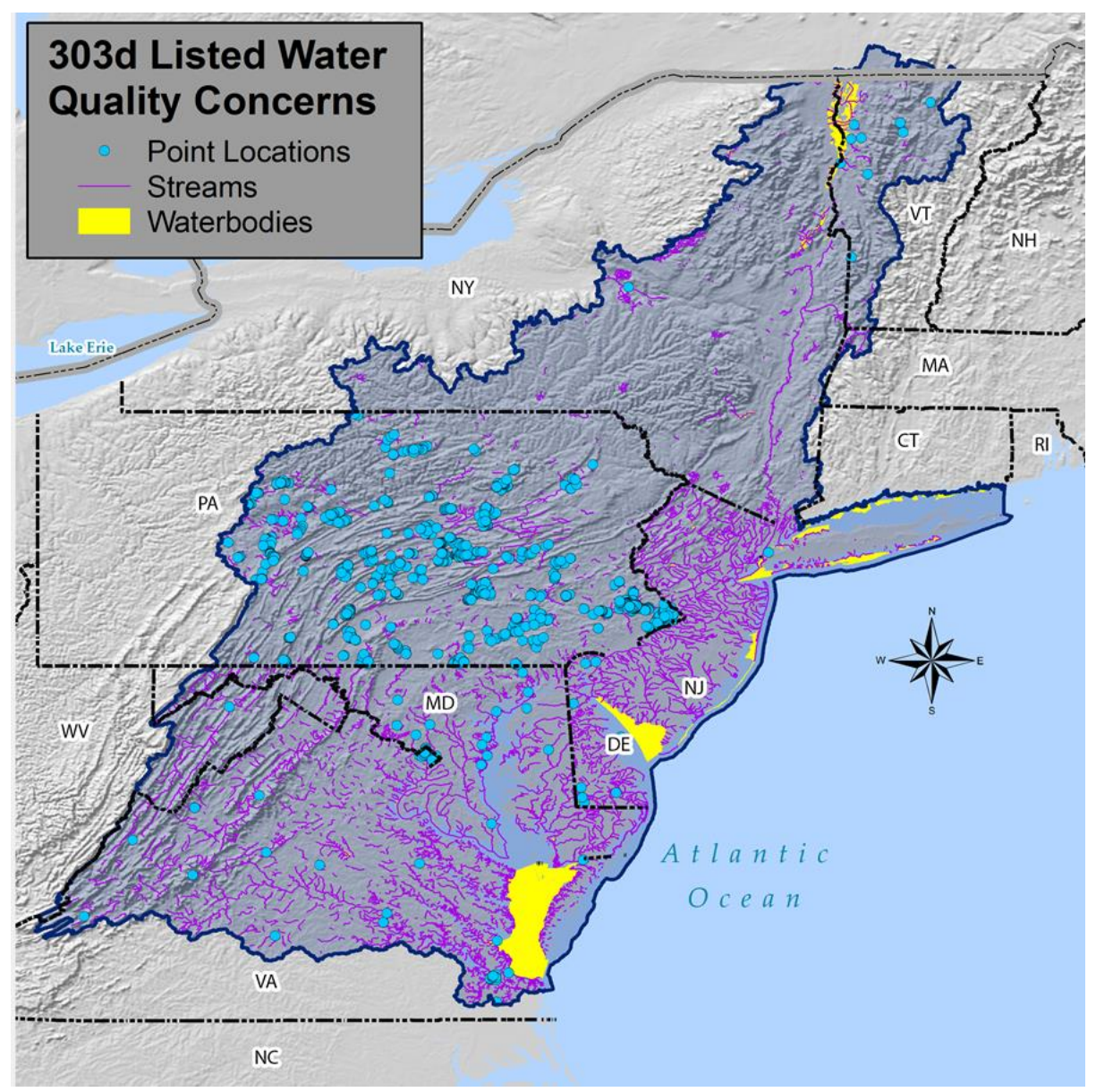

Figure 5.6. 303d listed streams and waterbodies in Region 2.

\section{ESA Critical Habitats}

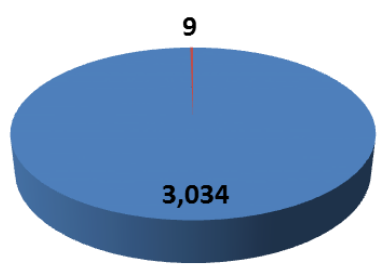

absent Present
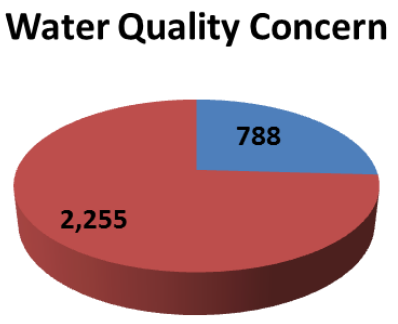

absent Present
Number ESA Listed Fish

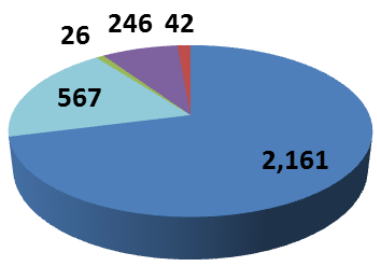

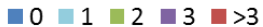
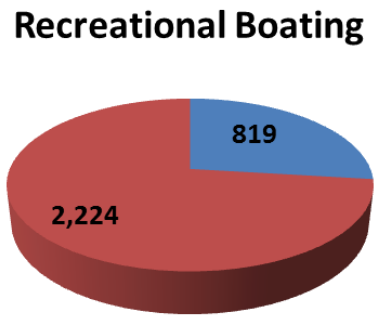

absent Present
National Park Lands

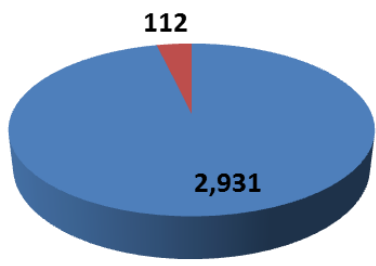

Absent Present

Fishing Access Areas

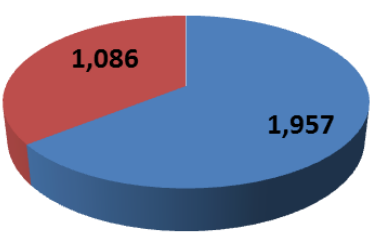

absent Present
Wild and Scenic Rivers

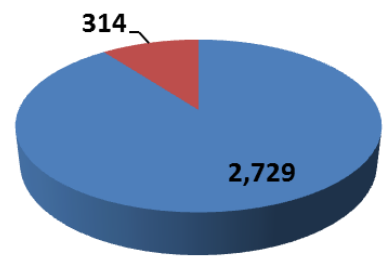

absent Present

Water Use

236

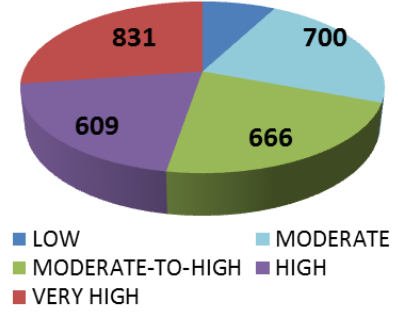

Figure 5.7. The potential capacity, in $\mathrm{MW}$, associated with environmental attributes in Region 2 -Mid-Atlantic (stream-reaches with potential capacity $>1 \mathrm{MW}$ ). 


\section{REGION 3-SOUTH ATLANTIC-GULF}

\subsection{Summary of Findings}

Following NSD methodology (Hadjerioua et al., 2013), the potential capacity, annual generation and mean capacity factors in the South Atlantic-Gulf Region are estimated and summarized in Table 6.1 for both larger ( $>1 \mathrm{MW})$ and smaller $(<1 \mathrm{MW})$ stream-reaches. For comparison, the year-2011 nameplate capacity, 2002-2011 average annual generation, and capacity factor of existing hydropower facilities are also listed (NHAAP, 2013). The total undeveloped NSD capacity is $2.56 \mathrm{GW}$, around $35 \%$ of existing conventional hydropower nameplate capacity. In terms of energy, the total undeveloped NSD generation is $14.21 \mathrm{TWh} / \mathrm{year}$, around $106 \%$ of annual net generation from existing conventional hydropower plants. Given the run-of-river assumption, NSD stream-reaches have higher capacity factors, especially compared with other larger-storage peaking-operation projects in this region. More detailed topographical analysis and environmental attribution are conducted for larger ( $>1 \mathrm{MW})$ stream-reaches and discussed in Sections 6.3 and 6.4 .

Table 6.1. Summary of NSD Findings in Region 3 - South Atlantic-Gulf

\begin{tabular}{l|r|r|r}
\hline & $\begin{array}{r}\text { Capacity } \\
(\mathbf{M W})\end{array}$ & $\begin{array}{r}\text { Generation } \\
(\mathbf{M W h})\end{array}$ & $\begin{array}{r}\text { Mean capacity } \\
\text { factor }\end{array}$ \\
\hline Potential in undeveloped stream-reaches $(>1 \mathrm{MW})$ & 1,389 & $7,785,000$ & $64 \%$ \\
\hline Potential in undeveloped stream-reaches $(<1 \mathrm{MW})$ & 1,172 & $6,420,000$ & $63 \%$ \\
\hline Existing hydropower-conventional hydro & 7,265 & $13,351,000$ & $21 \%$ \\
\hline Existing hydropower-pumped storage & 4,070 & & \\
\hline
\end{tabular}

\subsection{Background Hydrologic Setting}

The South Atlantic-Gulf Region encompasses approximately $722,476 \mathrm{~km}^{2}$ in the southeastern United States. The region is divided into two distinct geological sections by the fall line, which delineates the Coastal Plain (Florida, eastern Mississippi, southern parts of Alabama, Georgia, South and North Carolina, and a small part of Louisiana and Virginia) and parts of the Appalachian Highlands (northern parts of Alabama, Georgia, South and North Carolina, and a small part of Tennessee). The coastal plain consists of consolidated and semiconsolidated limestone, clay, and gravel and soft unconsolidated sand. This area contains the most productive groundwater because of its highly permeable clastic and limestone aquifers. The Appalachian Highlands area consists of hard consolidated rock that yields less groundwater flow. The groundwater outflow supports base flow for the streams in the region. For the Coastal Plain, base flow conservatively averages about 55\% of the total streamflow. For the Appalachian Highlands, base flow conservatively averages about $40 \%$ of the streamflow (Cederstrom et al., 1979).

Several river systems are located in the South Atlantic-Gulf Region (Figure 6.1), including the Roanoke, Neuse, Cape Fear, Pee Dee, Santee, Savannah, Altamaha, St. Johns, Caloosahatchee, Peace, Kissimmee, Withlacoochee, Aucilla, Suwannee, Ochlockonee, Apalachicola, Escambia, 
Choctawhatchee, Alabama, Coosa, Tallapoosa, Tombigbee, Black Warrior, and Pearl rivers, with a total length of 30,686 km (i.e., total length of streams with estimated discharge of more than 35 $\mathrm{cfs})$. Metropolitan areas within the region include Birmingham (AL), Montgomery (AL), Atlanta (GA), Albany (GA), Columbus (GA), Macon(GA), Savannah (GA), Thomasville (GA), Tallahassee (FL), Gainesville (FL), Jacksonville (FL), Tampa (FL), Orlando (FL), Fort Lauderdale (FL), Charleston (SC), Wilmington (NC), and Charlotte (NC), as well as some very small portions of southern Virginia. As shown in Figure 6.2, annual precipitation for the South Atlantic-Gulf region Ranges from 1000 to $1600 \mathrm{~mm} /$ year and annual runoff from 200 to 600 $\mathrm{mm} / \mathrm{year}$. Most of the precipitation occurs from late spring through early fall.

The existing hydropower plants and major non-powered dams (Hadjerioua et al., 2012) are also shown in Figure 6.1. The regions contain 149 hydropower dams and 61 major non-powered dams with storage capacities of about 64,345,241 ac-ft and 22,322,719 ac-ft, respectively.

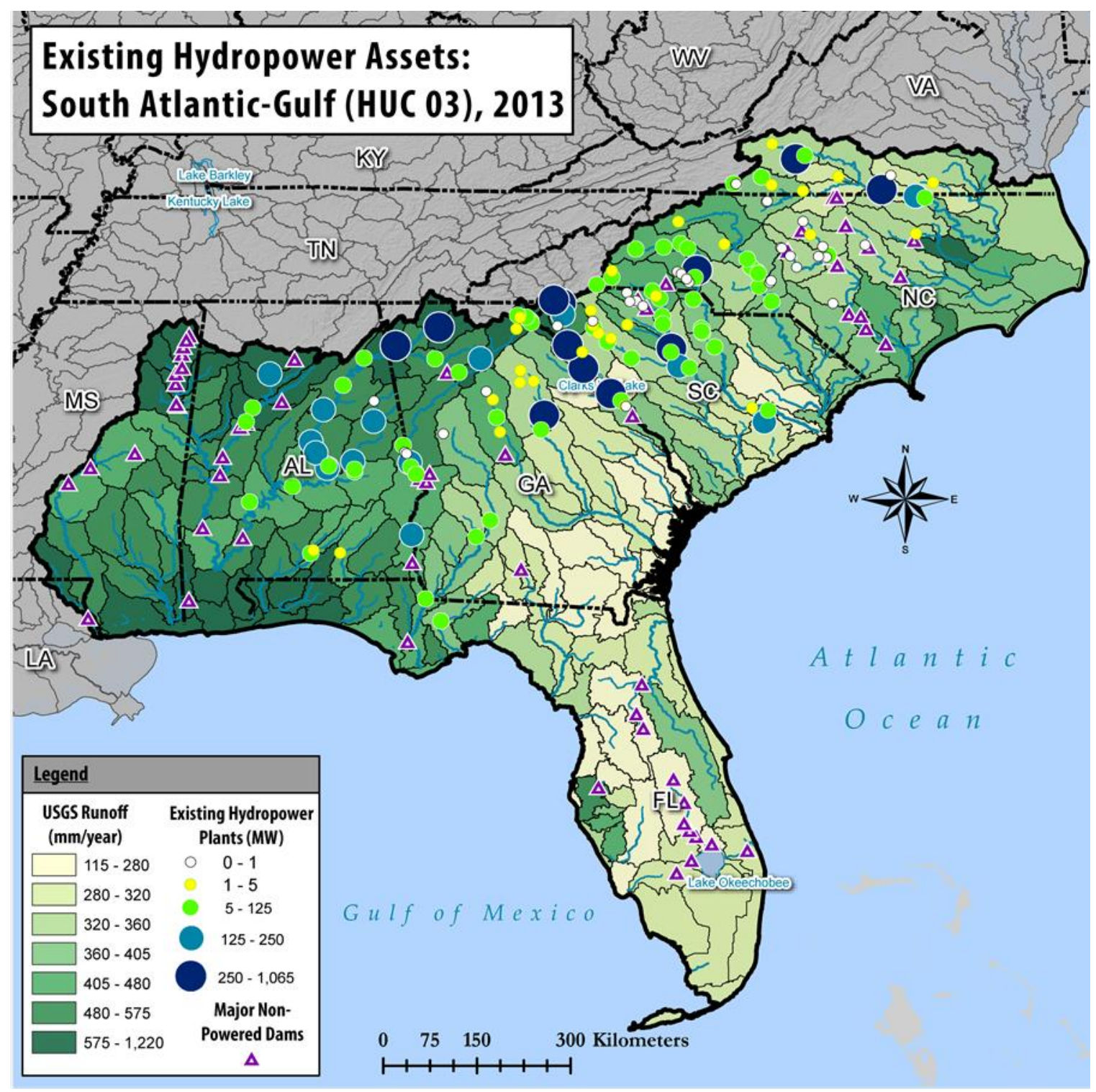

Figure 6.1. Locations of water control projects in Region 3-South Atlantic-Gulf. 


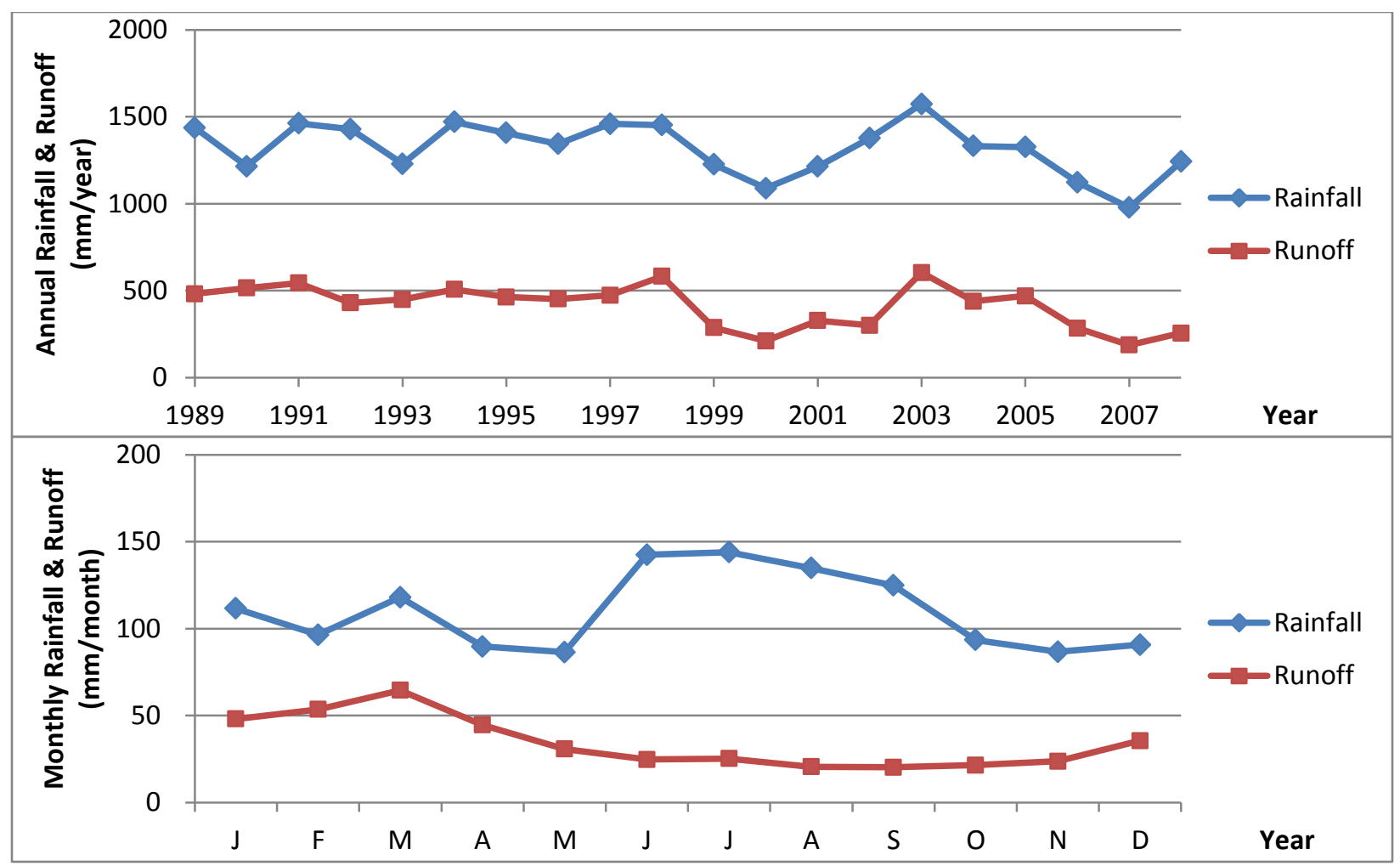

Figure 6.2. Annual and monthly rainfall and runoff of Region 3-South Atlantic-Gulf.

\subsection{Potential New Hydropower Resources}

A total of 393 stream-reaches of high energy density (with estimated potential capacity >1 MW per stream-reach) were identified in South Atlantic-Gulf Region. The NSD results based on HUC04 subregions are summarized in Table 6.2. The highest hydropower potentials are located in the Apalachicola and Alabama Subregions (HUC 0313 and 0315). In the Alabama Subregion, the highest hydropower potential is found in the Alabama, Tallapoosa, and Coosa rivers. In the Apalachicola Subregion, the highest hydropower potential is found in the Apalachicola and Chattahoochee rivers.

The summary statistics of hydraulic head $\mathrm{H}_{\mathrm{ref}}(\mathrm{ft})$, design flow $\mathrm{Q}_{30}(\mathrm{cfs})$, potential capacity $\mathrm{P}_{\mathrm{NSD}}$ $(\mathrm{MW})$, inundated area $\mathrm{A}_{\mathrm{NSD}}(\mathrm{ac})$, storage $\mathrm{V}_{\mathrm{NSD}}(\mathrm{ac}-\mathrm{ft})$, and residence time $\mathrm{T}_{\mathrm{NSD}}$ (day) are shown in Figure 6.3. The hydraulic head $\mathrm{H}_{\text {ref }}$ ranges from 5 to the 90th quantile of $40 \mathrm{ft}$ with a median of $22 \mathrm{ft}$, suggesting that many of the potential stream-reaches will require low-head hydropower technologies. The design flow $\mathrm{Q}_{30}$ ranges from 400 to $6000 \mathrm{cfs}$ with a median of about $1200 \mathrm{cfs}$. The potential capacity $\mathrm{P}_{\mathrm{NSD}}$ ranges from 1 to the 90th quantile of about $7 \mathrm{MW}$ with a median of about $2 \mathrm{MW}$. The inundated surface area $\mathrm{A}_{\mathrm{NSD}}$ ranges from 0 to the 90th quantile of 6000 ac with a median of $1000 \mathrm{ac}$. This results in storage values $\mathrm{V}_{\text {NSD }}$ ranging from 0 to the 90th quantile of 59,000 ac-ft with a median of about 10,000 ac-ft and very short residence times $\mathrm{T}_{\mathrm{NSD}}$ ranging from $<1$ day to the 90th quantile of 25 days with a median of about 2 days. In general, the relatively small inundation areas and storage volumes paired with the short retention times for this region are characteristic of run-of-river type hydro facilities. However, there are some sites that are characteristic of reservoir-storage type hydro projects but make up only a small 
Table 6.2. Summary of Potential New Hydropower Resources in Region 3-South Atlantic-Gulf (Stream-Reaches with Potential Capacity $>1 \mathrm{MW}$ )

\begin{tabular}{|c|c|c|c|c|c|c|c|c|}
\hline HUC04 & HUC04 name & $\begin{array}{r}\text { \# of } \\
\text { stream- } \\
\text { reaches }\end{array}$ & $\begin{array}{r}\text { Potential } \\
\text { capacity } \\
(\mathrm{MW})\end{array}$ & $\begin{array}{r}\text { Potential } \\
\text { energy } \\
(\mathrm{MWh}) \\
\end{array}$ & $\begin{array}{r}\begin{array}{r}\text { Average } \\
\text { head }\end{array} \\
(\mathrm{ft} / \mathrm{reach})\end{array}$ & $\begin{array}{r}\text { Average } \\
\text { flow } \\
\text { (cfs/reach) }\end{array}$ & $\begin{array}{r}\text { Average } \\
\text { storage (ac- } \\
\text { ft/reach) }\end{array}$ & $\begin{array}{r}\text { Average } \\
\text { residence } \\
\text { time (days) }\end{array}$ \\
\hline 0301 & Chowan-Roanoke & 29 & 100.3 & 594,149 & 29.3 & 2,525 & 22,748 & 16.1 \\
\hline 0302 & Neuse-Pamlico & 7 & 20.2 & 106,414 & 24.2 & 1,622 & 47,561 & 13.4 \\
\hline 0303 & Cape Fear & 15 & 58.1 & 296,619 & 30.1 & 2,296 & 11,805 & 5.5 \\
\hline 0304 & Pee Dee & 32 & 132.1 & 771,744 & 39.1 & 2,393 & 30,246 & 27.3 \\
\hline 0305 & Edisto-Santee & 41 & 166.6 & 993,938 & 32.8 & 2,553 & 29,621 & 14.9 \\
\hline 0306 & Ogeechee-Savannah & 29 & 78.0 & 475,897 & 31.2 & 1,798 & 5,286 & 3.6 \\
\hline 0307 & Altamaha-St. Marys & 22 & 69.8 & 383,546 & 12.5 & 3,569 & 12,950 & 2.7 \\
\hline 0308 & St. Johns & - & - & - & - & - & - & - \\
\hline 0309 & Southern Florida & - & - & - & - & - & - & - \\
\hline 0310 & Peace-Tampa Bay & - & - & - & - & - & - & - \\
\hline 0311 & Suwannee & 10 & 24.1 & 112,830 & 14.8 & 2,652 & 8,238 & 3.6 \\
\hline 0312 & Ochlockonee & 3 & 4.0 & 18,833 & 15.9 & 1,327 & 23,486 & 13.4 \\
\hline 0313 & Apalachicola & 48 & 214.5 & $1,295,550$ & 17.6 & 3,538 & 12,435 & 1.6 \\
\hline 0314 & $\begin{array}{l}\text { Choctawhatchee- } \\
\text { Escambia }\end{array}$ & 23 & 58.9 & 329,940 & 18.8 & 2,131 & 31,294 & 6.4 \\
\hline 0315 & Alabama & 44 & 206.1 & $1,154,046$ & 27.5 & 3,088 & 21,546 & 4.8 \\
\hline 0316 & Mobile-Tombigbee & 35 & 89.9 & 442,585 & 23.7 & 1,943 & 17,289 & 8.4 \\
\hline 0317 & Pascagoula & 27 & 72.7 & 363,452 & 26.0 & 1,521 & 48,561 & 25.1 \\
\hline 0318 & Pearl & 28 & 93.4 & 445,827 & 12.1 & 4,359 & 9,910 & 1.7 \\
\hline
\end{tabular}

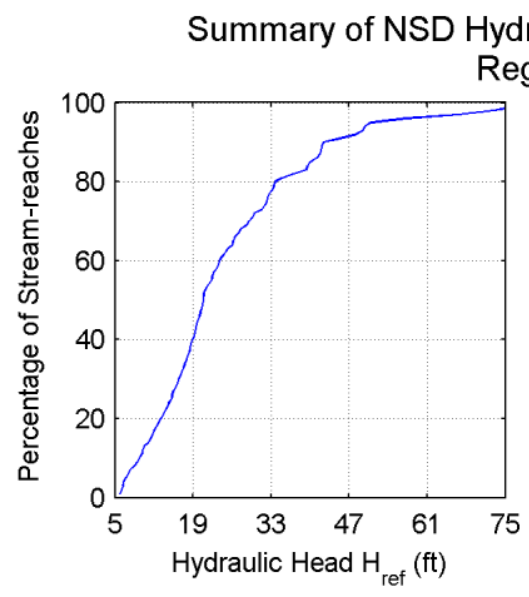

Hydropower Potential (stream-reaches with capacity > $1 \mathrm{MW}$ )

Region 3: 393 stream-reaches, $1388 \mathrm{MW}$
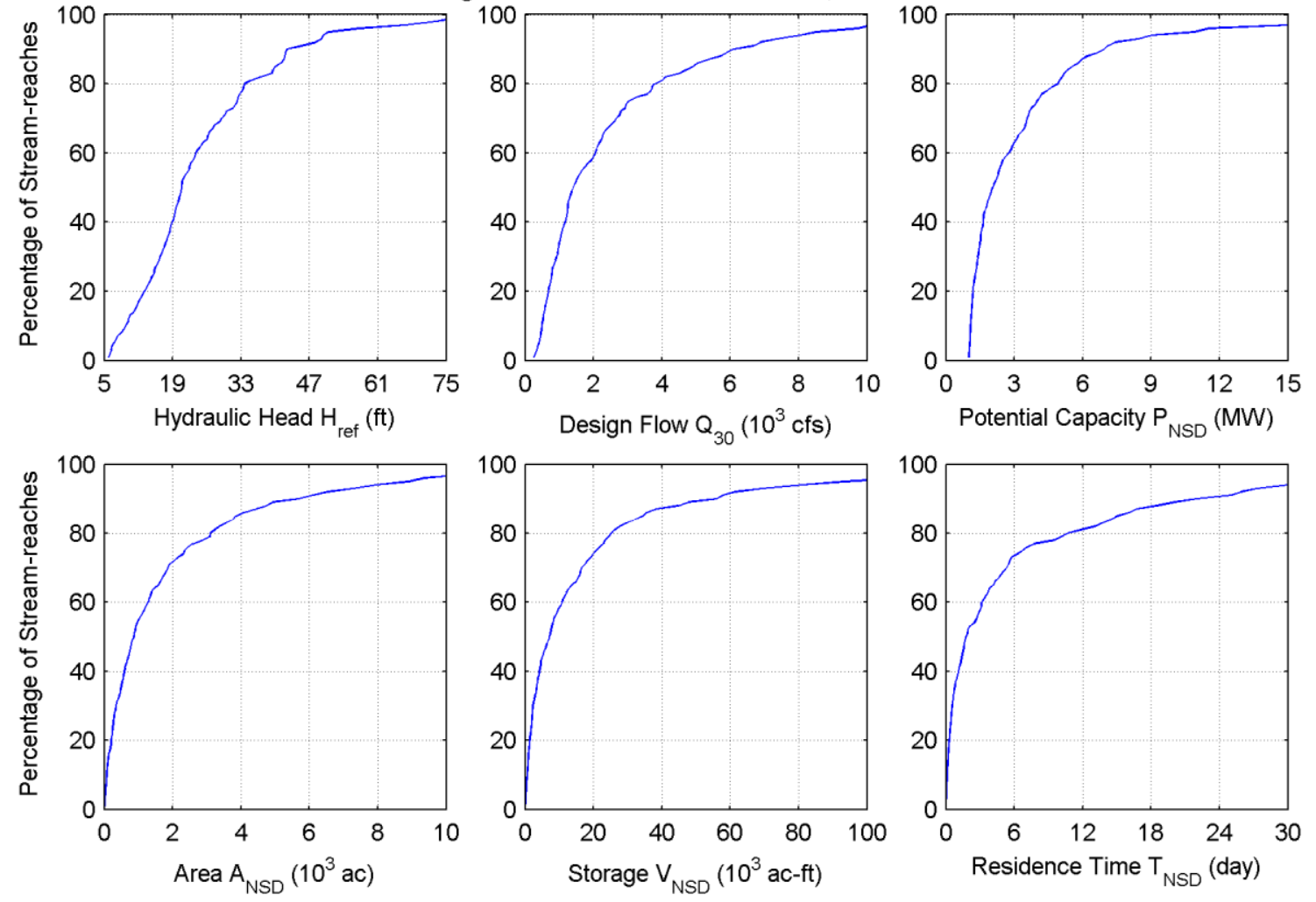

Figure 6.3. Cumulative distributions of hydraulic head $\mathrm{H}_{\text {ref }}$, design flow $\mathrm{Q}_{30}$, potential capacity $\mathrm{P}_{\mathrm{NSD}}$, inundated area $\mathrm{A}_{\mathrm{NSD}}$, storage $\mathrm{V}_{\mathrm{NSD}}$, and residence time $\mathrm{T}_{\mathrm{NSD}}$ in Region 3-South Atlantic-Gulf. 
percentage of the total sites of interest in this U.S. region. The results of > 1 MW stream-reach potential are illustrated in Figure 6.4, with potential capacity (MW) aggregated to the HUC08 subbasins. The higher-potential-capacity sites are generally located along the fall line that divides the two distinct coastal and mountainous regions and in the higher elevations along the northern section of the region. There are also a few higher potential sites located along larger rivers adjacent to the Gulf of Mexico.

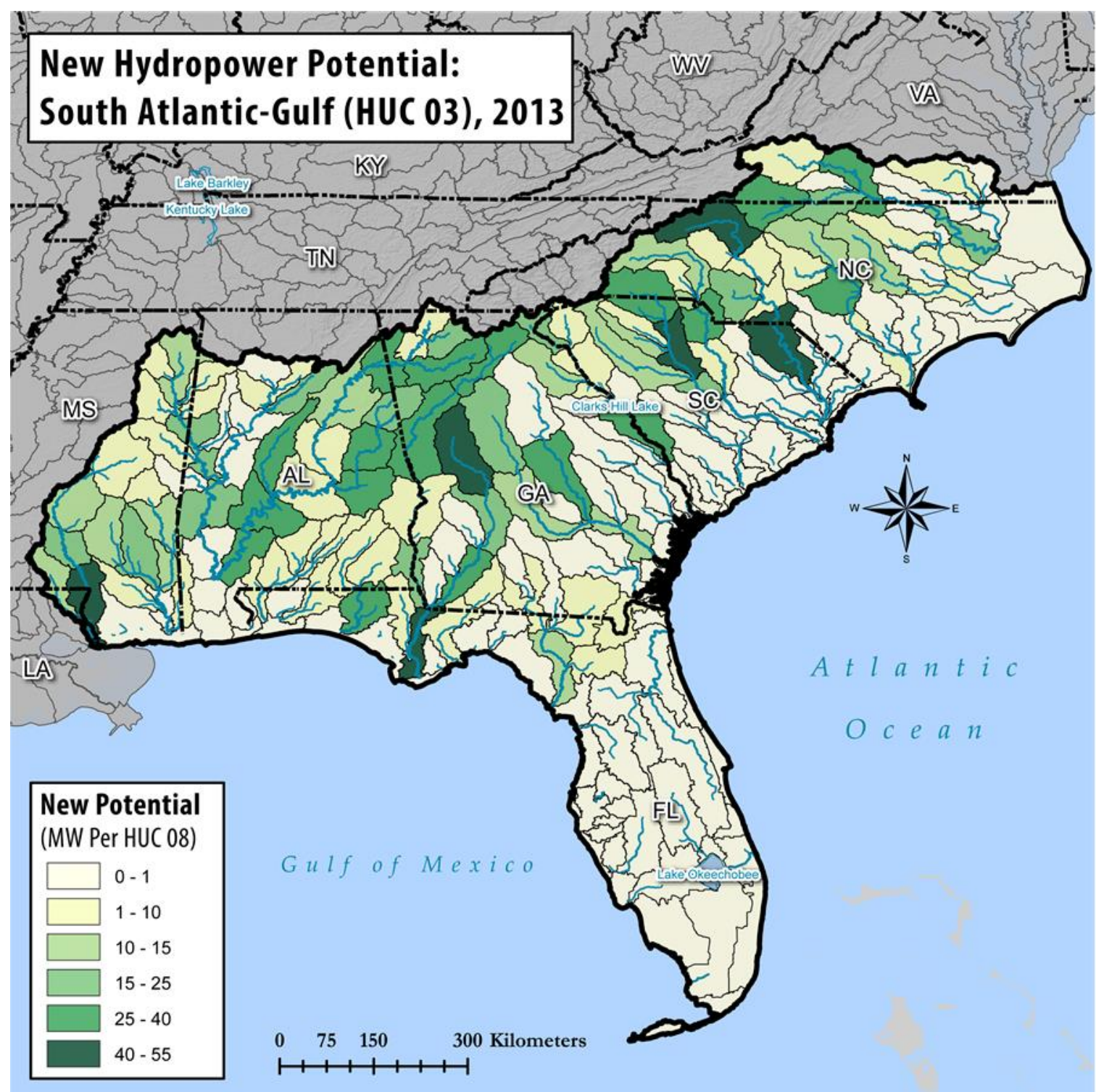

Figure 6.4. Potential new hydropower capacity in Region 3-South Atlantic-Gulf (higher-energy-density streamreaches with >1 MW per reach, aggregated to HUC08 subbasins for illustration).

\subsection{Environmental Characteristics}

Compared with other regions, Region 3 boasts the highest diversity of freshwater fish, including almost 600 native species. Region 3 contains some of the most diverse basins in the world, including the Mobile (236 fish species), Roanoke (90 species), and Conasauga (78 species) 
basins (USGS, 2001). Twenty-seven fish species fall under some ESA criteria with 17 of those species or one of their populations having threatened or endangered status (Figure 6.5 and Appendix B). Thirty-nine fish species fall under IUCN vulnerable status (Figure 6.5 and Appendix B). Over $40 \%$ of HUC08 subbasins in Region 3 are considered critical watersheds, containing 1 to more than 20 fish and mussel species at risk (Mathews et al. 1998). HUC08 subbasins with the most species at risk include the Conasauga (24), Spring (19), Upper Tombigee (15), Buttahtchee (15), and Sipsey (15). A total of 20 potadromous and anadromous fish species are documented in all subregions, suggesting a common potential concern (Table 6.3). Region 3 contains critical habitat designations for 2 amphibians, 1 arachnid, 1 insect, 3 birds, 19 clam species, 23 fish species, and 3 mammals (Figure 6.6 and Appendix B).

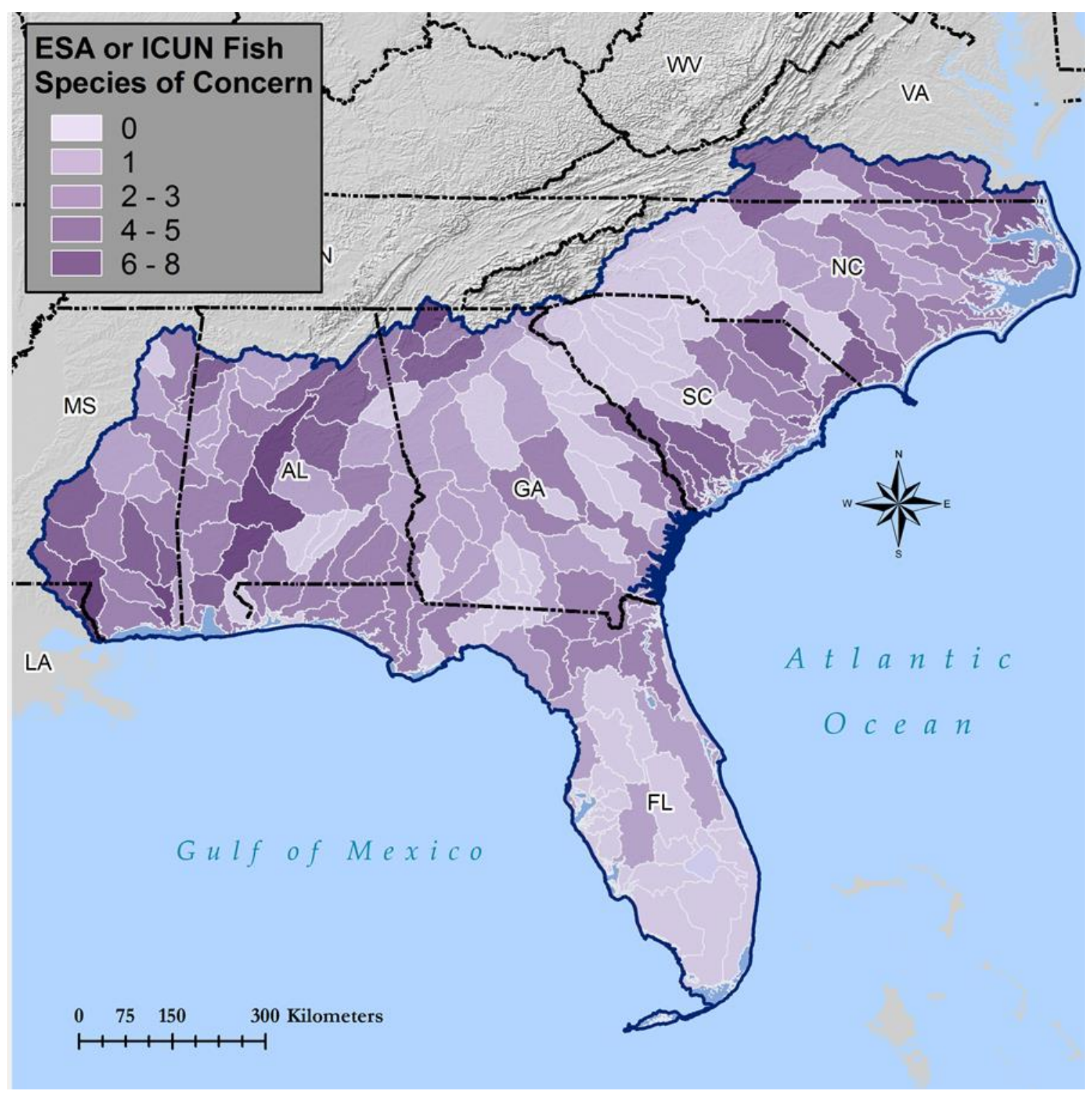

Figure 6.5. Fish species of concern (number per HUC08 sub-basin) in Region 3. 
There are over 20 million acres of protected lands (conservation lands) within Region 3, constituting over $11 \%$ of the total area. Most protected land is federally owned (61\%), predominately by USFS (23\%), NPS (14\%), and DOD (14\%). Among the largest national parks are Everglades, Biscayne, and Congaree. State lands constitute $33 \%$ of protected lands, comprising state fish and wildlife, departments of natural resources, department lands, and state parks. Approximately 4\% of protected lands fall under GAP 1 and 2 statuses and 5.3\% and 1.8\% of protected lands fall under GAP 3 and 4 statuses, respectively. Region 3 includes two national parkways (Blue Ridge and Natchez Trace parkways) and seven rivers protected under the National Wild and Scenic River Act. In total, there are 2345 boat ramp locations, 628 freshwater fishing access areas, and 409 recreational boating river sections. In addition, there are approximately 109 waterfalls within the region.

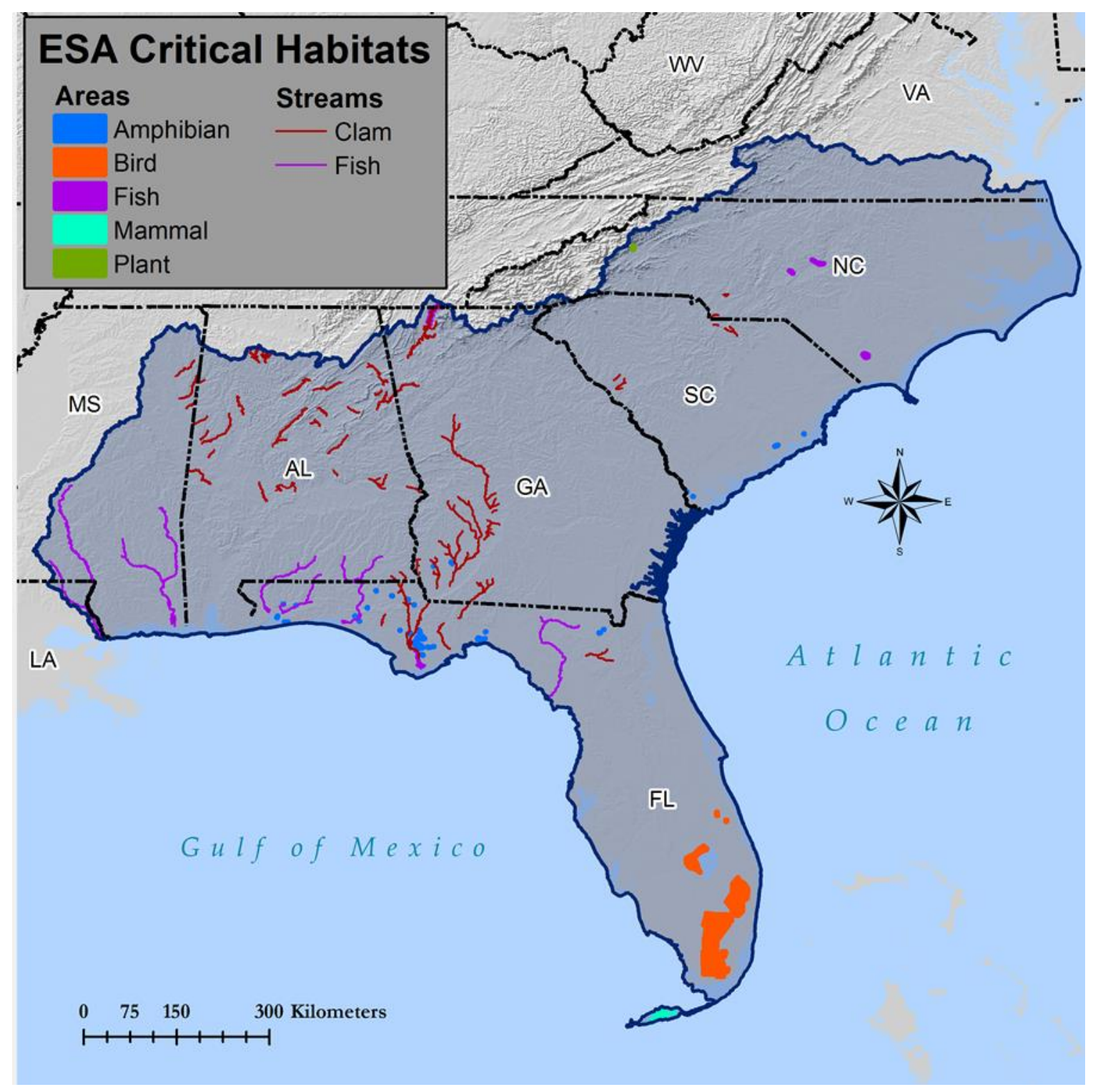

Figure 6.6. Critical habitats of federally endangered and threatened species in Region 3. 
Total freshwater use in Region 3 is moderate compared with other areas of the United States (Appendix B) with the highest usage occurring in the Edisto-Santee and Ogeechee-Savannah subregions (Table 6.3). Water usage is dominated by thermoelectric consumption, followed by public consumption and irrigation (Appendix B). The level of water quality concerns (number of 303D-listed waterbodies) is moderate in Region 3 compared with the rest of the United States (Appendix B). Harmful metals such as mercury and pathogens (e.g., E. coli bacteria) are the most prevalent water quality concerns.

Thirty-nine percent of stream-reaches, with a total of $542 \mathrm{MW}$, are located within the vicinity of designated critical habitats (Figure 6.7). Over $76 \%$ of stream-reaches are located in HUC08 subbasins containing at least one fish species falling under an ESA category. Sixty percent of stream-reaches intersect protected lands, but only one stream-reach intersects a national park. Twenty stream-reaches, totaling $30 \mathrm{MW}$, intersect Wild and Scenic Rivers. Water quality concerns are very prevalent, intersecting $67 \%$ of all stream-reaches. Recreational boating and boat ramps are also prevalent, intersecting $72 \%$ and $81 \%$ of stream-reaches, respectively. Fishing access locations are identified at $35 \%$ of stream-reaches. Almost $42 \%$ of stream-reaches are located in HUC08 subbasins with high or very high total water use ( $>60 \%$ for the region).

Table 6.3. Summary of Environmental Variables at HUC04 Subregions within Region 3 (Stream-Reaches with Potential Capacity $>1 \mathrm{MW})$

\begin{tabular}{|c|c|c|c|c|c|c|c|c|}
\hline HUC04 HUC04 name & $\begin{array}{r}\text { \# Critical } \\
\text { habitats }\end{array}$ & $\begin{array}{l}\text { \# Potad- } \\
\text { anad fish }\end{array}$ & $\begin{array}{r}\# \\
\text { ESA } \\
\text { fish } \\
\end{array}$ & $\begin{array}{r}\text { \# IUCN } \\
\text { fish }\end{array}$ & $\begin{array}{r}\text { \# Recreation } \\
\text { locations }^{a}\end{array}$ & $\begin{array}{r}\text { Protected } \\
\text { lands } \\
(\%)\end{array}$ & $\begin{array}{r}\text { Populatio } \\
\text { n density } \\
\left(\text { ind } / \mathbf{k m}^{2}\right)\end{array}$ & $\begin{array}{r}\text { Freshwater } \\
\text { use } \\
\left(\mathrm{l} / \mathrm{day} / \mathbf{k m}^{2}\right)\end{array}$ \\
\hline 0301 Chowan-Roanoke & 0 & 4 & 5 & 7 & $260 ; 34 ; 12$ & 7.68 & 28.59 & $2,060.03$ \\
\hline 0302 Neuse-Pamlico & 1 & 4 & 3 & 2 & $57 ; 13 ; 3$ & 7.02 & 55.06 & 852.42 \\
\hline 0303 Cape Fear & 2 & 4 & 5 & 4 & $47 ; 18 ; 1$ & 8.16 & 73.19 & 945.80 \\
\hline 0304 Pee Dee & 3 & 6 & 5 & 5 & $165 ; 19 ; 10$ & 3.79 & 53.44 & $2,045.02$ \\
\hline 0305 Edisto-Santee & 6 & 6 & 3 & 4 & $343 ; 83 ; 19$ & 7.52 & 73.95 & $4,682.41$ \\
\hline 0306 Ogeechee-Savannah & 4 & 7 & 3 & 3 & $270 ; 80 ; 23$ & 13.04 & 36.93 & $3,613.10$ \\
\hline 0307 Altamaha-St. Marys & 4 & 4 & 3 & 2 & $131 ; 21 ; 1$ & 5.98 & 48.66 & $1,170.85$ \\
\hline 0308 St. Johns & 4 & 2 & 3 & 2 & $157 ; 0 ; 0$ & 23.99 & 130.02 & $1,631.43$ \\
\hline 0309 Southern Florida & 7 & 2 & 0 & 0 & $178 ; 0 ; 0$ & 34.85 & 112.32 & $2,291.60$ \\
\hline 0310 Peace-Tampa Bay & 2 & 2 & 1 & 1 & $102 ; 1 ; 0$ & 14.69 & 225.55 & $1,844.47$ \\
\hline 0311 Suwannee & 10 & 4 & 1 & 3 & $74 ; 6 ; 0$ & 11.93 & 20.67 & 535.18 \\
\hline 0312 Ochlockonee & 9 & 4 & 1 & 3 & $36 ; 0 ; 0$ & 19.82 & 41.71 & 524.96 \\
\hline 0313 Apalachicola & 12 & 6 & 1 & 3 & $235 ; 50 ; 11$ & 9.33 & 46.53 & $1,137.78$ \\
\hline $\begin{array}{c}0314 \begin{array}{l}\text { Choctawhatchee- } \\
\text { Escambia }\end{array} \\
\end{array}$ & 16 & 5 & 3 & 5 & $98 ; 0 ; 1$ & 12.44 & 40.24 & 758.60 \\
\hline 0315 Alabama & 12 & 7 & 10 & 15 & $289 ; 63 ; 20$ & 6.92 & 43.81 & $1,702.72$ \\
\hline 0316 Mobile-Tombigbee & 9 & 6 & 6 & 9 & $261 ; 19 ; 6$ & 4.47 & 35.77 & $1,742.77$ \\
\hline 0317 Pascagoula & 3 & 6 & 3 & 5 & $106 ; 2 ; 2$ & 10.91 & 32.84 & 861.90 \\
\hline 0318 Pearl & 2 & 5 & 2 & 6 & $73 ; 0 ; 0$ & 4.45 & 26.50 & 329.43 \\
\hline
\end{tabular}

${ }^{a}$ Recreation locations refer to the number of boat-ramp and fishing access points; recreational boating; and waterfalls within each HUC04. 


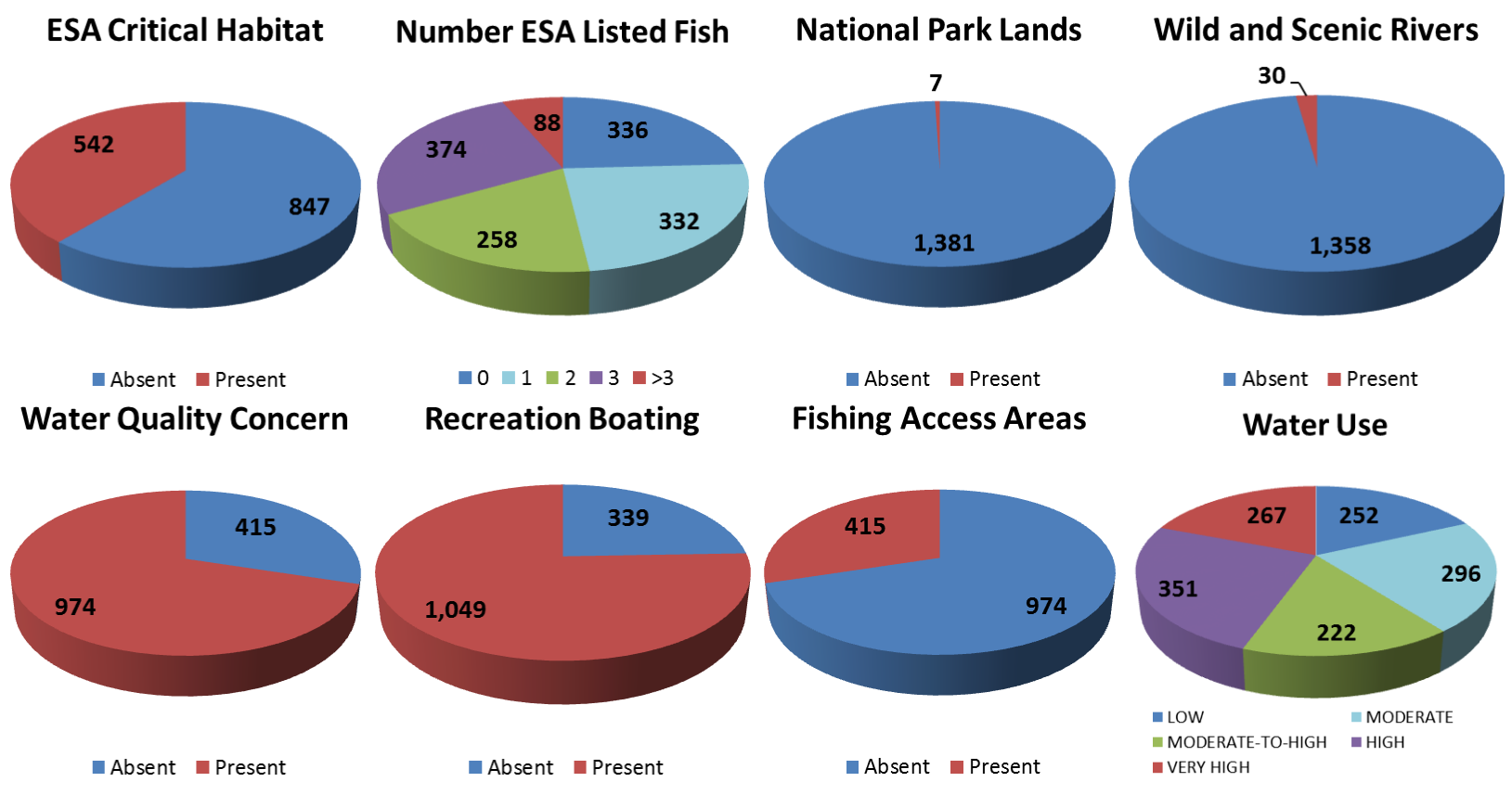

Figure 6.7. The potential capacity, in MW, associated with environmental attributes in Region 3-South AtlanticGulf (stream-reaches with potential capacity $>1 \mathrm{MW}$ ). 
(This Page Intentionally Left Blank) 


\section{REGION 4-GREAT LAKES}

\subsection{Summary of Findings}

Following NSD methodology (Hadjerioua et al., 2013), the potential capacity, annual generation, and mean capacity factors in the Great Lakes Region are estimated and summarized in Table 7.1 for both larger (>1 MW) and smaller (<1 MW) stream-reaches. For comparison, the year-2011 nameplate capacity, 2002-2011 average annual generation, and capacity factor of existing hydropower facilities are also listed (NHAAP, 2013). The total undeveloped NSD capacity is $1.43 \mathrm{GW}$, around $31 \%$ of existing conventional hydropower nameplate capacity. In terms of energy, the total undeveloped NSD generation is $8.44 \mathrm{TWh} /$ year, around $34 \%$ of annual net generation from existing conventional hydropower plants. The lower ratio of potential NSD resources to existing hydropower development suggests that many of the hydraulically feasible stream-reaches may have been used for hydropower development in this region. More detailed topographical analysis and environmental attribution are conducted for larger (>1 MW) streamreaches and discussed in Sections 7.3 and 7.4.

Table 7.1. Summary of NSD Findings in Region $4-$ Great Lakes

\begin{tabular}{l|r|r|r}
\hline & $\begin{array}{r}\text { Capacity } \\
(\mathbf{M W})\end{array}$ & $\begin{array}{r}\text { Generation } \\
(\mathbf{M W h})\end{array}$ & $\begin{array}{r}\text { Mean capacity } \\
\text { factor }\end{array}$ \\
\hline Potential in undeveloped stream-reaches $(>1 \mathrm{MW})$ & 265 & $1,538,000$ & $66 \%$ \\
\hline Potential in undeveloped stream-reaches $(<1 \mathrm{MW})$ & 1,160 & $6,906,000$ & $68 \%$ \\
\hline Existing hydropower-conventional hydro & 4,604 & $24,991,000$ & $62 \%$ \\
\hline Existing hydropower-pumped storage & 2,219 & & \\
\hline
\end{tabular}

\subsection{Background Hydrologic Setting}

The Great Lakes Region encompasses approximately $311,442 \mathrm{~km}^{2}$ in the mideastern United States. This region contains the most northern sections of Minnesota, Wisconsin, and Michigan and small parts of Indiana, Ohio, Pennsylvania, and New York.

In addition to the Great Lakes, several river systems are located in this region (Figure 7.1), including the St. Lawrence, Montreal, St. Louis, Carp, Milwaukee, Manistique, Fox, St. Joseph, Grand, Au Sable, St. Clair, Saginaw, Detroit, Huron, Vermilion, Ashtabula, Niagara, Genesee, Oswego and English rivers, with a total length of 30,380 km (i.e., total length of streams with estimated discharge greater than $35 \mathrm{cfs}$ ). Metropolitan areas within the region include Duluth $(\mathrm{MN})$, Milwaukee (WI), Grand Rapids (MI), Toledo (OH), Cleveland (OH), and Buffalo (NY). As shown in Figure 7.2, annual precipitation for the Great Lakes region ranges from 750 to 100 $\mathrm{mm} /$ year and annual runoff from 275 to $400 \mathrm{~mm} /$ year. Most of the precipitation falls from the summer to early fall. The peak of the runoff occurs the spring around April, which is indicative of the snowmelt runoff. 


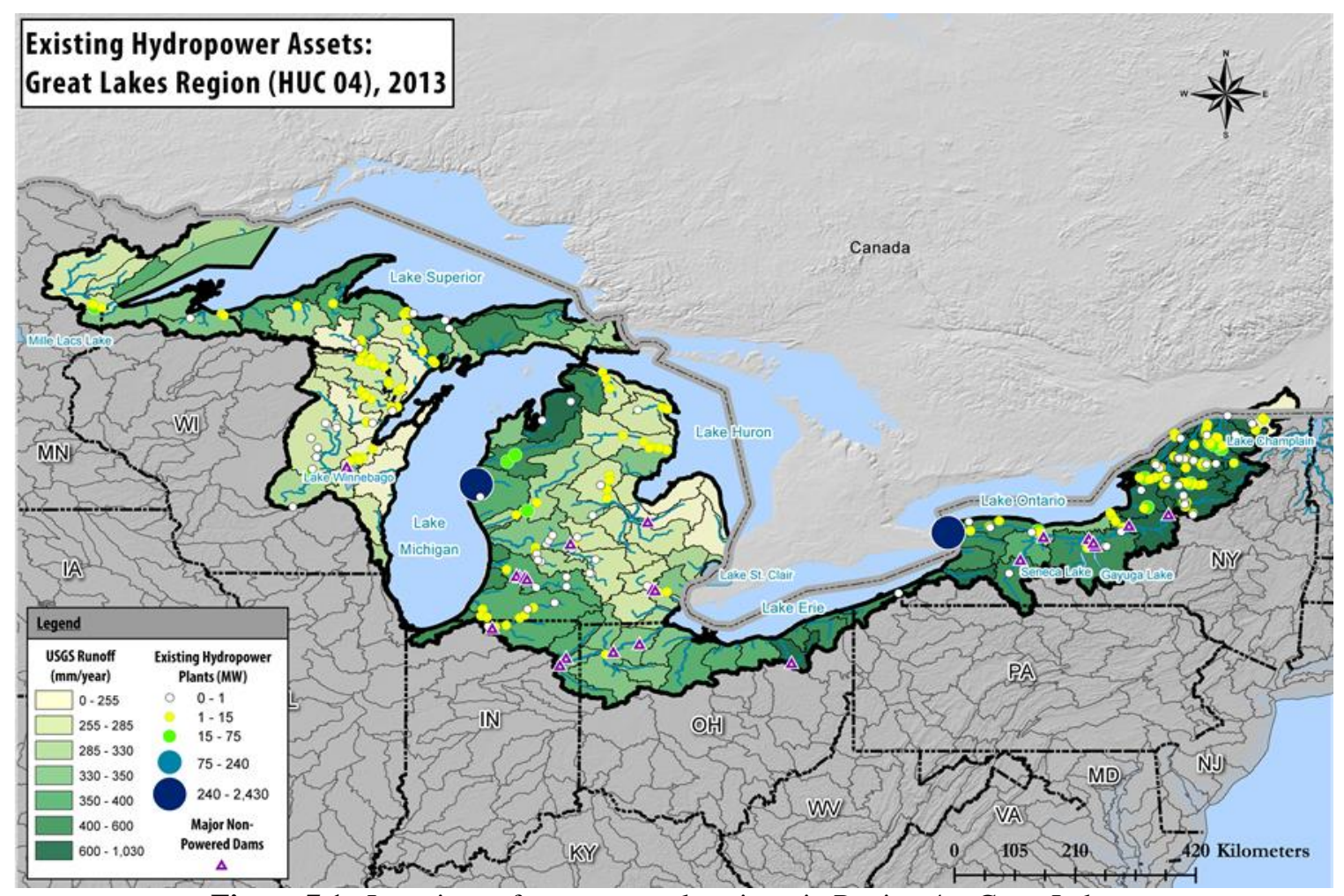

Figure 7.1. Locations of water control projects in Region 4-Great Lakes.

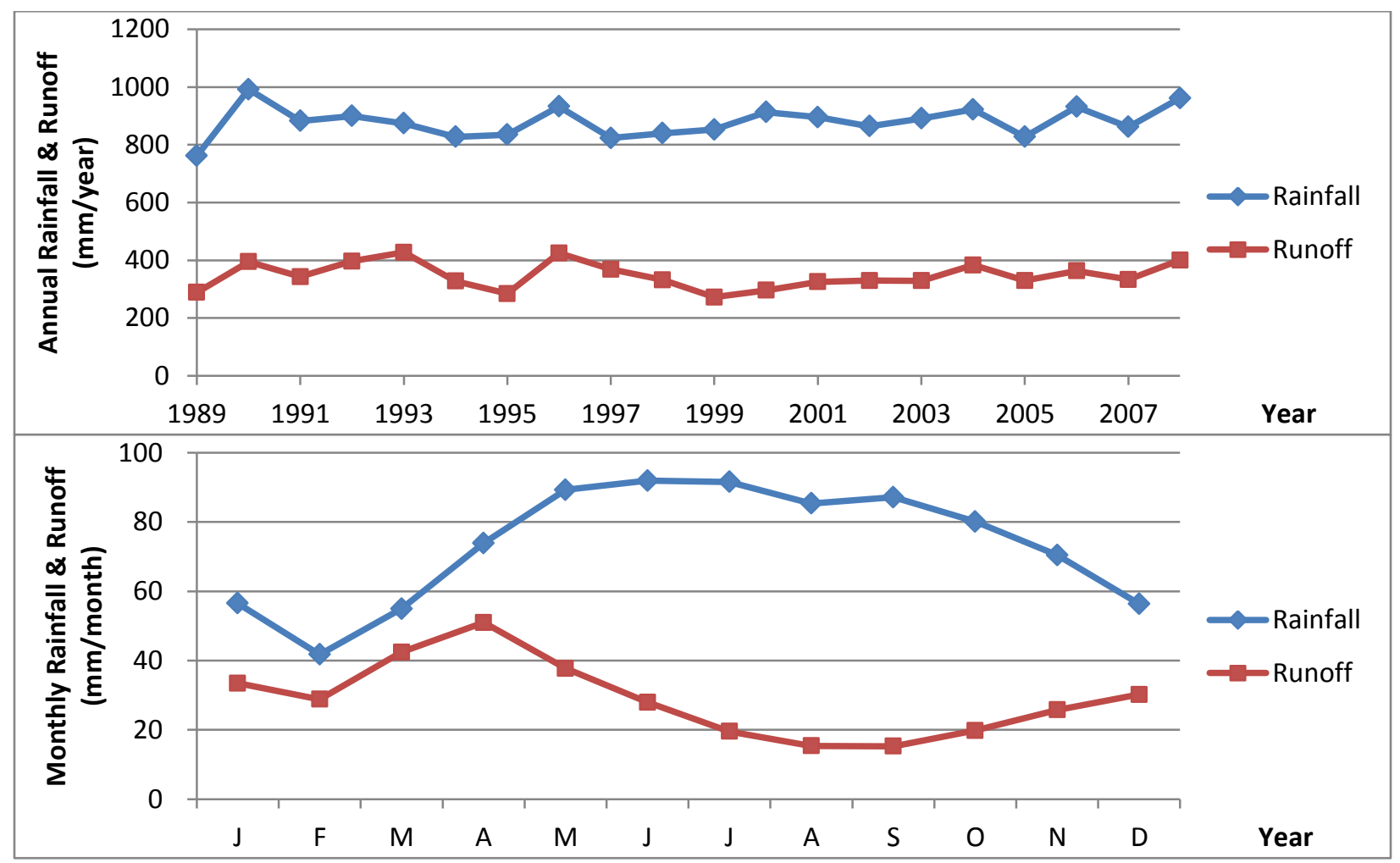

Figure 7.2. Annual and monthly rainfall and runoff of Region 4-Great Lakes. 
The existing hydropower plants and major non-powered dams (Hadjerioua et al., 2012) are also shown in Figure 7.1. The region contains 256 hydropower dams and 22 major non-powered dams, with total storage capacities of around 290,835,586 ac-ft and 2,459,560 ac-ft, respectively.

\subsection{Potential New Hydropower Resources}

A total of 131 stream-reaches of high energy density (with estimated potential capacity $>1 \mathrm{MW}$ per stream-reach) were identified in the Great Lakes Region. The NSD results based on HUC04 subregions are summarized in Table 7.2. The highest hydropower potential is located in the Northeastern Lake Ontario-Lake Ontario-St. Lawrence Subregion (HUC 0415), followed by the Southwestern Lake Ontario Subregion (HUC 0413), Western Lake Erie Subregion (HUC 0410), and the Southeastern Lake Michigan Subregion (HUC 0405). In the Northeastern Lake OntarioLake Ontario-St. Lawrence Subregion, the Black River contains the highest hydropower potential, followed by the Raquette and Oswehatchie rivers. The Genesee, Maumee, Grand, and Saint Joseph rivers contain the next-highest potential for the HUC 0413, HUC 0410, and HUC 0405 subregions.

Table 7.2. Summary of Potential New Hydropower Resources in Region 4-Great Lakes (Stream-Reaches with Potential Capacity $>1 \mathrm{MW}$ )

\begin{tabular}{|c|c|c|c|c|c|c|c|c|}
\hline HUC04 & HUC04 name & $\begin{array}{r}\text { \# of } \\
\text { Stream- } \\
\text { reaches }\end{array}$ & $\begin{array}{r}\text { Potential } \\
\text { capacity } \\
(\mathrm{MW}) \\
\end{array}$ & $\begin{array}{r}\text { Potential } \\
\text { energy } \\
(\mathrm{MWh}) \\
\end{array}$ & $\begin{array}{r}\text { Average } \\
\text { head } \\
(\text { ft } / \text { reach })\end{array}$ & $\begin{array}{r}\text { Average } \\
\text { flow } \\
\text { (cfs/reach) } \\
\end{array}$ & $\begin{array}{r}\text { Average } \\
\text { storage } \\
\text { (ac-ft/reach) } \\
\end{array}$ & $\begin{array}{r}\text { Average } \\
\text { residence } \\
\text { time (days) }\end{array}$ \\
\hline 0401 & Western Lake Superior & 3 & 3.1 & 18,026 & 6.3 & 2,282 & 446 & 0.1 \\
\hline 0402 & $\begin{array}{l}\text { Southern Lake } \\
\text { Superior-Lake } \\
\text { Superior }\end{array}$ & - & - & - & - & - & - & - \\
\hline 0403 & $\begin{array}{l}\text { Northwestern Lake } \\
\text { Michigan }\end{array}$ & 12 & 15.7 & 112,047 & 6.2 & 2,939 & 947 & 0.1 \\
\hline 0404 & $\begin{array}{l}\text { Southwestern Lake } \\
\text { Michigan }\end{array}$ & - & - & - & - & - & - & - \\
\hline 0405 & $\begin{array}{l}\text { Southeastern Lake } \\
\text { Michigan }\end{array}$ & 12 & 31.5 & 194,172 & 9.5 & 3,937 & 10,185 & 2.7 \\
\hline 0406 & $\begin{array}{l}\text { Northeastern Lake } \\
\text { Michigan-Lake } \\
\text { Michigan }\end{array}$ & - & - & - & - & - & - & - \\
\hline 0407 & $\begin{array}{l}\text { Northwestern Lake } \\
\text { Huron }\end{array}$ & - & - & - & - & - & - & - \\
\hline 0408 & $\begin{array}{l}\text { Southwestern Lake } \\
\text { Huron-Lake Huron }\end{array}$ & 1 & 1.3 & 7452 & 7.8 & 2,256 & 8,241 & 2.1 \\
\hline 0409 & St. Clair-Detroit & - & - & - & - & - & - & - \\
\hline 0410 & Western Lake Erie & 9 & 32.8 & 165,434 & 16.9 & 3,263 & 7,435 & 1.5 \\
\hline 0411 & Southern Lake Erie & - & - & - & - & - & - & - \\
\hline 0412 & $\begin{array}{l}\text { Eastern Lake Erie-Lake } \\
\text { Erie }\end{array}$ & 9 & 11.9 & 64,371 & 26.0 & 707 & 1,036 & 0.7 \\
\hline 0413 & $\begin{array}{l}\text { Southwestern Lake } \\
\text { Ontario }\end{array}$ & 28 & 43.6 & 228,785 & 16.1 & 1,349 & 2,921 & 0.9 \\
\hline 0414 & $\begin{array}{l}\text { Southeastern Lake } \\
\text { Ontario }\end{array}$ & 4 & 7.0 & 37,152 & 6.4 & 3,836 & 666 & 0.1 \\
\hline 0415 & $\begin{array}{l}\text { Northeastern Lake } \\
\text { Ontario-Lake Ontario-- } \\
\text { St. Lawrence }\end{array}$ & 53 & 118.1 & 710,109 & 15.6 & 2,022 & 703 & 0.2 \\
\hline
\end{tabular}


The summary statistics of hydraulic head $\mathrm{H}_{\text {ref }}\left(\mathrm{ft}\right.$ ), design flow $\mathrm{Q}_{30}(\mathrm{cfs})$, potential capacity $\mathrm{P}_{\mathrm{NSD}}$ $(\mathrm{MW})$, inundated area $\mathrm{A}_{\mathrm{NSD}}(\mathrm{ac})$, storage $\mathrm{V}_{\mathrm{NSD}}$ (ac-ft), and residence time $\mathrm{T}_{\mathrm{NSD}}$ (day) are shown in Figure 7.3. The hydraulic head $\mathrm{H}_{\text {ref }}$ ranges from 6 to the 90th quantile of $19 \mathrm{ft}$ with a median of about $15 \mathrm{ft}$, suggesting that many of the potential stream-reaches will require low-head hydropower technologies. The design flow $\mathrm{Q}_{30}$ ranges from about $759 \mathrm{cfs}$ to the 90th quantile of $4600 \mathrm{cfs}$ with a median of $1500 \mathrm{cfs}$. The potential capacity $\mathrm{P}_{\text {NSD }}$ ranges from 1 to the 90 th quantile of about $4 \mathrm{MW}$ with a median of about $1.75 \mathrm{MW}$. The inundated surface area $\mathrm{A}_{\mathrm{NSD}}$ ranges from 0 to the 90th quantile of 1000 ac with a median of 125 ac. This results in storage values $\mathrm{V}_{\text {NSD }}$ ranging from 0 to the 90th quantile of $5000 \mathrm{ac}-\mathrm{ft}$ with a median of about $1000 \mathrm{ac}-\mathrm{ft}$ and very short residence times $\mathrm{T}_{\mathrm{NSD}}$ ranging from $<1$ day to the 90th quantile of 1.5 days with a median on the order of hours. In general, the relatively small inundation areas and storage volumes paired with the short retention times for this region are characteristic of run-of-river type hydro facilities. The results of $>1 \mathrm{MW}$ stream-reach potential are illustrated in Figure 7.4, with potential capacity (MW) aggregated to the HUC08 subbasins. The higher-potential-capacity sites are generally located on the larger rivers in the northern New York and Ohio areas.

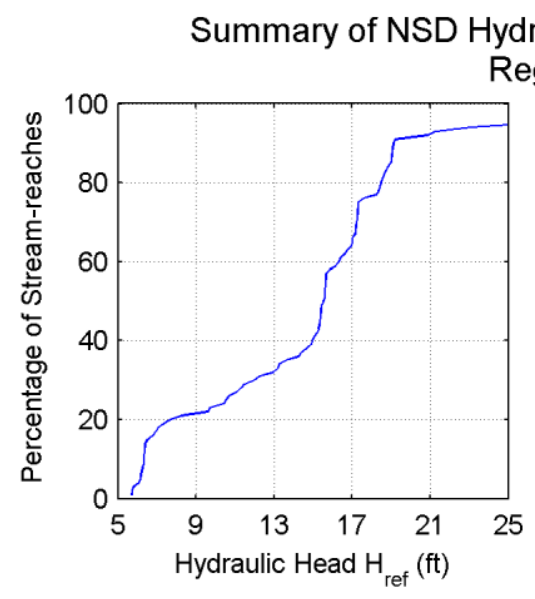

Hydropower Potential (stream-reaches with capacity $>1 \mathrm{MW}$ )

Region 4: 131 stream-reaches, $264 \mathrm{MW}$
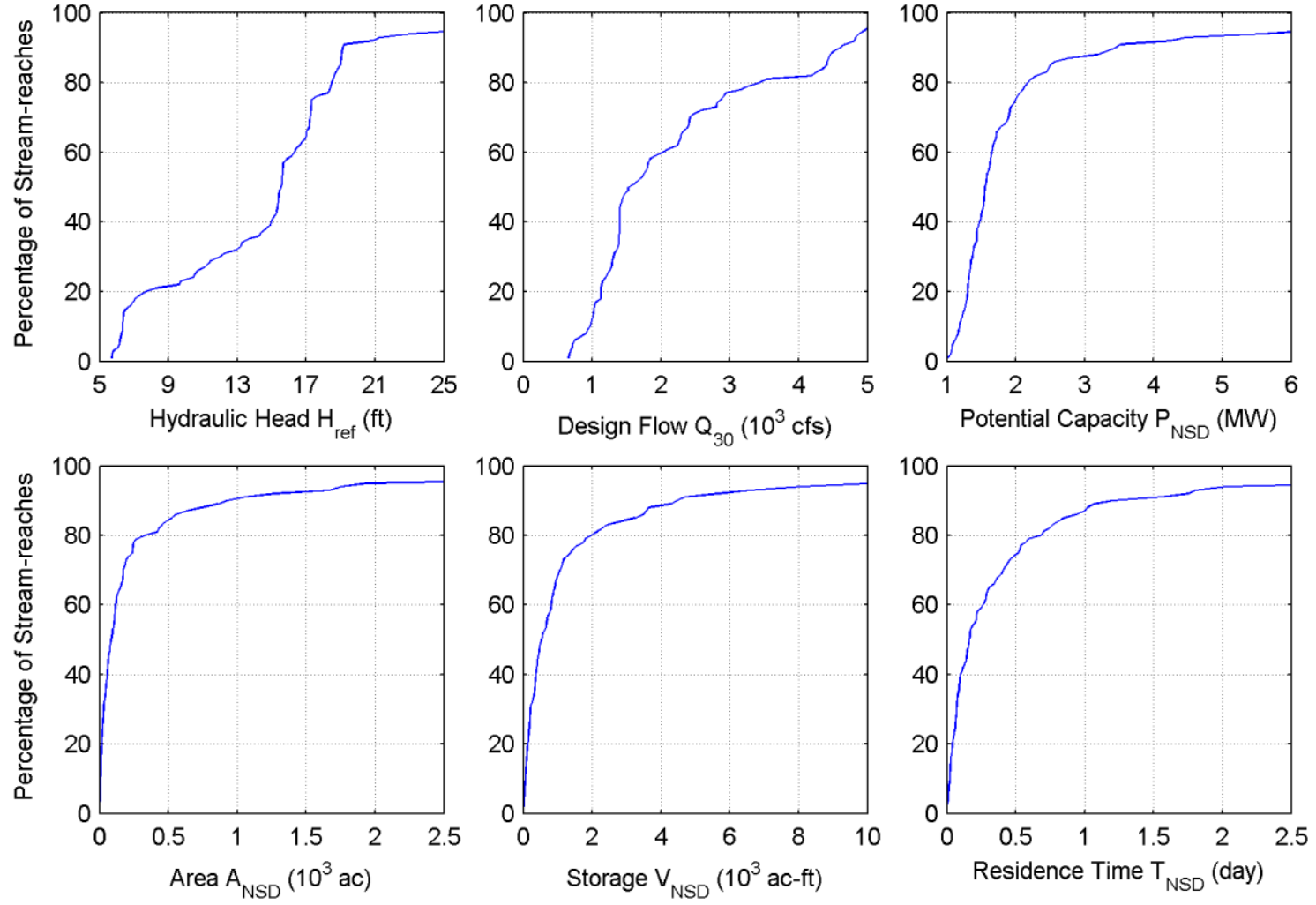

Figure 7.3. Cumulative distributions of hydraulic head $\mathrm{H}_{\text {ref }}$, design flow $\mathrm{Q}_{30}$, potential capacity $\mathrm{P}_{\mathrm{NSD}}$, inundated area $\mathrm{A}_{\mathrm{NSD}}$, storage $\mathrm{V}_{\mathrm{NSD}}$, and residence time $\mathrm{T}_{\mathrm{NSD}}$ in Region 4-Great Lakes. 


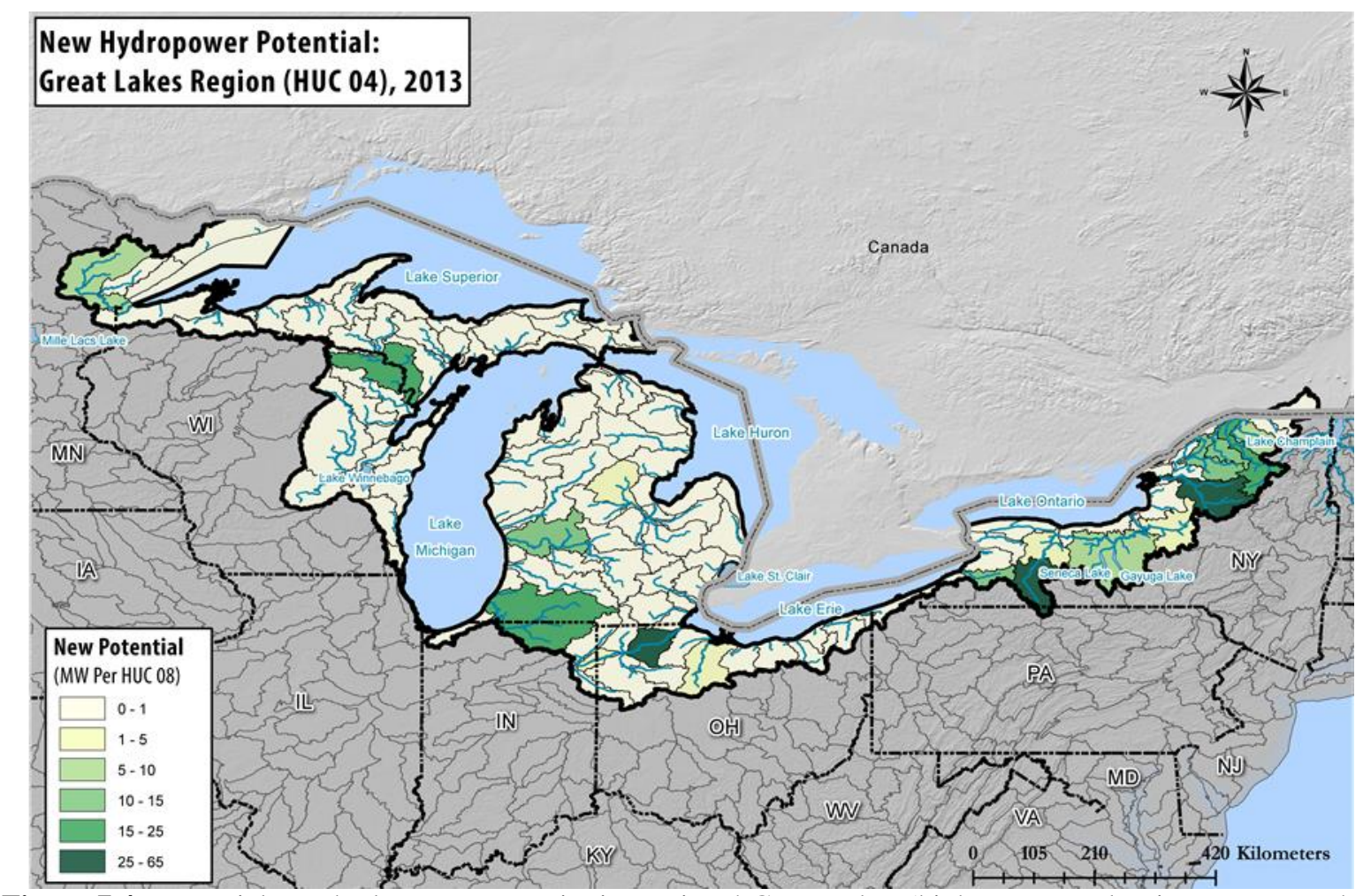

Figure 7.4. Potential new hydropower capacity in Region 4 Great Lakes (higher-energy-density stream-reaches with >1 MW per reach, aggregated to HUC08 subbasins for illustration).

\subsection{Environmental Characteristics}

Of the 155 native fish species in Region 4, alewife, Atlantic salmon, and arctic grayling (Thymallus arcticus) fall under an ESA category (Appendix B). Bloater (Coregonus hoyi), Eastern sand darter (Ammocrypta pellucida), kiyi (Coregonus kiyi), and shortjaw cisco (Coregonus zenithicus) fall under the IUCN vulnerable categories. Eighteen species of fish are considered potadromous or anadromous in the region. Four critical watersheds are located in Region 4, with the St. Joseph, Wolf, and Black HUC08 subbasins having the most fish and mussels at risk $(8,6$, and 4 , respectively). Species with critical habitat designations in the region include gray wolf (Canis lupus), Canada lynx, and Hine's emerald dragonfly (Somatochlora hineana) (Figure 7.5).

The 15 million acres of protected land in Region 4 are primarily state owned (55\%), followed by federally $(35 \%)$ and privately owned land (6\%). State forests $(41 \%)$ and habitat/species management areas (8\%) make up the bulk of state-owned lands. The USFS owns the most federal lands $(31 \%)$, followed by DOD (2\%) and USFWS (1\%). Most lands fall under GAP status $3(47 \%)$ and $2(39 \%)$. Fourteen rivers have protection under the National Wild and Scenic Rivers Act in Region 4. Recreation locations are numerous, totaling 2360 boat ramp locations, 778 fish access locations, 276 waterfalls, and 516 recreational boating river sections. 


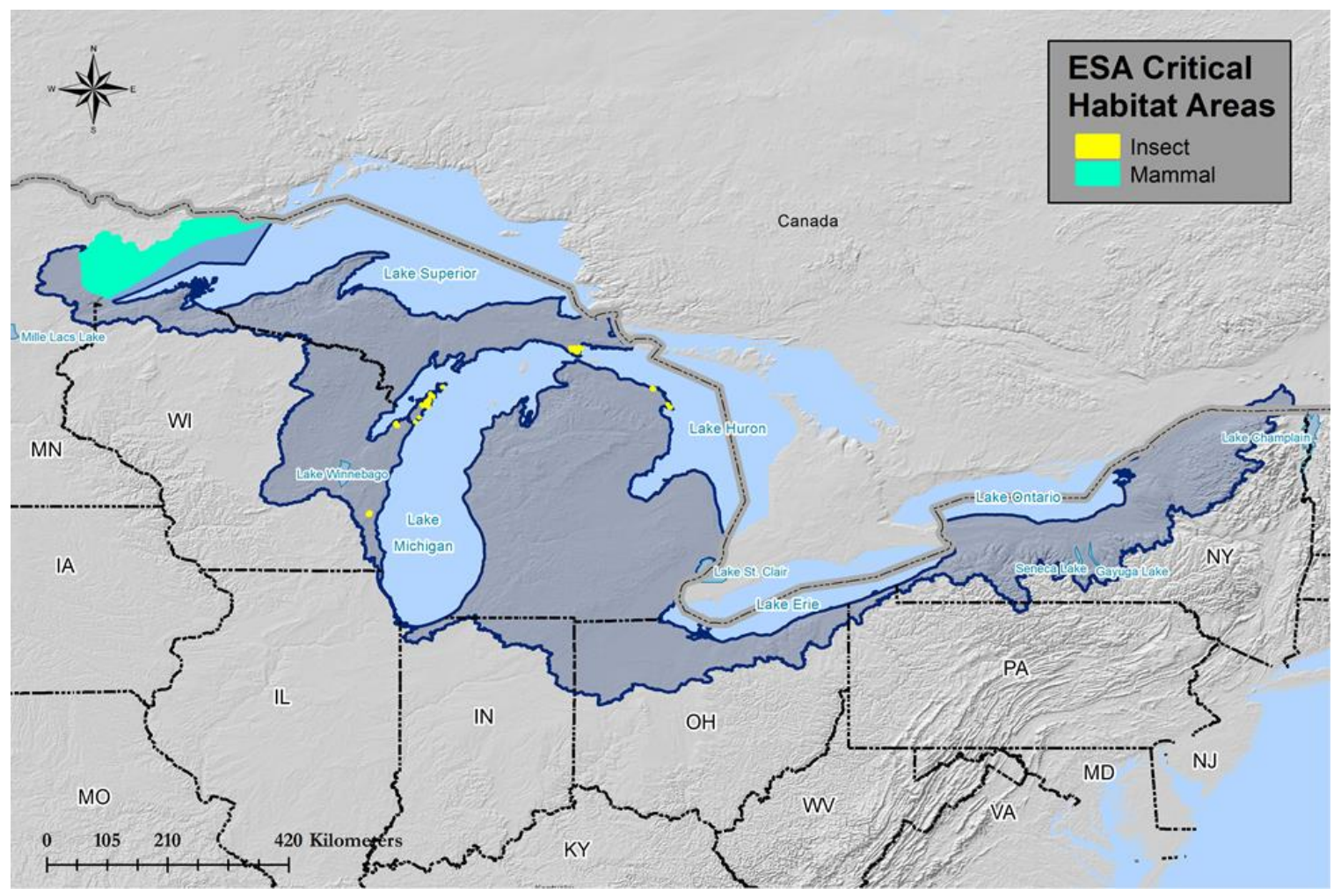

Figure 7.5. Critical habitats of federally endangered and threatened species in Region 4.

Water use is moderately high in Region 4, with most usage occurring as thermoelectric cooling, followed by public and industrial consumption (Appendix B). The highest amounts of water usage occur in the St. Clair-Detroit and Southwestern Lake Michigan Subbasins (Table 7.3). The highest number of water quality concerns in the United States is found in Region 4, most of which are classified as toxin or mercury contamination (Figure 7.6 and Appendix B).

Critical habitats are absent from 131 stream-reaches in Region 4 (Figure 7.7). Although 92\% of stream-reaches intersect protected lands, none intersect national parks or Wild and Scenic Rivers. Thirteen percent of sites with a total of $34 \mathrm{MW}$ are located in HUC08 subbasins containing at least one fish falling under ESA categories. Water quality concerns are common, occurring at $44 \%$ of stream-reaches. Recreational boating runs are very prevalent, overlapping with $85 \%$ of stream-reaches; however, boat ramps and fishing access locations are less common, only identified at $32 \%$ and $31 \%$ of stream-reaches, respectively. Most identified stream-reaches have low or moderate water usage. 
Table 7.3. Summary of Environmental Variables at HUC04 Subregions within Region 4 (Stream-Reaches with Potential Capacity $>1 \mathrm{MW}$ )

\begin{tabular}{|c|c|c|c|c|c|c|c|c|}
\hline HUC04 HUC04 name & $\begin{array}{r}\text { \# Critical } \\
\text { habitats }\end{array}$ & $\begin{array}{l}\text { \# Potad- } \\
\text { anad fish }\end{array}$ & $\begin{array}{r}\# \\
\text { ESA } \\
\text { fish } \\
\end{array}$ & $\begin{array}{r}\# \text { IUCN } \\
\text { fish }\end{array}$ & $\begin{array}{r}\text { \# Recreation } \\
\text { locations }^{a}\end{array}$ & $\begin{array}{r}\% \\
\text { Protected } \\
\text { lands } \\
\end{array}$ & $\begin{array}{r}\text { Populatio } \\
\text { n density } \\
\left(\text { ind } / \mathbf{k m}^{2}\right) \\
\end{array}$ & $\begin{array}{r}\text { Freshwater } \\
\text { use } \\
\left(1 / \text { day } / \mathrm{km}^{2}\right)\end{array}$ \\
\hline $\begin{array}{l}0401 \begin{array}{l}\text { Western Lake } \\
\text { Superior }\end{array} \\
\end{array}$ & 2 & 12 & 0 & 3 & $332 ; 79 ; 25$ & 38.69 & 7.15 & 470.18 \\
\hline $\begin{array}{l}\text { Southern Lake } \\
0402 \text { Superior-Lake } \\
\text { Superior } \\
\end{array}$ & 2 & 14 & 0 & 3 & $149 ; 68 ; 89$ & 28.05 & 6.52 & 235.30 \\
\hline $\begin{array}{l}0403 \begin{array}{l}\text { Northwestern Lake } \\
\text { Michigan }\end{array} \\
\end{array}$ & 1 & 14 & 0 & 1 & $889 ; 92 ; 36$ & 17.36 & 16.68 & $1,858.22$ \\
\hline $0404 \begin{array}{l}\text { Southwestern Lake } \\
\text { Michigan }\end{array}$ & 1 & 11 & 0 & 1 & $52 ; 12 ; 0$ & 5.47 & 412.64 & $10,401.13$ \\
\hline $0405 \begin{array}{l}\text { Southeastern Lake } \\
\text { Michigan }\end{array}$ & 0 & 10 & 0 & 1 & $371 ; 7 ; 0$ & 2.81 & 87.44 & $1,765.94$ \\
\hline $\begin{array}{l}\text { Northeastern Lake } \\
0406 \text { Michigan-Lake } \\
\text { Michigan } \\
\end{array}$ & 1 & 13 & 1 & 1 & $261 ; 3 ; 0$ & 33.06 & 9.70 & 277.07 \\
\hline $\begin{array}{l}0407 \begin{array}{l}\text { Northwestern Lake } \\
\text { Huron }\end{array} \\
\end{array}$ & 1 & 11 & 0 & 1 & $118 ; 2 ; 2$ & 40.29 & 8.31 & 141.23 \\
\hline $0408 \begin{array}{l}\text { Southwestern Lake } \\
\text { Huron-Lake Huron }\end{array}$ & 0 & 8 & 0 & 1 & $91 ; 1 ; 0$ & 7.15 & 63.47 & $1,964.24$ \\
\hline 0409 St. Clair-Detroit & 0 & 8 & 0 & 1 & $79 ; 3 ; 0$ & 3.63 & 511.60 & $13,356.97$ \\
\hline 0410 Western Lake Erie & 0 & 9 & 1 & 1 & $123 ; 9 ; 0$ & 0.97 & 84.36 & $3,661.46$ \\
\hline 0411 Southern Lake Erie & 0 & 6 & 1 & 1 & $36 ; 22 ; 9$ & 6.55 & 328.28 & $4,375.74$ \\
\hline $\begin{array}{c}0412 \begin{array}{l}\text { Eastern Lake Erie- } \\
\text { Lake Erie }\end{array} \\
\end{array}$ & 0 & 10 & 1 & 1 & $32 ; 26 ; 10$ & 3.30 & 173.10 & $4,412.90$ \\
\hline $0413 \begin{array}{l}\text { Southwestern Lake } \\
\text { Ontario }\end{array}$ & 0 & 6 & 0 & 1 & $43 ; 9 ; 8$ & 4.84 & 104.81 & 902.12 \\
\hline $0414 \begin{array}{l}\text { Southeastern Lake } \\
\text { Ontario }\end{array}$ & 0 & 11 & 0 & 1 & $141 ; 26 ; 29$ & 7.08 & 89.22 & $5,696.87$ \\
\hline $\begin{array}{l}\text { Northeastern Lake } \\
0415 \text { Ontario-Lake } \\
\text { Ontario-St. Lawrence }\end{array}$ & 1 & 14 & 1 & 1 & $442 ; 159 ; 72$ & 28.05 & 9.75 & 135.59 \\
\hline
\end{tabular}

${ }^{a}$ Recreation locations refer to the number of boat-ramp and fishing access points, recreational boating, and waterfalls within each HUC04. 


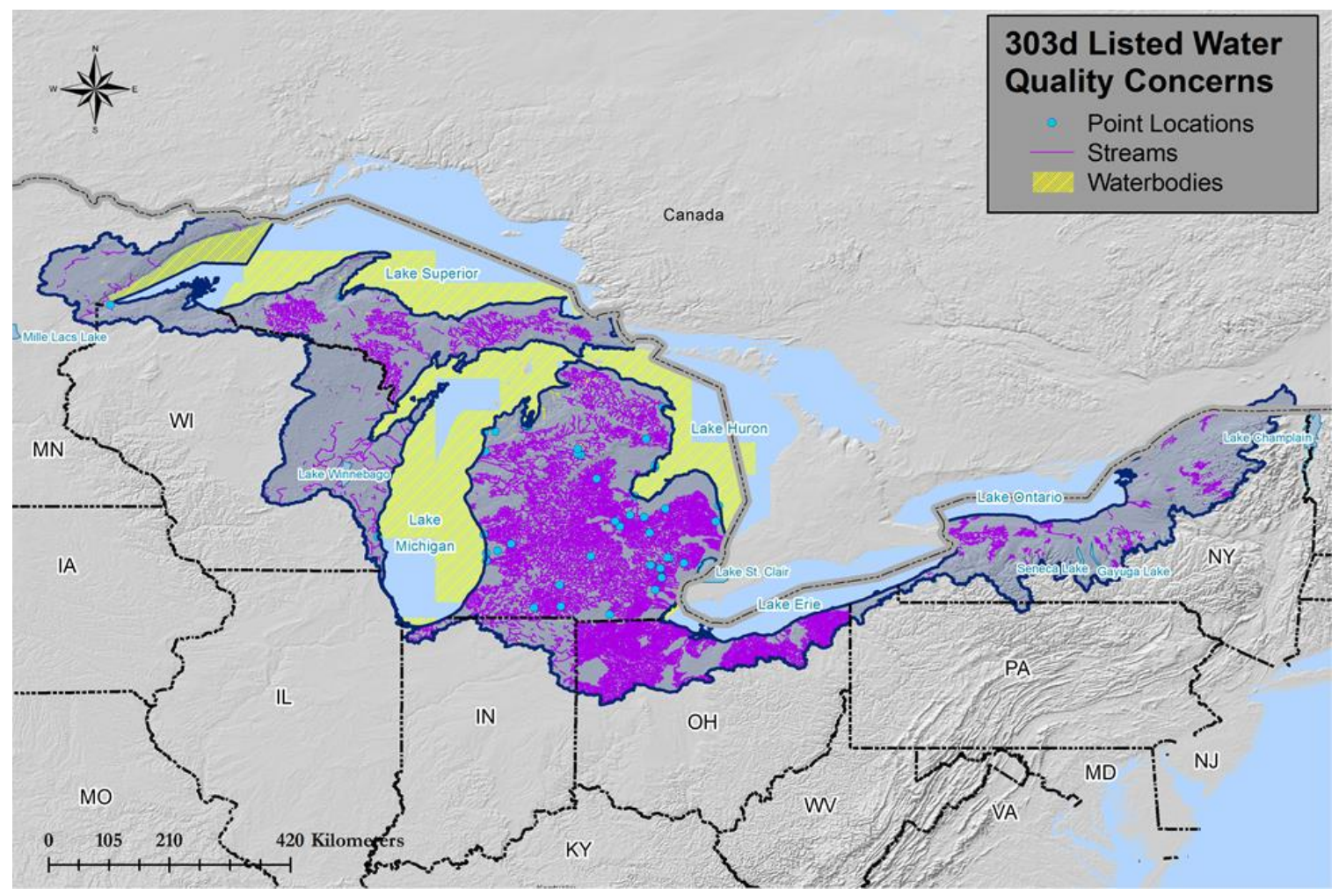

Figure 7.6. 303d listed streams and waterbodies in Region 4.

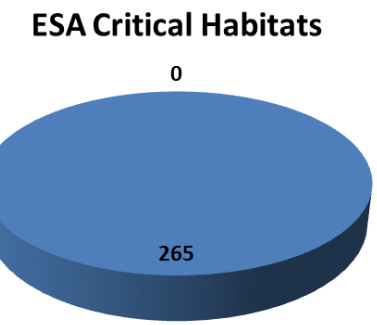

absent $\square$ Present

\section{Water Quality Concern}

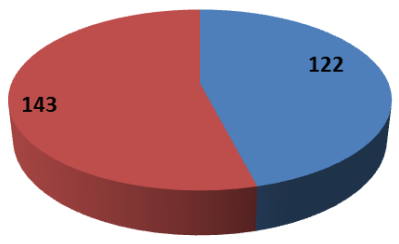

a Absent $\square$ Present
Number ESA Listed Fish

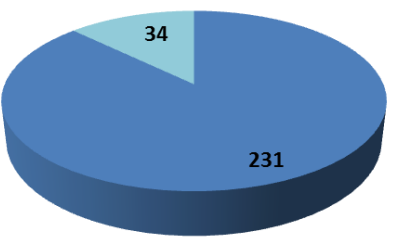

$0=1$

Recreation Boating

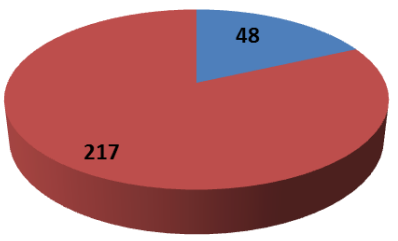

absent $=$ Present
National Park Lands

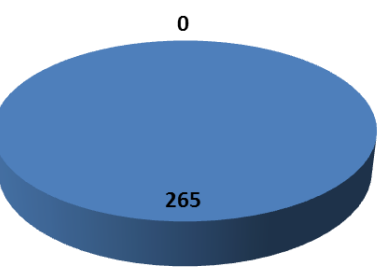

Absent m Present

Fishing Access Areas

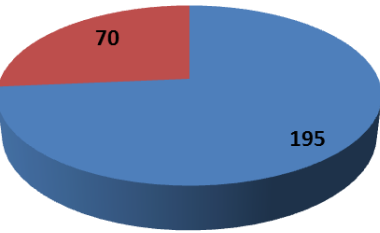

Absent $m$ Present
Wild and Scenic Rivers

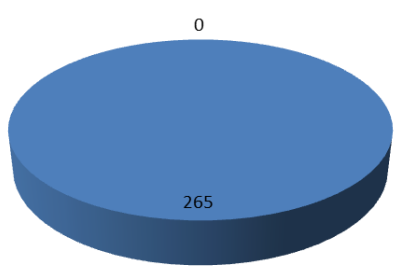

Absent Present

Water Use

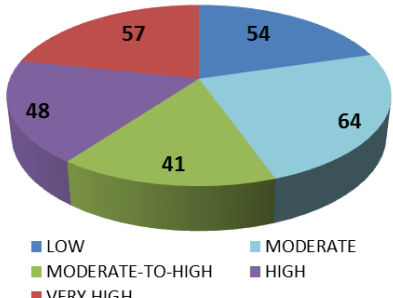

Figure 7.7. The potential capacity, in MW, associated with environmental attributes in Region 4 - Great Lakes (stream-reaches with potential capacity $>1 \mathrm{MW}$ ). 


\section{REGION 5-OHIO}

\subsection{Summary of Findings}

Following NSD methodology (Hadjerioua et al., 2013), the potential capacity, annual generation and mean capacity factors in the Ohio Region are estimated and summarized in Table 8.1 for both larger (>1 MW) and smaller (<1 MW) stream-reaches. For comparison, the year-2011 nameplate capacity, 2002-2011 average annual generation, and capacity factor of existing hydropower facilities are also listed (NHAAP, 2013). The total undeveloped NSD capacity is $4.76 \mathrm{GW}$, around $216 \%$ of existing conventional hydropower nameplate capacity. In terms of energy, the total undeveloped NSD generation is $25.29 \mathrm{TWh} / \mathrm{year}$, around $379 \%$ of annual net generation from existing conventional hydropower plants. Given the run-of-river assumption, NSD stream-reaches have higher capacity factors, especially compared with other larger-storage peaking-operation projects in this region. More detailed topographical analysis and environmental attribution are conducted for larger (>1 MW) stream-reaches and discussed in Sections 8.3 and 8.4 .

Table 8.1. Summary of NSD Findings in Region 5-Ohio

\begin{tabular}{l|r|r|r}
\hline & $\begin{array}{r}\text { Capacity } \\
\text { (MW) }\end{array}$ & $\begin{array}{r}\text { Generation } \\
\text { (MWh) }\end{array}$ & $\begin{array}{r}\text { Mean capacity } \\
\text { factor }\end{array}$ \\
\hline Potential in undeveloped stream-reaches $(<1 \mathrm{MW})$ & 3,043 & $16,304,000$ & $61 \%$ \\
\hline Potential in undeveloped stream-reaches $(>1 \mathrm{MW})$ & 1,714 & $8,984,000$ & $60 \%$ \\
\hline Existing hydropower-conventional hydro & 2,201 & $6,681,000$ & $35 \%$ \\
\hline Existing hydropower-pumped storage & 469 & & \\
\hline
\end{tabular}

\subsection{Background Hydrologic Setting}

The Ohio Region encompasses approximately $421,961 \mathrm{~km}^{2}$ in the mid-upper-west section of the United States. This region contains the eastern sections of Illinois, most of southern Indiana, most of Kentucky, southern sections of Ohio, western sections of Pennsylvania, some parts of Tennessee, North Carolina, Maryland, Virginia and New York, and most of West Virginia.

Several river systems are located in the Ohio Region (Figure 8.1), including the Ohio, Allegheny, Monongahela, Kanawha, Muskingum, Scioto, Big Sandy, Guyandotte, Great Miami, Kentucky, Licking, Green, Wabash, Patoka, White, and Cumberland rivers, with a total length of 51,632 km (i.e., total length of streams with estimated discharge greater than $35 \mathrm{cfs}$ ). Metropolitan areas within the region include Indianapolis (IN), Columbus (OH), Cincinnati (OH), Louisville (KY), Lexington (KY), Charleston (WV), and Pittsburg (PA). As shown in Figure 8.2, annual precipitation for the Ohio region ranges from 950 to $1350 \mathrm{~mm} /$ year and annual runoff from 300 to $700 \mathrm{~mm} /$ year. Most precipitation occurs from late spring through summer. The peak of the runoff occurs during early spring when the snow melts. 
The existing hydropower plants and major non-powered dams (Hadjerioua et al., 2012) are shown in Figure 8.1. The region contains 55 hydropower dams and 129 major non-powered dams, with storage capacities of about 22,542,131 ac-ft and 16,233,505 ac-ft, respectively.

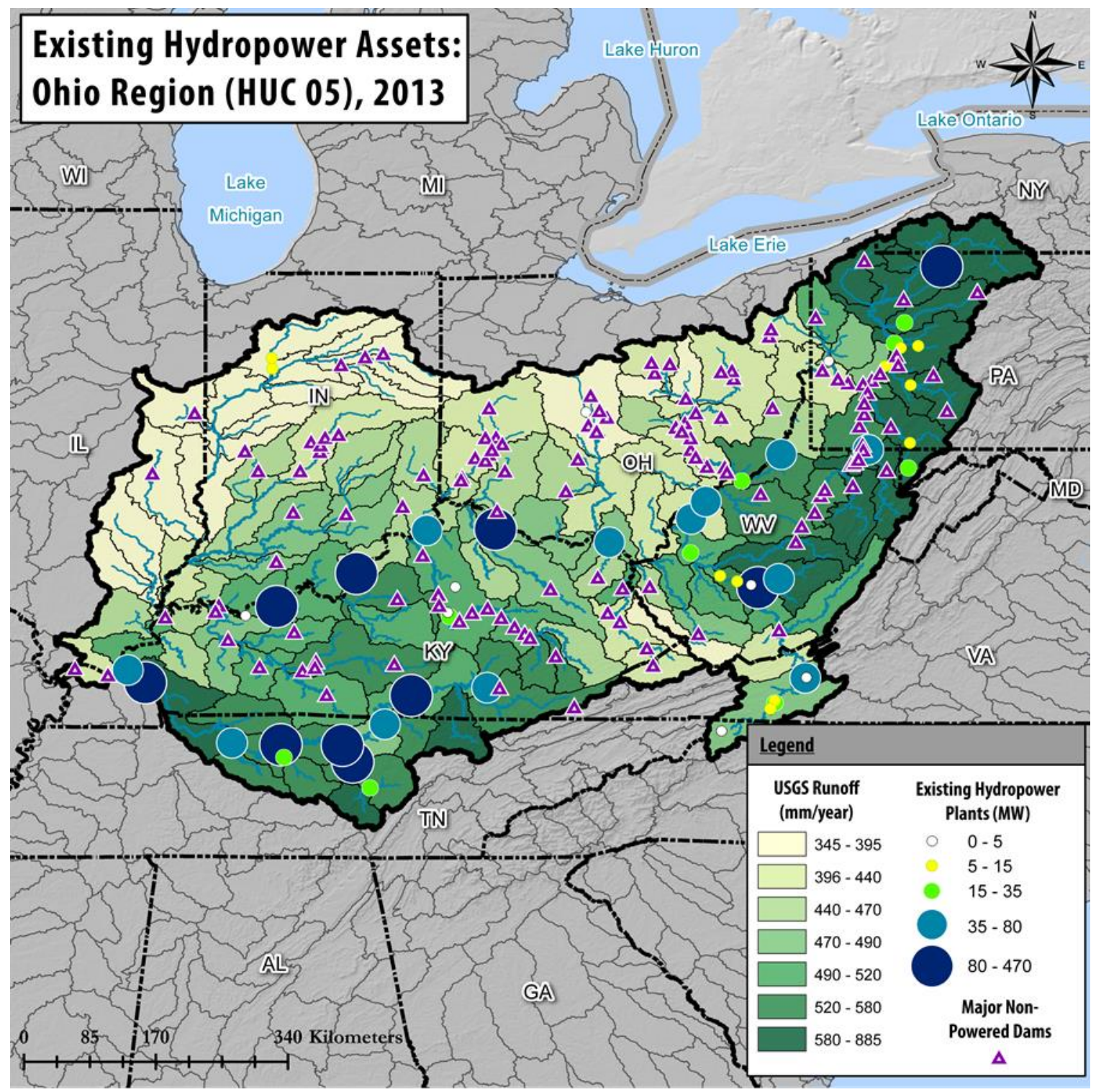

Figure 8.1. Locations of water control projects in Region 5-Ohio.

\subsection{Potential New Hydropower Resources}

A total of 699 stream-reaches of high energy density (with estimated potential capacity $>1$ MW per stream-reach) were identified in the Ohio Region. An aggregation of the NSD results into HUC04 subregions is shown in Table 8.2. The highest hydropower potentials are found in the Kanawha Subregion (HUC 0505), followed by the Allegheny Subregion (HUC 0501) and Wabash Subregion (HUC 0512) in the New, Allegheny, Wabash, and East Fork White rivers. 


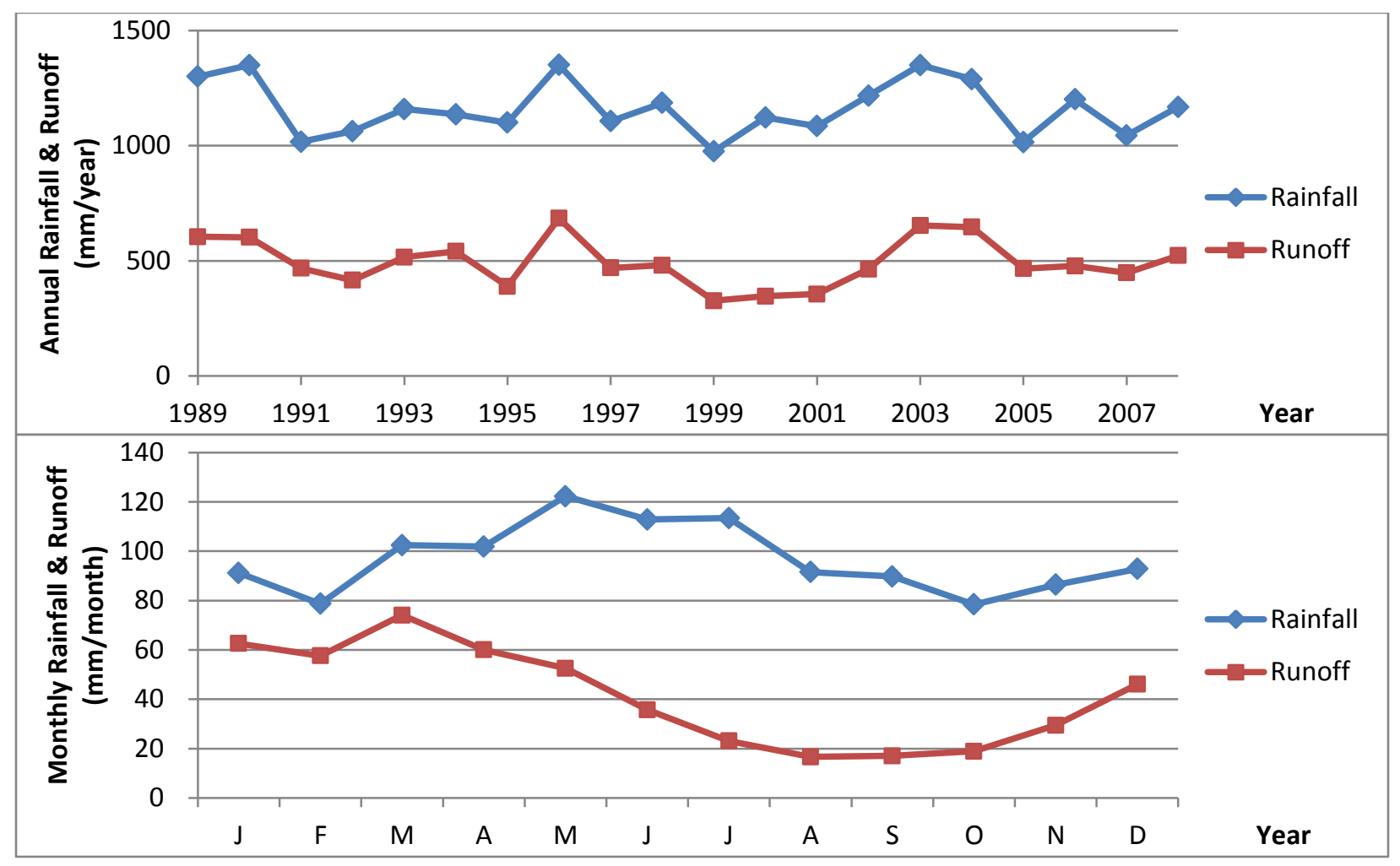

Figure 8.2. Annual and monthly rainfall and runoff of Region 5-Ohio.

Table 8.2. Summary of Potential new hydropower resources in Region 5-Ohio (Stream-Reaches with Potential Capacity $>1 \mathrm{MW})$

\begin{tabular}{llrrrrrrr}
\hline HUC04 & HUC04 name & $\begin{array}{r}\text { \# of } \\
\text { stream- } \\
\text { reaches }\end{array}$ & $\begin{array}{r}\text { Potential } \\
\text { capacity } \\
\text { (MW) }\end{array}$ & $\begin{array}{r}\text { Potential } \\
\text { energy } \\
(\mathbf{M W h})\end{array}$ & $\begin{array}{r}\text { Average } \\
\text { (ft/reach) }\end{array}$ & $\begin{array}{r}\text { Average } \\
\text { (cfs/reach) }\end{array}$ & $\begin{array}{r}\text { Average } \\
\text { storage (ac- } \\
\text { ft/reach) }\end{array}$ & $\begin{array}{r}\text { Average } \\
\text { residence } \\
\text { time (days) }\end{array}$ \\
\hline 0501 & Allegheny & 87 & 424.2 & $2,323,264$ & 23.5 & 3,282 & 5,918 & 2.4 \\
\hline 0502 & Monongahela & 111 & 371.1 & $2,008,181$ & 31.5 & 1,570 & 3,258 & 1.9 \\
\hline 0503 & Upper Ohio & 24 & 86.9 & 471,331 & 25.7 & 3,260 & 9,551 & 5.8 \\
\hline 0504 & Muskingum & 18 & 62.7 & 351,578 & 17.8 & 2,898 & 7,259 & 2.3 \\
\hline 0505 & Kanawha & 174 & 954.0 & $5,293,479$ & 37.2 & 2,069 & 6,596 & 3.6 \\
\hline 0506 & Scioto & 12 & 52.0 & 268,306 & 16.6 & 3,752 & 19,652 & 2.7 \\
\hline 0507 & Big Sandy-Guyandotte & 49 & 122.8 & 617,627 & 40.0 & 991 & 15,593 & 7.0 \\
\hline 0508 & Great Miami & 26 & 61.4 & 324,322 & 21.8 & 1,902 & 8,394 & 5.8 \\
\hline 0509 & Middle Ohio & 9 & 13.7 & 68,784 & 28.6 & 760 & 14,666 & 12.6 \\
\hline 0510 & Kentucky-Licking & 41 & 160.7 & 764,354 & 33.0 & 1,980 & 17,057 & 8.4 \\
\hline 0511 & Green & 23 & 76.1 & 386,285 & 23.6 & 2,256 & 17,995 \\
\hline 0512 & Wabash & 66 & 445.9 & $2,390,224$ & 22.7 & 4,260 & 51,803 & 8.0 \\
\hline 0513 & Cumberland & 50 & 195.7 & 960,886 & 45.3 & 1,498 & 17,656 & 17.2 \\
\hline 0514 & Lower Ohio & 9 & 16.0 & 74,987 & 26.1 & 1,180 & 10,634 \\
\hline
\end{tabular}

The summary statistics of hydraulic head $\mathrm{H}_{\text {ref }}(\mathrm{ft})$, design flow $\mathrm{Q}_{30}$ (cfs), potential capacity $\mathrm{P}_{\mathrm{NSD}}$ $(\mathrm{MW})$, inundated area $\mathrm{A}_{\mathrm{NSD}}(\mathrm{ac})$, storage $\mathrm{V}_{\mathrm{NSD}}$ (ac-ft), and residence time $\mathrm{T}_{\mathrm{NSD}}$ (day) are shown in Figure 8.3. The hydraulic head $\mathrm{H}_{\mathrm{ref}}$ ranges from 5 to the 90 th quantile of $57 \mathrm{ft}$ with a median of about $27 \mathrm{ft}$. The design flow $\mathrm{Q}_{30}$ ranges from about $400 \mathrm{cfs}$ to the 90 th quantile of $5000 \mathrm{cfs}$ 
with a median of 1500 cfs. The potential capacity $\mathrm{P}_{\mathrm{NSD}}$ ranges from 1 to the 90th quantile of about $9 \mathrm{MW}$ with a median of about $3.75 \mathrm{MW}$. The inundated surface area $\mathrm{A}_{\mathrm{NSD}}$ ranges from 0 to the 90th quantile of 2500 ac with a median of 400 ac. This results in storage values $\mathrm{V}_{\text {NSD }}$ ranging from 0 to the 90th quantile of 30,000 ac-ft with a median of about 4,000 ac- $\mathrm{ft}$ and residence times of $\mathrm{T}_{\mathrm{NSD}}$ ranging from $<1$ day to the 90th quantile of 18 days with a median on the order of a few days. The results of $>1 \mathrm{MW}$ stream-reach potential are illustrated in Figure 8.4 with potential capacity (MW) aggregated to the HUC08 subbasins.

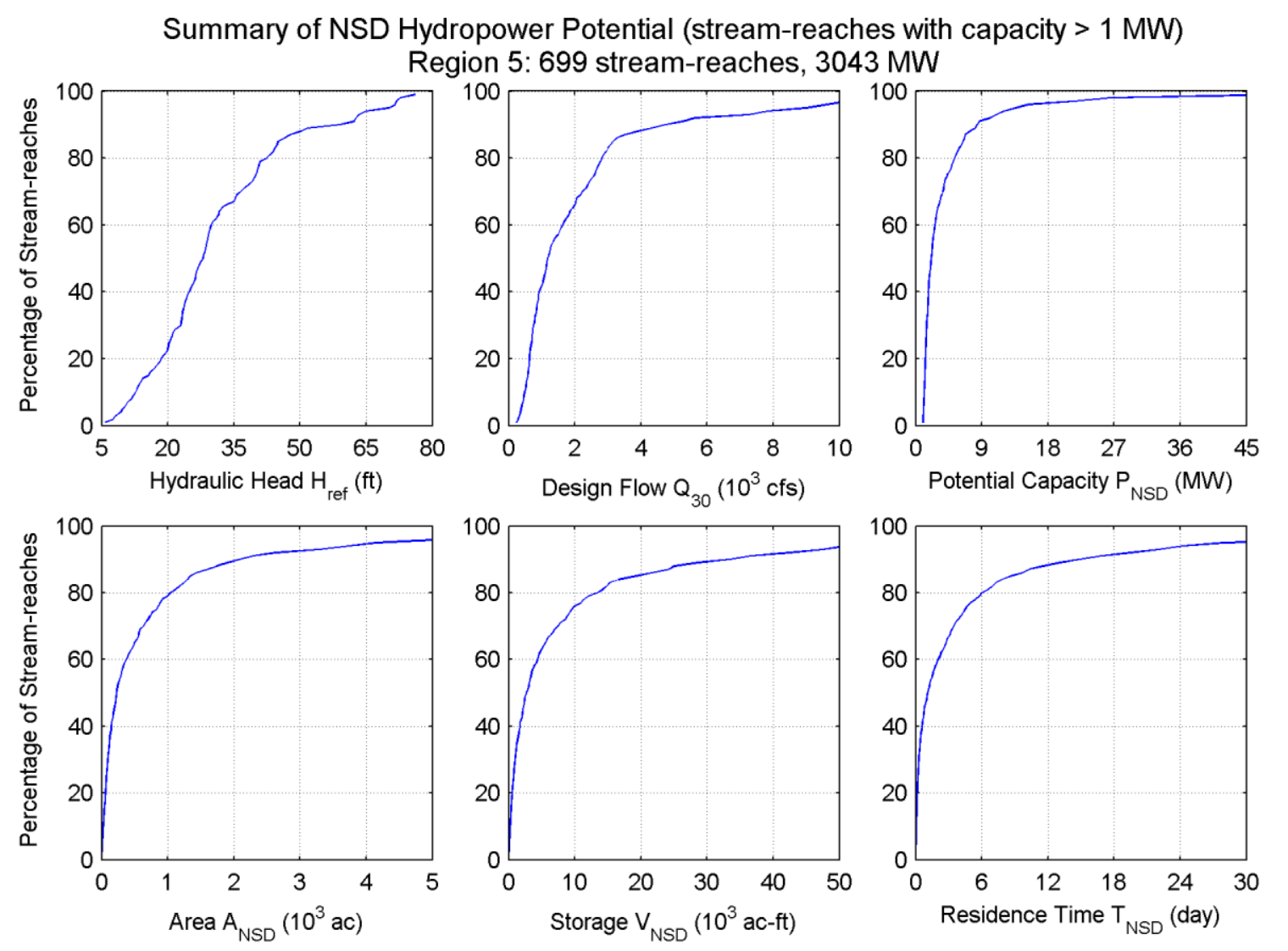

Figure 8.3. Cumulative distributions of hydraulic head $\mathrm{H}_{\text {ref }}$, design flow $\mathrm{Q}_{30}$, potential capacity $\mathrm{P}_{\mathrm{NSD}}$, inundated area $\mathrm{A}_{\mathrm{NSD}}$, storage $\mathrm{V}_{\mathrm{NSD}}$, and residence time $\mathrm{T}_{\mathrm{NSD}}$ in Region 5-Ohio.

\subsection{Environmental Characteristics}

In Region 5, eight fish species fall under ESA categories, two of which also fall under IUCN vulnerable categories. An additional 14 fish species fall under IUCN vulnerability status. Wellknown fish species of concern in the region include paddlefish (Polyodon spathula) and shortnose sturgeon (Acipenser brevirostrum). Of the 267 total native species, 13 are considered potadromous or anadromous (Figure 8.5). Twenty-eight HUC08 subbasins are considered critical watersheds, with the highest number of fish and mussels at risk in the Upper Green (29), South Fork Cumberland (22), and Tippecanoe (21) basins. Three mussel species, the Virginia big-eared bat, and Braun's rock-cress (Arabis perstellata), a plant species, have critical habitat designations in Region 5. 


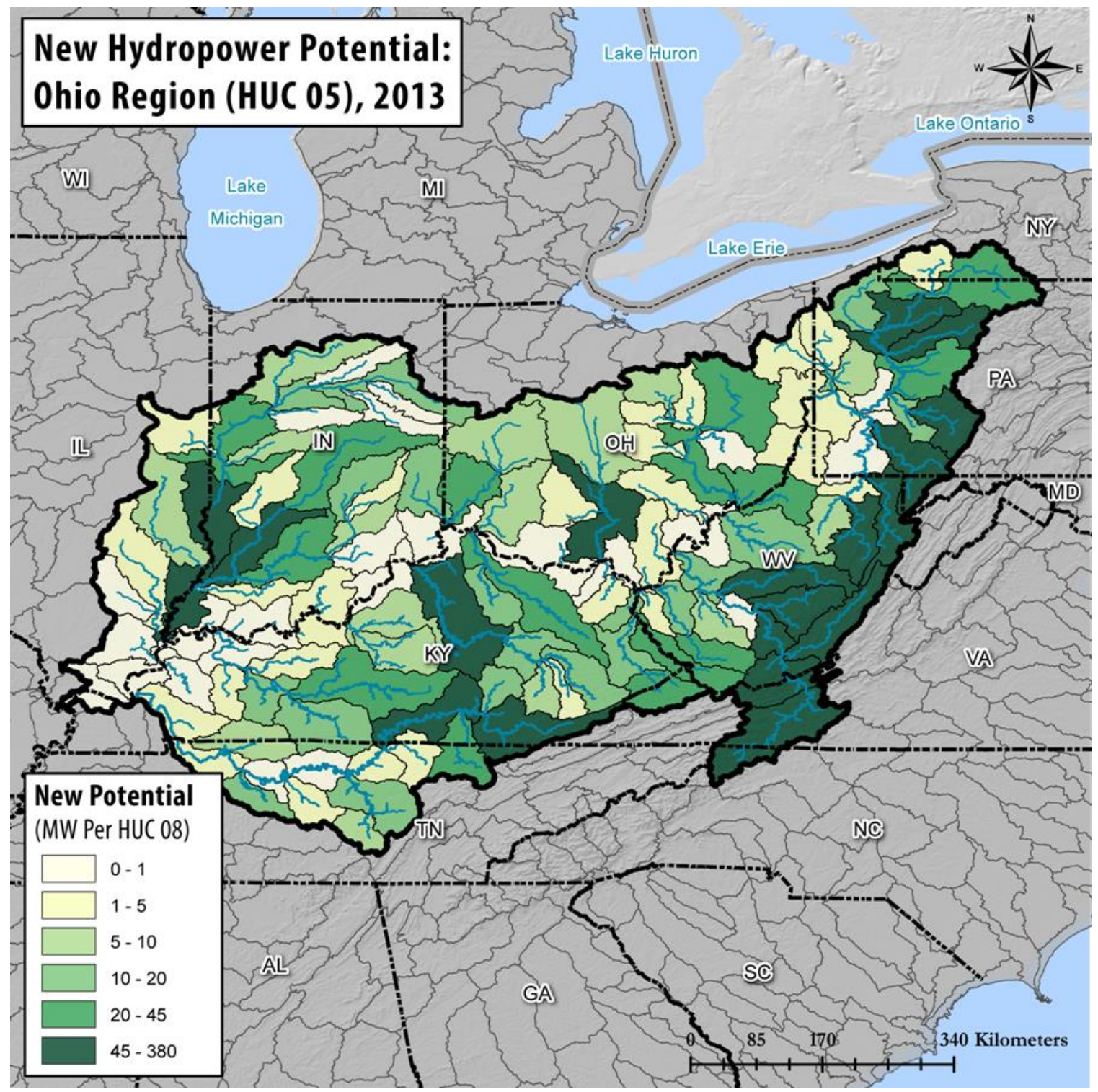

Figure 8.4. Potential new hydropower capacity in Region 5-Ohio (higher-energy-density stream-reaches with $>1$ MW per reach, aggregated to HUC08 subbasins for illustration).

Protected lands make up less than $8 \%$ of the total area in Region 5 (7.8 million acres). Most lands are federal (55\%) and are owned by the USFS (38\%), DOD (12\%), and NPS (4\%). Daniel Boone, Monongahela, Shawnee, and Allegheny National Forests are the largest contiguous protected land areas. Mammoth Cave is one of the more prominent national parks in the region. Most protected lands fall under GAP status 3 (51\%), followed by GAP status 2 (24\%), $4(20 \%)$, and $1(5 \%)$. Region 5 includes nine National Wild and Scenic Rivers and two national parkways, including sections of the Blue Ridge and Natchez Trace parkways (Figure 8.6). Recreation in Region 5 includes 1487 boat ramp locations, 792 fish access locations, 96 waterfalls, and 528 recreational boating river sections. 
Water use in Region 5 is moderately high with most usage occurring as thermoelectric cooling followed by public and industrial consumption (Appendix B). Water usage is mostly homogenous across the region; however, the lowest usage occurs in the Big Sandy-Guyandotte and Kentucky-Licking Subbasins (Table 8.3). Water quality concerns are average, with the majority classified as mercury, habitat, or toxins.

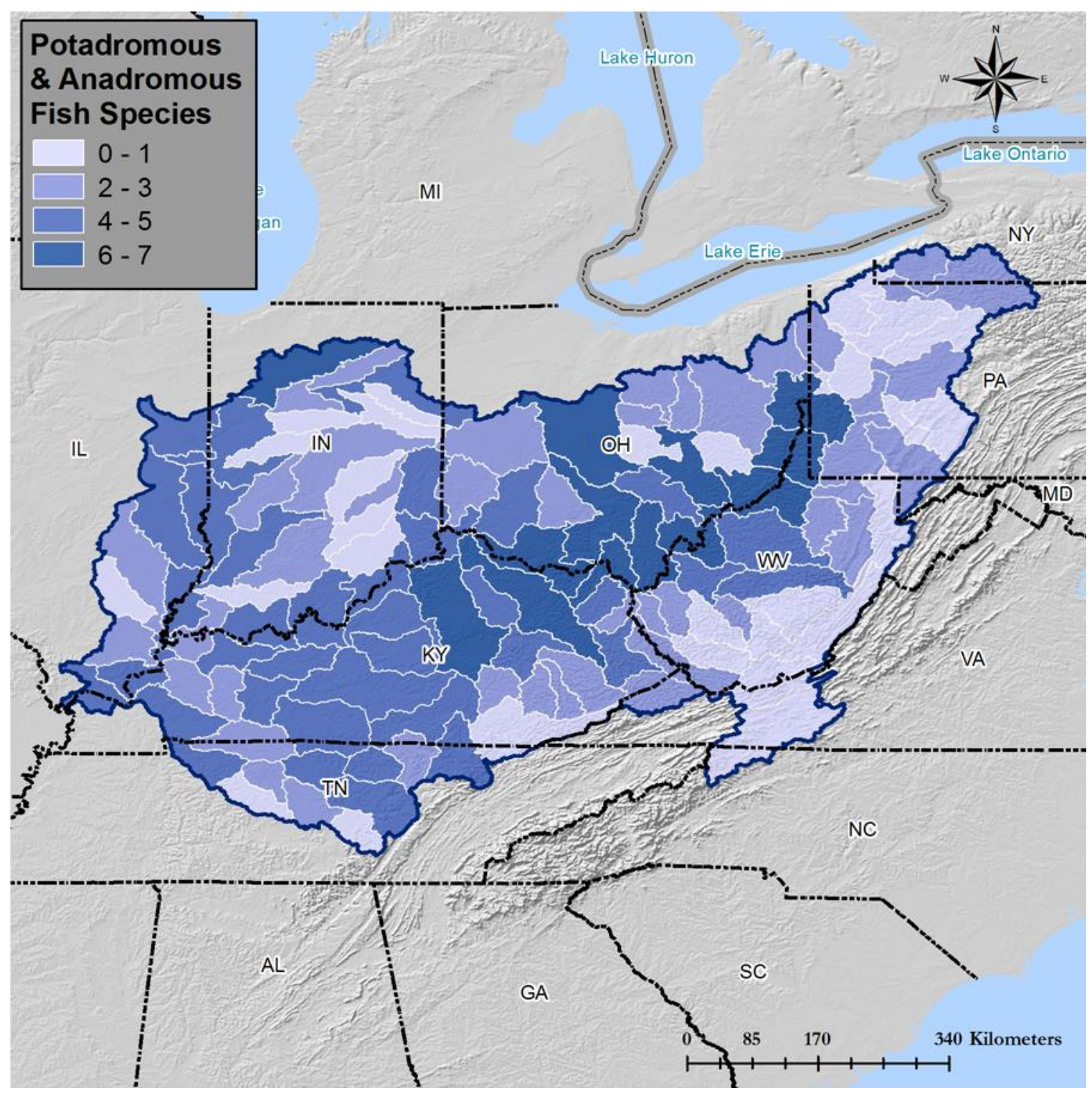

Figure 8.5. Potadromous and anadromous fish species (number per HUC08 subbasin) in Region 5. 


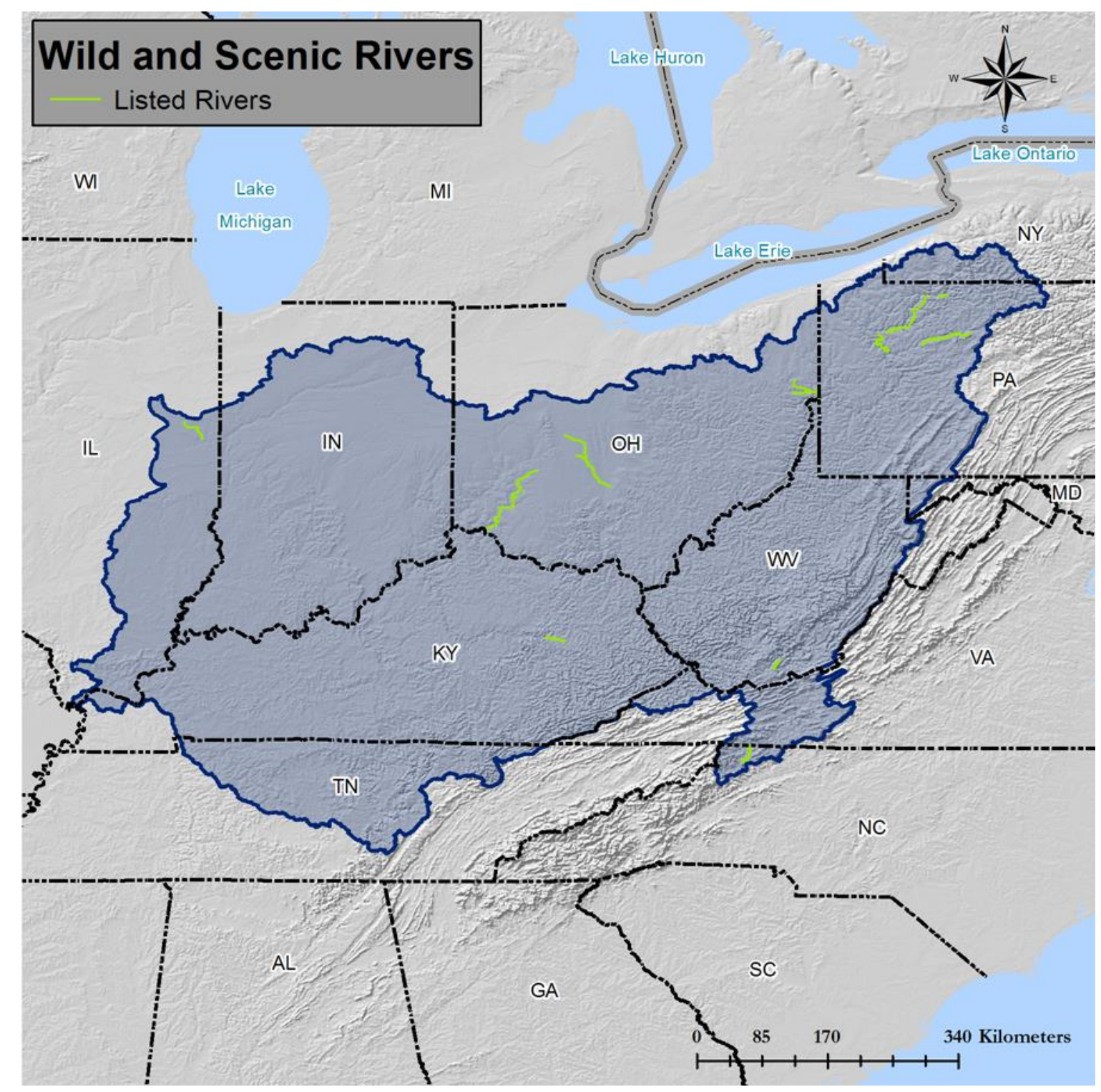

Figure 8.6. Wild and Scenic River Systems in Region 5.

Of the 699 total stream-reaches in Region 5, only 24 (86 MW) intersect critical habitat designations (Figure 8.7). Almost 16\% of stream-reaches are located within HUC08 subbasins with at least one fish falling under ESA categories. Over $72 \%$ of stream-reaches intersect protected lands $(\sim 2.5 \mathrm{GW})$; however, only one stream-reach intersects a national park. Fifty-five stream-reaches (298 MW) intersect Wild and Scenic Rivers. Most stream-reaches (83\%) overlap with water-quality concerns. Recreational boating is also very prevalent, overlapping with $64 \%$ of stream-reaches. Boat ramps and fishing access locations intersect $37 \%$ and $26 \%$ of streamreaches, respectively. Over $1.1 \mathrm{GW}$ of potential capacity overlaps within HUC08 subbasins having high or very high water use. 
Table 8.3. Summary of Environmental Variables at HUC04 Subregions within Region 5 (Stream-Reaches with Potential Capacity $>1 \mathrm{MW}$ )

\begin{tabular}{lrrrrrrrr}
\hline HUC04 HUC04 name & $\begin{array}{r}\text { \# Critical } \\
\text { habitats }\end{array}$ & $\begin{array}{r}\text { \# Potad- } \\
\text { anad fish }\end{array}$ & $\begin{array}{r}\text { ESA } \\
\text { fish }\end{array}$ & $\begin{array}{r}\text { \# IUCN } \\
\text { fish }\end{array}$ & $\begin{array}{r}\text { \# Recreation } \\
\text { locations }\end{array}$ & $\begin{array}{r}\text { Protected } \\
\text { lands } \\
(\mathbf{\%})\end{array}$ & $\begin{array}{r}\text { Populatio } \\
\mathbf{n} \text { density } \\
\left(\mathbf{i n d} / \mathbf{k m}^{\mathbf{2}}\right)\end{array}$ & $\begin{array}{r}\text { Freshwater } \\
\mathbf{u s e} \\
\left(\mathbf{l} / \mathbf{d a y} / \mathbf{k m}^{\mathbf{2}}\right)\end{array}$ \\
\hline 0501 Allegheny & 0 & 6 & 0 & 4 & $160 ; 38 ; 2$ & 14.72 & 86.94 & $1,766.49$ \\
\hline 0502 Monongahela & 1 & 5 & 0 & 0 & $139 ; 108 ; 14$ & 13.00 & 61.12 & $2,270.68$ \\
\hline 0503 Upper Ohio & 0 & 8 & 1 & 3 & $233 ; 14 ; 6$ & 5.22 & 84.59 & $6,981.28$ \\
\hline 0504 Muskingum & 0 & 8 & 0 & 4 & $86 ; 6 ; 2$ & 3.94 & 61.56 & $1,279.91$ \\
\hline 0505 Kanawha & 0 & 8 & 1 & 7 & $265 ; 162 ; 19$ & 14.67 & 28.68 & $2,442.36$ \\
\hline 0506 Scioto & 0 & 8 & 1 & 4 & $56 ; 7 ; 1$ & 3.90 & 81.87 & $1,045.67$ \\
\hline 0507 Big Sandy- & 0 & 6 & 0 & 2 & $76 ; 17 ; 0$ & 2.57 & 18.16 & 461.47 \\
\hline Guyandotte & 0 & 6 & 1 & 3 & $42 ; 18 ; 3$ & 1.90 & 134.77 & $2,516.45$ \\
\hline 0509 Great Miami & 0 & 8 & 2 & 5 & $141 ; 27 ; 3$ & 6.15 & 72.72 & $4,791.39$ \\
\hline 0510 Kentucky-Licking & 0 & 7 & 1 & 4 & $150 ; 29 ; 1$ & 6.45 & 10.15 & 528.03 \\
\hline 0511 Green & 0 & 7 & 0 & 7 & $110 ; 3 ; 0$ & 2.69 & 9.02 & $2,448.17$ \\
\hline 0512 Wabash & 0 & 10 & 1 & 6 & $323 ; 19 ; 6$ & 3.34 & 44.90 & $1,832.05$ \\
\hline 0513 Cumberland & 4 & 7 & 5 & 9 & $340 ; 59 ; 22$ & 10.97 & 56.86 & $2,021.17$ \\
\hline 0514 Lower Ohio & 0 & 6 & 1 & 6 & $158 ; 21 ; 17$ & 12.02 & 45.54 & $5,773.60$ \\
\hline
\end{tabular}

${ }^{a}$ Recreation locations refer to the number of boat-ramp and fishing access points, recreational boating, and waterfalls within each HUC04.

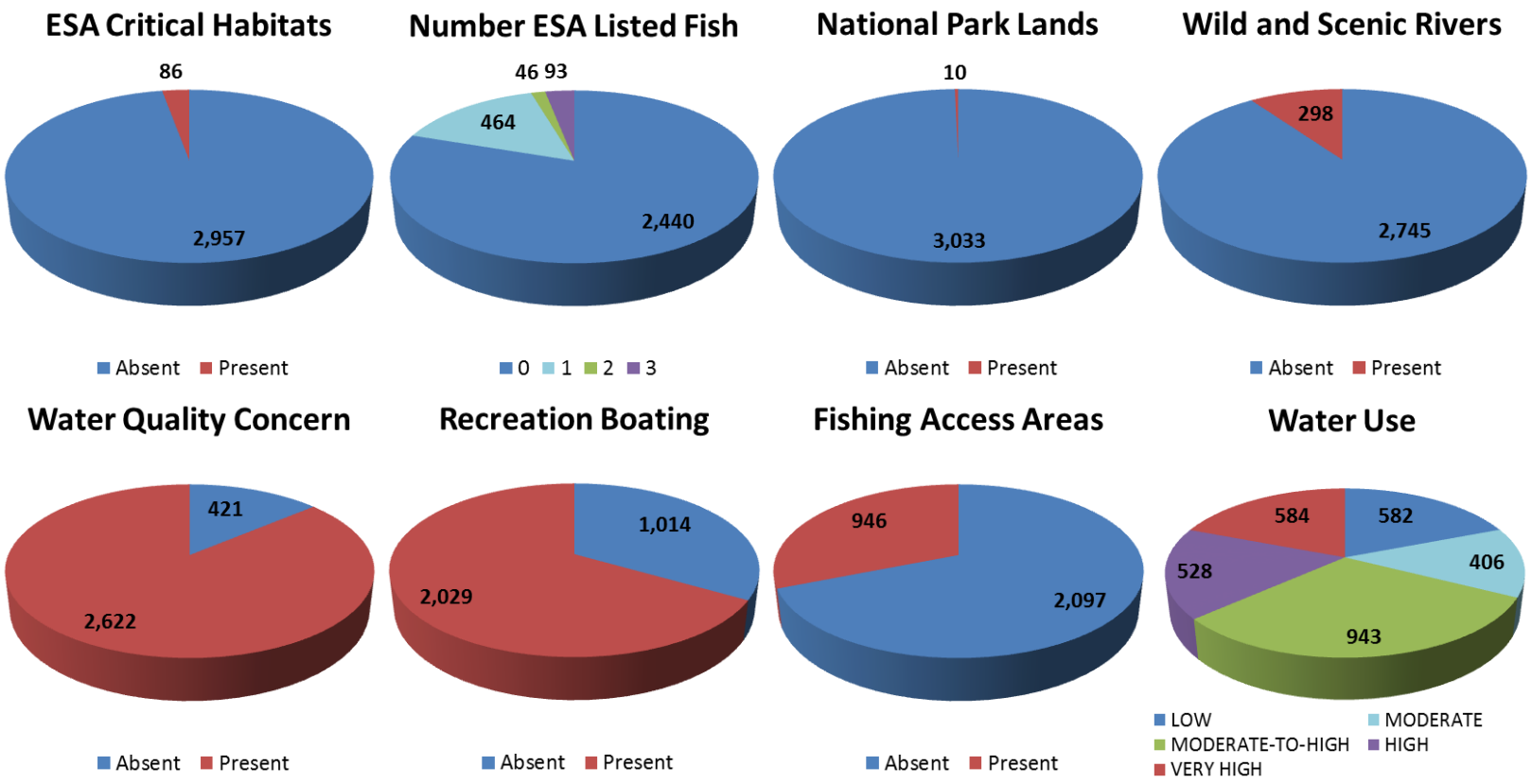

Figure 8.7. The potential capacity, in MW, associated with environmental attributes in Region 5-Ohio (streamreaches with potential capacity $>1 \mathrm{MW}$ ). 


\section{REGION 6-TENNESSEE}

\subsection{Summary of Findings}

Following NSD methodology (Hadjerioua et al., 2013), the potential capacity, annual generation and mean capacity factors in the Tennessee Region are estimated and summarized in Table 9.1 for both larger (>1 MW) and smaller (<1 MW) stream-reaches. For comparison, the year-2011 nameplate capacity, 2002-2011 average annual generation, and capacity factor of existing hydropower facilities are also listed (NHAAP, 2013). The total undeveloped NSD capacity is $1.36 \mathrm{GW}$, around $33 \%$ of existing conventional hydropower nameplate capacity. In terms of energy, the total undeveloped NSD generation is $8.00 \mathrm{TWh} /$ year, around $55 \%$ of annual net generation from existing conventional hydropower plants. The lower ratios of potential NSD resources to existing hydropower development suggest that many of the hydraulically feasible stream-reaches may have been used for hydropower development in this region. Given the runof-river assumption, NSD stream-reaches have higher capacity factors, especially compared with other larger-storage peaking-operation projects in this region. More detailed topographical analysis and environmental attribution are conducted for larger (>1 MW) stream-reaches and discussed in Sections 9.3 and 9.4.

Table 9.1. Summary of NSD Findings in Region 6-Tennessee

\begin{tabular}{l|r|r|r}
\hline & $\begin{array}{r}\text { Capacity } \\
(\mathbf{M W})\end{array}$ & $\begin{array}{r}\text { Generation } \\
(\mathbf{M W h})\end{array}$ & $\begin{array}{r}\text { Mean capacity } \\
\text { factor }\end{array}$ \\
\hline Potential in undeveloped stream-reaches $(>1 \mathrm{MW})$ & 747 & $4,383,000$ & $67 \%$ \\
\hline Potential in undeveloped stream-reaches $(<1 \mathrm{MW})$ & 616 & $3,612,000$ & $67 \%$ \\
\hline Existing hydropower-conventional hydro & 4,166 & $14,542,000$ & $40 \%$ \\
\hline Existing hydropower-pumped storage & 1,809 & & \\
\hline
\end{tabular}

\subsection{Background Hydrologic Setting}

The Tennessee Region encompasses approximately $105,949 \mathrm{~km}^{2}$ in the Tennessee valley and contains parts of Tennessee and North Carolina and small sections of Virginia, Georgia, Alabama, Kentucky and Mississippi. The region comprises mountainous, valley, and plateau geography.

Several river systems are located in the Tennessee Region (Figure 9.1), including the Tennessee, French Broad, Holston, and Sequatchie rivers, with a total length of $14,893 \mathrm{~km}$ (i.e., total length of streams with estimated discharge greater than $35 \mathrm{cfs}$ ). Metropolitan areas within the region include Knoxville (TN), Chattanooga (TN), and Huntsville (AL). As shown in Figure 9.2, annual precipitation for the Tennessee region ranges from 900 to $1700 \mathrm{~mm} / \mathrm{year}$, and annual runoff from 250 to $900 \mathrm{~mm} /$ year. Most of the precipitation occurs predominately in the winter and some in late summer. 
The existing hydropower plants and major non-powered dams (Hadjerioua et al., 2012) are shown in Figure 9.1. The region contains 50 hydropower dams and 9 major non-powered dams, with storage capacities of about 28,961,324 ac-ft and 405,235 ac-ft, respectively. These facilities are mainly owned by the Tennessee Valley Authority (TVA).

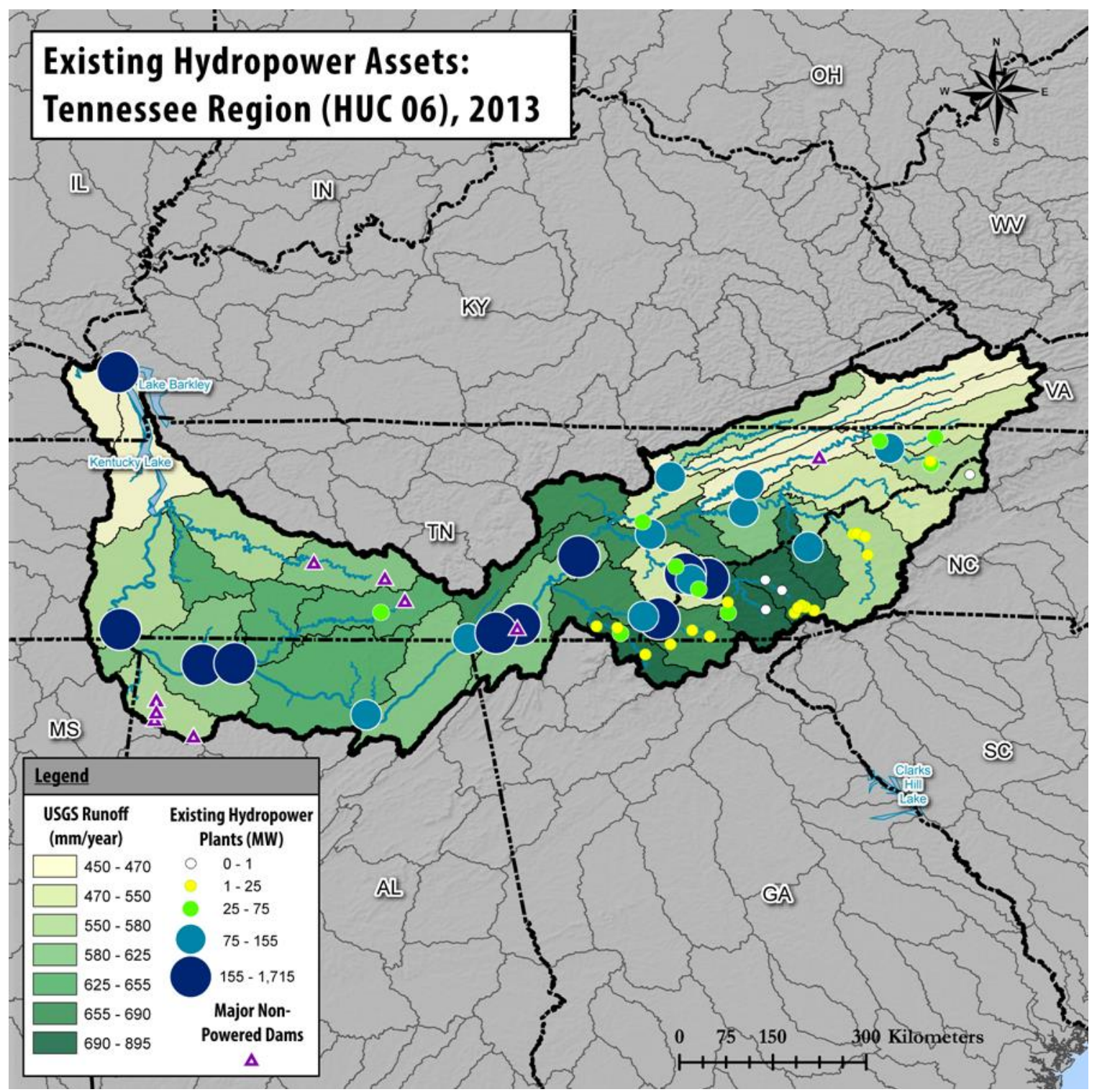

Figure 9.1. Locations of water control projects in Region 6-Tennessee.

\subsection{Potential New Hydropower Resources}

A total of 235 stream-reaches of high energy density (with estimated potential capacity $>1 \mathrm{MW}$ per stream-reach) were identified in the Tennessee Region. The NSD results for the HUC04 subregions are summarized in Table 9.2. The highest hydropower potentials are found in the Upper Tennessee Subregion (HUC 0601) in the Tennessee, French Broad, Holston, and Clinch rivers. 


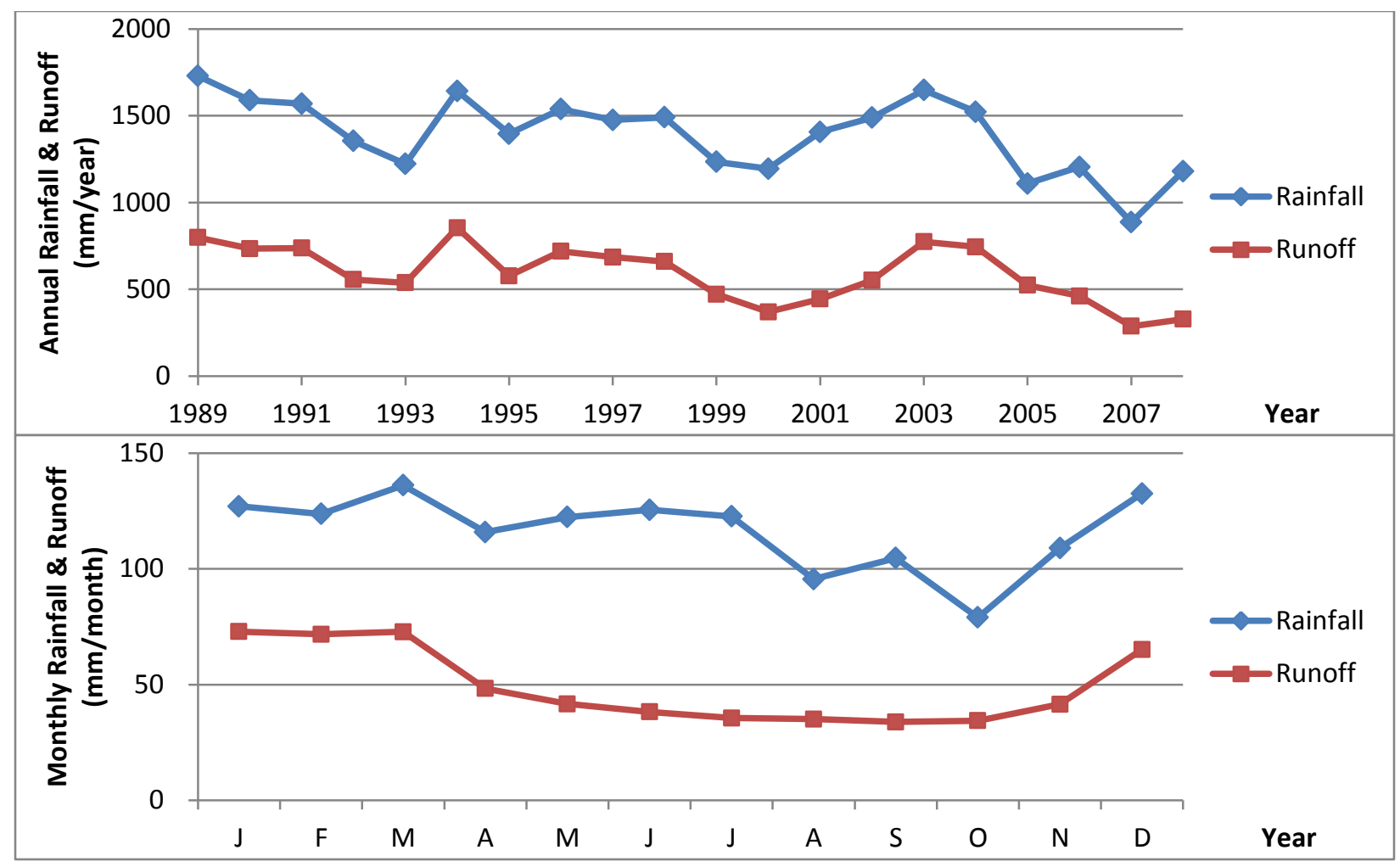

Figure 9.2. Annual and monthly rainfall and runoff of Region 6-Tennessee.

Table 9.2. Summary of Potential New Hydropower Resources in Region 6-Tennessee (Stream-Reaches With Potential Capacity $>1 \mathrm{MW}$ )

\begin{tabular}{llrrrrrrr}
\hline HUC04 & HUC04 name & $\begin{array}{r}\text { \# of } \\
\text { stream- } \\
\text { reaches }\end{array}$ & $\begin{array}{r}\text { Potential } \\
\text { capacity } \\
\text { (MW) }\end{array}$ & $\begin{array}{r}\text { Potential } \\
\text { energy } \\
\text { (MWh) }\end{array}$ & $\begin{array}{r}\text { Average } \\
\text { (ft/reach) }\end{array}$ & $\begin{array}{r}\text { Average } \\
\text { (cfs/reach) }\end{array}$ & $\begin{array}{r}\text { Average } \\
\text { storage (ac- } \\
\text { ft/reach) }\end{array}$ & $\begin{array}{r}\text { Average } \\
\text { residence } \\
\text { time (days) }\end{array}$ \\
\hline 0601 & Upper Tennessee & 175 & 601.9 & $3,574,050$ & 37.4 & 1,397 & 15,949 & 12.7 \\
\hline 0602 & $\begin{array}{l}\text { Middle Tennessee- } \\
\text { Hiwassee }\end{array}$ & 24 & 55.6 & 353,524 & 23.1 & 1,457 & 6,114 & 3.4 \\
\hline 0603 & Middle Tennessee-Elk & 14 & 26.0 & 135,005 & 20.0 & 1,299 & 9,054 & 4.3 \\
\hline 0604 & Lower Tennessee & 22 & 63.6 & 320,656 & 24.6 & 1,740 & 10,614 & 3.3 \\
\hline
\end{tabular}

The summary statistics of hydraulic head $\mathrm{H}_{\mathrm{ref}}(\mathrm{ft})$, design flow $\mathrm{Q}_{30}(\mathrm{cfs})$, potential capacity $\mathrm{P}_{\mathrm{NSD}}$ (MW), inundated area $\mathrm{A}_{\mathrm{NSD}}(\mathrm{ac})$, storage $\mathrm{V}_{\mathrm{NSD}}\left(\mathrm{ac}-\mathrm{ft}\right.$ ), and residence time $\mathrm{T}_{\mathrm{NSD}}$ (day) are shown in Figure 9.3. The hydraulic head $\mathrm{H}_{\text {ref }}$ ranges from 5 to the 90th quantile of $77 \mathrm{ft}$ with a median of about $27 \mathrm{ft}$. The design flow $\mathrm{Q}_{30}$ ranges from about $250 \mathrm{cfs}$ to the 90 th quantile of $3000 \mathrm{cfs}$ with a median of $1000 \mathrm{cfs}$. The potential capacity $\mathrm{P}_{\mathrm{NSD}}$ ranges from 1 to the 90 th quantile of about $5 \mathrm{MW}$ with a median of about $2 \mathrm{MW}$. The inundated surface area $\mathrm{A}_{\mathrm{NSD}}$ ranges from 0 to the 90th quantile of 1500 acres with a median of 250 acres. This results in storage values $\mathrm{V}_{\mathrm{NSD}}$ ranging from 0 to the 90th quantile of 30,000 ac- $\mathrm{ft}$ with a median of about 4,000 ac-ft and residence times $\mathrm{T}_{\mathrm{NSD}}$ ranging from $<1$ day to the 90th quantile of 20 days with a median on the order of a few days. The results of $>1 \mathrm{MW}$ stream-reach potential are illustrated in Figure 9.4 with potential capacity (MW) aggregated to the HUC08 subbasins. 


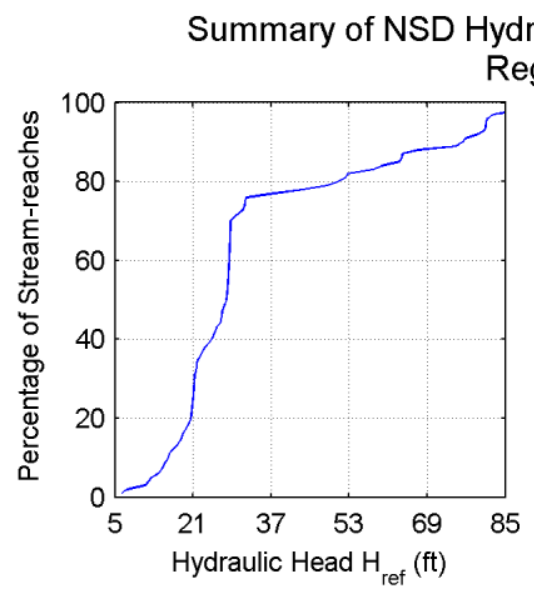

Region 6: 235 stream-reaches, $747 \mathrm{MW}$
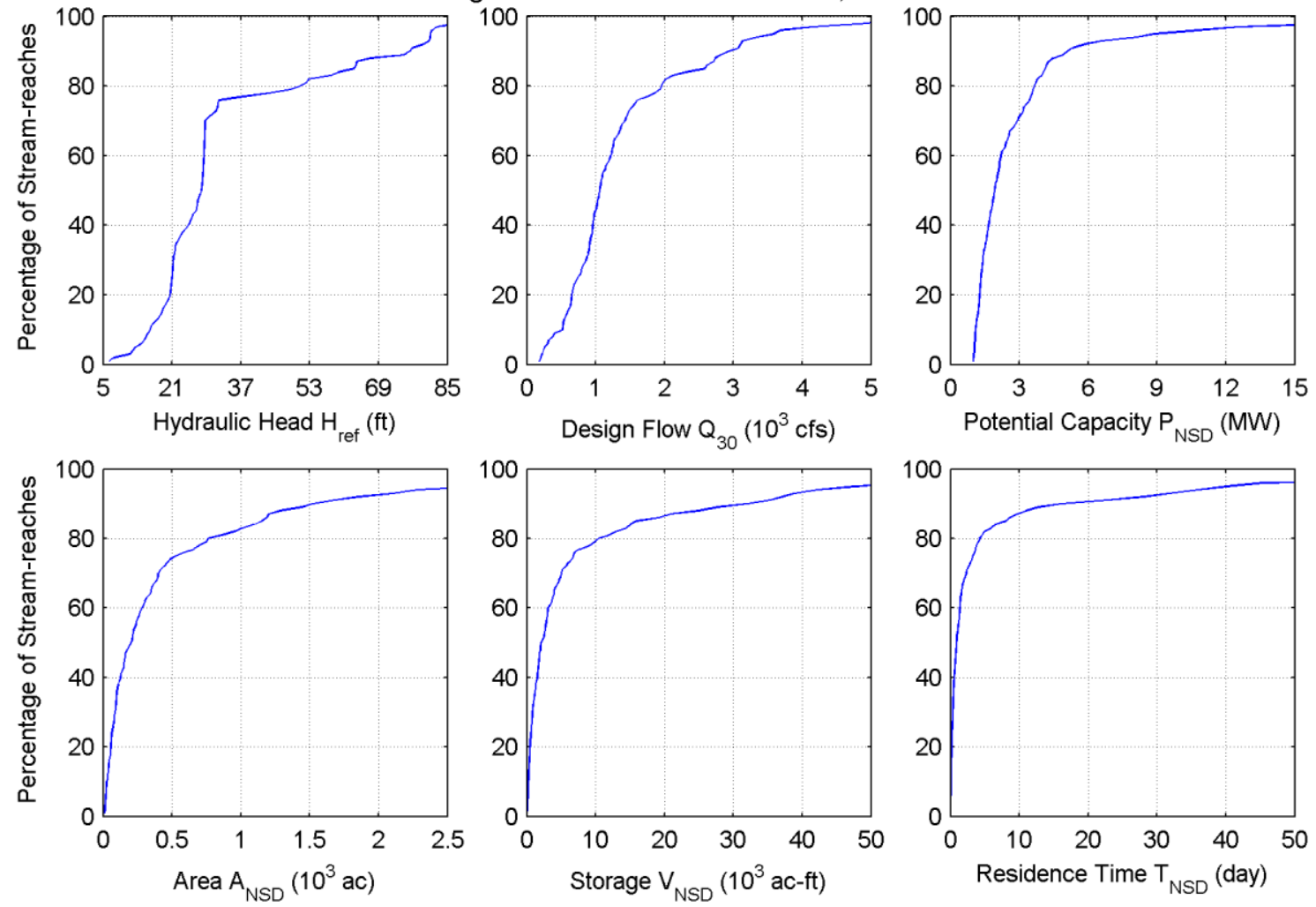

Figure 9.3. Cumulative distributions of hydraulic head $\mathrm{H}_{\text {ref }}$, design flow $\mathrm{Q}_{30}$, potential capacity $\mathrm{P}_{\mathrm{NSD}}$, inundated area $\mathrm{A}_{\mathrm{NSD}}$, storage $\mathrm{V}_{\mathrm{NSD}}$, and residence time $\mathrm{T}_{\mathrm{NSD}}$ in Region 6-Tennessee.

\subsection{Environmental Characteristics}

Considering its small size, the Tennessee Region is one of the areas richest in aquatic species in the United States, with more than 250 native fish species and more than 100 freshwater mussel species (http://tn.water.usgs.gov/lten/tenn.html). The Clinch and Duck rivers are responsible for most of the high diversity found in the region (USGS, 2001). Fifty-one aquatic species (fish and mollusks) are listed as either threatened or endangered (USGS, 2001). Approximately 16 fish species are under ESA categories (Figure 9.5), 6 of which are currently listed as endangered and 6 of which are listed as threatened. Twenty-eight fish and mussel species are listed as endangered or threatened and 50 species are considered "at risk" in the Clinch River drainage alone (Master et al., 1998). Sixty-two percent of HUC08 subbasins in Region 6 are considered critical watersheds with 14 subbasins having at least 15 fish or mussel species at risk (Master et al., 1998). Fourteen additional fish species besides those under ESA categories also fall solely under IUCN vulnerable categories (Figure 9.5). Among the fishes of concern are paddlefish, sturgeon, and many endemic darter, madtom, minnow, and sucker species (Appendix B). Eleven species are potadromous or anadromous in the region. Five mussels, five fish, one plant, and one arachnid have critical habitat designations in the region (Figure 9.6). 


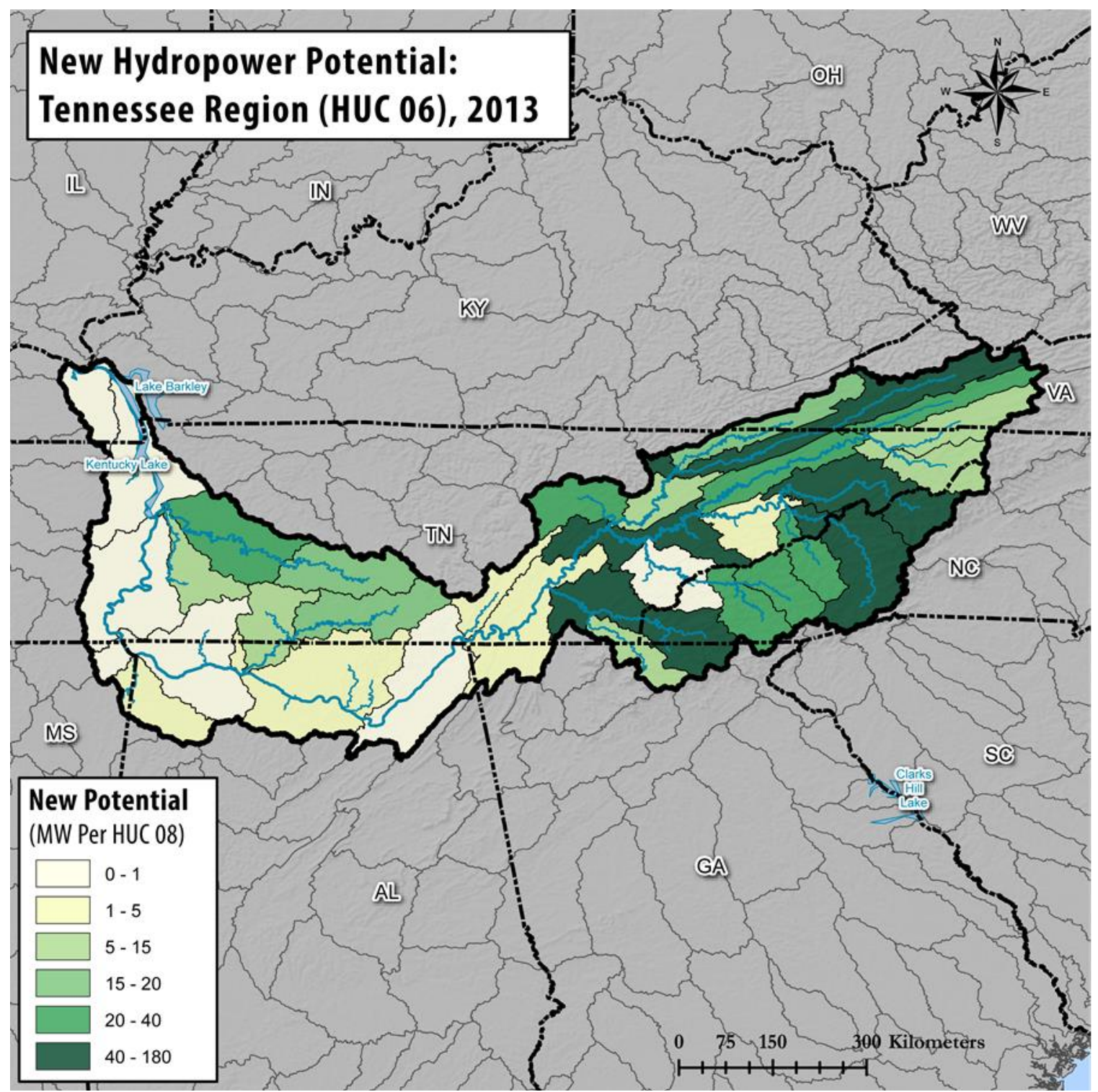

Figure 9.4. Potential new hydropower capacity in Region 6-Tennessee (higher-energy-density stream-reaches with >1 MW per reach, aggregated to HUC08 subbasins for illustration).

Over $85 \%$ of the 3.5 million acres of protected land in Region 6 are federally owned by the USFS (57\%), NPS (17\%), TVA (9\%), and DOD (2\%). Great Smoky Mountains National Park is the largest parcel of protected land in this region. Cherokee, Nantahala, Pisgah, Chattahoochee, and George Washington-Jefferson National Forests are also among the largest tracts of protected land. State lands constitute approximately $11 \%$ of protected lands. The Eastern Cherokee Indian reservation, almost 50,000 acres, is located in the eastern section of the region. GAP status 3 lands are predominant (63\%), followed by status $1(18 \%)$ and $2(15 \%)$ lands. The Obed River is the only National Wild and Scenic River in Region 6. The Blue Ridge and Natchez Trace parkways also have sections within the region. Despite its being among the smallest regions, the Tennessee region has a large number of recreational uses, with a total of 675 boat ramp locations, 286 fishing access locations, 149 waterfalls, and 258 recreational boating river sections. 
On average, the highest amount of water use in the United States occurs in Region 6. Water use is fairly homogenous in the region (Table 9.3 and Figure 9.7), with the vast majority occurring as thermoelectric cooling, followed by industrial and public consumption. Water-quality concerns in Region 6 are average with most classified as mercury or toxin contamination.

Seventy-four percent of stream-reaches (497 MW) are located within HUC08 subbasins with at least one fish falling under an ESA category (Figure 9.8). Over $42 \%$ of stream-reaches (223 MW) intersect critical habitat designations. Almost $83 \%$ of stream-reaches (667 MW) potentially overlap with protected lands; 27 and 18 reaches overlap with a national park or Wild and Scenic River, respectively. Almost $79 \%$ of stream-reaches (643 MW) intersect water-quality concerns. Recreation is prevalent, with recreational boating, boat ramps, and fishing access locations intersecting 54\%, 34\%, and 15\% of stream-reaches. Most stream-reaches overlap within HUC08 subbasins with high or very high water use values.

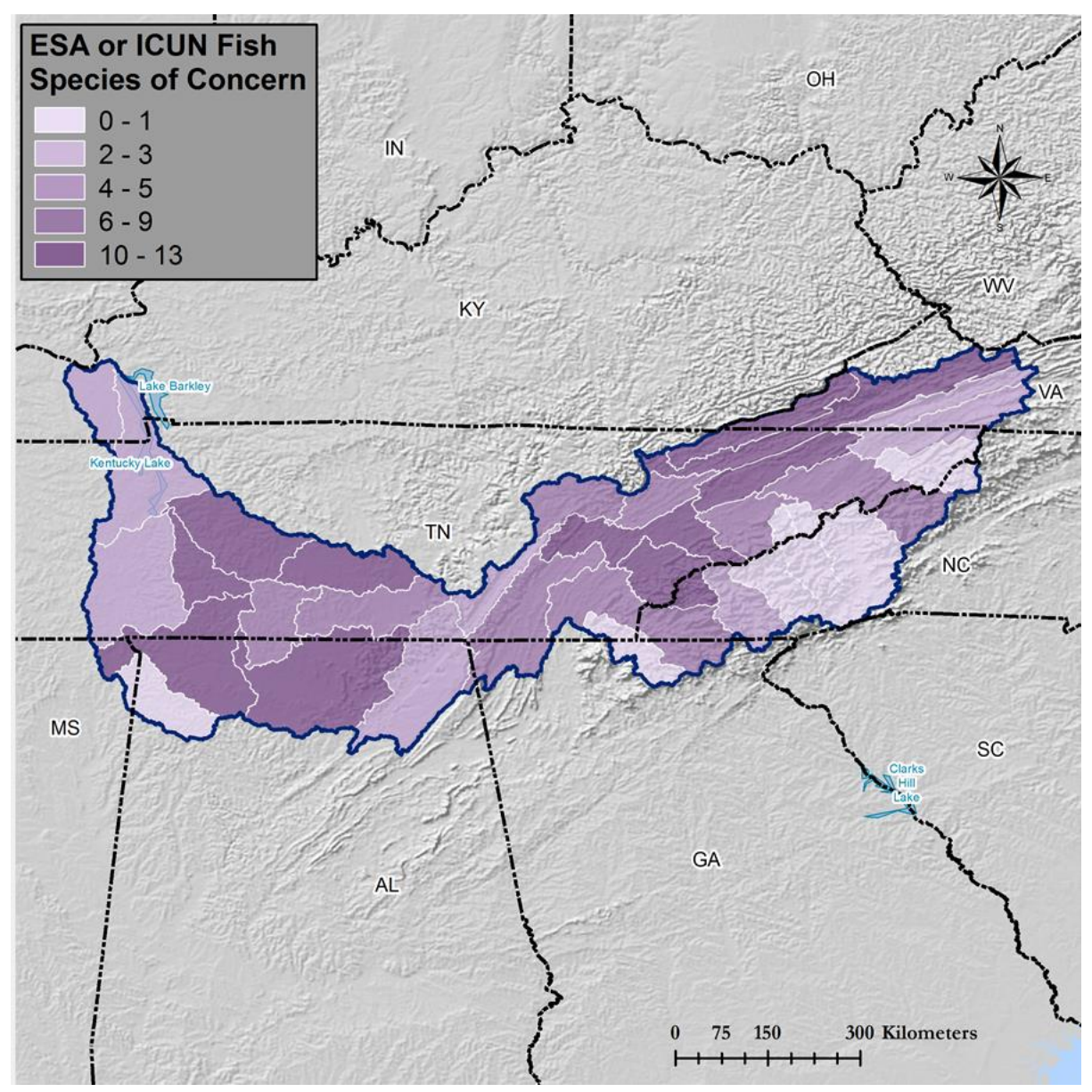

Figure 9.5. Fish species of concern (number per HUC08 subbasin) in Region 6. 


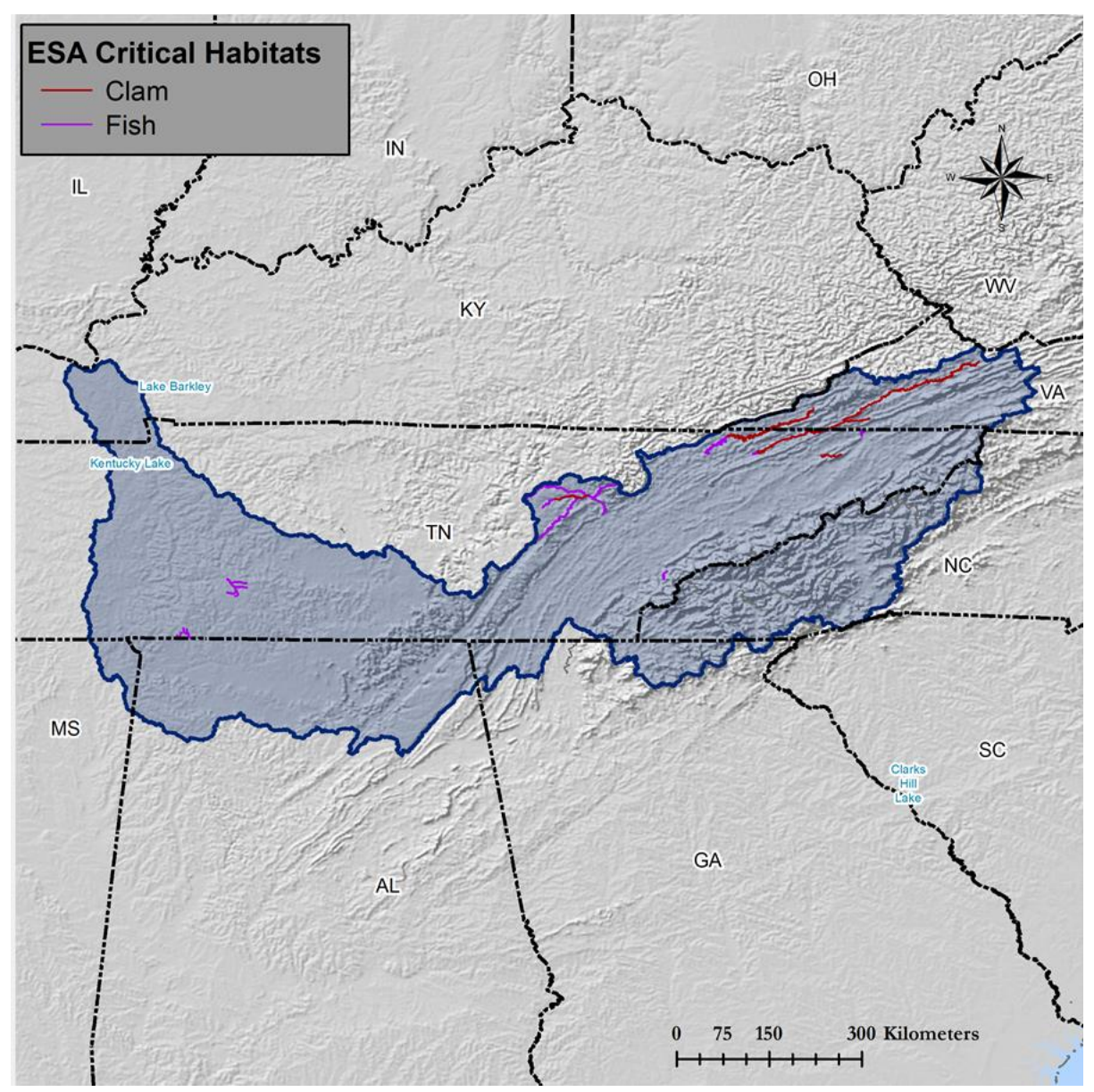

Figure 9.6. Critical habitats of federally endangered and threatened species in Region 6.

Table 9.3. Summary of Environmental Variables at HUC04 Subregions Within Region 6 (Stream-Reaches with Potential Capacity $>1 \mathrm{MW}$ )

\begin{tabular}{|c|c|c|c|c|c|c|c|c|}
\hline HUC04 HUC04 name & $\begin{array}{r}\text { \# Critical } \\
\text { habitats }\end{array}$ & $\begin{array}{l}\text { \# Potad- } \\
\text { anad fish }\end{array}$ & $\begin{array}{r}\text { \# ESA } \\
\text { fish }\end{array}$ & $\begin{array}{r}\text { \# IUCN } \\
\text { fish }\end{array}$ & $\begin{array}{r}\text { \# Recreation } \\
\text { locations }^{a}\end{array}$ & $\begin{array}{r}\% \\
\begin{array}{r}\% \\
\text { Protected } \\
\text { lands }\end{array} \\
\end{array}$ & $\begin{array}{r}\text { Population } \\
\text { density } \\
\left(\text { ind } / \mathbf{k m}^{2}\right)\end{array}$ & $\begin{array}{r}\text { Freshwater } \\
\text { use } \\
\left(\mathrm{l} / \mathrm{day} / \mathrm{km}^{2}\right)\end{array}$ \\
\hline 0601 Upper Tennessee & 10 & 9 & 11 & 14 & $509 ; 226 ; 93$ & 20.85 & 50.85 & $4,114.52$ \\
\hline $\begin{array}{l}\text { Middle Tennessee- } \\
0602 \text { Hiwassee }\end{array}$ & 0 & 8 & 3 & 6 & $109 ; 63 ; 18$ & 17.84 & 42.53 & $3,872.73$ \\
\hline $\begin{array}{l}0603 \begin{array}{l}\text { Middle Tennessee- } \\
\text { Elk }\end{array} \\
\end{array}$ & 3 & 7 & 6 & 13 & $165 ; 29 ; 23$ & 5.18 & 33.93 & $6,845.33$ \\
\hline 0604 Lower Tennessee & 4 & 8 & 3 & 14 & $178 ; 3 ; 15$ & 4.15 & 24.92 & $4,409.94$ \\
\hline
\end{tabular}

${ }^{a}$ Recreation locations refer to the number of boat-ramp and fishing access points, recreational boating, and waterfalls within each HUC04. 


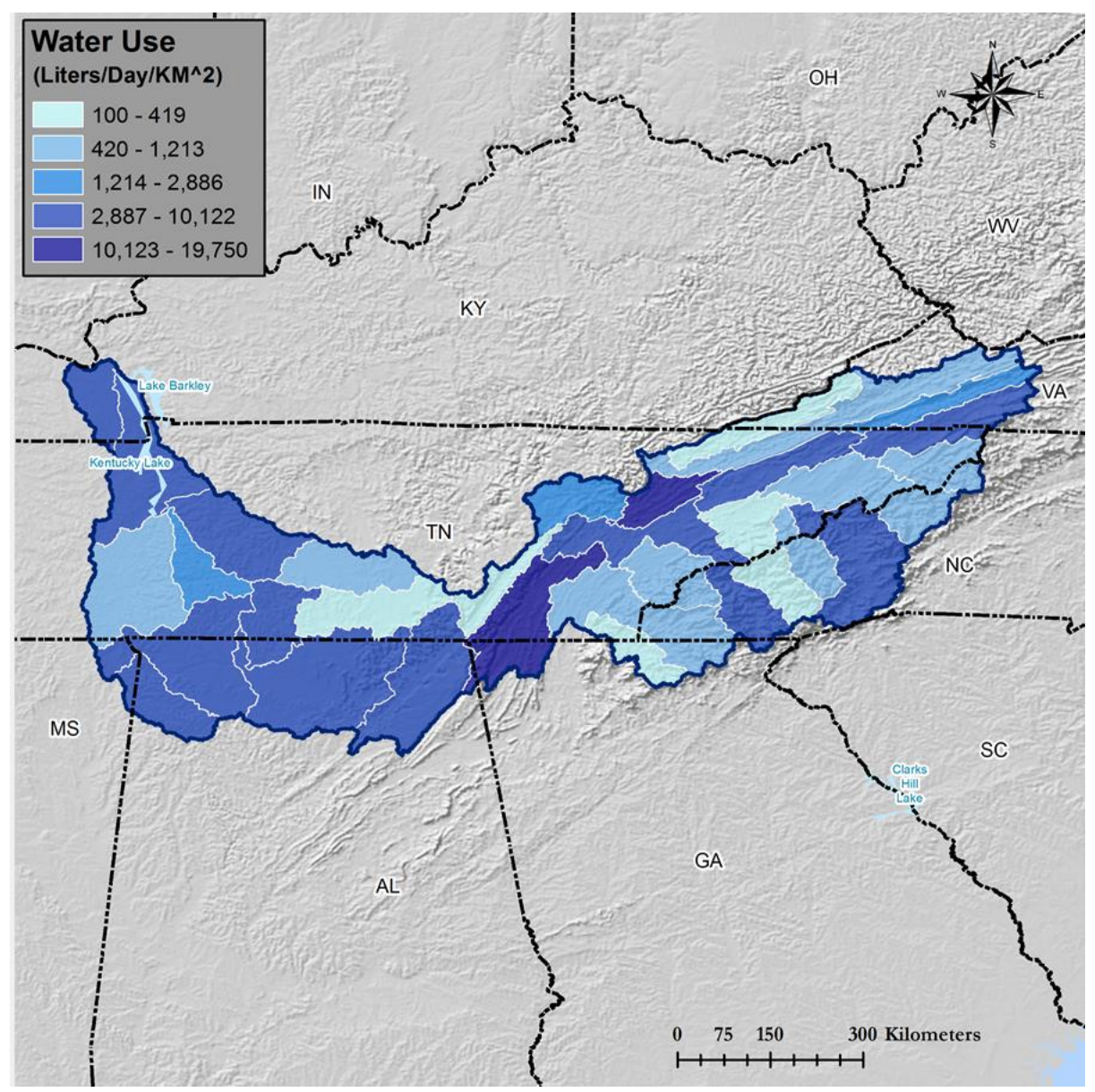

Figure 9.7. Average water use per HUC08 subbasin in Region 6.

ESA Critical Habitats

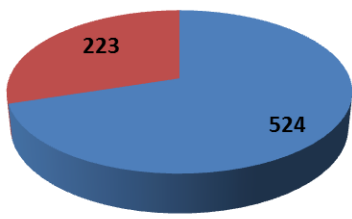

absent $\quad$ Present

Water Quality Concern

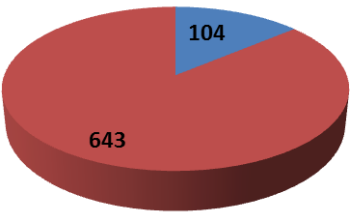

absent Present
Number ESA Listed Fish

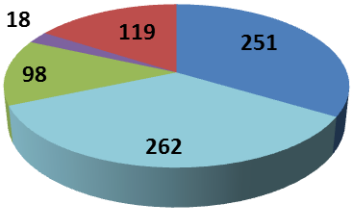

$\square 01 \square 2 \square 3 \square>3$

Recreation Boating

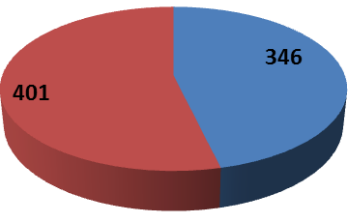

Absent Present
National Park Lands

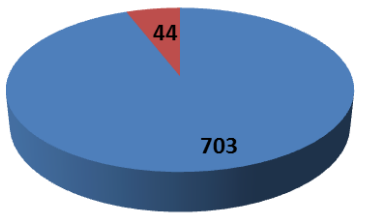

absent $\square$ Present

Fishing Access Areas

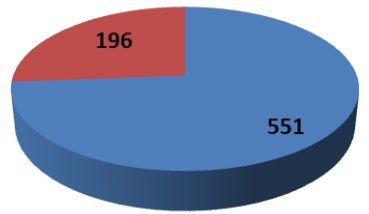

Absent Present
Wild and Scenic Rivers

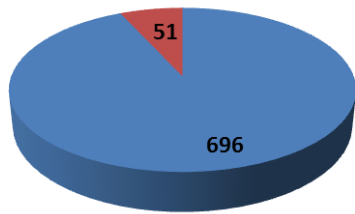

absent Present

Water Use

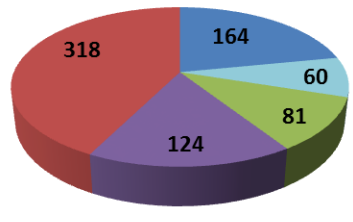

m LOW MODERATE MODERATE-TO-HIGH $=$ HIGH - VERY HIGH

Figure 9.8. The potential capacity, in MW, associated with environmental attributes in Region 6-Tennessee ( stream-reaches with potential capacity $>1 \mathrm{MW}$ ). 


\section{REGION 7-UPPER MISSISSIPPI}

\subsection{Summary of Findings}

Following NSD methodology (Hadjerioua et al., 2013), the potential capacity, annual generation and mean capacity factors in the Upper Mississippi Region are estimated and summarized in Table 10.1 for both larger ( $>1 \mathrm{MW})$ and smaller (<1 MW) stream-reaches. For comparison, the year-2011 nameplate capacity, 2002-2011 average annual generation, and capacity factor of existing hydropower facilities are also listed (NHAAP, 2013). The total undeveloped NSD capacity is $2.08 \mathrm{GW}$, around $225 \%$ of existing conventional hydropower nameplate capacity. In terms of energy, the total undeveloped NSD generation is $11.55 \mathrm{TWh} / \mathrm{year}$, around $398 \%$ of annual net generation from existing conventional hydropower plants. Given the run-of-river assumption, NSD stream-reaches have higher capacity factors, especially compared with other larger-storage peaking-operation projects in this region. More detailed topographical analysis and environmental attribution are conducted for larger (>1 MW) stream-reaches and discussed in Sections 10.3 and 10.4 .

Table 10.1. Summary of NSD Findings in Region 7-Upper Mississippi

\begin{tabular}{l|r|r|r}
\hline & $\begin{array}{r}\text { Capacity } \\
\text { (MW) }\end{array}$ & $\begin{array}{r}\text { Generation } \\
\text { (MWh) }\end{array}$ & $\begin{array}{r}\text { Mean capacity } \\
\text { factor }\end{array}$ \\
\hline Potential in undeveloped stream-reaches $(>1 \mathrm{MW})$ & 1,055 & $5,979,000$ & $65 \%$ \\
\hline Potential in undeveloped stream-reaches $(<1 \mathrm{MW})$ & 1,026 & $5,567,000$ & $62 \%$ \\
\hline Existing hydropower-conventional hydro & 923 & $2,903,000$ & $36 \%$ \\
\hline Existing hydropower-pumped storage & 31 & & \\
\hline
\end{tabular}

\subsection{Background Hydrologic Setting}

The Upper Mississippi Region encompasses approximately 492,026 $\mathrm{km}^{2}$ of drainage area along the northern sections of the Mississippi River. This region contains eastern Minnesota, Iowa, and northeastern Missouri, in addition to the western sections of Wisconsin and Illinois and small sections of Nebraska and Indiana.

Several river systems are located in the Upper Mississippi Region (Figure 10.1), including the Mississippi, Minnesota, St. Croix, Root, La Crosse, Chippewa, Wisconsin, Iowa, Rock, Des Moines, Illinois, Fox, and Kaskaskia rivers, with a total length of 41,716 km (i.e., total length of streams with estimated discharge greater than $35 \mathrm{cfs}$ ). Metropolitan areas within the region include Minneapolis (MN), Cedar Rapids (IA), Davenport (IO), St. Louis (MO), and Chicago (IL). As shown in Figure 10.2, annual precipitation for the region ranges from 650 to $1100 \mathrm{~mm} /$ year and annual runoff from 100 to $500 \mathrm{~mm} /$ year. Most of the precipitation occurs during the summer; however, the peak runoff occurs in the early spring from snowmelt. 
The existing hydropower plants and major non-powered dams (Hadjerioua et al., 2012) are also shown in Figure 10.1. The region contains 113 hydropower dams and 61 major non-powered dams with total storage capacities of around 10,494,851 ac-ft and 19,529,673 ac-ft, respectively.

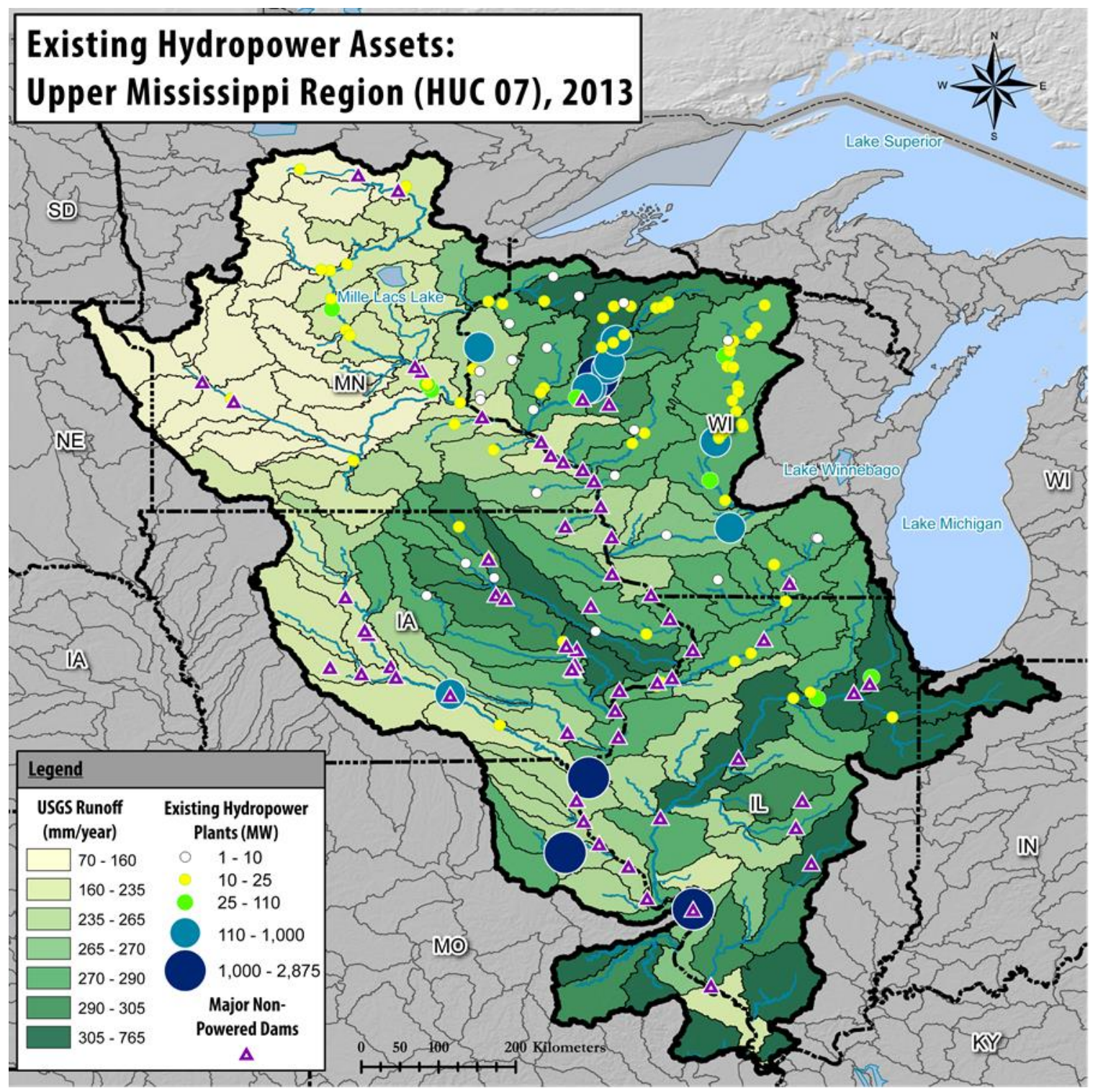

Figure 10.1. Locations of water control projects in Region 7-Upper Mississippi.

\subsection{Potential New Hydropower Resources}

A total of 230 stream-reaches of high energy density (with estimated potential capacity $>1 \mathrm{MW}$ per stream-reach) are identified in the Upper Mississippi Region. The NSD results based on the HUC04 subregions are summarized in Table 10.2. In the Upper Mississippi Region, the highest hydropower potential is located in the Upper Mississippi-Iowa-Skunk-Wapsipinicon Subregion (HUC 0708), followed by the Des Moines Subregion (HUC 0710), Upper MississippiKaskaskia-Meramec Subregion (HUC 0714), Mississippi Headwaters Subregion (HUC 0701), 
and Wisconsin Subregion (HUC 0707). In the Upper Mississippi-Iowa-Skunk-Wapsipinicon Subregion, the Mississippi River contains the highest hydropower potentials, followed by the Iowa, Des Moines, Kaskaskia, Meramec, and Wisconsin rivers in the other subregions.

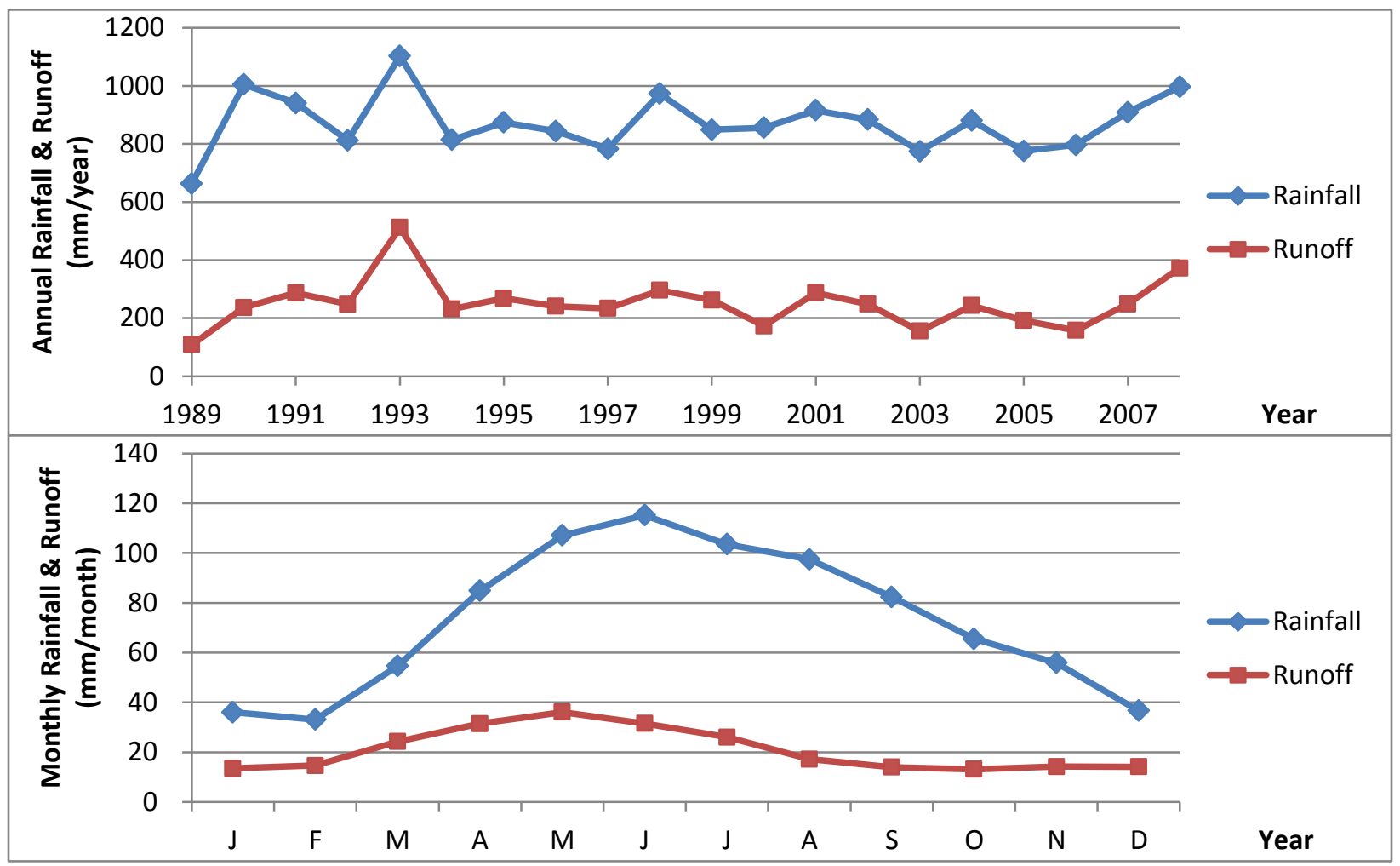

Figure 10.2. Annual and monthly rainfall and runoff of Region 7-Upper Mississippi.

Table 10.2. Summary of Potential New Hydropower Resources in Region 7-Upper Mississippi (Stream-Reaches with Potential Capacity >1 MW)

\begin{tabular}{|c|c|c|c|c|c|c|c|c|}
\hline HUC4 & HUC04 name & $\begin{array}{r}\text { \# of } \\
\text { stream- } \\
\text { reaches }\end{array}$ & $\begin{array}{r}\text { Potential } \\
\text { capacity } \\
(\mathrm{MW}) \\
\end{array}$ & $\begin{array}{r}\text { Potential } \\
\text { energy } \\
(\mathrm{MWh}) \\
\end{array}$ & $\begin{array}{r}\begin{array}{r}\text { Average } \\
\text { head }\end{array} \\
(\mathrm{ft} / \mathrm{reach})\end{array}$ & $\begin{array}{r}\text { Average } \\
\text { flow } \\
\text { (cfs/reach) } \\
\end{array}$ & $\begin{array}{r}\text { Average } \\
\text { storage (ac- } \\
\text { ft/reach) } \\
\end{array}$ & $\begin{array}{r}\text { Average } \\
\text { residence } \\
\text { time (days) }\end{array}$ \\
\hline 0701 & Mississippi Headwaters & 22 & 111.1 & 721,739 & 12.6 & 5,869 & 5,614 & 1.4 \\
\hline 0702 & Minnesota & 6 & 22.8 & 109,605 & 12.3 & 4,586 & 1,522 & 0.4 \\
\hline 0703 & St. Croix & 9 & 25.7 & 165,966 & 12.3 & 3,443 & 2,151 & 0.4 \\
\hline 0704 & $\begin{array}{l}\text { Upper Mississippi- } \\
\text { Black-Root }\end{array}$ & 8 & 13.9 & 73,439 & 13.6 & 1,804 & 5,028 & 1.8 \\
\hline 0705 & Chippewa & 22 & 63.9 & 392,519 & 12.4 & 3,507 & 6,665 & 0.8 \\
\hline 0706 & $\begin{array}{l}\text { Upper Mississippi- } \\
\text { Maquoketa-Plum }\end{array}$ & 5 & 34.4 & 208,710 & 16.8 & 8,788 & 50,575 & 3.2 \\
\hline 0707 & Wisconsin & 25 & 100.7 & 671,114 & 11.0 & 5,193 & 6,533 & 0.5 \\
\hline 0708 & $\begin{array}{l}\text { Upper Mississippi- } \\
\text { Iowa-Skunk- } \\
\text { Wapsipinicon }\end{array}$ & 43 & 198.1 & $1,060,741$ & 16.5 & 4,963 & 31,354 & 8.2 \\
\hline 0709 & Rock & 7 & 39.7 & 246,962 & 12.2 & 6,660 & 17,496 & 7.8 \\
\hline 0710 & Des Moines & 21 & 151.3 & 719,882 & 17.8 & 5,944 & 17,339 & 4.6 \\
\hline 0711 & Upper Mississippi-Salt & 6 & 43.6 & 248,504 & 33.5 & 15,704 & 143,444 & 189.3 \\
\hline 0712 & Upper Illinois & 15 & 42.2 & 241,112 & 9.5 & 4,226 & 8,576 & 2.7 \\
\hline 0713 & Lower Illinois & 17 & 61.9 & 312,960 & 19.4 & 3,321 & 21,963 & 6.6 \\
\hline 0714 & $\begin{array}{l}\text { Upper Mississippi- } \\
\text { Kaskaskia-Meramec }\end{array}$ & 24 & 145.4 & 805,400 & 21.5 & 10,135 & 24,185 & 9.5 \\
\hline
\end{tabular}


The summary statistics of hydraulic head $\mathrm{H}_{\text {ref }}(\mathrm{ft})$, design flow $\mathrm{Q}_{30}(\mathrm{cfs})$, potential capacity $\mathrm{P}_{\mathrm{NSD}}$ (MW), inundated area $\mathrm{A}_{\mathrm{NSD}}(\mathrm{ac})$, storage $\mathrm{V}_{\mathrm{NSD}}\left(\mathrm{ac}-\mathrm{ft}\right.$ ), and residence time $\mathrm{T}_{\mathrm{NSD}}$ (day) are shown in Figure 10.3. The hydraulic head $\mathrm{H}_{\text {ref }}$ ranges from 5 to the 90 th quantile of $28 \mathrm{ft}$ with a median of about $14 \mathrm{ft}$, suggesting that many of the potential stream-reaches will require low-head hydropower technologies. The design flow $\mathrm{Q}_{30}$ ranges from about $800 \mathrm{cfs}$ to the 90 th quantile of $8500 \mathrm{cfs}$ with a median of $2700 \mathrm{cfs}$. The potential capacity $\mathrm{P}_{\mathrm{NSD}}$ ranges from $1.5 \mathrm{MW}$ to the 90 th quantile of about 7.5 MW with a median of just under $3 \mathrm{MW}$. The inundated surface area $\mathrm{A}_{\mathrm{NSD}}$ ranges from 0 to the 90th quantile of 6000 acres with a median of 1000 acres. This results in storage values $\mathrm{V}_{\text {NSD }}$ ranging from 0 to the 90 th quantile of 50,000 ac- $\mathrm{ft}$ with a median of about $9,000 \mathrm{ac}-\mathrm{ft}$, with residence times $\mathrm{T}_{\mathrm{NSD}}$ ranging from $<1$ day to the 90th quantile of 12 days with a median on the order of a few days. In general, the inundation areas and storage volumes paired with the retention times for this region are characteristic of run-of-river to minor storage-type hydro facilities. The results of > $1 \mathrm{MW}$ stream-reach potential are illustrated in Figure 10.4, with potential capacity (MW) aggregated to the HUC08 subbasins. The higher-potential-capacity sites are generally located on the larger tributary rivers feeding directly into the Mississippi River.

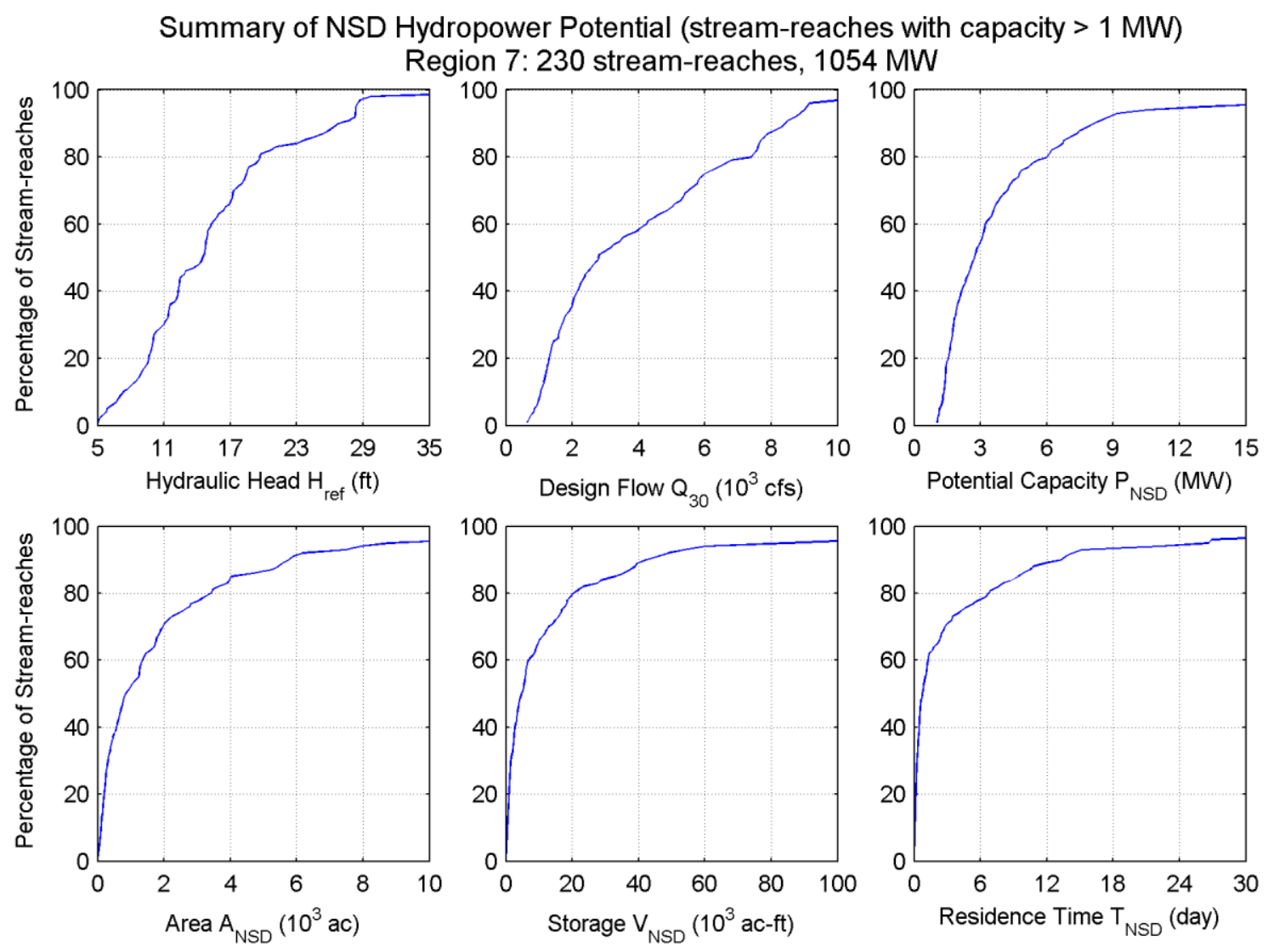

Figure 10.3. Cumulative distributions of hydraulic head $\mathrm{H}_{\text {ref }}$, design flow $\mathrm{Q}_{30}$, potential capacity $\mathrm{P}_{\mathrm{NSD}}$, inundated area $\mathrm{A}_{\mathrm{NSD}}$, storage $\mathrm{V}_{\mathrm{NSD}}$, and residence time $\mathrm{T}_{\mathrm{NSD}}$ in Region 7-Upper Mississippi. 


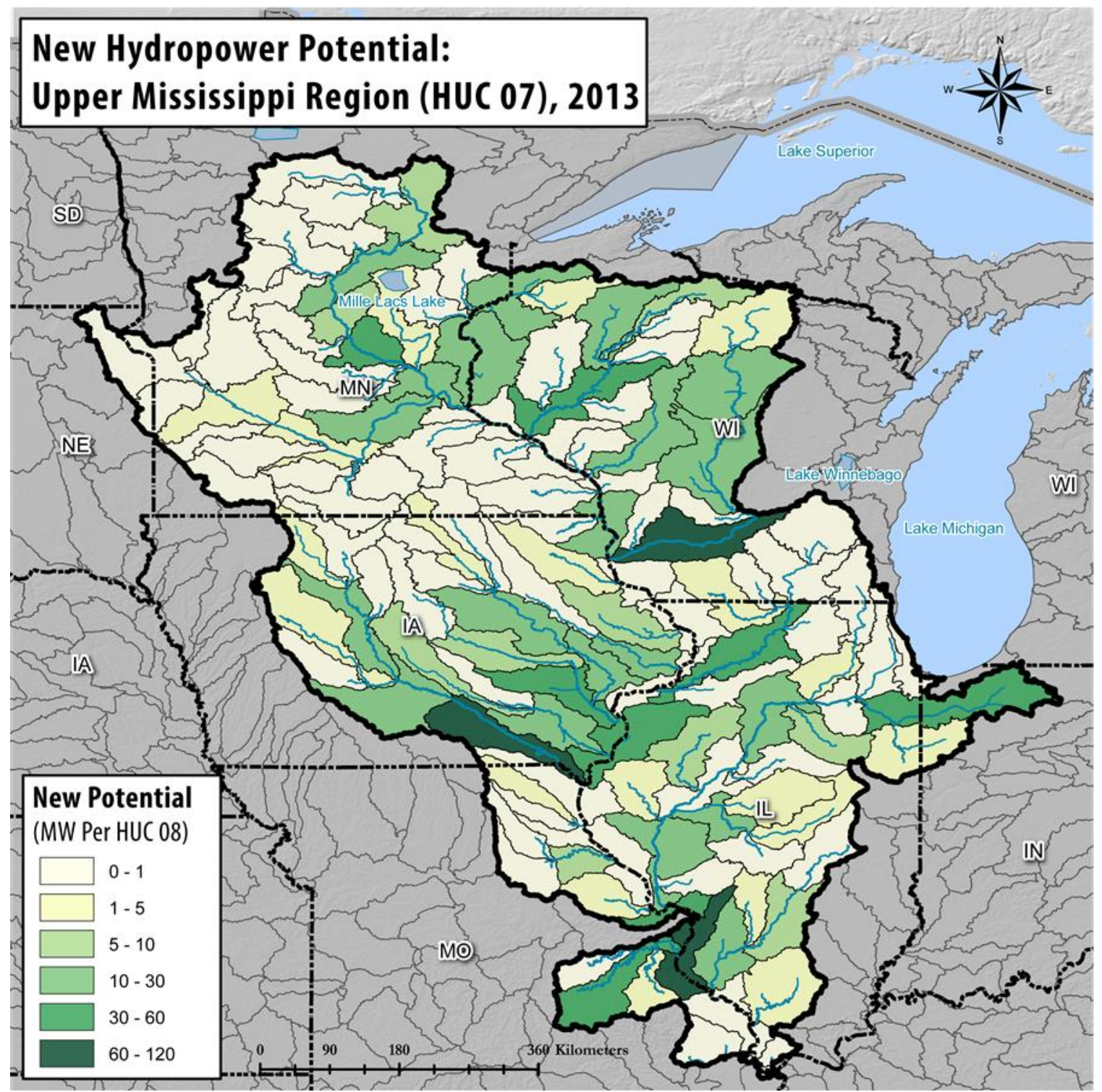

Figure 10.4. Potential new hydropower capacity in Region 7-Upper Mississippi (higher-energy-density streamreaches with >1 MW per reach, aggregated to HUC08 subbasins for illustration).

\subsection{Environmental Characteristics}

The Upper Mississippi Region includes 193 native fish species, 4 of which fall under an ESA category. Eight additional species fall under IUCN categories. Paddlefish, shovelnose sturgeon (Scaphirhynchus platorynchus), pallid sturgeon (Scaphirhynchus albus), and Topeka shiner (Notropis topeka) are among the fishes of concern in Region 7. Sixteen potadromous or anadromous fish species are documented in Region 7 (Figure 10.5). Eight critical watersheds are located in the region and contain anywhere from three to nine fish and mussel species at risk (Mathews et al., 1998). Only two species, Hine's emerald dragonfly (Somatochlora hineana) and Topeka shiner, have critical habitat designations. 


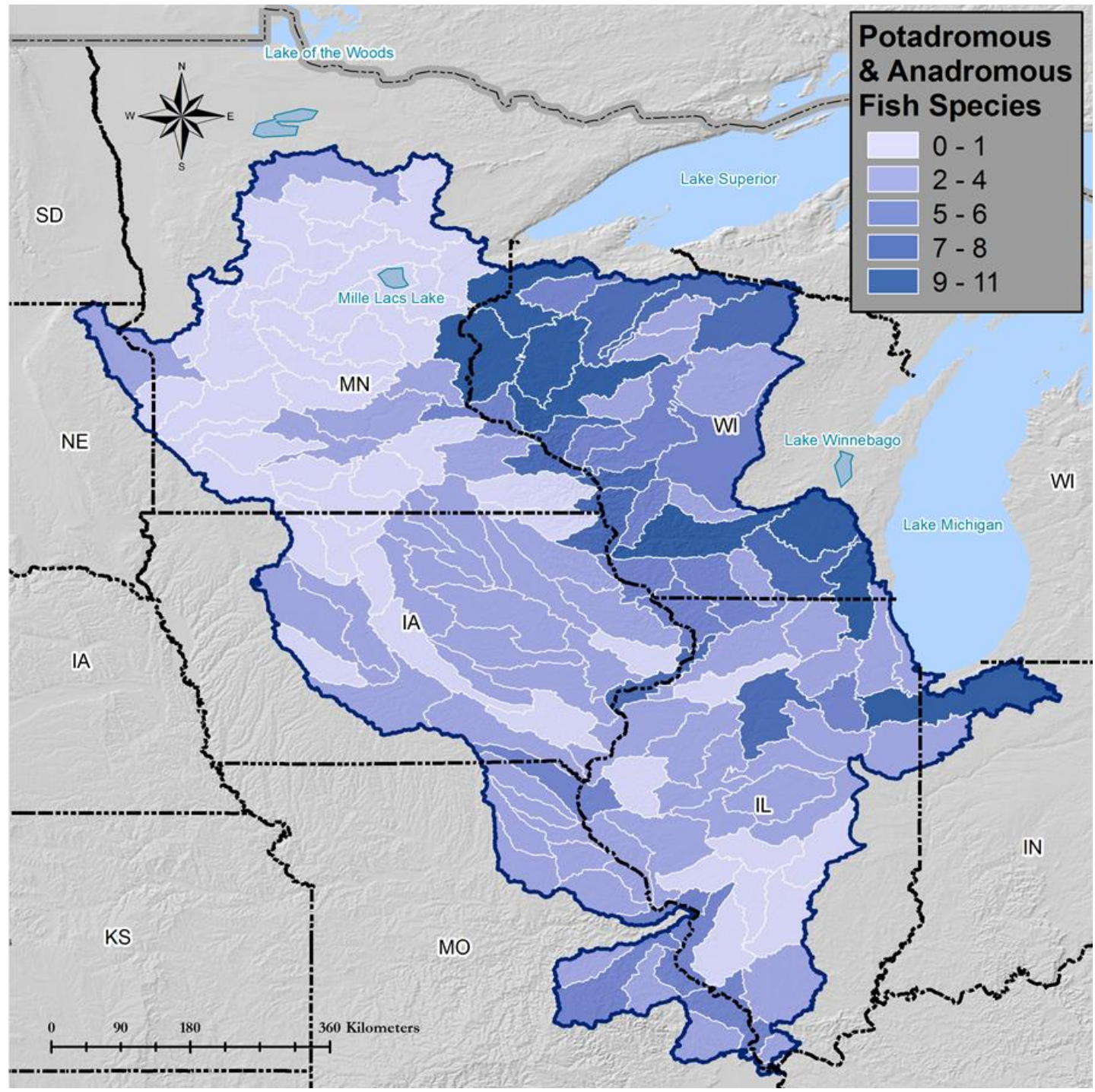

Figure 10.5. Potadromous and anadromous fish species (number per HUC08 subbasin) in Region 7.

Of the 9.6 million total acres of protected land in Region 7, over 54\% are state-owned. State lands are primarily made up of state forests, habitat species management areas, and state parks. Among the largest tracts of land in the region are the Richard J. Dorer Memorial Hardwood and Chengwatana State Forests. Federal lands make up almost 35\% of protected lands and are primarily owned by the USFS (16\%), USFWS (7\%), DOD (6\%), and NPS (5\%). Most federal lands are national forests, the largest of which is the Chippewah National Forest. Although there is no national park in this region, there are other types of NPS-owned properties, including historic sites, protected management areas, and national trails. Most of the protected lands fall under GAP statuses 3 (42\%) and 2 (39\%). Two National Wild and Scenic Rivers, the Paint and St. Croix, are located in this region. Recreation facilities include 4315 boat ramp locations, 839 fishing access locations, 24 waterfalls, and 161 recreational boating river sections (Figure 10.6).

Water use in Region 7 is slightly above the US average (Appendix B). Water use is fairly homogenous with the exception of extremely high values in the Upper Illinois Subbasin (Table 10.3). Most usage occurs as thermoelectric cooling or public consumption (Appendix B). Water- 
quality concerns are average in the region. Water-quality concerns are varied, however; many are related to mercury or nutrient issues, followed by algae, toxin, and pathogen concerns (Appendix B).

Of the 230 stream-reaches, seven reaches (18 MW) overlap with critical habitat designations (Figure 10.7). Almost 33\% of stream-reaches overlap within HUC08 subbasins with one or more fish falling under ESA categories. No stream-reaches intersect national parks; however, nine stream-reaches (26 MW) intersect Wild and Scenic Rivers. Over 90\% of stream-reaches overlap with protected lands $(>1 \mathrm{GW})$. Most stream-reaches $(88 \%)$ are associated with water-quality concerns. Recreational boating and fishing access areas are not as prevalent, overlapping with only $17 \%$ and $20 \%$ of stream-reaches. Boat ramps are abundant, overlapping with $63 \%$ of stream-reaches. Most of the stream-reaches are located in HUC08 subregions with very high water usage.

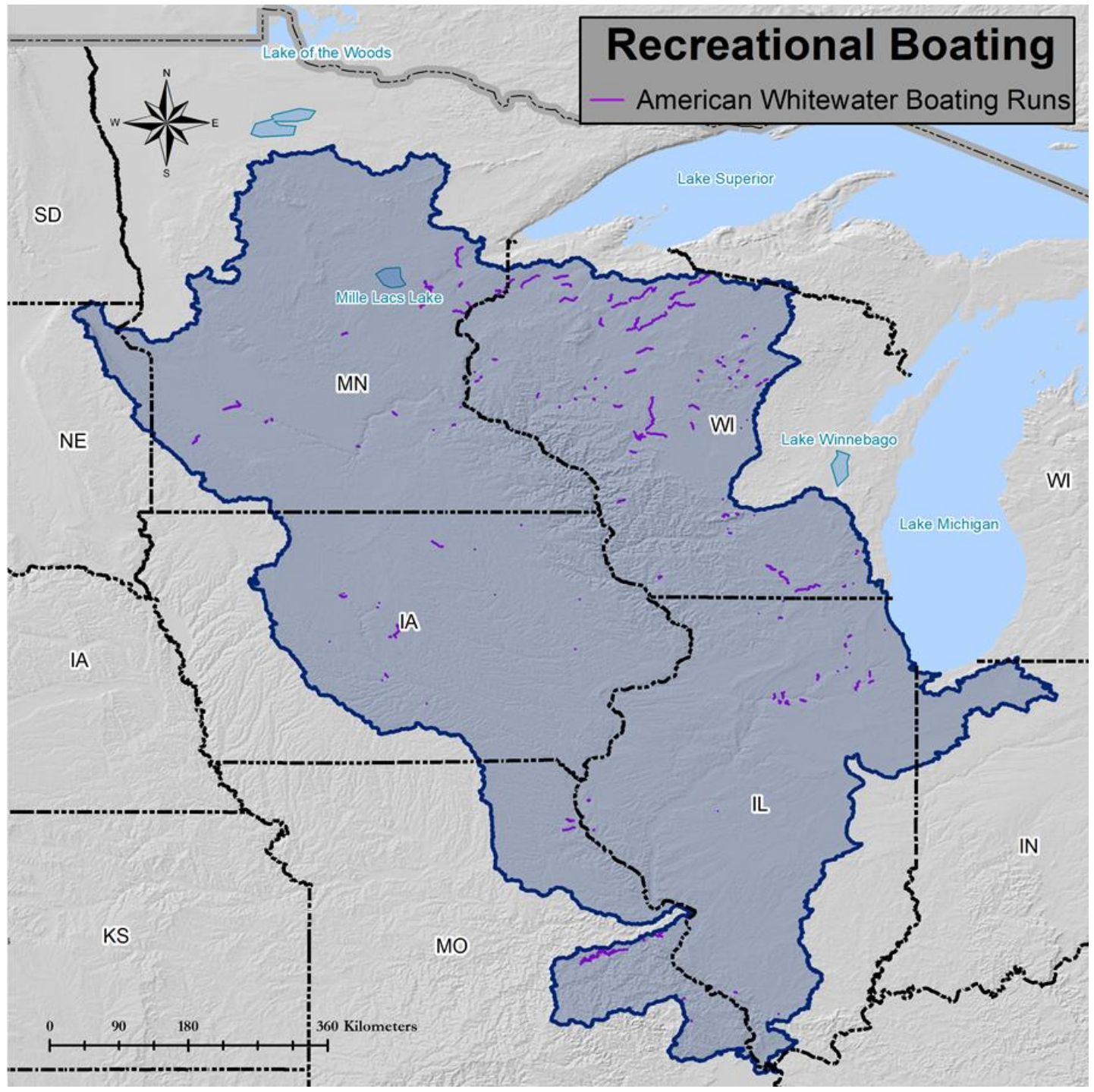

Figure 10.6. Whitewater boating runs in Region 7 . 
Table 10.3. Summary of Environmental Variables at HUC04 Subregions within Region 7 (Stream-Reaches with Potential Capacity $>1 \mathrm{MW}$ )

\begin{tabular}{|c|c|c|c|c|c|c|c|c|}
\hline HUC04 HUC04 name & $\begin{array}{r}\text { \# Critical } \\
\text { habitats }\end{array}$ & $\begin{array}{l}\text { \# Potad- } \\
\text { anad fish }\end{array}$ & $\begin{array}{r}\text { \# ESA } \\
\text { fish }\end{array}$ & $\begin{array}{r}\text { \# IUCN } \\
\text { fish }\end{array}$ & $\begin{array}{r}\text { \# } \\
\text { Recreation } \\
\text { locations }^{a} \\
\end{array}$ & $\begin{array}{r}\% \\
\text { Protected } \\
\text { lands } \\
\end{array}$ & $\begin{array}{r}\text { Population } \\
\text { density } \\
\left(\text { ind } / \mathbf{k m}^{2}\right)\end{array}$ & $\begin{array}{r}\text { Freshwater } \\
\text { use } \\
\left(\mathbf{l} / \mathbf{d a y} / \mathbf{k m}^{2}\right) \\
\end{array}$ \\
\hline $0701 \begin{array}{l}\text { Mississippi } \\
\text { Headwaters }\end{array}$ & 0 & 7 & 1 & 3 & 1,$061 ; 2 ; 3$ & 19.93 & 45.99 & $1,244.02$ \\
\hline 0702 Minnesota & 1 & 7 & 2 & 3 & $327 ; 7 ; 4$ & 3.88 & 3.64 & 261.89 \\
\hline 0703 St. Croix & 0 & 12 & 1 & 4 & $507 ; 21 ; 2$ & 14.02 & 17.29 & 387.23 \\
\hline $\begin{array}{l}0704 \begin{array}{l}\text { Upper Mississippi- } \\
\text { Black-Root }\end{array} \\
\end{array}$ & 0 & 9 & 1 & 4 & $232 ; 14 ; 2$ & 18.15 & 14.22 & $2,291.11$ \\
\hline 0705 Chippewa & 0 & 13 & 1 & 5 & $663 ; 26 ; 5$ & 14.98 & 10.82 & 274.22 \\
\hline $0706 \begin{array}{l}\text { Upper Mississippi- } \\
\text { Maquoketa-Plum }\end{array}$ & 0 & 9 & 2 & 4 & $137 ; 4 ; 1$ & 5.81 & 16.61 & $1,342.24$ \\
\hline 0707 Wisconsin & 0 & 12 & 1 & 3 & $624 ; 26 ; 4$ & 8.89 & 16.02 & $1,161.11$ \\
\hline $\begin{array}{l}\text { Upper Mississippi- } \\
0708 \text { Iowa-Skunk- } \\
\text { Wapsipinicon } \\
\end{array}$ & 1 & 9 & 1 & 3 & $209 ; 6 ; 0$ & 1.24 & 28.35 & $1,463.54$ \\
\hline 0709 Rock & 0 & 10 & 1 & 1 & $260 ; 7 ; 0$ & 2.73 & 67.54 & $1,401.02$ \\
\hline 0710 Des Moines & 1 & 5 & 1 & 0 & $156 ; 9 ; 0$ & 2.05 & 9.25 & 141.12 \\
\hline $\begin{array}{l}0711 \begin{array}{l}\text { Upper Mississippi- } \\
\text { Salt }\end{array} \\
\end{array}$ & 0 & 8 & 3 & 4 & $121 ; 5 ; 1$ & 2.03 & 25.92 & $1,534.93$ \\
\hline 0712 Upper Illinois & 1 & 12 & 0 & 1 & $343 ; 14 ; 1$ & 7.06 & 457.28 & $11,144.55$ \\
\hline 0713 Lower Illinois & 0 & 8 & 1 & 3 & $219 ; 8 ; 0$ & 2.28 & 32.21 & $3,335.85$ \\
\hline $0714 \begin{array}{l}\text { Upper Mississippi- } \\
\text { Kaskaskia-Meramec }\end{array}$ & 1 & 9 & 3 & 9 & $295 ; 12 ; 1$ & 8.74 & 47.24 & $2,902.05$ \\
\hline
\end{tabular}

${ }^{a}$ Recreation locations refer to the number of boat-ramp and fishing access points, recreational boating, and waterfalls within each HUC04.

ESA Critical Habitats

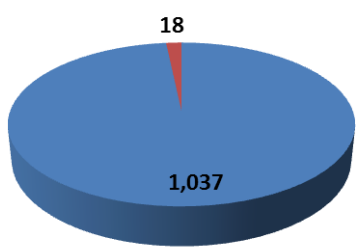

- Absent Present

Water Quality Concern

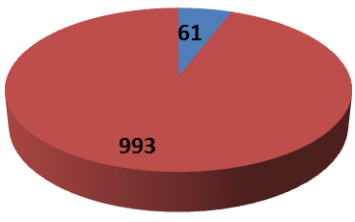

Absent Present
Number ESA Listed Fish

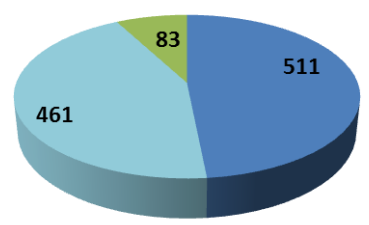

$\square 0 \square 1 \square 2$

Recreation Boating

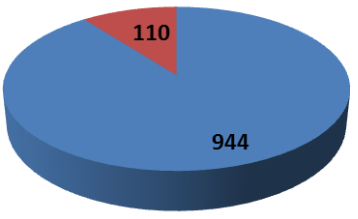

Absent $\quad$ Present
National Park Lands

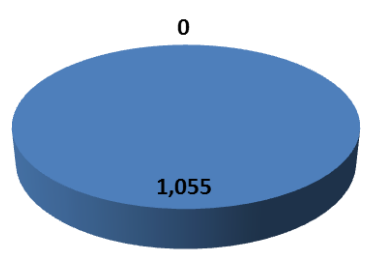

absent $\square$ Present

Fishing Access Areas

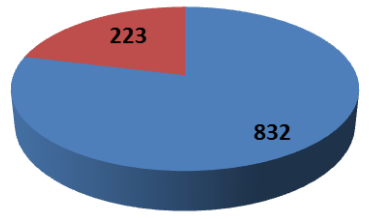

Absent Present
Wild and Scenic Rivers

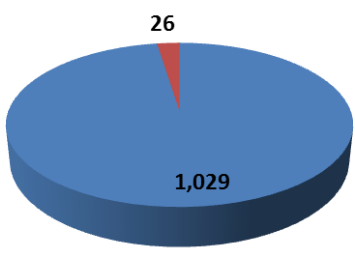

Absent Present

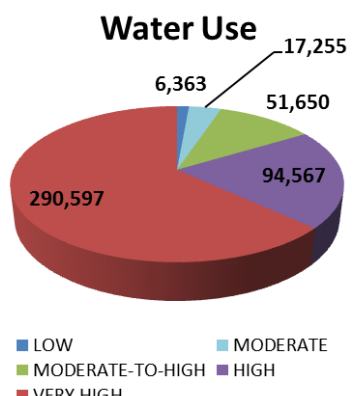

Figure 10.7. The potential capacity, in MW, associated with environmental attributes in Region 7-Upper Mississippi (stream-reaches with potential capacity $>1 \mathrm{MW}$ ). 


\section{REGION 8-LOWER MISSISSIPPI}

\subsection{Summary of Findings}

Following NSD methodology (Hadjerioua et al., 2013), the potential capacity, annual generation and mean capacity factors in the Lower Mississippi Region are estimated and summarized in Table 11.1 for both larger $(>1 \mathrm{MW})$ and smaller $(<1 \mathrm{MW})$ stream-reaches. For comparison, the year-2011 nameplate capacity, 2002-2011 average annual generation, and capacity factor of existing hydropower facilities are also listed (NHAAP, 2013). The total undeveloped NSD capacity is $2.07 \mathrm{GW}$, around $414 \%$ of existing conventional hydropower nameplate capacity. In terms of energy, the total undeveloped NSD generation is $12.07 \mathrm{TWh} / \mathrm{year}$, around $712 \%$ of annual net generation from existing conventional hydropower plants. The larger ratios of potential NSD resources to existing hydropower development should be mainly a result of the relatively lower hydropower development in this region. As the downstream area of the Mississippi River, the stream-reaches tend to be larger in flow but lower in hydraulic head. Therefore, although the power estimates may seem large (proportional to flow times head), it will require low-head technology that is generally more expensive and less efficient. In-stream navigation is also a more important function than hydropower in this region. More detailed topographical analysis and environmental attribution are conducted for larger (>1 MW) streamreaches and discussed in Sections 11.3 and 11.4.

Table 11.1. Summary of NSD Findings in Region 8-Lower Mississippi

\begin{tabular}{l|r|r|r}
\hline & $\begin{array}{r}\text { Capacity } \\
\text { (MW) }\end{array}$ & $\begin{array}{r}\text { Generation } \\
\text { (MWh) }\end{array}$ & $\begin{array}{r}\text { Mean capacity } \\
\text { factor }\end{array}$ \\
\hline Potential in undeveloped stream-reaches $(>1 \mathrm{MW})$ & 1,741 & $10,395,000$ & $68 \%$ \\
\hline Potential in undeveloped stream-reaches $(<1 \mathrm{MW})$ & 331 & $1,679,000$ & $58 \%$ \\
\hline Existing hydropower-conventional hydro & 500 & $1,695,000$ & $39 \%$ \\
\hline Existing hydropower-pumped storage & 28 & & \\
\hline
\end{tabular}

\subsection{Background Hydrologic Setting}

The Lower Mississippi Region encompasses approximately $271,879 \mathrm{~km}^{2}$ of drainage area along the southern sections of the Mississippi River. This region includes eastern sections of Missouri, Arkansas, western sections of Kentucky, Tennessee and Mississippi, and most of Louisiana. The region comprises primarily a flood plain all along the Mississippi River with tributary rivers feeding into the Mississippi River.

Several river systems are located in the Lower Mississippi Region (Figure 11.1), including the Mississippi, Arkansas, White, St. Francis, Yazoo, Red, Ouachita, Boeuf, Tensas, Lower Old, Buffalo, Lower Grand, Tangipahoa, and Sabine rivers, with a total length of 33,791 km (i.e., total length of streams with estimated discharge greater than $35 \mathrm{cfs}$ ). Metropolitan areas within the region include Jonesboro (AR), Shreveport (LA), and Memphis (TN). As shown in Figure 11.2, annual precipitation for the Lower Mississippi ranges from 1050 to $1700 \mathrm{~mm} / \mathrm{year}$ and 
annual runoff from 250 to $750 \mathrm{~mm} /$ year. Most precipitation occurs from late winter through midsummer. Most of the runoff occurs from winter through early spring.

The existing hydropower plants and major non-powered dams (Hadjerioua et al., 2012) are shown in Figure 11.1. The region contains 7 hydropower dams and 17 major non-powered dams with total storage capacities of around 7,531,461 ac-ft and 9,721,495 ac-ft, respectively.

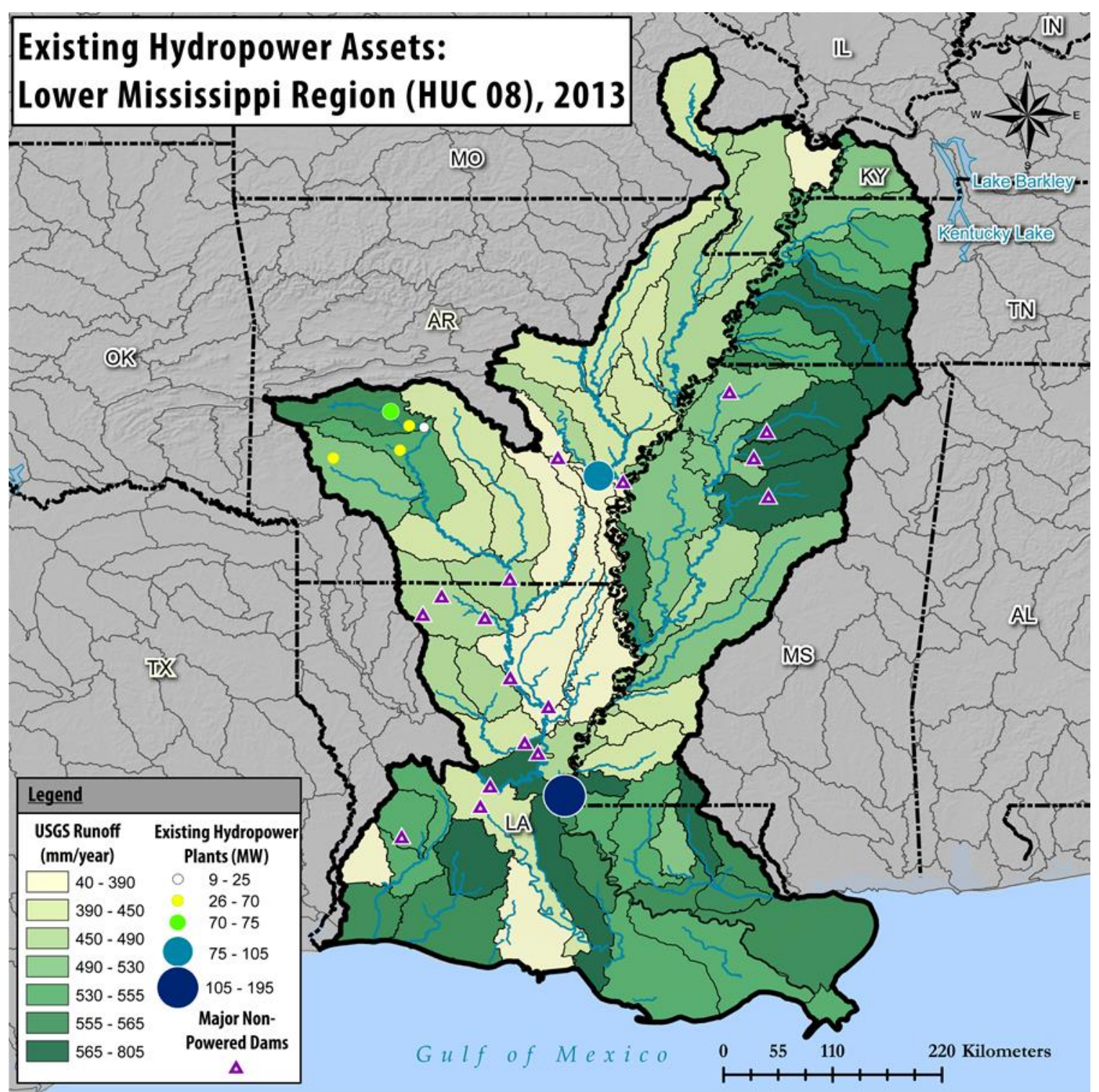

Figure 11.1. Locations of water control projects in Region 8-Lower Mississippi.

\subsection{Potential New Hydropower Resources}

A total of 90 stream-reaches of high energy density (with estimated potential capacity $>1 \mathrm{MW}$ per stream-reach) are identified in the Lower Mississippi region. The NSD results based on the HUC04 subregions are summarized in Table 11.2. The highest hydropower potential is found in 
the Lower Mississippi-Big Black and St. Francis Subregions (HUC 0806 and 0802). In these two subregions, the Mississippi River contains the highest hydropower potential, with the Big Black, Arkansas, and White rivers providing the next highest potential.

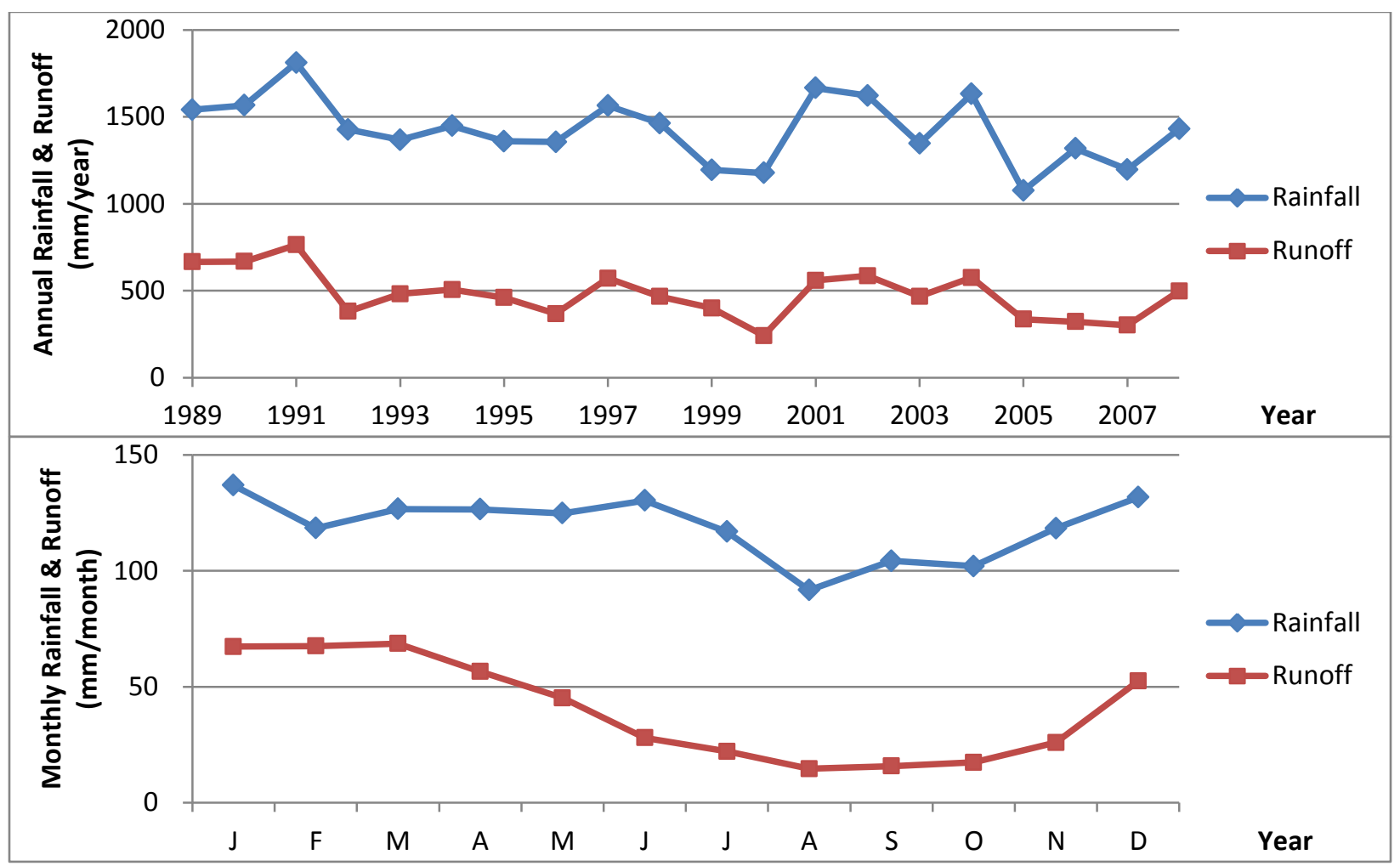

Figure 11.2. Annual and monthly rainfall and runoff of Region 8 - Lower Mississippi.

Table 11.2. Summary of Potential New Hydropower Resources in Region 8 Lower Mississippi (Stream-Reaches with Potential Capacity $>1 \mathrm{MW}$ )

\begin{tabular}{|c|c|c|c|c|c|c|c|c|}
\hline HUC04 & HUC04 name & $\begin{array}{r}\text { \# of } \\
\text { stream- } \\
\text { reaches }\end{array}$ & $\begin{array}{r}\text { Potential } \\
\text { capacity } \\
(\mathrm{MW})\end{array}$ & $\begin{array}{r}\text { Potential } \\
\text { energy } \\
(\mathrm{MWh}) \\
\end{array}$ & $\begin{array}{r}\text { Average } \\
\text { head } \\
\text { (ft/reach) }\end{array}$ & $\begin{array}{r}\text { Average } \\
\text { flow } \\
\text { (cfs/reach) } \\
\end{array}$ & $\begin{array}{r}\text { Average } \\
\text { storage (ac } \\
\text { ft/reach) }\end{array}$ & $\begin{array}{r}\text { Average } \\
\text { residence } \\
\text { time (days) }\end{array}$ \\
\hline 0801 & $\begin{array}{l}\text { Lower Mississippi- } \\
\text { Hatchie }\end{array}$ & 14 & 31.8 & 166,503 & 12.5 & 2,535 & 22,043 & 6.6 \\
\hline 0802 & $\begin{array}{l}\text { Lower Mississippi-St. } \\
\text { Francis }\end{array}$ & 19 & 633.4 & $3,776,083$ & 21.6 & 48,359 & 29,794 & 9.8 \\
\hline 0803 & $\begin{array}{l}\text { Lower Mississippi- } \\
\text { Yazoo }\end{array}$ & 9 & 27.8 & 151,636 & 15.2 & 3,919 & 32,757 & 14.8 \\
\hline 0804 & Lower Red-Ouachita & 27 & 86.3 & 444,381 & 23.0 & 2,635 & 63,471 & 87.9 \\
\hline 0805 & Boeuf-Tensas & 1 & 1.2 & 5,220 & 17.7 & 921 & 417 & 0.2 \\
\hline 0806 & $\begin{array}{l}\text { Lower Mississippi- } \\
\text { Big Black }\end{array}$ & 18 & 957.9 & $5,836,007$ & 20.0 & 29,156 & 37,747 & 9.8 \\
\hline 0807 & $\begin{array}{l}\text { Lower Mississippi- } \\
\text { Lake Maurepas }\end{array}$ & - & - & - & - & - & - & - \\
\hline 0808 & Louisiana Coastal & 2 & 3.1 & 14,879 & 10.9 & 1,969 & 13,065 & 2.6 \\
\hline
\end{tabular}


The summary statistics of hydraulic head $\mathrm{H}_{\text {ref }}\left(\mathrm{ft}\right.$ ), design flow $\mathrm{Q}_{30}(\mathrm{cfs})$, potential capacity $\mathrm{P}_{\mathrm{NSD}}$ $(\mathrm{MW})$, inundated area $\mathrm{A}_{\mathrm{NSD}}(\mathrm{ac})$, storage $\mathrm{V}_{\mathrm{NSD}}\left(\mathrm{ac}-\mathrm{ft}\right.$ ), and residence time $\mathrm{T}_{\mathrm{NSD}}$ (day) are shown in Figure 11.3. The hydraulic head $\mathrm{H}_{\mathrm{ref}}$ ranges from 0 to the 90 th quantile of $35 \mathrm{ft}$ with a median of about $19 \mathrm{ft}$, suggesting that many of the potential stream-reaches will require low-head hydropower technologies. The design flow $\mathrm{Q}_{30}$ ranges from about $0 \mathrm{cfs}$ to the 90th quantile of $9000 \mathrm{cfs}$ with a median of $2000 \mathrm{cfs}$. The potential capacity $\mathrm{P}_{\mathrm{NSD}}$ ranges from about $2 \mathrm{MW}$ to the 90th quantile of about $9 \mathrm{MW}$ with a median of just under $3 \mathrm{MW}$. The inundated surface area $\mathrm{A}_{\mathrm{NSD}}$ ranges from 0 to the 90th quantile of 12,000 acres with a median of 2,000 acres. This results in storage values $\mathrm{V}_{\mathrm{NSD}}$ ranging from 0 to the 90th quantile of $90,000 \mathrm{ac}-\mathrm{ft}$ median of about 15,000 ac-ft with residence times $\mathrm{T}_{\mathrm{NSD}}$ ranging from $<1$ day to the 90th quantile of about 22 days with a median on the order of about 4 days. The results of $>1$ MW stream-reach potential are illustrated in Figure 11.4, with potential capacity (MW) aggregated to the HUC08 subbasins. The higher-potential-capacity sites are generally located on the larger tributary rivers feeding directly into the Mississippi River and in the hills of Arkansas.

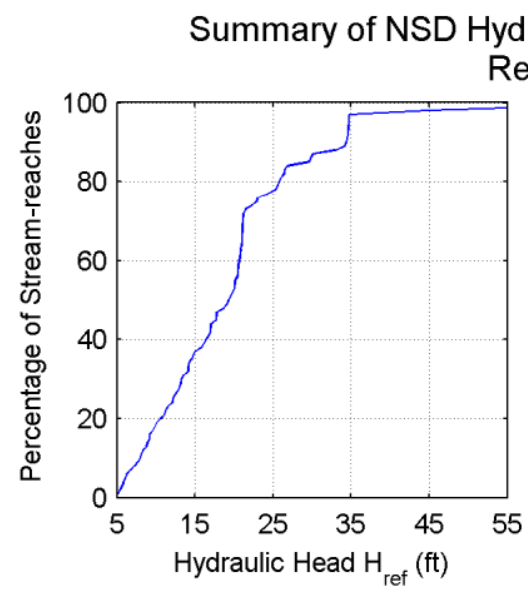

Region 8: 90 stream-reaches, $1741 \mathrm{MW}$
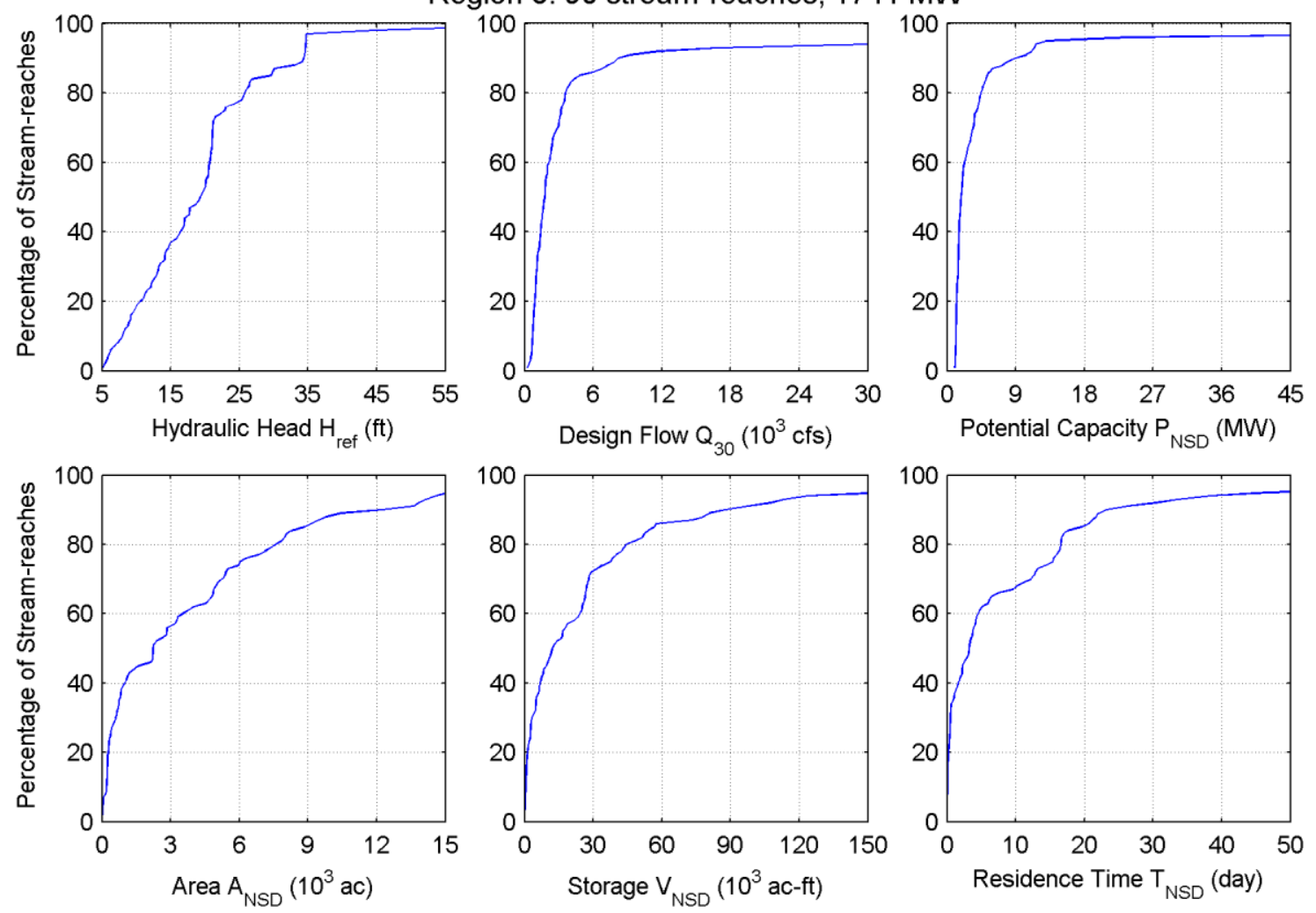

Figure 11.3. Cumulative distributions of hydraulic head $\mathrm{H}_{\text {ref }}$, design flow $\mathrm{Q}_{30}$, potential capacity $\mathrm{P}_{\mathrm{NSD}}$, inundated area $\mathrm{A}_{\mathrm{NSD}}$, storage $\mathrm{V}_{\mathrm{NSD}}$, and residence time $\mathrm{T}_{\mathrm{NSD}}$ in Region 8-Lower Mississippi. 


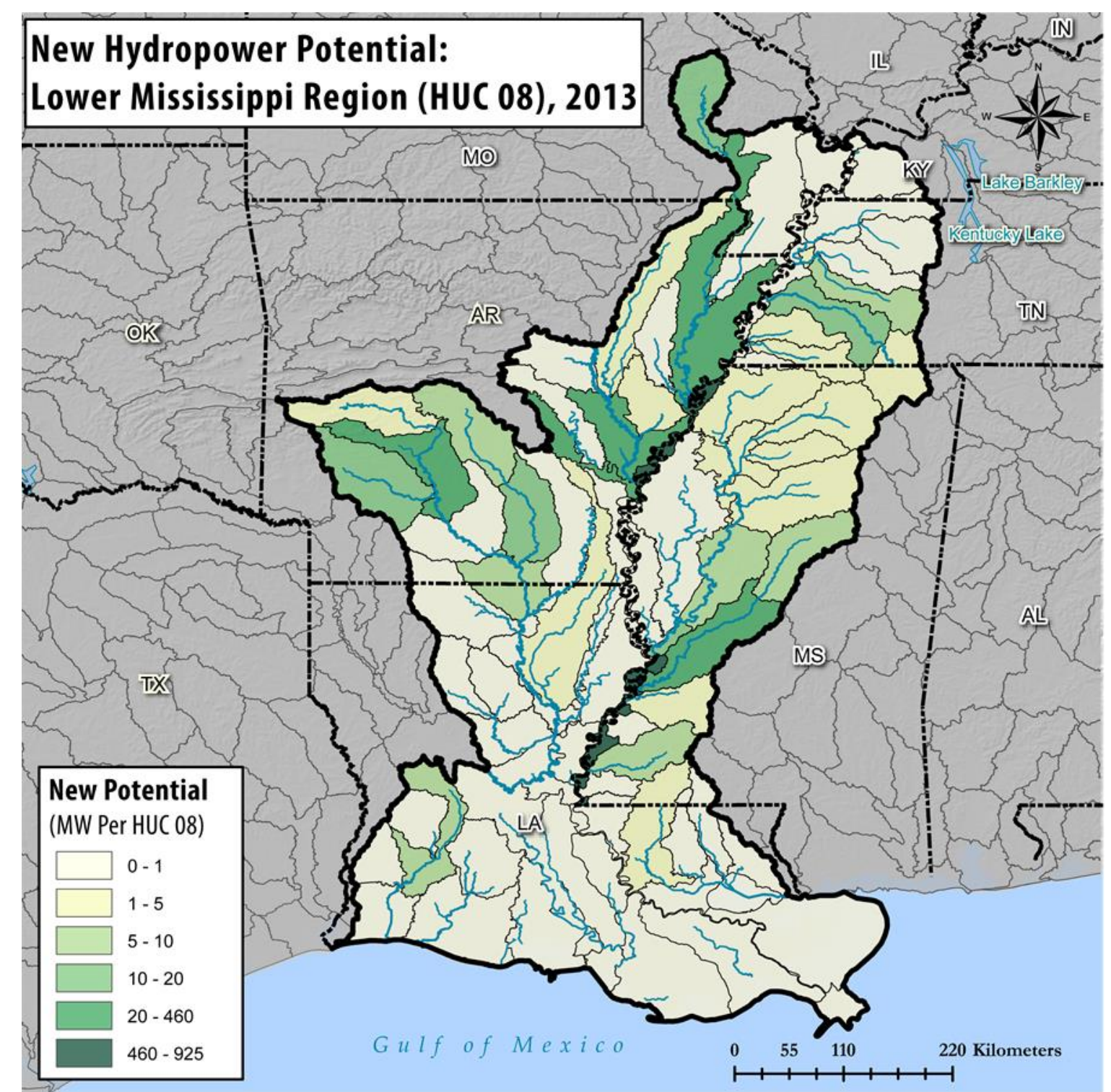

Figure 11.4. Potential new hydropower capacity in Region 8 Lower Mississippi (higher-energy-density streamreaches with $>1 \mathrm{MW}$ per reach, aggregated to HUC08 subbasins for illustration).

\subsection{Environmental Characteristics}

The Lower Mississippi Region is home to 220 native fish species, 19 of which are fishes of concern. Of those species, 6 fall under an ESA category and 17 fall under IUCN vulnerable categories (Figure 11.5 and Appendix B). Paddlefish, shortnose sturgeon, pallid sturgeon, Atlantic sturgeon, relict darter (Etheostoma chienense), and bayou darter (Etheostoma rubrum) are among the fishes of concern. Ten potadromous or anadromous species are documented in this region. At least one ESA fish species is found in all subbasins (Figure 11.6 and Table 11.3). Almost $21 \%$ of the HUC08 subbasins in Region 8 are critical watersheds, with the highest number of fish and mussels at risk in the Upper Ouachita Subbasin (20 species) (Mathews et al., 1998). Region 8 has critical habitat designations for Gulf sturgeon (Acipenser oxyrinchus 
desotoi), Louisiana black bear (Ursus americanus luteolus), and piping plover (Charadrius melodus).

Protected land coverage is not as extensive in Region 8 as in other areas of the United States. Approximately 4.9 million acres are protected, constituting only $7 \%$ of the total area. Most protected lands $(57 \%)$ are federally owned by the USFS (29\%, primarily national forest), USFWS (20\%, primarily national wildlife refuge), and DOD (8\%). Ouachita, Kisatchie, Homochitto, and Holly Springs are among the largest national forests, and White River is the largest national wildlife refuge. State lands make up $38 \%$ of protected lands and are primarily composed of habitat/species management areas. Hot Springs is the only national park in the region. The Little Missouri National Wild and Scenic River is the only river protected under the National Wild and Scenic River Act (NWSRA) in Region 8. A section of the Natchez Trace Parkway is also located in the region. Region 8 includes 601 boat ramps, 217 freshwater fishing access areas, 3 waterfalls, and 38 recreational boating river sections.

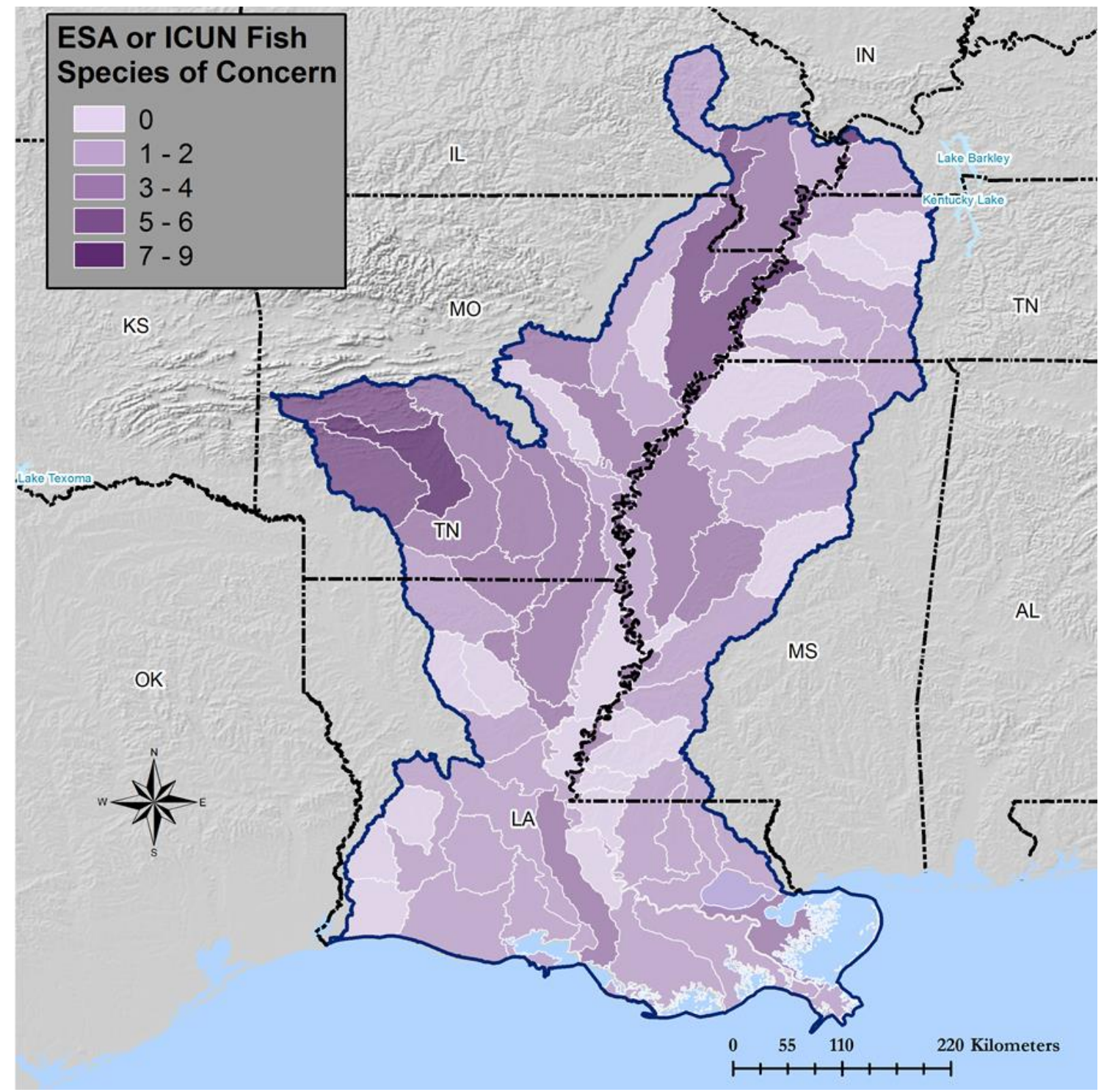

Figure 11.5. Fish species of concern (number per HUC08 subbasin) in Region 8. 


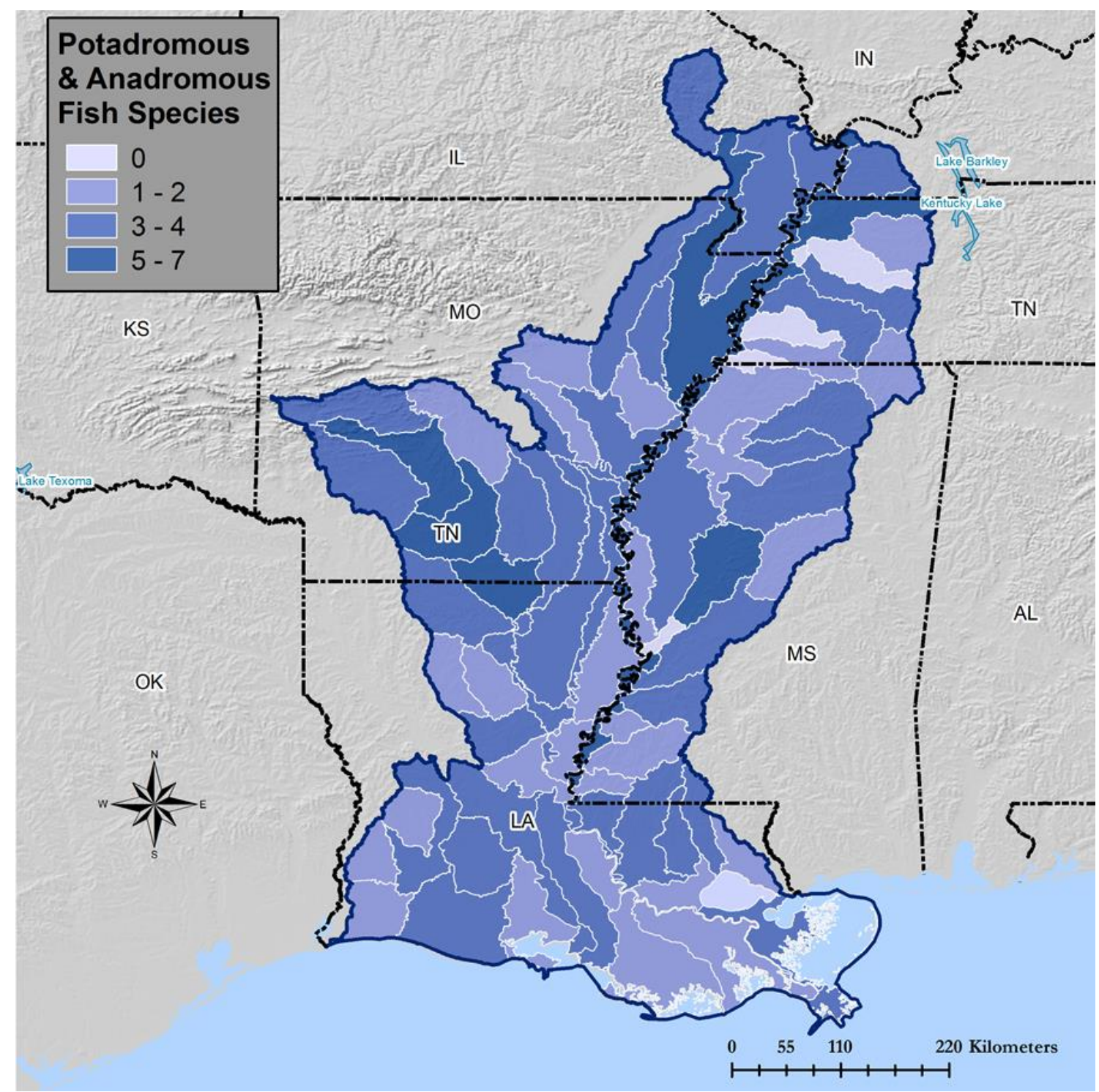

Figure 11.6. Potadromous and anadromous fish species (number per HUC08 subbasin) in Region 8.

Water use is relatively high in Region 8 compared with other regions in the United States. Most usage occurs as thermoelectric cooling or irrigation (Appendix B), with the highest values found in the Lower Mississippi and Lower Mississippi-St. Fancis Subbasins (Table 11.3). Waterquality concerns in Region 8 are average for the United States. Most water quality concerns are related to mercury contamination, pathogens, or dissolved oxygen (Appendix B).

Critical habitat designations overlap with only one stream-reach, which has a capacity of 920 MW (Figure 11.7). Over 15\% of stream-reaches are located within HUC08 subbasins with at least one fish falling within an ESA category. Fifty-eight percent of stream-reaches (1.09 GW) overlap with protected lands; however, no stream-reaches intersect national parks and two intersect Wild and Scenic Rivers. Water-quality concerns are prevalent, occurring at $80 \%$ of stream-reaches. Recreational boating is not as common, found only at six stream-reaches. Boat ramps and fishing access areas intersect $54 \%$ and $24 \%$ of stream-reaches, respectively. Forty stream-reaches $(>1.63 \mathrm{GW})$ are located in watersheds with high or very high water use. 
Table 11.3. Summary of Environmental Variables at HUC04 Subregions within Region 8 (Stream-Reaches with Potential Capacity $>1 \mathrm{MW}$ )

\begin{tabular}{|c|c|c|c|c|c|c|c|c|}
\hline HUC04 HUC04 name & $\begin{array}{r}\text { \# Critical } \\
\text { habitats }\end{array}$ & $\begin{array}{l}\text { \# Potad- } \\
\text { anad fish }\end{array}$ & $\begin{array}{r}\text { \# ESA } \\
\text { fish }\end{array}$ & $\begin{array}{r}\text { \# IUCN } \\
\text { fish }\end{array}$ & $\begin{array}{r}\# \\
\text { Recreation } \\
\text { locations }^{a} \\
\end{array}$ & $\begin{array}{r}\text { Protected } \\
\text { lands } \\
(\%) \\
\end{array}$ & $\begin{array}{r}\text { Population } \\
\text { density } \\
\left(\text { ind } / \mathbf{k m}^{2}\right) \\
\end{array}$ & $\begin{array}{r}\text { Freshwater } \\
\text { use } \\
\left(1 / \mathrm{day} / \mathrm{km}^{2}\right) \\
\end{array}$ \\
\hline $\begin{array}{l}\text { Lower Mississippi- } \\
\text { Hatchie }\end{array}$ & 0 & 8 & 3 & 7 & $60 ; 0 ; 0$ & 3.28 & 75.84 & $1,831.26$ \\
\hline $\begin{array}{l}0802 \begin{array}{l}\text { Lower Mississippi-St. } \\
\text { Francis }\end{array} \\
\end{array}$ & 0 & 9 & 2 & 8 & $266 ; 16 ; 0$ & 6.21 & 17.94 & $7,130.38$ \\
\hline $\begin{array}{l}0803 \text { Lower Mississippi- } \\
\text { Yazoo }\end{array}$ & 0 & 7 & 3 & 6 & $163 ; 0 ; 0$ & 5.54 & 18.51 & $2,194.36$ \\
\hline 0804 Lower Red-Ouachita & 1 & 7 & 1 & 11 & $246 ; 22 ; 0$ & 10.64 & 15.75 & 900.62 \\
\hline 0805 Boeuf-Tensas & 1 & 5 & 1 & 3 & $20 ; 0 ; 0$ & 6.05 & 11.33 & $2,546.70$ \\
\hline $\begin{array}{l}0806 \text { Lower Mississippi- } \\
\text { Big Black }\end{array}$ & 1 & 6 & 2 & 6 & $23 ; 0 ; 2$ & 5.95 & 19.19 & 526.48 \\
\hline $\begin{array}{c}0807 \begin{array}{l}\text { Lower Mississippi- } \\
\text { Lake Maurepas }\end{array} \\
\end{array}$ & 1 & 7 & 2 & 3 & $12 ; 0 ; 1$ & 3.79 & 50.24 & $5,855.48$ \\
\hline 0808 Louisiana Coastal & 2 & 5 & 2 & 2 & $27 ; 0 ; 0$ & 10.52 & 30.82 & $2,156.62$ \\
\hline 0809 Lower Mississippi & 2 & 6 & 3 & 3 & $10 ; 0 ; 0$ & 7.80 & 148.91 & $9,943.24$ \\
\hline
\end{tabular}

${ }^{a}$ Recreation locations refer to the number of boat-ramp and fishing access points, recreational boating, and waterfalls within each HUC04.

\section{ESA Critical Habitats}

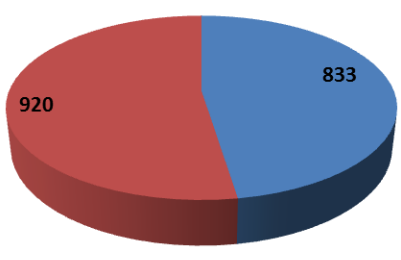

Absent Present

\section{Water Quality Concern}

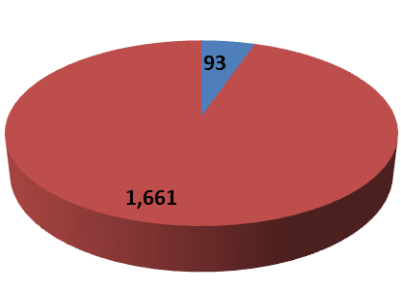

Absent $\square$ Present
Number ESA Listed Fish

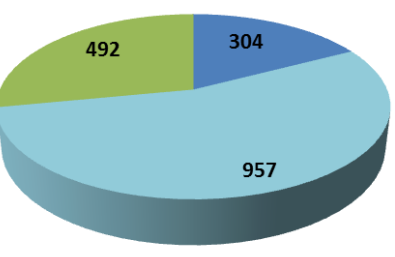

$\square 01 \square 2$

Recreation Boating

10

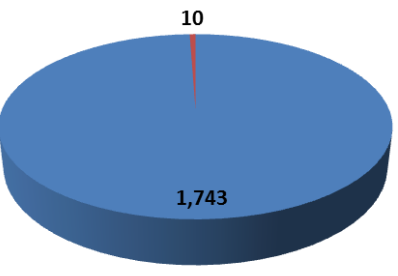

absent Present
National Park Lands

0

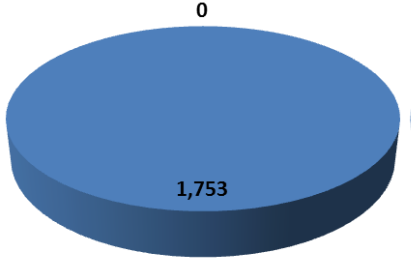

Absent Present

Fishing Access Areas

68

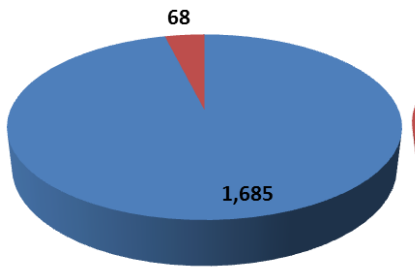

absent Present
Wild and Scenic Rivers

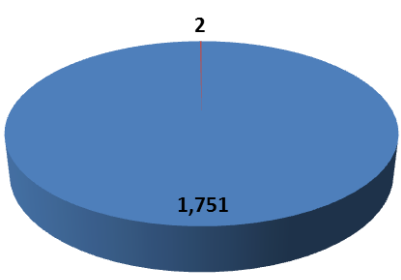

absent $\square$ Present

Water Use

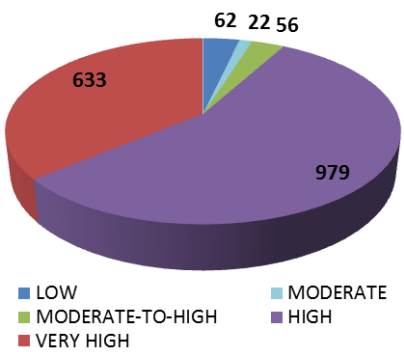

Figure 11.7. The potential capacity, in MW, associated with environmental attributes in Region 8-Lower Mississippi (stream-reaches with potential capacity $>1 \mathrm{MW}$ ). 


\section{REGION 9-SOURIS-RED-RAINY}

\subsection{Summary of Findings}

Following NSD methodology (Hadjerioua et al., 2013), the potential capacity, annual generation and mean capacity factors in the Souris-Red-Rainy Region are estimated and summarized in Table 12.1 for both larger ( $>1 \mathrm{MW})$ and smaller ( $<1 \mathrm{MW})$ stream-reaches. For comparison, the year-2011 nameplate capacity, 2002-2011 average annual generation, and capacity factor of existing hydropower facilities are also listed (NHAAP, 2013). The total undeveloped NSD capacity is $151 \mathrm{MW}$, around $685 \%$ of existing conventional hydropower nameplate capacity. In terms of energy, the total undeveloped NSD generation is $787 \mathrm{GWh} /$ year, around $1034 \%$ of annual net generation from existing conventional hydropower plants. The larger ratios of potential NSD resources to existing hydropower development should be mainly a result of the relatively lower hydropower development in this region. Souris-Red-Rainy was relatively rural with lower population and power demand; hence hydropower may not be the most economical choice for energy investment in this region. More detailed topographical analysis and environmental attribution are conducted for larger (>1 MW) stream-reaches and discussed in Sections 12.3 and 12.4 .

Table 12.1. Summary of NSD Findings in Region 9-Souris-Red-Rainy

\begin{tabular}{l|r|r|r}
\hline & $\begin{array}{r}\text { Capacity } \\
(\mathbf{M W})\end{array}$ & $\begin{array}{r}\text { Generation } \\
(\mathbf{M W h})\end{array}$ & $\begin{array}{r}\text { Mean capacity } \\
\text { factor }\end{array}$ \\
\hline Potential in undeveloped stream-reaches $(>1 \mathrm{MW})$ & 68.3 & 375,000 & $63 \%$ \\
\hline Potential in undeveloped stream-reaches $(<1 \mathrm{MW})$ & 82.4 & 412,000 & $57 \%$ \\
\hline Existing hydropower-conventional hydro & 22 & 76,080 & $39 \%$ \\
\hline Existing hydropower-pumped storage & 0 & & \\
\hline
\end{tabular}

\subsection{Background Hydrologic Setting}

The Souris-Red-Rainy Region, situated along the Canadian border, encompasses approximately $153,318 \mathrm{~km}^{2}$ of drainage area in the most northern sections of Minnesota and North Dakota, and a very small section of South Dakota. The region is made up of mostly of farmland and livestock.

Few river systems are located in the Souris-Red-Rainy Region (Figure 12.1), including the Souris, Red, Goose, Marsh, Sheyenne, and Rainy rivers, with a total length of $8315 \mathrm{~km}$ (i.e., total length of streams with estimated discharge greater than $35 \mathrm{cfs}$ ). Metropolitan areas within the region include Fargo (ND) and Grand Forks (ND). As shown in Figure 12.2, annual precipitation for the Souris-Red-Rainy region ranges from 420 to $650 \mathrm{~mm} / \mathrm{year}$ and annual runoff from 25 to $130 \mathrm{~mm} /$ year. The precipitation occurs predominately in the summer. The runoff peak occurs during the early spring snowmelt. 
The existing hydropower plants and major non-powered dams (Hadjerioua et al., 2012) are shown in Figure 12.1. The region contains eight hydropower dams and seven major non-powered dams with storage capacities of about 4,047,027 ac-ft and 900,300 ac-ft, respectively.

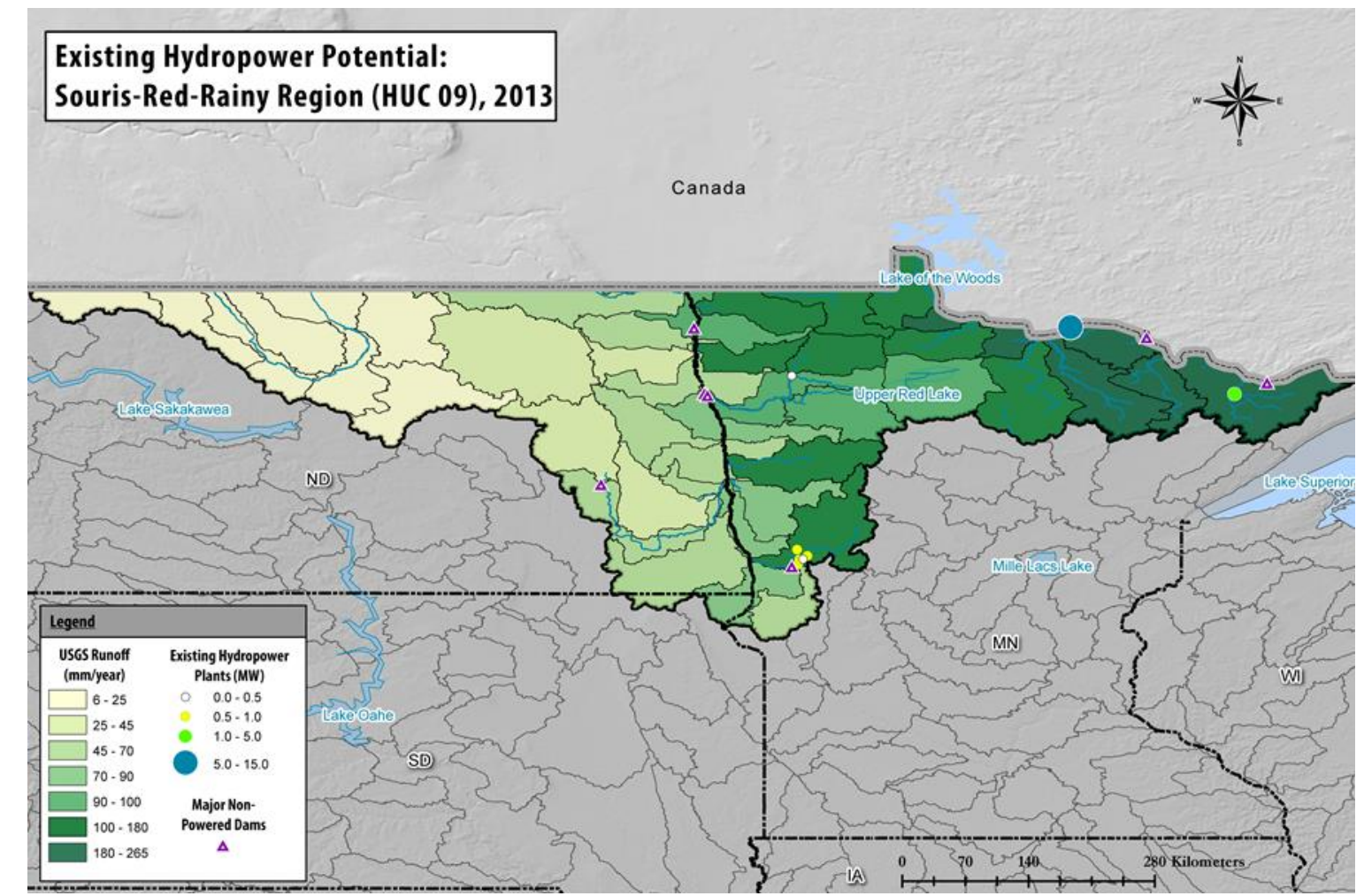

Figure 12.1. Locations of water control projects in Region 9-Souris-Red-Rainy.

\subsection{Potential New Hydropower Resources}

A total of 15 stream-reaches of high energy density (with estimated potential capacity $>1 \mathrm{MW}$ per stream-reach) are identified in the Souris-Red-Rainy region. The NSD results based on the HUC04 subregions are shown in Table 12.2. The highest hydropower potential is found in the Red Subregion (HUC 0902), followed closely by the Rainy Subregion (HUC 0903). In these regions, the Red Lake River and the Rainy River contain the highest hydropower potential.

The summary statistics of hydraulic head $\mathrm{H}_{\text {ref }}(\mathrm{ft})$, design flow $\mathrm{Q}_{30}(\mathrm{cfs})$, potential capacity $\mathrm{P}_{\mathrm{NSD}}$ $(\mathrm{MW})$, inundated area $\mathrm{A}_{\mathrm{NSD}}(\mathrm{ac})$, storage $\mathrm{V}_{\mathrm{NSD}}$ (ac-ft), and residence time $\mathrm{T}_{\mathrm{NSD}}$ (day) are shown in Figure 12.3. The hydraulic head $\mathrm{H}_{\mathrm{ref}}$ ranges from 7 to the 90th quantile of $41 \mathrm{ft}$ with a median of $21 \mathrm{ft}$, suggesting that most of the potential stream-reaches will require low-head hydropower technologies. The design flow $\mathrm{Q}_{30}$ ranges from 1,000 to the 90th quantile of 10,500 cfs with a median of 2,500 cfs. The potential capacity $\mathrm{P}_{\mathrm{NSD}}$ ranges from 1.5 to the 90th quantile of $7 \mathrm{MW}$ with a median of $5 \mathrm{MW}$. The inundated surface area $\mathrm{A}_{\mathrm{NSD}}$ ranges from 0 to the 90th quantile of 1600 acres with a median of 600 acres. This results in storage values $V_{\text {NSD }}$ ranging from 0 to the 90th quantile of 25,000 ac-ft with a median of 5,000 ac-ft, with residence times $\mathrm{T}_{\mathrm{NSD}}$ ranging from $<1$ day to the 90th quantile of 1 day a week with a median of about 2 days. The results of $>$ 1 MW stream-reach potential are illustrated in Figure 12.4, with potential capacity (MW) aggregated to the HUC08 subbasins. 


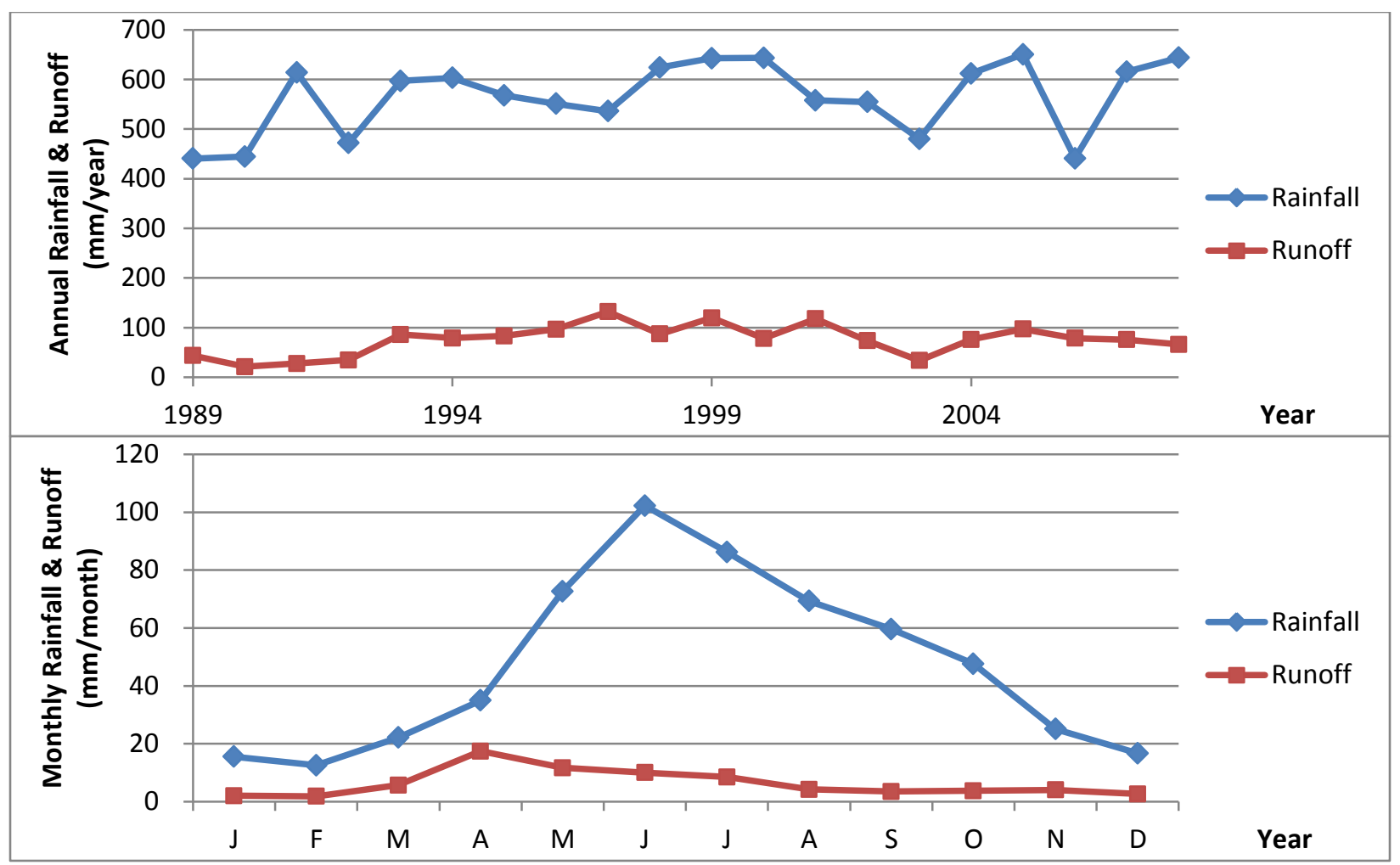

Figure 12.2. Annual and monthly rainfall and runoff of Region 9 - Souris-Red-Rainy.

\subsection{Environmental Characteristics}

The Souris--Red-Rainy Region has 84 native fish species, with no fish falling under ESA categories and only 1 fish species, shortjaw cisco, falling under IUCN vulnerability categories (Appendix B). Ten fish species are potadromous or anadromous (Figure 12.5). There are no critical watersheds in Region 9 (Mathews et al., 1998). Three species have critical habitat designations, including the gray wolf, Canada lynx, and piping plover.

In Region 9, there are over 10.8 million acres of protected lands, which make up approximately $19 \%$ of the total area. Most of these lands are owned by states (47\%), the federal government (44\%), or Native Americans (8\%). State forests are the primary state-owned land type. The USFWS owns most of the federal lands in the region (21\%), including the largest tract in the region, Dakota Tallgrass Prairie Wildlife Management Area. The USFS owns 17\% of the protected lands, the largest of which includes the Boundary Waters Canoe Area Wilderness, part of Superior National Forest. Other federal entities include NPS (4\% of lands) and Bureau of Indian Affairs (1\% of lands). Voyageurs National Park is the only national park in the region. There are several tribal lands and reservations, the largest of which include the Lake Traverse, Spirit Lake, and Blackfeet reservations. GAP status 3 lands make up the largest area (47\%), followed by status $2(32 \%)$, status $1(12 \%)$, and status $4(9 \%)$ lands. There are no rivers protected under the NWSRA in Region 9. Recreation is average in the region, with 478 boat ramps, 152 fishing access locations, 48 waterfalls, and 13 recreational boating river sections. 
On average, Region 9 has the lowest amount of water use in the United States. Most usage is for irrigation or thermoelectric cooling (Appendix B), with the highest values reported in the Rainy Subbasin (Table 12.3). Water-quality concerns are average and are primarily related to elevated nutrient loads and mercury contamination (Figure 12.6 and Appendix B).

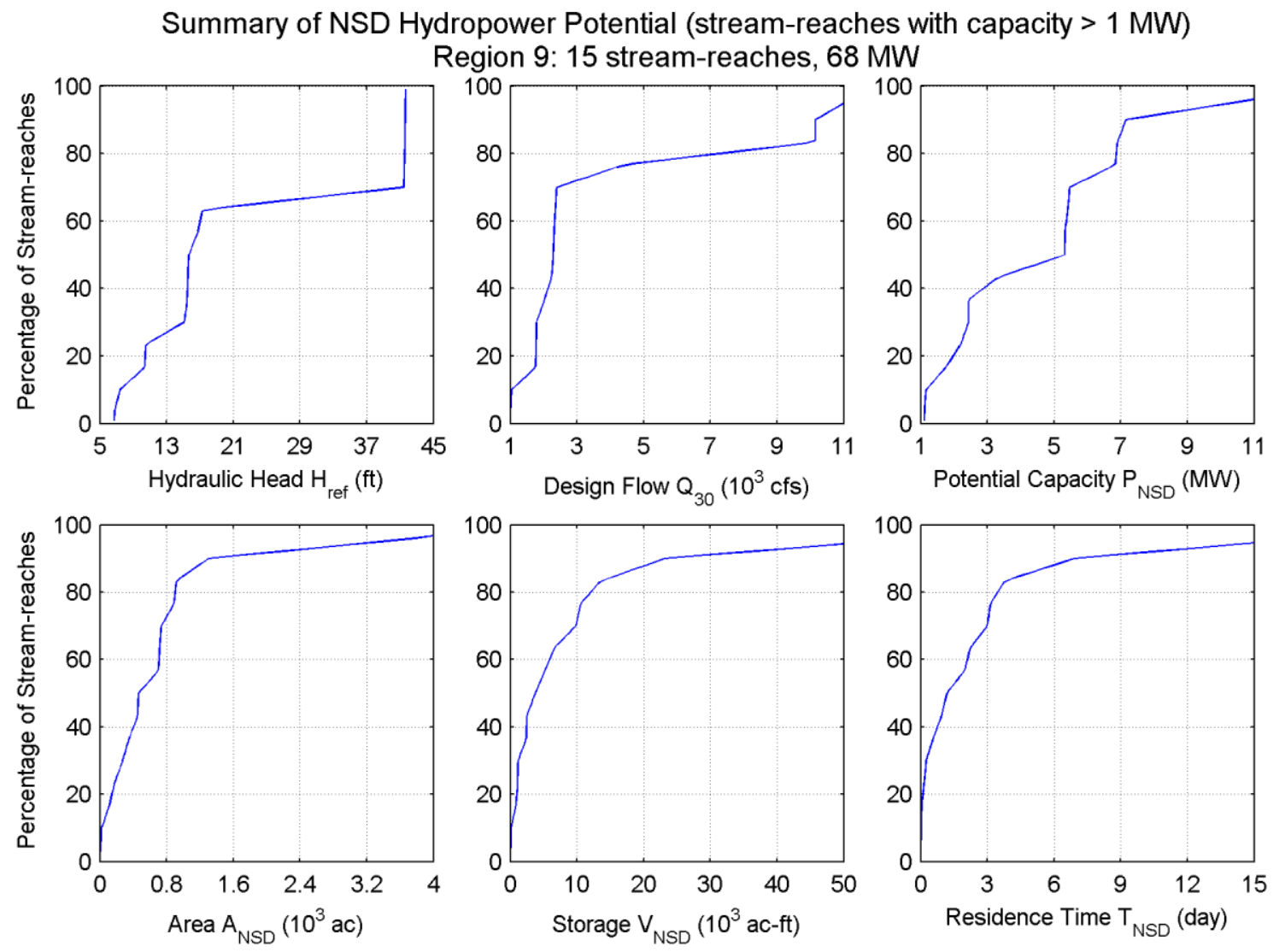

Figure 12.3. Cumulative distributions of hydraulic head $\mathrm{H}_{\mathrm{ref}}$, design flow $\mathrm{Q}_{30}$, potential capacity $\mathrm{P}_{\mathrm{NSD}}$, inundated area $\mathrm{A}_{\mathrm{NSD}}$, storage $\mathrm{V}_{\mathrm{NSD}}$, and residence time $\mathrm{T}_{\mathrm{NSD}}$ in Region 9-Souris-Red-Rainy.

Table 12.2. Summary of Potential New Hydropower Resources in Region 9 Souris-Red-Rainy (Stream-Reaches with Potential Capacity >1 MW)

\begin{tabular}{llrrrrrrr}
\hline HUC04 & HUC04 name & $\begin{array}{r}\text { \# of } \\
\text { stream- } \\
\text { reaches }\end{array}$ & $\begin{array}{r}\text { Potential } \\
\text { capacity } \\
\text { (MW) }\end{array}$ & $\begin{array}{r}\text { Potential } \\
\text { energy } \\
\text { (MWh) }\end{array}$ & $\begin{array}{r}\text { Average } \\
\text { (ft/reach) }\end{array}$ & $\begin{array}{r}\text { Average } \\
\text { flow } \\
\text { (cfs/reach) }\end{array}$ & $\begin{array}{r}\text { Average } \\
\text { storage (ac- } \\
\text { ft/reach) }\end{array}$ & $\begin{array}{r}\text { Average } \\
\text { residence } \\
\text { time (days) }\end{array}$ \\
\hline 0901 & Souris & - & - & - & - & - & - & - \\
\hline 0902 & Red & 8 & 37.9 & 209,219 & 31.5 & 2,087 & 15,401 & 4.7 \\
\hline 0903 & Rainy & 7 & 30.3 & 165,440 & 12.4 & 5,757 & 3,184 & 0.7 \\
\hline
\end{tabular}

Table 12.3. Summary of Environmental Variables at HUC04 Subregions within Region 9 (Stream-Reaches with Potential Capacity $>1 \mathrm{MW}$ )

\begin{tabular}{|c|c|c|c|c|c|c|c|c|}
\hline HUC04 HUC04 name & $\begin{array}{r}\text { \# Critical } \\
\text { habitats }\end{array}$ & $\begin{array}{l}\text { \# Potad- } \\
\text { anad fish }\end{array}$ & $\begin{array}{r}\text { \# ESA } \\
\text { fish }\end{array}$ & $\begin{array}{r}\text { \# IUCN } \\
\text { fish }\end{array}$ & $\begin{array}{r}\# \\
\text { Recreation } \\
\text { locations }\end{array}$ & $\begin{array}{r}\% \\
\text { Protected } \\
\text { lands } \\
\end{array}$ & $\begin{array}{r}\text { Population } \\
\text { density } \\
\left(\mathrm{ind} / \mathrm{km}^{2}\right)\end{array}$ & $\begin{array}{r}\text { Freshwater } \\
\text { use } \\
\left(1 / \text { day } / \mathbf{k m}^{2}\right)\end{array}$ \\
\hline 0901 Souris & 1 & 0 & 0 & 0 & $18 ; 0 ; 0$ & 4.37 & 3.13 & 42.57 \\
\hline 0902 Red & 2 & 3 & 0 & 0 & $345 ; 4 ; 0$ & 15.28 & 6.14 & 85.57 \\
\hline 0903 Rainy & 3 & 8 & 0 & 1 & $239 ; 9 ; 15$ & 77.21 & 3.61 & 359.09 \\
\hline
\end{tabular}

${ }^{a}$ Recreation locations refer to the number of boat-ramp and fishing access points, recreational boating, and waterfalls within each HUC04. 


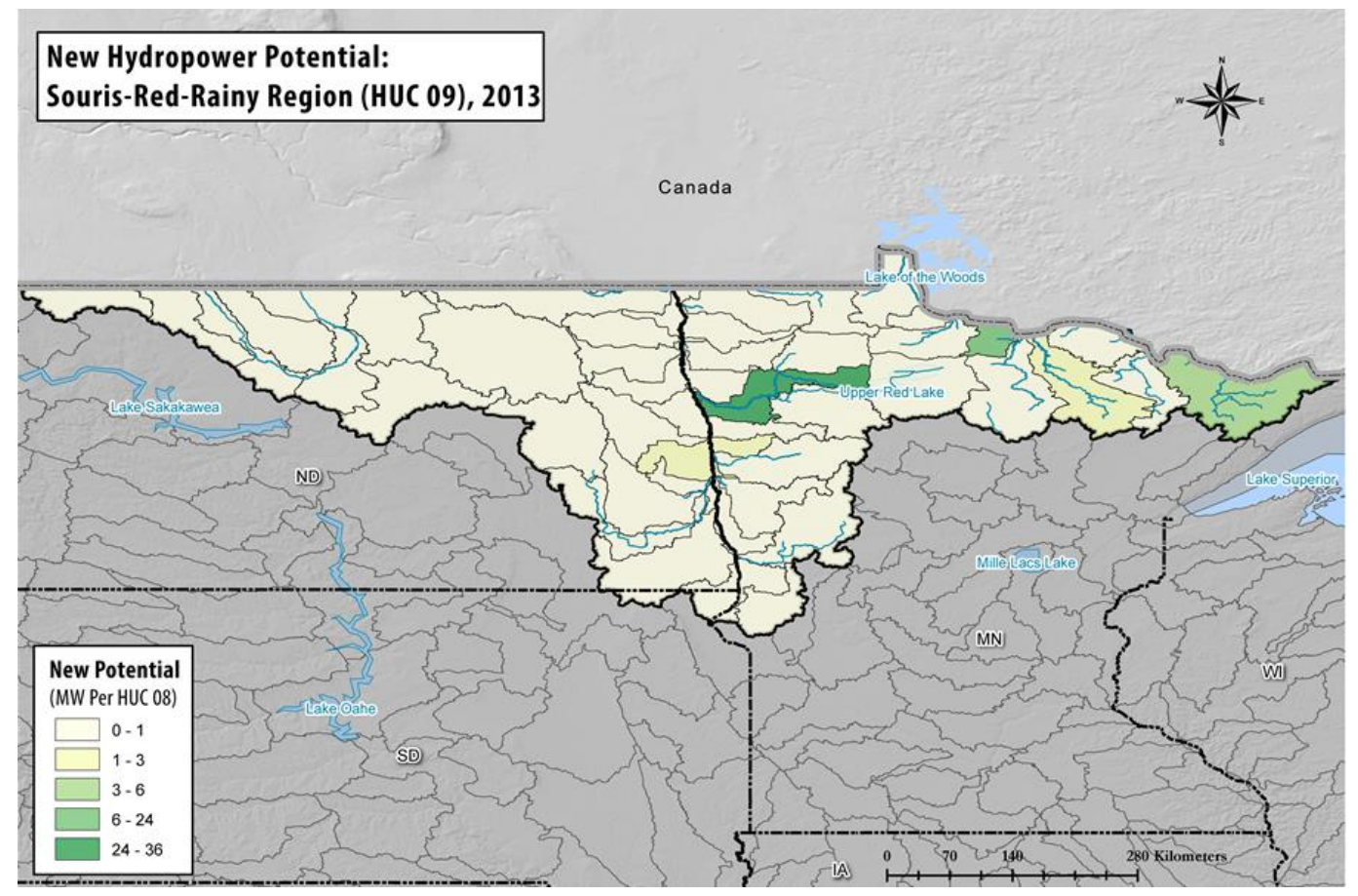

Figure 12.4. Potential new hydropower capacity in Region 9 - Souris-Red-Rainy (higher-energy-density streamreaches with >1 MW per reach, aggregated to HUC08 subbasins for illustration).

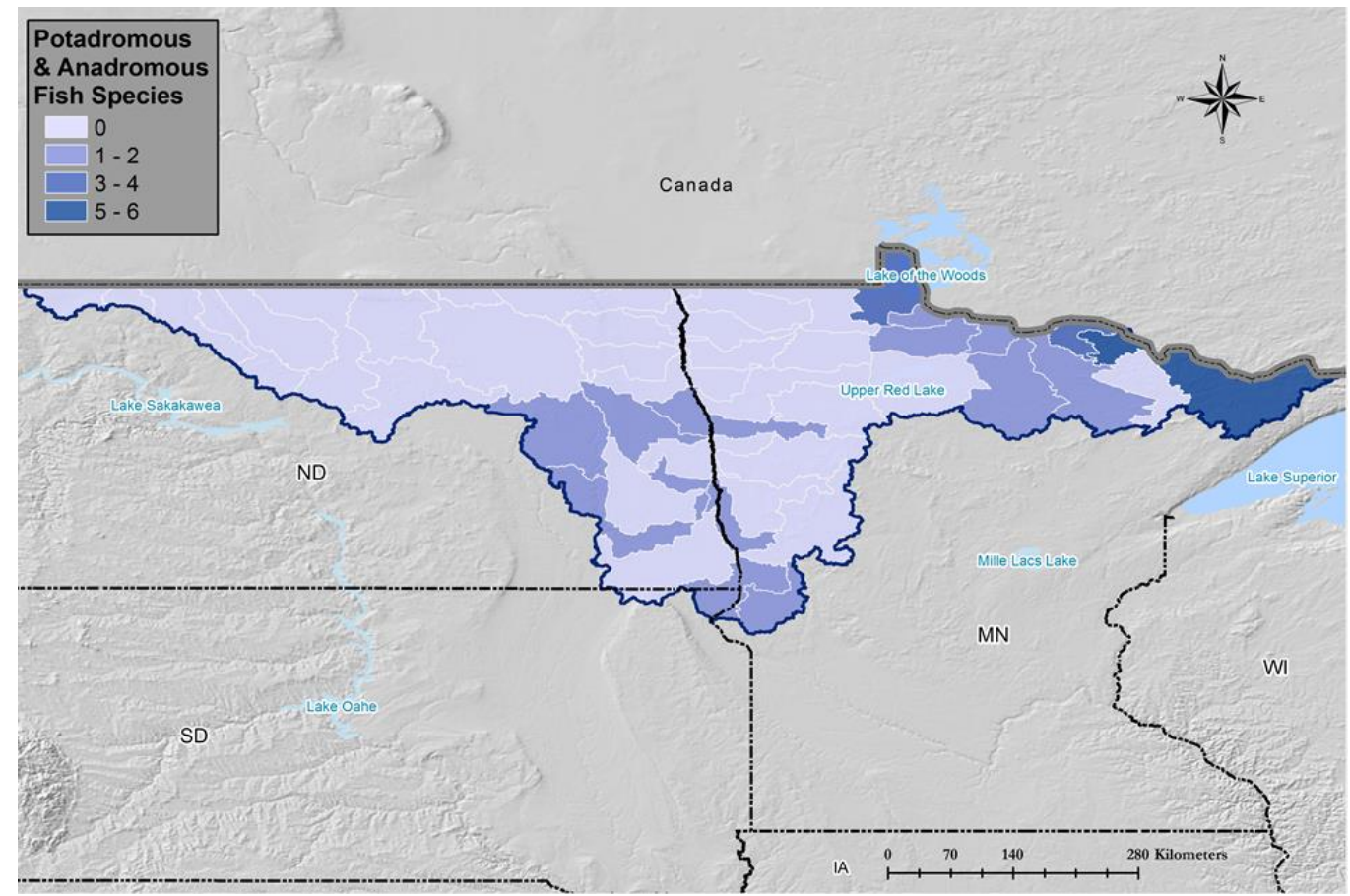

Figure 12.5. Potadromous and anadromous fish species (number per HUC08 subbasin) in Region 9.

Seven of the 15 stream-reaches in Region 9 intersect critical habitat designations, none of them for aquatic organisms (Figure 12.7). As mentioned previously, there are neither ESA fish species nor Wild and Scenic Rivers in this region. Twelve stream-reaches (44 MW) overlap with protected lands, but no stream-reaches intersect a national park. Water-quality concerns are 
present at almost all stream-reaches (14 reaches). Stream-reaches do not overlap with recreational boating runs and overlap with only one fishing access location. Ten stream-reaches (46 MW) overlap with boat ramps. Most stream-reaches are located within HUC08 subbasins with low water use for the region.

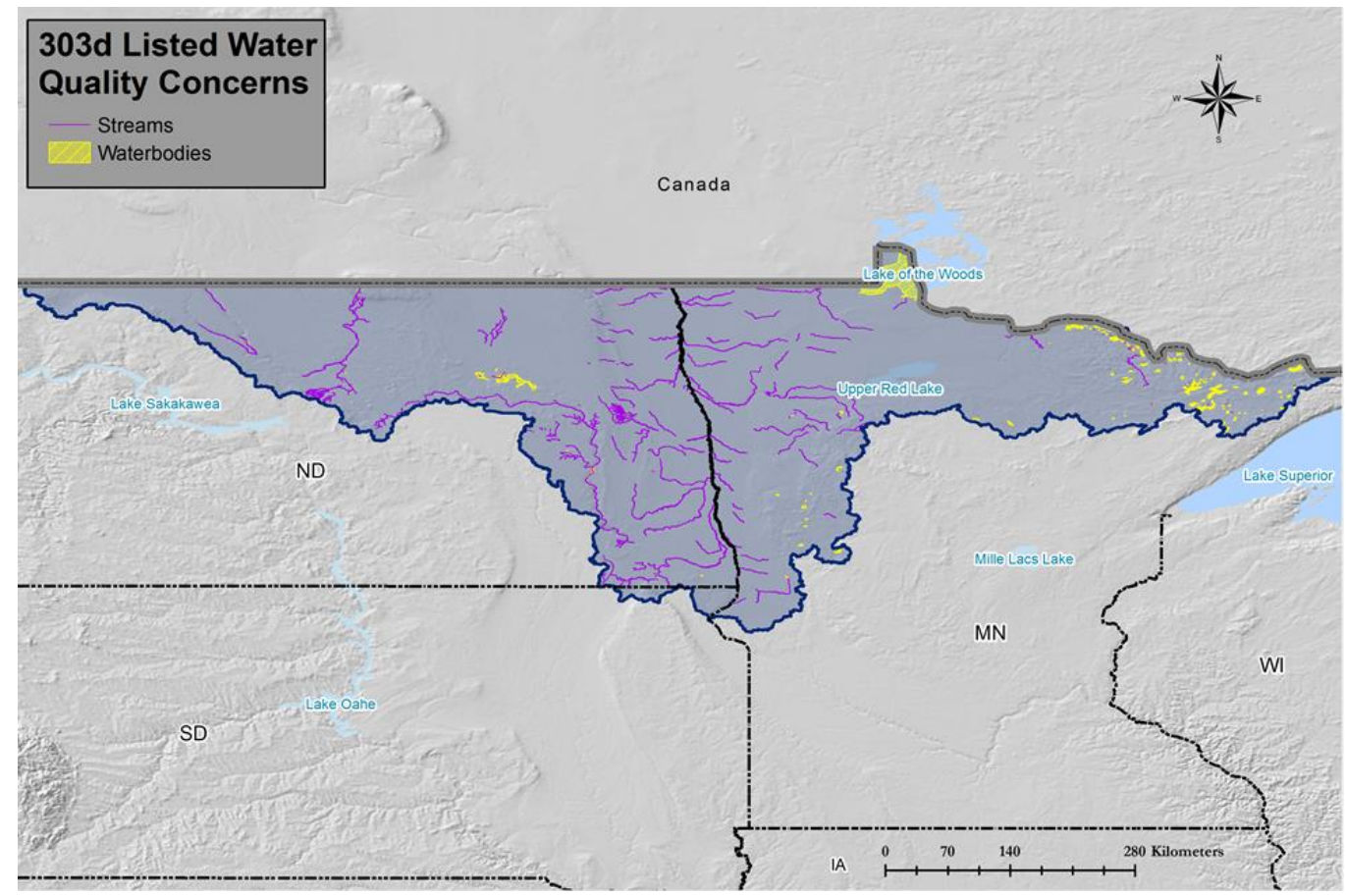

Figure 12.6. $303 d$ listed streams and waterbodies in Region 9.

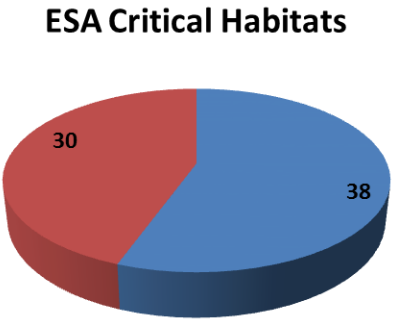

absent $\quad$ Present

\section{Water Quality Concern}

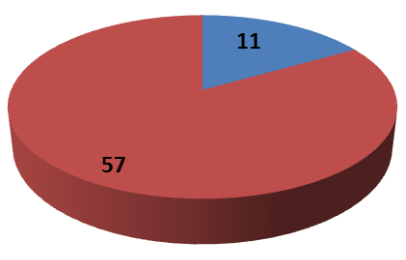

absent $\square$ Present

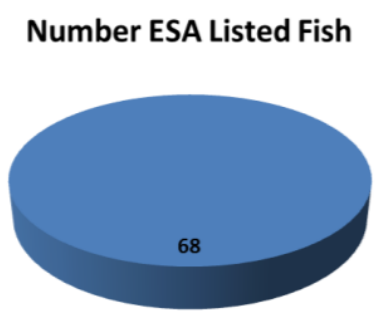

$\because 0$

\section{Recreation Boating}

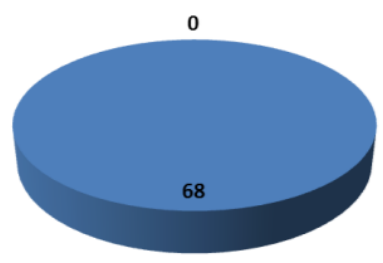

absent $=$ Present
National Park Lands

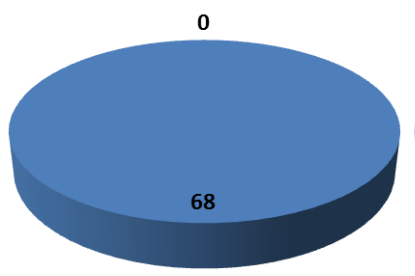

absent $\square$ Present

Fishing Access Areas

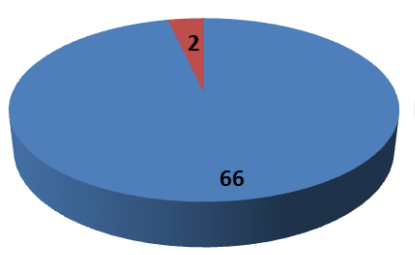

Absent $\square$ Present
Wild and Scenic Rivers

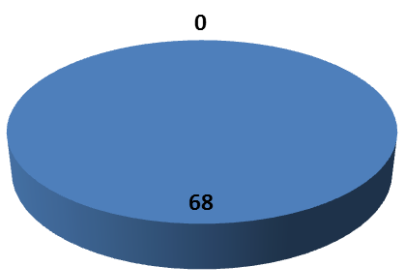

absent $\square$ Present

Water Use

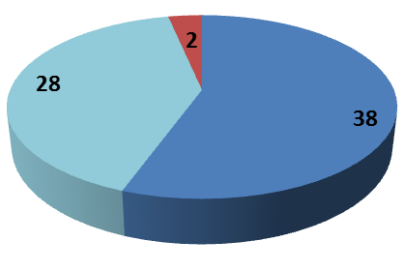

$\square$ LOW MODERATE $\square$ VERY HIGH

Figure 12.7. The potential capacity, in MW, associated with environmental attributes in Region 9-Souris-RedRainy (stream-reaches with potential capacity $>1 \mathrm{MW}$ ). 


\section{REGION 10-MISSOURI}

\subsection{Summary of Findings}

Following NSD methodology (Hadjerioua et al., 2013), the potential capacity, annual generation and mean capacity factors in the Missouri Region are estimated and summarized in Table 13.1, for both larger ( $>1 \mathrm{MW})$ and smaller (<1 MW) stream-reaches. For comparison, the year-2011 nameplate capacity, 2002-2011 average annual generation, and capacity factor of existing hydropower facilities are also listed (NHAAP, 2013). The total undeveloped NSD capacity is $11.69 \mathrm{GW}$, around $280 \%$ of existing conventional hydropower nameplate capacity. In terms of energy, the total undeveloped NSD generation is $69.01 \mathrm{TWh} /$ year, around $567 \%$ of annual net generation from existing conventional hydropower plants. Given the run-of-river assumption, NSD stream-reaches have higher capacity factors, especially compared with other larger-storage peaking-operation projects in this region. More detailed topographical analysis and environmental attribution are conducted for larger $(>1 \mathrm{MW})$ stream-reaches and discussed in Sections 13.3 and 13.4 .

Table 13.1. Summary of NSD Findings in Region $10-$ Missouri

\begin{tabular}{l|r|r|r}
\hline & $\begin{array}{r}\text { Capacity } \\
(\mathbf{M W})\end{array}$ & $\begin{array}{r}\text { Generation } \\
\text { (MWh) }\end{array}$ & $\begin{array}{r}\text { Mean capacity } \\
\text { factor }\end{array}$ \\
\hline Potential in undeveloped stream-reaches $(>1 \mathrm{MW})$ & 8,659 & $51,826,000$ & $68 \%$ \\
\hline Potential in undeveloped stream-reaches $(<1 \mathrm{MW})$ & 3,027 & $17,185,000$ & $65 \%$ \\
\hline Existing hydropower-conventional hydro & 4,172 & $12,178,000$ & $33 \%$ \\
\hline Existing hydropower-pumped storage & 470 & & \\
\hline
\end{tabular}

\subsection{Background Hydrologic Setting}

The Missouri Region encompasses approximately $1,323,893 \mathrm{~km}^{2}$ of drainage area in the upper midwestern section of the United States and contains parts of Missouri, Kansas, Colorado, Wyoming, North Dakota, South Dakota, Minnesota, Iowa, and all of Nebraska and Montana.

Multiple river systems are located in the Missouri Region (Figure 13.1), including the Missouri, Saskatchewan, Gallatin, Jefferson, Madison, Marias, Musselshell, Milk, Yellowstone, Big Horn, Powder, Tongue, Cheyenne, Belle Fourche, Cannonball, Heart, Knife, Grand, Moreau, White, Niobrara, James, Big Sioux, Platte, Loup, Elkhorn, Republican, Smoky Hill, Kansas, Big Blue, Chariton, Grand, Gasconade, and Osage rivers, with a total length of 48,904 km (i.e., total length of streams with estimated discharge greater than $35 \mathrm{cfs}$ ). Metropolitan areas within the subregion include Great Falls (MT), Billings (MT), Bismarck (ND), Rapid City (SD), Lincoln (NE), Topeka (KS), Denver (CO), and Kansas City (MO). As shown in Figure 13.2, annual precipitation for the Missouri region ranges from 400 to $700 \mathrm{~mm} / \mathrm{year}$, and annual runoff ranges from 20 to $120 \mathrm{~mm} /$ year. Precipitation occurs predominately in mid-summer, coincident with the peak runoff. 


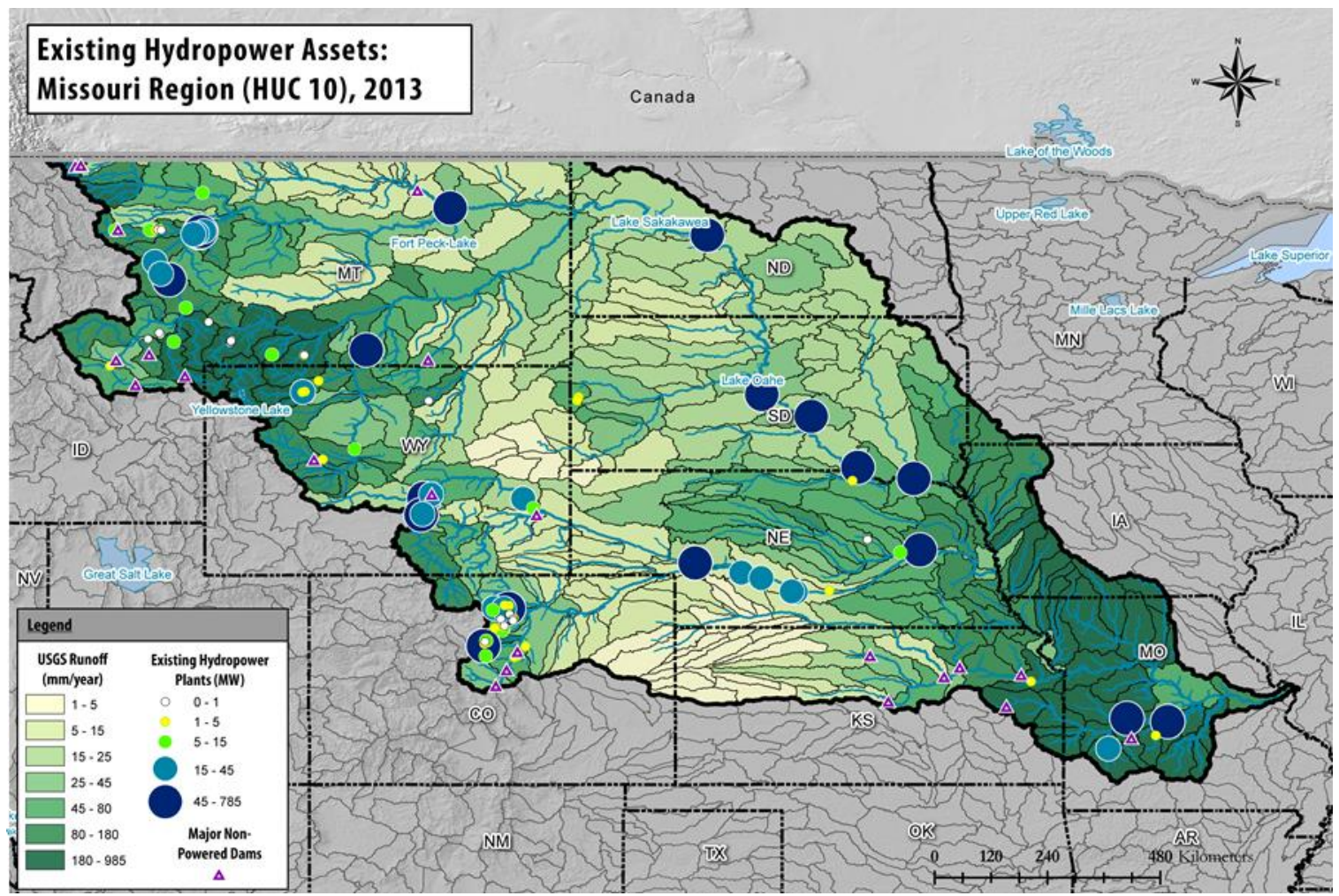

Figure 13.1. Locations of water control projects in Region 10-Missouri.

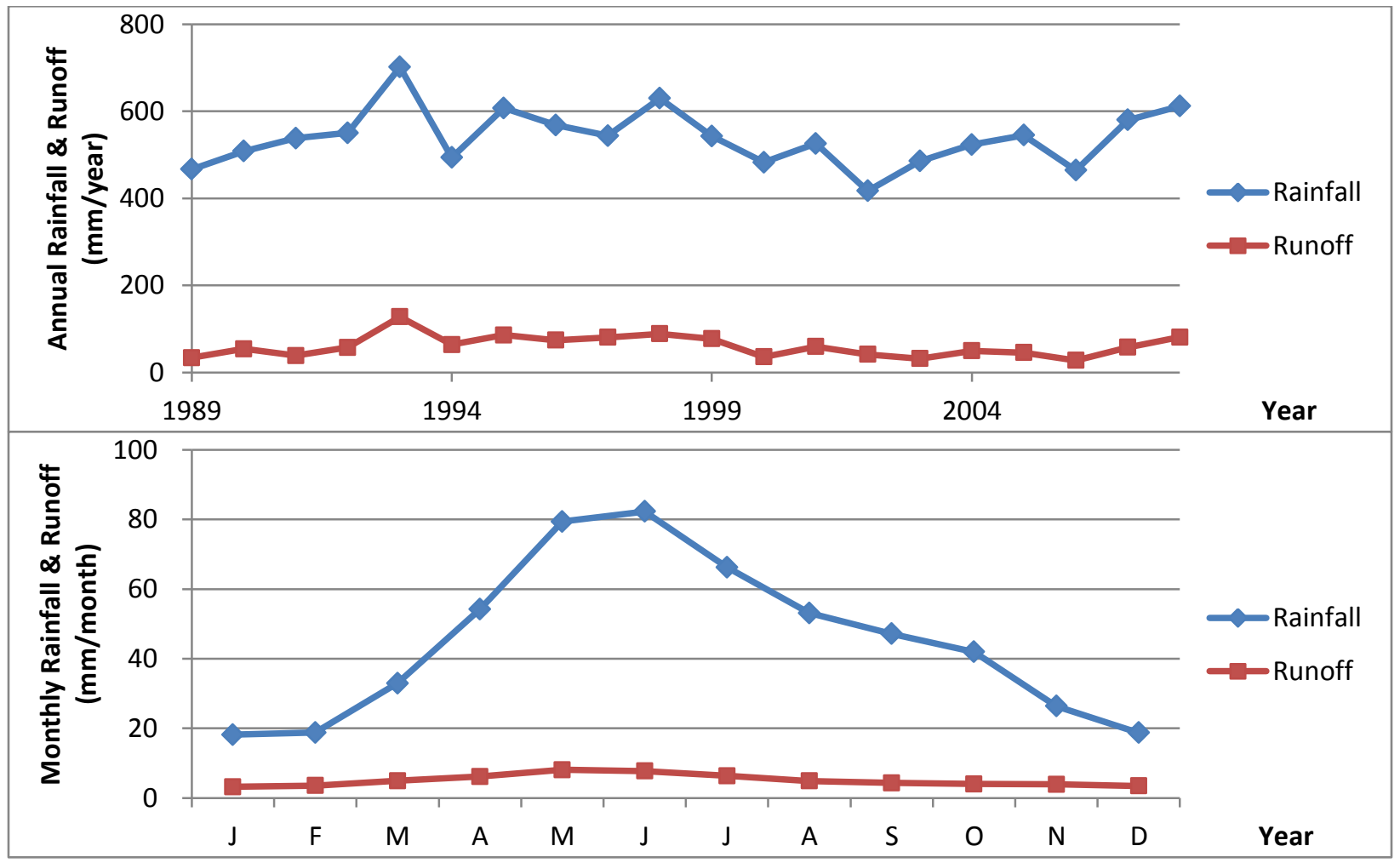

Figure 13.2. Annual and monthly rainfall and runoff of Region 10-Missouri. 
The existing hydropower plants and major non-powered dams (Hadjerioua et al., 2012) are also shown in Figure 13.1. The region contains 92 hydropower dams and 22 major non-powered dams, with total storage capacities of around 158,121,517 ac-ft and 8,008,551 ac-ft, respectively.

\subsection{Potential New Hydropower Resources}

A total of 1462 stream-reaches of high energy density (with estimated potential capacity $>1$ MW per stream-reach) are identified in the Missouri Region. The NSD results based on the HUC04 subregions are summarized in Table 13.2. The highest hydropower potentials are found in the North Platte Subregion (HUC 1018) and Lower Missouri Subregion (HUC 1030) and located on the North Platte and Missouri rivers. The second highest potentials are located in the Upper Yellowstone Subregion (HUC 1007), Lower Yellowstone Subregion (HUC1010), South Platte Subregion (HUC1019), and Missouri-Nishnabotna Subregion (HUC 1024) and located on the Yellowstone, South Platte, and Missouri rivers.

Table 13.2. Summary of Potential New Hydropower Resources in Region 10 Missouri (Stream-Reaches with Potential Capacity $>1 \mathrm{MW}$ )

\begin{tabular}{|c|c|c|c|c|c|c|c|c|}
\hline HUC04 & HUC04 name & $\begin{array}{r}\text { \# of } \\
\text { stream- } \\
\text { reaches }\end{array}$ & $\begin{array}{r}\text { Potential } \\
\text { capacity } \\
(\mathrm{MW})\end{array}$ & $\begin{array}{r}\text { Potential } \\
\text { energy } \\
(\mathrm{MWh})\end{array}$ & $\begin{array}{r}\text { Average } \\
\text { head } \\
(\mathrm{ft} / \mathrm{reach})\end{array}$ & $\begin{array}{r}\text { Average } \\
\text { flow } \\
\text { (cfs/reach) }\end{array}$ & $\begin{array}{r}\text { Average } \\
\text { storage (ac- } \\
\text { ft/reach) }\end{array}$ & $\begin{array}{r}\text { Average } \\
\text { residence } \\
\text { time (days) }\end{array}$ \\
\hline 1001 & Saskatchewan & 16 & 20.4 & 95,702 & 14.2 & 1,251 & 343 & 0.1 \\
\hline 1002 & Missouri Headwaters & 78 & 112.2 & 782,309 & 16.7 & 1,202 & 532 & 0.2 \\
\hline 1003 & Missouri-Marias & 87 & 208.7 & $1,339,531$ & 11.5 & 2,948 & 1,978 & 0.2 \\
\hline 1004 & Missouri-Musselshell & 9 & 102.9 & 687,868 & 32.2 & 4,947 & 27,123 & 0.9 \\
\hline 1005 & Milk & 12 & 13.4 & 74,873 & 18.1 & 859 & 10,492 & 2.0 \\
\hline 1006 & Missouri-Poplar & 9 & 70.6 & 466,223 & 16.8 & 6,484 & 27,354 & 0.7 \\
\hline 1007 & Upper Yellowstone & 233 & 733.2 & $4,275,948$ & 17.6 & 2,624 & 2,722 & 0.4 \\
\hline 1008 & Big Horn & 157 & 368.9 & $2,121,414$ & 19.8 & 2,333 & 3,392 & 0.7 \\
\hline 1009 & Powder-Tongue & 30 & 31.9 & 184,015 & 27.6 & 536 & 13,462 & 4.7 \\
\hline 1010 & Lower Yellowstone & 37 & 688.0 & $4,216,257$ & 20.7 & 12,492 & 18,372 & 0.5 \\
\hline 1011 & $\begin{array}{l}\text { Missouri-Little } \\
\text { Missouri }\end{array}$ & 2 & 34.9 & 220,585 & 9.4 & 25,855 & 13,716 & 0.2 \\
\hline 1012 & Cheyenne & 10 & 22.2 & 131,736 & 28.2 & 1,094 & 14,810 & 15.3 \\
\hline 1013 & Missouri-Oahe & 4 & 168.5 & $1,046,233$ & 11.5 & 51,032 & 22,679 & 0.3 \\
\hline 1014 & Missouri-White & - & - & - & - & - & - & - \\
\hline 1015 & Niobrara & - & - & - & - & - & - & - \\
\hline 1016 & James & - & - & - & - & - & - & - \\
\hline 1017 & Missouri-Big Sioux & 7 & 218.2 & $1,349,706$ & 13.4 & 32,312 & 28,854 & 0.3 \\
\hline 1018 & North Platte & 384 & $2,259.0$ & $13,097,866$ & 12.9 & 7,030 & 1,744 & 0.3 \\
\hline 1019 & South Platte & 163 & 672.8 & $4,095,478$ & 8.2 & 7,196 & 954 & 0.2 \\
\hline 1020 & Platte & 162 & 361.3 & $2,298,111$ & 7.8 & 3,975 & 840 & 0.0 \\
\hline 1021 & Loup & - & - & - & - & - & - & - \\
\hline 1022 & Elkhorn & - & - & - & - & - & - & - \\
\hline 1023 & Missouri-Little Sioux & 8 & 180.4 & $1,101,906$ & 9.5 & 33,104 & 7,972 & 0.1 \\
\hline 1024 & Missouri-Nishnabotna & 9 & 676.3 & $4,165,794$ & 22.5 & 46,302 & 260,204 & 2.2 \\
\hline 1025 & Republican & - & - & - & - & - & - & - \\
\hline 1026 & Smoky Hill & - & - & - & - & - & - & - \\
\hline 1027 & Kansas & 15 & 106.0 & 540,519 & 21.0 & 4,924 & 29,571 & 11.4 \\
\hline 1028 & Chariton-Grand & 4 & 18.2 & 78,231 & 22.9 & 2,931 & 18,466 & 10.5 \\
\hline 1029 & Gasconade-Osage & 11 & 56.8 & 282,130 & 22.3 & 4,105 & 19,545 & 9.8 \\
\hline 1030 & Lower Missouri & 15 & $1,533.8$ & $9,173,726$ & 18.7 & 76,245 & 197,175 & 1.4 \\
\hline
\end{tabular}




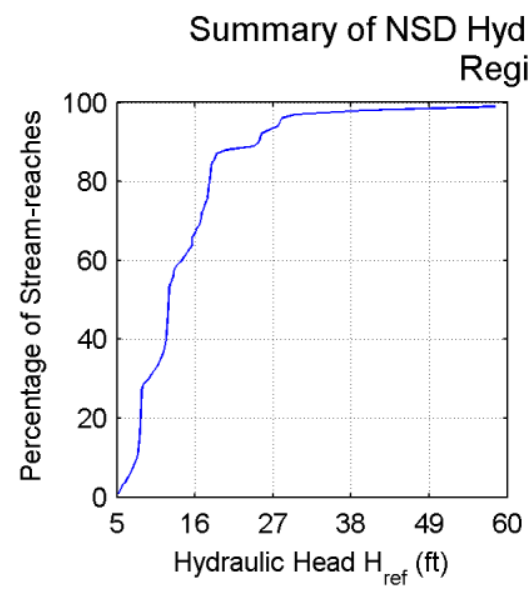

Hydropower Potential (stream-reaches with capacity > $1 \mathrm{MW}$ )

Region 10: 1462 stream-reaches, $8658 \mathrm{MW}$
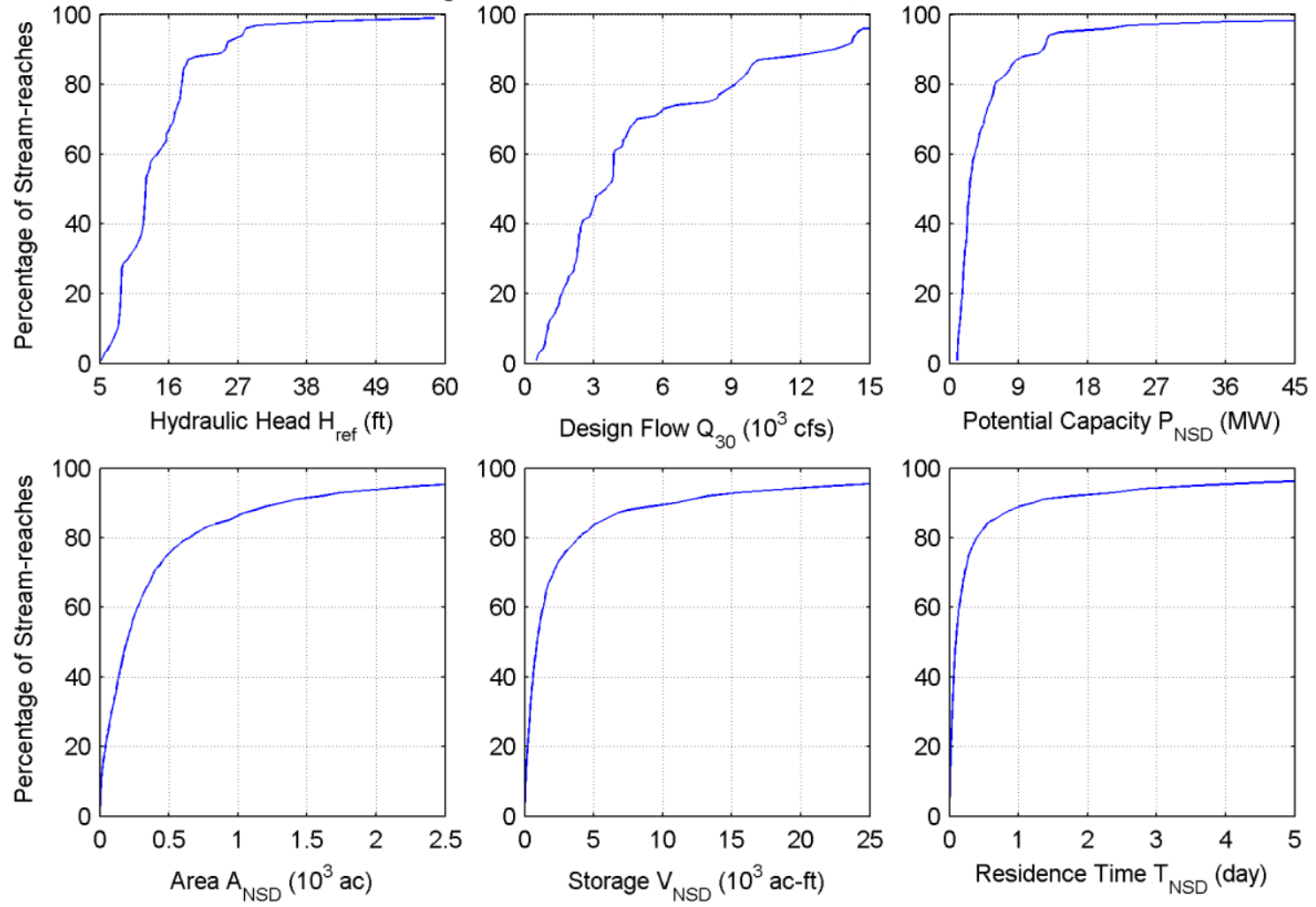

Figure 13.3. Cumulative distributions of hydraulic head $\mathrm{H}_{\mathrm{ref}}$, design flow $\mathrm{Q}_{30}$, potential capacity $\mathrm{P}_{\mathrm{NSD}}$, inundated area $\mathrm{A}_{\mathrm{NSD}}$, storage $\mathrm{V}_{\mathrm{NSD}}$, and residence time $\mathrm{T}_{\mathrm{NSD}}$ in Region 10-Missouri.

The summary statistics of hydraulic head $\mathrm{H}_{\text {ref }}(\mathrm{ft})$, design flow $\mathrm{Q}_{30}$ (cfs), potential capacity $\mathrm{P}_{\mathrm{NSD}}$ $(\mathrm{MW})$, inundated area $\mathrm{A}_{\mathrm{NSD}}(\mathrm{ac})$, storage $\mathrm{V}_{\mathrm{NSD}}$ (ac-ft), and residence time $\mathrm{T}_{\mathrm{NSD}}$ (day) are shown in Figure 13.3. The hydraulic head $\mathrm{H}_{\text {ref }}$ ranges from 5 to the 90th quantile of $21 \mathrm{ft}$ with a median of $12 \mathrm{ft}$, suggesting that many of the potential stream-reaches will require low-head hydropower technologies. The design flow $\mathrm{Q}_{30}$ ranges from 900 to the 90th quantile of 12,000 cfs with a median of 4,000 cfs. The potential capacity $\mathrm{P}_{\mathrm{NSD}}$ ranges from 1.5 to the 90 th quantile of $12 \mathrm{MW}$ with a median of about $3.5 \mathrm{MW}$. The inundated surface area $A_{N S D}$ ranges from 1250 to the 90th quantile of 1500 acres with a median of 250 acres. This results in storage values $\mathrm{V}_{\text {NSD }}$ ranging from 0 to the 90th quantile of 12,500 ac-ft with a median of $1 \mathrm{ac}-\mathrm{ft}$ with residence times $\mathrm{T}_{\mathrm{NSD}}$ ranging from < 1 day to the 90th quantile of a few days with a median on the order of a few hours. The results of $>1 \mathrm{MW}$ stream-reach potential are illustrated in Figure 13.4, with potential capacity (MW) aggregated to the HUC08 subbasins.

\subsection{Environmental Characteristics}

At least 160 native fish species are documented in the Missouri Region. Nine fish species fall under ESA categories, and 14 species fall under IUCN vulnerability status (Figure 13.5 and Appendix B). Well known fishes of concern include arctic grayling, cutthroat trout sub-species (Oncorhynchus clarkia spp.), bull trout (Salvelinus confluentus), paddlefish, pallid sturgeon, shovelnose sturgeon, and Topeka shiner. Fourteen potadromous or anadromous fish species are 
reported, many of which are of concern. There are eight critical watersheds in the region, with the highest number of at risk fish and mussel species in the Niangua (five species) and Sac (five species) subbasins (Mathews et al., 1998). Twelve species have critical habitat designations, including three birds, two insects, two mammals, two plants, and three fish. Fish species with critical habitat designations include bull trout, Niangua darter (Etheostoma nianguae), and Topeka shiner.

Over 78 million acres of protected lands are located in Region 10 (23\% of total area, Figure 13.6). Most of the protected lands are federal (56\%), Native American (25\%), or state (15\%). The USFS (27\%), Bureau of Land Management (BLM) (21\%), NPS (3\%), and DOD (2\%) own most of the federal lands in this region. Most protected lands fall into GAP status 3 (58\%) or 4 (27\%) (Figure 13.6). Yellowstone is the largest national park found in the region. Four rivers are protected under NWSRA in Region 10, including the Clarks Fork Yellowstone, Missouri, Niobrara, and Cache rivers. A total of 1045 boat ramps, 1218 fishing access locations, 131 waterfalls, and 178 recreational boating river sections are located in the region.

Water use is below average in Region 10 compared with the remainder of the United States (Figure 13.7 and Appendix B). Most usage is reported as irrigation or cooling for thermoelectric power plants (Table 13.3 and Appendix B). Similarly, water-quality concerns in Region 10 are below average but also varied, with concerns including (from greatest to least prevalence): mercury contamination, algal nuisance, elevated nutrient loads, reduced dissolved oxygen, elevated pathogen levels, and temperature issues.

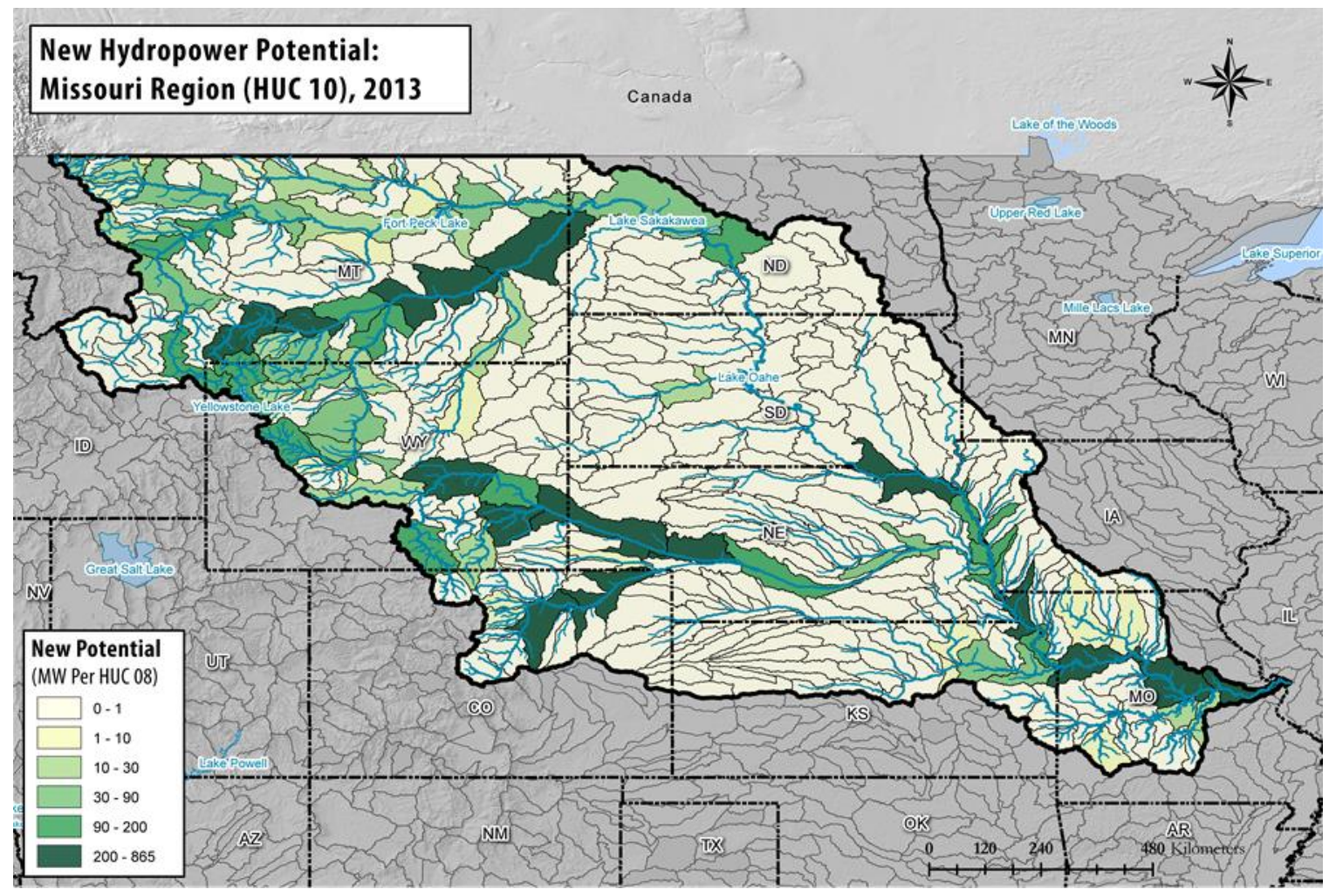

Figure 13.4. Potential new hydropower capacity in Region 10-Missouri (aggregated to HUC08 subbasins for illustration). 


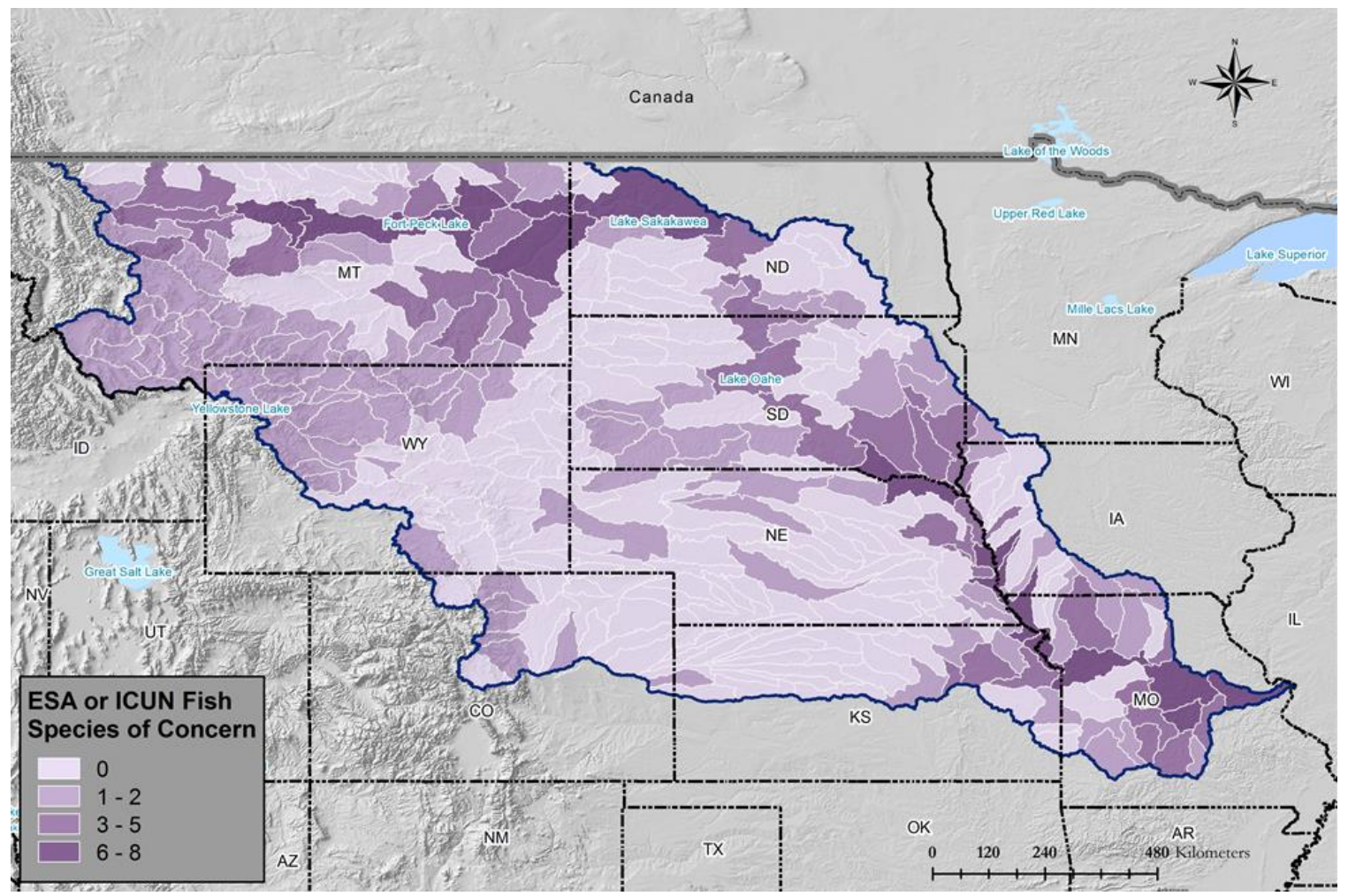

Figure 13.5. Fish species of concern (number per HUC08 subbasin) in Region 10.

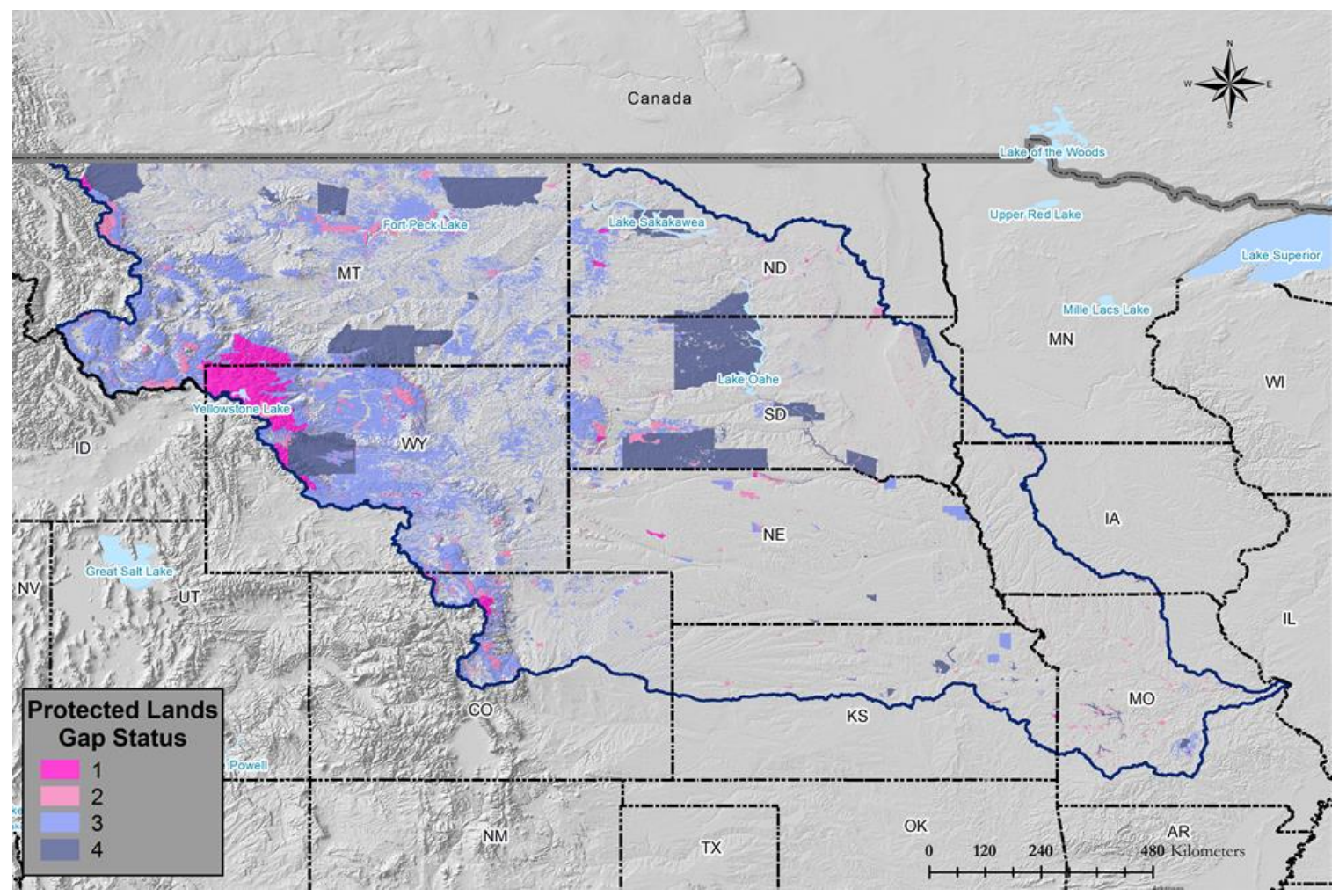

Figure 13.6. Protected lands according to Gap Status (conservation management regime) in Region 10. 


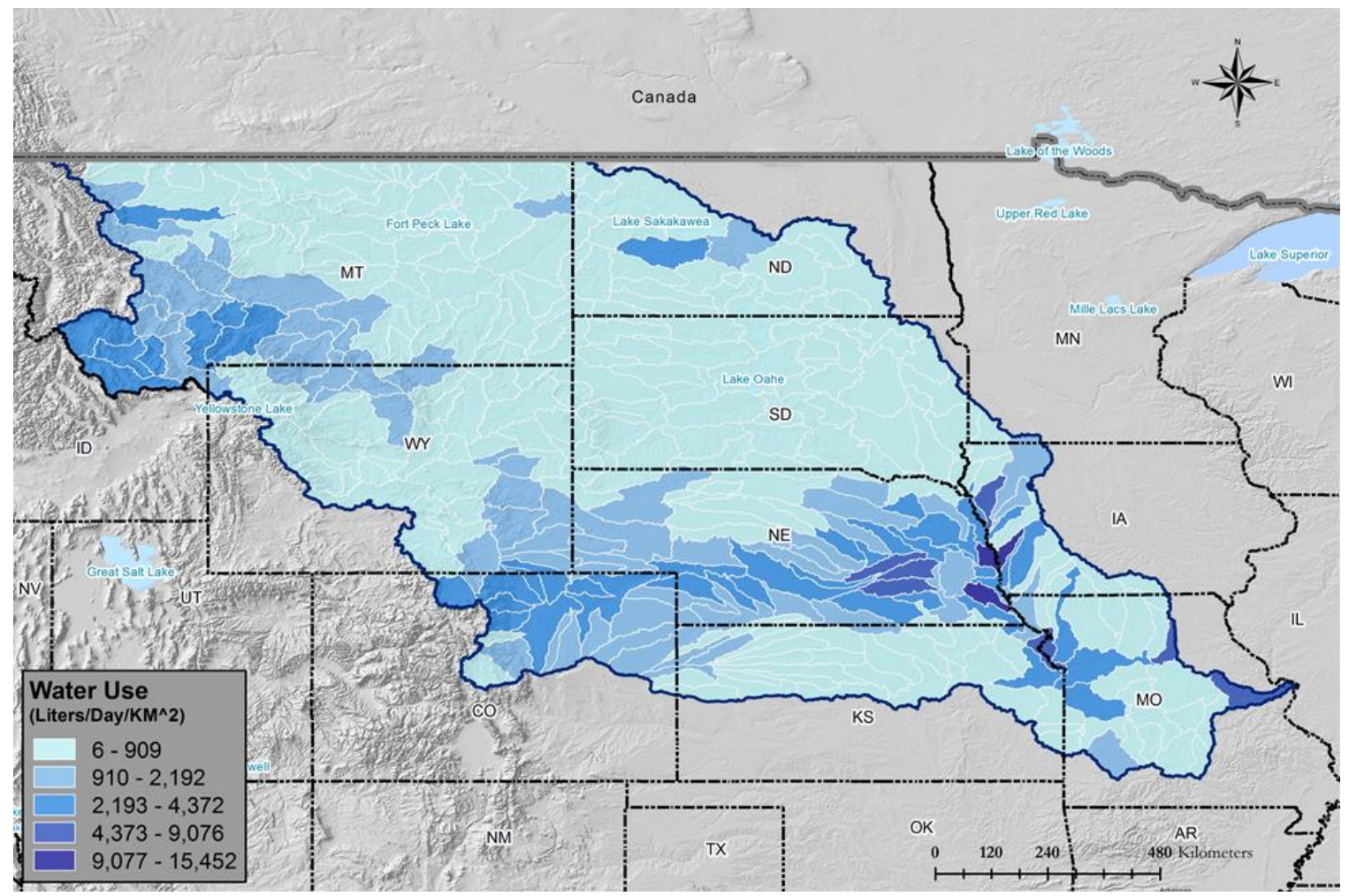

Figure 13.7. Average water use per HUC08 subbasin in Region 10.

ESA Critical Habitats

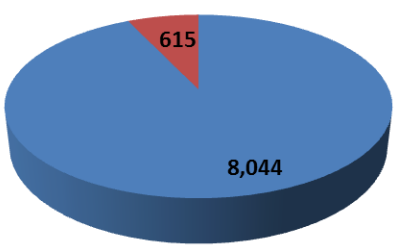

Absent Present

\section{Water Quality Concern}

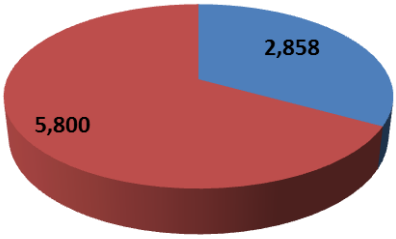

absent $\square$ Present
Number ESA Listed Fish

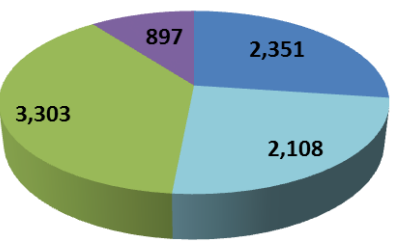

$\square 0 \square 1 \square 2 \square 3$

Recreation Boating

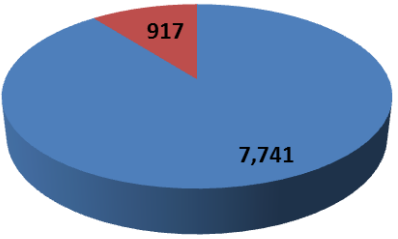

Absent Present
National Park Lands

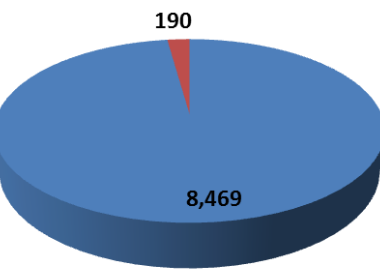

Absent Present

Fishing Access Areas

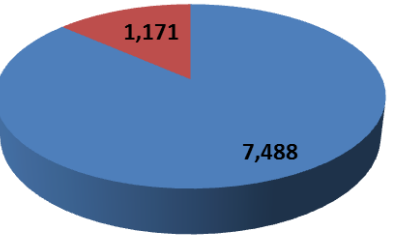

Absent Present
Wild and Scenic Rivers

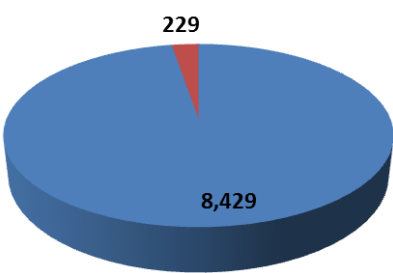

absent $\square$ Present

Water Use
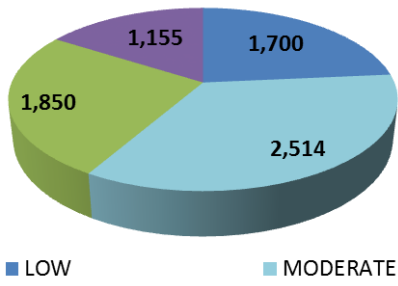

MODERATE-TO-HIGH $\quad$ HIGH

Figure 13.8. The potential capacity, in MW, associated with environmental attributes in Region 10-Missouri (stream-reaches with potential capacity $>1 \mathrm{MW}$ ).

Of the 1462 stream-reaches in Region 10, 7\% intersect critical habitat designations (Figure 13.8). Sixty-four percent of stream-reaches are located in HUC08 subbasins with at least one fish falling under an ESA category. Protected lands are prevalent, overlapping $95 \%$ of stream- 
reaches $(\sim 8.09 \mathrm{GW})$. National parks and Wild and Scenic Rivers intersect $7 \%$ and $2.5 \%$ of stream-reaches, respectively. Water-quality concerns are associated with $54 \%$ of stream-reaches $(\sim 5.8 \mathrm{GW})$. Recreation is less common at stream-reaches than in other regions, with recreational boating, boat ramps, and fishing access areas identified at $22 \%, 11 \%$, and $11 \%$ of streamreaches, respectively. Most of the stream-reaches are located in HUC08 subbasins with low and moderate water usage.

Table 13.3. Summary of Environmental Variables at HUC04 Subregions within Region 10 (Stream-Reaches with Potential Capacity $>1 \mathrm{MW}$ )

\begin{tabular}{|c|c|c|c|c|c|c|c|c|}
\hline HUC04 HUC04 name & $\begin{array}{r}\text { \# Critical } \\
\text { habitats }\end{array}$ & $\begin{array}{l}\text { \# Potad- } \\
\text { anad fish }\end{array}$ & $\begin{array}{r}\# \\
\text { ESA } \\
\text { fish } \\
\end{array}$ & $\begin{array}{r}\text { \# IUCN } \\
\text { fish }\end{array}$ & $\begin{array}{r}\# \\
\begin{array}{r}\text { Recreation } \\
\text { locations }\end{array} \\
\end{array}$ & $\begin{array}{r}\% \\
\begin{array}{r}\text { Protected } \\
\text { lands }\end{array} \\
\end{array}$ & $\begin{array}{r}\text { Population } \\
\text { density } \\
\left(\text { ind } / \mathbf{k m}^{2}\right)\end{array}$ & $\begin{array}{l}\text { Freshwater use } \\
(\text { liters/day/km²) }\end{array}$ \\
\hline 1001 Saskatchewan & 0 & 4 & 1 & 1 & $26 ; 0 ; 27$ & 76.65 & 1.87 & 409.46 \\
\hline 1002 Missouri Headwaters & 1 & 3 & 2 & 0 & $44 ; 12 ; 26$ & 67.39 & 2.68 & $2,443.70$ \\
\hline 1003 Missouri-Marias & 1 & 6 & 4 & 5 & $55 ; 14 ; 20$ & 27.00 & 3.54 & $1,314.89$ \\
\hline 1004 Missouri-Musselshell & 1 & 7 & 3 & 6 & $23 ; 1 ; 1$ & 34.02 & 0.53 & 396.51 \\
\hline 1005 Milk & 2 & 5 & 1 & 4 & $10 ; 0 ; 0$ & 28.13 & 1.01 & 488.58 \\
\hline 1006 Missouri-Poplar & 1 & 5 & 2 & 6 & $9 ; 0 ; 0$ & 10.02 & 1.06 & 539.74 \\
\hline 1007 Upper Yellowstone & 1 & 4 & 1 & 0 & $35 ; 33 ; 22$ & 47.95 & 5.43 & $1,733.54$ \\
\hline 1008 Big Horn & 1 & 4 & 1 & 1 & $90 ; 12 ; 11$ & 56.06 & 1.56 & 849.07 \\
\hline 1009 Powder-Tongue & 0 & 6 & 3 & 5 & $28 ; 7 ; 0$ & 34.13 & 1.05 & 425.20 \\
\hline 1010 Lower Yellowstone & 0 & 5 & 2 & 6 & $4 ; 0 ; 0$ & 19.62 & 0.89 & 595.89 \\
\hline \begin{tabular}{|l}
$011 \begin{array}{l}\text { Missouri-Little } \\
\text { Missouri }\end{array}$ \\
\end{tabular} & 1 & 5 & 2 & 6 & $40 ; 0 ; 0$ & 22.50 & 1.20 & 102.93 \\
\hline 1012 Cheyenne & 1 & 2 & 0 & 1 & $76 ; 9 ; 6$ & 23.48 & 2.42 & 342.11 \\
\hline 1013 Missouri-Oahe & 1 & 4 & 2 & 5 & $148 ; 0 ; 0$ & 7.57 & 1.93 & 373.91 \\
\hline 1014 Missouri-White & 0 & 6 & 1 & 4 & $88 ; 0 ; 0$ & 7.53 & 1.75 & 88.44 \\
\hline 1015 Niobrara & 0 & 4 & 2 & 2 & $64 ; 3 ; 5$ & 4.05 & 1.35 & 582.22 \\
\hline 1016 James & 1 & 4 & 3 & 4 & $119 ; 0 ; 0$ & 3.28 & 2.38 & 59.69 \\
\hline 1017 Missouri-Big Sioux & 2 & 6 & 3 & 6 & $185 ; 1 ; 2$ & 2.63 & 7.80 & 251.34 \\
\hline 1018 North Platte & 3 & 4 & 2 & 1 & $133 ; 26 ; 7$ & 34.67 & 2.76 & $1,312.58$ \\
\hline 1019 South Platte & 3 & 3 & 2 & 1 & $111 ; 53 ; 27$ & 21.53 & 44.64 & $1,899.59$ \\
\hline 1020 Platte & 3 & 3 & 2 & 5 & $86 ; 0 ; 0$ & 0.80 & 30.20 & $3,695.51$ \\
\hline 1021 Loup & 0 & 1 & 1 & 0 & $35 ; 1 ; 2$ & 1.58 & 2.19 & $1,440.86$ \\
\hline 1022 Elkhorn & 1 & 2 & 2 & 2 & $18 ; 0 ; 0$ & 0.22 & 12.35 & $2,467.79$ \\
\hline 1023 Missouri-Little Sioux & 1 & 7 & 3 & 6 & $91 ; 0 ; 0$ & 1.66 & 34.81 & $3,981.06$ \\
\hline $1024 \begin{array}{l}\text { Missouri- } \\
\text { Nishnabotna }\end{array}$ & 1 & 6 & 2 & 6 & $105 ; 0 ; 1$ & 1.01 & 16.46 & $2,898.51$ \\
\hline 1025 Republican & 0 & 2 & 0 & 0 & $65 ; 0 ; 0$ & 2.37 & 2.36 & $1,444.07$ \\
\hline 1026 Smoky Hill & 0 & 1 & 1 & 1 & $61 ; 0 ; 1$ & 1.18 & 3.62 & 354.61 \\
\hline 1027 Kansas & 0 & 5 & 2 & 4 & $88 ; 2 ; 0$ & 2.13 & 22.11 & $2,181.77$ \\
\hline 1028 Chariton-Grand & 0 & 6 & 2 & 5 & $97 ; 0 ; 0$ & 2.20 & 7.84 & $1,144.68$ \\
\hline 1029 Gasconade-Osage & 2 & 8 & 3 & 11 & $256 ; 0 ; 0$ & 5.91 & 13.23 & 495.52 \\
\hline 1030 Lower Missouri & 0 & 9 & 3 & 7 & $99 ; 4 ; 0$ & 2.38 & 70.25 & $2,702.27$ \\
\hline
\end{tabular}

${ }^{a}$ Recreation locations refer to the number of boat-ramp and fishing access points, recreational boating, and waterfalls within each HUC04. 


\section{REGION 11-ARKANSAS-WHITE-RED}

\subsection{Summary of Findings}

Following NSD methodology (Hadjerioua et al., 2013), the potential capacity, annual generation and mean capacity factors in the Arkansas-White-Red Region are estimated and summarized in Table 14.1 for both larger ( $>1 \mathrm{MW})$ and smaller ( $<1 \mathrm{MW})$ stream-reaches. For comparison, the year-2011 nameplate capacity, 2002-2011 average annual generation, and capacity factor of existing hydropower facilities are also listed (NHAAP, 2013). The total undeveloped NSD capacity is $6.01 \mathrm{GW}$, around $279 \%$ of existing conventional hydropower nameplate capacity. In terms of energy, the total undeveloped NSD generation is $33.99 \mathrm{TWh} / \mathrm{year}$, around $579 \%$ of annual net generation from existing conventional hydropower plants. Given the run-of-river assumption, NSD stream-reaches have higher capacity factors, especially compared with other larger-storage peaking-operation projects in this region. More detailed topographical analysis and environmental attribution are conducted for larger (>1 MW) stream-reaches and discussed in Sections 14.3 and 14.4.

Table 14.1. Summary of NSD Findings in Region 11 -Arkansas-White-Red

\begin{tabular}{l|r|r|r}
\hline & $\begin{array}{r}\text { Capacity } \\
(\mathbf{M W})\end{array}$ & $\begin{array}{r}\text { Generation } \\
(\mathbf{M W h})\end{array}$ & $\begin{array}{r}\text { Mean capacity } \\
\text { factor }\end{array}$ \\
\hline Potential in undeveloped stream-reaches $(>1 \mathrm{MW})$ & 4,442 & $25,865,000$ & $66 \%$ \\
\hline Potential in undeveloped stream-reaches $(<1 \mathrm{MW})$ & 1,571 & $8,129,000$ & $59 \%$ \\
\hline Existing hydropower-conventional hydro & 2,157 & $5,872,000$ & $31 \%$ \\
\hline Existing hydropower-pumped storage & 896 & & \\
\hline
\end{tabular}

\subsection{Background Hydrologic Setting}

The Arkansas-White-Red Region encompasses approximately $642,284 \mathrm{~km}^{2}$ of drainage area in the central states of the United States, containing parts of Colorado, Kansas, New Mexico, Texas, Louisiana, Arkansas, and Missouri, and all of Oklahoma.

Several river systems are located in the Arkansas-White-Red Region (Figure 14.1), including the Arkansas, White, Red, Walnut, Cimarron, Neosho, Verdigris, Canadian, Beaver, Washita, Little, Big Cypress, and Sulphur rivers, with a total length of 40,139 km (i.e., total length of streams with estimated discharge greater than $35 \mathrm{cfs})$. Metropolitan areas within the region include Wichita (KS), Tulsa (OK), Oklahoma City (OK), and Little Rock (AR). As shown in Figure 14.2, annual precipitation for the Arkansas-White-Red region ranges from 800 to 1600 $\mathrm{mm} /$ year, and annual runoff ranges from 630 to $900 \mathrm{~mm} /$ year. Most of the precipitation occurs from early spring through summer. The runoff generally coincides with this pattern for the region. 
The existing hydropower plants and major non-powered dams (Hadjerioua et al., 2012) are shown in Figure 14.1. The region contains 41 hydropower dams and 55 major non-powered dams, with total storage capacities of around 72,548,529 ac-ft and 25,687,289 ac-ft, respectively.

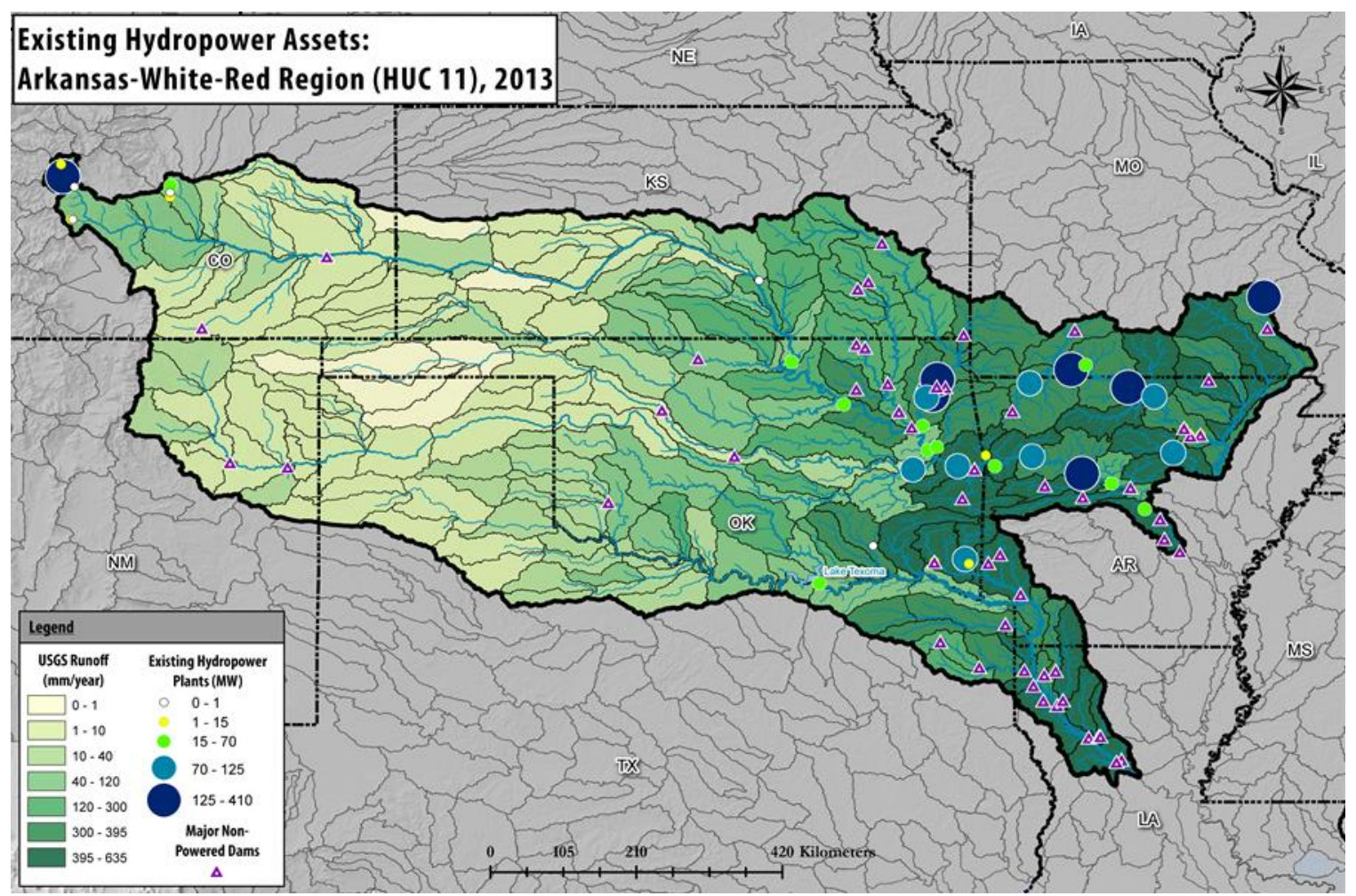

Figure 14.1. Locations of water control projects in Region 11-Arkansas-White-Red.

\subsection{Potential New Hydropower Resources}

A total of 781 stream-reaches of high energy density (with estimated potential capacity $>1 \mathrm{MW}$ per stream-reach) are identified in the Arkansas-White-Red Region. The NSD results based on the HUC04 subregions are summarized in Table 14.2. The highest hydropower potentials are found in the Middle Arkansas Subregion (HUC 1103), followed by the Upper Arkansas Subregion (HUC1102) located in the Arkansas River.

The summary statistics of hydraulic head $\mathrm{H}_{\text {ref }}(\mathrm{ft})$, design flow $\mathrm{Q}_{30}(\mathrm{cfs})$, potential capacity $\mathrm{P}_{\mathrm{NSD}}$ $(\mathrm{MW})$, inundated area $\mathrm{A}_{\mathrm{NSD}}(\mathrm{ac})$, storage $\mathrm{V}_{\mathrm{NSD}}$ (ac-ft), and residence time $\mathrm{T}_{\mathrm{NSD}}$ (day) are shown in Figure 14.3. The hydraulic head $\mathrm{H}_{\text {ref }}$ ranges from 5 to the 90th quantile of $29 \mathrm{ft}$ with a median of $20 \mathrm{ft}$, suggesting that many of the potential stream-reaches will require low-head hydropower technologies. The design flow $\mathrm{Q}_{30}$ ranges from 700 to the 90 th quantile of 13,500 cfs with a median of $2,700 \mathrm{cfs}$. The potential capacity $\mathrm{P}_{\mathrm{NSD}}$ ranges from 1.5 to the 90 th quantile of $11 \mathrm{MW}$ with a median of about $4 \mathrm{MW}$. The inundated surface area $\mathrm{A}_{\mathrm{NSD}}$ ranges from 0 to the 90th quantile of 3,000 acres with a median of 500 acres. This results in storage values $\mathrm{V}_{\mathrm{NSD}}$ ranging from 0 to the 90th quantile of 32,000 ac-ft with a median of 1,500 ac- $\mathrm{ft}$ with residence times $\mathrm{T}_{\mathrm{NSD}}$ ranging from $<1$ day to the 90 th quantile of about 11 days with a median on the order of a 
day. The results of $>1 \mathrm{MW}$ stream-reach potential are illustrated in Figure 14.4, with potential capacity (MW) aggregated to the HUC08 subbasins.

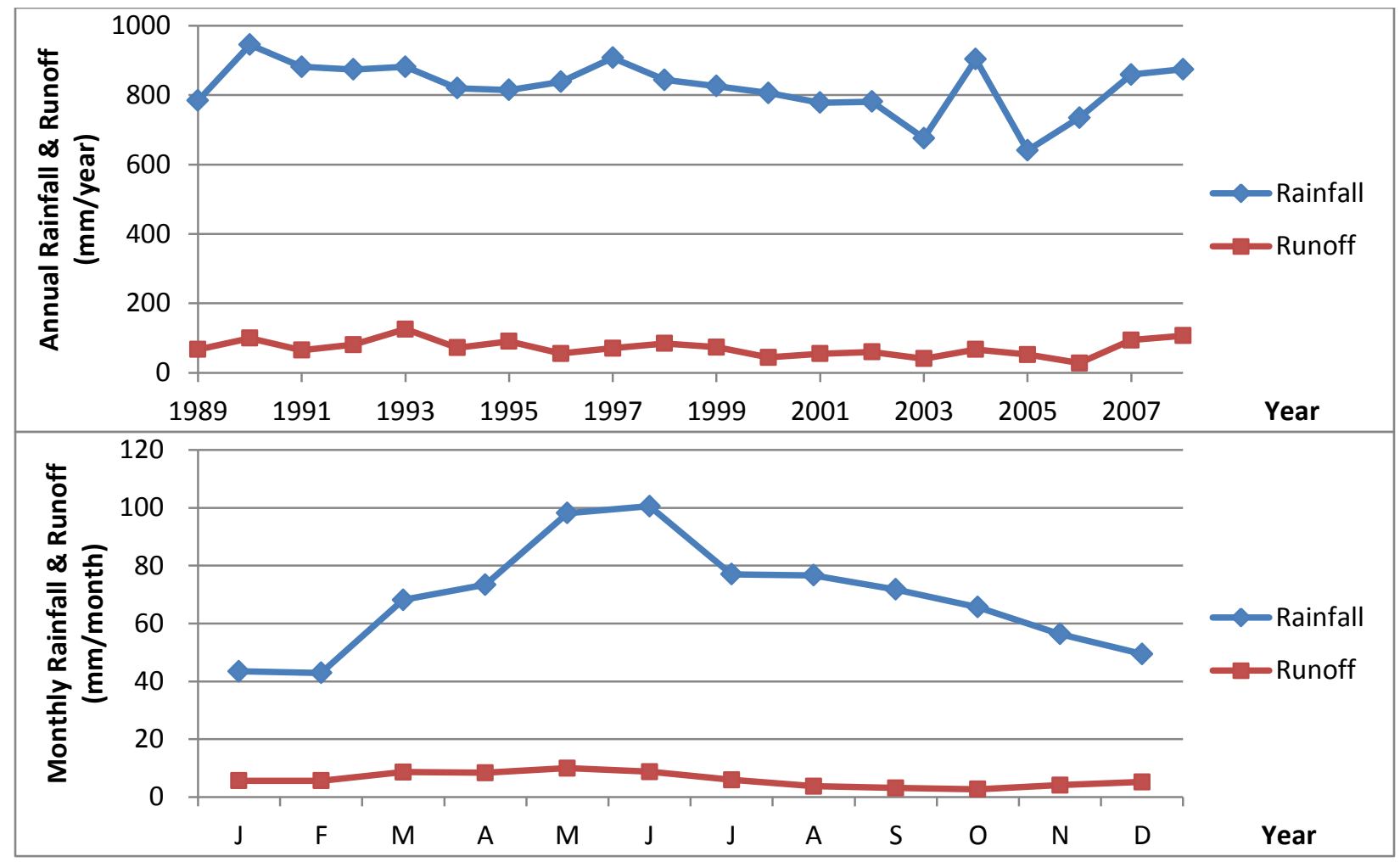

Figure 14.2. Annual and monthly rainfall and runoff of Region 11-Arkansas-White-Red.

Table 14.2. Summary of Potential New Hydropower Resources in Region 11 Arkansas-White-Red (StreamReaches with Potential Capacity $>1 \mathrm{MW}$ )

\begin{tabular}{|c|c|c|c|c|c|c|c|c|}
\hline HUC04 & HUC04 name & $\begin{array}{r}\text { \# of } \\
\text { stream- } \\
\text { reaches }\end{array}$ & $\begin{array}{r}\text { Potential } \\
\text { capacity } \\
(\mathrm{MW})\end{array}$ & $\begin{array}{r}\text { Potential } \\
\text { energy } \\
(\mathrm{MWh})\end{array}$ & $\begin{array}{r}\text { Average } \\
\text { head } \\
\text { (ft/reach) }\end{array}$ & $\begin{array}{r}\text { Average } \\
\text { flow } \\
\text { (cfs/reach) }\end{array}$ & $\begin{array}{r}\text { Average } \\
\text { storage (ac- } \\
\text { ft/reach) }\end{array}$ & $\begin{array}{r}\text { Average } \\
\text { residence } \\
\text { time (days) }\end{array}$ \\
\hline 1101 & Upper White & 66 & 390.8 & $2,147,334$ & 37.0 & 2,695 & 34,751 & 23.3 \\
\hline 1102 & Upper Arkansas & 181 & 678.4 & $4,306,507$ & 18.4 & 2,822 & 3,164 & 0.5 \\
\hline 1103 & Middle Arkansas & 220 & $1,897.8$ & $11,830,373$ & 9.2 & 13,079 & 864 & 0.1 \\
\hline 1104 & Upper Cimarron & - & - & - & - & - & - & - \\
\hline 1105 & Lower Cimarron & 17 & 26.7 & 138,590 & 21.0 & 1,057 & 17,747 & 9.3 \\
\hline 1106 & Arkansas-Keystone & 14 & 192.6 & $1,019,757$ & 21.1 & 9,000 & 25,907 & 2.6 \\
\hline 1107 & Neosho-Verdigris & 34 & 86.8 & 374,648 & 19.1 & 2,130 & 12,163 & 4.3 \\
\hline 1108 & Upper Canadian & 13 & 23.7 & 128,702 & 23.6 & 1,075 & 4,314 & 3.4 \\
\hline 1109 & Lower Canadian & 104 & 414.7 & $2,236,791$ & 24.5 & 2,274 & 20,621 & 7.4 \\
\hline 1110 & North Canadian & 4 & 4.8 & 24,904 & 15.8 & 1,053 & 3,490 & 1.4 \\
\hline 1111 & Lower Arkansas & 30 & 222.4 & $1,130,952$ & 25.0 & 6,415 & 24,872 & 15.4 \\
\hline 1112 & Red headwaters & - & - & - & - & - & - & - \\
\hline 1113 & Red-Washita & 42 & 79.4 & 406,362 & 21.9 & 1,279 & 22,976 & 10.2 \\
\hline 1114 & Red-Sulphur & 56 & 423.9 & $2,119,858$ & 23.7 & 7,059 & 38,420 & 22.9 \\
\hline
\end{tabular}




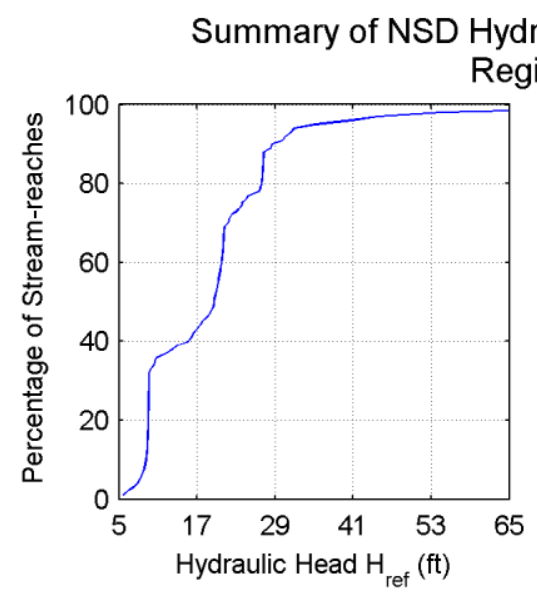

Hydropower Potential (stream-reaches with capacity > $1 \mathrm{MW}$ )

Region 11: 781 stream-reaches, $4441 \mathrm{MW}$
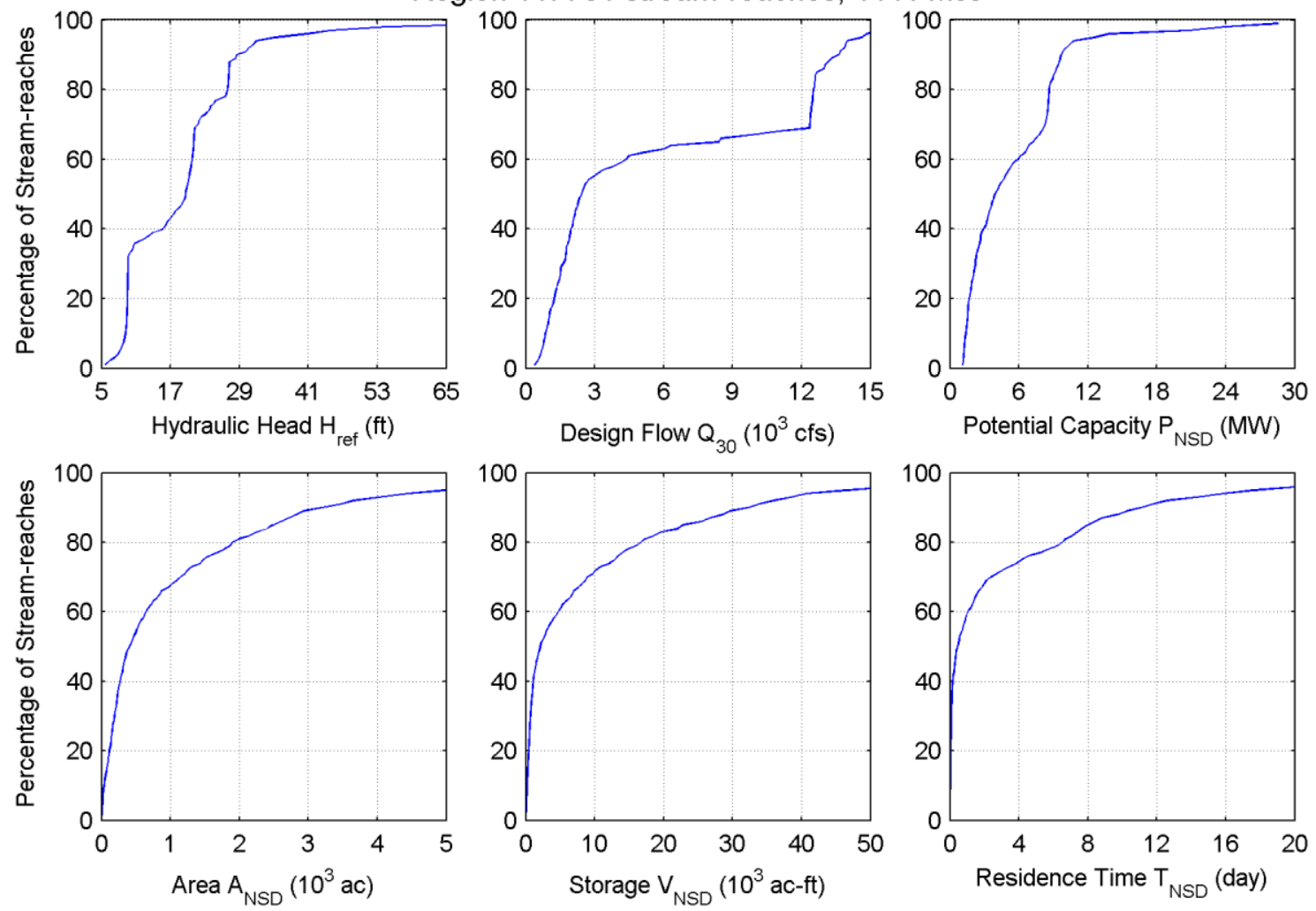

Figure 14.3. Cumulative distributions of hydraulic head $\mathrm{H}_{\text {ref }}$, design flow $\mathrm{Q}_{30}$, potential capacity $\mathrm{P}_{\mathrm{NSD}}$, inundated area $\mathrm{A}_{\mathrm{NSD}}$, storage $\mathrm{V}_{\mathrm{NSD}}$, and residence time $\mathrm{T}_{\mathrm{NSD}}$ in Region 11-Arkansas-White-Red.

\subsection{Environmental Characteristics}

The Arkansas-White-Red Region is home to 210 native fish species and has a high number of vulnerable fish species. Nine fish fall under ESA categories, including Leopard darter (Percina pantherina), Neosho madtom (Noturus placidus), Ozark cavefish (Amblyopsis rosae), shovelnose sturgeon, Topeka shiner, and populations of cutthroat trout (Figure 14.5). An additional nine fish species fall under IUCN vulnerability categories (Figure 14.5 and Appendix B). Eight potadromous/anadromous fish species are found in Region 11. Sixteen subbasins, most of which are located in the eastern half of the region, are considered critical watersheds with anywhere from 1 to 19 fish and mussel species at risk (Mathews et al., 1998). An additional four subbasins not classified as critical watersheds have multiple species at risk. Six fish species have critical habitat designations in Region 11, including Leopard darter and Arkansas River shiner (Notropis girardi). 


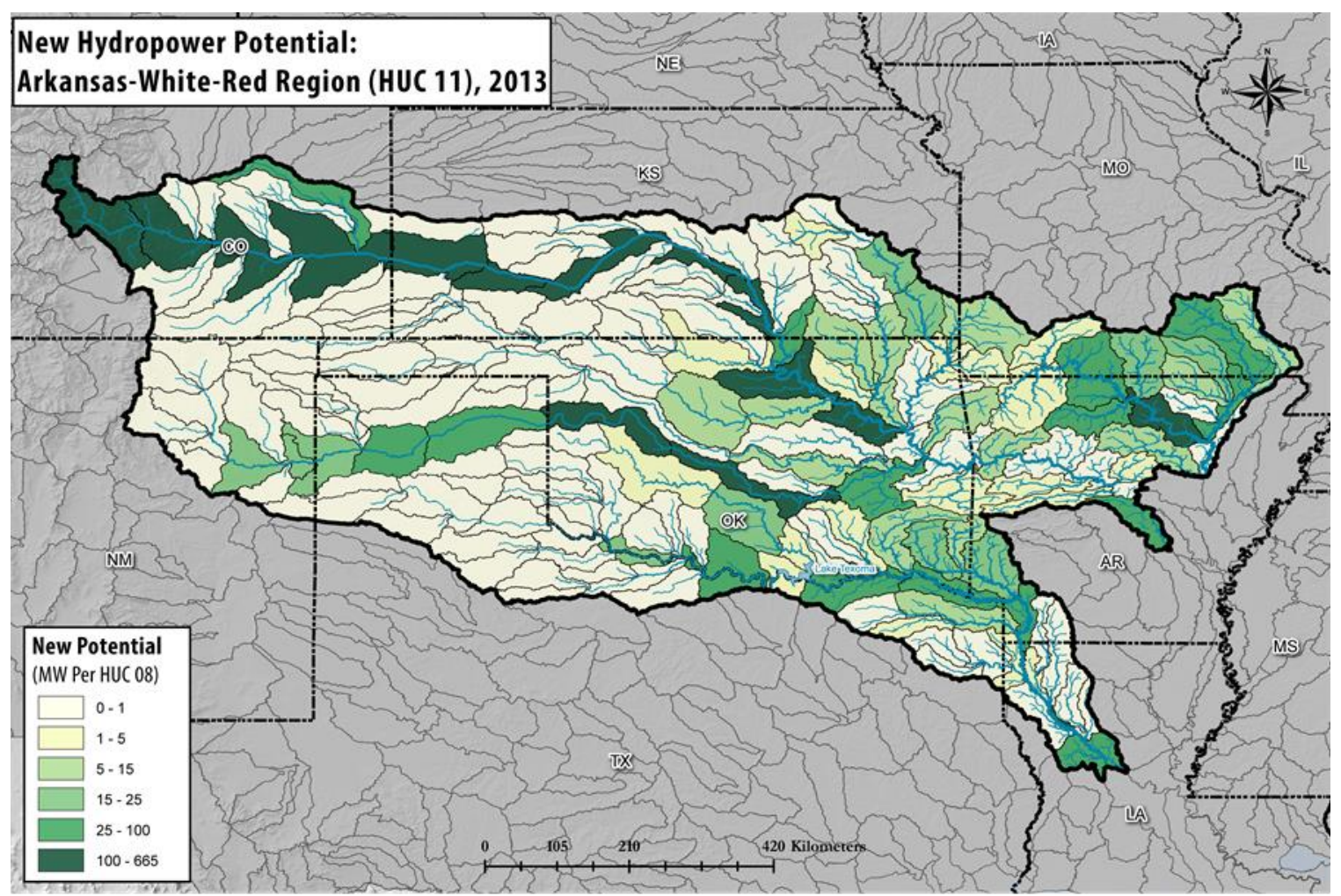

Figure 14.4. Potential new hydropower capacity in Region 11-Arkansas-White-Red (higher-energy-density stream-reaches with >1 MW per reach, aggregated to HUC08 subbasins for illustration).

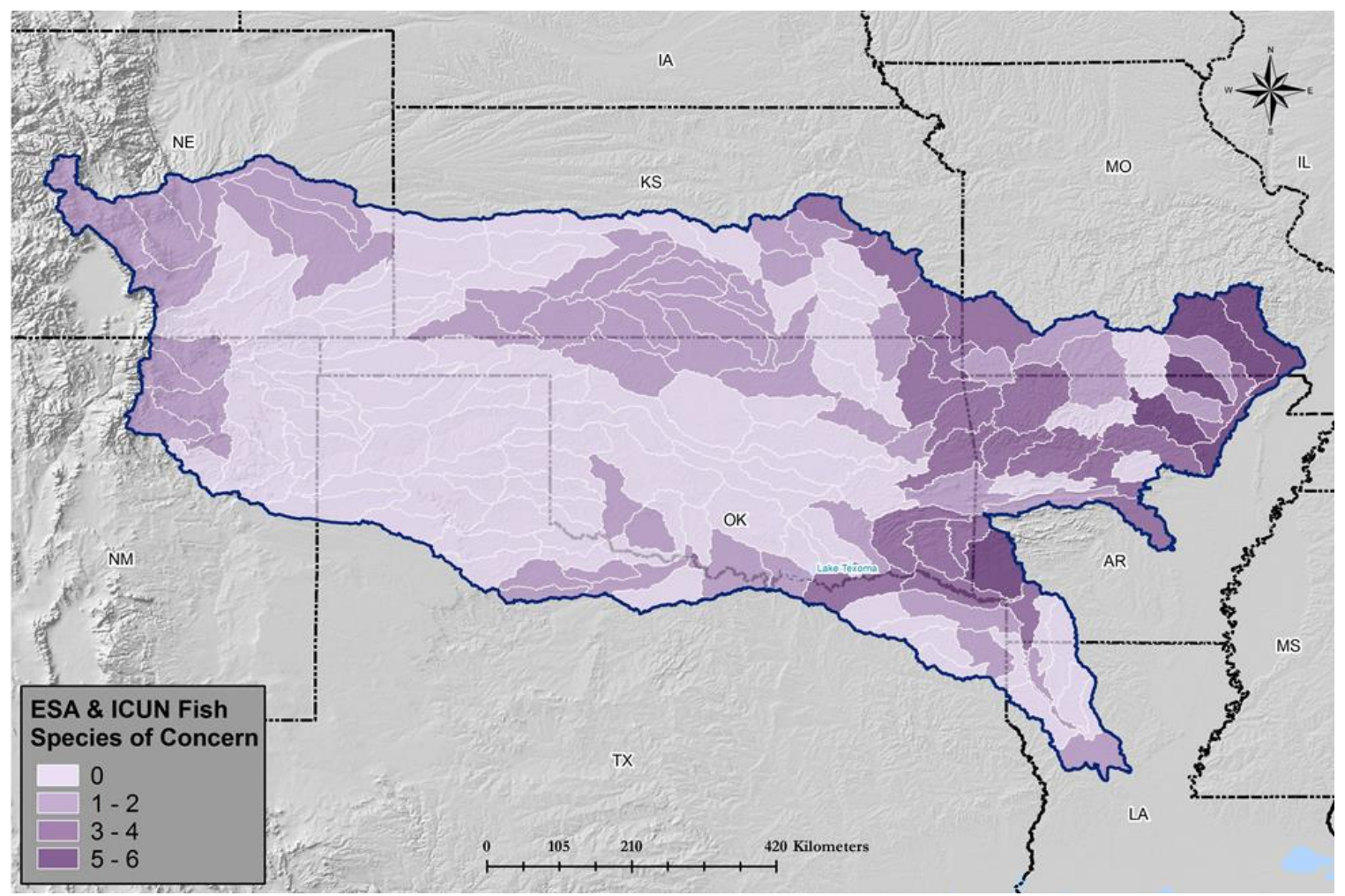

Figure 14.5. Fish species of concern (number per HUC08 subbasin) in Region 11. 
Over $9.5 \%$ of the total area (15.1 million acres) in Region 11 is protected lands. Fifty-nine percent of protected lands are federally owned, and $36 \%$ are state-owned. Federal lands are primarily owned by the USFS (37\%), DOD (14\%), BLM (4.2\%), FWS (2\%), and NPS (1\%). San Isabel, Mark Twain, Ouachita, and Ozark national forests, Comanche National Grassland, and Fort Carson Military Reservation are among the largest tracts of land in the region. State trust lands make up most of the state-owned lands. GAP status 3, 4, and 2 lands make up 41\%, 31\%, and $25 \%$ of protected lands, respectively. Nine National Wild and Scenic Rivers are located in Region 11. Recreation is prevalent and includes 1390 boat ramps, 486 fishing access locations, 60 waterfalls, and 204 recreational boating river sections.

Water use is well below the national average in Region 11 (Figure 14.6); however, the region receives far less rainfall than other areas (Figure 14.2). Main water consumption is irrigation, followed by thermoelectric cooling (Table 14.3 and Appendix B). Water quality is also below the U.S. average with most of the concerns related to dissolved oxygen, followed by mercury contamination, algal nuisance, and toxin and pathogen contamination (Appendix B).

Fifteen percent of stream-reaches (514 MW) overlap critical habitats (Figure 14.7). Almost 54\% of stream-reaches $(\sim 2.48 \mathrm{GW})$ are located in HUC08 subbasins, with at least one fish falling under an ESA category. Fifty-nine percent of stream-reaches intersect protected lands, with none falling on national parks and 13 falling on WSRs. Water-quality concerns are associated with almost $87 \%$ of stream-reaches $(>4 \mathrm{GW})$. Recreational boating, boat ramps, and fishing access areas overlapped with $32 \%, 25 \%$, and $20 \%$ of stream-reaches, respectively. Most of the streamreaches are located in HUC08 subbasins with low-to- moderate-to-high water use values.

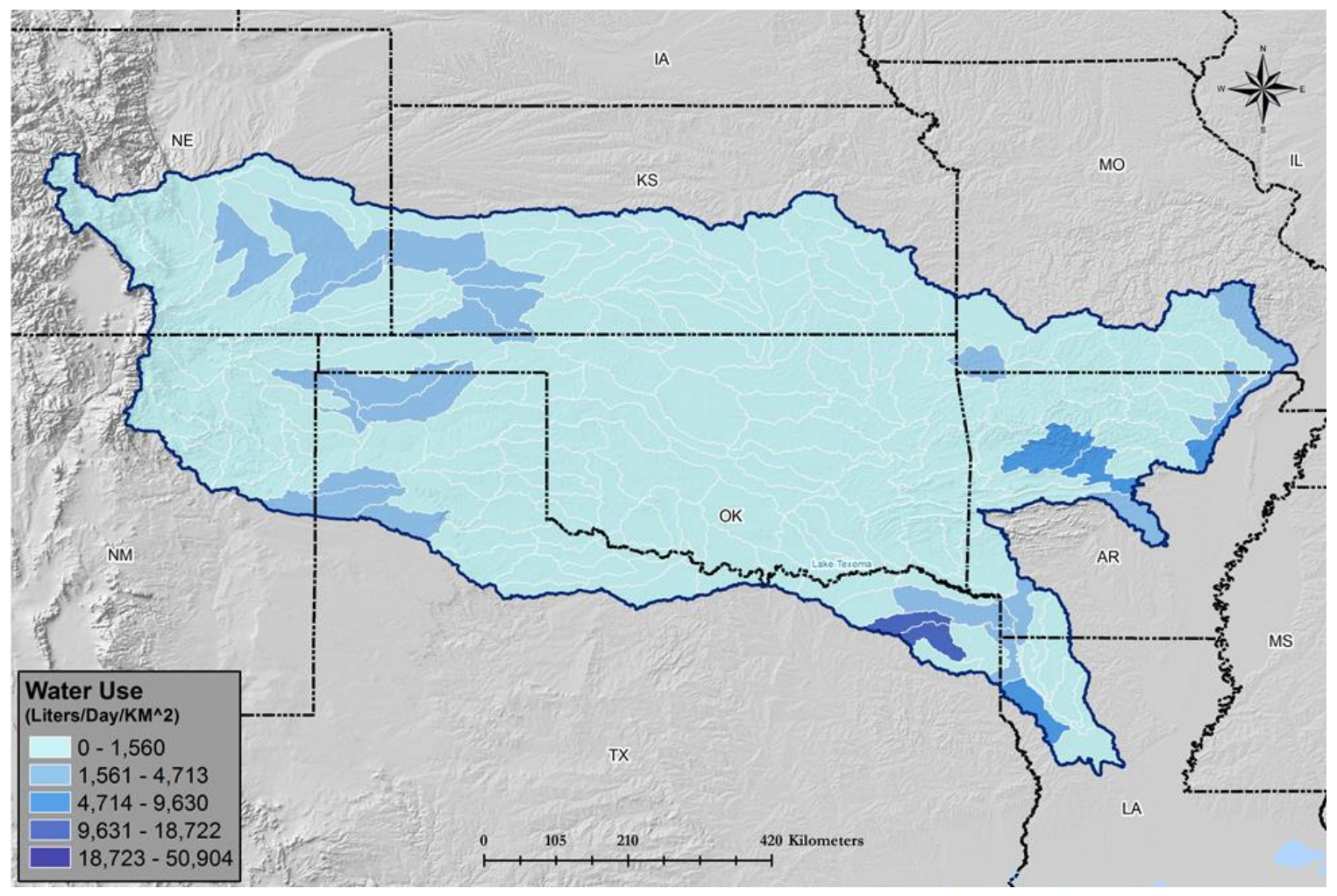

Figure 14.6. Average water use per HUC08 subbasin in Region 11. 
Table 14.3. Summary of Environmental Variables at HUC04 Subregions within Region 11 (Stream-Reaches with Potential Capacity $>1 \mathrm{MW}$ )

\begin{tabular}{|c|c|c|c|c|c|c|c|c|}
\hline HUC04 HUC04 name & $\begin{array}{r}\text { \# Critical } \\
\text { habitats }\end{array}$ & $\begin{array}{l}\text { \# Potad- } \\
\text { anad fish }\end{array}$ & $\begin{array}{r}\# \\
\text { ESA } \\
\text { fish } \\
\end{array}$ & $\begin{array}{r}\# \text { IUCN } \\
\text { fish } \\
\end{array}$ & $\begin{array}{r}\# \\
\text { Recreation } \\
\text { locations }^{\text {a }} \\
\end{array}$ & $\begin{array}{r}\% \\
\begin{array}{r}\% \text { Protected } \\
\text { lands }\end{array} \\
\end{array}$ & $\begin{array}{r}\text { Population } \\
\text { density } \\
\left(\text { ind } / \mathbf{k m}^{2}\right) \\
\end{array}$ & $\begin{array}{r}\text { Freshwater } \\
\text { use (liters/day/ } \\
\mathbf{k m}^{\mathbf{2}} \text { ) } \\
\end{array}$ \\
\hline 1101 Upper White & 1 & 6 & 3 & 9 & $410 ; 66 ; 13$ & 15.03 & 12.99 & $1,390.27$ \\
\hline 1102 Upper Arkansas & 1 & 1 & 2 & 1 & $77 ; 15 ; 13$ & 25.32 & 19.08 & $1,154.73$ \\
\hline 1103 Middle Arkansas & 1 & 3 & 3 & 2 & $49 ; 0 ; 0$ & 0.79 & 20.74 & 944.50 \\
\hline 1104 Upper Cimarron & 1 & 1 & 1 & 1 & $11 ; 0 ; 1$ & 9.77 & 2.20 & $1,261.41$ \\
\hline 1105 Lower Cimarron & 1 & 2 & 1 & 1 & $30 ; 1 ; 0$ & 3.58 & 18.51 & 172.97 \\
\hline 1106 Arkansas-Keystone & 1 & 5 & 2 & 3 & $55 ; 1 ; 0$ & 2.78 & 7.29 & 203.52 \\
\hline 1107 Neosho-Verdigris & 0 & 5 & 5 & 6 & $249 ; 4 ; 2$ & 3.12 & 20.20 & 446.06 \\
\hline 1108 Upper Canadian & 2 & 1 & 1 & 0 & $16 ; 4 ; 0$ & 22.36 & 1.41 & 154.80 \\
\hline 1109 Lower Canadian & 1 & 3 & 0 & 0 & $73 ; 1 ; 0$ & 5.75 & 15.59 & 870.35 \\
\hline 1110 North Canadian & 0 & 2 & 0 & 0 & $90 ; 0 ; 0$ & 4.73 & 15.30 & $1,169.79$ \\
\hline 1111 Lower Arkansas & 0 & 6 & 3 & 7 & $370 ; 81 ; 5$ & 21.94 & 38.54 & $1,541.17$ \\
\hline 1112 Red Headwaters & 0 & 0 & 1 & 1 & $25 ; 0 ; 1$ & 1.73 & 6.38 & $1,049.74$ \\
\hline 1113 Red-Washita & 0 & 5 & 2 & 2 & $175 ; 4 ; 19$ & 3.82 & 11.34 & 328.07 \\
\hline 1114 Red-Sulphur & 1 & 5 & 2 & 7 & $246 ; 27 ; 6$ & 7.49 & 20.46 & $1,738.51$ \\
\hline
\end{tabular}

${ }^{a}$ Recreation locations refer to the number of boat-ramp and fishing access points, recreational boating, and waterfalls within each HUC04.

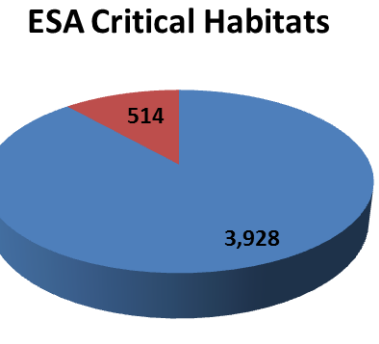

absent $\square$ Present

\section{Water Quality Concern}

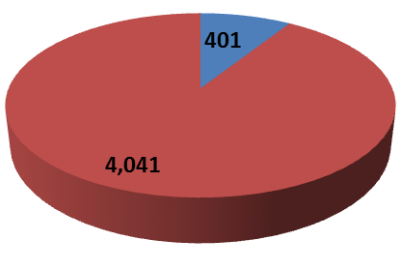

absent $\square$ Present
Number ESA Listed Fish

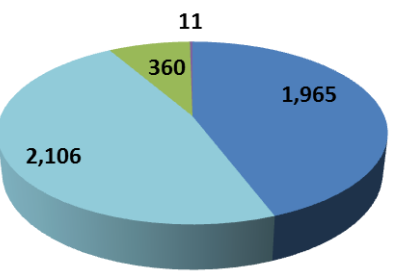

$\square \square 1 \square 2 \square 3$

Recreation Boating

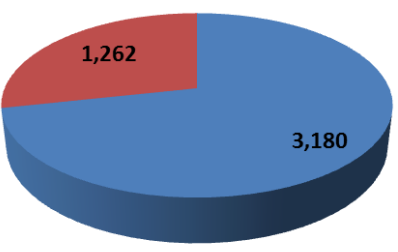

Absent $\square$ Present
National Park Lands

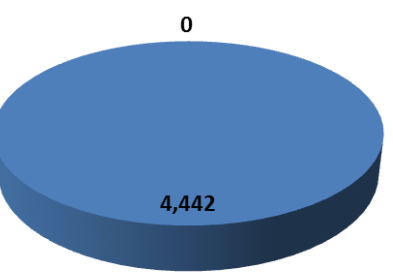

absent Present

Fishing Access Areas

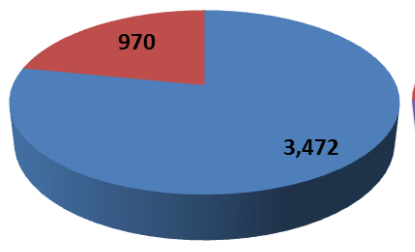

Absent $\square$ Present
Wild and Scenic Rivers

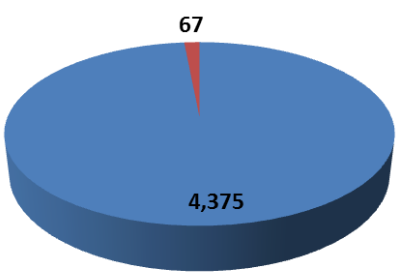

absent $\square$ Present

Water Use

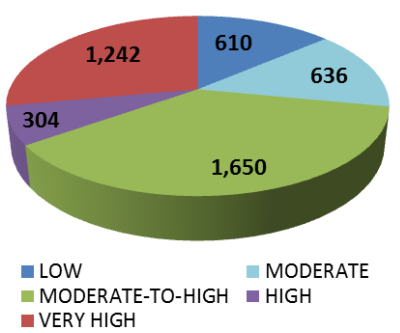

Figure 14.7. The potential capacity, in MW, associated with environmental attributes in Region 11-ArkansasWhite-Red (stream-reaches with potential capacity $>1 \mathrm{MW}$ ). 
(This Page Intentionally Left Blank) 


\section{REGION 12-TEXAS-GULF}

\subsection{Summary of Findings}

Following NSD methodology (Hadjerioua et al., 2013), the potential capacity, annual generation, and mean capacity factors in the Texas-Gulf Region are estimated and summarized in Table 15.1 for both larger ( $>1 \mathrm{MW})$ and smaller ( $<1 \mathrm{MW})$ stream-reaches. By comparison, the year-2011 nameplate capacity, 2002-2011 average annual generation and capacity factor of existing hydropower facilities are also listed (NHAAP, 2013). The total undeveloped NSD capacity is $783 \mathrm{MW}$, around $149 \%$ of existing conventional hydropower nameplate capacity. In terms of energy, the total undeveloped NSD generation is $3.67 \mathrm{TWh} /$ year, around $523 \%$ of annual net generation from existing conventional hydropower plants. Given the run-of-river assumption, NSD stream-reaches have higher capacity factors, especially compared with other larger-storage peaking-operation projects in this region. More detailed topographical analysis and environmental attribution are conducted for larger ( $>1 \mathrm{MW})$ stream-reaches and discussed in Sections 15.3 and 15.4 .

Table 15.1. Summary of NSD Findings in Region $12-$ Texas-Gulf

\begin{tabular}{l|r|r|r}
\hline & $\begin{array}{r}\text { Capacity } \\
(\mathbf{M W})\end{array}$ & $\begin{array}{r}\text { Generation } \\
(\mathbf{M W h})\end{array}$ & $\begin{array}{r}\text { Mean capacity } \\
\text { factor }\end{array}$ \\
\hline Potential in undeveloped stream-reaches $(>1 \mathrm{MW})$ & 395 & $1,917,000$ & $55 \%$ \\
\hline Potential in undeveloped stream-reaches $(<1 \mathrm{MW})$ & 388 & $1,749,000$ & $52 \%$ \\
\hline Existing hydropower-conventional hydro & 525 & 701,000 & $15 \%$ \\
\hline Existing hydropower-pumped storage & 0 & & \\
\hline
\end{tabular}

\subsection{Background Hydrologic Setting}

The Texas-Gulf Region encompasses approximately $471,053 \mathrm{~km}^{2}$ of drainage area in the western Gulf region of the United States; it contains very small sections of Mississippi and New Mexico and a large central section of Texas.

Several river systems are located in the Texas-Gulf Region (Figure 15.1), including the Sabine, Neches, Trinity, San Jacinto, Brazos, Little, Colorado, San Saba, Lavaca, Guadalupe, San Antonio, and Nueces rivers, with a total length of $25,079 \mathrm{~km}$ (i.e., total length of streams with estimated discharge greater than $35 \mathrm{cfs})$. Metropolitan areas within the region include Houston (TX), Dallas/Fort Worth (TX), San Antonio (TX), and Corpus Christi (TX). As shown in Figure 15.2, annual precipitation for the Texas-Gulf region ranges from 590 to $1100 \mathrm{~mm} / \mathrm{year}$, and annual runoff ranges from 10 to $150 \mathrm{~mm} /$ year. Most of the precipitation occurs in early summer and again in late fall during hurricane season.

The existing hydropower plants and major non-powered dams (Hadjerioua et al., 2012) are shown in Figure 15.1. The region contains 24 hydropower dams and 50 major non-powered dams, with storage capacities of about 44,984,357 ac-ft and 2,978,445 ac-ft, respectively. 


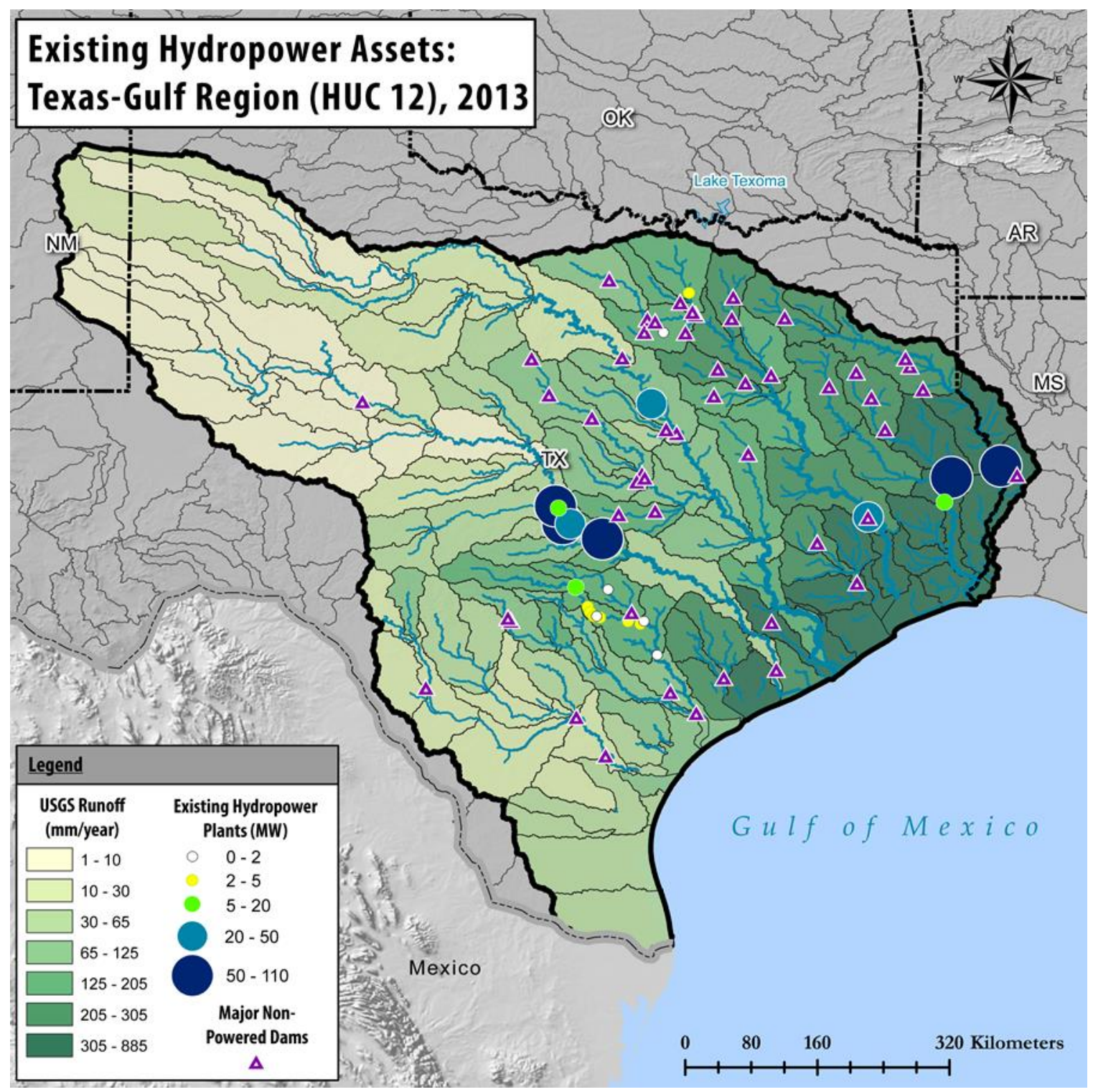

Figure 15.1. Locations of water control projects in Region 12-Texas-Gulf.

\subsection{Potential New Hydropower Resources}

A total of 117 stream-reaches of high energy density (with estimated potential capacity $>1 \mathrm{MW}$ per stream-reach) are identified in the Texas-Gulf Region. The NSD results based on the HUC04 subregions are summarized in Table 15.2. The highest hydropower potential is found in the Lower Brazos Subregion (HUC 1207) located in the Brazos and Little rivers. The next highest hydropower potential is located in the Trinity Subregion (HUC 1203) and Central Texas Coastal Subregion (HUC1210) in the Trinity and San Antonio rivers, respectively.

The summary statistics of hydraulic head $\mathrm{H}_{\text {ref }}(\mathrm{ft})$, design flow $\mathrm{Q}_{30}(\mathrm{cfs})$, potential capacity $\mathrm{P}_{\mathrm{NSD}}$ (MW), inundated area $A_{N S D}(\mathrm{ac})$, storage $\mathrm{V}_{\mathrm{NSD}}\left(\mathrm{ac}-\mathrm{ft}\right.$ ), and residence time $\mathrm{T}_{\mathrm{NSD}}$ (day) are shown in Figure 15.3. The hydraulic head $\mathrm{H}_{\text {ref }}$ ranges from 5 to the 90 th quantile of $54 \mathrm{ft}$ with a median of $25 \mathrm{ft}$. The design flow $\mathrm{Q}_{30}$ ranges from 400 to the 90 th quantile of $7000 \mathrm{cfs}$ with a median of 
about 1900 cfs. The potential capacity $\mathrm{P}_{\mathrm{NSD}}$ ranges from 1 to the 90th quantile of $6.5 \mathrm{MW}$ with a median of about 2.5 MW. The inundated surface area $A_{N S D}$ ranges from 0 to the 90th quantile of 7500 acres with a median of 1500 acres. This results in storage values $\mathrm{V}_{\text {NSD }}$ ranging from 0 to the $90^{\text {th }}$ quantile of 80,000 ac- $\mathrm{ft}$ with a median of 15,000 ac-ft with residence times $\mathrm{T}_{\mathrm{NSD}}$ ranging from < 1 day to the 90th quantile of about 45 days with a median on the order of a day or two. The results of $>1 \mathrm{MW}$ stream-reach potential are illustrated in Figure 15.4, with potential capacity (MW) aggregated to the HUC08 subbasins.

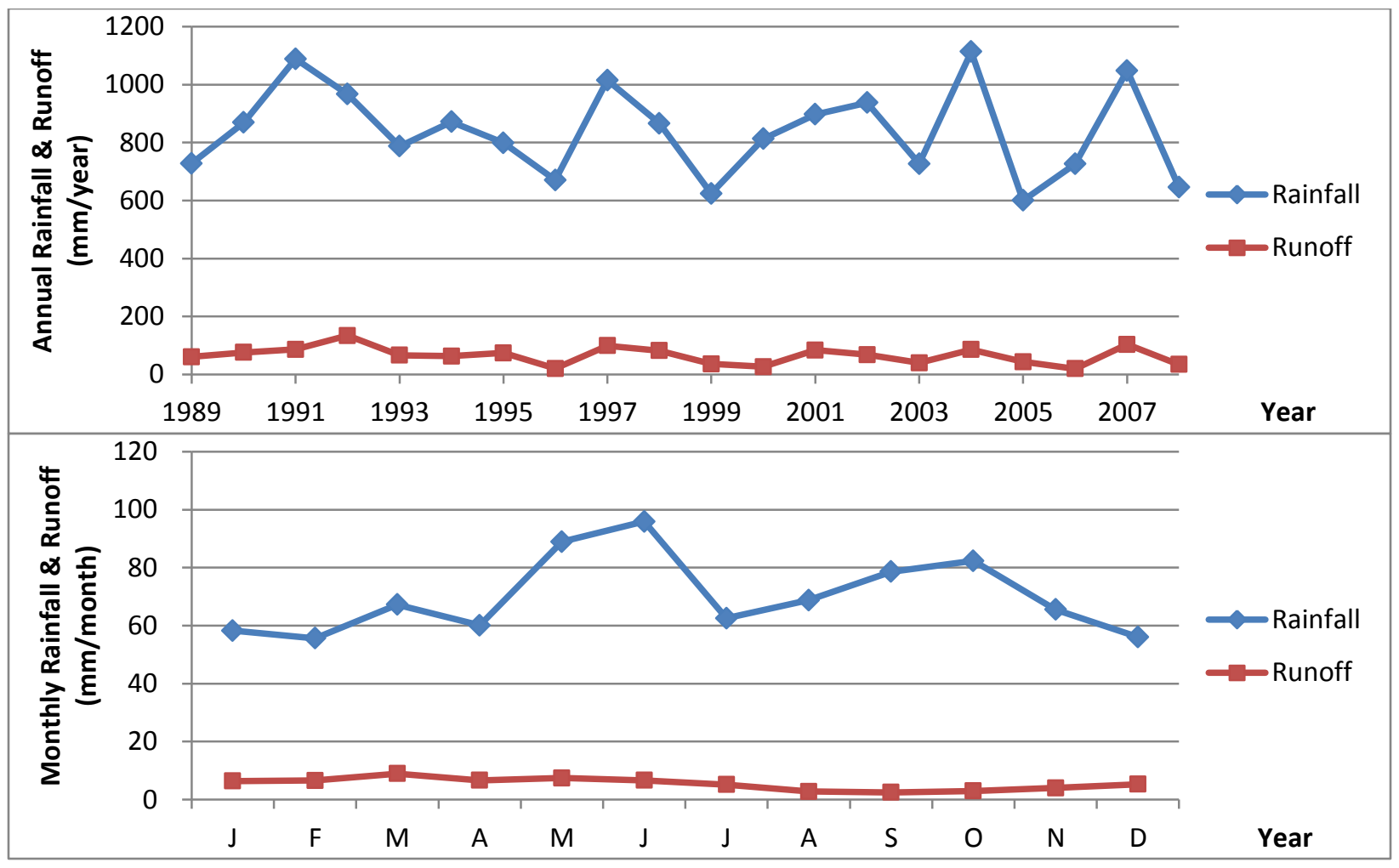

Figure 15.2. Annual and monthly rainfall and runoff of Region $12-$ Texas-Gulf.

Table 15.2. Summary of Potential New Hydropower Resources in Region 12-Texas-Gulf (Stream-Reaches with Potential Capacity $>1$ MW)

\begin{tabular}{|c|c|c|c|c|c|c|c|c|}
\hline HUC04 & HUC04 name & $\begin{array}{r}\text { \# of } \\
\text { stream- } \\
\text { reaches }\end{array}$ & $\begin{array}{r}\text { Potential } \\
\text { capacity } \\
(\mathrm{MW})\end{array}$ & $\begin{array}{r}\text { Potential } \\
\text { energy } \\
(\mathrm{MWh})\end{array}$ & $\begin{array}{r}\text { Average } \\
\text { head } \\
(\mathbf{f t} / \mathrm{reach})\end{array}$ & $\begin{array}{r}\text { Average } \\
\text { flow } \\
\text { (cfs/reach) }\end{array}$ & $\begin{array}{r}\text { Average } \\
\text { storage (ac- } \\
\text { ft/reach) }\end{array}$ & $\begin{array}{r}\text { Average } \\
\text { residence } \\
\text { Time (days) }\end{array}$ \\
\hline 1201 & Sabine & 10 & 33.4 & 151,158 & 12.2 & 5,185 & 16,310 & 3.8 \\
\hline 1202 & Neches & 15 & 33.7 & 157,166 & 14.5 & 2,391 & 21,587 & 8.6 \\
\hline 1203 & Trinity & 20 & 88.6 & 421,400 & 16.8 & 4,591 & 17,449 & 5.4 \\
\hline 1204 & $\begin{array}{l}\text { Galveston Bay-San } \\
\text { Jacinto }\end{array}$ & - & - & - & - & - & - & - \\
\hline 1205 & Brazos headwaters & - & - & - & - & - & - & - \\
\hline 1206 & Middle Brazos & 3 & 3.9 & 18,606 & 30.6 & 586 & 10,876 & 2.7 \\
\hline 1207 & Lower Brazos & 23 & 126.2 & 569,401 & 41.7 & 3,052 & 116,691 & 63.7 \\
\hline 1208 & Upper Colorado & - & - & - & - & - & - & - \\
\hline 1209 & $\begin{array}{l}\text { Lower Colorado-San } \\
\text { Bernard Coastal }\end{array}$ & 17 & 40.3 & 211,478 & 28.6 & 1,210 & 14,184 & 2.5 \\
\hline 1210 & Central Texas Coastal & 29 & 69.3 & 387,527 & 34.7 & 1,059 & 20,008 & 9.5 \\
\hline 1211 & $\begin{array}{l}\text { Nueces-Southwestern } \\
\text { Texas Coastal }\end{array}$ & - & - & - & - & - & - & - \\
\hline
\end{tabular}




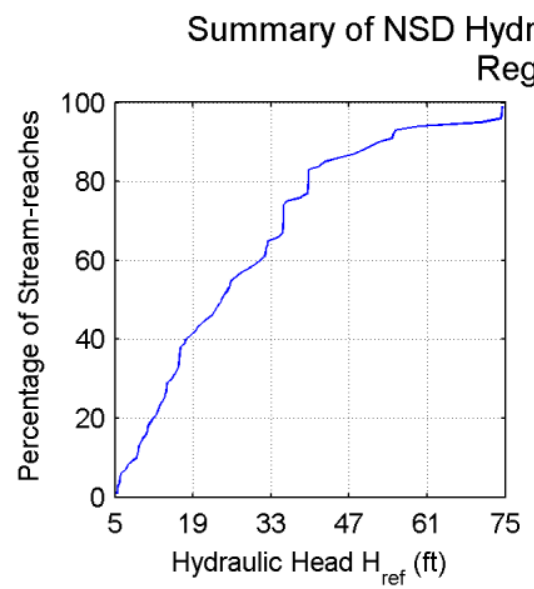

Rydropower Potential (stream-reaches with
Region 12: 117 stream-reaches, $395 \mathrm{MW}$
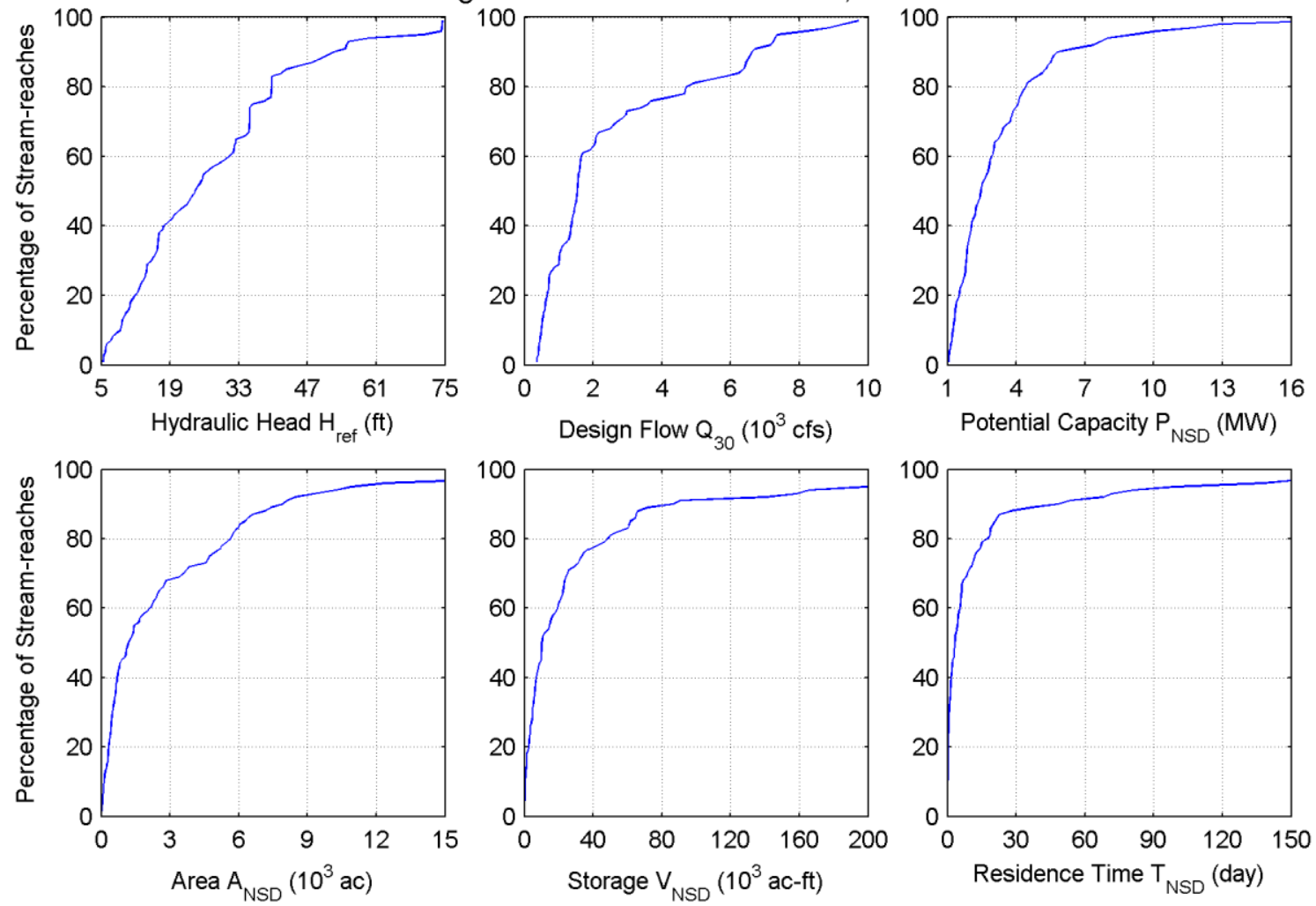

Figure 15.3. Cumulative distributions of hydraulic head $\mathrm{H}_{\text {ref }}$, design flow $\mathrm{Q}_{30}$, potential capacity $\mathrm{P}_{\mathrm{NSD}}$, inundated area $\mathrm{A}_{\mathrm{NSD}}$, storage $\mathrm{V}_{\mathrm{NSD}}$, and residence time $\mathrm{T}_{\mathrm{NSD}}$ in Region 12-Texas-Gulf.

\subsection{Environmental Characteristics}

The Texas-Gulf Region includes 133 native fish species, 9 of which are species of concern. Of the five fish species falling under ESA categories, two species-Clear Creek gambusia (Gambusia heterochir) and fountain darter (Etheostoma fonticola) - are listed as endangered. An additional four species, including paddlefish, fall under IUCN vulnerability categories. Five species are considered potadromous or anadromous in the region. Twenty subbasins are considered critical watersheds, and the Middle Sabine and San Saba sub-basins have six fish and mussel species at risk (Mathews et al., 1998). Twenty-two species have critical habitat designations, including two fish species-San Marcos gambusia (Gambusia georgei) and fountain darter (Figure 15.5).

In Region 12, protected lands comprise almost 4.2 million acres, only $3.6 \%$ of the total area. Federal $(65 \%)$, state $(33 \%)$, and NGO (2\%) lands make up the largest proportion of protected areas. The dominant federal entities include the USFS (29\%), DOD (19\%), FWS (10\%), NPS $(5 \%)$, and Bureau of Outdoor Recreation (1\%). Among the largest tracts of USFS lands in the region are the Sabine, Davy Crockett, Angelina, and Sam Houston national forests and the Lyndon B. Johnson National Grassland. Other large tracts include Fort Hood Military Base, Padre Island National Seashore, and Aransas National Wildlife Refuge. State trust lands make up the vast majority of state-owned lands in the region. GAP status 4, 3, and 2 lands make up 37\%, 
$34 \%$, and $23 \%$ of protected areas, respectively. There are no National Wild and Scenic Rivers in Region 12. Recreation, which is not as prevalent as in other regions, includes 501 boat ramps, 150 fishing access locations, 23 waterfalls, and 112 recreational boating river sections.

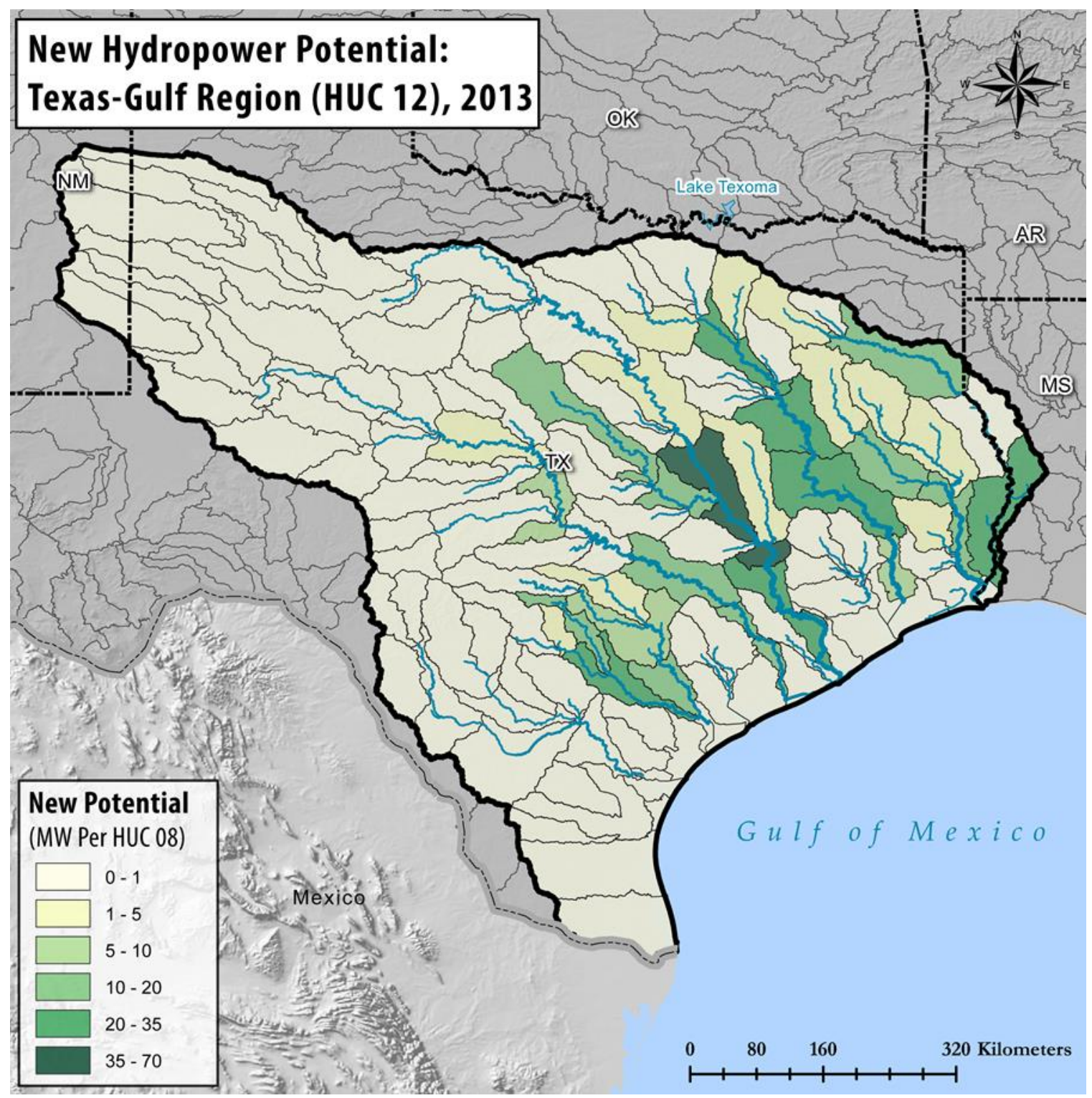

Figure 15.4. Potential new hydropower capacity in Region 12-Texas-Gulf (higher-energy-density stream-reaches with >1 MW per reach, aggregated to HUC08 subbasins for illustration). 


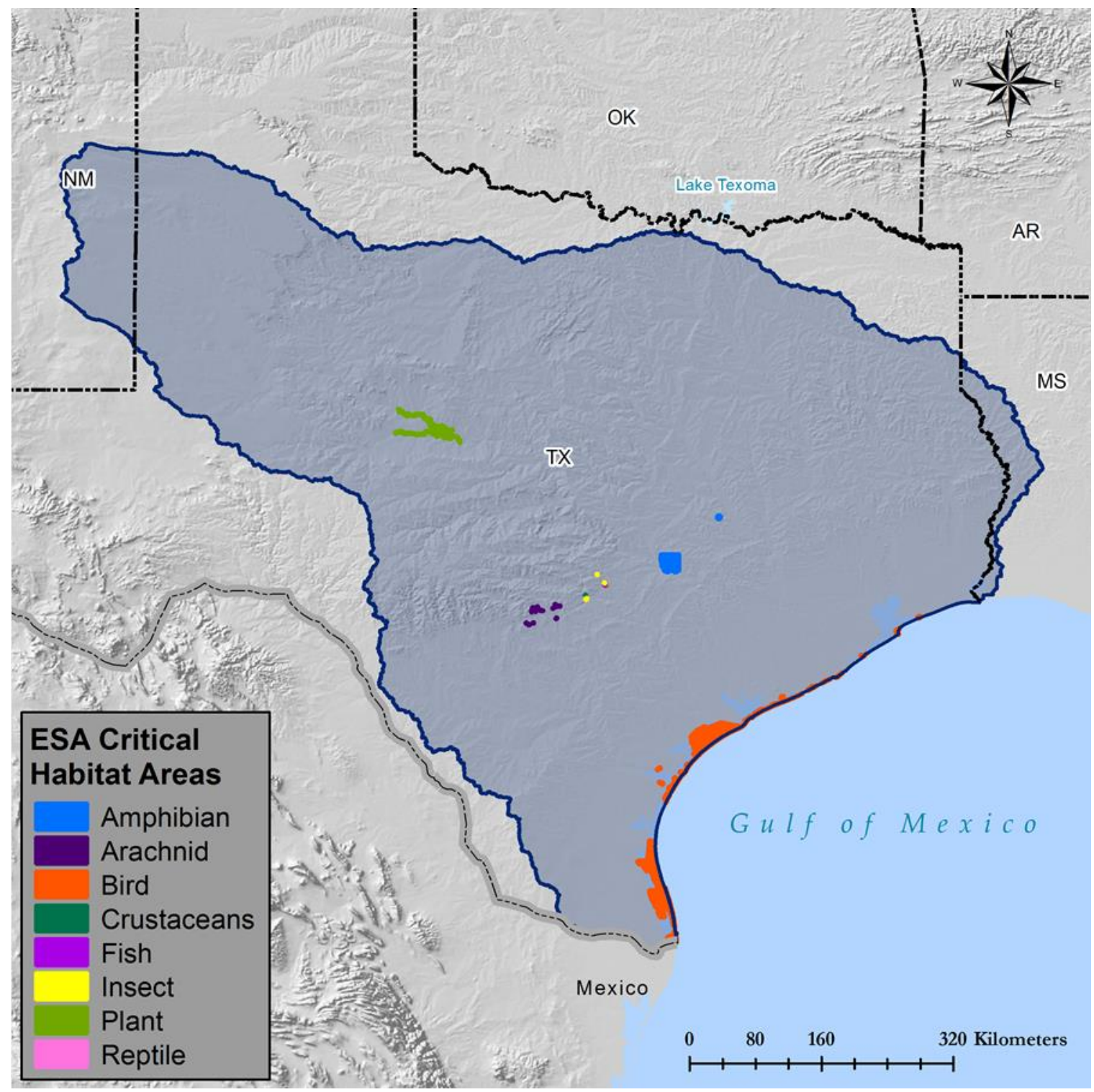

Figure 15.5. Critical habitats for federally endangered and threatened species in Region 12 .

Water use is average in Region 12, with most of the usage for thermoelectric cooling, irrigation, or public consumption (Figure 15.6 and Appendix B). More water usage is reported in the eastern region, with the Galveston Bay-San Jacinto Subbasin having the highest values (Table 15.3). Water quality concerns are average in Region 12 , with most concerns related to dissolved oxygen, mercury contamination, or elevated pathogen levels.

Only three stream-reaches (8 MW) intersect critical habitats (Figure 15.7). Almost $18 \%$ of stream-reaches (104 MW) are located within HUC08 subbasins containing one fish falling under ESA categories. Over $32 \%$ of stream-reaches intersect protected lands, with none at national parks. Roughly half $(51 \%)$ of stream-reaches intersect water quality concerns. Recreational boating is uncommon, only overlapped with nine reaches. Boat ramps are identified at $18 \%$ of 
reaches, but fishing access areas are absent from reaches. Approximately one-third of potential capacity was associated with stream-reaches located within HUC08 subbasins with high or very high water usage.

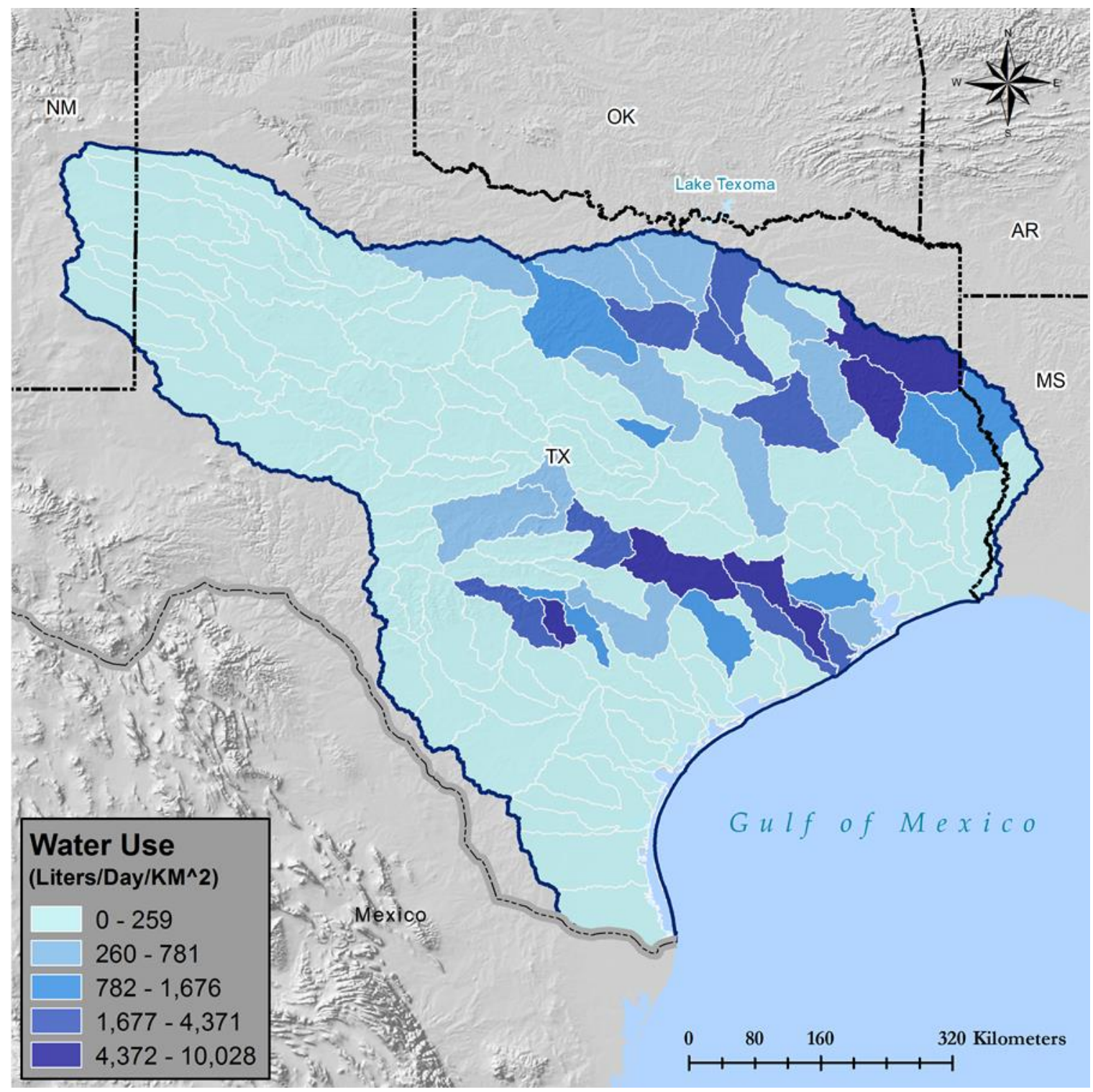

Figure 15.6. Average water use per HUC08 subbasin in Region 12 . 
Table 15.3. Summary of Environmental Variables at HUC04 Subregions within Region 12 (Stream-Reaches with Potential Capacity $>1 \mathrm{MW}$ )

\begin{tabular}{|c|c|c|c|c|c|c|c|c|}
\hline HUC04 HUC04 name & $\begin{array}{r}\text { \# Critical } \\
\text { habitats }\end{array}$ & $\begin{array}{l}\text { \# Potad- } \\
\text { anad fish }\end{array}$ & $\begin{array}{r}\text { \# ESA } \\
\text { fish }\end{array}$ & $\begin{array}{r}\text { \# IUCN } \\
\text { fish }\end{array}$ & $\begin{array}{r}\# \\
\text { Recreation } \\
\text { locations }\end{array}$ & $\begin{array}{r}\% \\
\begin{array}{r}\% \\
\text { Protected } \\
\text { lands }\end{array} \\
\end{array}$ & $\begin{array}{r}\text { Population } \\
\text { density } \\
\left(\mathrm{ind} / \mathbf{k m}^{2}\right) \\
\end{array}$ & $\begin{array}{r}\text { Freshwater } \\
\text { use (liters/day/ } \\
\mathbf{k m}^{\mathbf{2}} \text { ) } \\
\end{array}$ \\
\hline 1201 Sabine & 0 & 5 & 0 & 2 & $57 ; 7 ; 0$ & 9.35 & 25.70 & $2,150.72$ \\
\hline 1202 Neches & 0 & 5 & 0 & 2 & $77 ; 1 ; 0$ & 14.52 & 23.88 & $2,341.71$ \\
\hline 1203 Trinity & 0 & 2 & 0 & 0 & $152 ; 14 ; 3$ & 2.92 & 128.41 & $2,707.82$ \\
\hline $\begin{array}{l}\text { Galveston Bay-San } \\
\text { Jacinto }\end{array}$ & 2 & 5 & 1 & 1 & $55 ; 0 ; 0$ & 7.92 & 234.47 & $3,519.64$ \\
\hline 1205 Brazos Headwaters & 0 & 0 & 2 & 1 & $3 ; 4 ; 3$ & 2.24 & 13.89 & $2,436.98$ \\
\hline 1206 Middle Brazos & 0 & 2 & 2 & 1 & $74 ; 11 ; 2$ & 0.69 & 16.86 & 653.82 \\
\hline 1207 Lower Brazos & 2 & 3 & 2 & 2 & $65 ; 15 ; 3$ & 2.85 & 34.48 & $1,361.90$ \\
\hline 1208 Upper Colorado & 0 & 0 & 0 & 0 & $14 ; 0 ; 0$ & 6.04 & 9.05 & 643.17 \\
\hline $1209 \begin{array}{l}\text { Lower Colorado-San } \\
\text { Bernard Coastal }\end{array}$ & 5 & 3 & 2 & 2 & $71 ; 34 ; 6$ & 0.95 & 21.35 & $1,259.56$ \\
\hline 1210 Central Texas Coastal & 19 & 3 & 1 & 4 & $78 ; 18 ; 6$ & 2.01 & 56.69 & $1,372.05$ \\
\hline $\begin{array}{l}1211 \begin{array}{l}\text { Nueces-Southwestern } \\
\text { Texas Coastal }\end{array} \\
\end{array}$ & 2 & 2 & 0 & 1 & $30 ; 8 ; 0$ & 1.34 & 27.83 & 617.98 \\
\hline
\end{tabular}

${ }^{a}$ Recreation locations refer to the number of boat-ramp and fishing access points, recreational boating, and waterfalls within each HUC04.
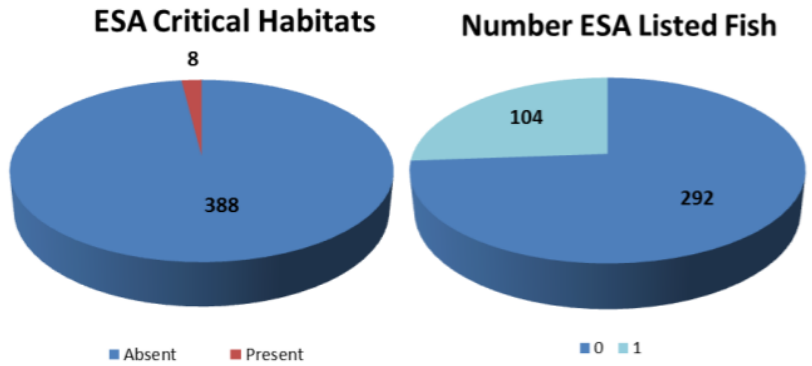

$\| 0=1$
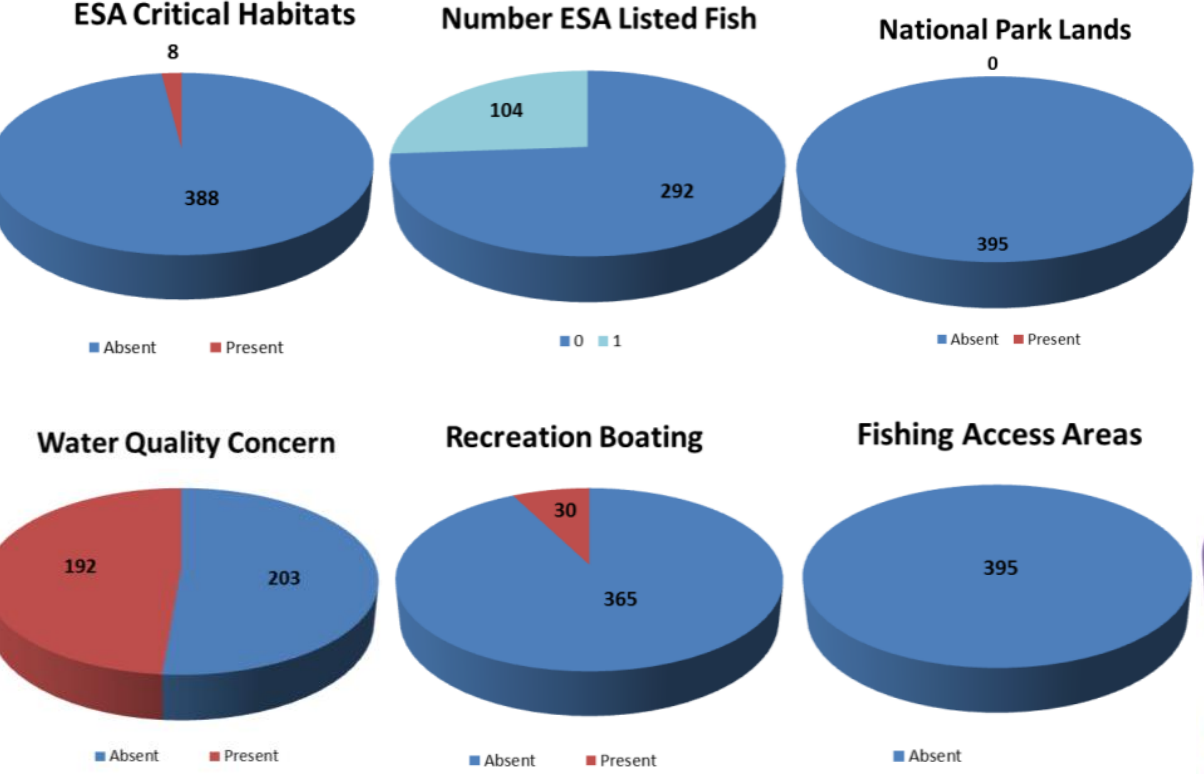

Wild and Scenic Rivers
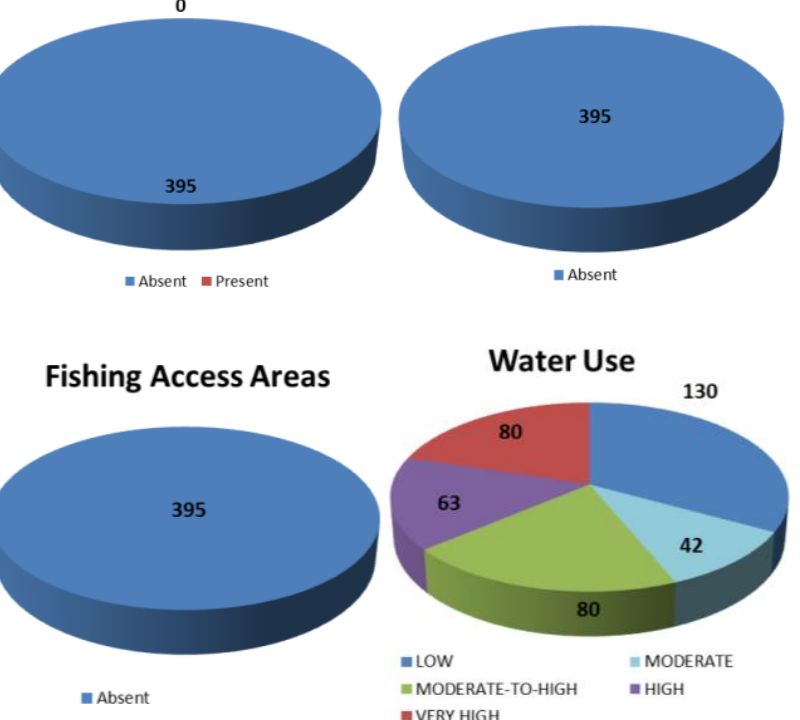

Water Use

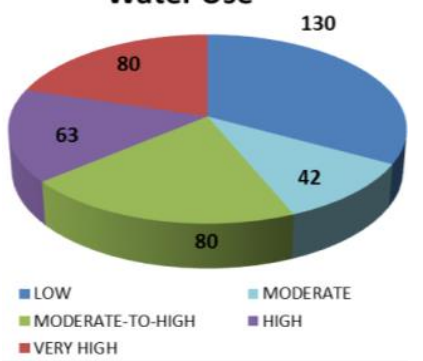

Figure 15.7. The potential capacity, in MW, associated with environmental attributes in Region 12-Texas-Gulf (stream-reaches with potential capacity $>1 \mathrm{MW}$ ). 


\section{REGION 13-RIO GRANDE}

\subsection{Summary of Findings}

Following NSD methodology (Hadjerioua et al., 2013), the potential capacity, annual generation, and mean capacity factors in the Rio Grande Region are estimated and summarized in Table 16.1 for both larger ( $>1 \mathrm{MW})$ and smaller ( $<1 \mathrm{MW})$ stream-reaches. For comparison, the year-2011 nameplate capacity, 2002-2011 average annual generation, and capacity factor of existing hydropower facilities are also listed (NHAAP, 2013). The total undeveloped NSD capacity is $1.64 \mathrm{GW}$, around $1030 \%$ of existing conventional hydropower nameplate capacity. In terms of energy, the total undeveloped NSD generation is $9.31 \mathrm{TWh} /$ year, around $2984 \%$ of annual net generation from existing conventional hydropower plants. The largest ratios of potential NSD resources to existing hydropower development mainly should be because of the relatively lower hydropower development in this region. The Rio Grande Region is one of the driest in this country, and hydropower may not be a prioritized usage for its limited fresh water resource. Given the run-of-river assumption, NSD stream-reaches have higher capacity factors, especially compared with other larger-storage peaking-operation projects in this region. More detailed topographical analysis and environmental attribution are conducted for larger (>1 MW) streamreaches and discussed in Sections 16.3 and 16.4.

Table 16.1. Summary of NSD Findings in Region 13-Rio Grande

\begin{tabular}{l|r|r|r}
\hline & $\begin{array}{r}\text { Capacity } \\
\text { (MW) }\end{array}$ & $\begin{array}{r}\text { Generation } \\
\text { (MWh) }\end{array}$ & $\begin{array}{r}\text { Mean capacity } \\
\text { factor }\end{array}$ \\
\hline Potential in undeveloped stream-reaches $(>1 \mathrm{MW})$ & 1,336 & $7,705,000$ & $66 \%$ \\
\hline Potential in undeveloped stream-reaches $(<1 \mathrm{MW})$ & 301 & $1,605,000$ & $61 \%$ \\
\hline Existing hydropower-conventional hydro & 159 & 312,000 & $22 \%$ \\
\hline Existing hydropower-pumped storage & 0 & & \\
\hline
\end{tabular}

\subsection{Background Hydrologic Setting}

The Rio Grande Region encompasses approximately 343,023 $\mathrm{km}^{2}$ of drainage area in the lower mid-southwestern section of the United States and contains parts of Texas, New Mexico, and Colorado.

Several river systems are located in the Rio Grande Region (Figure 16.1), including the Rio Grande, Jornada Draw, Mimbres, Devils, Pecos, and Delaware rivers, with a total length of 5762 $\mathrm{km}$ (i.e., total length of streams with estimated discharge greater than $35 \mathrm{cfs}$ ). Metropolitan areas within the region include Albuquerque (NM) and Las Cruces (NM). As shown in Figure 16.2, annual precipitation for the Rio Grande region ranges from 270 to $1600 \mathrm{~mm} / \mathrm{year}$, and annual runoff ranges from 200 to $700 \mathrm{~mm} /$ year. The main precipitation falls in early spring and summer. 
The existing hydropower plants and major non-powered dams (Hadjerioua et al., 2012) are also shown in Figure 16.1. The region contains 8 hydropower dams and 10 major non-powered dams, with total storage capacities of around 15,570,696 ac-ft and 2,918,093 ac-ft, respectively.

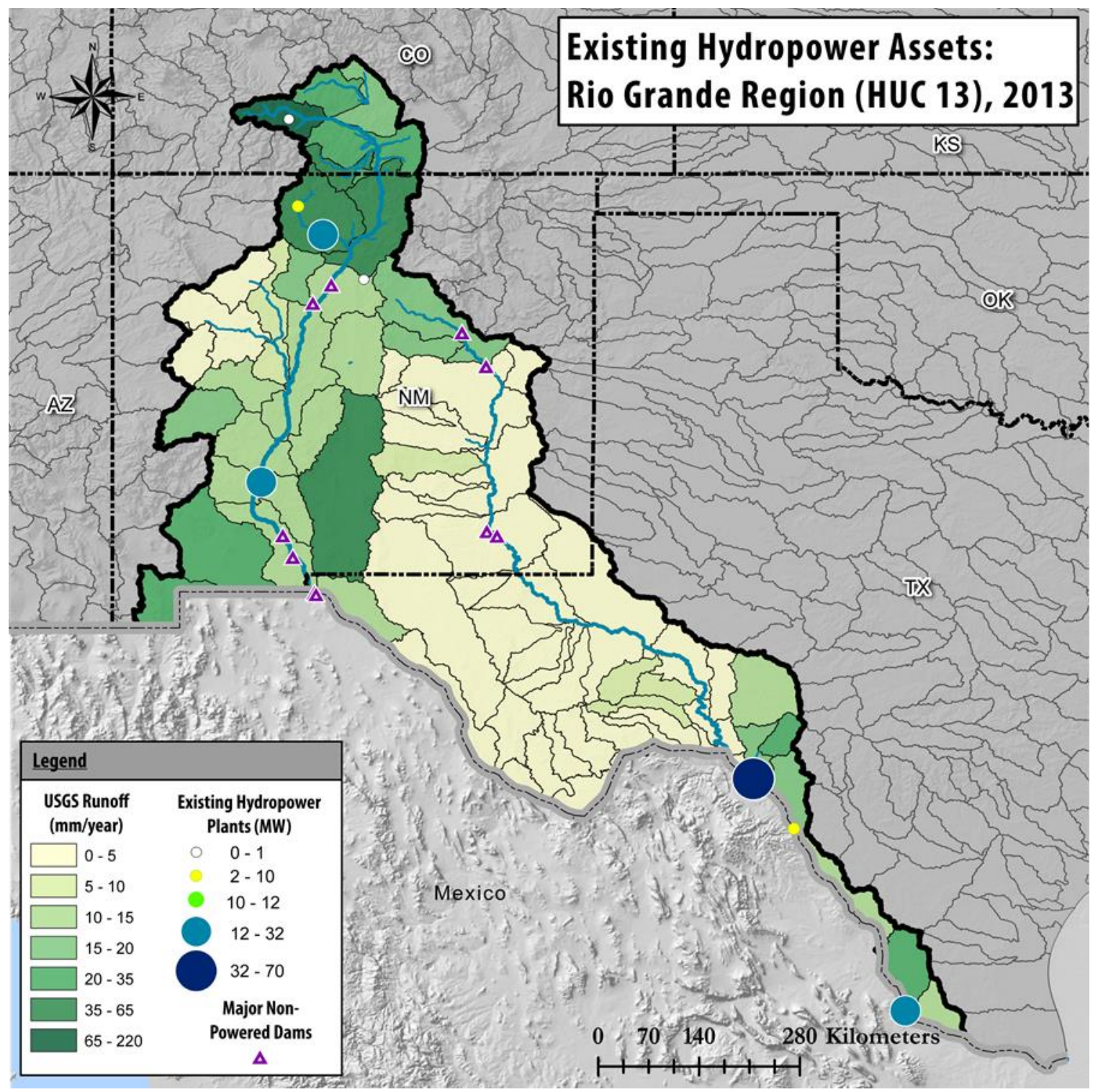

Figure 16.1. Locations of water control projects in Region 13-Rio Grande.

\subsection{Potential New Hydropower Resources}

A total of 267 stream-reaches of high energy density (with estimated potential capacity $>1 \mathrm{MW}$ per stream-reach) are identified in the Rio Grande Region. The NSD results based on the HUC04 subregions are summarized in Table 16.2. The highest hydropower potentials are found in the Rio Grande-Elephant Butte Subregion (HUC 1302) located on the Rio Grande River. The second highest potential is located in the Rio Grande-Amistad Subregion (HUC 1304) also located on the Rio Grande River. 


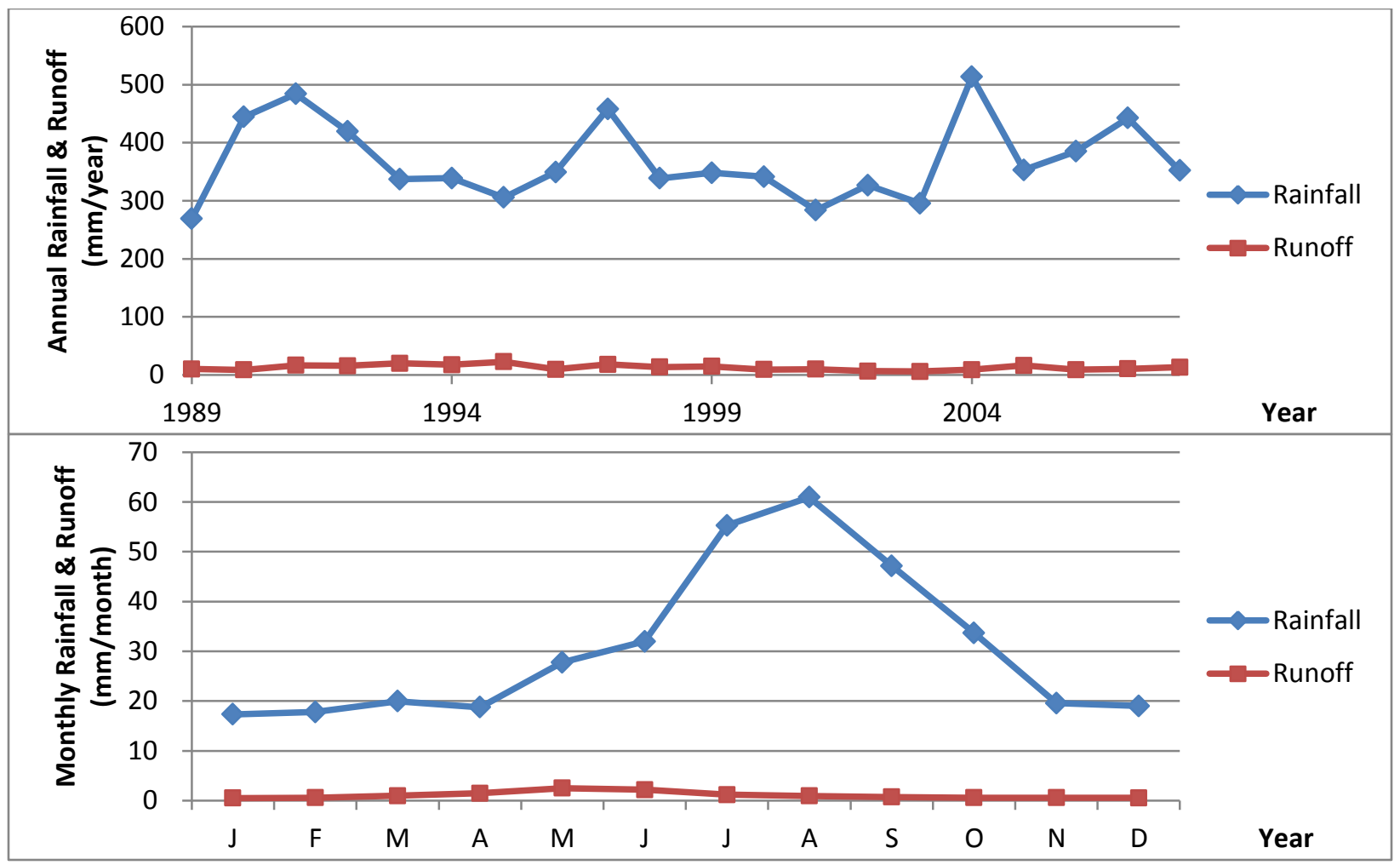

Figure 16.2. Annual and monthly rainfall and runoff of Region 13 - Rio Grande.

Table 16.2. Summary of Potential New Hydropower Resources in Region 13—Rio Grande (Stream-Reaches with Potential Capacity $>1 \mathrm{MW}$ )

\begin{tabular}{|c|c|c|c|c|c|c|c|c|}
\hline HUC04 & HUC04 name & $\begin{array}{r}\text { \# of } \\
\text { stream- } \\
\text { reaches }\end{array}$ & $\begin{array}{r}\text { Potential } \\
\text { capacity } \\
(\mathrm{MW})\end{array}$ & $\begin{array}{r}\text { Potential } \\
\text { energy } \\
(\mathrm{MWh})\end{array}$ & $\begin{array}{r}\text { Average } \\
\text { head } \\
(\mathrm{ft} / \mathrm{reach})\end{array}$ & $\begin{array}{r}\text { Average } \\
\text { flow } \\
\text { (cfs/reach) }\end{array}$ & $\begin{array}{r}\text { Average } \\
\text { storage (ac- } \\
\text { ft/reach) }\end{array}$ & $\begin{array}{r}\text { Average } \\
\text { residence } \\
\text { time (days) }\end{array}$ \\
\hline 1301 & $\begin{array}{l}\text { Rio Grande } \\
\text { headwaters }\end{array}$ & 48 & 88.4 & 474,255 & 14.6 & 1,762 & 3,026 & 1.0 \\
\hline 1302 & $\begin{array}{l}\text { Rio Grande-Elephant } \\
\text { Butte }\end{array}$ & 137 & 747.7 & $4,303,001$ & 18.8 & 4,031 & 6,608 & 0.8 \\
\hline 1303 & Rio Grande-Mimbres & 17 & 42.2 & 244,629 & 21.9 & 1,573 & 28,078 & 3.0 \\
\hline 1304 & Rio Grande-Amistad & 42 & 324.7 & $1,905,382$ & 53.9 & 1,976 & 162,904 & 15.6 \\
\hline 1305 & $\begin{array}{l}\text { Rio Grande closed } \\
\text { basins }\end{array}$ & - & - & - & - & - & - & - \\
\hline 1306 & Upper Pecos & - & - & - & - & - & - & - \\
\hline 1307 & Lower Pecos & - & - & - & - & - & - & - \\
\hline 1308 & Rio Grande-Falcon & 20 & 117.3 & 688,849 & 27.1 & 3,000 & 24,448 & 1.4 \\
\hline 1309 & Lower Rio Grande & 3 & 15.8 & 88,945 & 17.9 & 4,196 & 130,797 & 5.1 \\
\hline
\end{tabular}

The summary statistics of hydraulic head $\mathrm{H}_{\text {ref }}(\mathrm{ft})$, design flow $\mathrm{Q}_{30}(\mathrm{cfs})$, potential capacity $\mathrm{P}_{\mathrm{NSD}}$ $(\mathrm{MW})$, inundated area $\mathrm{A}_{\mathrm{NSD}}(\mathrm{ac})$, storage $\mathrm{V}_{\mathrm{NSD}}$ (ac-ft), and residence time $\mathrm{T}_{\mathrm{NSD}}$ (day) are shown in Figure 16.3. The hydraulic head $\mathrm{H}_{\text {ref }}$ ranges from 5 to the 90 th quantile of $47 \mathrm{ft}$ with a median of $22 \mathrm{ft}$. The design flow $\mathrm{Q}_{30}$ ranges from 1100 to the 90th quantile of $4700 \mathrm{cfs}$ with a median of about $3200 \mathrm{cfs}$. The potential capacity $\mathrm{P}_{\mathrm{NSD}}$ ranges from 1 to the 90th quantile of $9 \mathrm{MW}$ with a median of about $5 \mathrm{MW}$. The inundated surface area $A_{\mathrm{NSD}}$ ranges from 0 to the 90th quantile of 4500 acres with a median of 500 acres. This results in storage values $V_{\text {NSD }}$ ranging from 0 to the 
90th quantile of 85,000 ac-ft with a median of 6,000 ac- $\mathrm{ft}$ with residence times $\mathrm{T}_{\mathrm{NSD}}$ ranging from $<1$ day to the 90th quantile of about a week with a median of less than a day. The results of $>1 \mathrm{MW}$ stream-reach potential are illustrated in Figure 16.4, with potential capacity (MW) aggregated to the HUC08 subbasins.

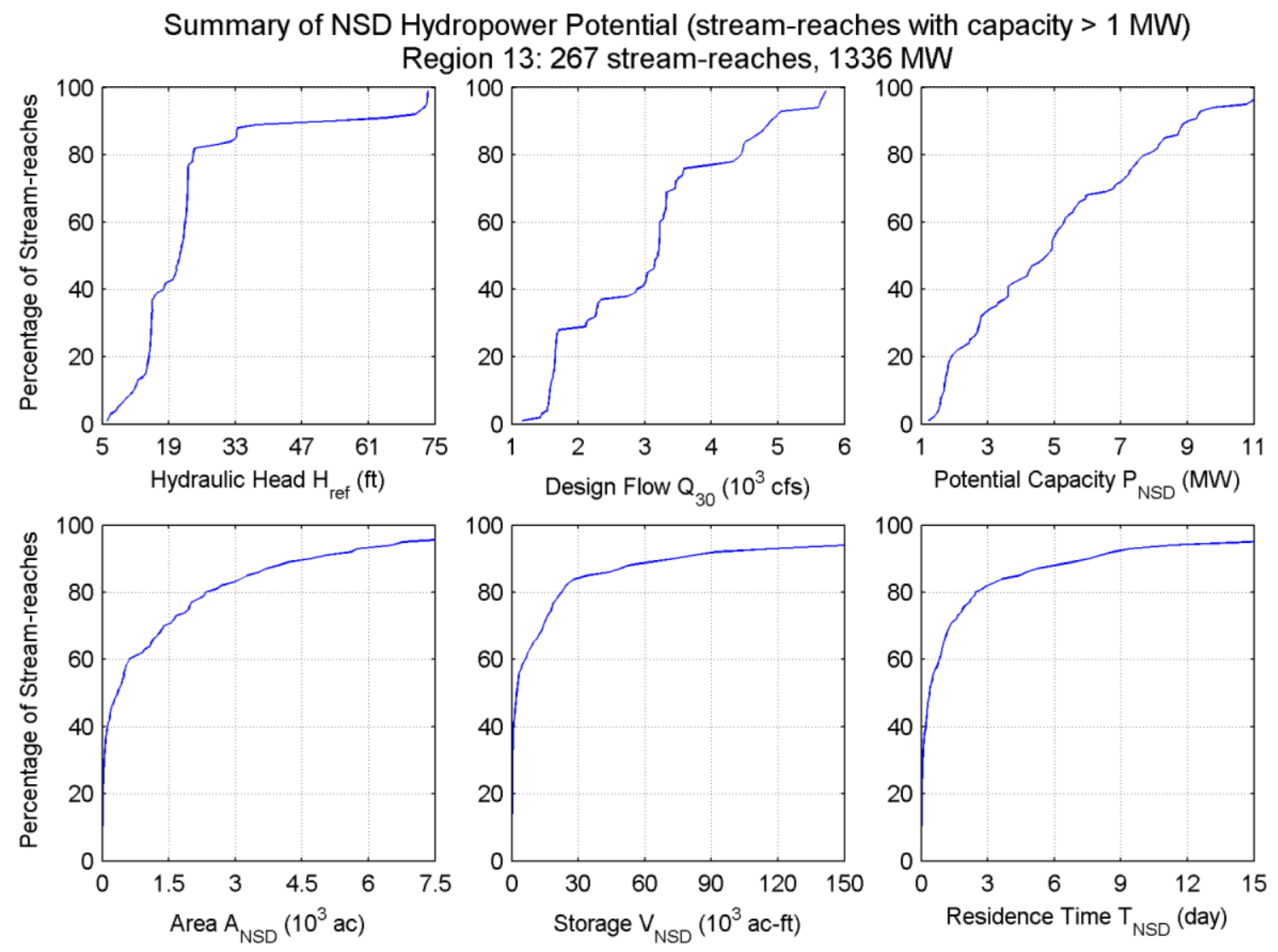

Figure 16.3. Cumulative distributions of hydraulic head $\mathrm{H}_{\text {ref }}$, design flow $\mathrm{Q}_{30}$, potential capacity $\mathrm{P}_{\mathrm{NSD}}$, inundated area $\mathrm{A}_{\mathrm{NSD}}$, storage $\mathrm{V}_{\mathrm{NSD}}$, and residence time $\mathrm{T}_{\mathrm{NSD}}$ in Region 13-Rio Grande.

\subsection{Environmental Characteristics}

The number of fishes of concern in the Rio Grande Region is remarkable (Figure 16.5), given that only 79 native fish species inhabit the entire region, one of the smallest areas in the United States. Almost 14\% (11) of fish species fall under ESA categories, and almost 18\% (14) fall under IUCN vulnerability categories (Figure 16.5). Natural spring-fed pools in the arid region are unique habitats for many endemic small fishes, including the endangered Big Bend gambusia (Gambusia gaigei), Pecos gambusia (Gambusia nobilis), Commanche springs pupfish (Cyprinodon elegans), and Leon springs pupfish (Cyprinodon bovinus). Other endangered species in the region include Rio Grande silvery minnow (Hybognathus amarus) and speckled dace (Rhinichthys osculus, population endangered). Threatened species include Chihuahua chub (Gila nigrescens), Devils River minnow (Dionda diabolic), and Apache Trout (Oncorhynchus 
gilae). Three fish species are considered potadromous or anadromous in the region. Nineteen of the 70 subbasins in the region are classified as critical watersheds. Twelve species have critical habitat designations; these include Devils River minnow, Leon Springs pupfish, Pecos bluntnose shiner (Notropis simus peconsensis), and Rio Grande Silvery minnow (Figure 16.6).

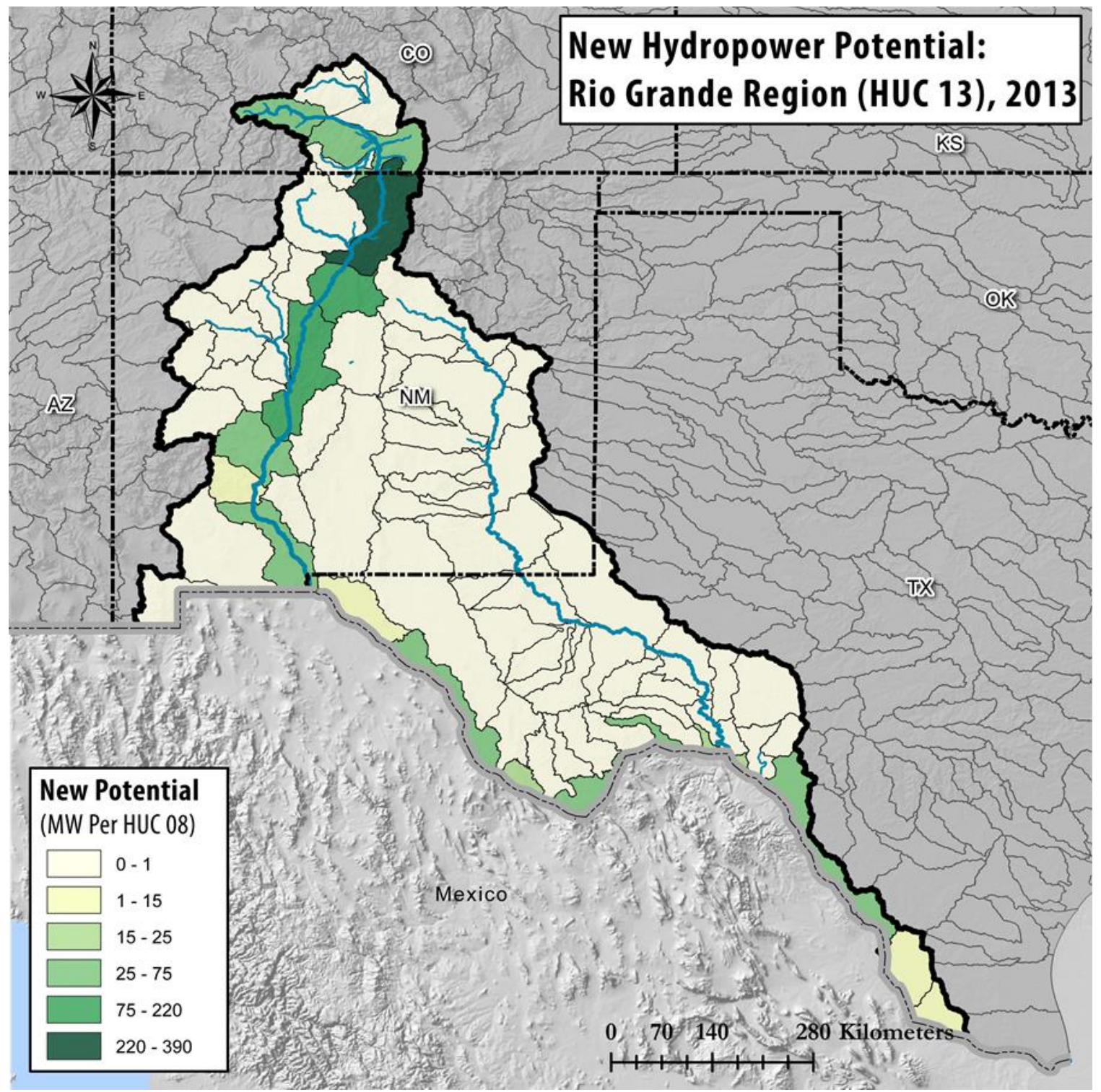

Figure 16.4. Potential new hydropower capacity in Region 13 - Rio Grande (higher-energy-density stream-reaches with >1 MW per reach, aggregated to HUC08 subbasins for illustration).

Almost 34 million acres of land (40\% of the total area) are protected in Region 13. Most of the protected lands are federally owned (70\%), followed by state (19\%) and Native American (9\%) owned lands. The dominant federal agencies in the region are BLM (31\% of protected lands), USFS (23\%), DOD (9\%), NPS (4\%), and USFWS (1\%). The largest tracts in the region include BLM public lands, state trust lands, White Sands Missile Range, Fort Bliss, and several national forests, including Rio Grande, Cibola, Santa Fe, Carson, and Lincoln. National parks in the region include Big Bend, Great Sand Dunes, Guadalupe Mountains, and Carlsbad Caverns. The 
Rio Grande, Rio Chama, Pecos, and East Fork Jemez National Wild and Scenic Rivers are located in Region 13. Far fewer recreation areas are found in Region 13 compared with other regions. The region includes 481 boat ramps, 56 fishing access locations, 20 waterfalls, and 49 recreational boating river sections.

Water use in Region 13 is well below the national average, most likely because of the arid climate. The highest water use is irrigation, occurring in the headwaters of the Rio Grande (Table 16.3). Water-quality concerns are low in the region, with most occurring as mercury contamination, low dissolved oxygen, or elevated toxin levels (Appendix B).

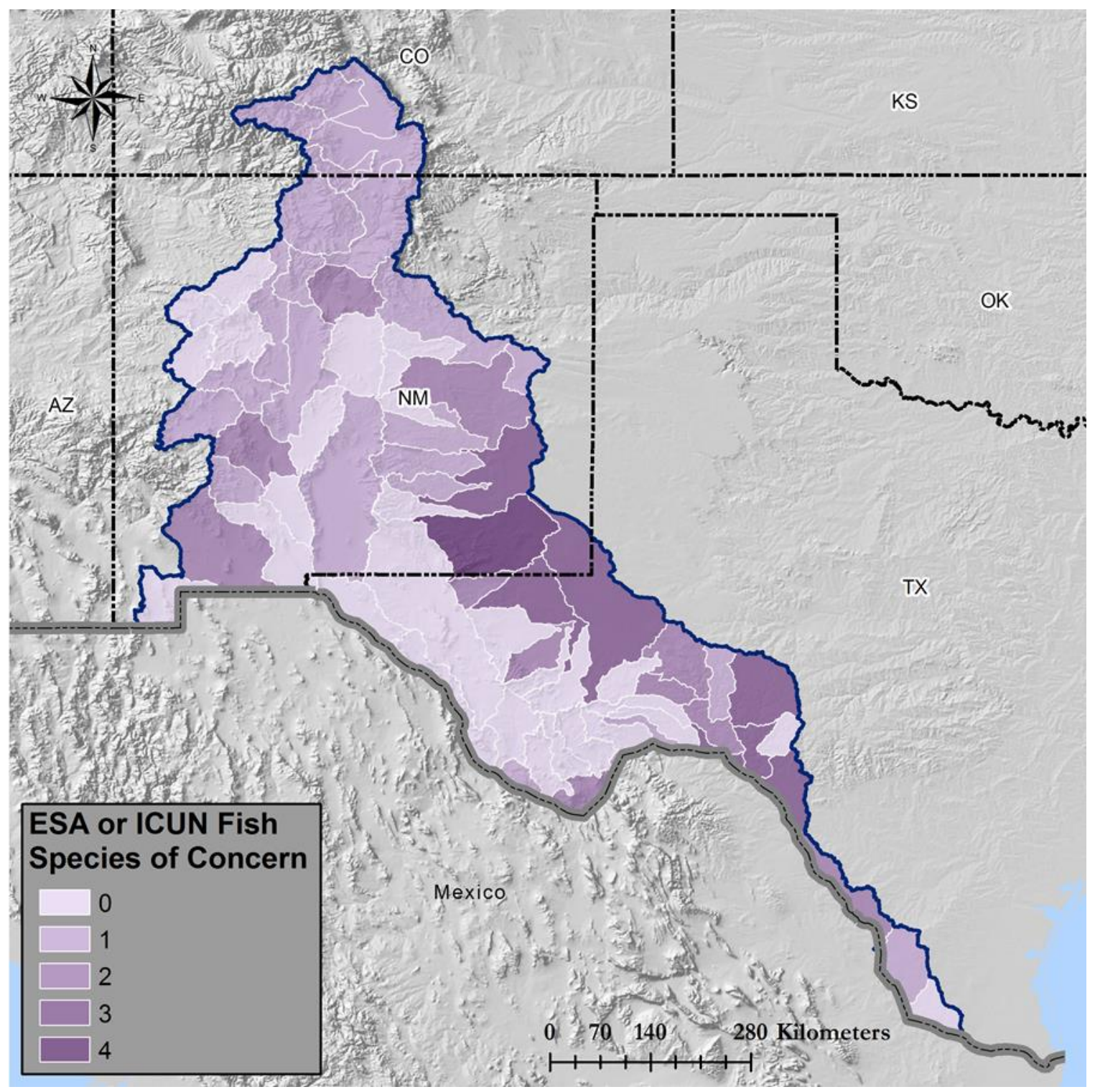

Figure 16.5. Fish species of concern (number per HUC08 subbasin) in Region 13. 


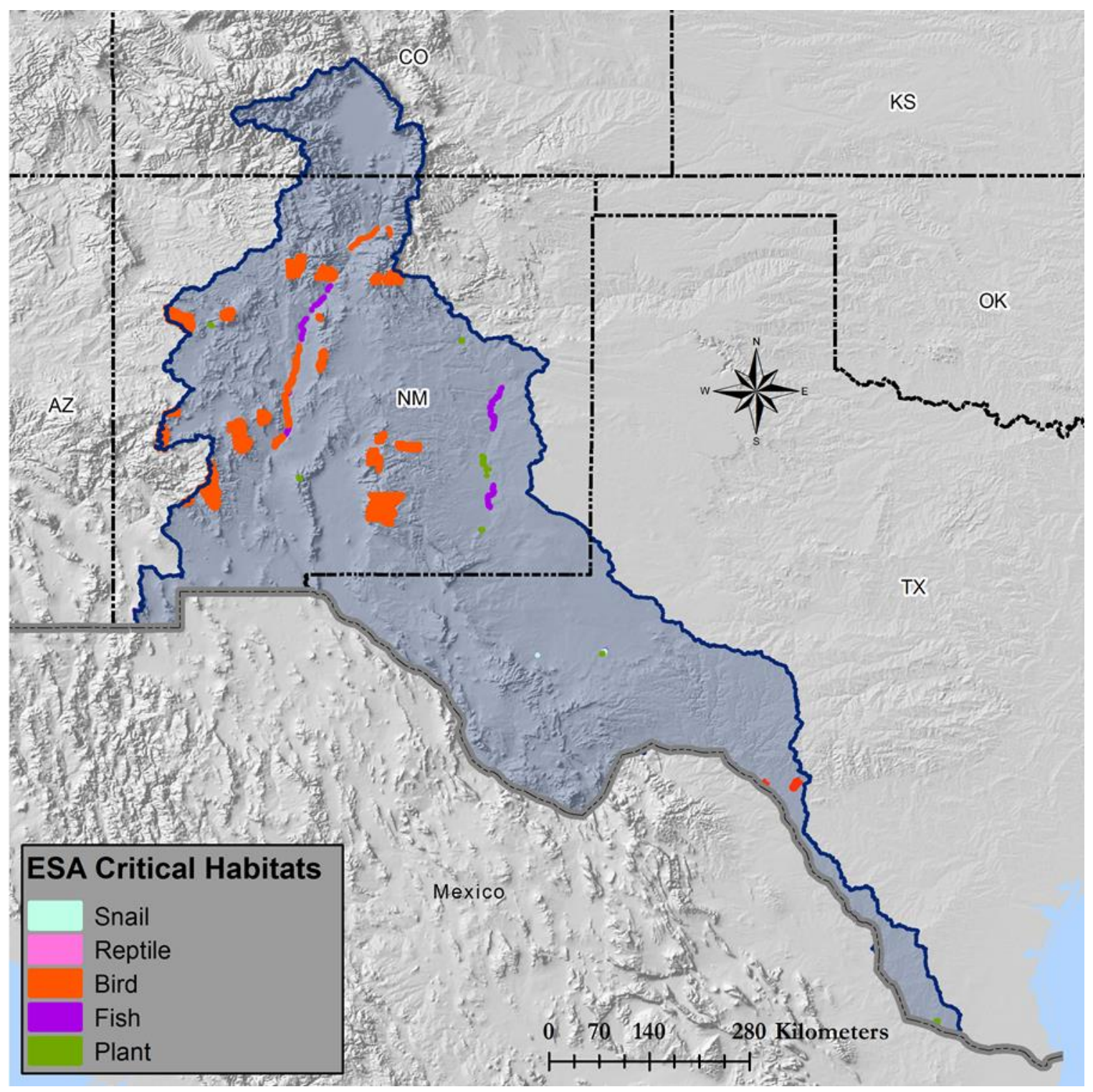

Figure 16.6. Critical habitats for federally endangered or threatened species in Region 13 .

Critical habitat designations overlapped with $32 \%$ of the 267 stream-reaches (Figure 16.7). Seventy-two percent of stream-reaches $(877 \mathrm{MW})$ are located within HUC08 subbasins, with one to two fish falling under an ESA category. Almost $87 \%$ of stream-reaches overlap with protected lands (1122 MW), with 13 stream-reaches (4.8\%) falling on national parks and 68 streamreaches $(25 \%)$ on WSRs. Water quality concerns are associated with almost $81 \%$ of streamreaches. Recreational boating, boat ramps, and fishing access areas are identified at 43\%, 1.5\%, and $16 \%$ of stream-reaches, respectively. Water use is relatively evenly distributed among stream-reaches. 
Table 16.3. Summary of Environmental Variables at HUC04 Subregions within Region 13 (Stream-Reaches with Potential Capacity $>1 \mathrm{MW}$ )

\begin{tabular}{|c|c|c|c|c|c|c|c|c|}
\hline HUC04 HUC04 name & $\begin{array}{r}\text { \# } \\
\text { Critical } \\
\text { habitats } \\
\end{array}$ & $\begin{array}{l}\text { \# Potad- } \\
\text { anad fish }\end{array}$ & $\begin{array}{r}\text { \# ESA } \\
\text { fish }\end{array}$ & $\begin{array}{r}\# \\
\text { IUCN } \\
\text { fish } \\
\end{array}$ & $\begin{array}{r}\# \\
\text { Recreation } \\
\text { locations }^{\text {a }} \\
\end{array}$ & $\begin{array}{r}\% \\
\begin{array}{r}\text { Protected } \\
\text { lands }\end{array} \\
\end{array}$ & $\begin{array}{r}\text { Population } \\
\text { density } \\
\left(\text { ind } / \mathbf{k m}^{2}\right) \\
\end{array}$ & $\begin{array}{r}\text { Freshwater } \\
\text { use (liters/day/ } \\
\mathbf{k m}^{\mathbf{2}} \text { ) } \\
\end{array}$ \\
\hline $1301 \begin{array}{l}\text { Rio Grande } \\
\text { Headwaters }\end{array}$ & 0 & 1 & 1 & 0 & $28 ; 8 ; 5$ & 59.44 & 2.23 & $3,412.16$ \\
\hline $\begin{array}{l}1302 \begin{array}{l}\text { Rio Grande-Elephant } \\
\text { Butte }\end{array} \\
\end{array}$ & 6 & 2 & 3 & 1 & $30 ; 23 ; 8$ & 52.53 & 10.88 & 358.22 \\
\hline 1303 Rio Grande-Mimbres & 2 & 2 & 3 & 2 & $4 ; 0 ; 0$ & 72.30 & 6.79 & 700.69 \\
\hline 1304 Rio Grande-Amistad & 0 & 2 & 2 & 5 & $13 ; 15 ; 4$ & 12.61 & 8.81 & 171.36 \\
\hline $\begin{array}{l}1305 \begin{array}{l}\text { Rio Grande Closed } \\
\text { Basins }\end{array} \\
\end{array}$ & 2 & 0 & 0 & 1 & $0 ; 0 ; 0$ & 44.91 & 6.47 & 265.84 \\
\hline 1306 Upper Pecos & 4 & 2 & 3 & 4 & $18 ; 2 ; 3$ & 43.03 & 2.66 & 330.88 \\
\hline 1307 Lower Pecos & 3 & 1 & 3 & 7 & $4 ; 2 ; 0$ & 5.52 & 1.63 & 140.76 \\
\hline 1308 Rio Grande-Falcon & 1 & 1 & 1 & 4 & $6 ; 0 ; 0$ & 0.32 & 10.92 & 241.93 \\
\hline 1309 Lower Rio Grande & 2 & 1 & 0 & 0 & $1 ; 0 ; 0$ & 4.51 & 83.35 & $1,709.69$ \\
\hline
\end{tabular}

${ }^{\bar{a}}$ Recreation locations refer to the number of boat-ramp and fishing access points, recreational boating, and waterfalls within each HUC04.

\section{ESA Critical Habitats}

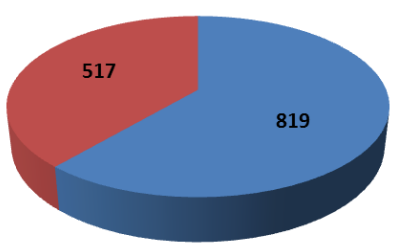

- Absent $=$ Present

Water Quality Concern

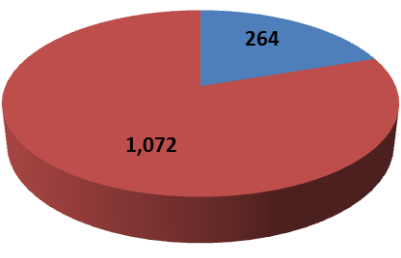

absent $\square$ Present

\section{Number ESA Listed Fish}

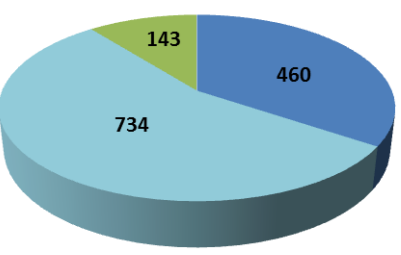

$\square 0 \backsim 1 \square 2$

Recreation Boating

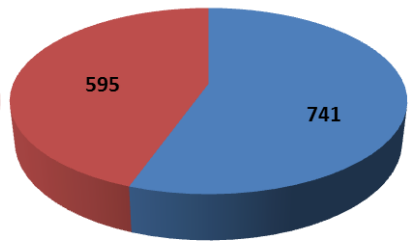

Absent $\square$ Present
National Park Lands

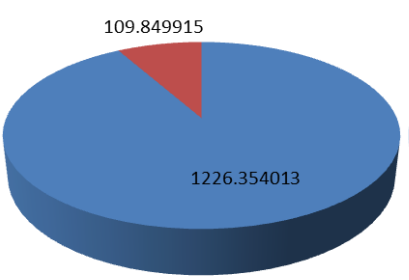

$\because$ Absent $\square$ Present

Fishing Access Areas

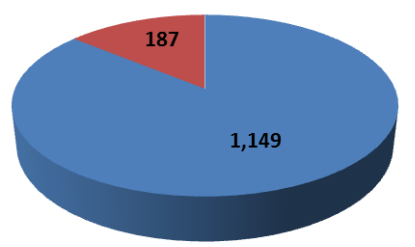

absent $\quad$ Present
Wild and Scenic Rivers

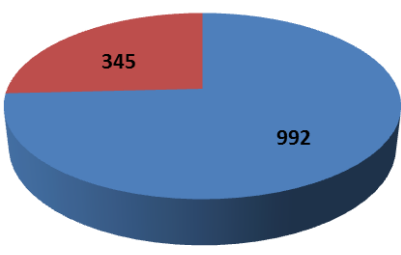

- Absent $\square$ Present

Water Use

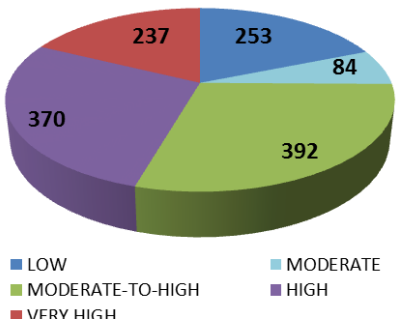

Figure 16.7. The potential capacity, in MW, associated with environmental attributes in Region 13-Rio Grande (stream-reaches with potential capacity $>1 \mathrm{MW}$ ). 


\section{REGION 14-UPPER COLORADO}

\subsection{Summary of Findings}

Following NSD methodology (Hadjerioua et al., 2013), the potential capacity, annual generation, and mean capacity factors in the Upper Colorado Region are estimated and summarized in Table 17.1 for both larger $(>1 \mathrm{MW})$ and smaller $(<1 \mathrm{MW})$ stream-reaches. For comparison, the year2011 nameplate capacity, 2002-2011 average annual generation, and capacity factor of existing hydropower facilities are also listed (NHAAP, 2013). The total undeveloped NSD capacity is $3.03 \mathrm{GW}$, around $160 \%$ of existing conventional hydropower nameplate capacity. In terms of energy, the total undeveloped NSD generation is $18.23 \mathrm{TWh} /$ year, around $349 \%$ of annual net generation from existing conventional hydropower plants. Given the run-of-river assumption, NSD stream-reaches have higher capacity factors, especially compared with other larger-storage peaking-operation projects in this region. More detailed topographical analysis and environmental attribution are conducted for larger $(>1 \mathrm{MW})$ stream-reaches and discussed in Sections 17.3 and 17.4.

Table 17.1. Summary of NSD Findings in Region 14-Upper Colorado

\begin{tabular}{l|r|r|r}
\hline & $\begin{array}{r}\text { Capacity } \\
(\mathbf{M W})\end{array}$ & $\begin{array}{r}\text { Generation } \\
(\mathbf{M W h})\end{array}$ & $\begin{array}{r}\text { Mean capacity } \\
\text { factor }\end{array}$ \\
\hline Potential in undeveloped stream-reaches $(>1 \mathrm{MW})$ & 1,942 & $11,845,000$ & $70 \%$ \\
\hline Potential in undeveloped stream-reaches $(<1 \mathrm{MW})$ & 1,091 & $6,387,000$ & $67 \%$ \\
\hline Existing hydropower-conventional hydro & 1,888 & $5,222,000$ & $32 \%$ \\
\hline Existing hydropower-pumped storage & 0 & & \\
\hline
\end{tabular}

\subsection{Background Hydrologic Setting}

The Upper Colorado Region encompasses approximately $293,568 \mathrm{~km}^{2}$ of drainage area in the lower west section of the United States and contains parts of Colorado, Utah, Arizona, New Mexico, and Wyoming.

Several river systems are located in the Upper Colorado Region (Figure 17.1), including the Colorado, Gunnison, Green, Yampa, White, San Juan, and Mancos rivers, with a total length of $14,111 \mathrm{~km}$ (i.e., total length of streams with estimated discharge greater than $35 \mathrm{cfs}$ ). Metropolitan areas within the region include Grand Junction (CO). As shown in Figure 17.2, annual precipitation for the Upper Colorado region ranges from 260 to $480 \mathrm{~mm} / \mathrm{year}$, and annual runoff ranges from 30 to $75 \mathrm{~mm} /$ year. Most of the precipitation occurs in the spring and fall.

The existing hydropower plants and major non-powered dams (Hadjerioua et al., 2012) are also shown in Figure 17.1. The regions contain 47 hydropower dams and 9 major non-powered dams, with total storage capacities of about 38,948,518 ac-ft and 985,929 ac-ft, respectively. 


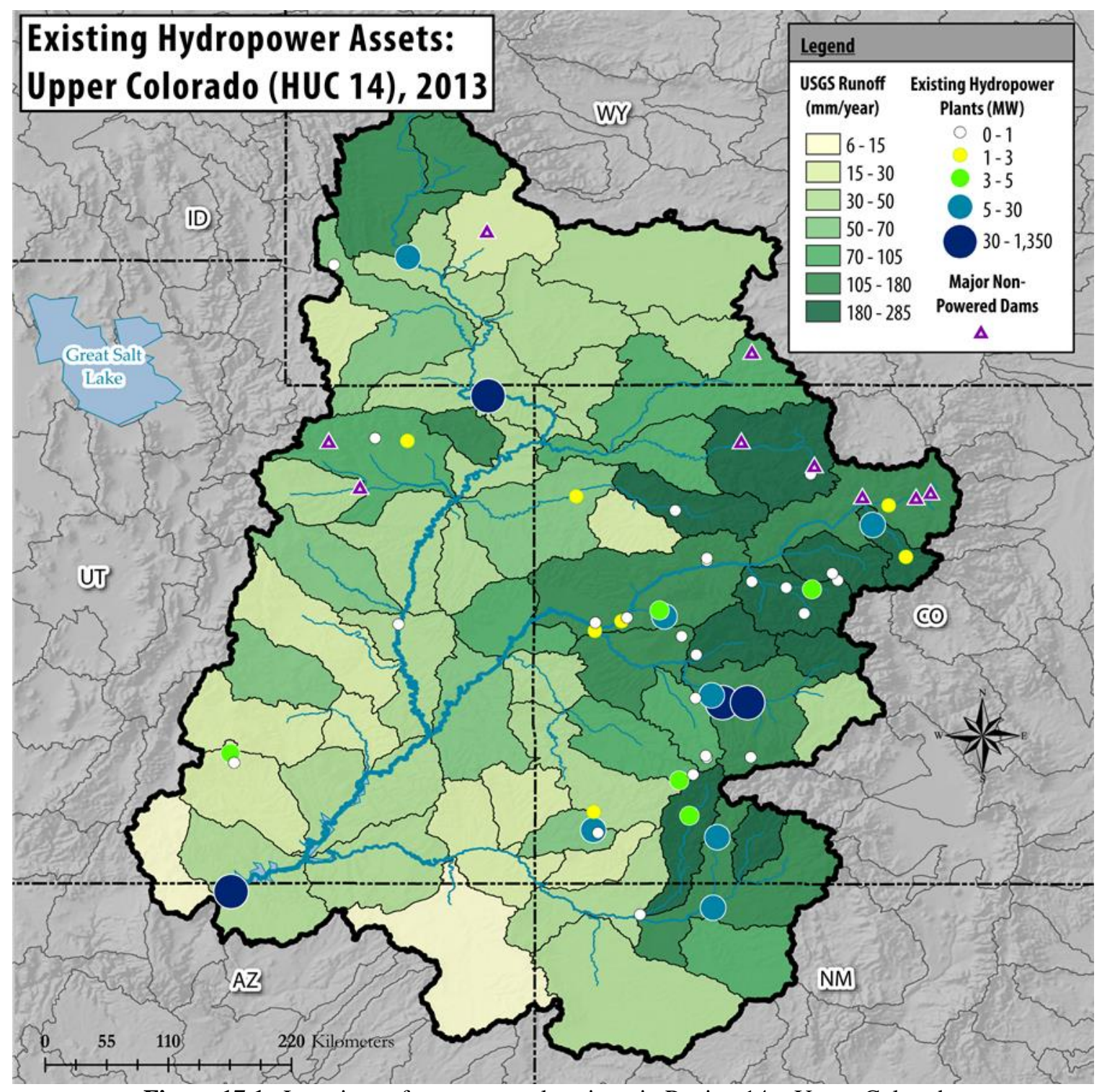

Figure 17.1. Locations of water control projects in Region 14-Upper Colorado.

\subsection{Potential New Hydropower Resources}

A total of 548 stream-reaches of high energy density (with estimated potential capacity $>1 \mathrm{MW}$ per stream-reach) are identified in the Upper Colorado region. The NSD results based on the HUC04 subregions are summarized in Table 17.2. The highest hydropower potential is found in the Colorado Headwaters Subregion (HUC 1401) and Lower Green Subregion (HUC 1406) in the Colorado and Green rivers. The next significant hydropower potential is located in the San Juan Subregion (HUC 1408) and Gunnison Subregion (HUC 1402) in the San Juan and Gunnison rivers. 


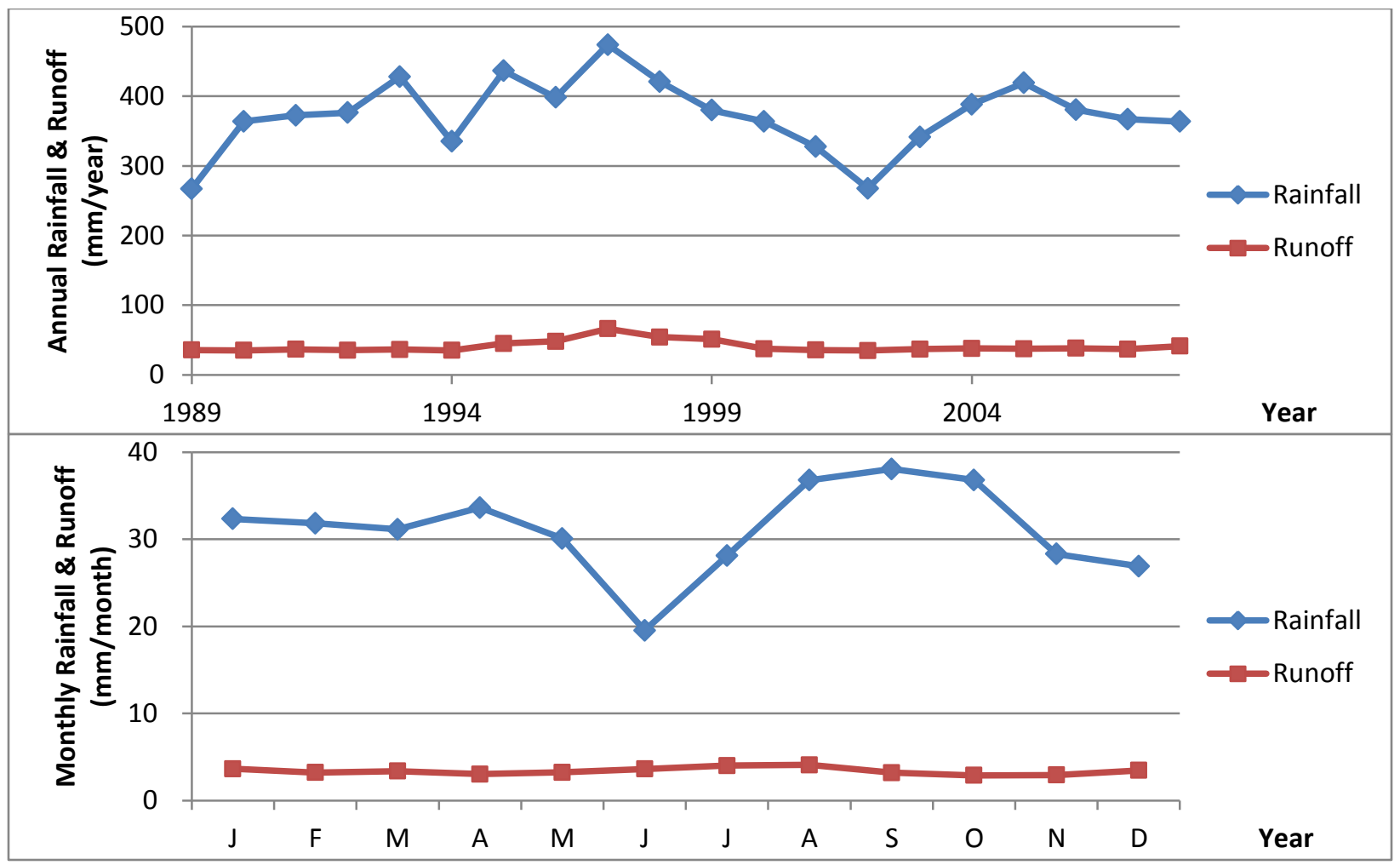

Figure 17.2. Annual and monthly rainfall and runoff of Region 14-Upper Colorado.

Table 17.2. Summary of Potential New Hydropower Resources in Region 14-Upper Colorado (Stream-Reaches with Potential Capacity $>1 \mathrm{MW}$ )

\begin{tabular}{|c|c|c|c|c|c|c|c|c|}
\hline HUC04 & HUC04 name & $\begin{array}{r}\text { \# of } \\
\text { stream- } \\
\text { reaches }\end{array}$ & $\begin{array}{r}\text { Potential } \\
\text { capacity } \\
(\mathrm{MW}) \\
\end{array}$ & $\begin{array}{r}\text { Potential } \\
\text { energy } \\
(\mathrm{MWh}) \\
\end{array}$ & $\begin{array}{r}\begin{array}{r}\text { Average } \\
\text { head }\end{array} \\
(\mathbf{f t} / \mathrm{reach}) \\
\end{array}$ & $\begin{array}{r}\text { Average } \\
\text { flow } \\
\text { (cfs/reach) } \\
\end{array}$ & $\begin{array}{r}\text { Average } \\
\text { storage (ac- } \\
\text { ft/reach) }\end{array}$ & $\begin{array}{r}\text { Average } \\
\text { residence } \\
\text { time (days) } \\
\end{array}$ \\
\hline 1401 & Colorado headwaters & 145 & 477.2 & $3,094,896$ & 16.8 & 2,742 & 1,069 & 0.1 \\
\hline 1402 & Gunnison & 73 & 245.8 & $1,521,138$ & 23.6 & 2,169 & 881 & 0.1 \\
\hline 1403 & $\begin{array}{l}\text { Upper Colorado-- } \\
\text { Dolores }\end{array}$ & 10 & 187.3 & $1,197,535$ & 42.5 & 6,143 & 24,262 & 1.0 \\
\hline 1404 & $\begin{array}{l}\text { Great Divide-Upper } \\
\text { Green }\end{array}$ & 50 & 75.0 & 484,209 & 9.4 & 2,243 & 323 & 0.0 \\
\hline 1405 & White-Yampa & 86 & 122.0 & 630,902 & 15.0 & 1,367 & 3,881 & 1.5 \\
\hline 1406 & Lower Green & 53 & 396.0 & $2,275,176$ & 21.1 & 4,882 & 6,679 & 0.3 \\
\hline 1407 & $\begin{array}{l}\text { Upper Colorado-Dirty } \\
\text { Devil }\end{array}$ & 8 & 186.2 & $1,182,748$ & 24.5 & 13,181 & 1,189 & 0.0 \\
\hline 1408 & San Juan & 123 & 252.0 & $1,458,867$ & 11.3 & 2,516 & 1,373 & 0.2 \\
\hline
\end{tabular}

The summary statistics of hydraulic head $\mathrm{H}_{\text {ref }}(\mathrm{ft})$, design flow $\mathrm{Q}_{30}(\mathrm{cfs})$, potential capacity $\mathrm{P}_{\mathrm{NSD}}$ $\left(\mathrm{MW}\right.$ ), inundated area $\mathrm{A}_{\mathrm{NSD}}(\mathrm{ac})$, storage $\mathrm{V}_{\mathrm{NSD}}$ (ac-ft), and residence time $\mathrm{T}_{\mathrm{NSD}}$ (day) are shown in Figure 17.3. The hydraulic head $\mathrm{H}_{\text {ref }}$ ranges from 0 to the 90 th quantile of $25 \mathrm{ft}$ with a median of $14 \mathrm{ft}$, suggesting that many of the potential stream-reaches will require low-head hydropower technologies. The design flow $\mathrm{Q}_{30}$ ranges from 1000 to the 90th quantile of $5500 \mathrm{cfs}$ with a median of about $2100 \mathrm{cfs}$. The potential capacity $\mathrm{P}_{\mathrm{NSD}}$ ranges from 1.75 to the 90 th quantile of $7.5 \mathrm{MW}$ with a median of about $2.5 \mathrm{MW}$. The inundated surface area $\mathrm{A}_{\mathrm{NSD}}$ ranges from 0 to the 90th quantile of 500 acres with a median of 100 acres. This results in storage values $\mathrm{V}_{\mathrm{NSD}}$ 
ranging from 0 to the 90th quantile of 4000 ac-ft with a median of 800 ac-ft with residence times $\mathrm{T}_{\mathrm{NSD}}$ ranging from a few hours to the 90th quantile of about 14 hours with a median on the order of a few hours. The results of $>1 \mathrm{MW}$ stream-reach potential are illustrated in Figure 17.4, with potential capacity (MW) aggregated to the HUC08 subbasins.

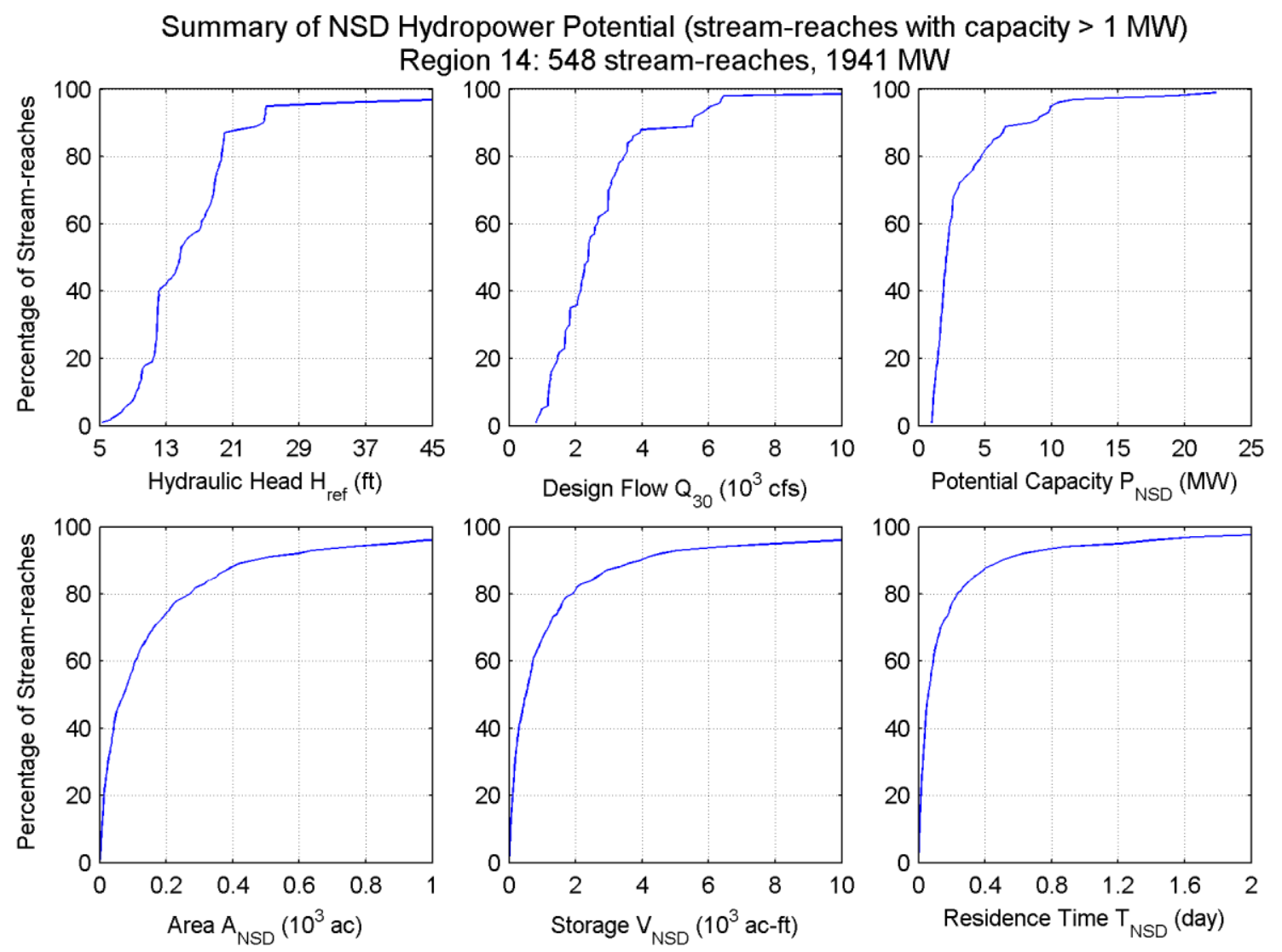

Figure 17.3. Cumulative distributions of hydraulic head $\mathrm{H}_{\text {ref }}$, design flow $\mathrm{Q}_{30}$, potential capacity $\mathrm{P}_{\mathrm{NSD}}$, inundated area $\mathrm{A}_{\mathrm{NSD}}$, storage $\mathrm{V}_{\mathrm{NSD}}$, and residence time $\mathrm{T}_{\mathrm{NSD}}$ in Region 14-Upper Colorado.

\subsection{Environmental Characteristics}

Of the 17 native fish species in the Upper Colorado Region, 11 fall under ESA and 14 fall under IUCN vulnerability categories. Endangered fish species include Bonytail (Gila elegans), Colorado pikeminnow (Ptychocheilus Lucius), humpback chub (Gila cypha), and razorback sucker (Xyrauchen texanus), all of which have critical habitat designations. Species with populations falling under ESA categories include Cutthroat trout, speckled dace, and bluehead sucker (Catostomus discobolus). Cutthroat trout and associated sub-species are the only fish species classified as potadromous in the region. Nine critical watersheds are located in this region, including mainstem or tributaries of the Green, Yampa, Gunnison, and Upper Colorado River systems (Mathews et al., 1998). In total, nine species, including the four fish listed above, have critical habitat designations in the region (Figure 17.5). 


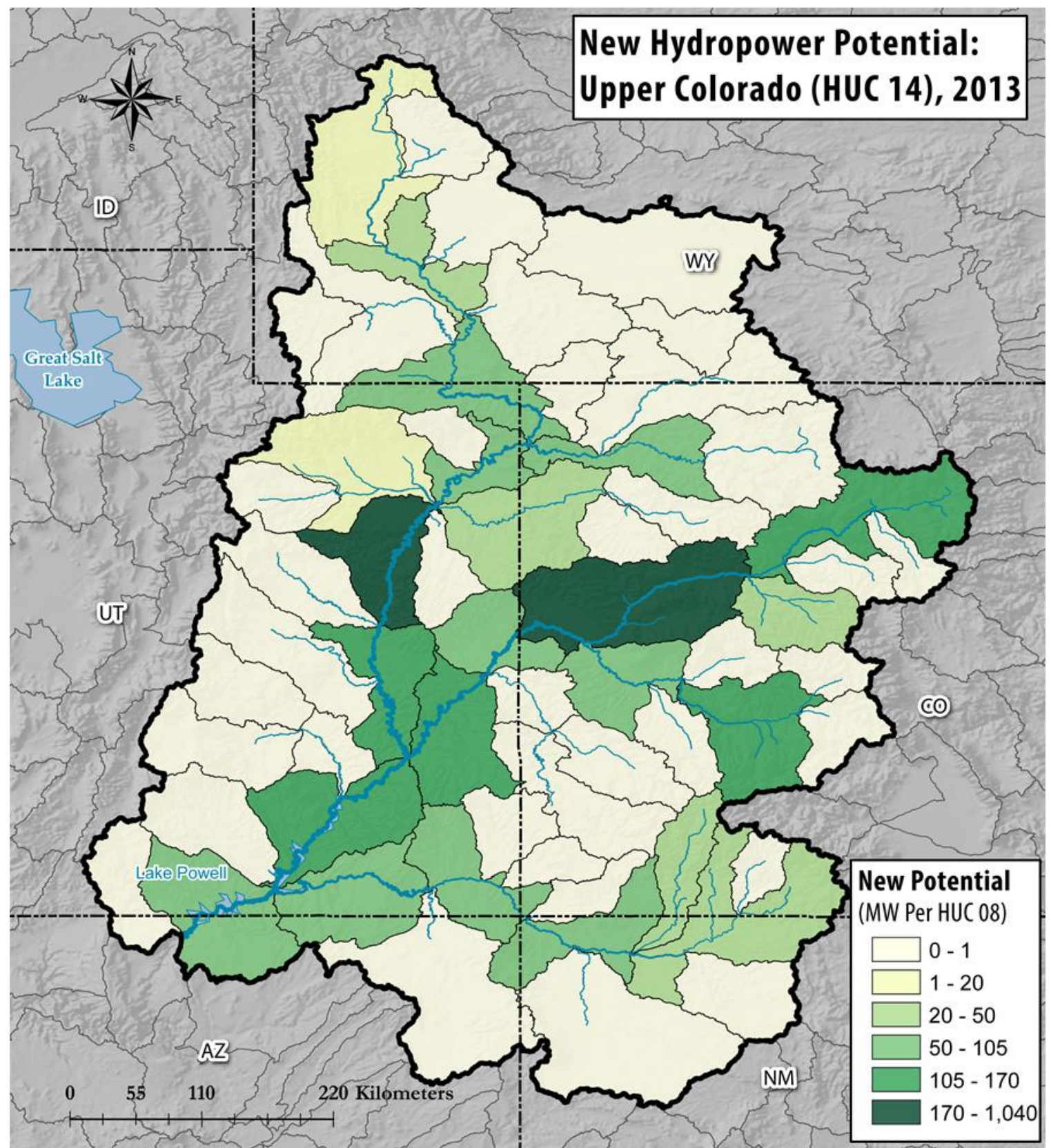

Figure 17.4. Potential new hydropower capacity in Region 14-Upper Colorado (higher-energy-density streamreaches with >1 MW per reach, aggregated to HUC08 subbasins for illustration).

Approximately 58 million acres of protected land (80\% of the total area) are identified in Region 14 (Figure 17.6). Over 75\% of protected lands are owned by federal entities, including BLM (31\%), USFS (23\%), DOD (9\%), NPS (4\%), and USFWS (1\%). Native American lands, composed of many reservations, make up $19 \%$ of protected lands, followed by state-owned areas $(6 \%)$, which are primarily composed of state trust lands. Besides BLM and state trust lands, the largest tracts include the Navajo Indian Reservation, Unitah and Ouray Indian Reservation, Glen Canyon National Recreation Area, and White River, San Juan, and Gunnison national forests. NPS lands include Canyonlands National Park, Rocky Mountain National Park, and Dinosaur National Monument. Region 14 has no rivers falling under NWSRA protection. Fewer boat 
ramps (113) are identified in Region 14 compared with other regions. However, other recreation types are common, including 226 fishing access locations, 52 waterfalls, and 172 recreational boating river sections.

The water usage of Region 14, primarily irrigation consumption, is slightly below the national average (Table 17.3 and Appendix B), with the highest values reported in the Gunnison Subregion. Overall, water quality concerns are very low relative to the remainder of the United States. Mercury contamination and low dissolved oxygen issues are the primary concerns (Appendix B).

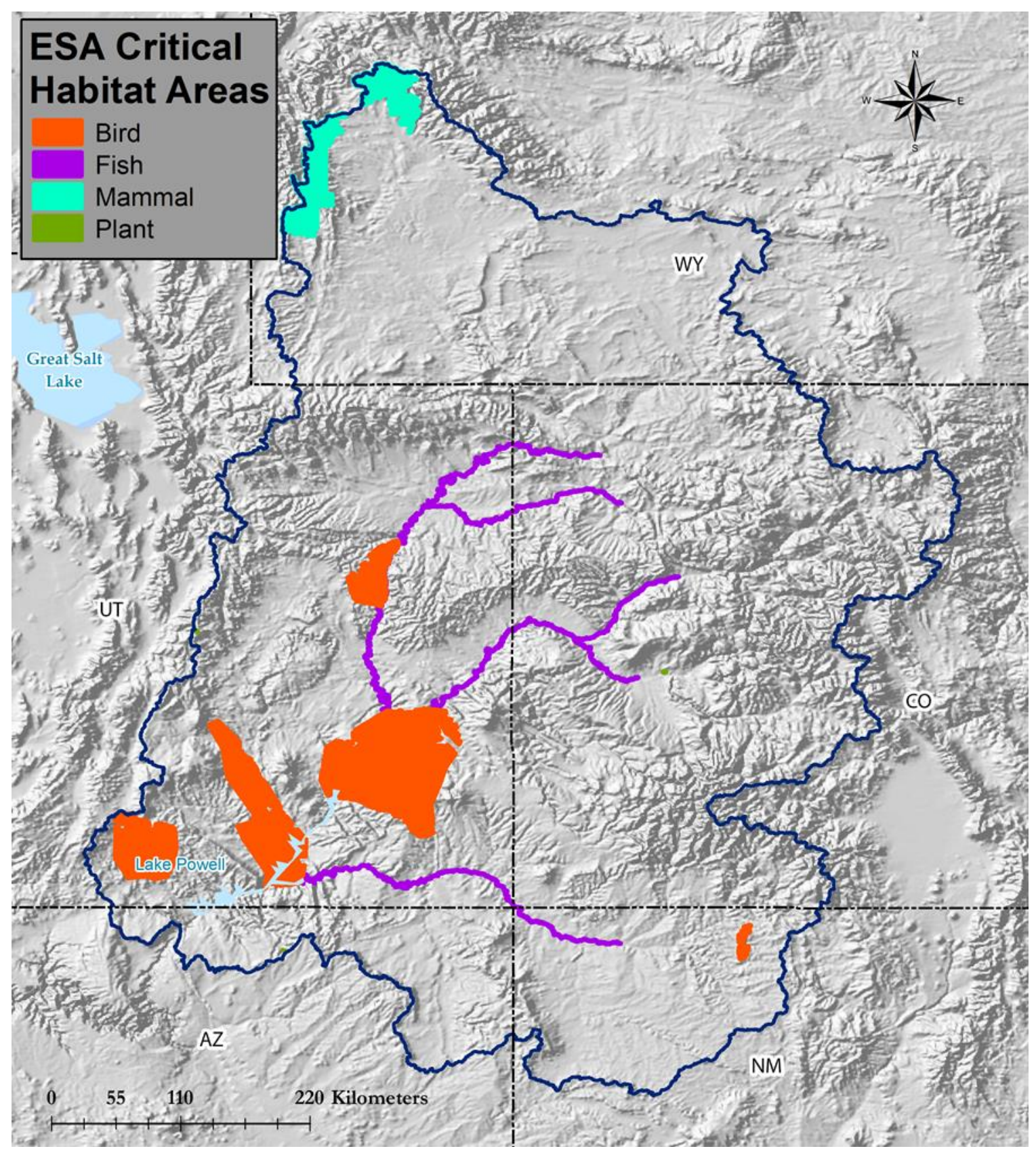

Figure 17.5. Critical habitats for federally endangered and threatened species in Region 14 . 


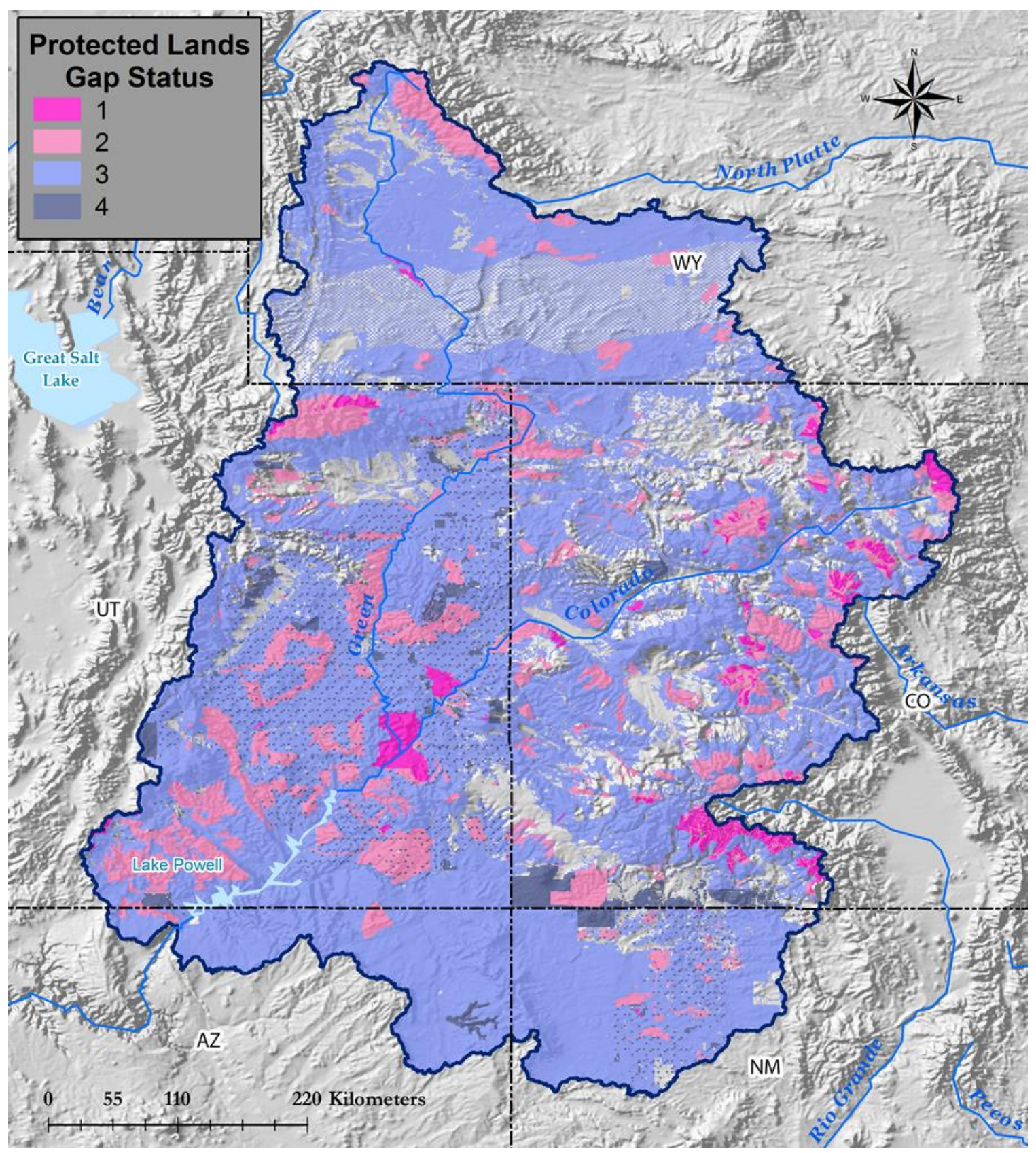

Figure 17.6. Protected lands according to Gap Status (conservation management regime) in Region 14.

Almost $67 \%$ of the 548 stream-reaches overlap with critical habitats (Figure 17.7). All streamreaches are located within HUC08 subbasins with at least 1 fish falling under ESA categories. Similarly, all stream-reaches intersect protected lands, with 41 stream-reaches (402 MW) overlapped with national parks. Water-quality concerns are present at $50 \%$ of stream-reaches $(>1.2 \mathrm{GW})$. Recreational boating is identified at $58 \%$ of stream-reaches; boat ramps and fishing access areas are present at $13 \%$ of stream-reaches with a total of 365 and $270 \mathrm{MW}$, respectively. Water usage is around uniform across stream-reaches, with $38 \%$ of reaches falling in the low to moderate categories. 
Table 17.3. Summary of Environmental Variables at HUC04 Subregions within Region 14 (Stream-Reaches with Potential Capacity $>1 \mathrm{MW})$

\begin{tabular}{|c|c|c|c|c|c|c|c|c|}
\hline HUC04 HUC04 name & $\begin{array}{r}\text { \# Critical } \\
\text { habitats }\end{array}$ & $\begin{array}{l}\text { \# Potad- } \\
\text { anad fish }\end{array}$ & $\begin{array}{r}\text { \# ESA } \\
\text { fish }\end{array}$ & $\begin{array}{r}\text { \# IUCN } \\
\text { fish }\end{array}$ & $\begin{array}{r}\# \\
\begin{array}{r}\text { Recreation } \\
\text { locations }\end{array}\end{array}$ & $\begin{array}{r}\% \\
\text { Protected } \\
\text { lands }\end{array}$ & $\begin{array}{r}\begin{array}{r}\text { Population } \\
\text { density } \\
\left(\text { ind } / \mathbf{k m}^{2}\right)\end{array} \\
\end{array}$ & $\begin{array}{r}\text { Freshwater } \\
\text { use (liters/day/ } \\
\left.\text { km }^{2}\right)\end{array}$ \\
\hline 1401 Colorado Headwaters & 4 & 1 & 6 & 3 & $47 ; 55 ; 12$ & 71.10 & 8.58 & $1,866.29$ \\
\hline 1402 Gunnison & 3 & 1 & 5 & 2 & $28 ; 23 ; 7$ & 72.94 & 4.16 & $3,340.47$ \\
\hline $\begin{array}{l}1403 \text { Upper Colorado- } \\
\text { Dolores }\end{array}$ & 5 & 1 & 7 & 4 & $18 ; 16 ; 7$ & 82.71 & 3.65 & $1,422.87$ \\
\hline $\begin{array}{l}\text { Great Divide-Upper } \\
\text { Green }\end{array}$ & 5 & 1 & 5 & 2 & $77 ; 13 ; 13$ & 73.40 & 1.47 & 431.49 \\
\hline 1405 White-Yampa & 4 & 1 & 6 & 3 & $20 ; 17 ; 3$ & 67.91 & 1.48 & 846.68 \\
\hline 1406 Lower Green & 6 & 1 & 7 & 4 & $84 ; 24 ; 2$ & 70.36 & 2.71 & 872.61 \\
\hline $\begin{array}{l}1407 \begin{array}{l}\text { Upper Colorado-Dirty } \\
\text { Devil }\end{array} \\
\end{array}$ & 7 & 1 & 6 & 3 & $25 ; 6 ; 2$ & 87.21 & 0.90 & 327.39 \\
\hline 1408 San Juan & 3 & 1 & 5 & 2 & $40 ; 31 ; 6$ & 31.08 & 4.08 & 833.26 \\
\hline
\end{tabular}

${ }^{a}$ Recreation locations refer to the number of boat-ramp and fishing access points, recreational boating, and waterfalls within each HUC04.

\section{ESA Critical Habitats}

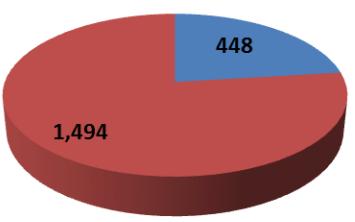

- Absent $\square$ Present

Water Quality Concern

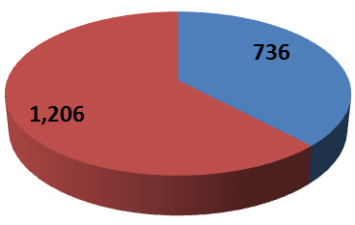

absent $\square$ Present
Number ESA Listed Fish

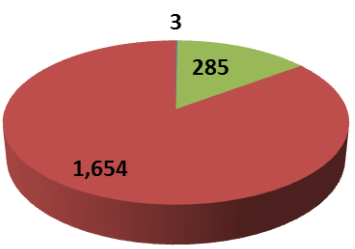

$\because 1 \backsim 2 \backsim 3 \square>3$

Recreation Boating

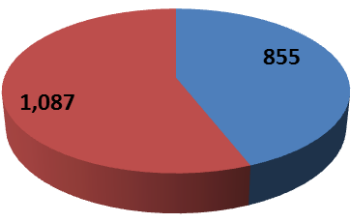

Absent Present
National Park Lands

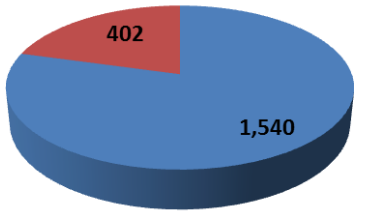

absent $\square$ Present

Fishing Access Areas

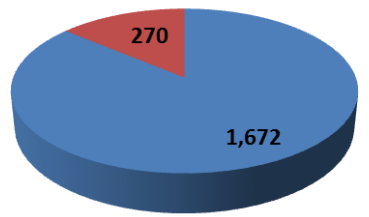

$\square$ Absent $\square$ Present
Wild and Scenic Rivers

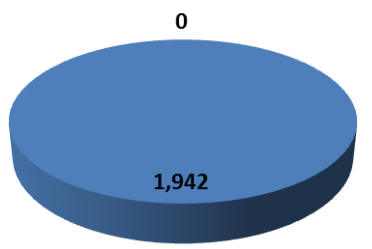

absent $\quad$ Present

Water Use

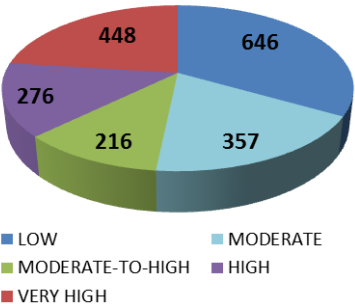

Figure 17.7. The potential capacity, in MW, associated with environmental attributes in Region 14-Upper Colorado (stream-reaches with potential capacity $>1 \mathrm{MW}$ ). 


\section{REGION 15-LOWER COLORADO}

\subsection{Summary of Findings}

Following NSD methodology (Hadjerioua et al., 2013), the potential capacity, annual generation, and mean capacity factors in the Lower Colorado Region are estimated and summarized in Table 18.1 for both larger ( $>1 \mathrm{MW})$ and smaller (<1 MW) stream-reaches. For comparison, the year2011 nameplate capacity, 2002-2011 average annual generation, and capacity factor of existing hydropower facilities are also listed (NHAAP, 2013). The total undeveloped NSD capacity is $2.61 \mathrm{GW}$, around $100 \%$ of existing conventional hydropower nameplate capacity. In terms of energy, the total undeveloped NSD generation is $18.23 \mathrm{TWh} /$ year, around $276 \%$ of annual net generation from existing conventional hydropower plants. Given the run-of-river assumption, NSD stream-reaches have higher capacity factors, especially compared with other larger-storage peaking-operation projects in this region. More detailed topographical analysis and environmental attribution are conducted for larger $(>1 \mathrm{MW})$ stream-reaches and discussed in Sections 18.3 and 18.4 .

Table 18.1. Summary of NSD Findings in Region 15-Lower Colorado

\begin{tabular}{l|r|r|r}
\hline & $\begin{array}{r}\text { Capacity } \\
\text { (MW) }\end{array}$ & $\begin{array}{r}\text { Generation } \\
(\mathbf{M W h})\end{array}$ & $\begin{array}{r}\text { Mean capacity } \\
\text { factor }^{\mathbf{b}}\end{array}$ \\
\hline Potential in undeveloped stream-reaches $(>1 \mathrm{MW})$ & 2,166 & $13,577,000$ & $72 \%$ \\
\hline Potential in undeveloped stream-reaches $(<1 \mathrm{MW})$ & 447 & $2,696,000$ & $69 \%$ \\
\hline Existing hydropower-conventional hydro & 2,625 & $5,892,000$ & $26 \%$ \\
\hline Existing hydropower-pumped storage & 194 & & \\
\hline
\end{tabular}

\subsection{Background Hydrologic Setting}

The Lower Colorado Region encompasses approximately $362,981 \mathrm{~km}^{2}$ of drainage area in the Southwest United States and contains parts of New Mexico, Utah, Nevada, California, and most of Arizona.

Several river systems are located in the Lower Colorado Region (Figure 18.1), including the Colorado, Bill Williams, Gila, Salt, San Pedro, Santa Cruz, and Verde rivers, with a total length of $4708 \mathrm{~km}$ (i.e., total length of streams with estimated discharge greater than $35 \mathrm{cfs}$ ). Metropolitan areas within the region include Tucson (AZ), Flagstaff (AZ), and Las Vegas (NV). As shown in Figure 18.2, annual precipitation for the Lower Colorado region ranges from 190 to $460 \mathrm{~mm} /$ year, and annual runoff ranges from a trace to $40 \mathrm{~mm} /$ year. Most precipitation occurs from late summer to early fall, yielding a relatively small runoff.

The existing hydropower plants and major non-powered dams (Hadjerioua et al., 2012) are also shown in Figure 18.1. The region contains 30 hydropower dams and 8 major non-powered dams, with total storage capacities of around 36,983,949 ac-ft and 6,718,025 ac-ft, respectively. 


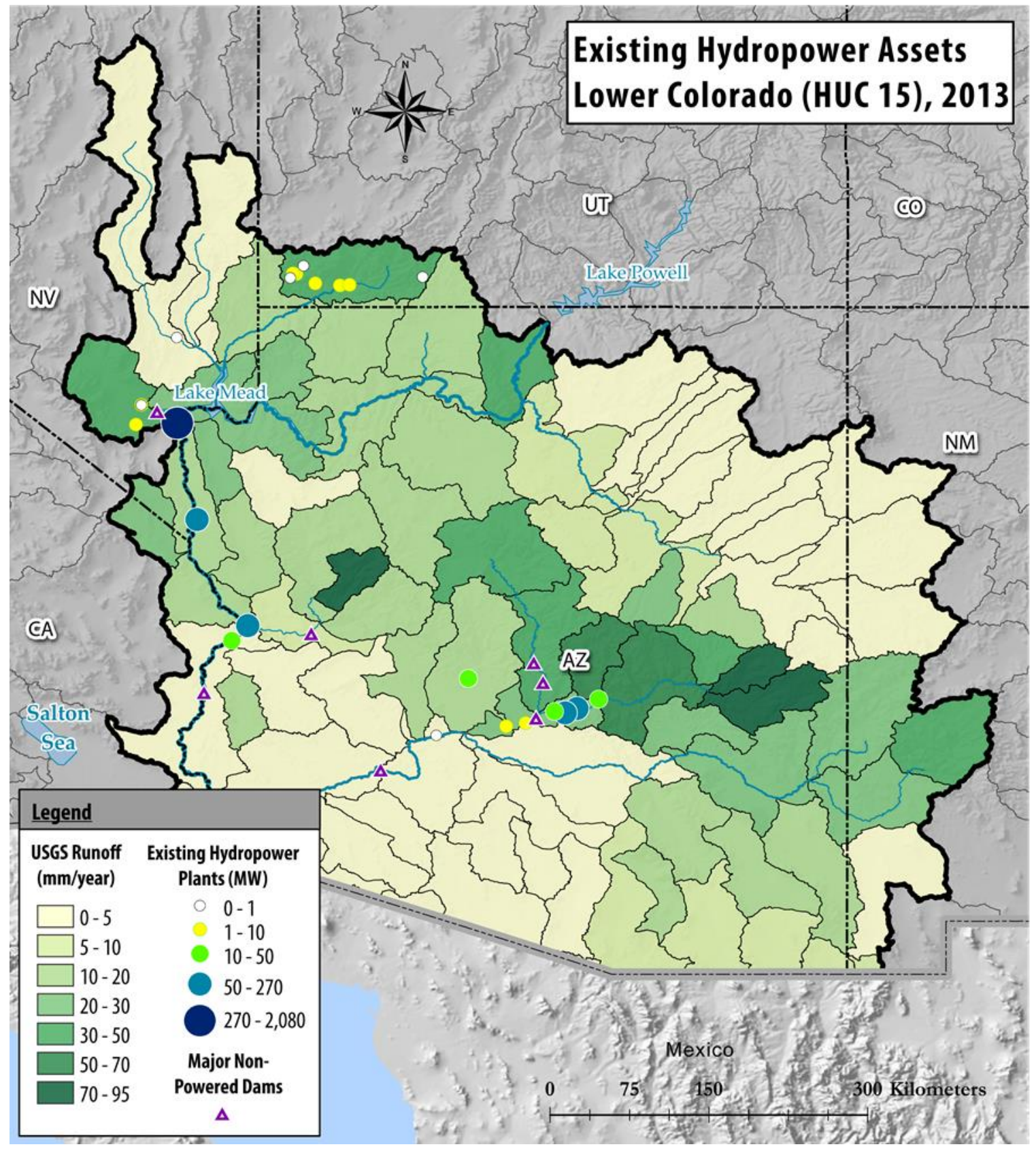

Figure 18.1. Locations of water control projects in Region 15-Lower Colorado.

\subsection{Potential New Hydropower Resources}

A total of 166 stream-reaches of high energy density (with estimated potential capacity $>1 \mathrm{MW}$ per stream-reach) are identified in the Lower Colorado Region. The NSD results based on the HUC04 subregions are summarized in Table 18.2. The highest hydropower potential is located in the Lower Colorado-Lake Mead Subregion (HUC 1501) in the Colorado River. The next highest potential is located in the Lower Colorado Subregion (HUC 1503) in the Colorado River as well. 


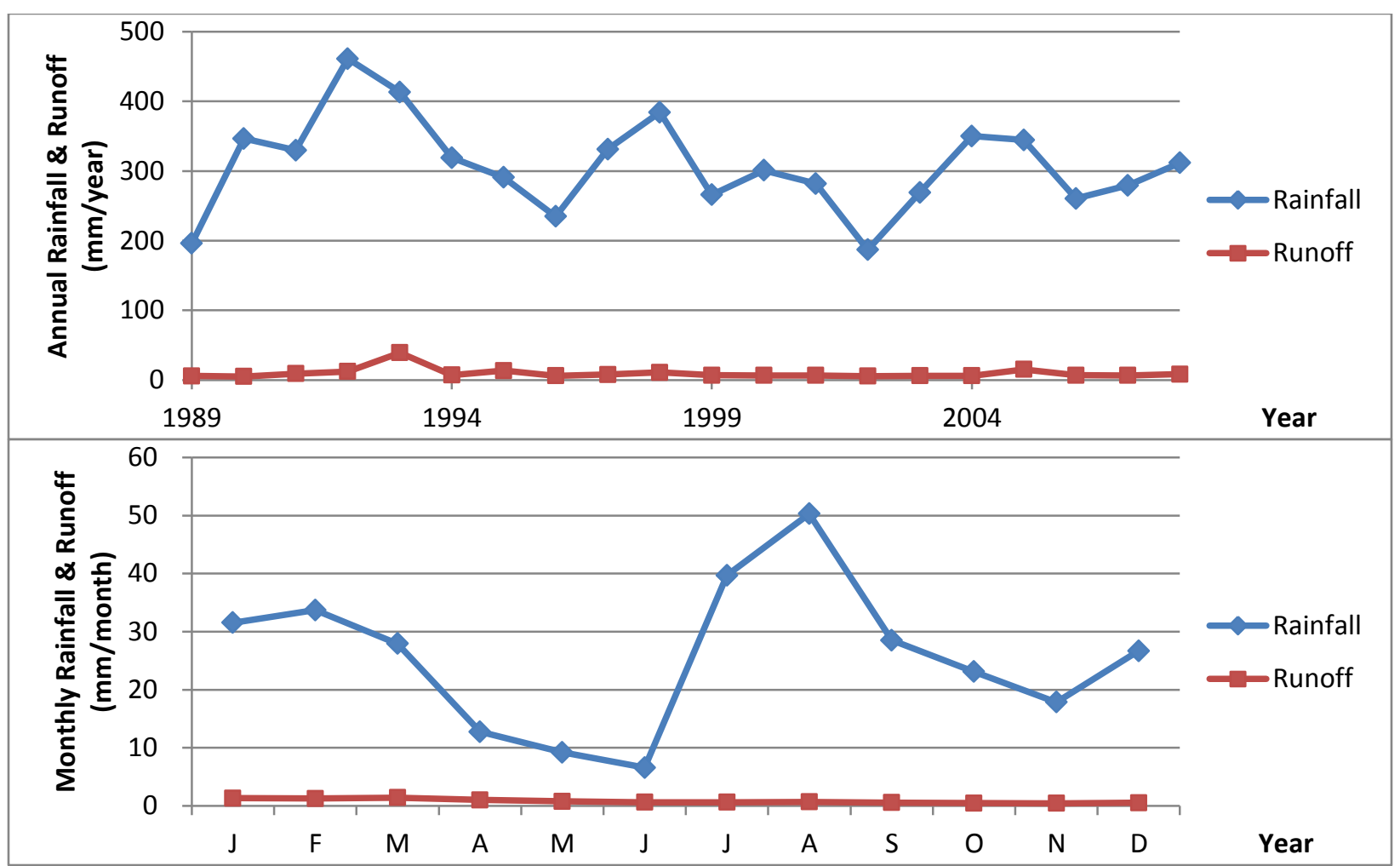

Figure 18.2. Annual and monthly rainfall and runoff of Region 15-Lower Colorado.

Table 18.2. Summary of Potential New Hydropower Resources in Region 15-Lower Colorado (Stream-Reaches with Potential Capacity >1 MW)

\begin{tabular}{|c|c|c|c|c|c|c|c|c|}
\hline HUC04 & HUC04 name & $\begin{array}{r}\text { \# of } \\
\text { stream- } \\
\text { reaches }\end{array}$ & $\begin{array}{r}\text { Potential } \\
\text { capacity } \\
(\mathrm{MW})\end{array}$ & $\begin{array}{r}\text { Potential } \\
\text { energy } \\
(\mathrm{MWh})\end{array}$ & $\begin{array}{r}\text { Average } \\
\text { head } \\
(\mathrm{ft} / \mathrm{reach})\end{array}$ & $\begin{array}{r}\text { Average } \\
\text { flow } \\
\text { (cfs/reach) }\end{array}$ & $\begin{array}{r}\text { Average } \\
\text { storage (ac- } \\
\text { ft/reach) }\end{array}$ & $\begin{array}{r}\text { Average } \\
\text { residence } \\
\text { time (days) }\end{array}$ \\
\hline 1501 & $\begin{array}{l}\text { Lower Colorado- } \\
\text { Lake Mead }\end{array}$ & 53 & $1,719.0$ & $10,784,611$ & 32.4 & 13,901 & 1,568 & 0.0 \\
\hline 1502 & Little Colorado & - & - & - & - & - & - & - \\
\hline 1503 & Lower Colorado & 20 & 299.2 & $1,898,739$ & 14.3 & 14,583 & 20,421 & 0.3 \\
\hline 1504 & Upper Gila & 14 & 15.6 & 92,507 & 25.9 & 601 & 11,333 & 20.3 \\
\hline 1505 & Middle Gila & 41 & 55.1 & 337,288 & 23.5 & 797 & 7,587 & 9.9 \\
\hline 1506 & Salt & 8 & 10.5 & 67,184 & 33.6 & 531 & 8,039 & 14.5 \\
\hline 1507 & Lower Gila & 30 & 67.0 & 396,501 & 22.7 & 1,363 & 28,900 & 22.3 \\
\hline 1508 & Sonora & - & - & - & - & - & - & - \\
\hline
\end{tabular}

The summary statistics of hydraulic head $\mathrm{H}_{\mathrm{ref}}$ (ft), design flow $\mathrm{Q}_{30}$ (cfs), potential capacity $\mathrm{P}_{\mathrm{NSD}}$ (MW), inundated area $A_{N S D}(\mathrm{ac})$, storage $\mathrm{V}_{\mathrm{NSD}}$ (ac-ft), and residence time $\mathrm{T}_{\mathrm{NSD}}$ (day) are shown in Figure 18.3. The hydraulic head $\mathrm{H}_{\text {ref }}$ ranges from 5 to the 90th quantile of $41 \mathrm{ft}$ with a median of $25 \mathrm{ft}$. The design flow $\mathrm{Q}_{30}$ ranges from 700 to the 90th quantile of $1400 \mathrm{cfs}$ with a median of about 1500 cfs. The potential capacity $P_{\text {NSD }}$ ranges from 1 to the 90th quantile of $40 \mathrm{MW}$ with a median of about 3.7 MW. The inundated surface area $A_{\mathrm{NSD}}$ ranges from 0 to the 90th quantile of 3800 acres with a median of 500 acres. This results in storage values $\mathrm{V}_{\mathrm{NSD}}$ ranging from 0 to the 90th quantile of 32,000 ac- $\mathrm{ft}$ with a median of 5,000 ac-ft, with residence times $\mathrm{T}_{\mathrm{NSD}}$ ranging from a few hours to the 90th quantile of about 1 month with a median of a few days. The results of $>1 \mathrm{MW}$ stream-reach potential are illustrated in Figure 18.4, with potential capacity (MW) aggregated to the HUC08 subbasins. 


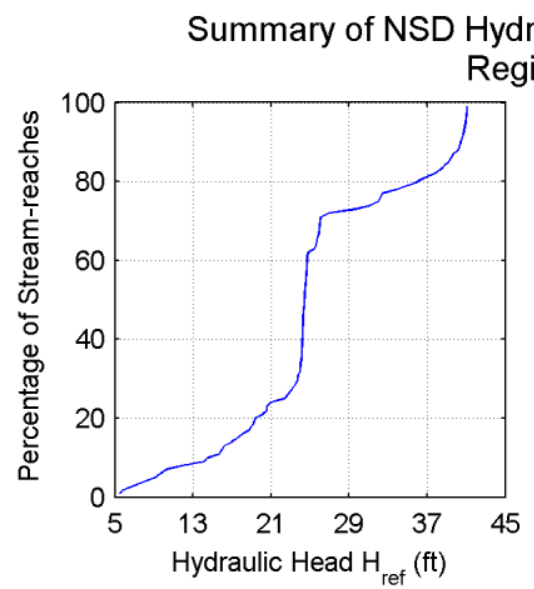

Hydropower Potential (stream-reaches with
Region 15: 166 stream-reaches, $2166 \mathrm{MW}$
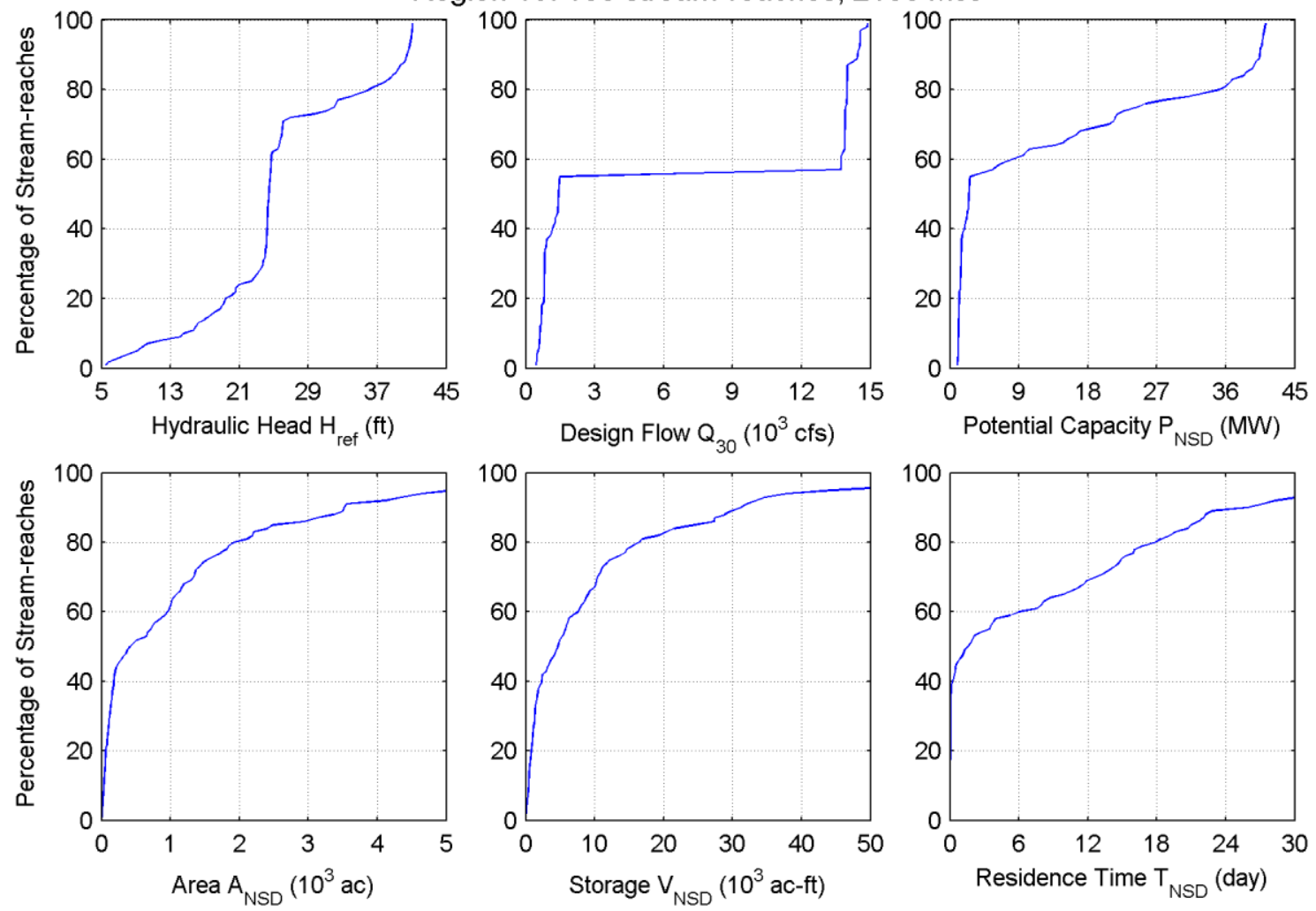

Figure 18.3. Cumulative distributions of hydraulic head $\mathrm{H}_{\text {ref }}$, design flow $\mathrm{Q}_{30}$, potential capacity $\mathrm{P}_{\mathrm{NSD}}$, inundated area $\mathrm{A}_{\mathrm{NSD}}$, storage $\mathrm{V}_{\mathrm{NSD}}$, and residence time $\mathrm{T}_{\mathrm{NSD}}$ in Region 15-Lower Colorado.

\subsection{Environmental Characteristics}

Twenty-three of the 34 native fish species in the Lower Colorado Region fall under ESA categories, including 11 endangered and 6 threatened species. Four species have populations that are endangered (2) or threatened (2). Six of the fish under ESA categories are western chubs, a species in the Gila genus (Cyprinidae or minnow family). Razorback sucker, desert pupfish (Cyprinodon macularius), Devil's Hole pupfish (Cyprinodon diabolis), Moapa dace (Moapa coriacea), White River spinedace (Lepidomeda albivallis), and woundfin (Plagopterus argentissimus) are other endangered fishes in the region. Cutthroat trout is the only species considered potadromous in the region. Eighteen critical watersheds located in this region each have one to seven fish or mussel species at risk (Mathews et al., 1998). Twenty-six species have critical habitat designations, including several listed above (Figure 18.5).

Almost 74 million acres of protected land, 82\% of the total area, are located in Region 15 (Figure 18.6). Federal lands comprise $61 \%$ of protected areas and are owned by BLM (30\%), USFS (20\%), NPS (4.5\%), DOD (4\%), and USFWS (3\%). Many Indian reservations are located in this region, with a total of $23 \%$ of protected lands. State lands, primarily state trust areas, account for $14 \%$ of protected lands. Besides BLM and state lands, the largest tracts include Indian reservations, national forests, and military bases. Among the largest tracts is the 1.2 million acre Grand Canyon National Park (Figure 18.6). The vast majority of protected areas fall under GAP 
Status 3 lands (61\%), followed by status 4 (20\%) and status 2 (15\%) lands (Figure 18.6). The Verge National Wild and Scenic River is located in Region 15. Recreation includes 182 boat ramps, 196 fishing access locations, and 39 waterfalls. Of the 49 recreational boating river sections, three include various sections of the Colorado River.

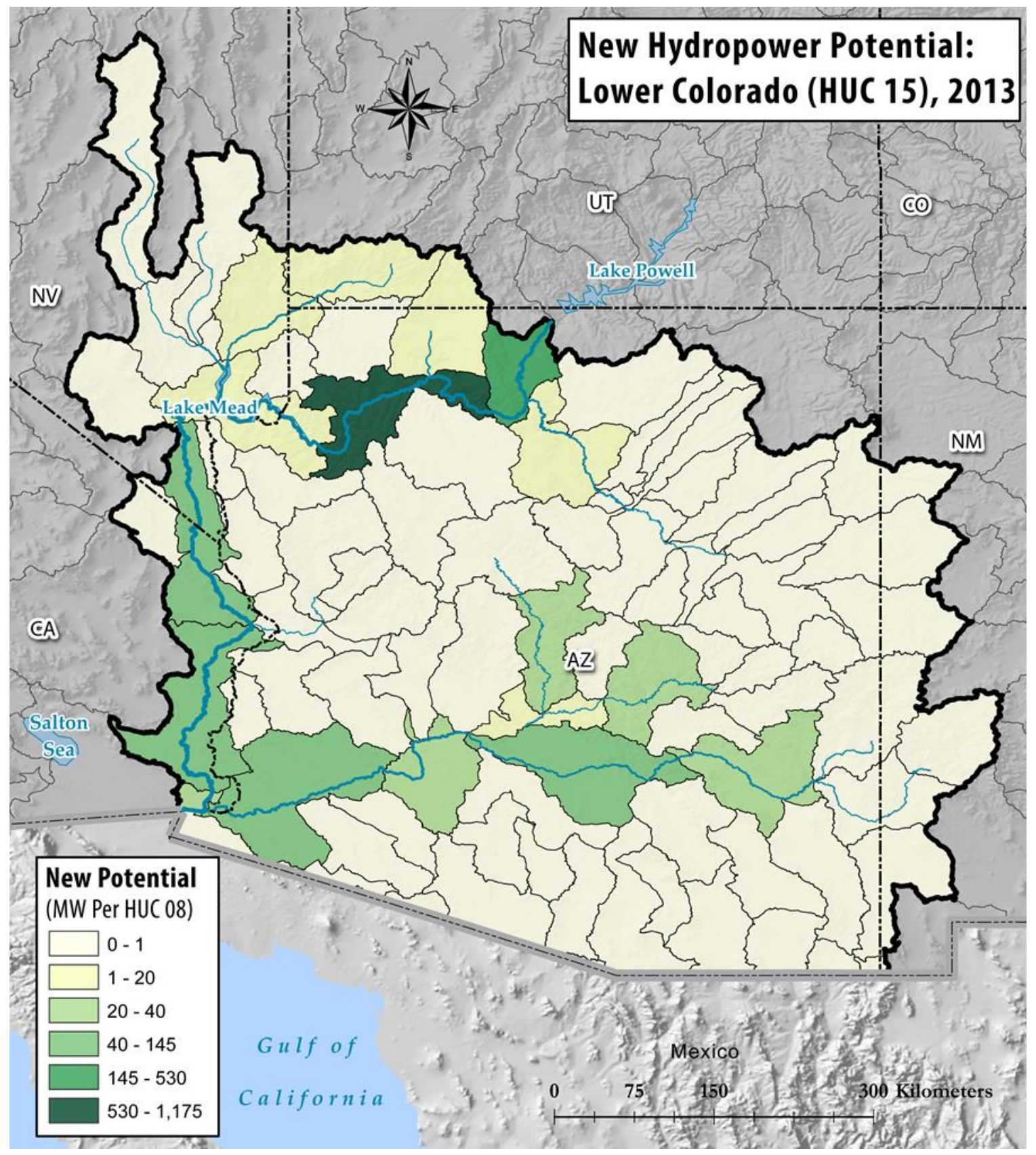

Figure 18.4. Potential new hydropower capacity in Region 15-Lower Colorado (higher-energy-density streamreaches with >1 MW per reach, aggregated to HUC08 subbasins for illustration). 


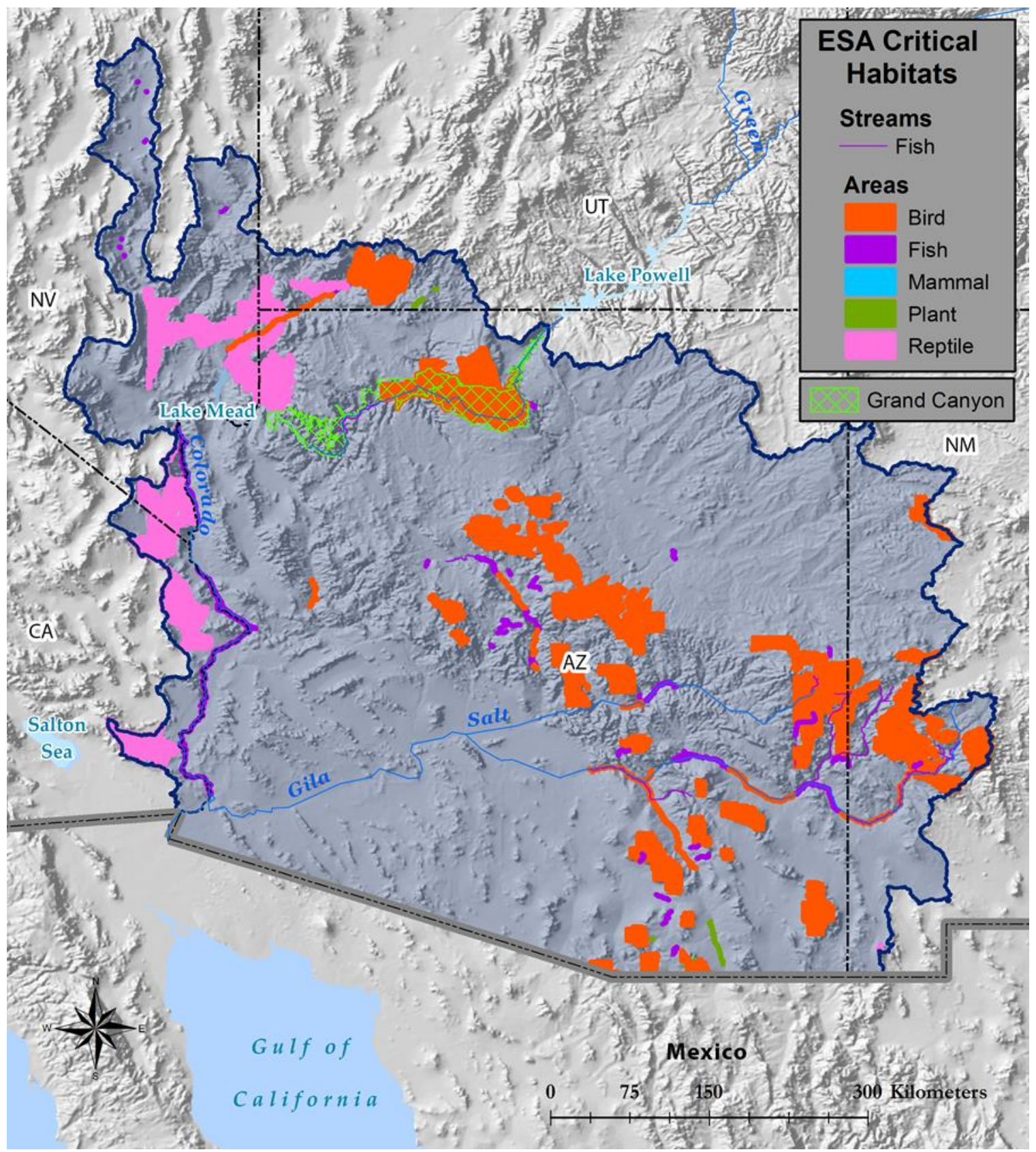

Figure 18.5. Critical habitats for federally endangered and threatened species along with spatial coverage of Grand Canyon National Park in Region 15.

Similar to the Upper Colorado Region, water use is below the national average in Region 15. Most water use is for irrigation, followed by domestic consumption (Appendix B). Highest levels of water use are reported in the Lower Gila Subregion (Table 18.3). Water quality concerns are the least prevalent in Region 15. Mercury contamination, dissolved oxygen, nutrient loading, and toxins are the main concerns. 


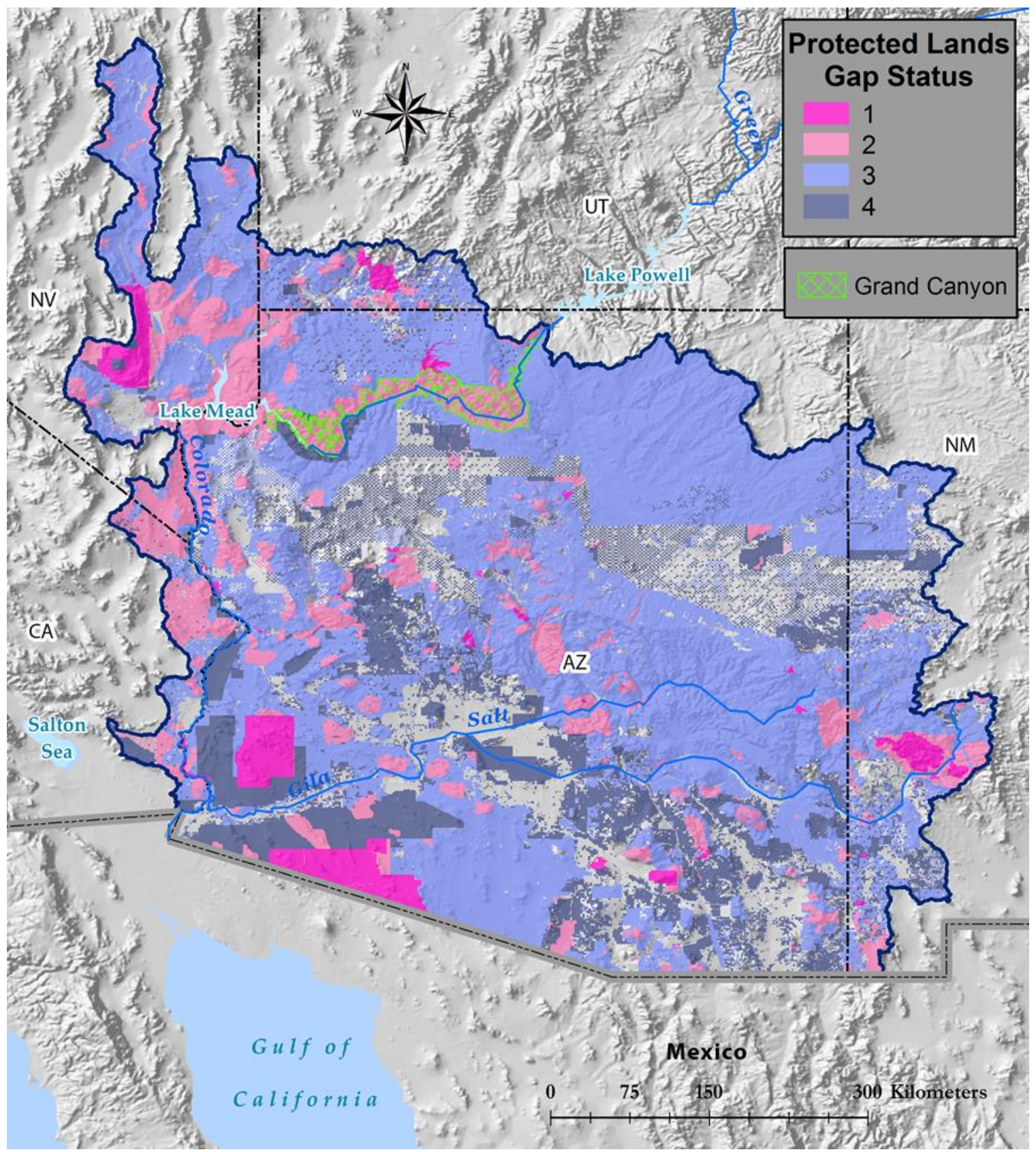

Figure 18.6. Protected lands according to Gap Status (conservation management regime) in Region 15. Grand Canyon National Park location is labeled.

Over $54 \%$ of the 166 stream-reaches $(1.65 \mathrm{GW})$ overlap with critical habitats (Figure 18.7). Most stream-reaches $(82 \%)$ are located in HUC08 subbasins with at least one fish falling under an ESA category. All stream-reaches intersect protected lands, with $32 \%$ percent of stream-reaches overlapping national parks, primarily Grand Canyon National Park. The total potential capacity associated with those reaches is around $1.7 \mathrm{GW}$, roughly $79 \%$ of the total energy capacity for Region 15. Eleven stream-reaches intersect Wild and Scenic Rivers. Water quality concerns are 
not as prevalent as in other regions, intersecting only 33\% of stream-reaches. Recreational boating is relatively common, identified at $46 \%$ of stream-reaches $(\sim 1.45 \mathrm{GW})$. Other recreation - boat ramps and fishing access areas - are less common, only identified at 9 and 16 stream-reaches, respectively. The majority of stream-reaches fall within HUC08 subbasins with low water use values.

Table 18.3. Summary of Environmental Variables at HUC04 Subregions within Region 15 (Stream-Reaches with Potential Capacity $>1 \mathrm{MW}$ )

\begin{tabular}{|c|c|c|c|c|c|c|c|c|}
\hline HUC04 HUC04 name & $\begin{array}{r}\text { \# Critical } \\
\text { habitats }\end{array}$ & $\begin{array}{l}\text { \# Potad- } \\
\text { anad fish }\end{array}$ & $\begin{array}{r}\text { \# ESA } \\
\text { fish }\end{array}$ & $\begin{array}{r}\# \\
\text { IUCN } \\
\text { fish } \\
\end{array}$ & $\begin{array}{r}\# \\
\text { Recreation } \\
\text { locations }^{\mathrm{a}}\end{array}$ & $\begin{array}{r}\% \\
\text { Protected } \\
\text { lands } \\
\end{array}$ & $\begin{array}{r}\text { Population } \\
\text { density } \\
\left(\text { ind } / \mathbf{k m}^{2}\right) \\
\end{array}$ & $\begin{array}{r}\text { Freshwater } \\
\text { use (liters/day/ } \\
\left.\mathbf{k m}^{\mathbf{2}}\right) \\
\end{array}$ \\
\hline $\begin{array}{l}1501 \begin{array}{l}\text { Lower Colorado-Lake } \\
\text { Mead }\end{array} \\
\end{array}$ & 11 & 1 & 11 & 6 & $59 ; 11 ; 20$ & 79.34 & 13.84 & 297.60 \\
\hline 1502 Little Colorado & 5 & 0 & 7 & 5 & $85 ; 4 ; 4$ & 29.99 & 2.95 & 63.38 \\
\hline 1503 Lower Colorado & 6 & 0 & 6 & 4 & $87 ; 3 ; 3$ & 79.79 & 12.95 & $1,582.63$ \\
\hline 1504 Upper Gila & 8 & 0 & 7 & 4 & $28 ; 8 ; 4$ & 71.54 & 2.53 & 294.56 \\
\hline 1505 Middle Gila & 7 & 0 & 5 & 3 & $16 ; 1 ; 3$ & 54.77 & 24.70 & $1,315.55$ \\
\hline 1506 Salt & 7 & 0 & 7 & 5 & $93 ; 23 ; 2$ & 59.90 & 22.01 & 564.42 \\
\hline 1507 Lower Gila & 2 & 0 & 3 & 1 & $10 ; 0 ; 3$ & 80.69 & 72.59 & $2,297.38$ \\
\hline 1508 Sonora & 8 & 0 & 3 & 3 & $0 ; 0 ; 0$ & 37.68 & 18.44 & 716.79 \\
\hline
\end{tabular}

${ }^{a}$ Recreation locations refer to the number of boat-ramp and fishing access points, recreational boating, and waterfalls within each HUC04.

ESA Critical Habitats

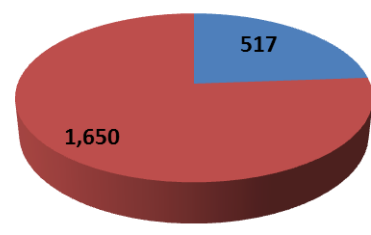

absent $\square$ Present

Water Quality Concern

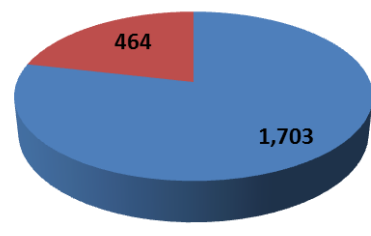

absent $\square$ Present

\section{Number ESA Listed Fish}

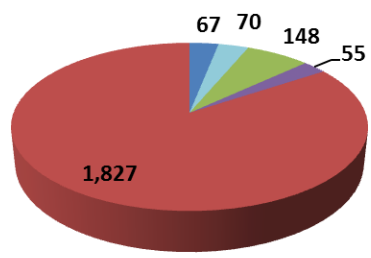

$\because 0=1=2 \llbracket 3=>3$

Recreation Boating

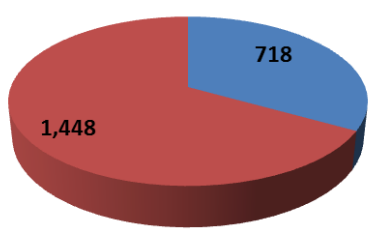

Absent m Present
National Park Lands

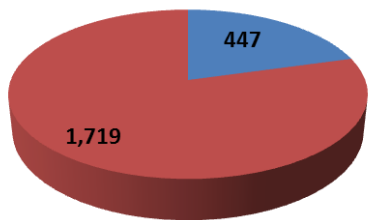

absent $=$ Present

Fishing Access Areas

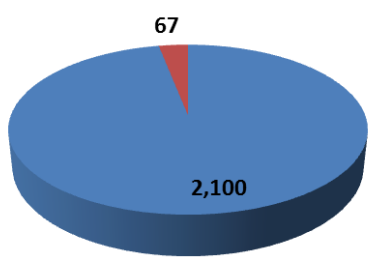

— Absent $\square$ Present
Wild and Scenic Rivers

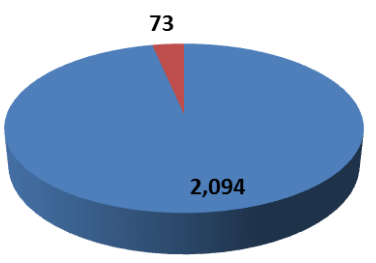

absent $\square$ Present

Water Use

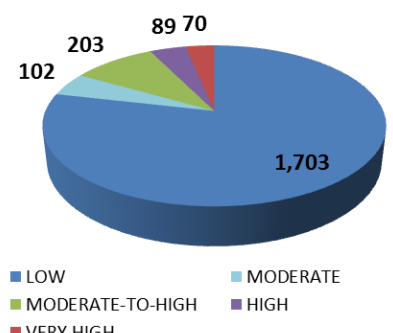

I VERY HIGH

Figure 18.7. The potential capacity, in MW, associated with environmental attributes in Region 15-Lower Colorado (stream-reaches with potential capacity $>1 \mathrm{MW}$ ). 


\section{REGION 16-GREAT BASIN}

\subsection{Summary of Findings}

Following NSD methodology (Hadjerioua et al., 2013), the potential capacity, annual generation, and mean capacity factors in the Great Basin Region are estimated and summarized in Table 19.1 for both larger ( $>1 \mathrm{MW})$ and smaller (<1 MW) stream-reaches. For comparison, the year-2011 nameplate capacity, 2002-2011 average annual generation, and capacity factor of existing hydropower facilities are also listed (NHAAP, 2013). The total undeveloped NSD capacity is $564 \mathrm{MW}$, around $262 \%$ of existing conventional hydropower nameplate capacity. In terms of energy, the total undeveloped NSD generation is $3.11 \mathrm{TWh} / \mathrm{year}$, around $650 \%$ of annual net generation from existing conventional hydropower plants. Given the run-of-river assumption, NSD stream-reaches have higher capacity factors, especially compared with other larger-storage peaking-operation projects in this region. More detailed topographical analysis and environmental attribution are conducted for larger $(>1 \mathrm{MW})$ stream-reaches and discussed in Sections 19.3 and 19.4.

Table 19.1. Summary of NSD Findings in Region 16-Great Basin

\begin{tabular}{l|r|r|r}
\hline & $\begin{array}{r}\text { Capacity } \\
\text { (MW) }\end{array}$ & $\begin{array}{r}\text { Generation } \\
\text { (MWh) }\end{array}$ & $\begin{array}{r}\text { Mean capacity } \\
\text { factor }\end{array}$ \\
\hline Potential in undeveloped stream-reaches $(>1 \mathrm{MW})$ & 148 & 845,000 & $65 \%$ \\
\hline Potential in undeveloped stream-reaches $(<1 \mathrm{MW})$ & 416 & $2,260,000$ & $62 \%$ \\
\hline Existing hydropower-conventional hydro & 0 & & $25 \%$ \\
\hline Existing hydropower-pumped storage & 0 & & \\
\hline
\end{tabular}

\subsection{Background Hydrologic Setting}

The Great Basin Region encompasses approximately $367,049 \mathrm{~km}^{2}$ of drainage area in the western lower-central part of the United States and contains small sections of California, Wyoming, Idaho, and Oregon, and larger sections of Nevada and Utah.

Several river systems are located in the Great Basin Region (Figure 19.1), including Bear, Weber, Jordan, Humboldt, Carson, Truckee, and Walker rivers, with a total length of $7662 \mathrm{~km}$ (i.e., total length of streams with estimated discharge greater than $35 \mathrm{cfs}$ ). Metropolitan areas within the region include Salt Lake City (UT). As shown in Figure 19.2, the annual precipitation for the Great Basin region ranges from 210 to $470 \mathrm{~mm} /$ year, and annual runoff ranges from 20 to $90 \mathrm{~mm} /$ year. Most precipitation occurs during the winter months. The peak runoff coincides with the spring snowmelt.

The existing hydropower plants and major non-powered dams (Hadjerioua et al., 2012) are also shown in Figure 19.1. The region contains 73 hydropower dams and 6 major non-powered dams, with total storage capacities of around 1,304,569 ac-ft and 451,670 ac-ft, respectively. 


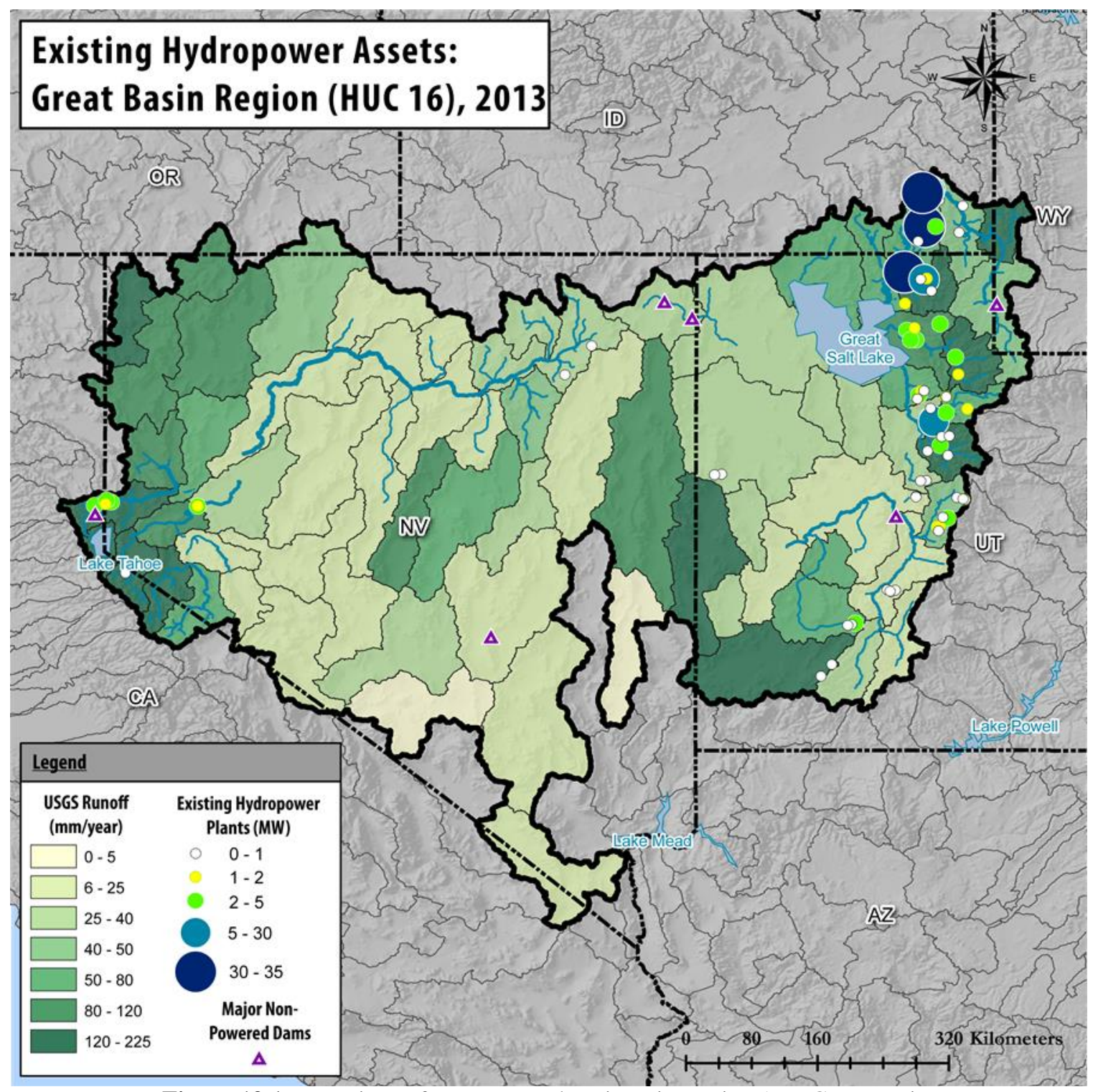

Figure 19.1. Locations of water control projects in Region 16- Great Basin.

\subsection{Potential New Hydropower Resources}

A total of 106 stream-reaches of high energy density (with estimated potential capacity $>1 \mathrm{MW}$ per stream-reach) are identified in the Great Basin Region. The NSD results based on the HUC04 Subregions are summarized in Table 19.2. The highest hydropower potentials are found in Bear Subregion (HUC 1601), followed by the Central Lahontan Subregion (HUC 1605), and the Bear, West Walker, West Fork of Old River, Carson, and Truckee rivers.

The summary statistics of hydraulic head $\mathrm{H}_{\mathrm{ref}}(\mathrm{ft})$, design flow $\mathrm{Q}_{30}(\mathrm{cfs})$, potential capacity $\mathrm{P}_{\mathrm{NSD}}$ (MW), inundated area $\mathrm{A}_{\mathrm{NSD}}(\mathrm{ac})$, storage $\mathrm{V}_{\mathrm{NSD}}\left(\mathrm{ac}-\mathrm{ft}\right.$ ), and residence time $\mathrm{T}_{\mathrm{NSD}}$ (day) are shown in Figure 19.3. The hydraulic head $\mathrm{H}_{\text {ref }}$ ranges from 11 to the 90th quantile of $41 \mathrm{ft}$ with a median of $21 \mathrm{ft}$, suggesting that many of the potential stream-reaches will require low-head hydropower technologies. The design flow $\mathrm{Q}_{30}$ ranges from 300 to the 90th quantile of $1200 \mathrm{cfs}$ with a 
median of about $1000 \mathrm{cfs}$. The potential capacity $\mathrm{P}_{\mathrm{NSD}}$ ranges from 1.1 to the 90 th quantile of 1.8 MW with a median of about 1.3 MW. The inundated surface area $A_{N S D}$ ranges from 0 to the 90 th quantile of 1200 acres with a median of 150 acres. This results in storage values $\mathrm{V}_{\text {NSD }}$ ranging from 0 to the 90th quantile of 12,000 ac-ft with a median of $1,500 \mathrm{ac}-\mathrm{ft}$, with residence times $\mathrm{T}_{\mathrm{NSD}}$ ranging from a few hours to the 90th quantile of about 4 days with a median of less than a day. The results of $>1 \mathrm{MW}$ stream-reach potential are illustrated in Figure 19.4, with potential capacity (MW) aggregated to the HUC08 subbasins.

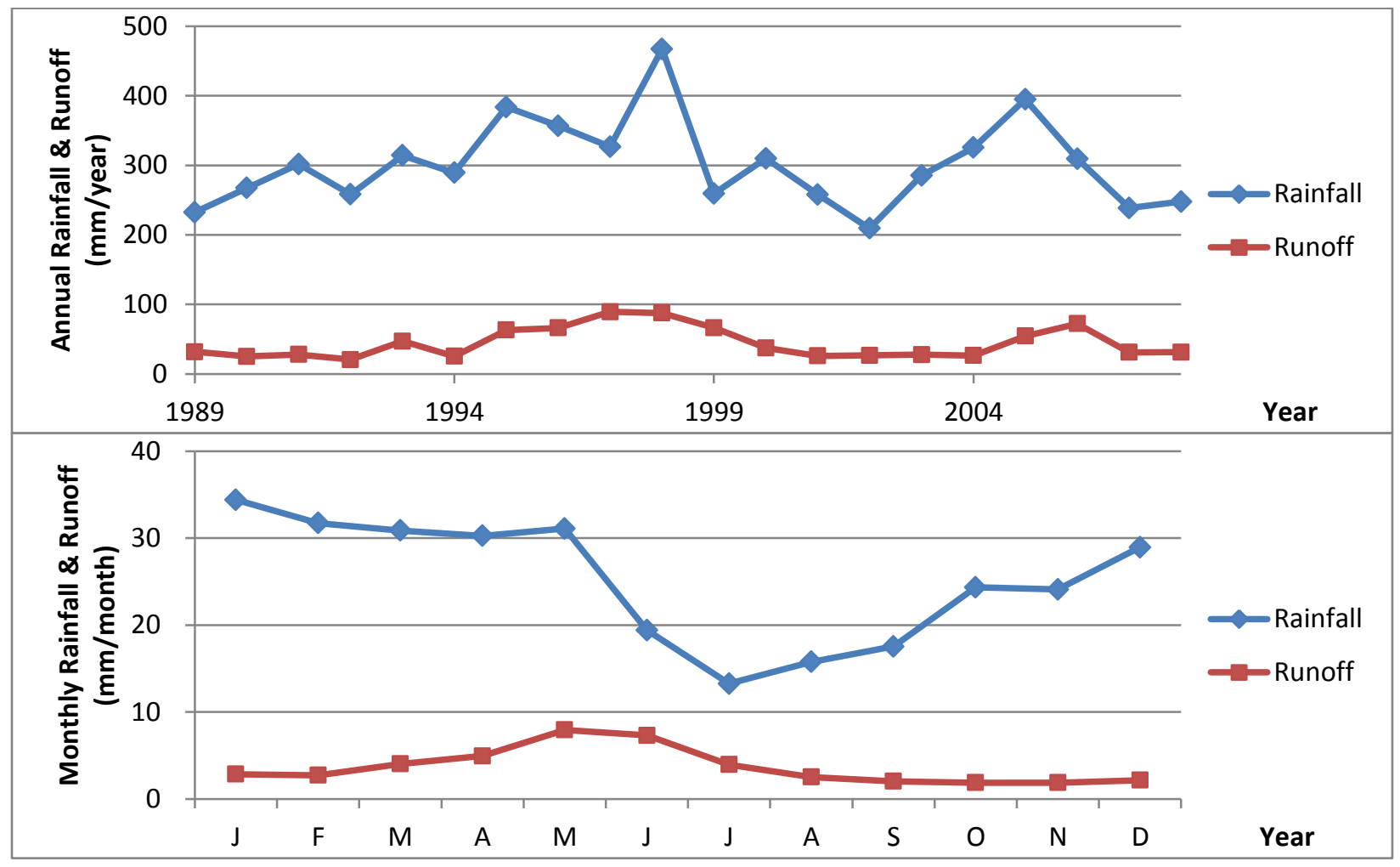

Figure 19.2. Annual and monthly rainfall and runoff of Region 16-Great Basin.

Table 19.2. Summary of Potential New Hydropower Resources in Region 16-Great Basin (Stream-Reaches with Potential Capacity $>1 \mathrm{MW}$ )

\begin{tabular}{|c|c|c|c|c|c|c|c|c|}
\hline HUC04 & HUC04 name & $\begin{array}{r}\text { \# of } \\
\text { stream- } \\
\text { reaches }\end{array}$ & $\begin{array}{r}\text { Potential } \\
\text { capacity } \\
(\mathrm{MW})\end{array}$ & $\begin{array}{r}\text { Potential } \\
\text { energy } \\
(\mathrm{MWh})\end{array}$ & $\begin{array}{r}\text { Average } \\
\text { head } \\
\text { (ft/reach) }\end{array}$ & $\begin{array}{r}\text { Average } \\
\text { flow } \\
\text { (cfs/reach) }\end{array}$ & $\begin{array}{r}\text { Average } \\
\text { storage (ac- } \\
\text { ft/reach) }\end{array}$ & $\begin{array}{r}\text { Average } \\
\text { residence } \\
\text { time (days) }\end{array}$ \\
\hline 1601 & Bear & 47 & 71.8 & 418,909 & 19.3 & 1,125 & 2,309 & 0.4 \\
\hline 1602 & Great Salt Lake & 15 & 19.4 & 106,384 & 40.5 & 444 & 2,281 & 2.0 \\
\hline 1603 & $\begin{array}{l}\text { Escalante Desert- } \\
\text { Sevier Lake }\end{array}$ & - & - & - & - & - & - & - \\
\hline 1604 & $\begin{array}{l}\text { Black Rock Desert- } \\
\text { Humboldt }\end{array}$ & - & - & - & - & - & - & - \\
\hline 1605 & Central Lahontan & 44 & 57.1 & 320,117 & 24.4 & 929 & 7,993 & 4.4 \\
\hline 1606 & $\begin{array}{l}\text { Central Nevada } \\
\text { Desert Basins }\end{array}$ & - & - & - & - & - & - & - \\
\hline
\end{tabular}




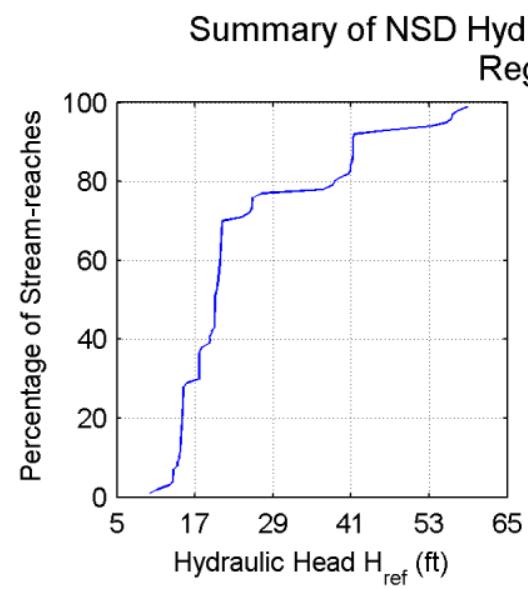

Rydropower Potential (stream-reaches with
Region 16: 106 stream-reaches, $148 \mathrm{MW}$
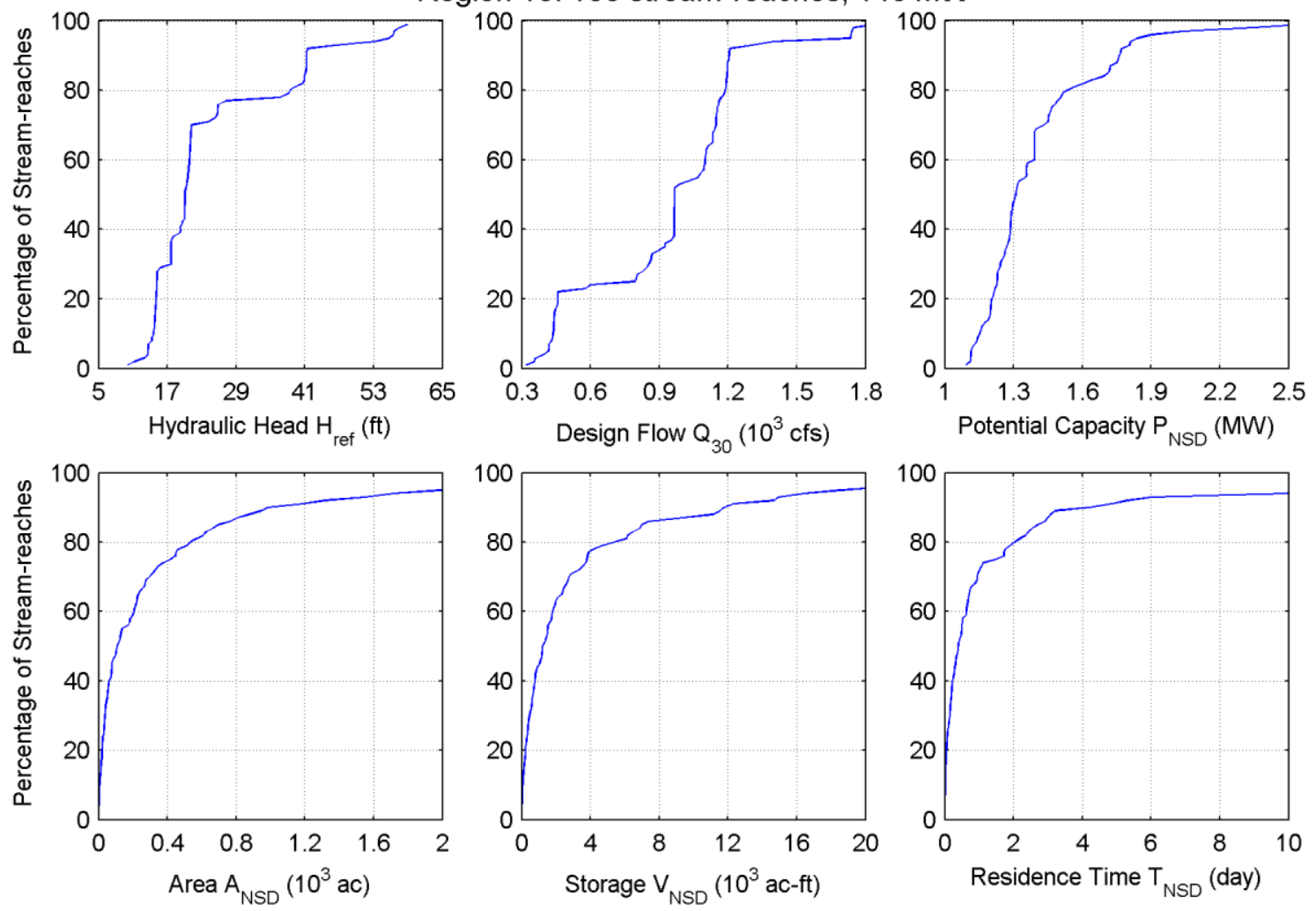

Figure 19.3. Cumulative distributions of hydraulic head $\mathrm{H}_{\text {ref }}$, design flow $\mathrm{Q}_{30}$, potential capacity $\mathrm{P}_{\mathrm{NSD}}$, inundated area $\mathrm{A}_{\mathrm{NSD}}$, storage $\mathrm{V}_{\mathrm{NSD}}$, and residence time $\mathrm{T}_{\mathrm{NSD}}$ in Region 16- Great Basin.

\subsection{Environmental Characteristics}

The Great Basin Region includes 31 native fish species, 9 of which fall under ESA categories and 7 of which fall under IUCN vulnerability categories (12 total fish species, Figure 19.5). Endangered fish include Cui-Cui (Chasmistes cujus) and June sucker (Chasmistes liorus), and threatened species include desert dace (Eremichthys acros) and Railroad Valley springfish (Crenichthys nevadae). Eight fish species are considered potadromous or anadromous in the region. Thirteen subbasins are critical watersheds, with the Bear Lake Subbasin containing the most species at risk (Mathews et al., 1998). Six species have critical habitat designations, including Mexican spotted owl, Canada lynx, desert tortoise (Gopherus agassizii), and all the fish listed above except Cui-Cui. 


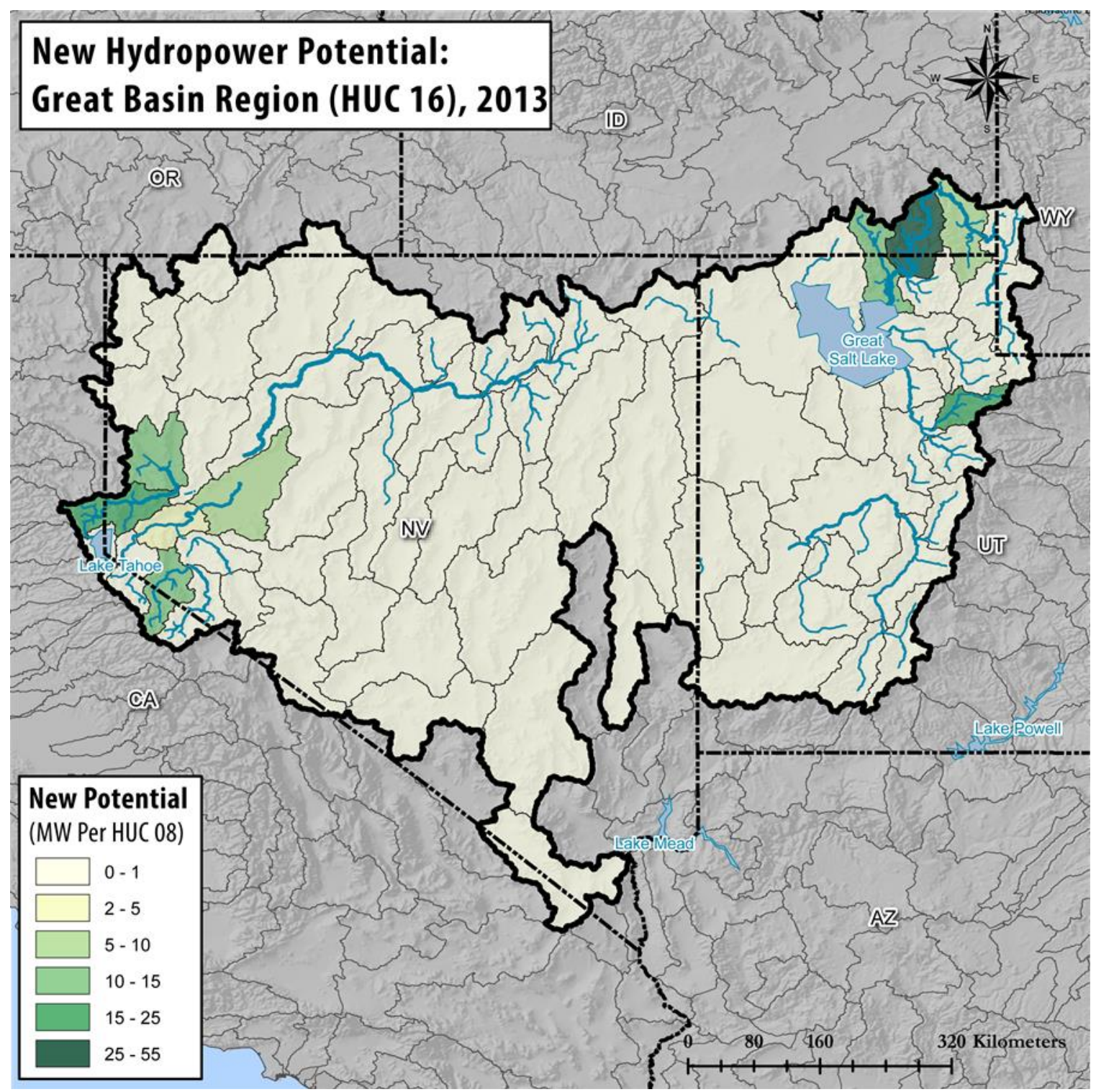

Figure 19.4. Potential new hydropower capacity in Region 16 - Great Basin (higher-energy-density stream-reaches with >1 MW per reach, aggregated to HUC08 subbasins for illustration).

Seventy-eight percent (over 71 million acres) of the total area in Region 16 comprises protected lands. The vast majority of lands are federally owned (95\%), followed by state (3\%) and Native American (1\%) ownership. The primarily owners of federal lands are the BLM (71\%), USFS (15\%), DOD (6\%), and USFWS (2\%). State lands are primarily composed of state land board areas. Among the largest tracts of land are BLM public lands, DOD's Nevada Test and Training Range, State Trust lands, and Toiyabe, Fishlake, Humboldt, and Dixie national forests. Seventyeight percent of protected lands in Region 16 are classified as GAP Status 3. No NWSR sections are located in Region 16. As with Region 14, boat ramps (83) are not as prevalent as in most other regions. Other recreation includes 267 fishing access locations, 22 waterfalls, and 47 recreational boating river sections. 


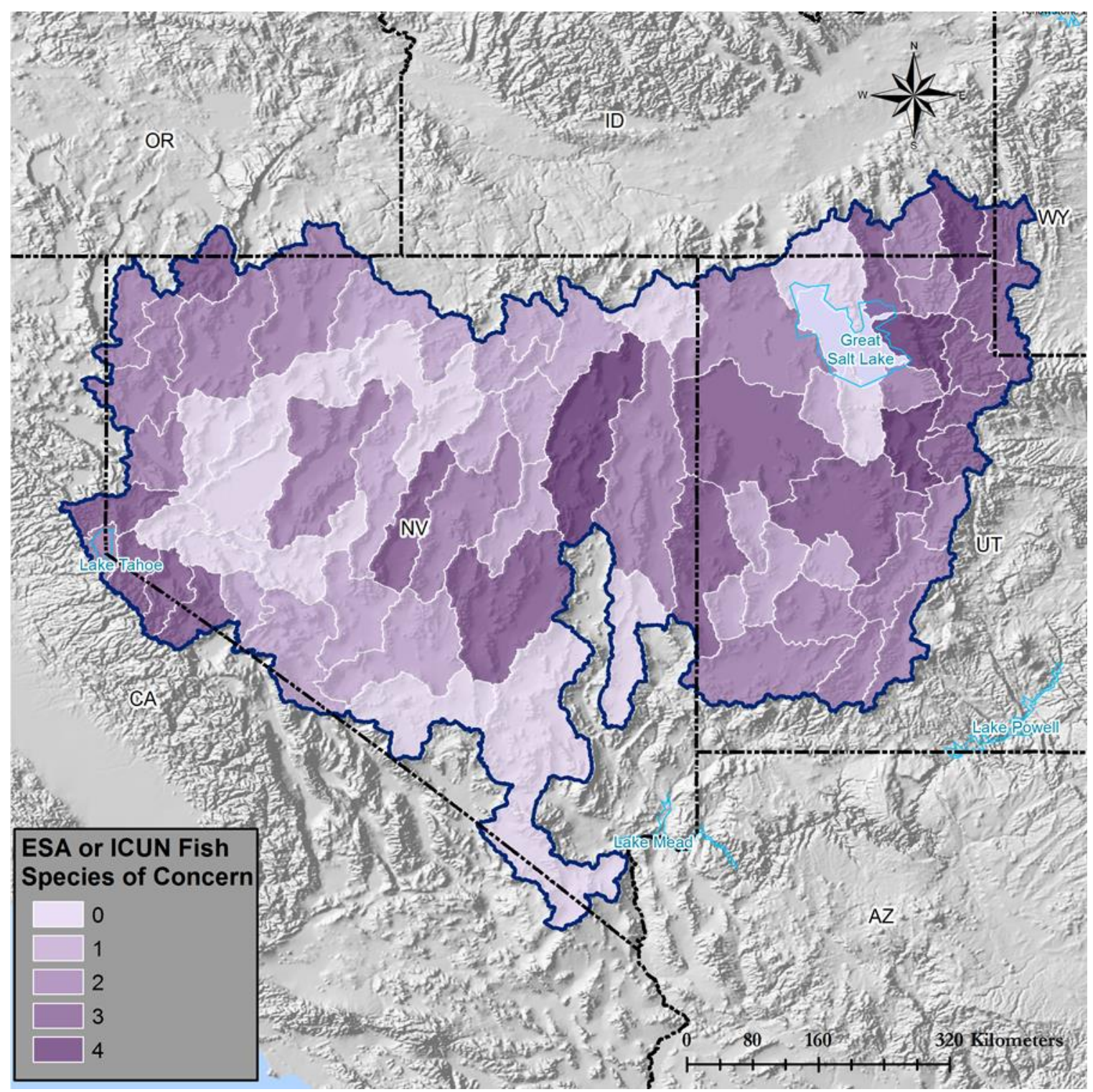

Figure 19.5. Fish species of concern (number per HUC08 sub-basin) in Region 16.

Water use is well below the national average (Figure 19.6); however, many areas are highly arid and lack substantial annual precipitation (Figure 19.2). Irrigation and public consumption make up most of the water use in the region (Figure 19.6, Table 19.3, and Appendix B). Water quality concerns are average with elevated nutrient loads, mercury contamination, and elevated total dissolved solids making up most of the issues. 


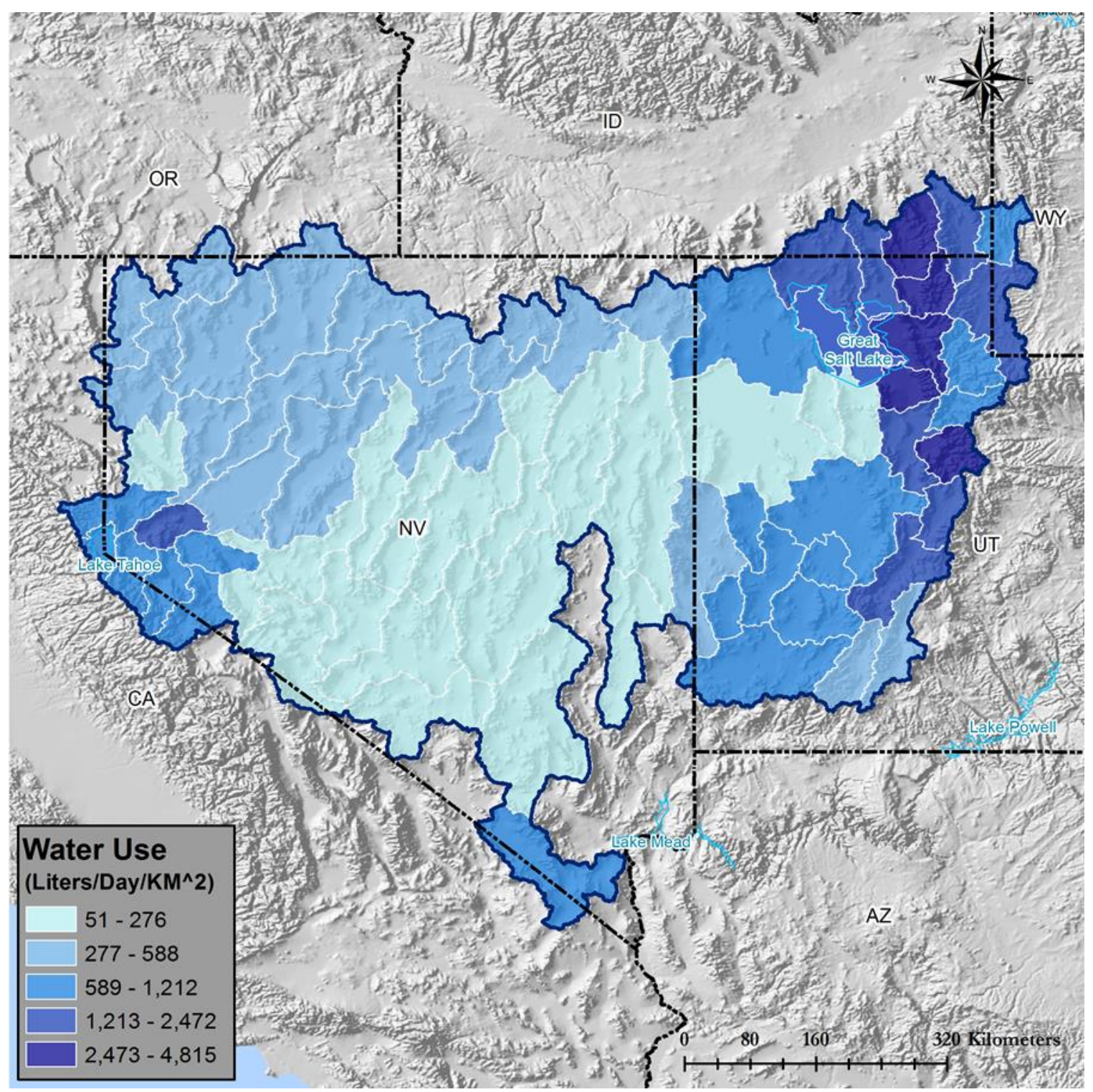

Figure 19.6. Average water use per HUC08 subbasin in Region 16.

Eleven of the 106 stream-reaches in Region 16 intersect critical habitats (Figure 19.7). The vast majority of stream-reaches (93\%) are located in HUC08 subbasins with at least one fish falling under ESA categories. Almost all reaches (98\%) intersect protected lands; however, none overlap with national parks. Water quality concerns are identified at $66 \%$ of stream-reaches, with a total of $91 \mathrm{MW}$. Recreational boating, boat ramps, and fishing access areas intersect 36\%, $6.6 \%$, and $27 \%$ of stream-reaches, respectively, with a total of $51 \mathrm{MW}, 11 \mathrm{MW}$, and $40 \mathrm{MW}$, respectively. Very few stream-reaches are located in HUC08 subbasins with high or very high water use. 
Table 19.3. Summary of Environmental Variables at HUC04 Subregions within Region 16 (Stream-Reaches with Potential Capacity $>1 \mathrm{MW}$ )

\begin{tabular}{|c|c|c|c|c|c|c|c|c|}
\hline HUC04 HUC04 name & $\begin{array}{r}\text { \# Critical } \\
\text { habitats }\end{array}$ & $\begin{array}{l}\text { \# Potad- } \\
\text { anad fish }\end{array}$ & $\begin{array}{r}\text { \# ESA } \\
\text { fish }\end{array}$ & $\begin{array}{r}\text { \# IUCN } \\
\text { fish }\end{array}$ & $\begin{array}{l}\text { \# Recreation } \\
\text { locations }^{\mathrm{a}}\end{array}$ & $\begin{array}{r}\% \\
\text { Protected } \\
\text { lands }\end{array}$ & $\begin{array}{r}\text { Population } \\
\text { density } \\
\left(\text { ind } / \mathbf{k m}^{2}\right)\end{array}$ & $\begin{array}{r}\text { Freshwater } \\
\text { use (liters/day/ } \\
\left.\text { km }^{2}\right)\end{array}$ \\
\hline 1601 Bear & 1 & 3 & 3 & 1 & $43 ; 9 ; 0$ & 44.11 & 8.94 & $2,200.34$ \\
\hline 1602 Great Salt Lake & 1 & 4 & 5 & 1 & $57 ; 22 ; 9$ & 64.38 & 50.45 & $1,287.22$ \\
\hline $\begin{array}{l}1603 \begin{array}{l}\text { Escalante Desert- } \\
\text { Sevier Lake }\end{array} \\
\end{array}$ & 1 & 3 & 3 & 1 & $52 ; 4 ; 1$ & 75.92 & 2.08 & $1,019.42$ \\
\hline $\begin{array}{l}\text { Black Rock Desert- } \\
\text { Humboldt }\end{array}$ & 1 & 3 & 4 & 2 & $78 ; 0 ; 1$ & 75.51 & 3.29 & 338.87 \\
\hline 1605 Central Lahontan & 0 & 5 & 4 & 1 & $83 ; 12 ; 10$ & 65.86 & 12.90 & 713.53 \\
\hline $1606 \begin{array}{l}\text { Central Nevada } \\
\text { Desert Basins }\end{array}$ & 3 & 3 & 4 & 2 & $37 ; 0 ; 1$ & 95.06 & 4.16 & 203.87 \\
\hline
\end{tabular}

${ }^{a}$ Recreation locations refer to the number of boat-ramp and fishing access points, recreational boating, and waterfalls within each HUC04.

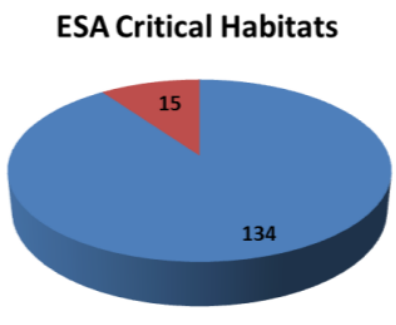

= Absent $=$ Present

Water Quality Concern

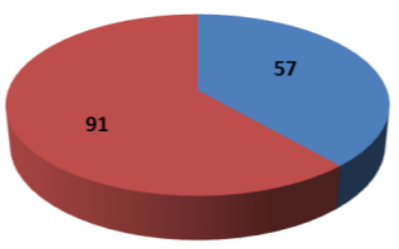

a Absent a Present

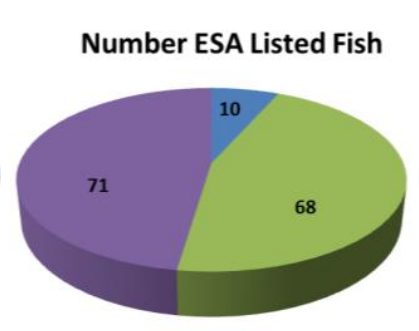

$m=1=2 \equiv 3$

Recreation Boating

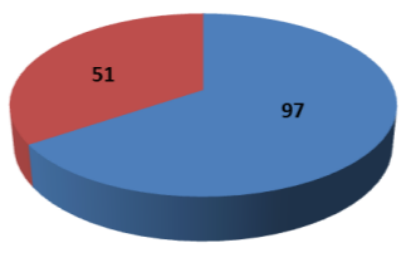

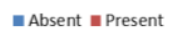

National Park Lands

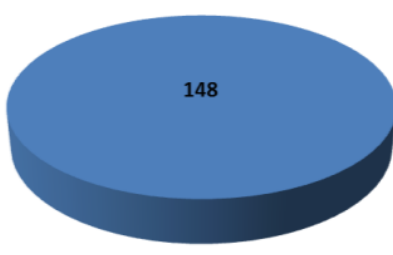

m Absent

Fishing Access Areas

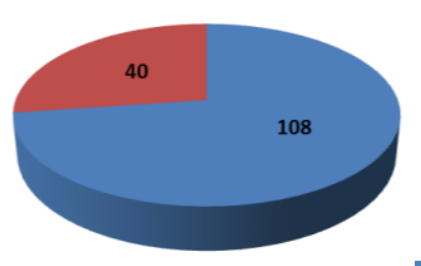

a Absent $\mathbf{m}$ Present
Wild and Scenic Rivers

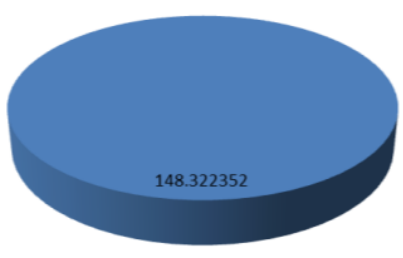

- Absent

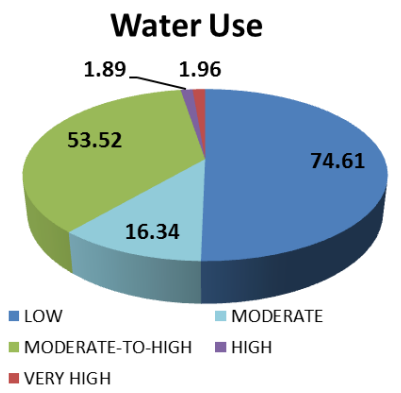

Figure 19.7. The potential capacity, in MW, associated with environmental attributes in Region 16-Great Basin ( stream-reaches with potential capacity $>1 \mathrm{MW}$ ). 


\section{REGION 17-PACIFIC NORTHWEST}

\subsection{Summary of Findings}

Following NSD methodology (Hadjerioua et al., 2013), the potential capacity, annual generation and mean capacity factors in the Pacific Northwest Region are estimated and summarized in Table 20.1 for both larger ( $>1 \mathrm{MW}$ ) and smaller (<1 MW) stream-reaches. For comparison, the year-2011 nameplate capacity, 2002-2011 average annual generation, and capacity factor of existing hydropower facilities are also listed (NHAAP, 2013). The total undeveloped NSD capacity is $25.23 \mathrm{GW}$, around $76 \%$ of existing conventional hydropower nameplate capacity. In terms of energy, the total undeveloped NSD generation is $149.00 \mathrm{TWh} / \mathrm{year}$, around $118 \%$ of annual net generation from existing conventional hydropower plants. Given the run-of-river assumption, NSD stream-reaches have higher capacity factors, especially compared with other larger-storage peaking-operation projects in this region. More detailed topographical analysis and environmental attribution are conducted for larger ( $>1 \mathrm{MW})$ stream-reaches and discussed in Sections 20.3 and 20.4 .

Table 20.1. Summary of NSD Findings in Region 17 -Pacific Northwest

\begin{tabular}{l|r|r|r}
\hline & $\begin{array}{r}\text { Capacity } \\
\text { (MW) }\end{array}$ & $\begin{array}{r}\text { Generation } \\
\text { (MWh) }\end{array}$ & $\begin{array}{r}\text { Mean capacity } \\
\text { factor }\end{array}$ \\
\hline Potential in undeveloped stream-reaches $(>1 \mathrm{MW})$ & 15,997 & $96,756,000$ & $69 \%$ \\
\hline Potential in undeveloped stream-reaches $(<1 \mathrm{MW})$ & 9,228 & $52,244,000$ & $65 \%$ \\
\hline Existing hydropower-conventional hydro & 33,324 & $126,084,000$ & $43 \%$ \\
\hline Existing hydropower-pumped storage & 314 & & \\
\hline
\end{tabular}

\subsection{Background Hydrologic Setting}

The Pacific Northwest Region encompasses approximately $711,654 \mathrm{~km}^{2}$ in the Northwestern United States. The region consists of the entire state of Washington, most of Oregon (except a small area in the southern part of the state), most of Idaho, western Montana, and very small regions of northern Nevada, Utah and California. The region comprises mountains, plateaus, and a major river plain. The coastal mountain range, the Cascade Mountain range, and the Rocky Mountain Range encompass the Columbia and Central Oregon Plateau and the Snake River Plain (USGS, 2013). The coastal plain consists of consolidated and semiconsolidated limestone, clay, gravel, and soft unconsolidated sand. This area contains the most productive groundwater because of its highly permeable clastic and limestone aquifers. The groundwater outflow supports base flow for the streams in the region. For the Coastal Plain, base flow conservatively averages about 55 percent of the total streamflow.

Several river systems are located in the Pacific Northwest Region (Figure 20.1), including the Columbia, Kootenai, Pend Oreille, Spokane, Snake, Yakima, Weiser, Salmon, Clearwater, John Day, Deschutes, Willamette, and Umpqua rivers, with a total length of 63,372 km (i.e., total length of streams with estimated discharge greater than $35 \mathrm{cfs}$ ). The Columbia River, its 
tributaries, and other streams that discharge into the Pacific Ocean are responsible for most of the drainage of the Pacific Northwest region. Metropolitan areas within the region include Seattle (WA), Yakima (WA), Spokane (WA), Walla Walla (WA), Portland (OR), Eugene (OR), and Boise (ID). As shown in Figure 20.2, annual precipitation in the Pacific Northwest Region ranges from 700 to $1150 \mathrm{~mm} /$ year, and annual runoff ranges from 200 to $500 \mathrm{~mm} /$ year. Most precipitation occurs from late fall through winter and a slight amount into early spring.

The existing hydropower plants and major non-powered dams (Hadjerioua et al., 2012) are also shown in Figure 20.1. The Pacific Northwest Region contains 336 hydropower dams and 27 major non-powered dams, with total storage capacities of around 59,987,949 ac-ft and 1,477,693 ac-ft, respectively.

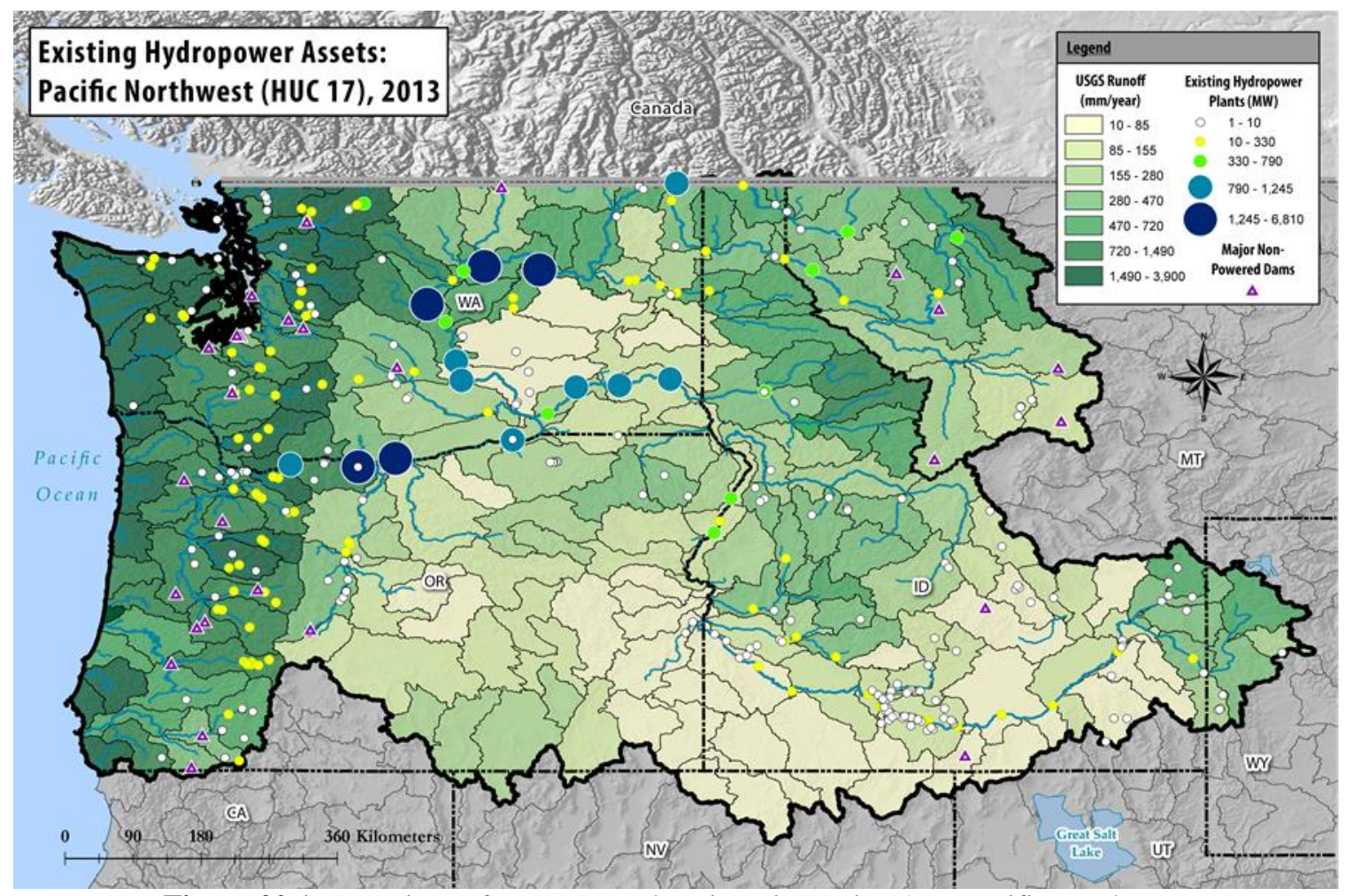

Figure 20.1. Locations of water control projects in Region 17—Pacific Northwest.

\subsection{Potential New Hydropower Resources}

A total of 3,793 stream-reaches of high energy density (with estimated potential capacity >1 MW per stream-reach) are identified in the Pacific Northwest Region. The NSD results based on HUC04 subregions are summarized in Table 20.2. The highest hydropower potentials are located in the Lower Snake Subregion (HUC 1706) and Middle Columbia Subregion (HUC 1707). In the Lower Snake Subregion, the highest hydropower potentials are located predominantly in the Snake River, followed by the Clearwater and Salmon rivers. In the Middle Columbia Subregion, the highest hydropower potential is found predominantly in the Deschutes River.

The summary statistics of hydraulic head $\mathrm{H}_{\mathrm{ref}}(\mathrm{ft})$, design flow $\mathrm{Q}_{30}(\mathrm{cfs})$, potential capacity $\mathrm{P}_{\mathrm{NSD}}$ $(\mathrm{MW})$, inundated area $\mathrm{A}_{\mathrm{NSD}}(\mathrm{ac})$, storage $\mathrm{V}_{\mathrm{NSD}}(\mathrm{ac}-\mathrm{ft})$, and residence time $\mathrm{T}_{\mathrm{NSD}}$ (day) are shown 
in Figure 20.3. The hydraulic head $\mathrm{H}_{\text {ref }}$ ranges from 5 to the 90th quantile of $41 \mathrm{ft}$ with a median of about $14 \mathrm{ft}$, suggesting that many of the potential stream-reaches will require low-head hydropower technologies. The design flow $\mathrm{Q}_{30}$ ranges from 0 to the 90 th quantile of $11,000 \mathrm{cfs}$ with a median of $2,500 \mathrm{cfs}$. The potential capacity $\mathrm{P}_{\mathrm{NSD}}$ ranges from 1 to the 90 th quantile of about $10 \mathrm{MW}$ with a median of about $2 \mathrm{MW}$. The inundated surface area $\mathrm{A}_{\mathrm{NSD}}$ ranges from 0 to 400 acres with a median of about 50 acres. This results in storage values $\mathrm{V}_{\mathrm{NSD}}$ ranging from 0 to

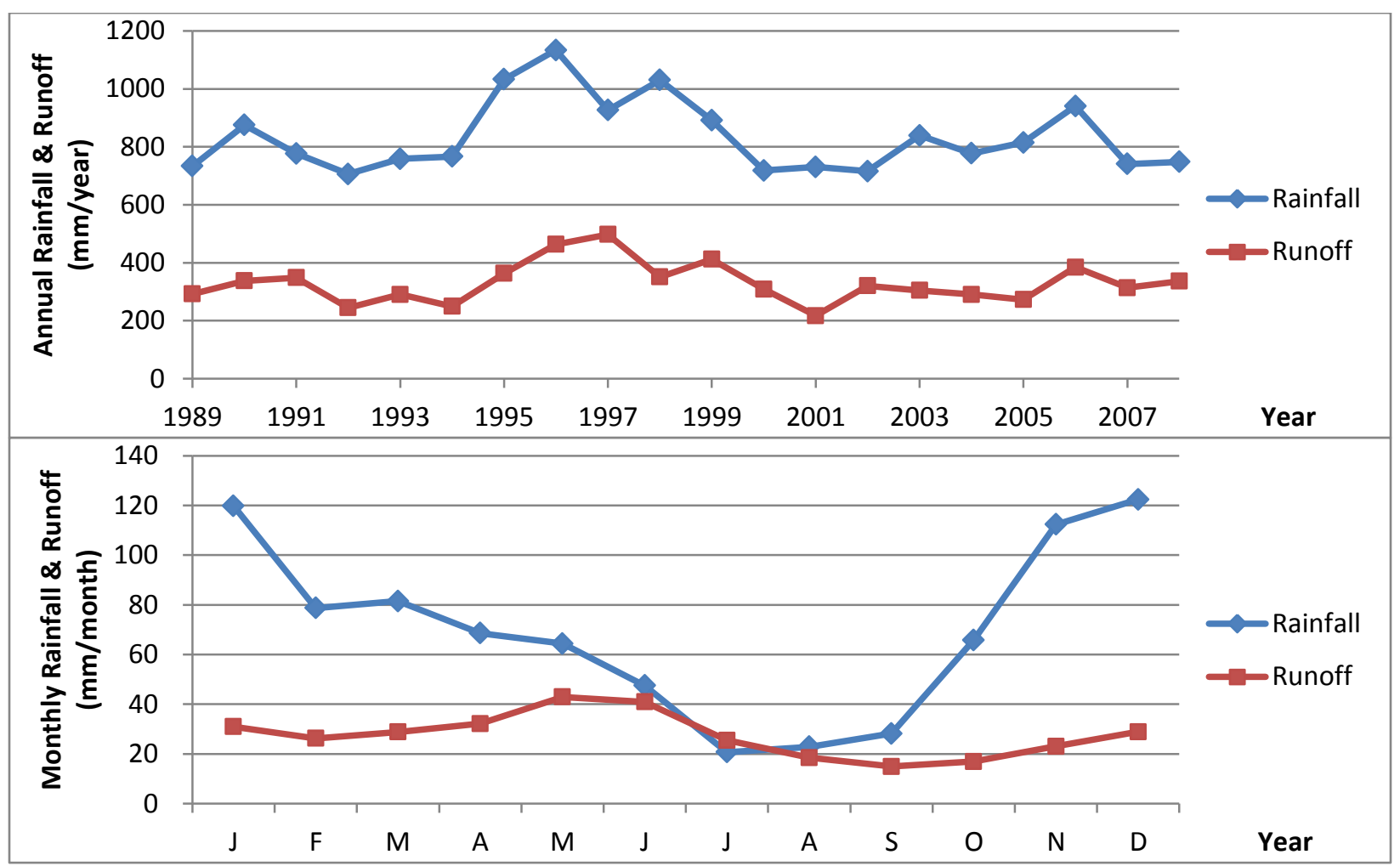

Figure 20.2. Annual and monthly rainfall and runoff of Region 17-Pacific Northwest.

Table 20.2. Summary of Potential New Hydropower Resources in Region 17—Pacific Northwest (Stream-Reaches with Potential Capacity $>1 \mathrm{MW}$ )

\begin{tabular}{|c|c|c|c|c|c|c|c|c|}
\hline HUC04 & HUC04 name & $\begin{array}{r}\text { \# of } \\
\text { stream- } \\
\text { reaches }\end{array}$ & $\begin{array}{r}\text { Potential } \\
\text { capacity } \\
(\mathrm{MW})\end{array}$ & $\begin{array}{r}\text { Potential } \\
\text { energy } \\
(\mathrm{MWh})\end{array}$ & $\begin{array}{r}\text { Average } \\
\text { head } \\
(\mathbf{f t} / \mathrm{reach})\end{array}$ & $\begin{array}{r}\text { Average } \\
\text { flow } \\
\text { (cfs/reach) }\end{array}$ & $\begin{array}{r}\text { Average } \\
\text { storage } \\
\text { (ac- } \\
\text { ft/reach) }\end{array}$ & $\begin{array}{r}\text { Average } \\
\text { residence } \\
\text { time (days) }\end{array}$ \\
\hline 1701 & $\begin{array}{l}\text { Kootenai-Pend } \\
\text { Oreille-Spokane }\end{array}$ & 365 & $1,534.0$ & $8,668,534$ & 19.0 & 3,675 & 2,264 & 0.7 \\
\hline 1702 & Upper Columbia & 198 & $1,075.1$ & $6,583,428$ & 11.7 & 5,489 & 1,509 & 0.1 \\
\hline 1703 & Yakima & 116 & 423.6 & $2,609,643$ & 18.0 & 2,829 & 2,214 & 0.3 \\
\hline 1704 & Upper Snake & 172 & $1,626.6$ & - & 34.5 & 5,180 & 11,118 & 7.9 \\
\hline 1705 & Middle Snake & 140 & 516.9 & $3,120,023$ & 12.7 & 3,182 & 5,049 & 0.5 \\
\hline 1706 & Lower Snake & 984 & $3,696.7$ & $22,302,267$ & 9.3 & 6,211 & 379 & 0.2 \\
\hline 1707 & Middle Columbia & 326 & $2,137.5$ & $15,178,105$ & 25.5 & 3,262 & 5,951 & 6.2 \\
\hline 1708 & Lower Columbia & 154 & 622.0 & $3,663,198$ & 15.4 & 5,357 & 691 & 0.2 \\
\hline 1709 & Willamette & 288 & $1,355.6$ & $8,138,632$ & 32.8 & 2,644 & 9,923 & 3.5 \\
\hline 1710 & $\begin{array}{l}\text { Oregon-Washington } \\
\text { Coastal }\end{array}$ & 602 & $1,804.7$ & $9,497,362$ & 24.9 & 2,285 & 3,738 & 2.6 \\
\hline 1711 & Puget Sound & 448 & $1,204.0$ & $7,624,078$ & 15.2 & 2,689 & 1,060 & 0.2 \\
\hline 1712 & $\begin{array}{l}\text { Oregon closed } \\
\text { basins }\end{array}$ & - & - & - & - & - & - & - \\
\hline
\end{tabular}


the 90th quantile of 5000 ac-ft with a median of about 750 ac- $\mathrm{ft}$ and very short residence times $\mathrm{T}_{\mathrm{NSD}}$ ranging from $<1$ day to the 90th quantile of about 1.5 days with a median on the order of several hours. In general, the relatively small inundation areas and storage volumes paired with the short retention times for this region are characteristic of run-of-river type hydro facilities. The results of >1 MW stream-reach potential are illustrated in Figure 20.4, with potential capacity (MW) aggregated to the HUC08 subbasins. The higher potential capacity sites are generally located in the mountainous regions.
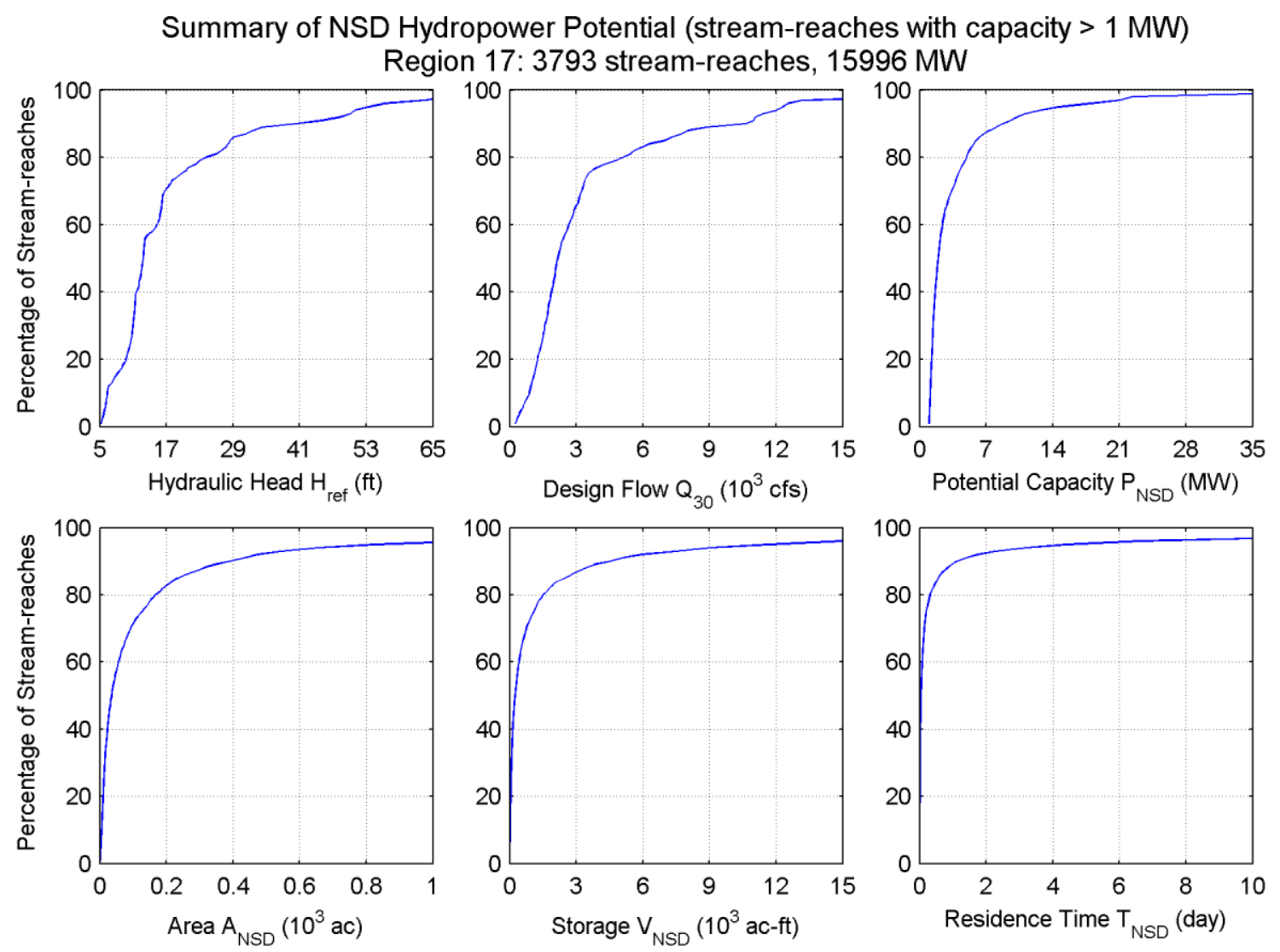

Figure 20.3. Cumulative distributions of hydraulic head $\mathrm{H}_{\mathrm{ref}}$, design flow $\mathrm{Q}_{30}$, potential capacity $\mathrm{P}_{\mathrm{NSD}}$, inundated area $\mathrm{A}_{\mathrm{NSD}}$, storage $\mathrm{V}_{\mathrm{NSD}}$, and residence time $\mathrm{T}_{\mathrm{NSD}}$ in Region 17-Pacific Northwest.

\subsection{Environmental Characteristics}

Region 17 has 70 native species of fish; for 16 of these species, either the entire species or a population falls under an ESA listing or candidate listing (Figure 20.5 and Appendix B). Eight of the species with ESA listing are salmon species, including populations of Chinook (Oncorhynchus tshawytscha), Chum (O. keta), Coho (O. kisutch), or Sockeye (O. nerka) salmon. Four trout species fall under ESA categories, including populations of cutthroat (O. clarkii), bull trout, dolly varden (Salvelinus malma), and steelhead (O. mykiss). Green sturgeon (Acipenser medirostris) along with two Gila species, Tui chub and Borax Lake Chub (G. boraxobius), are also documented in the region. Nineteen fish species are considered potadromous or anadromous, the majority of which are salmon or trout. The Lower Columbia, Grande Ronde, and Willapa Bay subbasins are among the 19 critical watersheds in the region. Twenty-eight 
species have critical habitat designations in Region 17, including 3 birds (marbeled murrelet, northern spotted owl, and western snowy plover), 1 crustacean (vernal pool shrimp), 15 fish, 2 insects, 1 mammal (Canada lynx), and 6 plants, as noted in Figure 20.6 and Appendix B. ESA and IUCN listed fish, potadromous fish, and critical habitats are documented in all subregions (Table 20.3).

Over 110 million acres of protected lands are identified in Region 17 (57\% of total area, Figure 20.7). Most of the protected lands are federally owned (83\%), followed by state (8.5\%), and Native American ownership (6.6\%). The predominant owner of protected lands is the USFS (49\%), followed by BLM (27\%), Bureau of Indian Affairs (6.6\%), and NPS (3.25). Among the largest national parks are Glacier (635k acres), Yellowstone (448k acres), Grand Teton (310k acres), Mount Rainier (236k acres), and Mt. St. Helens (110k acres). Nineteen percent of protected lands fall under GAP 1 and 2 statuses, while $70 \%$ and $10 \%$ fall under GAP 3 and 4 statuses, respectively (Figure 20.7). Fifty-one river sections, totaling almost $3900 \mathrm{~km}$ of river, are protected under the Wild and Scenic Rivers Act. Recreation locations are abundant in region 17 , including 1595 boat ramps, 1157 freshwater fishing access areas, 550 waterfalls, and 867 recreational boating river sections.

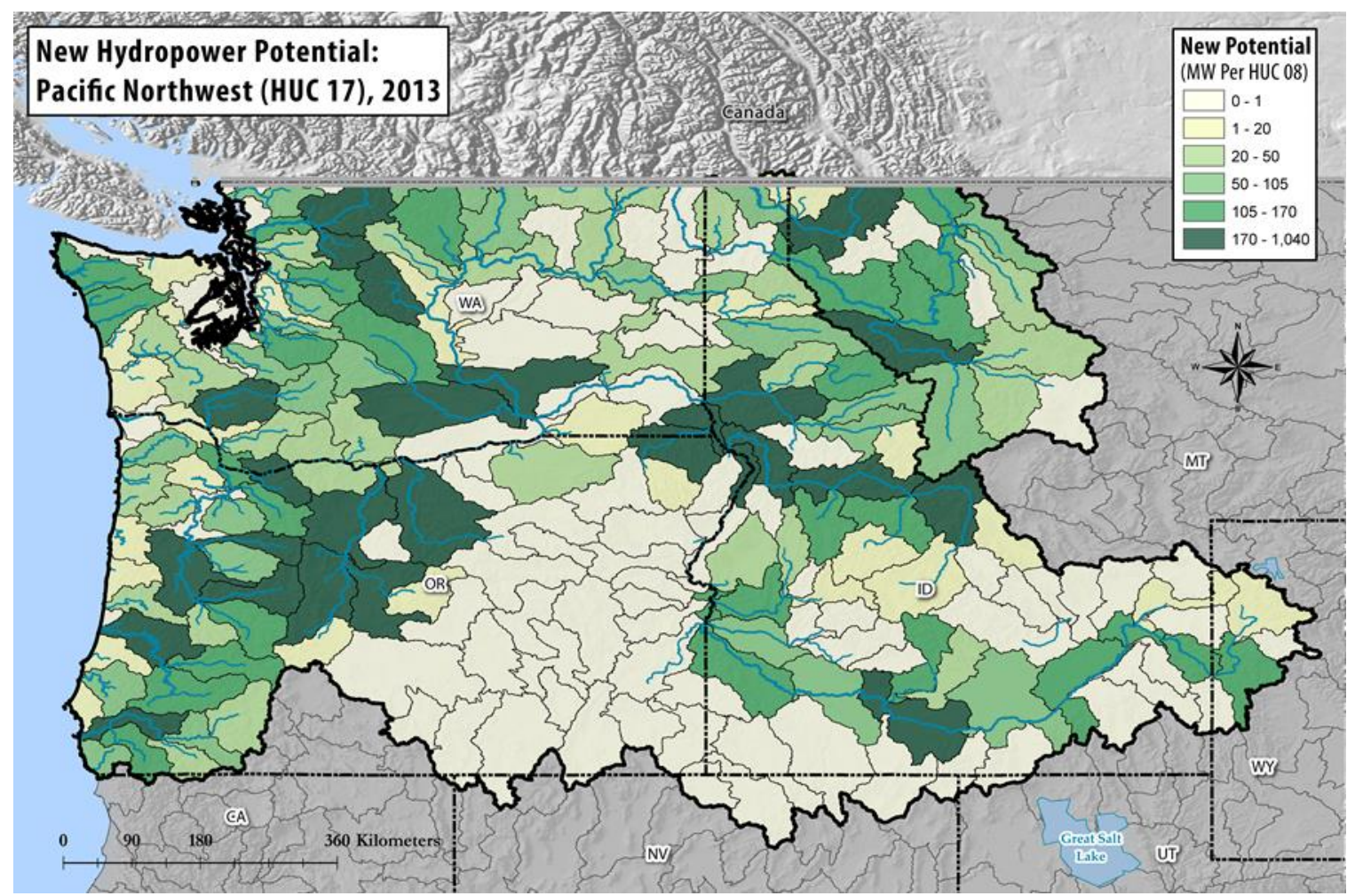

Figure 20.4. Potential new hydropower capacity in Region 17-Pacific Northwest (higher-energy-density streamreaches with $>1 \mathrm{MW}$ per reach, aggregated to HUC08 subbasins for illustration). 


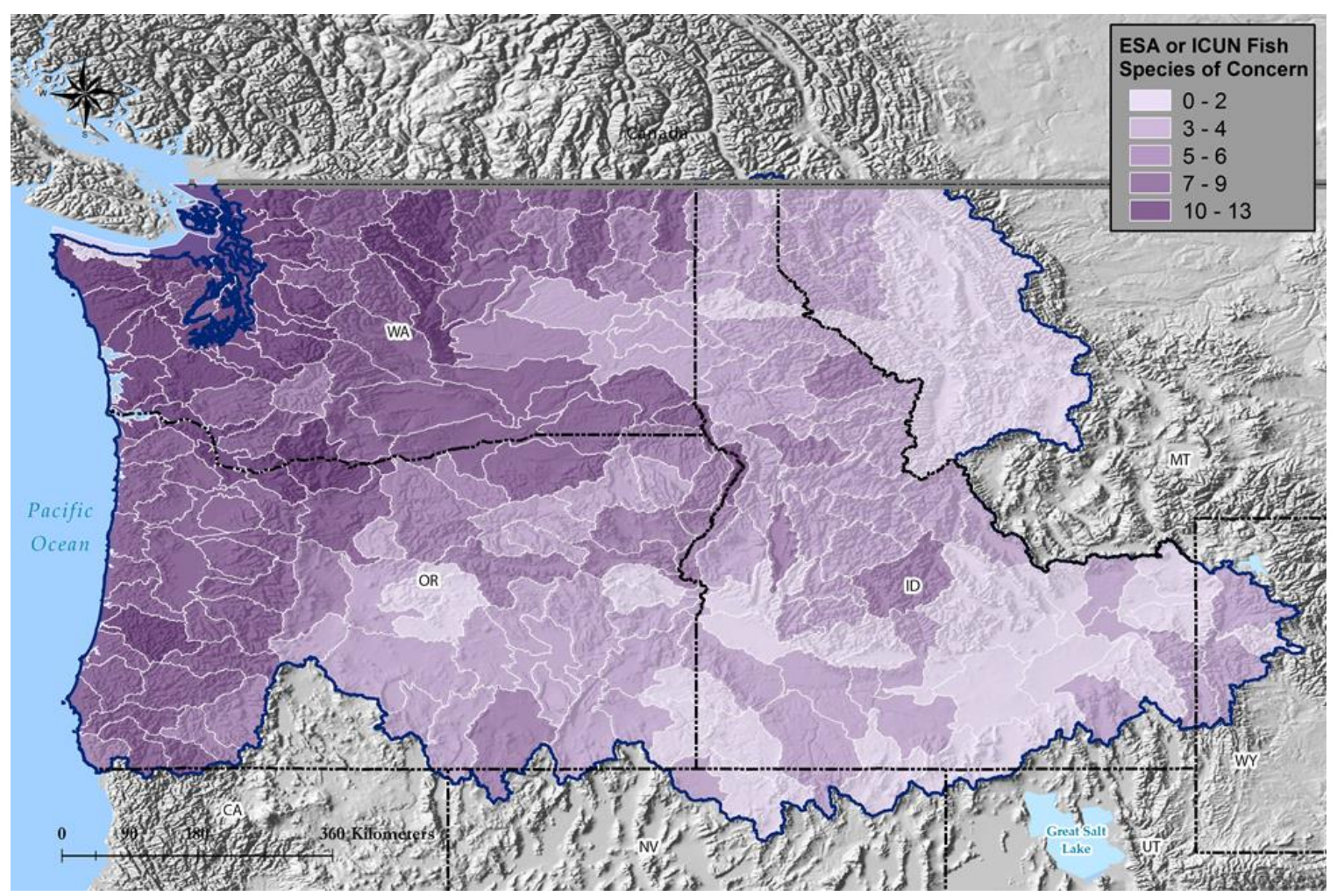

Figure 20.5. Fish species of concern (number per HUC08 subbasin) in Region 17.

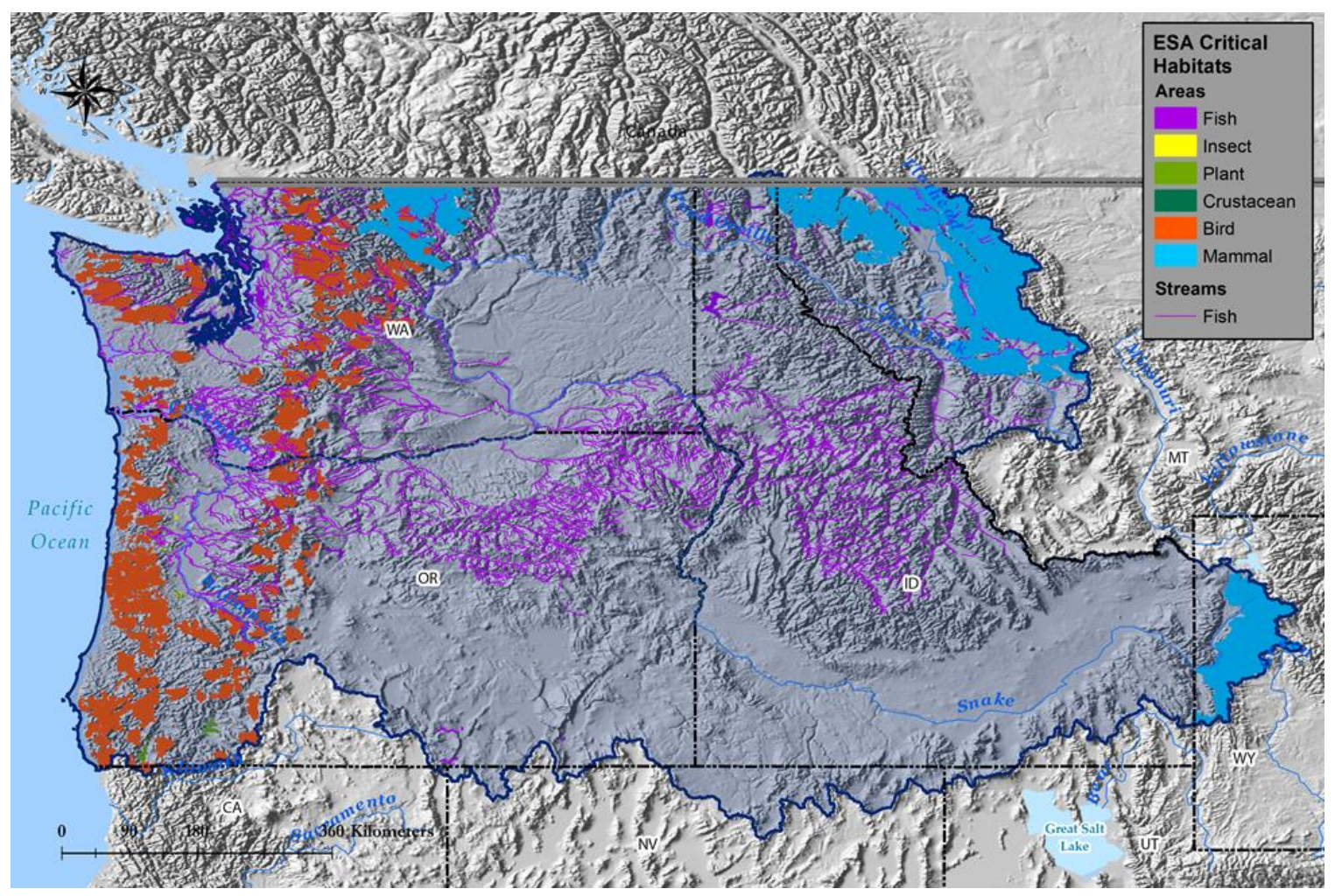

Figure 20.6. Critical habitats for federally endangered and threatened species in Region 17. 


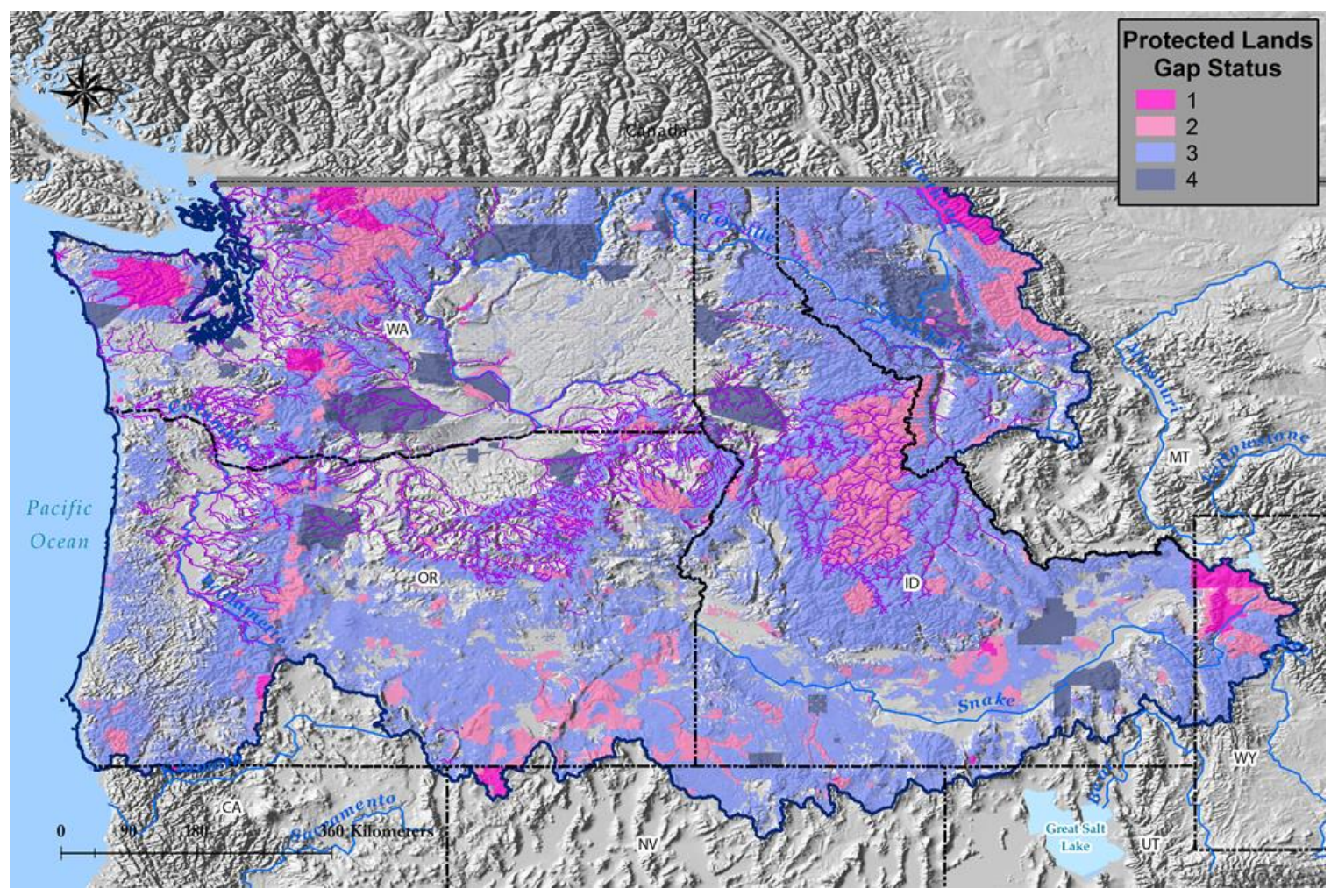

Figure 20.7. Protected lands according to Gap Status (conservation management regime) in Region 17.

Table 20.3. Summary of Environmental Variables at HUC04 Subregions within Region 17 (Stream-Reaches with Potential Capacity $>1 \mathrm{MW}$ )

\begin{tabular}{|c|c|c|c|c|c|c|c|c|}
\hline HUC04 HUC04 name & $\begin{array}{r}\text { \# Critical } \\
\text { habitats }\end{array}$ & $\begin{array}{l}\text { \# Potad- } \\
\text { anad fish }\end{array}$ & $\begin{array}{r}\text { \# ESA } \\
\text { fish }\end{array}$ & $\begin{array}{r}\text { \# IUCN } \\
\text { fish }\end{array}$ & $\begin{array}{r}\# \\
\text { Recreation } \\
\text { locations }^{\text {a }}\end{array}$ & $\begin{array}{r}\% \\
\text { Protected } \\
\text { lands } \\
\end{array}$ & $\begin{array}{r}\text { Population } \\
\text { density } \\
\left(\text { ind } / \mathbf{k m}^{2}\right)\end{array}$ & $\begin{array}{r}\text { Freshwater } \\
\text { use (liters/ } \\
\text { day } / \mathrm{km}^{2} \text { ) }\end{array}$ \\
\hline $1701 \begin{array}{l}\text { Kootenai-Pend } \\
\text { Oreille-Spokane }\end{array}$ & 4 & 8 & 8 & 1 & $283 ; 77 ; 65$ & 66.50 & 11.94 & 584.59 \\
\hline 1702 Upper Columbia & 7 & 9 & 11 & 1 & $221 ; 35 ; 34$ & 40.64 & 6.28 & $1,228.79$ \\
\hline 1703 Yakima & 4 & 7 & 10 & 1 & $41 ; 19 ; 6$ & 45.64 & 17.06 & $2,428.92$ \\
\hline 1704 Upper Snake & 1 & 4 & 6 & 3 & $191 ; 57 ; 63$ & 65.84 & 4.89 & $5,347.28$ \\
\hline 1705 Middle Snake & 1 & 5 & 7 & 2 & $208 ; 47 ; 16$ & 71.86 & 6.35 & $2,379.08$ \\
\hline 1706 Lower Snake & 2 & 6 & 9 & 1 & $170 ; 88 ; 26$ & 66.81 & 3.54 & 685.44 \\
\hline 1707 Middle Columbia & 10 & 6 & 11 & 1 & $218 ; 60 ; 52$ & 37.62 & 5.83 & $1,215.52$ \\
\hline 1708 Lower Columbia & 10 & 8 & 11 & 2 & $92 ; 76 ; 68$ & 48.53 & 56.89 & $1,092.68$ \\
\hline 1709 Willamette & 12 & 8 & 11 & 3 & $287 ; 113 ; 66$ & 37.89 & 79.80 & $1,589.98$ \\
\hline $1710 \begin{array}{l}\text { Oregon-Washington } \\
\text { Coastal }\end{array}$ & 11 & 9 & 12 & 4 & $511 ; 149 ; 80$ & 49.91 & 16.20 & 505.89 \\
\hline 1711 Puget Sound & 9 & 11 & 11 & 3 & $454 ; 145 ; 73$ & 45.70 & 103.38 & 688.68 \\
\hline $\begin{array}{l}1712 \begin{array}{l}\text { Oregon Closed } \\
\text { Basins }\end{array} \\
\end{array}$ & 4 & 4 & 7 & 4 & $43 ; 1 ; 1$ & 78.25 & 0.85 & 779.63 \\
\hline
\end{tabular}

${ }^{a}$ Recreation locations refer to the number of boat-ramp and fishing access points, recreational boating, and waterfalls within each HUC04. 
Population density is highest in the Puget Sound and Willamette subbasins and lowest in the Upper and Middle Snake River subbasins (Table 20.3). Water use is moderate in region 17 compared with other regions of the country (Appendix B); however, water usage is relatively high in the Middle and Lower Columbia subbasins (Table 20.3). Irrigation is by far the largest water usage category (Appendix B). Water quality concerns are average in region 17 compared with other regions of the United States, with most concerns classified as mercury/metal contamination, temperature, and algal issues.

Out of 3793 stream-reaches, 83\% intersect at least one critical habitat (Figure 20.8). Almost all stream-reaches (99.9\%) fell into HUC08 subbasins with at least one fish falling under an ESA category. Likewise, 99\% of stream-reaches intersect protected lands, with $4.2 \%$ of streamreaches (353 MW) overlapped with national parks and 41\% (> 5.99 GW) overlapped with Wild and Scenic Rivers. Almost $66 \%$ of stream-reaches are associated with water quality concerns. Recreation is abundant with recreational boating, boat ramps, and fishing access areas intersecting $81 \%, 25 \%$, and $78 \%$ of stream-reaches, respectively. Water use values are about equally distributed among stream-reaches in this region.

ESA Critical Habitats

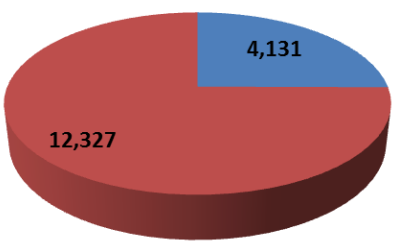

absent $\square$ Present

National Park Lands

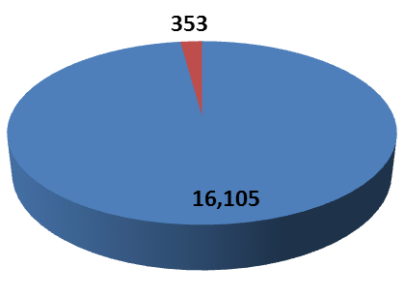

Absent Present
Number ESA Listed Fish

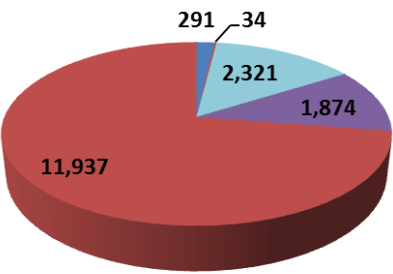

$\square 0 \square 1 \square 2 \square 3 \square>3$

Wild and Scenic Rivers

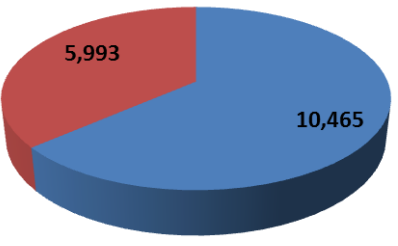

absent $\quad$ Present
Water Quality Concern

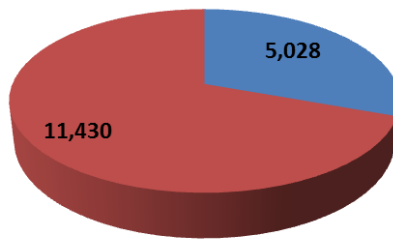

absent $\square$ Present

Fishing Access Areas

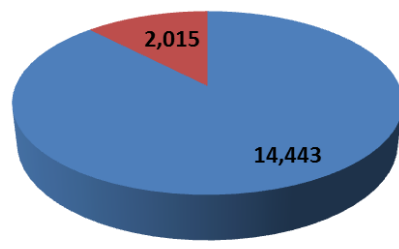

Absent $\quad$ Present
Recreation Boating

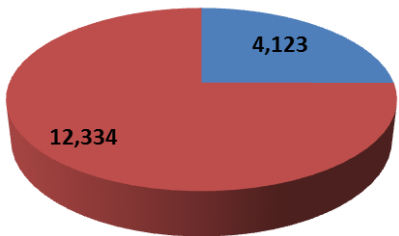

absent $\square$ Present

Water Use

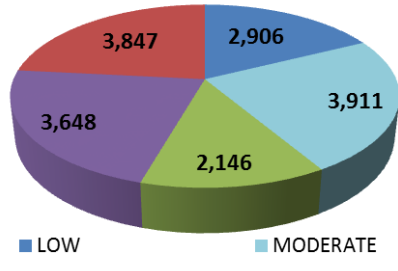

$\square$ MODERATE-TO-HIGH $\square$ HIGH

- VERY HIGH

Figure 20.8. The potential capacity, in MW, associated with environmental attributes in Region 17-Pacific

Northwest (stream-reaches with potential capacity $>1 \mathrm{MW}$ ). 


\section{REGION 18-CALIFORNIA}

\subsection{Summary of Findings}

Following NSD methodology (Hadjerioua et al., 2013), the potential capacity, annual generation, and mean capacity factors in the California Region are estimated and summarized in Table 21.1 for both larger (>1 MW) and smaller (<1 MW) stream-reaches. For comparison, the year-2011 nameplate capacity, 2002-2011 average annual generation, and capacity factor of existing hydropower facilities are also listed (NHAAP, 2013). The total undeveloped NSD capacity is $7.05 \mathrm{GW}$, around $69 \%$ of existing conventional hydropower nameplate capacity. In terms of energy, the total undeveloped NSD generation is $37.99 \mathrm{TWh} /$ year, around $112 \%$ of annual net generation from existing conventional hydropower plants. Given the run-of-river assumption, NSD stream-reaches have higher capacity factors, especially compared with other larger-storage peaking-operation projects in this region. More detailed topographical analysis and environmental attribution are conducted for larger (>1 MW) stream-reaches and discussed in Sections 21.3 and 21.4.

Table 21.1. Summary of NSD Findings in Region 18-California

\begin{tabular}{l|r|r|r}
\hline & $\begin{array}{r}\text { Capacity } \\
\text { (MW) }\end{array}$ & $\begin{array}{r}\text { Generation } \\
\text { (MWh) }\end{array}$ & $\begin{array}{r}\text { Mean capacity } \\
\text { factor }\end{array}$ \\
\hline Potential in undeveloped stream-reaches $(>1 \mathrm{MW})$ & 4,029 & $22,108,000$ & $63 \%$ \\
\hline Potential in undeveloped stream-reaches $(<1 \mathrm{MW})$ & 3,025 & $15,879,000$ & $60 \%$ \\
\hline Existing hydropower-conventional hydro & 10,292 & $34,034,000$ & $38 \%$ \\
\hline Existing hydropower-pumped storage & 3,393 & & \\
\hline
\end{tabular}

\subsection{Background Hydrologic Setting}

The California Region encompasses approximately $417,288 \mathrm{~km}^{2}$ in the Western United States. The region consists of most of the state of California and much smaller sections of southern Oregon and southwest Nevada. The region comprises mountains, plateaus, and a major river plain. The coastal mountain range, the Cascade Mountain range, and the Rocky Mountain Range encompass the Columbia and Central Oregon Plateau, and the Snake River Plain.

Several river systems are located in the California Region (Figure 21.1), including the Smith, Klamath, Sacramento, San Joaquin, and San Gabriel rivers, with a total length of 21,545 km (i.e., total length of streams with estimated discharge greater than $35 \mathrm{cfs}$ ). Metropolitan areas within the region include all the major cities in California-Los Angeles, San Diego, and Sacramentoin addition to Oregon's Klamath Falls. As shown in Figure 21.2, annual precipitation for the California region ranges from 380 to $950 \mathrm{~mm} / \mathrm{year}$, and annual runoff ranges from 100 to 450 $\mathrm{mm} /$ year. Most precipitation occurs in the winter months.

The existing hydropower plants and major non-powered dams (Hadjerioua et al., 2012) are also shown in Figure 21.1. The California Region contains 388 hydropower dams and 20 major non- 
powered dams, with total storage capacities of around 72,054,825 ac-ft and 914,994 ac-ft, respectively.

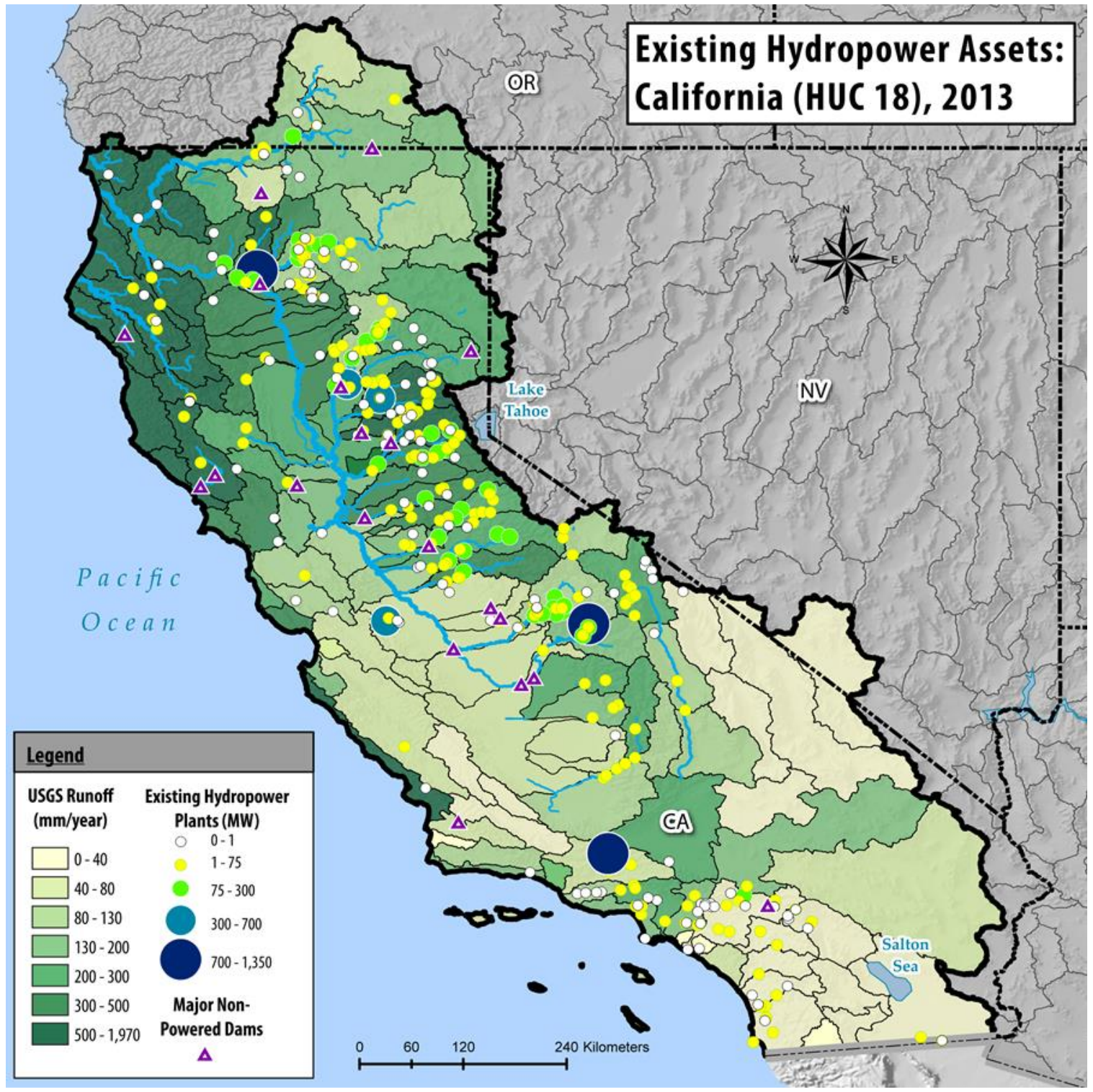

Figure 21.1. Locations of water control projects in Region 18-California.

\subsection{Potential New Hydropower Resources}

A total of 1145 stream-reaches of high energy density (with estimated potential capacity $>1$ MW per stream-reach) are identified in the California Region. The NSD results based on HUC04 subregions are summarized in Table 21.2. The highest hydropower potentials are located in the Klamath-Northern California Coastal Subregion (HUC 1801), followed by the Sacramento Subregion (HUC 1802). The hydropower potential in the remaining subregions is much lower. The highest hydropower potential in the Klamath-Northern California Coastal Subregion are located in the Klamath and Trinity rivers and to a lesser extent in the South Fork Smith, Eel, Salmon, and Smith rivers. For the Sacramento Subregion, the highest potential for hydropower is 
located mostly in the Sacramento River and, to a lesser extent, the Middle Fork American, McCloud, Feather, and Yuba rivers.

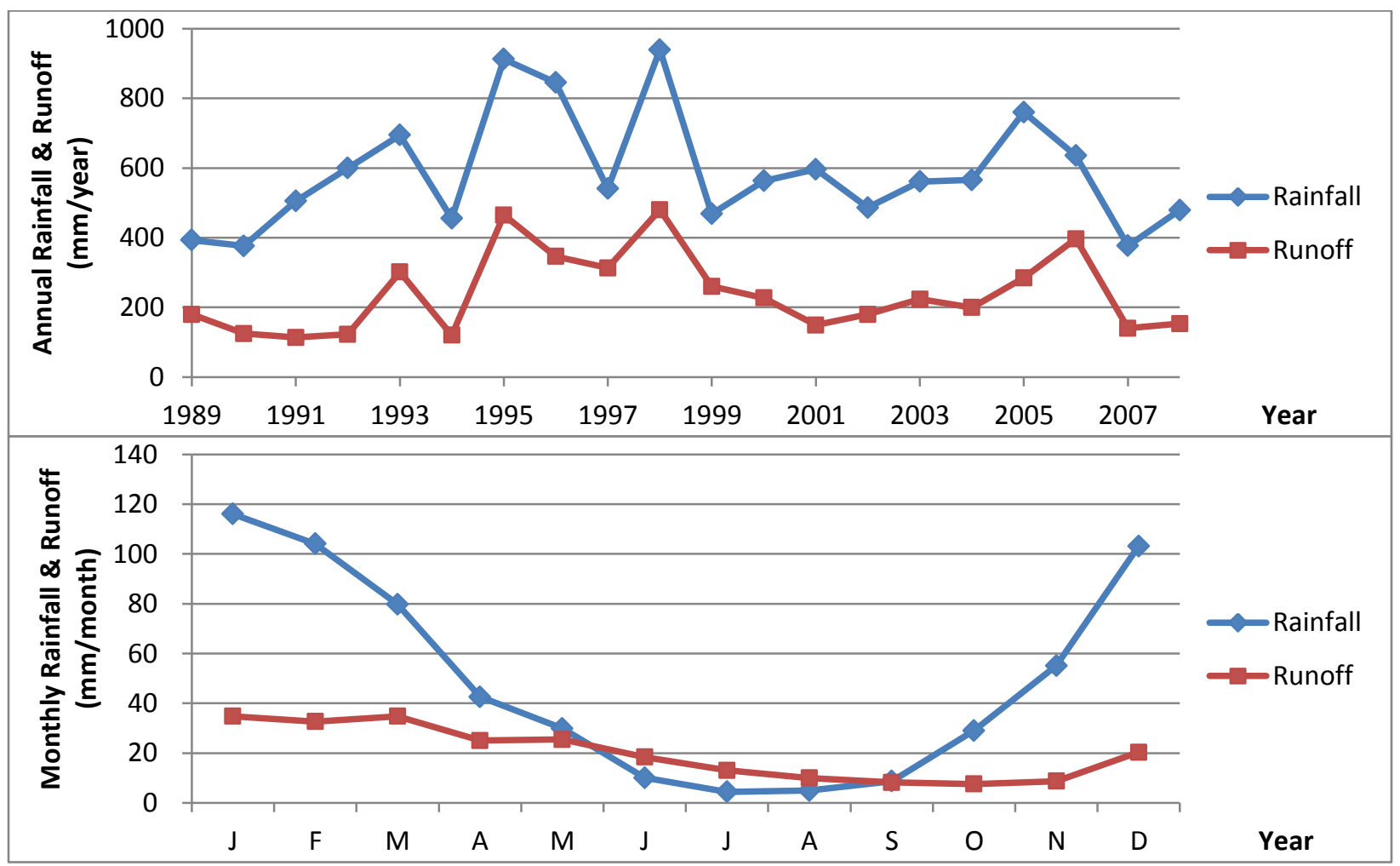

Figure 21.2. Annual and monthly rainfall and runoff of Region 18 - California.

Table 21.2. Summary of Potential New Hydropower Resources in Region 18 - California (Stream-Reaches with Potential Capacity $>1 \mathrm{MW}$ )

\begin{tabular}{|c|c|c|c|c|c|c|c|c|}
\hline HUC04 & HUC04 name & $\begin{array}{r}\text { \# of } \\
\text { stream- } \\
\text { reaches }\end{array}$ & $\begin{array}{r}\text { Potential } \\
\text { capacity } \\
(\mathrm{MW})\end{array}$ & $\begin{array}{r}\text { Potential } \\
\text { energy } \\
(\mathrm{MWh})\end{array}$ & $\begin{array}{r}\text { Average } \\
\text { head } \\
\text { (ft/reach) }\end{array}$ & $\begin{array}{r}\text { Average } \\
\text { flow } \\
\text { (cfs/reach) }\end{array}$ & $\begin{array}{r}\text { Average } \\
\text { storage (ac- } \\
\text { ft/reach) }\end{array}$ & $\begin{array}{r}\text { Average } \\
\text { residence } \\
\text { time (days) }\end{array}$ \\
\hline 1801 & $\begin{array}{l}\text { Klamath-Northern } \\
\text { California Coastal }\end{array}$ & 449 & $2,485.5$ & $12,941,370$ & 30.2 & 2,782 & 1,606 & 0.8 \\
\hline 1802 & Sacramento & 435 & $1,062.4$ & $6,509,479$ & 27.3 & 1,695 & 2,756 & 2.0 \\
\hline 1803 & $\begin{array}{l}\text { Tulare-Buena Vista } \\
\text { Lakes }\end{array}$ & 72 & 114.3 & 592,711 & 23.2 & 1,278 & 4,991 & 2.1 \\
\hline 1804 & San Joaquin & 174 & 339.5 & $1,871,301$ & 27.7 & 1,158 & 10,198 & 2.3 \\
\hline 1805 & San Francisco Bay & - & - & - & - & - & - & - \\
\hline 1806 & $\begin{array}{l}\text { Central California } \\
\text { Coastal }\end{array}$ & - & - & - & - & - & - & - \\
\hline 1807 & $\begin{array}{l}\text { Southern California } \\
\text { Coastal }\end{array}$ & - & - & - & - & - & - & - \\
\hline 1808 & North Lahontan & - & - & - & - & - & - & - \\
\hline 1809 & $\begin{array}{l}\text { Northern Mojave-- } \\
\text { Mono Lake }\end{array}$ & 15 & 27.3 & 193,242 & 16.7 & 1,517 & 7,145 & 2.9 \\
\hline 1810 & $\begin{array}{l}\text { Southern Mojave-- } \\
\text { Salton Sea }\end{array}$ & - & - & - & - & - & - & - \\
\hline
\end{tabular}

The summary statistics of hydraulic head $\mathrm{H}_{\mathrm{ref}}$ (ft), design flow $\mathrm{Q}_{30}$ (cfs), potential capacity $\mathrm{P}_{\mathrm{NSD}}$ (MW), inundated area $\mathrm{A}_{\mathrm{NSD}}(\mathrm{ac})$, storage $\mathrm{V}_{\mathrm{NSD}}$ (ac-ft), and residence time $\mathrm{T}_{\mathrm{NSD}}$ (day) are shown in Figure 21.3. The hydraulic head $\mathrm{H}_{\text {ref }}$ ranges from 7 to the 90 th quantile of $48 \mathrm{ft}$ with a median 
of $23 \mathrm{ft}$, suggesting that most of the potential stream-reaches in theCalifornia region may require low-head hydropower technologies. The design flow $\mathrm{Q}_{30}$ ranges from 300 to the 90th quantile of $5000 \mathrm{cfs}$ with a median of $1200 \mathrm{cfs}$. The potential capacity $\mathrm{P}_{\text {NSD }}$ ranges from 1 to the 90th quantile of $8 \mathrm{MW}$ with a median of $2.5 \mathrm{MW}$. The inundated surface area $\mathrm{A}_{\mathrm{NSD}}$ ranges from about 10 to the 90th quantile of 300 acres with a median of 50 acres. This results in storage values $\mathrm{V}_{\mathrm{NSD}}$ ranging from 200 to the 90th quantile of 4000 ac- $\mathrm{ft}$ with a median of 500 ac- $\mathrm{ft}$ and very short residence times $\mathrm{T}_{\mathrm{NSD}}$ ranging from $<1$ day to the 90th quantile of 2 days with a median on the order of hours. The results of $>1$ MW stream-reach potential are illustrated in Figure 21.4, with potential capacity (MW) aggregated to the HUC08 subbasins. In general, higher potential capacity is located in the mountainous regions.

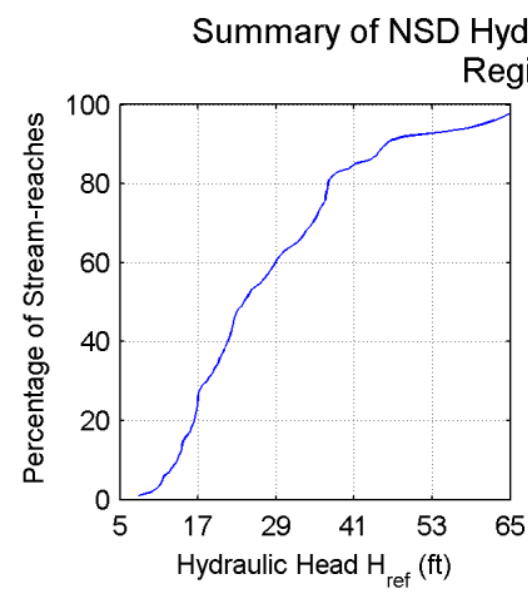

Hydropower Potential (stream-reaches with capacity > $1 \mathrm{MW}$ ) Region 18: 1145 stream-reaches, $4028 \mathrm{MW}$
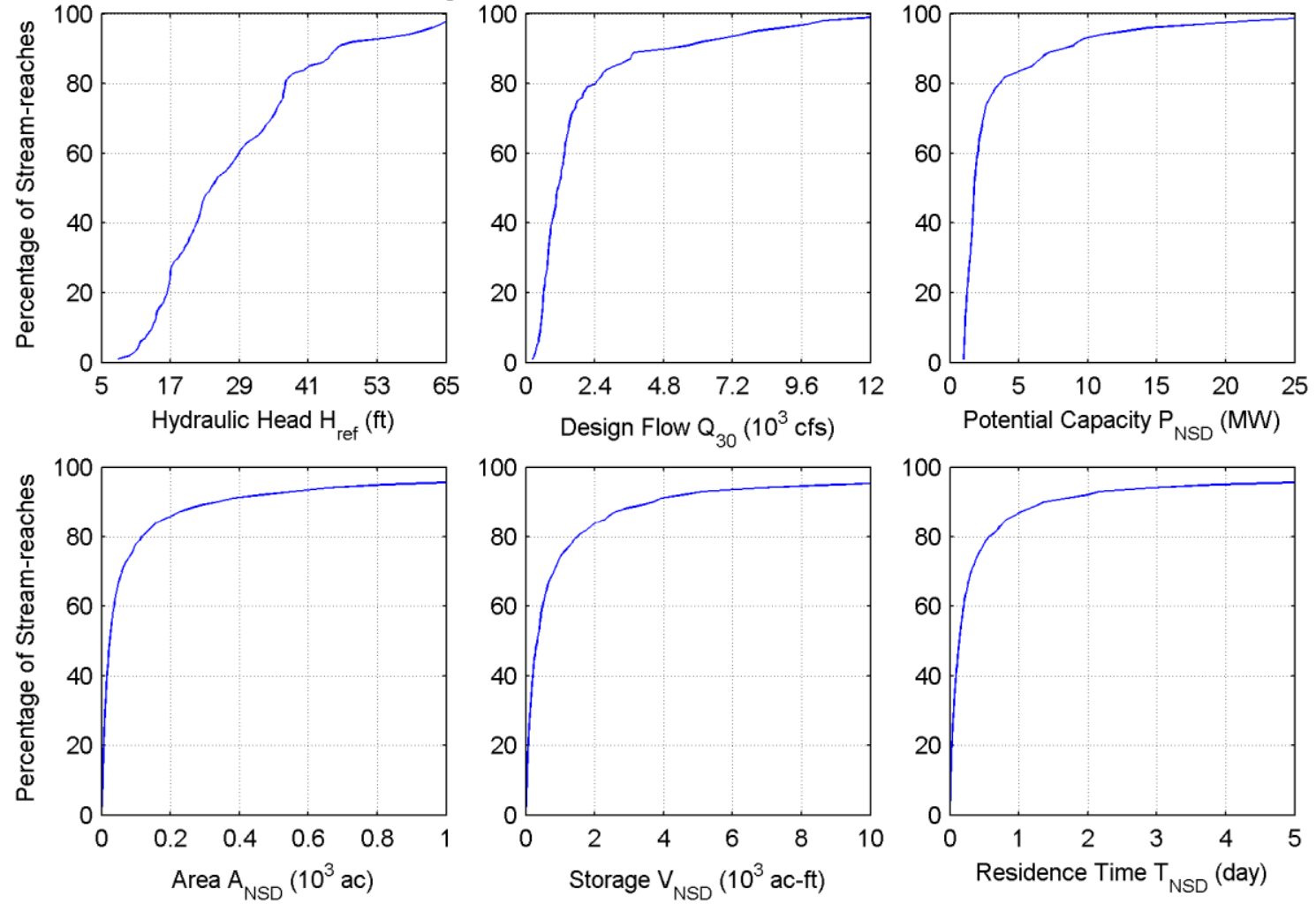

Figure 21.3. Cumulative distributions of hydraulic head $\mathrm{H}_{\text {ref }}$, design flow $\mathrm{Q}_{30}$, potential capacity $\mathrm{P}_{\mathrm{NSD}}$, inundated area $\mathrm{A}_{\mathrm{NSD}}$, storage $\mathrm{V}_{\mathrm{NSD}}$, and residence time $\mathrm{T}_{\mathrm{NSD}}$ in Region 18 - California.

\subsection{Environmental Characteristics}

The California Region is home to at least 60 fish species, 21 of which are listed or have a population listed under ESA categories (Figure 21.5). An additional five species fall under IUCN vulnerability categories (Figure 21.5). Similar to Region 17, many of these species are salmon or trout. Fourteen species are potadromous or anadromous. There are at least eight different steelhead populations, two Chinook salmon populations, and one Coho salmon population in this region. Although Chum salmon is found in the region, population status is uncertain as small 
spawning runs are confined to the Klamath, Trinity, and Smith rivers (UC, 2013). Only a subspecies of Sockeye Salmon (Kokanee) is reported in this region (Lake Tahoe) (UC, 2013).

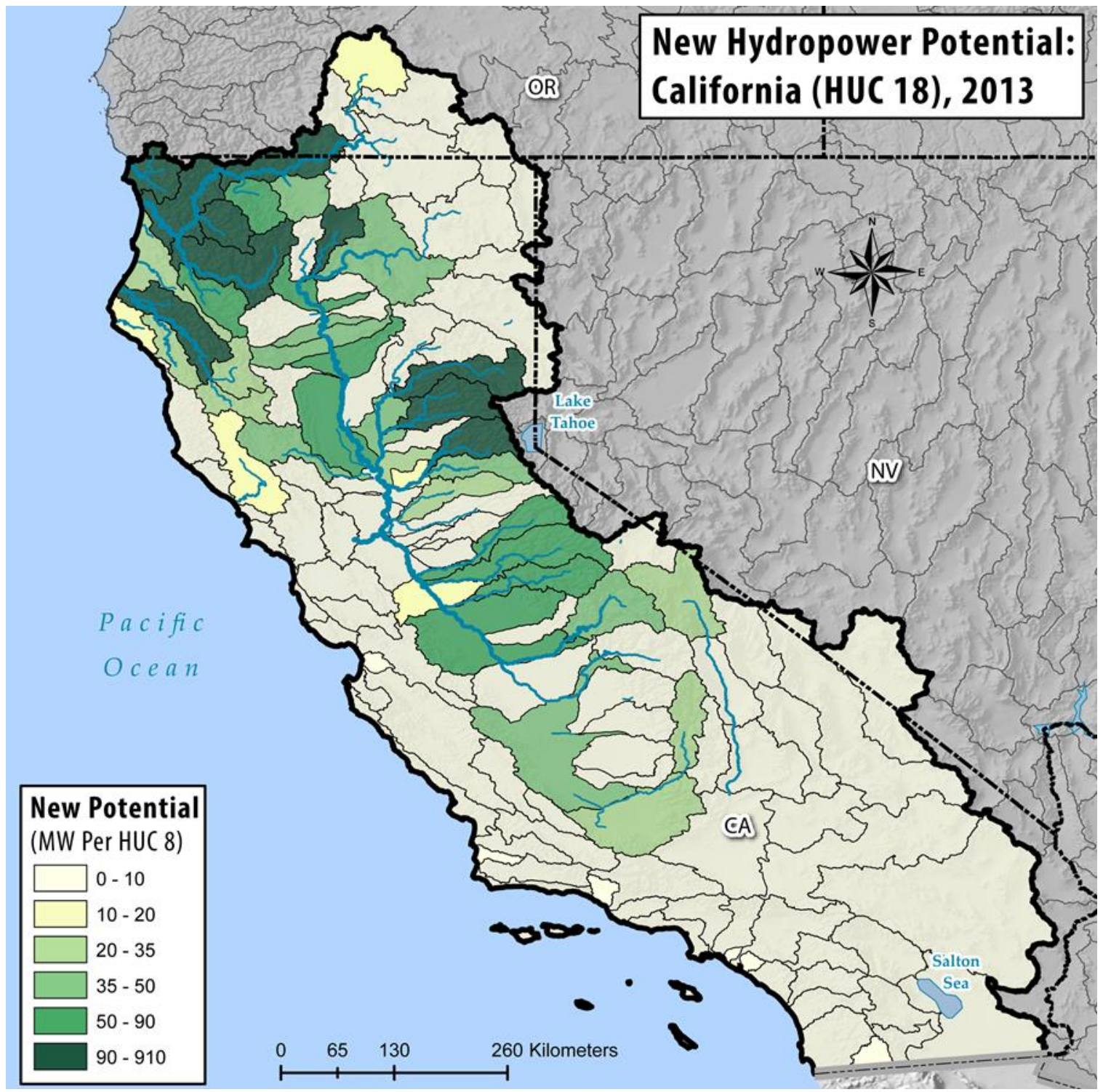

Figure 21.4. Potential new hydropower capacity in Region 18 California (higher-energy-density stream-reaches with >1 MW per reach, aggregated to HUC08 subbasins for illustration).

Several pupfish species (Cyprinodon spp.), sucker species (Deltistes, Chasmistes, Catostomus spp.), and white sturgeon (Acipenser transmontanus) are among other listed or vulnerable species in the region. Critical watersheds make up over $20 \%$ of the subbasins in the region, with the Lost (10 species), Upper Klamath Lake (9 species), and Sprague (8 species) subbasins having the highest number of fish species at risk. In Region 18, over 100 species have critical habitat designations, more than any other region in the conterminous United States (Figure 21.6). Species with critical habitats in Region 18 include 14 fish, many of which are mentioned above. 


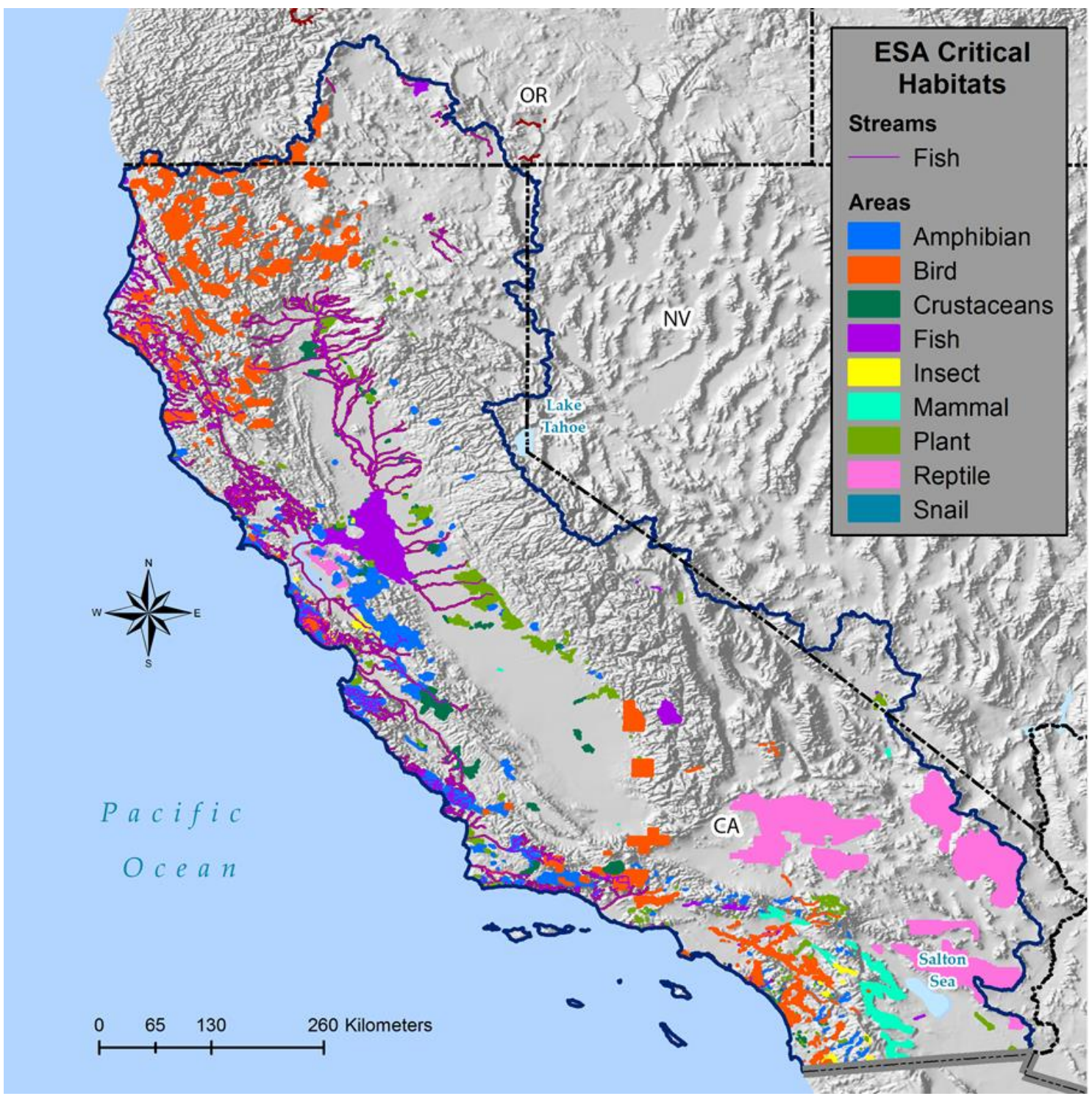

Figure 21.5. Critical habitats for federally endangered and threatened species in Region 18.

The California Region has a wide array of different protected lands, ranging from open BLM and national forests to national parks and monuments. In Region 18, there are over 57 million acres of protected land, which is more than $53 \%$ of the total area. Most protected lands are federally owned $(91 \%)$, followed by state $(4 \%)$ and local government lands $(2 \%)$. Federal lands are owned primarily by the USFS (37\%), BLM (32\%), NPS (13\%), and DOD (7.3\%). The largest tracts of land are held by the BLM, followed by Death Valley National Park and California Coastal National Monument. Many national forests are found in the region, among the largest including Modoc, Fremont-Winema, Shasta-Trinity, Klamath, Plumas, Lassen, Los Padres, Inyo, Sierra, and Sequoia. In addition to many national parks, monuments and preserves are found throughout Region 18, including Mojave National Preserve, John Muir National Monument, and Joshua Tree, Sequoia-Kings Canyon, and Yosemite national parks. Yosemite Falls, located within Yosemite National Park, is the highest waterfall in the United States with a vertical drop of 2425 ft. Among the largest DOD lands are China Lake Naval Air Weapons Station and Fort Irwin. Most of the protected lands fall under GAP status 3 (52\%), followed by status $2(20 \%)$ and status 
1 (19\%) lands. In Region 18, 16 river sections are protected under the NWSRA, totaling over 2600 river $\mathrm{km}$. Recreation includes 544 boat ramps, 351 freshwater fishing access locations, 165 waterfalls, and 347 recreational boating river sections.

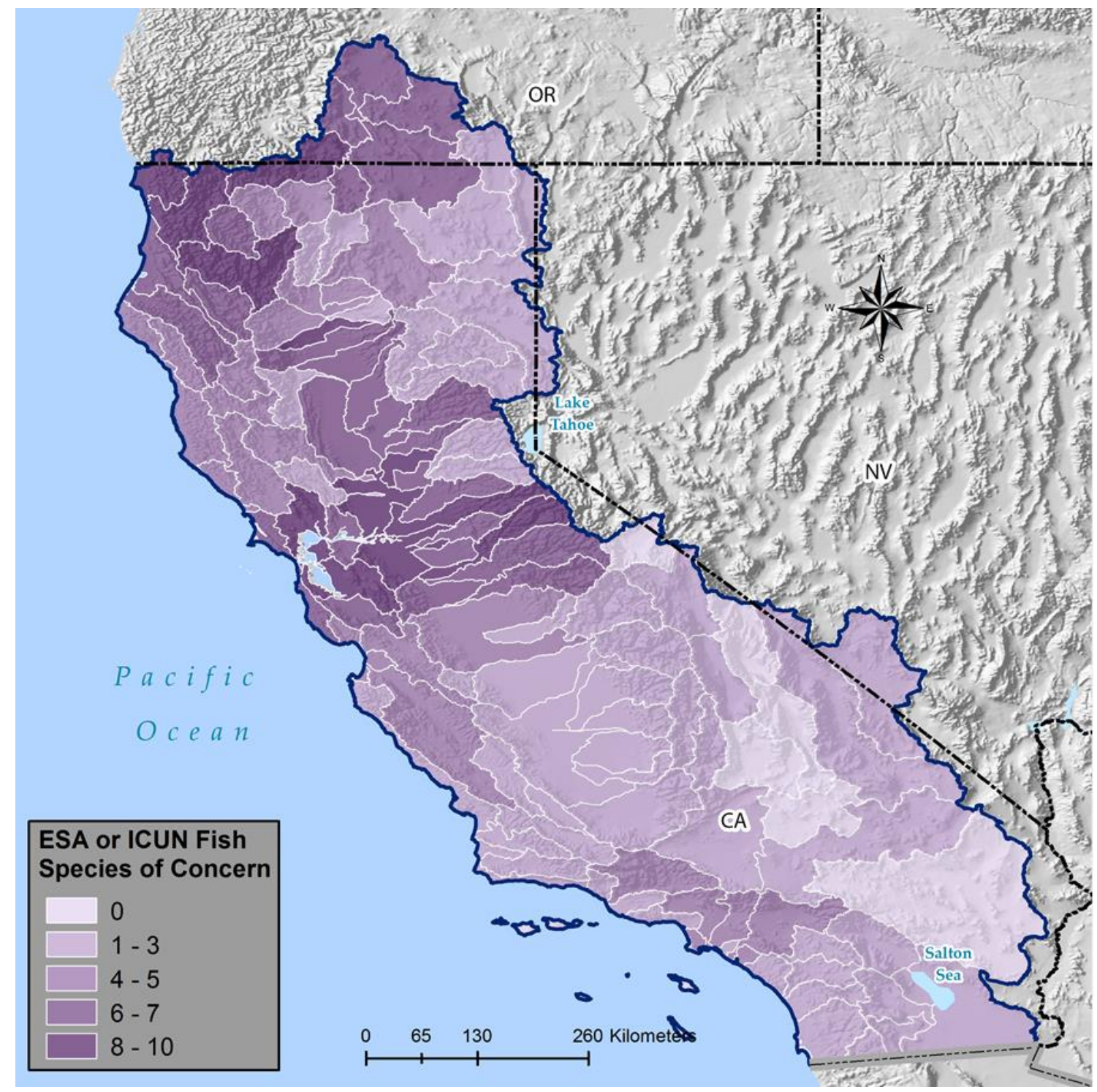

Figure 21.6. Fish species of concern (number per HUC08 subbasin) in Region 18.

Water use is above the national average in Region 18 with the Tulare-Buena-Vista Lakes and San Joaquin subregions having the highest values (Table 21.3). Irrigation consumption is quite high, followed by public consumption (Appendix B). Water quality concerns are average for the nation with most issues classified as elevated nutrient loads, toxins, or mercury contamination (Appendix B).

Critical habitat designations are present at $56 \%$ of stream-reaches $(>2.99 \mathrm{GW})$ in Region 18 (Figure 21.7). All stream-reaches are located in HUC08 subbasins with at least one fish falling under an ESA category. Almost $99 \%$ of stream-reaches intersect protected lands, with $4.2 \%$ of reaches overlapping national parks (145 MW) and 59\% (> 2.9 GW) overlapping Wild and Scenic 
Rivers. Water quality concerns are present at $50 \%$ of stream-reaches. Recreational boating is abundant, identified at $85 \%$ of stream-reaches; however, boat ramps and fishing access areas are less prevalent, identified at approximately $9 \%$ and $14 \%$ of stream-reaches, respectively. Approximately, $50 \%$ of stream-reaches are associated with low or moderate water use.

Table 21.3. Summary of Environmental Variables at HUC04 Subregions within Region 18 (Stream-Reaches with Potential Capacity $>1 \mathrm{MW}$ )

\begin{tabular}{|c|c|c|c|c|c|c|c|c|}
\hline HUC04 HUC04 name & $\begin{array}{r}\text { \# Critical } \\
\text { habitats }\end{array}$ & $\begin{array}{l}\text { \# Potad- } \\
\text { anad fish }\end{array}$ & $\begin{array}{r}\text { \# ESA } \\
\text { fish }\end{array}$ & $\begin{array}{r}\text { \# IUCN } \\
\text { fish }\end{array}$ & $\begin{array}{r}\# \\
\text { Recreation } \\
\text { locations }\end{array}$ & $\begin{array}{r}\% \\
\text { Protected } \\
\text { lands }\end{array}$ & $\begin{array}{r}\text { Population } \\
\text { density } \\
\text { (ind } / \mathbf{k m}^{2} \text { ) }\end{array}$ & $\begin{array}{r}\text { Freshwater } \\
\text { use } \\
\text { (liters/day } \\
\left./ \mathbf{k m}^{2}\right)\end{array}$ \\
\hline $1801 \begin{array}{l}\text { Klamath-Northern } \\
\text { California Coastal }\end{array}$ & 12 & 11 & 13 & 6 & $145 ; 82 ; 18$ & 50.34 & 13.69 & 668.87 \\
\hline 1802 Sacramento & 21 & 8 & 10 & 5 & $\begin{array}{r}247 ; 113 ; \\
37\end{array}$ & 40.49 & 42.77 & $3,664.09$ \\
\hline $\begin{array}{l}1803 \text { Tulare-Buena Vista } \\
\text { Lakes }\end{array}$ & 13 & 3 & 2 & 1 & $38 ; 44 ; 15$ & 31.87 & 35.48 & $6,647.19$ \\
\hline 1804 San Joaquin & 21 & 6 & 6 & 4 & $143 ; 74 ; 42$ & 34.91 & 76.97 & $6,050.93$ \\
\hline 1805 San Francisco Bay & 17 & 8 & 8 & 4 & $47 ; 8 ; 14$ & 27.48 & 444.02 & $3,043.11$ \\
\hline $\begin{array}{l}1806 \begin{array}{l}\text { Central California } \\
\text { Coastal }\end{array} \\
\end{array}$ & 32 & 5 & 5 & 1 & $33 ; 12 ; 10$ & 33.04 & 65.00 & $1,143.16$ \\
\hline $1807 \begin{array}{l}\text { Southern California } \\
\text { Coastal }\end{array}$ & 38 & 0 & 5 & 2 & $138 ; 13 ; 16$ & 41.66 & 566.10 & $3,781.03$ \\
\hline 1808 North Lahontan & 1 & 2 & 2 & 0 & $7 ; 1 ; 0$ & 61.90 & 5.25 & 759.61 \\
\hline $1809 \begin{array}{l}\text { Northern Mojave- } \\
\text { Mono Lake }\end{array}$ & 27 & 0 & 6 & 2 & $51 ; 1 ; 8$ & 84.93 & 43.37 & 896.27 \\
\hline $1810 \begin{array}{l}\text { Southern Mojave- } \\
\text { Salton Sea }\end{array}$ & 20 & 0 & 1 & 0 & $16 ; 0 ; 5$ & 80.03 & 109.47 & $3,110.28$ \\
\hline
\end{tabular}

${ }^{a}$ Recreation locations refer to the number of boat-ramp and fishing access points, recreational boating, and waterfalls within each HUC04.

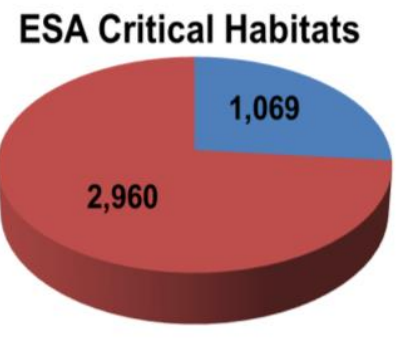

absent Present

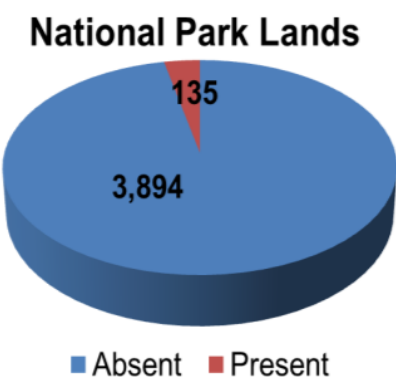

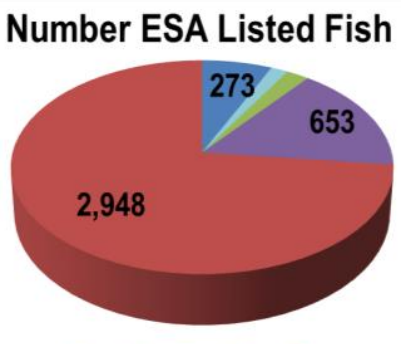

$\|0=1=2\| 3=>3$

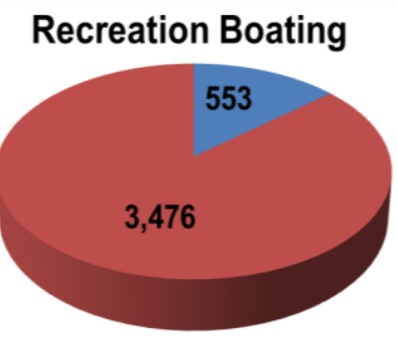

- Absent $\quad$ Present

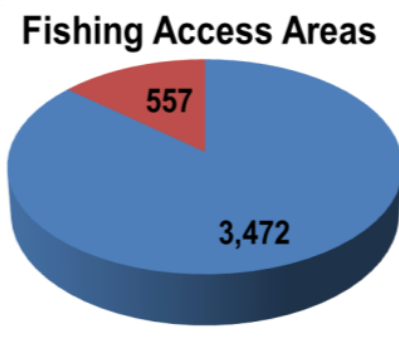

absent $\quad$ Present
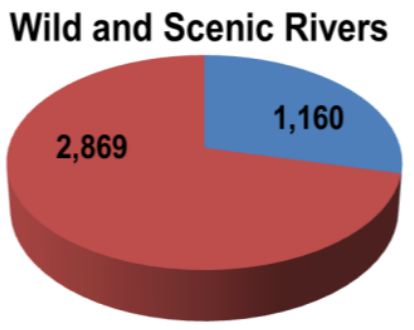

- Absent $\quad$ Present

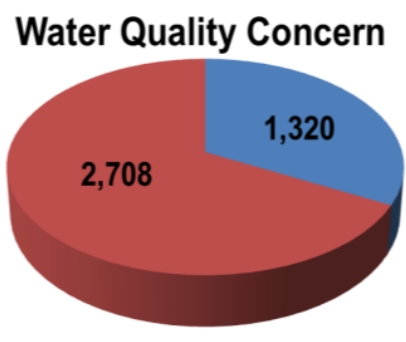

- Absent $\quad$ Present

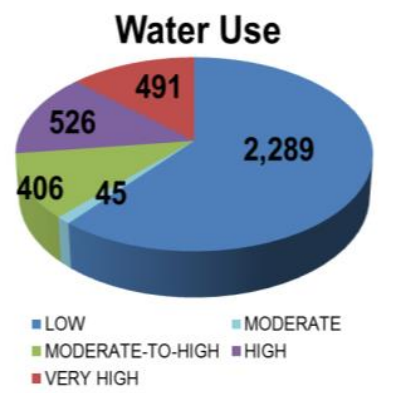

Figure 21.7. The potential capacity, in MW, associated with environmental attributes in Region 18 - California (stream-reaches with potential capacity $>1 \mathrm{MW}$ ). 


\section{REGION 19-ALASKA}

\subsection{Background and Data Collection}

Hydropower is the largest source of renewable energy in Alaska, producing around 20\% of the state's annual energy. The abundant hydrologic resources in Alaska maintain hydropower as an ideal and highly potential source of new capacity. Nevertheless, given data limitations (e.g., no NHDPlus coverage), the NSD resource potential cannot be evaluated through the same approach as used for the conterminous United States. Instead of conducting a new geospatial assessment based on limited data, this analysis relied on inputs from Alaska Energy Authority (AEA) and USACE Alaska District to summarize undeveloped hydropower potential from existing literatures.

The primary documentation source of undeveloped hydropower resources in Alaska is the AEA Hydropower Database (AEA, 2011), a comprehensive online hydropower database containing evaluated sites summarized in hundreds of hydropower reports since 1947. These reports range from reconnaissance-level studies with limited information to FERC permitting documents containing a wealth of information, such as design-level cost estimates.

\subsection{Data Processing and Quality Control}

Given that some project information in the AEA database was obtained from earlier studies, quality control was performed to select suitable sites according to the NSD objectives. Data for a total of 2,200 projects from 404 reports were included. Initial data screening was jointly conducted with the AEA and USACE staffs to identify duplicate or overlapping projects in multiple reports. In addition, high-level feasibility analysis was performed to exclude sites based on the following criteria jointly developed by AEA and USACE staffs:

1. Sites too large for rural hydroelectric production purposes

2. Sites involving land compatibility issues

3. Sites involving environmental concerns

4. Negative evaluation in original report

5. Sites located too far from the nearest community

6. Sites that are being or have been developed

7. Sites not feasible based on professional judgment

8. Other miscellaneous issues

The original database contains a conglomerate of information, often with inconsistent measurement units and types. Therefore, data were converted to consistent units, with a focus on run-of-river projects with estimated net head, annual average, and other essential information. In cases where a range of head, flow, or capacity is provided, an engineering judgment was made to select the most appropriate value. Efforts were also made to screen potential unit conversion errors within the database. 
Given the immense number of projects in the database and the effort needed to cross-reference source documentation for accurate information, more in-depth quality control was performed on selected references. Within the AEA database, many projects lack capacity information or have unrealistic capacity factor values. Upon evaluation, questionable references were identified and intensively reviewed to verify, update, and modify other information when appropriate. In addition, projects that fall under other resource classes(e.g., non-powered dams and existing infrastructure) were also excluded and satellite imagery was used for verification.

\subsection{Results}

For "feasible" NSD potential, 1143 of the original 2200 sites were removed for being unfeasible or not applicable. In addition, 466 sites were excluded, since the capacity information was not available in the AEA database. From the remaining 591 sites, 154 duplicates were removed, with preference given to designs according to the project type (level of effort), project feasibility, and report date, among other factors. The resulting 437 sites have a total potential capacity of 4,723 MW.

A map of existing and feasible NSD hydropower sites in Alaska is provided in Figure 22.1. Since feasible projects had to meet various high-level feasibility criteria, most identified hydropower potential is located in South-central or Southeast Alaska, near population centers or in mountainous terrain.

Figure 22.2 provides a graphical representation of NSD project size distribution. Of the 437 projects identified, $76 \%$ have a capacity of less than $5 \mathrm{MW}$. As seen in Figure 22.3, however, $75 \%$ of the total feasible NSD potential stems from 31 large hydropower projects above $30 \mathrm{MW}$.

The single-largest NSD project identified could provide $820 \mathrm{MW}$ of capacity, nearly double the total current installed capacity in Alaska. 


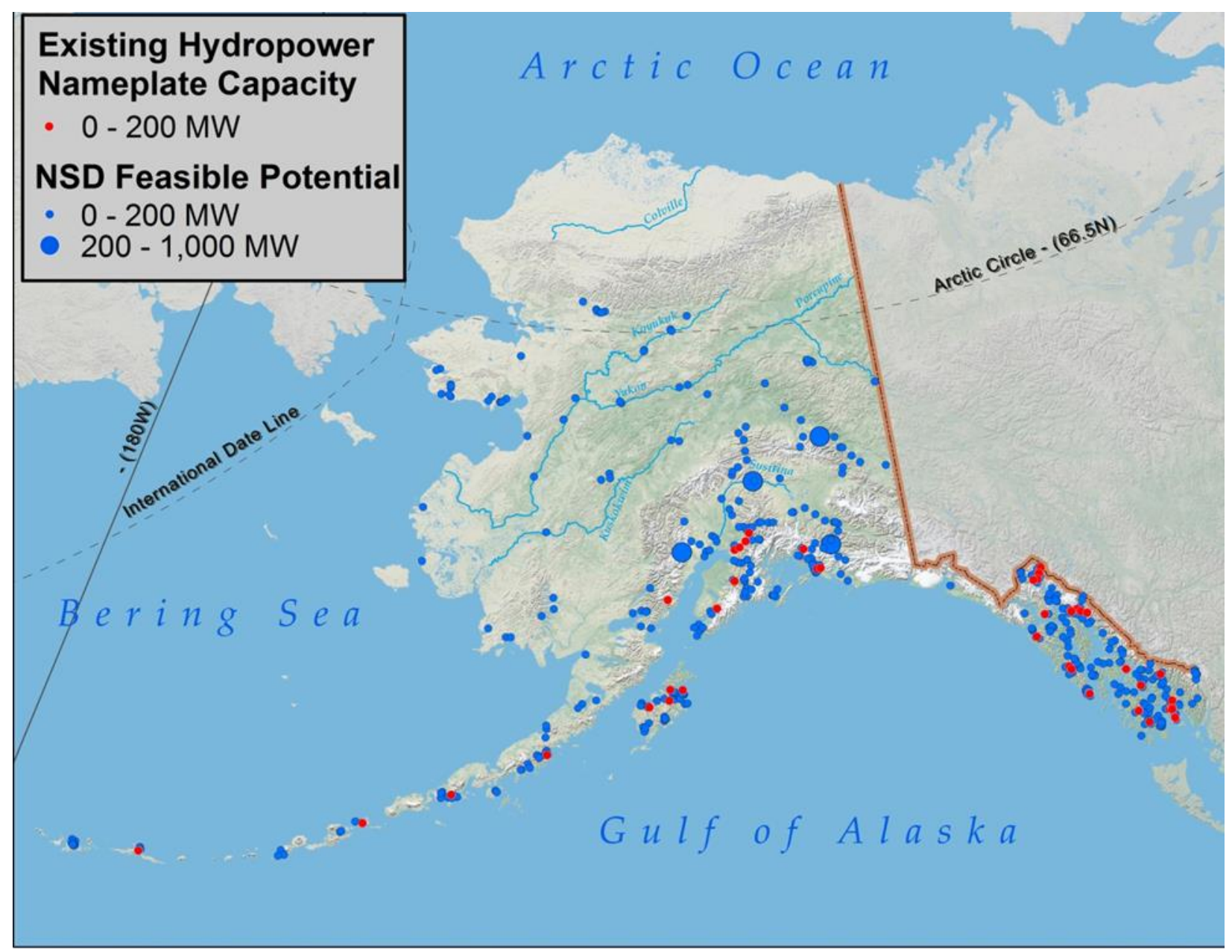

Figure 22.1. Map of existing and NSD hydropower sites in Alaska. 


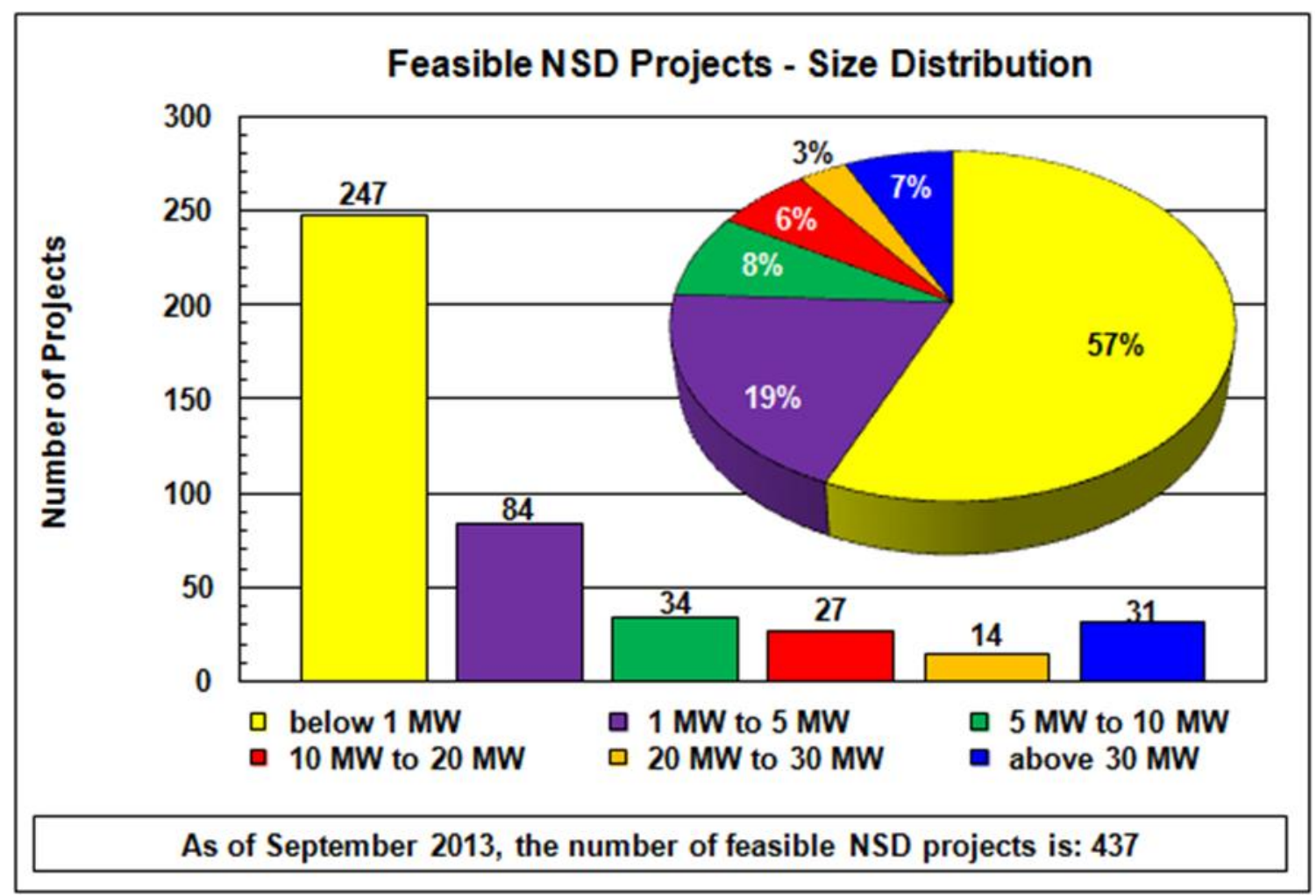

Figure 22.2. Project size distribution of Alaska NSD sites.

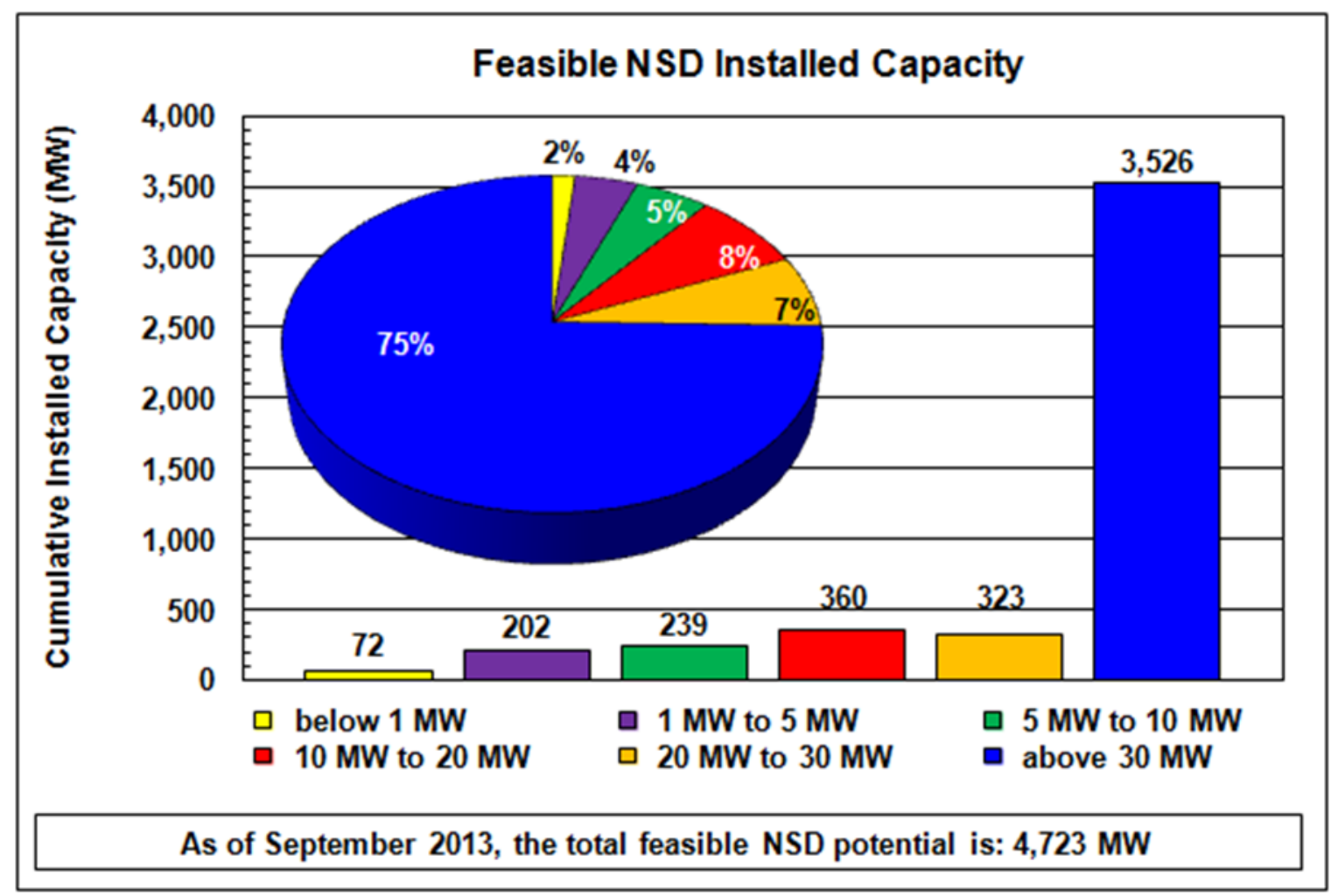

Figure 22.3. Cumulative potential installed capacity by size for Alaska. 


\section{REGION 20-HAWAII}

\subsection{Background and Data Collection}

Given data limitations (e.g., no NHDPlus coverage), the NSD resource potential cannot be evaluated using the same approach as used for the conterminous United States. After consulting with the Hawaii Department of Business, Economic Development and Tourism (DBEDT) and USACE, the researchers decided to summarize the undeveloped hydropower potential from existing literatures rather than by conducting new geospatial assessment based on limited data. The USACE Honolulu District recently published a comprehensive assessment, Hydroelectric Power Assessment-State of Hawaii" (USACE, 2011) of Hawaii's current and potential hydropower resources. This study provided reconnaissance-level analysis of more than 160 potential sites collected from more than 50 previous studies. The status of potential sites ranged from operating, inactive, or previously-developed to proposed new projects; the study covered both conventional-hydro and pump-storage opportunities.

Because our focus is NSD potential, the operating, inactive, previously-developed, and pumpedstorage projects were excluded from examination. Further quality control was performed by reviewing satellite images at project locations. Periodic consultation with USACE and DBEDT was also conducted to ensure the accuracy of the organized dataset.

\subsection{Results}

From the original 166 sites in USACE (2011), 76 existing, inactive, or duplicate sites were removed. In additional, 34 pumped-storage and 9 non-powered dam sites were also excluded. The remaining 47 potential projects, located across five different islands, are reported in this study.

A map of existing hydropower plant and NSD sites is shown in Figure 23.1. The island of Kauai has the most concentrated hydropower potential, while Hawaii and Maui also contain notable hydropower potential. The largest existing hydropower site-the 12 MW Wailuku River hydroelectric plant - is located on the island of Hawaii. Minor hydropower potential also has been identified on Molokai and Oahu.

Figure 23.2 provides a graphical representation of NSD project size distribution. Most of the identified projects would provide relatively low capacity- $81 \%$ of identified sites are below 5 MW, and only three of the 47 sites are above $10 \mathrm{MW}$. Figure 23.3 shows the cumulative installed capacity for NSD projects, according to project size. The single-largest identified NSD site could provide $25 \mathrm{MW}$ of capacity, representing $17 \%$ of the state's NSD potential. In addition, the nine sites with capacity above $5 \mathrm{MW}$ comprise $65 \%$ of Hawaii's NSD potential. As noted by DBEDT staff and evidenced by the 34 identified projects removed from the USACE database, pumped storage hydropower is often considered for energy production in Hawaii, as flow availability is often highly seasonal. 


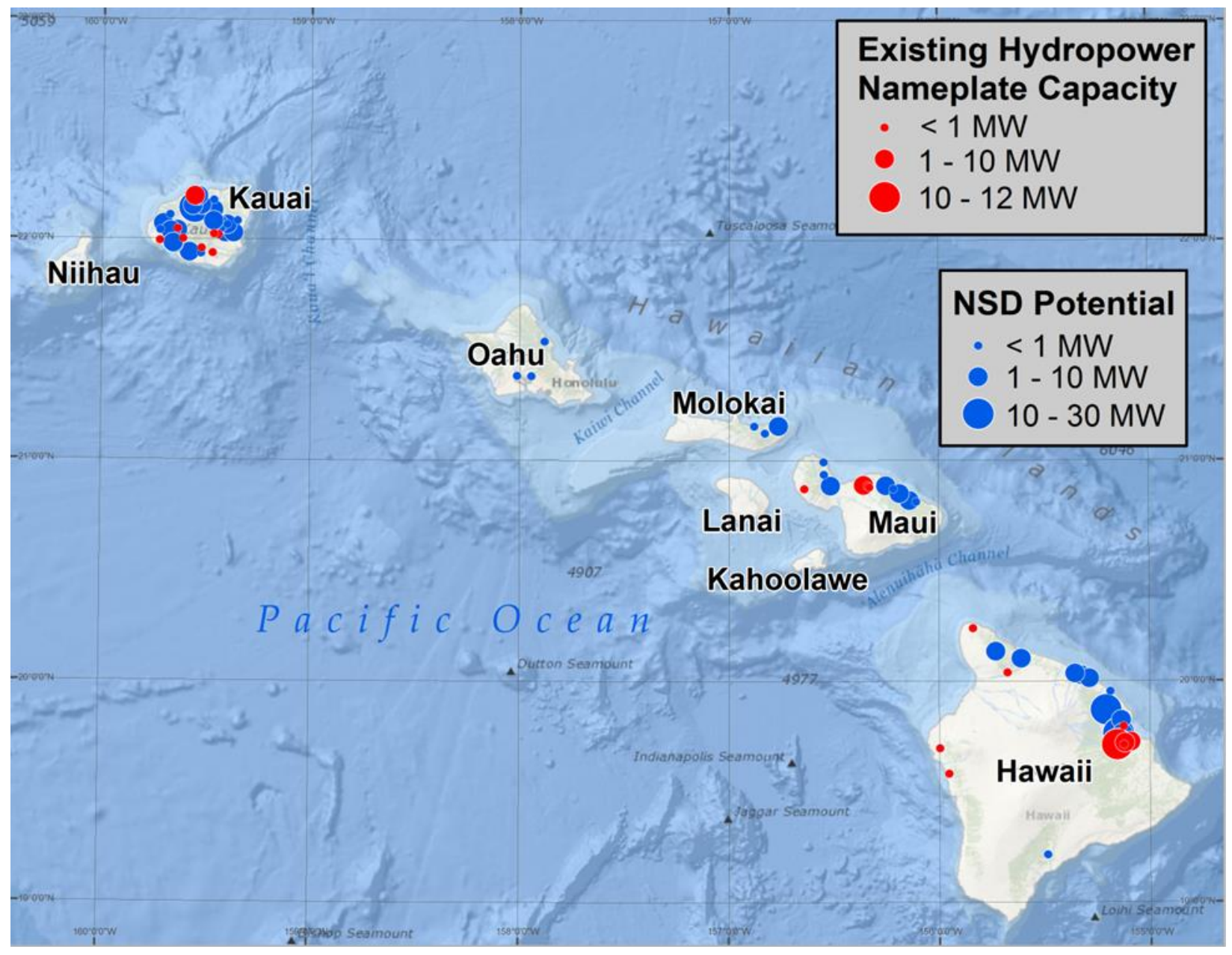

Figure 23.1. Map of existing and NSD hydropower sites in Hawaii. 


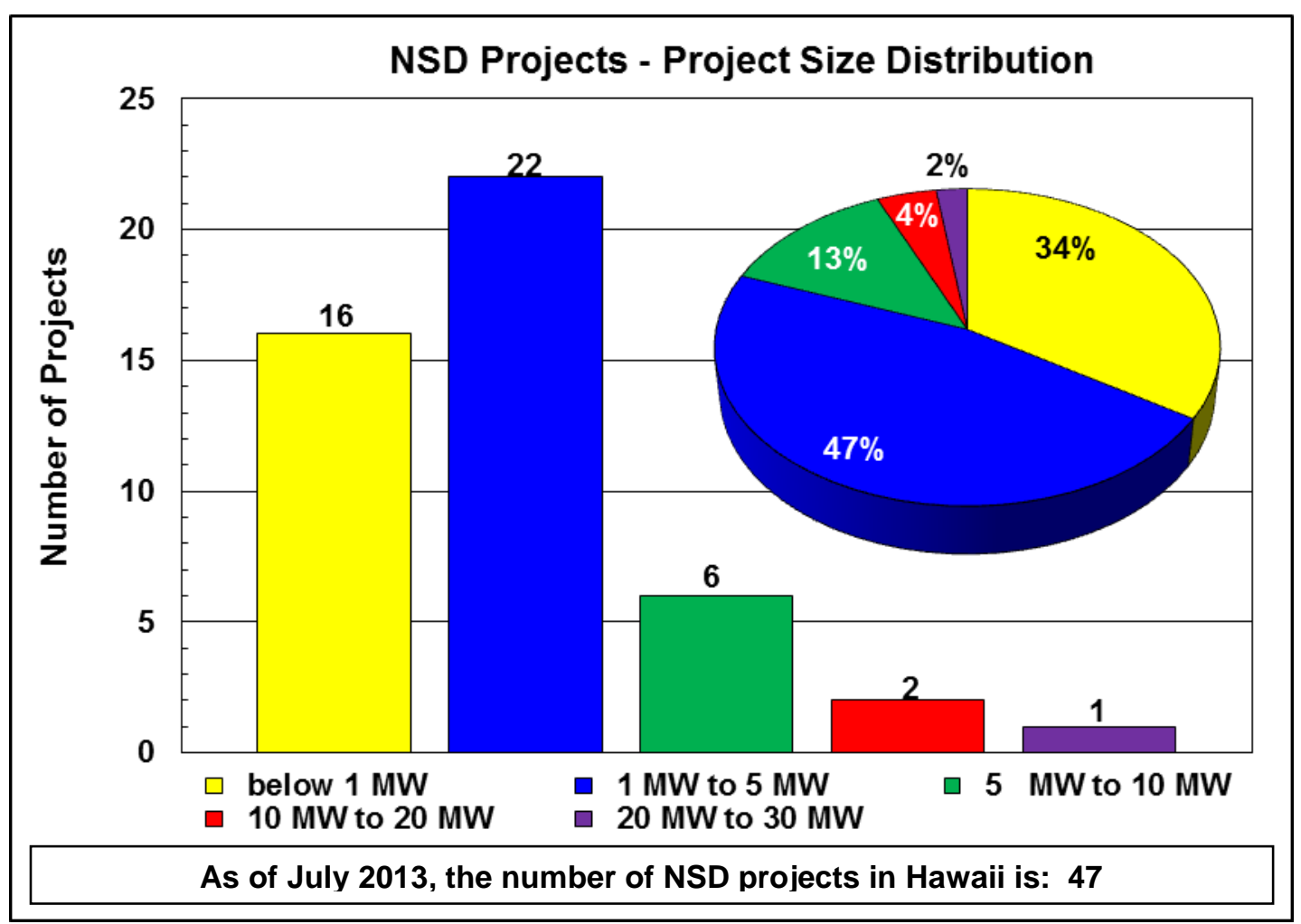

Figure 23.2. Project size distribution of Hawaii NSD sites.

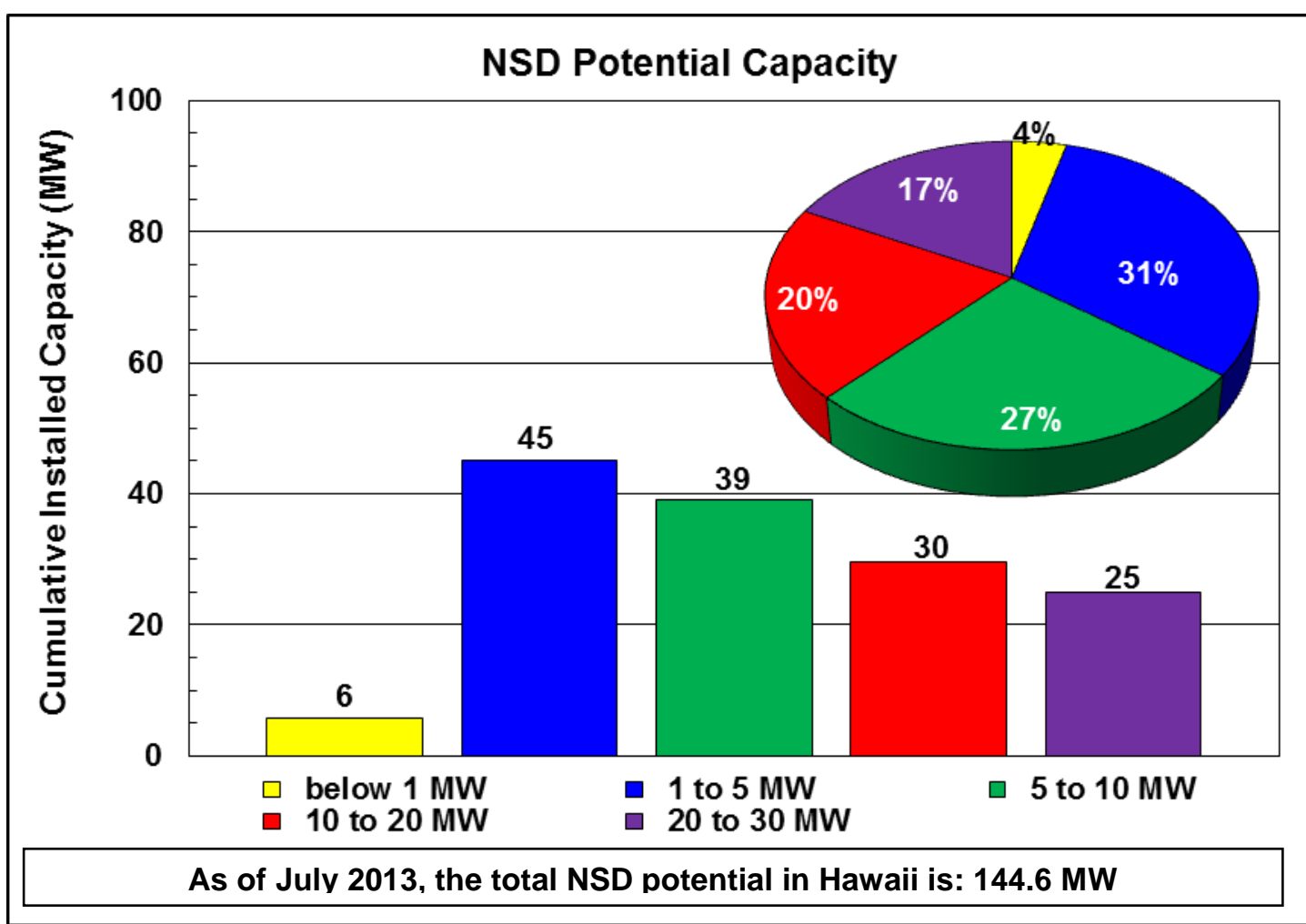

Figure 23.3. Cumulative potential installed capacity by size for Hawaii. 
(This Page Intentionally Left Blank) 


\section{CONCLUDING REMARKS}

To evaluate the hydropower potential from new stream-reach development resources, a national assessment of more than 3 million U.S. streams was conducted in this study. Utilizing a comprehensive set of recent U.S. geographic, topographic, hydrologic, hydropower, environmental, and socio-political datasets, a spatially consistent method was designed for new run-of-river projects (Hadjerioua et al., 2013). The method contains three main components: (1) identification of stream-reaches with high energy density (Pasha et al., 2014); (2) topographical analysis of promising stream-reaches to estimate the characteristics of potential inundations of reservoirs; and (3) environmental attribution to spatially join the energy potential of streamreaches with information related to the natural ecological systems; social and cultural settings; and policies, management, and legal constraints. Comparing to the previous assessments that included all streams types regardless of the presence of existing river infrastructure (i.e., hydropower plants or non-powered dams), this new assessment focuses specifically on undeveloped stream-reaches and may provide more direct estimates of new hydropower opportunities.

After the assessment was implemented across the entire United States, major findings in each hydrologic region were summarized in this final report. The estimated NSD capacity and generation, including both higher-energy-density (>1 MW per reach) and lower-energy-density ( $<1 \mathrm{MW}$ per reach) stream-reaches, were estimated to be $84.7 \mathrm{GW}$ and $460 \mathrm{TWh} /$ year. When areas protected by federal legislation limiting the development of new hydropower (national parks, wild and scenic rivers, and wilderness areas) were excluded from the analysis, the estimated NSD capacity falls to $65.5 \mathrm{GW}$, slightly lower than the current existing U.S. conventional hydropower nameplate capacity (79.5 GW; NHAAP, 2013). Undeveloped NSD generation with these areas excluded is estimated to be $347.3 \mathrm{TWh} / \mathrm{year}$, roughly $128 \%$ of the average 2002-2011 net annual generation from existing plants (272 TWh/year; EIA, 2013). Given the run-of-river assumption, NSD stream-reaches have higher capacity factors $(53 \%-$ $71 \%$ ), especially compared with conventional larger-storage peaking-operation projects that usually have capacity factors of around $30 \%$. The highest potential was identified in the Pacific Northwest Region (32\%), followed by the Missouri Region (15\%) and the California Region $(9 \%)$. Among the states, the highest potential is found in Oregon, Washington, and Idaho- the three states in the Pacific Northwest - followed in order by California, Alaska, Montana, and Colorado. In addition to the resource potential, abundant environmental attributes were organized and attributed to the identified stream-reaches to support further hydropower market analysis. The prevalence of environmental variables and the proportion of capacity from streamreaches intersecting environmental variables varied according to hydrologic region.

Since this assessment is designed to accommodate more than 3 million U.S. streams, it was targeted at the higher "reconnaissance level" (RETScreen International, 2005). The methodology considers only the physical characteristics of each stream and landscape and does not consider feasibility issues arising from environmental impacts, cost, or benefits. Although the methodology allows for the identification of stream-reaches of high energy density, and classification of new potential areas for hydropower development using a range of technical, socioeconomic, and environmental characteristics, it does not produce estimates of capacity, production, cost, or impacts of sufficient accuracy to determine absolute economic feasibility or 
to justify financial investments in individual site development. These potential high-energydensity areas should be regarded as worthy of more detailed site-by-site evaluation by engineering and environmental professionals.

These results are distributed through the NHAAP Public Portal (http://nhaap.ornl.gov/) to support further research activities. The main NSD findings are aggregated by HUC10 Hydrologic Watersheds for public usage. Detailed results with location-specific features are available through a user agreement to ensure the appropriate use and interpretation of the location-specific results. In particular, neither DOE nor ORNL recommends the use of these results to justify financial investments for individual site development, or to replace at-site physical or environmental assessments. 


\section{REFERENCES}

AEA (Alaska Energy Authority) (2011), Hydropower Database, available at http://www.akenergyinventory.org/data/hyddata, accessed online March 2013.

Baban, S.M.J. and T. Parry (2001), Developing and applying a GIS-assisted approach to locating wind farms in the UK, Renewable Energy, 24: 59-71.

Bohlen, C. and L.Y. Lewis (2009), Examining the economic impacts of hydropower dams on property values using GIS, Journal of Environmental Management, 90: S258-S269.

Brakebill, J.W., D.M. Wolock, and S.E. Terziotti (2011), Digital hydrologic networks supporting applications related to spatially referenced regression modeling, Journal of the American Water Resources Association, 47(5): 916-932.

CARA (Consortium for Atlantic Regional Assessment) (2013), CARA Region: Land Characteristics, www.cara.psu.edu/land/physprov_regional.asp, accessed online August 2013.

Cederstrom, D.J., Boswell, E.H., and Tarver, G.R. (1979), Summary Appraisals of the Nation's Ground-Water Resources-South Atlantic-Gulf Region, Geological Survey Professional Paper 813-0.

DeLorme (2012), Mapping, GPS, and digital data technologies, available at: http://www.delorme.com/, accessed online: August 14, 2011.

DOI (Department of the Interior) et al. (2007), Potential Hydroelectric Development at Existing Federal Facilities, for Section 1834 of the Energy Policy Act of 2005, Department of the Interior.

EIA (Energy Information Administration) (2013), Form EIA-906/920/923 monthly dataset, http://www.eia.gov/electricity/data/eia923/, accessed August 2013.

EPA (Environmental Protection Agency) (2000), Progress in Water Quality : An Evaluation of the National Investment in Municipal Wastewater Treatment. Chapter 5 - Connecticut River Case Study : 5-1 - 5-12.

FERC (Federal Energy Regulatory Commission) (2003), Order issuing new license, Project 1934-010, July 22, 2003.

FERC (Federal Energy Regulatory Commission) (2011a), Order issuing new license, Project 2698-033, May 4, 2011.

FERC (Federal Energy Regulatory Commission) (2011b), Order issuing new license, Project 12632-002, August 26, 2011.

FERC (Federal Energy Regulatory Commission) (2011c), Order issuing new license, Project 2619-012, October 25, 2011.

FERC (Federal Energy Regulatory Commission) (2011d), Order issuing subsequent license, Project 2603-012, September 7, 2011.

Gesch, D., M. Oimoen, S. Greenlee, C. Nelson, M. Steuck and D. Tyler (2002), The National Elevation Dataset, Photogrammetric Engineering and Remote Sensing, 68(1): 5-11. 
Hadjerioua, B., S.-C. Kao, R.A. McManamay, M.F.K. Pasha, D. Yeasmin, A.A. Oubeidillah, N.M. Samu, K.M. Stewart, M.S. Bevelhimer, S.L. Hetrick, Y. Wei, B.T. Smith (2013), An Assessment of Energy Potential from New Stream-reach Development in the United States: Initial Report on Methodology, Technical Manual 2012/298, Oak Ridge National Laboratory, Oak Ridge, TN.

Hall, D. G., S. J. Cherry, K. S. Reeves, R. D. Lee, G. R. Carroll, G. L. Sommers and K. L. Verdin (2004), Water Energy Resources of the United States with Emphasis on Low Head/Low Power Resources, DOE/ID-11111, Idaho National Engineering and Environmental Laboratory, Idaho Falls, ID.

Hall, D. G., K. S. Reeves, J. Brizzee, R. D. Lee, G. R. Carroll, and G. L. Sommers (2006), Feasibility Assessment of the Water Energy Resources of the United States for New Low Power and Small Hydro Classes of Hydroelectric Plants, DOE-ID-11263, Idaho National Engineering and Environmental Laboratory, Idaho Falls, ID.

IUCN (International Union for the Conservation of Nature) (2001), IUCN Red List Categories and Criteria: Version 3.1, IUCN Species Survival Commission, IUCN, Gland, Switzerland and Cambridge, UK.

Krewitt, W. and J. Nitsch (2003), The potential for electricity generation from on-shore wind energy under the constraints of nature conservation: A case study for two regions in Germany, Renewable Energy, 28: 1645-1655.

Master, L.L., S. R. Flack, and B. A. Stein (eds) (1998), Rivers of life: Critical watersheds for protecting freshwater biodiversity, The Nature Conservancy, Arlington, Virginia.

NatureServe (2010), Digital Distribution Maps of the Freshwater Fishes in the Conterminous United States, Version 3.0, Arlington, VA. U.S.A, available at: http://www.natureserve.org/ getData/fishMaps.jsp, accessed online: October 25, 2011.

NCFS (North Carolina Forest Service) (2006), North Carolina Forest Service Best Management Practices Manual, available at: http://ncforestservice.gov/water_quality/bmp_manual.htm, accessed online June 20, 2012.

NRC (National Research Council) (2013), An Evaluation of the U.S. Department of Energy's Marine and Hydrokinetic Resource Assessments, The National Academies Press, Washington, DC.

Pasha, M. F. K., D. Yeasmin, S.-C. Kao, B. Hadjerioua, Y. Wei, and B. T. Smith (2014), Streamreach identification for new run-of-river hydropower development through a merit matrixbased geospatial algorithm, J. Water Res. Pl., in press.

Reclamation (U.S. Bureau of Reclamation) (2011), Hydropower Resource Assessment at Existing Reclamation Facilities, Denver, CO, March 2011.

RETScreen International (2005), Clean Energy Project Analysis: RETScreen Engineering \& Cases Textbook, 3rd Edition, Ministry of Natural Resources Canada.

Seaber, P. R., F. P. Kapinos, and G. L. Knapp (1987), Hydrologic Unit Maps, U.S. Geological Survey water supply paper 2294. 
UC (University of California) (2013), California Fish Species, California Fish Website. Available at: http://calfish.ucdavis.edu/species/?uid=21\&ds=241, Accessed September 6, 2013.

USACE (U.S. Army Corps of Engineers) (1983), National Hydroelectric Power Resources Study, Report No. IWR-82-H-1, Washington, D.C.

USACE (U.S. Army Corps of Engineers) (2011), Hydroelectric Power Assessment-State of Hawaii, http://energy.hawaii.gov/wp-content/uploads/2011/10/HydroelectricPowerAssess.pdf.

USFWS (U.S. Fish and Wildlife Service) (2012a), U.S. Fish and Wildlife Service Endangered Species Program, U.S. Species, available at: http://www.fws.gov/endangered/species/usspecies.html, accessed online October 20, 2011.

USFWS (U.S. Fish and Wildlife Service) (2012b), U.S. Fish and Wildlife Service Critical Habitat Portal - Critical habitat for threatened and endangered species, available at: http://criticalhabitat.fws.gov/crithab/, accessed online October 20, 2011.

USGS (U.S. Geological Survey) (2001), National Water Quality Assessment Program, Tennessee River (TENN) Basin Study, Available at: http://tn.water.usgs.gov/lten/tenn.html. Accessed September 6, 2013.

USGS (U.S. Geological Survey) (2012), USGS Gap Analysis Program Protected Areas Viewer, available at: http://gapanalysis.usgs.gov/padus/, accessed online November 15, 2011.

USGS (U.S. Geological Survey) (2013), Ground Water Atlas of the United States, Idaho, Oregon, Washington, HA 730-H, Available at http://pubs.usgs.gov/ha/ha730/ch_h/Htext1.html, Accessed online August 2013.

USGS (U.S. Geological Survey) and USDA-NRCS (U.S. Department of Agriculture, Natural Resources Conservation Service) (2009), Federal Guidelines, Requirements, and Procedures for the National Watershed Boundary Dataset, U.S. Geological Survey Techniques and Methods 11-A3, 55 p.

Vogel, R., Wilson, I., and Daly, C. (1999), Regional Regression Models of Annual Streamflow for the United States, J. Irrig. Drain Eng., 125(3), 148-157. 
(This Page Intentionally Left Blank) 


\section{APPENDIX A. SUMMARY OF DIFFERENCES FROM THE PREVIOUS NATIONAL HYDROPOWER RESOURCE ASSESSMENT}

As mentioned previously, one major motivation to re-evaluate the national hydropower resources in this NSD assessment is because of the improvement of various national geospatial datasets on hydrogeography, topography, hydrology, and water infrastructures in the recent decade. These newly available datasets not only help improve the accuracy of resource estimates but also allow the enhancement of assessment methodology. To help understand the difference between this NSD assessment and the previous national hydropower resource estimates (Hall et al., 2004 and 2006), a summary of data and methodological difference is provided in Table A.1.

Table A.1. Summary of Difference between Hall et al. (2004, 2006) and NSD Assessment

\begin{tabular}{|c|c|c|}
\hline Data/assessment & Hall et al. $(2004,2006)$ & NSD assessment \\
\hline Hydropower resource class & $\begin{array}{l}\text { Provide a total estimate of undeveloped } \\
\text { hydropower potential covering non- } \\
\text { powered dams, new hydro } \\
\text { development, and others. Breakdown of } \\
\text { each resource class is not possible }\end{array}$ & $\begin{array}{l}\text { Provide estimates of new hydro } \\
\text { development potential from } \\
\text { undeveloped U.S. streams, designed } \\
\text { specifically for new run-of-river } \\
\text { projects }\end{array}$ \\
\hline River geometry & $\begin{array}{l}\text { Synthesized rivers from } 30 \mathrm{~m} \\
\text { resolution digital elevation model } \\
\text { (EDNA, http://edna.usgs.gov/) }\end{array}$ & $\begin{array}{l}\text { More accurately digitalized rivers from } \\
\text { aerial maps (NHDPlus, } \\
\text { http://www.horizon- } \\
\text { systems.com/nhdplus/) }\end{array}$ \\
\hline $\begin{array}{l}\text { Existing lakes and dams } \\
\text { (used to exclude stream- } \\
\text { reaches under existing and } \\
\text { non-powered dam resource } \\
\text { class) }\end{array}$ & Not considered & $\begin{array}{l}\text { Use digitized lakes from aerial maps } \\
\text { (NHDPlus) and National Inventory of } \\
\text { Dams (NID, http://geo.usace.army.mil/) } \\
\text { to exclude stream-reaches covered by } \\
\text { existing lakes and dams }\end{array}$ \\
\hline $\begin{array}{l}\text { Treatment of existing } \\
\text { hydropower }\end{array}$ & $\begin{array}{l}\text { The new hydropower potential is } \\
\text { estimated by subtracting the total raw } \\
\text { power from existing hydropower } \\
\text { capacity. This approach involves larger } \\
\text { uncertainties }\end{array}$ & $\begin{array}{l}\text { Exclude stream-reaches that are } \\
\text { overlapped with existing hydropower } \\
\text { plants, using the latest hydro inventory } \\
\text { in the DOE/ORNL NHAAP Database } \\
\text { (http://nhaap.ornl.gov/) }\end{array}$ \\
\hline Elevation & $\begin{array}{l}30 \mathrm{~m} \text { resolution } \\
\mathrm{NED(http://ned.usgs.gov/)} \text { in the } \\
\text { conterminous United States }\end{array}$ & $\begin{array}{l}10 \mathrm{~m} \text { resolution NED } \\
\text { (http://ned.usgs.gov/) in the } \\
\text { conterminous United States }\end{array}$ \\
\hline Flow & $\begin{array}{l}\text { Annual mean flow estimated by } \\
\text { regional regression formula based on } \\
\text { drainage area, precipitation, and } \\
\text { temperature (Vogel et al., 1999) }\end{array}$ & $\begin{array}{l}\text { Annual and monthly flow estimated by } \\
\text { unit runoff that is derived from the } \\
\text { USGS NWIS gauge observation } \\
\text { (http://waterdata.usgs.gov/nwis) }\end{array}$ \\
\hline
\end{tabular}


Table A.1. Summary of difference between Hall et al. (2004, 2006) and NSD assessment (continued)

\begin{tabular}{|c|c|c|}
\hline Data/assessment & Hall et al. $(2004,2006)$ & NSD assessment \\
\hline $\begin{array}{l}\text { Identification of } \\
\text { stream-reaches }\end{array}$ & $\begin{array}{l}\text { Stream-reaches are fixed to be } 2 \text { miles } \\
\text { long. }\end{array}$ & $\begin{array}{l}\text { Stream-reaches are identified based on } \\
\text { higher product of head, flow, and slope. } \\
\text { The length may vary in different } \\
\text { geographical locations }\end{array}$ \\
\hline Estimate of capacity & $\begin{array}{l}\text { Raw power was calculated by using } \\
\text { annual mean flow with } 100 \% \text { full } \\
\text { efficiency }\end{array}$ & $\begin{array}{l}\text { Capacity was estimated by the } 30 \% \\
\text { exceedance flow quantiles }\left(\mathrm{Q}_{30}\right) \text { with } \\
85 \% \text { efficiency }\end{array}$ \\
\hline Estimate of energy & Not calculated & $\begin{array}{l}\text { Monthly energy was estimated by the } \\
\text { synthesized monthly flow time-series. } \\
\text { Spill is considered. The capacity factor } \\
\text { is around } 70 \%\end{array}$ \\
\hline $\begin{array}{l}\text { Other reservoir } \\
\text { characteristics (surface } \\
\text { inundation, reservoir } \\
\text { storage, and residence } \\
\text { time) }\end{array}$ & Not calculated & $\begin{array}{l}\text { Geospatial assessment was performed } \\
\text { using the } 10 \mathrm{~m} \text { resolution national } \\
\text { elevation dataset }\end{array}$ \\
\hline Environmental factors & $\begin{array}{l}\text { Use selected environmental variables to } \\
\text { directly exclude stream-reaches from } \\
\text { further consideration }\end{array}$ & $\begin{array}{l}\text { Attribute each stream-reach with } \\
\text { potential environmental concerns to } \\
\text { allow further policy analysis }\end{array}$ \\
\hline
\end{tabular}

To further understand the quantitative difference, a numerical comparison is performed. However, because of the drastic difference of data and methodology between these two assessments, a direct comparison (i.e., capacity to capacity) could be misleading. While capacity estimates are provided in both studies, they are based on different assumptions and have different physical meaning. The power equation used by Hall et al. $(2004,2006)$ is shown in Eq. A.1:

$$
\mathrm{P}=\kappa \gamma\left[Q_{i} * \mathrm{H}+\left(Q_{o}-Q_{i}\right) * \mathrm{H} / 2\right]
$$

where $\mathrm{P}(\mathrm{kWa})$ is the annual mean power, $\kappa=1 / 11.8$ is the unit conversion factor, $\mathrm{Q}_{\mathrm{i}}\left(\mathrm{ft}^{3} / \mathrm{s}\right)$ is the flow rate at the upstream end of a stream-reach, $\mathrm{Q}_{0}\left(\mathrm{ft}^{3} / \mathrm{s}\right)$ is the flow rate at the downstream end of a stream-reach, and $\mathrm{H}$ (ft) is the hydraulic head, defined as the elevation drop at each streamreach. Compared with Eq. 2.2, the biggest differences are as follows:

1. Annual mean flow is used in Eq. A.1 while $\mathrm{Q}_{30}$ is used in Eq. 2.2.

2. An efficiency factor as 0.85 is assumed in Eq. 2.2.

3. The annual mean power ( $\mathrm{kWa}, \mathrm{MWa}, \mathrm{GWa}$ ) based on annual mean flow is conceptually different to the installed capacity ( $\mathrm{kW}, \mathrm{MW}, \mathrm{GW})$.

In addition, Eq. A.1 was computed for all 2 mile long Elevation Derivatives for National Applications (EDNA) flowlines (i.e., stream-reaches in Hall et al., 2004 and 2006), but Eq. 2.2 was only computed for the identified NSD stream-reaches, which was based on the $150 \mathrm{~m}$ subsegments discretized from NHDPlus flowlines with annual mean flow greater than $35 \mathrm{ft}^{3} / \mathrm{s}$. 
Therefore, the total capacity reported by these two studies (127 GWa versus $80 \mathrm{GW}$ in the conterminous United States) should not be directly compared.

To evaluate the difference on a common ground, we start by computing the annual mean power for NHDPlus using the same approach as Hall et al. (2004, 2006). For each NHDPlus flowline, the annual mean power is computed using Eq. A.1. In Table A.2, the (a) total, (b) developed, (c) excluded, and (d) available annual mean power from Hall et al. $(2004,2006)$ are summarized for each hydrologic region. The sum of NHDPlus annual mean power from (e) total flowlines, (f) less than $35 \mathrm{ft}^{3} / \mathrm{s}$ flowlines, (g) flowlines overlapped with water bodies, (h) flowlines overlapped with existing hydro plants or infeasible for development, and (i) flowlines available for NSD assessment, are calculated for comparison.

By comparing the total annual mean power from both datasets (i.e., columns [a] and [e] in Table A.2), it can be seen that NHDPlus actually provides more total annual mean power (258 GWa) than EDNA does (208 GWa). Except for California and Great Lakes, the total NHDPlus mean power is consistently larger. The regional values are further illustrated in Figure A.1(a), in which a strong linear pattern can be observed. Since NHDPlus flowlines are accurately digitized from aerial maps (instead of indirectly derived from a digital elevation model), the NHDPlus flowlines can better capture the geographical locations of U.S. rivers and hence should be closer to reality.

Following total annual mean power, a series of deductions was performed in both assessments. In Hall et al. (2004, 2006), a "developed" annual mean power was estimated (35 GWa) by adjusting the total installed capacity $(\sim 100 \mathrm{GW})$ from existing hydropower plants. All EDNA stream-reaches were then overlapped with several selected environmental variables to identify the "excluded" stream-reaches and the corresponding annual mean power (47 GWa). After subtraction, a total of $126 \mathrm{GWa}$ annual mean power was considered to be available in the conterminous United States.

In this NSD assessment, all flowlines less than $35 \mathrm{ft}^{3} / \mathrm{s}$ (41 GWa) were excluded directly since they are less likely to be developed (Hadjerioua et al., 2013). The flowlines overlapped with existing NHDPlus water bodies were then identified $(38 \mathrm{GWa})$. During national assessment, it was observed that the NHDPlus water bodies have mostly been associated with existing dams (either powered or non-powered). Therefore, for the purpose of resource assessment on undeveloped stream-reaches, these flowlines were excluded since their hydropower potential fell under different hydropower resource classes (i.e., existing plant upgrade/expansion or nonpowered dam development). In addition, using the latest DOE/ORNL NHAAP Database (NHAAP, 2013) flowlines that overlapped with existing hydropower plants were excluded during the quality control process $(67 \mathrm{GWa})$. Some other flowlines that were judged to be infeasible for development (e.g., near an ocean) also were excluded during quality control. The result was $112 \mathrm{GWa}$ of annual mean power for the remaining flowlines. 
Table A.2. Comparison of Annual Mean Power in Conterminous United States

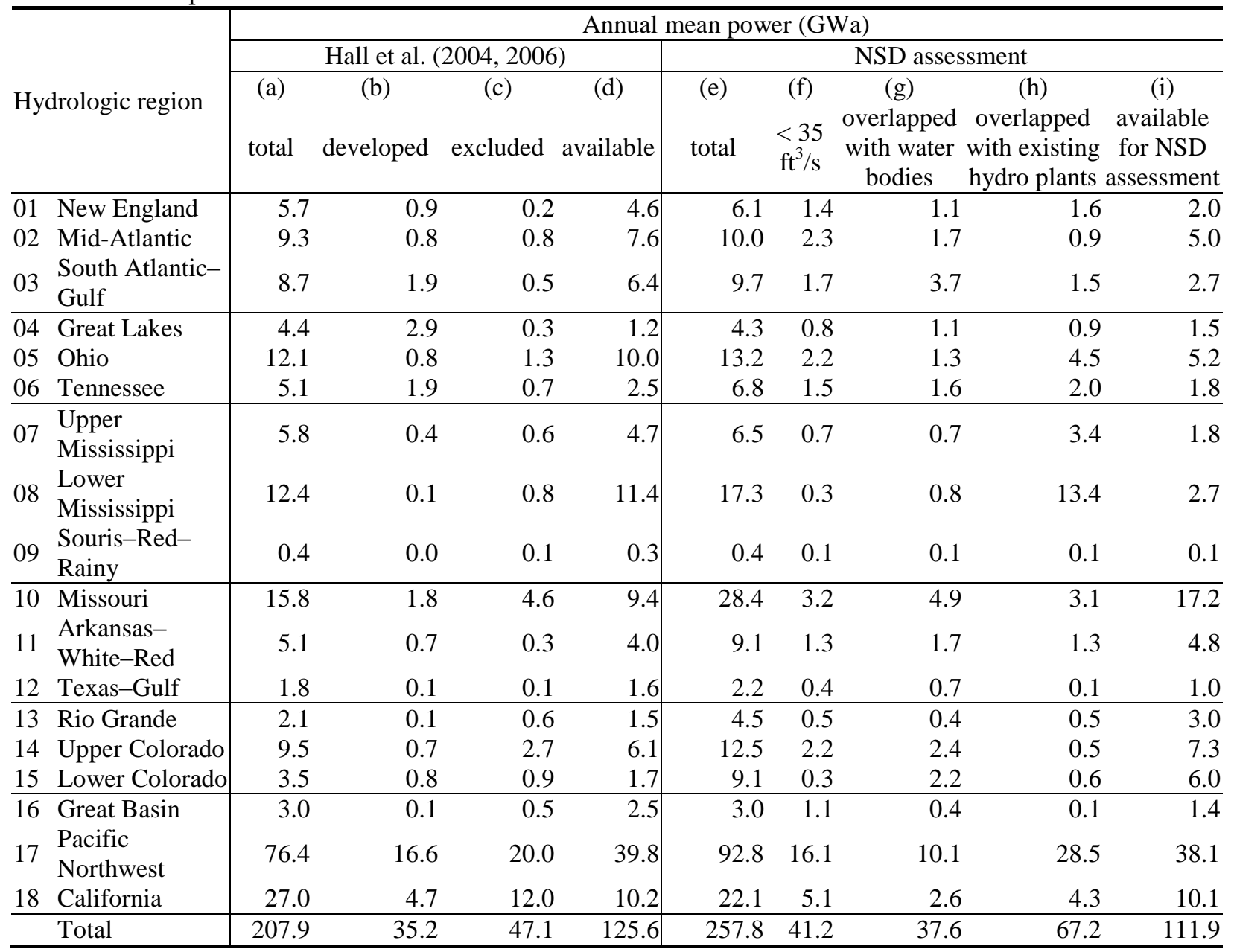
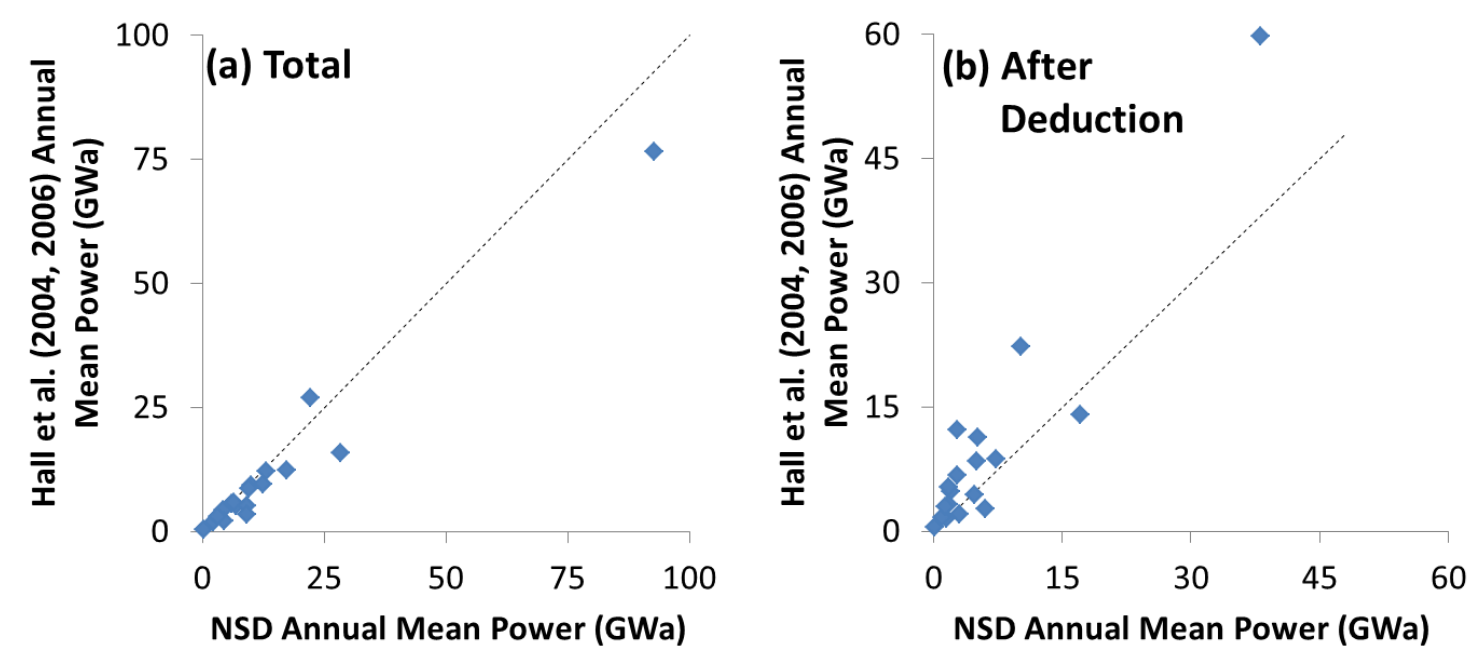

Figure A.1. Comparison of (a) total and (b) after deduction annual mean power between Hall et al. (2004, 2006) and NSD assessment. 
Given that the environmental factors were labeled instead of excluded in the NSD assessment, a more appropriate evaluation will be comparing the sum of "excluded" and "available" annual mean power from Hall et al. $(2004,2006)(173 \mathrm{GWa}$, columns [c] and [d] in Table A.2) to the available flowlines for NSD assessment (112 GWa, column [i] in Table A.2). The reduction for Hall et al. $(2004,2006)$ is $17 \%$, from $208 \mathrm{GWa}$ to $173 \mathrm{GWa}$, mainly addressing the annual mean power that was believed to have been developed by existing hydropower plants. For NSD assessment, the reduction is $57 \%$, from $258 \mathrm{GWa}$ to $112 \mathrm{GWa}$, covering several sources of exclusion (smaller flowlines, lakes, dams, and existing hydropower plants). The regional values are further illustrated in Figure A.1(b), in which a larger spread can be seen.

While it appears that NSD provides a smaller resource estimate, the meaning of these two resource values is different. Through the "subtraction" approach, Hall et al. (2004, 2006) provided the upper bound of undeveloped hydropower potential across all resource categories (upgrade/expansion, non-powered dam development, new stream-reaches, and others). However, it should be noted that the "developed" annual mean power calculated from existing installed capacity cannot be associated with stream-reaches directly because the location of existing hydropower plants was not identified in Hall et al. $(2004,2006)$ and the annual mean power calculated from overlapping stream-reaches could also be very different from the ones translated from existing plant installed capacity. Therefore, while the total undeveloped hydropower resource estimate is valid, such potential cannot be further broken down into each resource class by classifying each stream-reach. In addition, given the ambiguous meaning of annual mean power, additional calculation will be required to translate the resource values into possible install capacity.

To provide more specificity for future hydropower development, the NSD assessment focuses on undeveloped stream-reaches, particularly for new run-of-river projects. The stream-reaches that are not suitable for new run-of-river development were not considered in this study, even though some of them still could be developed through non-powered dams or other approaches. The calculation in Table A.2 suggests that, even after a century of hydropower development, $43 \%$ of annual mean power remains on undeveloped stream-reaches that could be suitable for new development. To estimate the full hydropower resources, separate resource evaluation should be conducted for each resource class, such as the recent non-powered dam study (Hadjerioua et al., 2012). Given the different nature of each hydropower resource class, the most suitable assessment approach should be designed accordingly.

The last step is to address the difference between annual mean power calculated in Table A.2 (column [i], $112 \mathrm{GWa}$ ) to the capacity identified in NSD assessment ( $80 \mathrm{GW}$ for both $>1$ and $<1$ MW stream-reaches). As mentioned, $\mathrm{Q}_{30}$ (instead of annual mean flow) and generation efficiency (0.85) are used in Eq. 2.2 to calculate NSD hydropower potential. By comparing $\mathrm{Q}_{30}$ derived from USGS NWIS daily streamflow gauge stations to the corresponding NHDPlus annual mean flow estimate, a conversion ratio was estimated for each HUC4 to help estimate $\mathrm{Q}_{30}$ for each NHDPlus flowline. By applying the ratio adjustment, the $112 \mathrm{GWa}$ annual mean power (column [a] in Table A.3) becomes $100 \mathrm{GWa}$ (column [b] in Table A.3). With further consideration of 0.85 efficiency, the value drops to $85 \mathrm{GWa}$ (column [c] in Table A.3), which is close to the $80 \mathrm{GW}$ NSD finding. The remaining difference should be mainly a result of different spatial units. While this appendix examined NHDPlus annual mean power in units of flowline (for a consistent comparison to Hall et al., 2004 and 2006), the NSD assessment was actually 
performed on discretized 150 meter sub-segments. As a result, some larger stream-reaches could cover multiple smaller NHDPlus flowlines, and other shorter stream-reaches could co-exist in a long NHDPlus flowline. The finer spatial resolution helps identify the location of potential stream-reaches more accurately.

Table A.3. Comparison of Annual Mean Power in the Conterminous United States

\begin{tabular}{|c|c|c|c|}
\hline Hydrologic region & $\begin{array}{c}\text { (a) } \\
\text { NSD annual mean power } \\
(\mathrm{GWa})\end{array}$ & $\begin{array}{l}\text { (b) } \\
\text { NSD annual mean power } \\
\text { with flow adjustment } \\
(\mathrm{GWa})\end{array}$ & $\begin{array}{l}\text { (c) } \\
\text { NSD annual mean power } \\
\text { with flow and efficiency } \\
\text { adjustment (GWa) }\end{array}$ \\
\hline $01 \quad$ New England & 2.0 & 2.2 & 1.9 \\
\hline 02 Mid-Atlantic & 5.0 & 5.4 & 4.6 \\
\hline 03 South Atlantic-Gulf & 2.7 & 2.5 & 2.1 \\
\hline $04 \quad$ Great Lakes & 1.5 & 1.6 & 1.4 \\
\hline 05 Ohio & 5.2 & 5.5 & 4.6 \\
\hline $06 \quad$ Tennessee & 1.8 & 1.7 & 1.4 \\
\hline $07 \quad$ Upper Mississippi & 1.8 & 2.2 & 1.9 \\
\hline 08 Lower Mississippi & 2.7 & 2.3 & 2.0 \\
\hline 09 Souris-Red-Rainy & 0.1 & 0.1 & 0.1 \\
\hline $10 \quad$ Missouri & 17.2 & 14.2 & 12.1 \\
\hline 11 Arkansas-White-Red & 4.8 & 6.5 & 5.5 \\
\hline 12 Texas-Gulf & 1.0 & 0.7 & 0.6 \\
\hline 13 Rio Grande & 3.0 & 2.0 & 1.7 \\
\hline 14 Upper Colorado & 7.3 & 4.1 & 3.5 \\
\hline 15 Lower Colorado & 6.0 & 2.9 & 2.5 \\
\hline $16 \quad$ Great Basin & 1.4 & 0.7 & 0.6 \\
\hline 17 Pacific Northwest & 38.1 & 35.1 & 29.8 \\
\hline 18 California & 10.1 & 10.0 & 8.5 \\
\hline Total & 111.9 & 99.6 & 84.7 \\
\hline
\end{tabular}




\section{APPENDIX B. ADDITIONAL ENVIRONMENTAL ATTRIBUTION DATA}

Table B.1. Fish Species Falling Under an ESA or IUCN Vulnerability Category and their Native Hydrologic Region(s)

\begin{tabular}{|c|c|c|c|c|c|c|}
\hline Common name & Scientific name & NS & ESA & IUCN & Regions & \# Regions \\
\hline $\begin{array}{l}\text { Alabama } \\
\text { Cavefish }\end{array}$ & $\begin{array}{l}\text { Speoplatyrhinus } \\
\text { poulsoni }\end{array}$ & G1 & LE & $\mathrm{CR}$ & 06 & 1 \\
\hline Alabama Shad & Alosa alabamae & G2G3 & & $\mathrm{EN}$ & $\begin{array}{c}03,06,07,08,10 \\
11\end{array}$ & 6 \\
\hline $\begin{array}{l}\text { Alabama } \\
\text { Sturgeon }\end{array}$ & Scaphirhynchus suttkusi & G1 & LE & $\mathrm{CR}$ & 03 & 1 \\
\hline Alewife & Alosa pseudoharengus & G5 & $\mathrm{SC}$ & & $01,02,03,04,05$ & 5 \\
\hline Alvord Chub & Gila alvordensis & G2 & & VU & 16,17 & 2 \\
\hline $\begin{array}{l}\text { Amargosa } \\
\text { Pupfish }\end{array}$ & Cyprinodon nevadensis & $\mathrm{G} 2$ & POPE & & 18 & 1 \\
\hline Amber Darter & Percina antesella & G1G2 & LE & VU & 03 & 1 \\
\hline Arctic Grayling & Thymallus arcticus & G5 & POPC & & 4,10 & 2 \\
\hline Arkansas Darter & Etheostoma cragini & G3G4 & $\mathrm{C}$ & NT & 10,11 & 2 \\
\hline Arrow Darter & Etheostoma sagitta & G3G4 & POPC & & 05 & 1 \\
\hline Ashy Darter & Etheostoma cinereum & G2G3 & & VU & 05,06 & 2 \\
\hline Atlantic Salmon & Salmo salar & G5 & POPE & $\mathrm{LC}$ & 01,04 & 2 \\
\hline Atlantic Sturgeon & Acipenser oxyrinchus & G3 & POPT & NT & $01,02,03,08$ & 4 \\
\hline $\begin{array}{l}\text { Barrens } \\
\text { Topminnow }\end{array}$ & Fundulus julisia & G1 & & VU & 05,06 & 2 \\
\hline Bayou Darter & Etheostoma rubrum & G1 & LT & NT & 08 & 1 \\
\hline $\begin{array}{l}\text { Bear Lake } \\
\text { Sculpin }\end{array}$ & Cottus extensus & G1 & & VU & 16 & 1 \\
\hline Beautiful Shiner & Cyprinella formosa & G3 & $\mathrm{LT}$ & VU & 15 & 1 \\
\hline $\begin{array}{l}\text { Big Bend } \\
\text { Gambusia }\end{array}$ & Gambusia gaigei & G1 & LE & VU & 13 & 1 \\
\hline $\begin{array}{l}\text { Blackmouth } \\
\text { Shiner }\end{array}$ & Notropis melanostomus & G2 & & VU & 03 & 1 \\
\hline Blackside Dace & $\begin{array}{l}\text { Phoxinus } \\
\text { cumberlandensis }\end{array}$ & G2 & $\mathrm{LT}$ & VU & 05,06 & 2 \\
\hline Bloater & Coregonus hoyi & G4 & & VU & 04,07 & 2 \\
\hline $\begin{array}{l}\text { Blotchside } \\
\text { Logperch }\end{array}$ & Percina burtoni & G2G3 & & VU & 05,06 & 2 \\
\hline Blue Shiner & Cyprinella caerulea & $\mathrm{G} 2$ & LT & VU & 03 & 1 \\
\hline Blue Sucker & Cycleptus elongatus & G3G4 & & NT & $\begin{array}{c}05,06,07,08,10 \\
11,12,13\end{array}$ & 8 \\
\hline Blueback Herring & Alosa aestivalis & G5 & $\mathrm{SC}$ & & $01,02,03$ & 3 \\
\hline $\begin{array}{l}\text { Bluebarred } \\
\text { Pygmy Sunfish }\end{array}$ & Elassoma okatie & G2G3 & & VU & 03 & 1 \\
\hline Bluehead Sucker & Catostomus discobolus & G4 & POPC & & $14,15,16,17$ & 4 \\
\hline Bluemask Darter & Etheostoma akatulo & G1 & LE & & 05 & 1 \\
\hline Bluestripe Darter & Percina cymatotaenia & G2 & & EN & 10 & 1 \\
\hline
\end{tabular}


Table B.1. Fish Species Falling Under an ESA or IUCN Vulnerability Category and their Native Hydrologic Region(s) (continued)

\begin{tabular}{|c|c|c|c|c|c|c|}
\hline Common name & Scientific name & NS & ESA & IUCN & Regions & \# Regions \\
\hline Bluestripe Shiner & Cyprinella callitaenia & G2G3 & & NT & 03 & 1 \\
\hline Bluntnose Shiner & Notropis simus & $\mathrm{G} 2$ & POPT & EN & 13 & 1 \\
\hline Bonytail & Gila elegans & G1 & LE & EN & 14,15 & 2 \\
\hline Borax Lake Chub & Gila boraxobius & G1 & LE & VU & 17 & 1 \\
\hline Boulder Darter & Etheostoma wapiti & G1 & LE & VU & 06 & 1 \\
\hline Bull Trout & Salvelinus confluentus & G3 & POPT & VU & $10,17,18$ & 3 \\
\hline Caddo Madtom & Noturus taylori & G1 & & VU & 08 & 1 \\
\hline Cahaba Shiner & Notropis cahabae & $\mathrm{G} 2$ & LE & $\mathrm{CR}$ & 03 & 1 \\
\hline Candy Darter & Etheostoma osburni & G3 & & NT & 05 & 1 \\
\hline Cape Fear Shiner & Notropis mekistocholas & G1 & LE & $\mathrm{CR}$ & 03 & 1 \\
\hline $\begin{array}{l}\text { Carolina Pygmy } \\
\text { Sunfish }\end{array}$ & Elassoma boehlkei & G2 & & NT & 03 & 1 \\
\hline Cherokee Darter & Etheostoma scotti & $\mathrm{G} 2$ & $\mathrm{LT}$ & & 03 & 1 \\
\hline Chihuahua Chub & Gila nigrescens & G1 & $\mathrm{LT}$ & $\mathrm{CR}$ & 13 & 1 \\
\hline Chinook Salmon & $\begin{array}{l}\text { Oncorhynchus } \\
\text { tshawytscha }\end{array}$ & G5 & POPT & & 17,18 & 2 \\
\hline Chucky Madtom & Noturus crypticus & G1 & PE & & 06 & 1 \\
\hline Chum Salmon & Oncorhynchus keta & G5 & POPT & & 17,18 & 2 \\
\hline $\begin{array}{l}\text { Clear Creek } \\
\text { Gambusia }\end{array}$ & Gambusia heterochir & G1 & LE & VU & 12 & 1 \\
\hline Coho Salmon & Oncorhynchus kisutch & G4 & POPT & & 17,18 & 2 \\
\hline Coldwater Darter & Etheostoma ditrema & G2 & & VU & 03 & 1 \\
\hline $\begin{array}{l}\text { Colorado } \\
\text { Pikeminnow }\end{array}$ & Ptychocheilus lucius & G1 & LE & VU & 14 & 1 \\
\hline $\begin{array}{l}\text { Comanche } \\
\text { Springs Pupfish }\end{array}$ & Cyprinodon elegans & G1 & LE & EN & 13 & 1 \\
\hline $\begin{array}{l}\text { Conasauga } \\
\text { Logperch }\end{array}$ & Percina jenkinsi & G1 & LE & VU & 03 & 1 \\
\hline $\begin{array}{l}\text { Coppercheek } \\
\text { Darter }\end{array}$ & Etheostoma aquali & G2G3 & & VU & 06 & 1 \\
\hline Crystal Darter & Crystallaria asprella & G3 & & VU & $03,07,08,10,11$ & 5 \\
\hline Cui-Cui & Chasmistes cujus & G1 & LE & $\mathrm{CR}$ & 16 & 1 \\
\hline $\begin{array}{l}\text { Cumberland } \\
\text { Darter }\end{array}$ & Etheostoma susanae & G1G2 & PE & & 05 & 1 \\
\hline Cutthroat Trout & Oncorhynchus clarkii & G4 & POPT & & $\begin{array}{c}10,11,13,14,15 \\
16,17,18\end{array}$ & 8 \\
\hline Delta Smelt & $\begin{array}{l}\text { Hypomesus } \\
\text { transpacificus }\end{array}$ & G1 & $\mathrm{LT}$ & EN & 18 & 1 \\
\hline Desert Dace & Eremichthys acros & G1 & $\mathrm{LT}$ & VU & 16 & 1 \\
\hline Desert Pupfish & Cyprinodon macularius & G1 & LE & & 15,18 & 2 \\
\hline $\begin{array}{l}\text { Devil's Hole } \\
\text { Pupfish }\end{array}$ & Cyprinodon diabolis & G1 & LE & VU & 15,18 & 2 \\
\hline $\begin{array}{l}\text { Devils River } \\
\text { Minnow }\end{array}$ & Dionda diaboli & G1 & $\mathrm{LT}$ & VU & 13 & 1 \\
\hline
\end{tabular}


Table B.1. Fish Species Falling Under an ESA or IUCN Vulnerability Category and their Native Hydrologic Region(s) (continued)

\begin{tabular}{|c|c|c|c|c|c|c|}
\hline Common name & Scientific name & NS & ESA & IUCN & Regions & \# Regions \\
\hline Diamond Darter & Crystallaria cincotta & G1 & $\mathrm{C}$ & & 05 & 1 \\
\hline Dolly Varden & Salvelinus malma & G5 & PT & & 17 & 1 \\
\hline Duskytail Darter & Etheostoma percnurum & G1 & LE & & 06 & 1 \\
\hline $\begin{array}{l}\text { Eastern Sand } \\
\text { Darter }\end{array}$ & Ammocrypta pellucida & G4 & & VU & 04,05 & 2 \\
\hline Etowah Darter & Etheostoma etowahae & G1 & LE & & 03 & 1 \\
\hline Fountain Darter & Etheostoma fonticola & G1 & LE & VU & 12 & 1 \\
\hline $\begin{array}{l}\text { Frecklebelly } \\
\text { Madtom }\end{array}$ & Noturus munitus & G3 & & NT & 03 & 1 \\
\hline Freckled Darter & Percina lenticula & $\mathrm{G} 2$ & & VU & 03 & 1 \\
\hline Gila Chub & Gila intermedia & $\mathrm{G} 2$ & LE & NT & 15 & 1 \\
\hline $\begin{array}{l}\text { Gila or Apache } \\
\text { Trout }\end{array}$ & Oncorhynchus gilae & G3 & LT & EN & 13,15 & 2 \\
\hline Goldline Darter & Percina aurolineata & $\mathrm{G} 2$ & $\mathrm{LT}$ & VU & 03 & 1 \\
\hline Green Sturgeon & Acipenser medirostris & G3 & & VU & 17,18 & 2 \\
\hline Grotto Sculpin & Cottus sp. 8 & $\mathrm{G} 2$ & $\mathrm{C}$ & & 07 & 1 \\
\hline Headwater Chub & Gila nigra & $\mathrm{G} 2$ & $\mathrm{C}$ & & 15 & 1 \\
\hline Humpback Chub & Gila cypha & G1 & LE & VU & 14,15 & 2 \\
\hline June Sucker & Chasmistes liorus & G1 & LE & & 16 & 1 \\
\hline Kanawha Darter & Etheostoma kanawhae & G4 & & NT & 05 & 1 \\
\hline $\begin{array}{l}\text { Kanawha } \\
\text { Minnow }\end{array}$ & Phenacobius teretulus & G3G4 & & VU & 05 & 1 \\
\hline $\begin{array}{l}\text { Kern Brook } \\
\text { Lamprey }\end{array}$ & Lampetra hubbsi & G1G2 & & NT & 18 & 1 \\
\hline Kiyi & Coregonus kiyi & G3 & & VU & 04 & 1 \\
\hline $\begin{array}{l}\text { Klamath } \\
\text { Largescale } \\
\text { Sucker }\end{array}$ & Catostomus snyderi & G3 & & NT & 18 & 1 \\
\hline Laurel Dace & Phoxinus saylori & G1 & $\mathrm{PE}$ & & 06 & 1 \\
\hline Least Chub & Iotichthys phlegethontis & G1 & $\mathrm{C}$ & VU & 16 & 1 \\
\hline $\begin{array}{l}\text { Leon Springs } \\
\text { Pupfish }\end{array}$ & Cyprinodon bovinus & G1 & LE & $\mathrm{CR}$ & 13 & 1 \\
\hline Leopard Darter & Percina pantherina & G1 & LT & VU & 11 & 1 \\
\hline $\begin{array}{l}\text { Little Colorado } \\
\text { Spinedace }\end{array}$ & Lepidomeda vittata & G1G2 & LT & VU & 15 & 1 \\
\hline Loach Minnow & Rhinichthys cobitis & $\mathrm{G} 2$ & LT & VU & 15 & 1 \\
\hline Longhead Darter & Percina macrocephala & G3 & & NT & 05,06 & 2 \\
\hline Longnose Darter & Percina nasuta & G3 & & NT & 08,11 & 2 \\
\hline Lost River Sucker & Deltistes luxatus & G1 & LE & EN & 18 & 1 \\
\hline Maryland Darter & Etheostoma sellare & GH & LE & EX & 02 & 1 \\
\hline Moapa Dace & Moapa coriacea & G1 & LE & $\mathrm{CR}$ & 15 & 1 \\
\hline Modoc Sucker & Catostomus microps & G2 & LE & EN & 18 & 1 \\
\hline Neosho Madtom & Noturus placidus & G2 & LT & NT & 11 & 1 \\
\hline
\end{tabular}


Table B.1. Fish Species Falling Under an ESA or IUCN Vulnerability Category and their Native Hydrologic Region(s) (continued)

\begin{tabular}{|c|c|c|c|c|c|c|}
\hline Common name & Scientific name & NS & ESA & IUCN & Regions & \# Regions \\
\hline Niangua Darter & Etheostoma nianguae & $\mathrm{G} 2$ & LT & VU & 10 & 1 \\
\hline $\begin{array}{l}\text { Northern } \\
\text { Cavefish }\end{array}$ & Amblyopsis spelaea & G4 & & VU & 05 & 1 \\
\hline Okaloosa Darter & Etheostoma okaloosae & G1 & LT & EN & 03 & 1 \\
\hline $\begin{array}{l}\text { Olympic } \\
\text { Mudminnow }\end{array}$ & Novumbra hubbsi & G3 & & NT & 17 & 1 \\
\hline $\begin{array}{l}\text { Orangefin } \\
\text { Madtom }\end{array}$ & Noturus gilberti & G2 & & VU & 02,03 & 2 \\
\hline Oregon Chub & Oregonichthys crameri & $\mathrm{G} 2$ & $\mathrm{LT}$ & VU & 17 & 1 \\
\hline Ouachita Madtom & Noturus lachneri & $\mathrm{G} 2$ & & VU & 08 & 1 \\
\hline Ouachita Shiner & Lythrurus snelsoni & G3 & & VU & 11 & 1 \\
\hline $\begin{array}{l}\text { Owens River } \\
\text { Pupfish }\end{array}$ & Cyprinodon radiosus & G1 & LE & EN & 18 & 1 \\
\hline Ozark Cavefish & Amblyopsis rosae & G3 & $\mathrm{LT}$ & VU & 10,11 & 2 \\
\hline Paddlefish & Polyodon spathula & G4 & & VU & $\begin{array}{c}03,05,06,07,08 \\
10,11,12\end{array}$ & 8 \\
\hline Paleback Darter & $\begin{array}{l}\text { Etheostoma } \\
\text { pallididorsum }\end{array}$ & G2 & & VU & 08 & 1 \\
\hline Palezone Shiner & Notropis albizonatus & G1 & LE & & 05,06 & 2 \\
\hline Pallid Sturgeon & Scaphirhynchus albus & G2 & LE & EN & $07,08,10$ & 3 \\
\hline Pearl Darter & Percina aurora & G1 & $\mathrm{C}$ & & 03 & 1 \\
\hline Pecos Gambusia & Gambusia nobilis & $\mathrm{G} 2$ & LE & VU & 13 & 1 \\
\hline Pecos Pupfish & Cyprinodon pecosensis & G1 & & $\mathrm{CR}$ & 13 & 1 \\
\hline Peppered Shiner & Notropis perpallidus & G3 & & NT & 08,11 & 2 \\
\hline Proserpine Shiner & Cyprinella proserpina & G3 & & VU & 13 & 1 \\
\hline Pygmy Madtom & Noturus stanauli & G1 & LE & VU & 06 & 1 \\
\hline Pygmy Sculpin & Cottus paulus & G1 & $\mathrm{LT}$ & $\mathrm{CR}$ & 03 & 1 \\
\hline $\begin{array}{l}\text { Railroad Valley } \\
\text { Springfish }\end{array}$ & Crenichthys nevadae & G2 & $\mathrm{LT}$ & VU & 16 & 1 \\
\hline $\begin{array}{l}\text { Rainbow Trout or } \\
\text { Steelhead }\end{array}$ & Oncorhynchus mykiss & G5 & POPT & & 17,18 & 2 \\
\hline Razorback Sucker & Xyrauchen texanus & G1 & LE & EN & 14,15 & 2 \\
\hline Redband Darter & $\begin{array}{l}\text { Etheostoma } \\
\text { luteovinctum }\end{array}$ & G4 & & NT & 05,06 & 2 \\
\hline Relict Dace & Relictus solitarius & G2G3 & & EN & 16 & 1 \\
\hline Relict Darter & Etheostoma chienense & G1 & LE & & 08 & 1 \\
\hline $\begin{array}{l}\text { Rio Grande } \\
\text { Darter }\end{array}$ & Etheostoma grahami & G2G3 & & VU & 13 & 1 \\
\hline $\begin{array}{l}\text { Rio Grande } \\
\text { Silvery Minnow }\end{array}$ & Hybognathus amarus & G1 & LE & EN & 13 & 1 \\
\hline Roanoke Bass & Ambloplites cavifrons & G3 & & VU & 03 & 1 \\
\hline $\begin{array}{l}\text { Roanoke } \\
\text { Logperch }\end{array}$ & Percina rex & G1G2 & LE & VU & 03 & 1 \\
\hline Rough Sculpin & Cottus asperrimus & $\mathrm{G} 2$ & & VU & 18 & 1 \\
\hline
\end{tabular}


Table B.1. Fish Species Falling Under an ESA or IUCN Vulnerability Category and their Native Hydrologic Region(s) (continued)

\begin{tabular}{|c|c|c|c|c|c|c|}
\hline Common name & Scientific name & NS & ESA & IUCN & Regions & \# Regions \\
\hline Rush Darter & $\begin{array}{l}\text { Etheostoma } \\
\text { phytophilum }\end{array}$ & G1 & $\mathrm{PE}$ & & 03 & 1 \\
\hline Rustyside Sucker & Thoburnia hamiltoni & G3 & & NT & 03 & 1 \\
\hline $\begin{array}{l}\text { Saltmarsh } \\
\text { Topminnow }\end{array}$ & Fundulus jenkinsi & G3 & $\mathrm{SC}$ & & $03,08,12$ & 3 \\
\hline Santa Ana Sucker & Catostomus santaanae & G1 & $\mathrm{LT}$ & VU & 18 & 1 \\
\hline Sharphead Darter & Etheostoma acuticeps & G3 & & NT & 06 & 1 \\
\hline Sharpnose Shiner & Notropis oxyrhynchus & G3 & $\mathrm{C}$ & DD & 11,12 & 2 \\
\hline Shortjaw Cisco & Coregonus zenithicus & G3 & & VU & 04,09 & 2 \\
\hline $\begin{array}{l}\text { Shortnose } \\
\text { Sturgeon }\end{array}$ & Acipenser brevirostrum & G3 & $\mathrm{LE}$ & VU & $01,02,03$ & 3 \\
\hline Shortnose Sucker & Chasmistes brevirostris & G1 & LE & EN & 18 & 1 \\
\hline Shoshone Sculpin & Cottus greenei & G2 & & VU & 17 & 1 \\
\hline $\begin{array}{l}\text { Shovelnose } \\
\text { Sturgeon }\end{array}$ & $\begin{array}{l}\text { Scaphirhynchus } \\
\text { platorynchus }\end{array}$ & G4 & $\mathrm{LT}$ & VU & $\begin{array}{c}05,06,07,08,10 \\
11\end{array}$ & 6 \\
\hline Sicklefin Chub & Macrhybopsis meeki & G3 & & NT & $07,08,10$ & 3 \\
\hline $\begin{array}{l}\text { Sicklefin } \\
\text { Redhorse }\end{array}$ & Moxostoma sp. 2 & G2 & $\mathrm{C}$ & & 06 & 1 \\
\hline Slackwater Darter & Etheostoma boschungi & G1 & $\mathrm{LT}$ & EN & 06 & 1 \\
\hline Slender Chub & Erimystax cahni & G1 & $\mathrm{LT}$ & VU & 06 & 1 \\
\hline Smalleye Shiner & Notropis buccula & $\mathrm{G} 2$ & $\mathrm{C}$ & VU & 12 & 1 \\
\hline Smoky Madtom & Noturus baileyi & G1 & LE & $\mathrm{CR}$ & 06 & 1 \\
\hline Snail Darter & Percina tanasi & G2G3 & $\mathrm{LT}$ & VU & 06 & 1 \\
\hline Sockeye Salmon & Oncorhynchus nerka & G5 & POPE & & 17,18 & 2 \\
\hline Sonora Chub & Gila ditaenia & $\mathrm{G} 2$ & $\mathrm{LT}$ & VU & 15 & 1 \\
\hline $\begin{array}{l}\text { Southern } \\
\text { Cavefish }\end{array}$ & $\begin{array}{l}\text { Typhlichthys } \\
\text { subterraneus }\end{array}$ & G4 & & VU & $\begin{array}{c}05,06,07,08,10 \\
11\end{array}$ & 6 \\
\hline Speckled Dace & Rhinichthys osculus & G5 & POPE & & $\begin{array}{c}13,14,15,16,17 \\
18\end{array}$ & 6 \\
\hline Spikedace & Meda fulgida & $\mathrm{G} 2$ & $\mathrm{LT}$ & VU & 15 & 1 \\
\hline Splittail & $\begin{array}{l}\text { Pogonichthys } \\
\text { macrolepidotus }\end{array}$ & G2 & & EN & 18 & 1 \\
\hline Spotfin Chub & Erimonax monachus & G2 & $\mathrm{LT}$ & NT & 06 & 1 \\
\hline Spotted Darter & Etheostoma maculatum & G2 & & NT & 05 & 1 \\
\hline Stargazing Darter & Percina uranidea & G3 & & NT & 08,11 & 2 \\
\hline Striated Darter & Etheostoma striatulum & G1 & & VU & 06 & 1 \\
\hline Sturgeon Chub & Macrhybopsis gelida & G3 & & VU & $07,08,10$ & 3 \\
\hline Suwannee Bass & Micropterus notius & G3 & & NT & 03 & 1 \\
\hline Tennessee Dace & Phoxinus tennesseensis & G3 & & NT & 06 & 1 \\
\hline $\begin{array}{l}\text { Threespine } \\
\text { Stickleback }\end{array}$ & Gasterosteus aculeatus & G5 & POPE & $\mathrm{LC}$ & $01,02,17,18$ & 4 \\
\hline Tidewater Goby & $\begin{array}{l}\text { Eucyclogobius } \\
\text { newberryi }\end{array}$ & G3 & LE & VU & 18 & 1 \\
\hline
\end{tabular}


Table B.1. Fish Species Falling Under an ESA or IUCN Vulnerability Category and their Native Hydrologic Region(s) (continued)

\begin{tabular}{|c|c|c|c|c|c|c|}
\hline Common name & Scientific name & NS & ESA & IUCN & Regions & \# Regions \\
\hline $\begin{array}{l}\text { Toothless } \\
\text { Blindcat }\end{array}$ & Trogloglanis pattersoni & G1G2 & & VU & 12 & 1 \\
\hline Topeka Shiner & Notropis topeka & G3 & LE & & $07,10,11$ & 3 \\
\hline Trispot Darter & Etheostoma trisella & G1 & & VU & 03 & 1 \\
\hline Tui Chub & Gila bicolor & G4 & POPE & & $16,17,18$ & 3 \\
\hline Tuscumbia Darter & Etheostoma tuscumbia & $\mathrm{G} 2$ & & VU & 06 & 1 \\
\hline $\begin{array}{l}\text { Umpqua Oregon } \\
\text { Chub }\end{array}$ & $\begin{array}{l}\text { Oregonichthys } \\
\text { kalawatseti }\end{array}$ & G2G3 & & NT & 17 & 1 \\
\hline Vermilion Darter & Etheostoma chermocki & G1 & LE & & 03 & 1 \\
\hline $\begin{array}{l}\text { Virgin River } \\
\text { Chub }\end{array}$ & Gila seminuda & G1 & LE & & 15 & 1 \\
\hline Virgin Spinedace & Lepidomeda mollispinis & G1G2 & POPT & & 15 & 1 \\
\hline $\begin{array}{l}\text { Waccamaw } \\
\text { Killifish }\end{array}$ & Fundulus waccamensis & G1 & & VU & 03 & 1 \\
\hline $\begin{array}{l}\text { Waccamaw } \\
\text { Silverside }\end{array}$ & Menidia extensa & G1 & $\mathrm{LT}$ & VU & 03 & 1 \\
\hline Warner Sucker & Catostomus warnerensis & G1 & $\mathrm{LT}$ & VU & 17 & 1 \\
\hline Watercress Darter & Etheostoma nuchale & G1 & LE & EN & 03 & 1 \\
\hline $\begin{array}{l}\text { White River } \\
\text { Spinedace }\end{array}$ & Lepidomeda albivallis & G1 & LE & $\mathrm{CR}$ & 15 & 1 \\
\hline $\begin{array}{l}\text { White River } \\
\text { Springfish }\end{array}$ & Crenichthys baileyi & $\mathrm{G} 2$ & POPE & VU & 15 & 1 \\
\hline $\begin{array}{l}\text { White Sands } \\
\text { Pupfish }\end{array}$ & Cyprinodon tularosa & G1 & & VU & 13 & 1 \\
\hline White Sturgeon & $\begin{array}{l}\text { Acipenser } \\
\text { transmontanus }\end{array}$ & G4 & POPE & $\mathrm{LC}$ & 17,18 & 2 \\
\hline $\begin{array}{l}\text { Widemouth } \\
\text { Blindcat }\end{array}$ & Satan eurystomus & G1G2 & & VU & 12 & 1 \\
\hline $\begin{array}{l}\text { Wood River } \\
\text { Sculpin }\end{array}$ & Cottus leiopomus & $\mathrm{G} 2$ & & VU & 17 & 1 \\
\hline Woundfin & $\begin{array}{l}\text { Plagopterus } \\
\text { argentissimus }\end{array}$ & G1 & LE & VU & 15 & 1 \\
\hline Yaqui Chub & Gila purpurea & G1 & LE & VU & 15 & 1 \\
\hline $\begin{array}{l}\text { Yellowcheek } \\
\text { Darter }\end{array}$ & Etheostoma moorei & G1 & $\mathrm{PE}$ & VU & 11 & 1 \\
\hline $\begin{array}{l}\text { Yellowfin } \\
\text { Madtom }\end{array}$ & Noturus flavipinnis & G1 & $\mathrm{LT}$ & VU & 06 & 1 \\
\hline
\end{tabular}


Table B.2. Average Water Use (liters/day/km2) in Different Usage Categories per Hydrologic Region

\begin{tabular}{|c|c|c|c|c|c|c|c|c|c|c|c|}
\hline 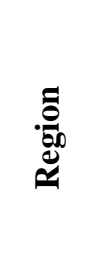 & 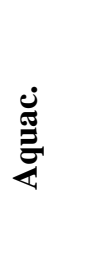 & $\begin{array}{l}\dot{\vec{g}} \\
\stackrel{\Xi}{0} \\
\text { : }\end{array}$ & $\stackrel{\vec{E}}{\stackrel{2}{E}}$ & & 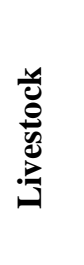 & 莦 & 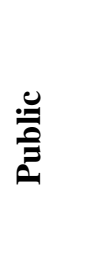 & 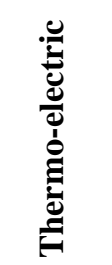 & 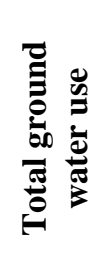 & 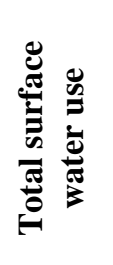 & 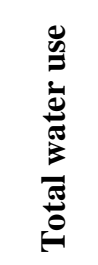 \\
\hline 01 & 30 & 271 & 104 & 30 & 2 & 7 & 431 & 356 & 168 & 2,844 & 3,012 \\
\hline 02 & 81 & 906 & 153 & 46 & 9 & 21 & 965 & 3,180 & 445 & 9,214 & 9,660 \\
\hline 03 & 14 & 197 & 109 & 255 & 13 & 16 & 302 & 854 & 395 & 2,253 & 2,648 \\
\hline 04 & 12 & 280 & 405 & 36 & 7 & 37 & 453 & 2,313 & 138 & 3,173 & 3,310 \\
\hline 05 & 10 & 165 & 297 & 11 & 10 & 30 & 296 & 1,902 & 187 & 2,396 & 2,583 \\
\hline 06 & 213 & 123 & 260 & 17 & 11 & 7 & 206 & 4,079 & 89 & 4,722 & 4,811 \\
\hline 07 & 11 & 154 & 131 & 76 & 18 & 16 & 234 & 1,557 & 244 & 1,819 & 2,063 \\
\hline 08 & 99 & 139 & 665 & 1,217 & 3 & 5 & 215 & 1,459 & 1,336 & 2,358 & 3,694 \\
\hline 09 & 4 & 11 & 18 & 112 & 3 & 22 & 16 & 46 & 22 & 202 & 224 \\
\hline 10 & 7 & 42 & 6 & 758 & 13 & 4 & 64 & 406 & 410 & 855 & 1,266 \\
\hline 11 & 6 & 60 & 21 & 534 & 22 & 1 & 97 & 200 & 499 & 404 & 903 \\
\hline 12 & 2 & 283 & 152 & 415 & 15 & 5 & 394 & 731 & 512 & 1,618 & 2,130 \\
\hline 13 & 4 & 75 & 2 & 691 & 4 & 8 & 87 & 11 & 284 & 536 & 820 \\
\hline 14 & 14 & 21 & 2 & 1,174 & 1 & 1 & 27 & 20 & 60 & 1,188 & 1,248 \\
\hline 15 & 2 & 135 & 3 & 660 & 2 & 17 & 193 & 10 & 412 & 480 & 892 \\
\hline 16 & 16 & 95 & 5 & 793 & 4 & 7 & 123 & 6 & 242 & 750 & 992 \\
\hline 17 & 108 & 107 & 81 & 1,150 & 5 & 5 & 143 & 34 & 367 & 1,179 & 1,546 \\
\hline 18 & 51 & 514 & 6 & 2,019 & 17 & 5 & 821 & 5 & 994 & 3,626 & 4,620 \\
\hline 19 & 37 & 3 & 1 & 0 & 0 & 0 & 4 & 0 & 26 & 21 & 47 \\
\hline 20 & 3 & 238 & 17 & 140 & 2 & 3 & 355 & 20 & 1,795 & 142 & 1,937 \\
\hline 21 & 1 & 423 & 9 & 47 & 10 & 2 & 859 & 3 & 156 & 3,124 & 3,280 \\
\hline Total & 27 & 182 & 122 & 517 & 10 & 11 & 269 & 811 & 429 & 1,872 & 2,301 \\
\hline
\end{tabular}


Table B.3. Approximated Arial Coverage (km2) of Dominant Water-Quality Concerns per Hydrologic Region

\begin{tabular}{|c|c|c|c|c|c|c|c|c|c|c|c|c|}
\hline 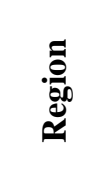 & 苞 & $\stackrel{\Xi}{\stackrel{0}{0}}$ & 矛 & 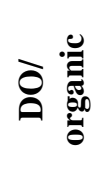 & 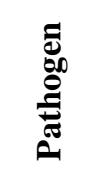 & $\frac{\pi}{2}$ & $\mathscr{\theta}$ & 氖 & 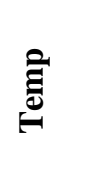 & 苞 & 递 & \& \\
\hline 01 & 106 & 244 & 685 & 180 & 154 & 1 & 1 & 1 & 0 & 4 & 37 & 1,459 \\
\hline 02 & 440 & 4,003 & 197 & 3,602 & 1,061 & 43 & 9 & 184 & 8 & 2 & 150 & 10,263 \\
\hline 03 & 787 & 184 & 2,137 & 919 & 1,501 & 58 & 4 & 8 & 2 & 26 & 145 & 5,907 \\
\hline 04 & 128 & 102,518 & 10,545 & 765 & 88 & 36 & 2 & 7 & 0 & 3 & 64 & 114,324 \\
\hline 05 & 239 & 305 & 555 & 142 & 320 & 8 & 5 & 58 & 1 & 40 & 304 & 2,507 \\
\hline 06 & 22 & 256 & 290 & 17 & 53 & 16 & 1 & 8 & 1 & 3 & 14 & 706 \\
\hline 07 & 644 & 311 & 920 & 149 & 209 & 5 & 7 & 8 & 0 & 48 & 85 & 2,812 \\
\hline 08 & 66 & 36 & 1,944 & 476 & 910 & 46 & 17 & 12 & 0 & 1 & 61 & 3,621 \\
\hline 09 & 1,266 & 0 & 789 & 26 & 48 & 0 & 0 & 4 & 0 & 13 & 28 & 2,174 \\
\hline 10 & 735 & 54 & 2,771 & 305 & 288 & 65 & 104 & 104 & 248 & 40 & 89 & 5,468 \\
\hline 11 & 92 & 280 & 394 & 980 & 206 & 8 & 132 & 81 & 11 & 340 & 9 & 2,928 \\
\hline 12 & 1 & 20 & 457 & 1,309 & 255 & 185 & 30 & 0 & 0 & 0 & 22 & 2,279 \\
\hline 13 & 6 & 23 & 83 & 29 & 18 & 1 & 2 & 7 & 1 & 2 & 4 & 177 \\
\hline 14 & 4 & 7 & 205 & 45 & 18 & 17 & 18 & 1 & 4 & 0 & 0 & 321 \\
\hline 15 & 9 & 8 & 25 & 16 & 4 & 1 & 2 & 0 & 4 & 1 & 1 & 70 \\
\hline 16 & 754 & 47 & 222 & 31 & 6 & 14 & 147 & 10 & 20 & 0 & 9 & 1,261 \\
\hline 17 & 55 & 65 & 1,308 & 32 & 81 & 12 & 1 & 106 & 482 & 1 & 213 & 2,660 \\
\hline 18 & 1,369 & 857 & 573 & 16 & 34 & 110 & 16 & 123 & 152 & 0 & 2 & 3,260 \\
\hline 19 & 0 & 8 & 0 & 1 & 0 & 0 & 0 & 0 & 0 & 6 & 0 & 15 \\
\hline 20 & 9 & 0 & 0 & 0 & 1 & 0 & 0 & 0 & 0 & 4 & 0 & 17 \\
\hline 21 & 4 & 0 & 113 & 93 & 23 & 5 & 0 & 0 & 0 & 5 & 0 & 242 \\
\hline Total & 6,736 & 109,224 & 24,216 & 9,131 & 5,278 & 631 & 499 & 723 & 935 & 540 & 1,238 & 162,469 \\
\hline
\end{tabular}




\section{Back Cover Images}

Images courtesy of Michael J. Sale, Low Impact Hydropower Institute (LIHI)

Left: Newfound Hydroelectric Project, NH (LIHI Certificate \#82)

Center: Oswego River Project, NY (LIHI Certificate \#35)

Right: Prospect No. 3 Hydroelectric Project, OR (LIHI Certificate \#109) 


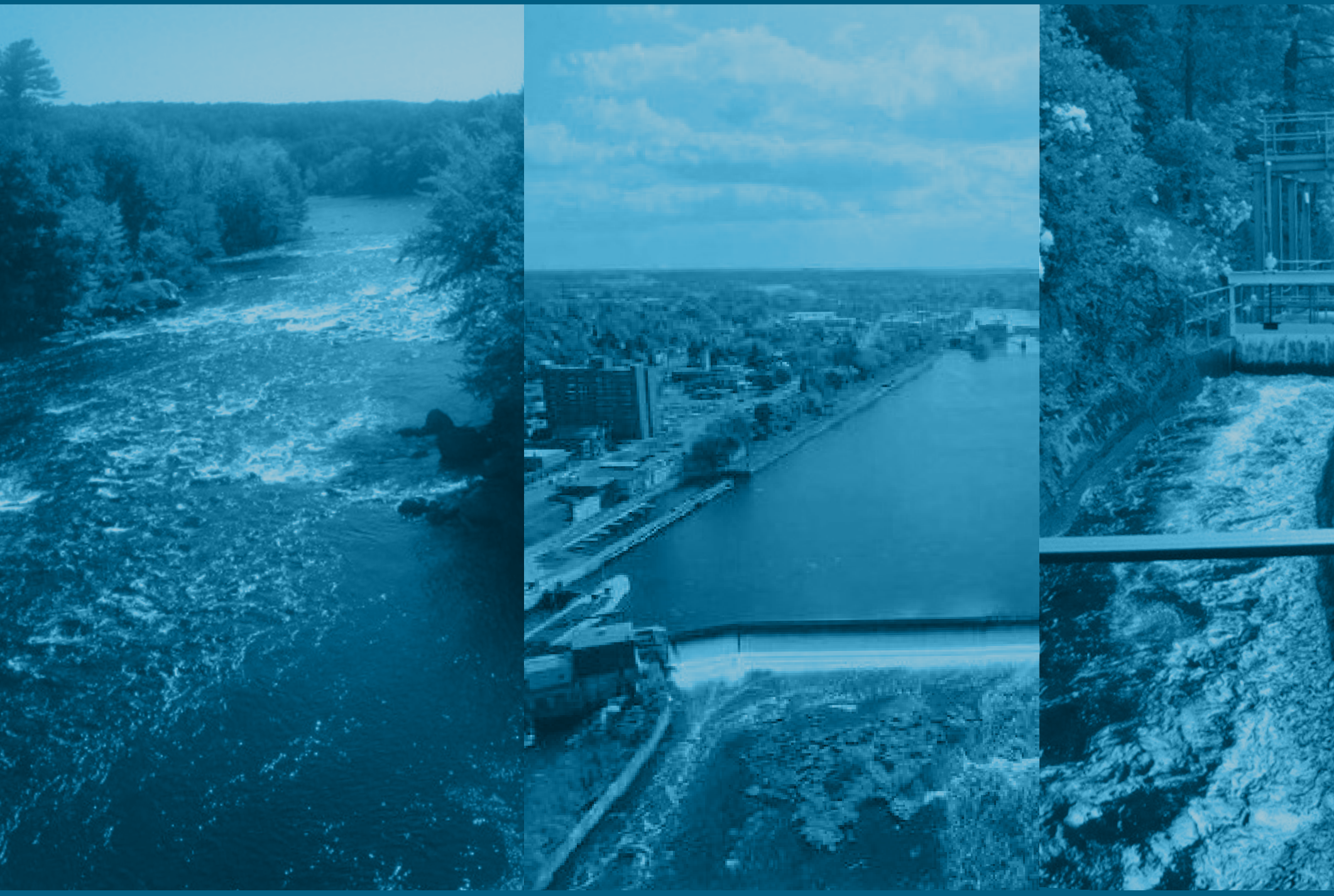

\section{a. \\ ENERGY}

Energy Efficiency \& Renewable Energy
GPO DOE/EE-1063 • April 2014

Printed with a renewable-source ink on paper containing at least $50 \%$ wastepaper, including $10 \%$ post consumer waste. 